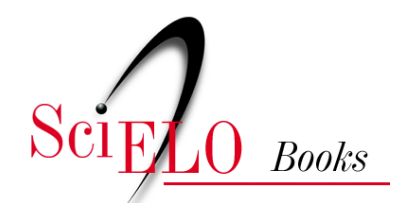

\title{
Saúde do trabalhador na sociedade brasileira contemporânea
}

\author{
Carlos Minayo Gomez \\ Jorge Mesquita Huet Machado \\ Paulo Gilvane Lopes Pena \\ (orgs.)
}

GOMEZ, C.M., MACHADO, J.M.H., and PENA, P.G.L., comps. Saúde do trabalhador na sociedade brasileira contemporânea [online]. Rio de Janeiro: Editora FIOCRUZ, 2011, 539 p. ISBN 978-85-7541365-4. https://doi.org/10.7476/9788575413654.

\section{International license.}

Todo o conteúdo deste trabalho, exceto quando houver ressalva, é publicado sob a licença Creative Commons Atribição 4.0. 


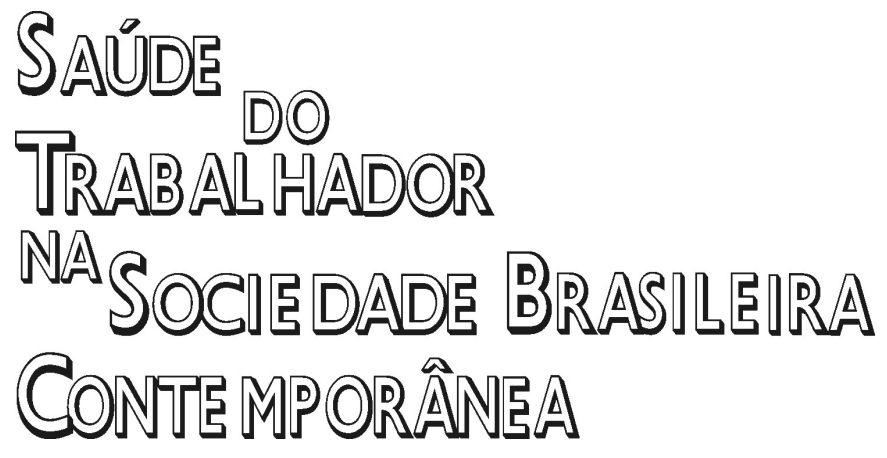




\section{FUNDAÇÃO OSWALDO CRUZ}

Presidente

Paulo Ernani Gadelha Vieira

Vice-Presidente de Ensino,

Informação e Comunicação

Maria do Carmo Leal

\section{EDITORA FIOCRUZ}

Diretora

Maria do Carmo Leal

Editor Executivo

João Carlos Canossa Mendes

Editores Científicos

Nísia Trindade Lima

Ricardo Ventura Santos

Conselho Editorial

Ana Lúcia Teles Rabello

Armando de Oliveira Schubach

Carlos E. A. Coimbra Jr.

Gerson Oliveira Penna

Gilberto Hochman

Joseli Lannes Vieira

Lígia Vieira da Silva

Maria Cecília de Souza Minayo 
Carlos Minayo Gomez

Jorge Mesquita Huet Machado

Paulo Gilvane Lopes Pena

Organizadores
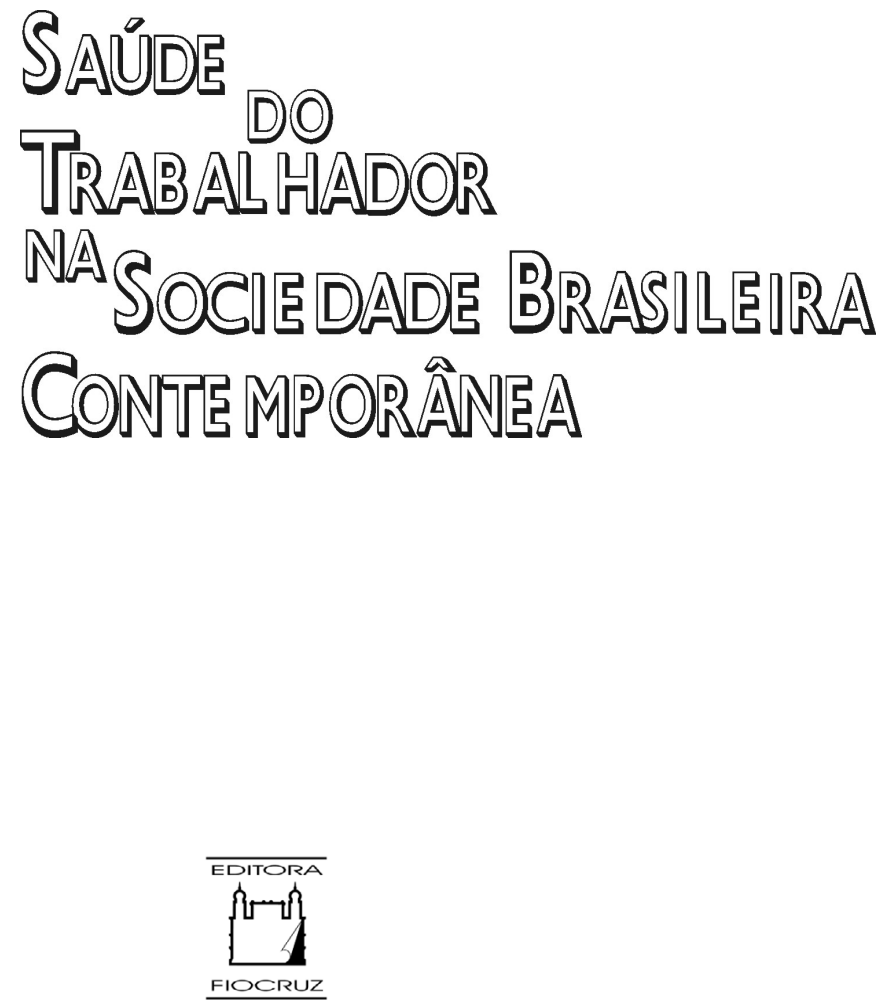
Copyright (C) 2011 dos autores

Todos os direitos desta edição reservados à

FUNDAÇÃO OSWALDO CRUZ / EDITORA

Capa, projeto gráfico

Carlota Rios

Estabelecimento de texto

Jorge Moutinho

Normalização de referências

Clarissa Bravo

Supervisão editorial

M. Cecilia B. Moreira

Catalogação na fonte

Centro de Informação Científica e Tecnológica

Biblioteca da Escola Nacional de Saúde Pública Sergio Arouca

M663 Minayo Gomez, Carlos (Org.)

Saúde do Trabalhador na Sociedade Brasileira Contemporânea./ organizado por Carlos Minayo Gomez, Jorge Mesquita Huet Machado e Paulo Gilvane Lopes Pena. - Rio de Janeiro, Editora FIOCRUZ, 2011..

540 p., il., tab

ISBN: 978-85-7541-204-6

1. Vigilância em Saúde do Trabalhador. 2. Sistema Único de Saúde. 3. Humanização da Assistência. 4. Políticas Públicas.

5. Saúde Mental. I. Machado, Jorge Mesquita Huet (Org.).

II. Pena, Paulo Gilvane Lopes (Org.). III. Título.

CDD - 363.110981

2011

EDITORA FIOCRUZ

Av. Brasil, 4036 - Térreo - sala 112 - Manguinhos

21040-361 - Rio de Janeiro - RJ

Tels: (21) 3882-9039 e 3882-9041

Telefax: (21) 3882-9006

e-mail: editora@fiocruz.br

http://www.fiocruz.br/editora 


\section{Autores}

\section{Ada Ávila Assunção}

Médica, doutora em Ergonomia pela École Pratique des Hautes Études de Paris, com pós-doutorado em Saúde Pública pela Escola Nacional de Saúde Pública Sergio Arouca da Fundação Oswaldo Cruz (Ensp/Fiocruz); professora associada do Departamento de Medicina Preventiva e Social da Faculdade de Medicina da Universidade Federal de Minas Gerais (DMPS/ FM/LFMG).

\section{Airton Marinho da Silva}

Médico do trabalho, mestre em Saúde Pública pela Universidade Federal de Minas Cerais (UFMC); auditor fiscal do Ministério do Trabalho e Emprego (MTE).

\section{Álvaro Roberto Crespo Merlo}

Médico, doutor em Sociologia pela Université de Paris VII-Denis Diderot; professor associado da Universidade Federal do Rio Grande do Sul (UFRCS).

\section{Ana Paula Lopes dos Santos}

Psicóloga, doutora em Saúde Coletiva pela Universidade Federal de São Paulo (Unifesp); assessora do Sindicato dos Trabalhadores do Judiciário Federal de São Paulo (Sintrajud/SP).

\section{Anísio José da Silva Araújo}

Psicólogo, doutor em Ciências da Saúde pela Escola Nacional de Saúde Pública Sergio Arouca da Fundação Oswaldo Cruz (Ensp/Fiocruz); professor associado da Universidade Federal da Parába (UFPB).

\section{Augusto de Souza Campos}

Psicólogo, mestre em Saúde Pública pela Universidade Federal de Minas Cerais (UFMG); consultor da Organização PanAmericana da Saúde (Opas) no Brasil.

\section{Bernadette Cunha Waldvogel}

Estatística, doutora em Saúde Pública pela Faculdade de Saúde Pública da Universidade de São Paulo (FSP/LSP); gerente de Indicadores e Estudos Populacionais da Fundação Sistema Estadual de Análise de Dados (Seade-SP).

\section{Carlos Alberto Diniz Silva}

Médico, com diploma em Études Approffondies do Conservatoire National des Arts et Metiers-Paris; auditor fiscal do Ministério do Trabalho e Emprego (MTE).

\section{Carlos Minayo Gomez}

Sociólogo, doutor em Ciências pela Universidade de Salamanca (Espanha); pesquisador da Escola Nacional de Saúde Pública Sergio Arouca da Fundação Oswaldo Cruz (Ensp/Fiocruz).

\section{Cláudia Vasques Chiavegatto}

Médica do trabalho; mestre em Saúde Pública pela Universidade Federal de Minas Gerais (UFMG).

\section{Christovam Barcelos}

Ceógrafo, doutor em Ceociências pela Universidade Federal Fluminense (UFF); pesquisador titular do Instituto de Comunicação e Informação Científica e Tecnológica em Saúde da Fundação Oswaldo Cruz (lcict/Fiocruz).

\section{Danilo Fernandes Costa}

Médico, doutor em Ciências pela Faculdade de Medicina da Universidade de São Paulo (USP); auditor fiscal do Trabalho no Ministério do Trabalho e Emprego (MTE/SP); pesquisador associado da Faculdade de Medicina da Universidade de São Paulo (FM/USP). 


\section{Edil Ferreira da Silva}

Psicólogo, doutor em Ciências da Saúde pela Escola Nacional de Saúde Pública Sergio Arouca da Fundação Oswaldo Cruz (Ensp/ Fiocruz); professor adjunto do Departamento de Psicologia da Universidade Estadual da Parába (UEPB).

\section{Élida Azevedo Hennington}

Médica, doutora em Saúde Coletiva pelo Departamento de Medicina Preventiva e Social da Faculdade de Ciências Médicas da Universidade Estadual de Campinas (DMPS/FCM/Unicamp); professora e pesquisadora do Instituto de Pesquisa Clínica Evandro Chagas da Fundação Oswaldo Cruz (Ipec/Fiocruz) e da Escola Nacional de Saúde Pública Sergio Arouca (Ensp) da Fiocruz.

\section{Elizabeth Costa Dias}

Médica sanitarista e do trabalho, doutora em Saúde Coletiva/ Saúde Ocupacional pela Universidade Estadual de Campinas (Unicamp); professora convidada do Departamento de Medicina Preventiva e Social da Universidade Federal de Minas Cerais (DMPS/UFMG).

\section{Francisco Antonio de Castro Lacaz}

Médico, doutor em Saúde Coletiva pela Universidade Estadual de Campinas (Unicamp); professor do Departamento de Medicina Preventiva da Universidade Federal de São Paulo (Unifesp).

\section{Francis Sodré}

Assistente social, doutora em Saúde Coletiva pela Universidade do Estado do Rio de Janeiro (Uerj); professora do Departamento de Serviço Social da Universidade Federal do Espírito Santo (DSS/Ufes).

\section{Guilherme Franco Netto}

Médico, doutor em Epidemiologia pela Tulane University de Louisiana (EUA); diretor do Departamento de Saúde Ambiental e Saúde do Trabalhador do Ministério da Saúde (MS).

\section{Ildeberto Muniz de Almeida}

Médico, doutor em Saúde Pública pelo Departamento de Saúde Ambiental da Faculdade de Saúde Pública da Universidade de São Paulo (FSP/USP); professor assistente do Departamento de Saúde Pública da Faculdade de Medicina de Botucatu da Universidade Estadual Paulista (Unesp).

\section{Jorge Mesquita Huet Machado}

Médico sanitarista, doutor em Saúde Pública pela Escola Nacional de Saúde Pública Sergio Arouca da Fundação Oswaldo Cruz (Ensp/Fiocruz); tecnologista em Saúde Pública da Fiocruz de Brasília e assessor do Departamento de Vigilância em Saúde Ambiental e de Saúde do Trabalhador do Ministério da Saúde (MS).

\section{Juliana do Carmo Reis}

Psicóloga, mestre em Psicologia pela Universidade Federal de Minas Cerais (UFMC); psicóloga do Núcleo de Apoio à Saúde da Família da Secretaria Municipal de Saúde de Belo Horizonte (Nasf/SMSA)

\section{Jussara Brito}

Engenheira, doutora em Saúde Pública pela Escola Nacional de Saúde Pública Sergio Arouca (Ensp/Fiocruz); pesquisadora do Centro de Estudos da Saúde do Trabalhador e Ecologia Humana (Cesteh) da Ensp/Fiocruz.

\section{Luiz Carlos Brant}

Psicanalista, doutor em Ciências da Saúde pela Escola Nacional de Saúde Pública Sergio Arouca da Fundação Oswaldo Cruz (Ensp/Fiocruz); professor da Universidade do Estado de Minas Cerais (UEMG).

\section{Luiz Carlos Fadel de Vasconcellos}

Médico, doutor em Saúde Pública pela Escola Nacional de Saúde Pública Sergio Arouca (Ensp/Fiocruz); pesquisador do Grupo de Direitos Humanos e Saúde Helena Besserman (DIHS) da Ensp/Fiocruz.

\section{Lys Esther Rocha}

Médica, doutora em Medicina Preventiva; professora do Departamento de Medicina Legal, Ética Médica e Medicina Social e do Trabalho da Faculdade de Medicina da Universidade de São Paulo (FM/USP).

\section{Marcelo Firpo de Souza Porto}

Engenheiro de produção e psicólogo, doutor em Engenharia de Produção pela Universidade Federal do Rio de Janeiro (UFRI); pesquisador titular da Escola Nacional de Saúde Pública Sergio Arouca da Fundação Oswaldo Cruz (Ensp/Fiocruz).

\section{Maria Elizabeth Barros de Barros}

Psicóloga, doutora em Educação e Sociedade pela Universidade Federal do Rio de Janeiro, com pós-doutorado em Saúde Pública pela Escola Nacional de Saúde Pública Sergio Arouca da Fundação Oswaldo Cruz (Ensp/Fiocruz); professora titular do Departamento de Psicologia da Universidade Federal do Espirito Santo (Ufes). 


\section{Maria de Lourdes Moure}

Engenheira civil, doutora em Engenharia de ProduçãoErgonomia pela Escola Politécnica da Universidade de São Paulo (USP), auditora fiscal do Ministério do Trabalho e Emprego (MTE-SP).

\section{Marilene Affonso Romualdo Verthein}

Psicóloga, doutora em Ciências pela Escola Nacional de Saúde Pública Sérgio Arouca da Fundação Oswaldo Cruz (Ensp/ Fiocruz); professora associada do Departamento de Psicologia da Universidade Federal Fluminense (UFF).

\section{Mary Yale Neves}

Psicóloga, doutora em Ciências da Saúde pelo Instituto de Psiquiatria da Universidade Federal do Rio de Janeiro (Ipub/ UFRJ); professora associada do Departamento de Psicologia da Universidade Federal Fluminense (UFF).

\section{Maurício Monken}

Geógrafo, doutor em Saúde Pública pela Escola Nacional de Saúde Pública Sergio Arouca da Fundação Oswaldo Cruz (Ensp/ Fiocruz); pesquisador do Laboratório de Educação Profissional em Vigilância em Saúde da Escola Politécnica de Saúde Joaquim Venâncio (EPSIV) da Fiocruz.

\section{Milton Athayde}

Psicólogo, doutor em Engenharia de Produção pela Universidade Federal do Rio de Janeiro (UFRI), com pósdoutorado em Ergologia na Université d'Aix-en-Provence (França); professor da Universidade do Estado do Rio de Janeiro (Ueri).

\section{Paulo Antônio Barros Oliveira}

Médico, doutor em Engenharia de Produção pela Universidade Federal do Rio de Janeiro (UFR); ; professor adjunto da Universidade Federal do Rio Grande do Sul (UFRCS) e auditor fiscal do Ministério do Trabalho e Emprego (MTE).

\section{Paulo Gilvane Lopes Pena}

Médico, doutor em Ciências Sociais pela École des Hautes Études en Sciences Sociales (EHESS-Paris); professor adjunto da Faculdade de Medicina da Universidade Federal da Bahia (Ufba).

\section{Serafim Barbosa dos Santos Filho}

Médico, doutorando em Ciência da Informação pela Universidade Federal de Minas Cerais (UFMG); professor da Pontifícia Universidade Católica (PUC-MG) e consultor do Ministério da Saúde (MS).

\section{Silvana Mendes Lima}

Psicóloga, doutora em Ciências da Saúde pela Escola Nacional de Saúde Pública Sergio Arouca da Fundação Oswaldo Cruz (Ensp/Fiocruz); professora adjunta do Departamento de Psicologia da Universidade Federal Fluminense (UFF).

\section{Simone Santos Oliveira}

Cientista social, doutora em Saúde Pública pela Escola Nacional de Saúde Pública Sergio Arouca da Fundação Oswaldo Cruz (Ensp/Fiocruz); pesquisadora da Ensp/Fiocruz.

\section{Tânia Maria de Araújo}

Psicóloga, doutora em Saúde Pública pela Universidade Federal da Bahia (Ufba), com pós-doutorado na University of Massachusetts Lowell (EUA); professora da Universidade Estadual de Feira de Santana (UEFS/BA).

\section{Thais Lacerda e Silva}

Fisioterapeuta, mestre em Saúde Pública e Ambiente pela Escola Nacional de Saúde Pública Sergio Arouca da Fundação Oswaldo Cruz (Ensp/Fiocruz); pesquisadora do Projeto Desenvolvimento de Ações de Saúde do Trabalhador na Atenção Primária à Saúde da Universidade Federal de Minas Cerais (APS/UFMG).

\section{Wanderlei Antonio Pignati}

Médico, doutor em Saúde Pública pela Escola Nacional de Saúde Pública Sergio Arouca da Fundação Oswaldo Cruz (Ensp/ Fiocruz); professor adjunto do Instituto de Saúde Coletiva da Universidade Federal de Mato Grosso (ISC/UFMT). 



\section{SUMÁRI0}

APResentação

\section{INTRODUÇÃO}

Campo da Saúde do Trabalhador: trajetória, configuração e transformações

Carlos Minayo Gomez

Parte I - Políticas e Estratégias de Vigilância e Prevenção

1. Política Nacional de Saúde do Trabalhador: ampliação do objeto em direção a uma política de Estado Luiz Carlos Fadel de Vasconcellos e Jorge Mesquita Huet Machado

2. Perspectivas e Pressupostos da Vigilância em Saúde do Trabalhador no Brasil Jorge Mesquita Huet Machado

3. Saúde do Trabalhador no SUS: contexto, estratégias e desafios

Ana Paula Lopes dos Santos e Francisco Antonio de Castro Lacaz

4. Desenvolvimento de Ações de Saúde do Trabalhador no SUS: a estratégia da Rede Nacional de Atenção Integral à Saúde do Trabalhador (Renast)

Elizabeth Costa Dias, Thais Lacerda e Silva, Cláudia Vasques Chiavegatto, Juliana do Carmo Reis e Augusto de Souza Campos

5. O Trabalho em Saúde nos Referenciais da Política Nacional de Humanização: construindo uma metodologia de análise e intervenção Maria Elizabeth Barros de Barros e Serafim Barbosa dos Santos Filho 
6. A Implantação de Políticas Públicas de Ergonomia na Saúde do Trabalhador: a experiência participativa do Ministério do Trabalho e Emprego

Paulo Antônio Barros Oliveira, Lys Esther Rocha, Airton Marinho da Silva, Carlos Alberto Diniz Silva e Maria de Lourdes Moure

7. Saúde, Trabalho, Ambiente e Território: contribuições teóricas e propostas de operacionalização 161 Maurício Monken, Christovam Barcellos e Marcelo Firpo de Souza Porto

8. Prevenção da Exposição ao Benzeno no Brasil: análise com base na experiência em São Paulo

Danilo Fernandes Costa

Parte II - Acidentes e Agravos 201

9. Acidentes de Trabalho e a Repolitização da Agenda da Saúde do Trabalhador Ildeberto Muniz de Almeida

10. Quantos Acidentes do Trabalho Ocorrem no Brasil? Proposta de integração de registros administrativos Bernadette Cunha Waldvogel

11. O Agronegócio e seus Impactos na Saúde dos Trabalhadores e da População do Estado de Mato Grosso Wanderlei Antonio Pignati e Jorge Mesquita Huet Machado

12. Movimentos de Assepsia Social: a doença do trabalho fora de alcance

Marilene Affonso Romualdo Verthein e Carlos Minayo Gomez

Parte III - Subjetividade e Trabalho

13. O Trabalho e as Redes

Francis Sodré

14. Produção de Conhecimento sobre a Tríade Saúde, Trabalho e Subjetividade Silvana Mendes Lima 
15. Revisão de Abordagens Teórico-Metodológicas sobre Saúde Mental e Trabalho

Tânia Maria de Araújo

16. Saúde 'Mental' e Trabalho: questões para discussão no campo da saúde do trabalhador Milton Athayde

17. O Trabalho e a Saúde Mental no Brasil: caminhos para novos conhecimentos e novos instrumentos de intervenção Álvaro Roberto Crespo Merlo

18. A Temática do Sofrimento nos Estudos sobre Trabalho e Saúde 385 Luiz Carlos Brant e Carlos Minayo Gomez

Parte IV - Trabalho em Serviços e Questões de Gênero

19. Aspectos Conceituais do Setor de Serviços e a Saúde do Trabalhador

Paulo Gilvane Lopes Pena

20. Entre o Criativo e o Precário: reflexões sobre constrangimentos e possibilidades do trabalhador da saúde em tempos líquidos Élida Azevedo Hennington

21. Condições de Trabalho e Saúde dos Trabalhadores da Saúde Ada Ávila Assunção

22. A Ergologia como Perspectiva de Análise: a saúde do trabalhador e o trabalho em saúde Jussara Brito

23. Relações Sociais de Gênero e Divisão Sexual do Trabalho: uma convocação teórico-analítica para estudos sobre a saúde das trabalhadoras da educação Mary Yale Neves, Jussara Brito, Anísio José da Silva Araújo e Edil Ferreira da Silva

24. Relação de Serviço, Telemarketing e Saúde: algumas aproximações Simone Santos Oliveira 



\section{APRESENTAÇ̃̃o}

Saúde do Trabalhador na Sociedade Brasileira Contemporânea traz para o leitor um conjunto de contribuições teóricas e frutos de experiências sobre mudanças sociais e nos processos de trabalho nos diversos campos produtivos e institucionais, bem como sobre tendências, dilemas, controvérsias, desafios e perspectivas de novos horizontes para a saúde do trabalhador. Seu conteúdo diz respeito ao cenário da produção científica e das ações institucionais do campo da saúde do trabalhador no Brasil, possibilitando interlocuções reflexivas, particularmente entre os pares envolvidos com a permanente construção desse campo no país. São também apresentadas as interações da área com campos fronteiriços e contempladas realidades do mundo do trabalho que ainda precisam ser mais bem conhecidas e compreendidas e que constituem desafios para o setor saúde.

Uma das principais características desta obra é reunir textos de referência que foram apresentados e discutidos por autores que pertencem a diversas instituições de ensino e pesquisa do país no I Simpósio Brasileiro de Saúde do Trabalhador (Simbrast), ocorrido em 2007, o que a torna uma produção com contribuições diversificadas, coletivas e atuais.

Consideramos que o ponto forte deste livro é a apresentação de um corpo de conhecimentos que permite situar o 'estado da arte' com base na reflexão acumulada no campo teórico de saúde do trabalhador, tal como entendido pela área de saúde coletiva brasileira. Os textos incorporam novos conhecimentos peculiares ao campo e também de áreas e de práticas afins. Neles encontramse análises dos caminhos percorridos, identificam-se lacunas no âmbito de conhecimento e apontam-se questões que deveriam ser aprofundadas com 
vistas a estabelecer novas estratégias de ação. Essa empreitada - que reúne o pensamento de grande parte dos autores que vêm construindo a história da área - permite dar continuidade à saga iniciada pelos formuladores do conceito de 'saúde do trabalhador'.

A organização dos capítulos procurou atender a uma lógica de leitura que parte de uma discussão teórica e institucional e tem como sequência temas estruturadores de ações e reflexões.

O texto introdutório abre o debate sobre a construção do campo da saúde do trabalhador, sua trajetória, configuração e transformações. Apresenta o corpo conceitual e a necessidade de adequação das práticas desse campo, levando em consideração as transformações do mundo do trabalho nos mais diferentes setores. Ressalta que essas mudanças acompanham um movimento mundial de reestruturação produtiva que associa, sem eliminá-las, formas arcaicas de produção e têm em comum a ênfase na globalização dos mercados, os processos de privatização dos serviços públicos, a rápida incorporação tecnológica para a produção de bens e serviços, o aumento acelerado do trabalho informal e a exclusão social. Todos esses aspectos, somados aos problemas estruturais da formação da sociedade brasileira, trazem profundas consequências para a vida e a saúde do trabalhador, evidenciadas nas importantes modificações na composição espacial da mão de obra, na dinâmica do emprego, do desemprego e do grau de formalização por gênero, idade e categorias. Observa-se, no entanto, uma distância entre o conhecimento já consolidado e o que é enunciado pelo desejo de que uma formulação clara e consistente possa subsidiar as políticas e a gestão institucional do setor.

A obra se divide em quatro partes, acompanhando o movimento de produção acadêmica e da área de interesse dos autores. Na primeira, é abordado um conjunto de temas relativos às políticas setoriais e institucionais e às estratégias hoje em curso para a vigilância e a prevenção de acidentes e agravos físicos e mentais. Os autores trabalham, sobretudo, com os conceitos gerados pelas políticas e pela regulação, normalização e gestão desse campo que, pela Constituição, é parte integrante do Sistema Único de Saúde (SUS). Em seus textos, existe sempre uma visão crítica sobre os avanços que vêm ocorrendo e as dificuldades de implementação de uma vigilância eficiente e eficaz.

O próprio título do primeiro capítulo, "Política Nacional de Saúde do Trabalhador: ampliação do objeto em direção a uma política de Estado”, já anuncia a reflexão que os autores desenvolvem sobre a necessidade de definição de uma política para esse campo mediante as diretrizes do SUS. Tomando 
como base a interpretação do percurso histórico institucional, os dispositivos legais, a produção acadêmica e a atuação do movimento sindical, os autores afirmam a pertinência de uma política de saúde direcionada para o mundo da produção e do desenvolvimento sustentável.

No arcabouço das políticas, o capítulo seguinte, "Perspectivas e Pressupostos da Vigilância em Saúde do Trabalhador no Brasil”, destaca os princípios que constituem uma proposta de transformação para a totalidade do sistema de saúde. Apresenta a ação de vigilância em saúde do trabalhador pensada como uma ação transversal à vigilância em saúde, de ressignificação coletiva das práticas de assistência e de conexão com as intervenções interinstitucionais que reorientam o modelo de atenção do SUS no processo de reforma da Reforma Sanitária brasileira.

Os capítulos 3 e 4 abordam especificamente o tema da saúde do trabalhador no SUS. "Saúde do Trabalhador no SUS: contexto, estratégias e desafios” descreve a trajetória da inserção da área de saúde do trabalhador no âmbito da saúde pública. Os autores destacam, particularmente, os Programas de Saúde do Trabalhador por associarem as ações de assistência à saúde às de vigilância dos ambientes laborais, com ênfase na interlocução com o movimento de trabalhadores e na atividade interinstitucional e multiprofissional. Eles se referem às possibilidades e dificuldades para a consolidação das ações da saúde dos trabalhadores na rede do SUS e os desafios para romper com a lógica assistencial. "Desenvolvimento de Ações de Saúde do Trabalhador no SUS: a estratégia da Rede Nacional de Atenção Integral à Saúde do Trabalhador (Renast)", além de apresentar um quadro geral da implementação dessa estratégia, com ênfase na legislação e nas atribuições institucionais, identifica os aspectos positivos e as dificuldades observadas na prática. $O$ texto também oferece sugestões para articular ações de vigilância, de assistência e de promoção da saúde visando a responder às demandas atuais dos trabalhadores.

Em "O Trabalho em Saúde nos Referenciais da Política Nacional de Humanização: construindo uma metodologia de análise e intervenção”, descrevem-se os referenciais teóricos que fundamentam essa proposta política. Ressalta-se o sentido conferido ao termo 'humanização' pelo setor saúde, sobretudo quando se busca a superação do excesso de tecnificação e de burocratismo que invadiu tanto a gestão como as práticas clínicas e de saúde pública. Além disso, tenta-se aplicar as bases teóricas da humanização ao campo de saúde do trabalhador, com ênfase no processo de trabalho em saúde. 
Um aspecto emergente que merece destaque na atuação do MTE é relatado no capítulo 6, "A Implantação de Políticas Públicas de Ergonomia na Saúde do Trabalhador: a experiência participativa do Ministério do Trabalho e Emprego", no qual se sistematiza uma prática implantada em diversos setores produtivos por meio da Coordenação Nacional das Ações em Ergonomia. Essa iniciativa veio responder às demandas incessantes e inquestionáveis para prevenção e solução dos distúrbios osteomusculares relacionados ao trabalho.

A importância do 'território' como categoria articuladora entre abordagens epidemiológicas e sociais é discutida em "Saúde, Trabalho, Ambiente e Território: contribuições teóricas e propostas de operacionalização”. Os autores mostram como critérios referentes ao espaço territorial estão na base da organização da atenção à saúde e são fundamentais para as ações de vigilância em saúde do trabalhador, em relação a processos produtivos e às populações. Eles alertam, no entanto, para a devida apropriação de categorias de cunho geográfico como espaço, território e lugar na saúde pública.

A experiência brasileira de luta contra a exposição ao benzeno como exemplo bem-sucedido de vigilância em saúde é debatida em "Prevenção da Exposição ao Benzeno no Brasil: análise com base na experiência em São Paulo", cujo foco é a construção de uma ação de vigilância que integra os campos da saúde do trabalhador e da saúde ambiental. O autor apresenta esse caso em seu contexto histórico de evolução da exposição e de intervenção com a implantação de processos de informação, formação e organização de estruturas de acompanhamento. Sublinha a importância da produção técnico-científica combinada com situações institucionais favoráveis e estratégias de articulação entre trabalhadores e profissionais do serviço público.

A segunda parte do livro trata dos acidentes e agravos vinculados aos processos de trabalho. Apesar da insuficiência de informações sobre esses eventos - fato ressaltado pelos autores - os dados existentes têm o importante papel de assinalar fatores associados e predisponentes, bem como de indicar caminhos possíveis para melhorar as condições de trabalho e qualidade de vida dos trabalhadores. Essa temática clássica da área de saúde do trabalhador, tanto nas cidades como no campo, vem apresentando fortes mudanças de perfil e configura uma dinâmica de relações sociais de produção, dialeticamente articulada aos históricos conflitos sociais mais amplos da sociedade brasileira.

O capítulo 9, "Acidentes de Trabalho e a Repolitização da Agenda da Saúde do Trabalhador”, parte da constatação da inexistência, até hoje, de proposta específica no tocante à prevenção desses eventos nos três níveis de governo. 
Chama a atenção para a importância de incluir na reflexão e nas estratégias de vigilância e prevenção as mortes e mutilações relacionadas ao trabalho, dentro e fora do espaço das empresas. Ainda que existam boas iniciativas dispersas por instituições e regiões do país - algumas das quais constam no texto -, o autor apresenta uma série de pontos para discussão de uma agenda de prevenção, visando a contribuir para o fortalecimento dessa prática na área de saúde do trabalhador.

Em "Quantos Acidentes do Trabalho Ocorrem no Brasil? Proposta de integração de registros administrativos", a autora propõe a construção de base integrada de dados de acidentes e doenças do trabalho, mediante a vinculação das fontes de dados já existentes. Embora cada uma delas seja parcial e incompleta e tenha sido concebida para cumprir funções distintas, o tratamento conjunto visa à redução dessas limitações, podendo gerar informações necessárias para o monitoramento da questão acidentária no país. A proposta vem referendada no trabalho realizado nessa direção no estado de São Paulo, do qual a autora participou.

"O Agronegócio e seus Impactos na Saúde dos Trabalhadores e da População do Estado de Mato Grosso" traz uma reflexão sobre a saúde do trabalhador rural e de sua relação com o ambiente, mediada pela análise de informações secundárias relativas ao perfil de adoecimento e ao processo da implantação do agronegócio nesse estado. Tal correlação é explorada de forma inovadora, na qual se destaca a criação de um indicador de esforço produtivo como condicionante epidemiológico.

Os conflitos existentes no estabelecimento dos nexos entre trabalho e agravos à saúde são abordados no capítulo 12, "Movimentos de Assepsia Social: a doença do trabalho fora de alcance". Com base no mapeamento das pesquisas das lesões por esforços repetitivos/distúrbios osteomusculares relacionados ao trabalho (LER/Dort), os autores dão visibilidade às condutas de negação desses nexos que visam à redução de indenizações trabalhistas e dos custos securitários. Contextualizam também a proposição do Nexo Técnico Epidemiológico Previdenciário como política diferenciada emergente que faz a inversão da prova do nexo, com o Estado organizando informações estatísticas capazes de proporcionarem diagnósticos ou nexos presuntivos. Advertem, entretanto, dos riscos de subnotificações, injustiças e limitações inerentes ao próprio modelo estatístico, além da sua restrição à economia formal.

A terceira parte do livro aprofunda a questão da subjetividade vinculada ao trabalho. Os autores partem do princípio de que é a pessoa por inteiro 
que vivencia os processos e as condições de trabalho e que, ao produzir bens e serviços, os trabalhadores ao mesmo tempo se relacionam hierárquica e horizontalmente, se envolvem emocionalmente e criam representações de sua prática que tanto podem contribuir para sua saúde como para seu adoecimento ou sofrimento psíquico. Nas contribuições dos diversos autores existem algumas divergências teóricas e conceituais, o que é importante do ponto de vista acadêmico e prático, pois elas alimentam novas interpretações que podem redundar em atuações mais adequadas e precisas.

Em "O Trabalho e as Redes", analisa-se a temática do trabalho em rede como trabalho imaterial, em um tipo novo de economia que produz formas particulares de subjetivação e de produção e uma consequente colonização do tempo de trabalho sobre todo o tempo de vida. Na organização do trabalho em rede, ressalta-se a substituição das linhas de montagem fordista pelas redes imateriais pós-fordistas que tornam complexas as relações de produção e reprodução. Propõe-se ainda o aprofundamento dessas novas questões trazidas pelo avanço do mundo da informação e da comunicação e, em suas teias, a 'rede das redes' de saúde do trabalhador.

O capítulo 14, "Produção de Conhecimento sobre a Tríade Saúde, Trabalho e Subjetividade", parte do pressuposto, na esfera da psicologia social, de que o capitalismo desenvolveu modos particulares de subjetivar a produção e de que a subjetividade é, ela própria, um capital de valor essencial no universo do trabalho. A noção de subjetividade é apresentada segundo as principais escolas teóricas. Considera-se que houve uma forte inflexão trazida pela contribuição dos estudos qualitativos sobre as noções de sujeito, desejo e inconsciente. A reflexão desenvolvida converge para propor a superação da lógica binária entre subjetivo e objetivo, numa perspectiva de enfrentamento das adversidades no mundo do trabalho.

No capítulo seguinte, "Revisão de Abordagens Teórico-Metodológicas sobre Saúde Mental e Trabalho”, a autora realiza uma análise das principais tendências sobre essa temática. Identifica os modelos teóricos predominantes nos estudos brasileiros e considera incipiente a preocupação com a delimitação conceitual e metodológica, o que redunda em sérios prejuízos e limitações para a prática dos serviços. Observa também que, dada a pouca visibilidade do problema nas estatísticas das doenças ocupacionais, um importante desafio é dar legitimidade ao processo de adoecimento mental, sem desconhecer o lugar próprio do trabalho como fonte de saúde.

Em "Saúde 'Mental' e Trabalho: questões para discussão no campo da saúde do trabalhador", a perspectiva ergológica, centrada em conceitos desenvolvidos por 
vários autores, é apresentada como uma nova abordagem para a compreensão do que existe de 'mental' nas relações de trabalho. $O$ autor problematiza essa noção com base na ergologia. E, por considerar limitante o conceito de processo de trabalho na construção do campo da saúde do trabalhador, recorre ao conceito de atividade como estratégia central de compreensão e intervenção no mundo do trabalho.

No capítulo 17, "O Trabalho e a Saúde Mental no Brasil: caminhos para novos conhecimentos e novos instrumentos de intervenção”, o autor se concentra na metodologia da psicodinâmica do trabalho como estratégia central na compreensão das relações entre saúde mental e trabalho, até mesmo no reconhecimento do nexo causal como uma problemática ainda não resolvida no campo das práticas da saúde do trabalhador. Ressalta a importância dessa estratégia para caracterizar condições pré-patológicas ou infrapatológicas como valiosa estratégia para intervenção preventiva.

O sofrimento em toda a sua abrangência como construto teórico-metodológico na sua relação com a saúde mental e o trabalho é objeto da revisão desenvolvida em "A Temática do Sofrimento nos Estudos sobre Trabalho e Saúde". Os autores encontram diversas formas de caracterização do sofrimento e descrevem os instrumentos metodológicos empregados no âmbito da produção científica da área da saúde do trabalhador. Diferentemente da maioria das publicações analisadas, compreendem a manifestação do sofrimento como um bem do sujeito, inscrito na própria condição humana, capaz de impulsionar o indivíduo para ações de proteção diante do perigo.

$\mathrm{Na}$ quarta parte, os autores abordam temas relativos à saúde dos trabalhadores do setor de serviços e apresentam alguns estudos sobre determinadas categorias desse setor. A relevância da temática advém não só do evidente crescimento desse universo de trabalhadores, mas também da sua especificidade. Nos últimos anos, superando o modelo industrialista hegemônico nas pesquisas sobre saúde dos trabalhadores, a ampliação do setor terciário da economia no país e no mundo exigiu a criação de novos instrumentos teóricos e conceituais para sua análise e compreensão. Os autores apresentam as características básicas dos trabalhadores do setor, mostrando que o serviço é uma atividade interativa, exigindo canais de sustentação de seu fluxo e de manutenção do vínculo entre prestadores e usuários. Essa relação direta e imediata, que pode ser fonte de prazer, também é fonte de estresse, de sofrimento e de exploração que provoca adoecimentos. A configuração desse universo, embora tenha diversas características comuns com a dos trabalhadores da indústria, deve ser realizada levando em conta suas peculiaridades. 
Em "Aspectos Conceituais do Setor de Serviços e a Saúde do Trabalhador", o autor busca a compreensão do trabalho nesse setor, que se caracteriza pela proximidade entre o trabalhador e o consumidor em processos simultâneos de realização da atividade e do consumo. Ademais, mostra como a situação interativa do trabalho, em que cada produto é finalizado no atendimento imediato, tem repercussões importantes para a saúde do trabalhador e do usuário, uma vez que o cerne é a relação estabelecida entre ambos.

No capítulo 20, "Entre o Criativo e o Precário: reflexões sobre constrangimentos e possibilidades do trabalhador da saúde em tempos líquidos”, a autora se concentra no trabalho em saúde do SUS. Identifica o trabalho de saúde como algo além da sua expressão imaterial, caracterizando-o como um tipo de trabalho 'biopolítico' de condições 'líquidas', volúveis, que geram incertezas para o trabalhador da saúde. Sua reflexão parte das ideias de Zygmunt Bauman, que utiliza metáforas de uma modernidade em transição de uma fase 'sólida' para uma era volátil 'líquida', incerta, incontrolável e indeterminável.

Em "Condições de Trabalho e Saúde dos Trabalhadores da Saúde", a autora revisa vários estudos que constatam altas taxas de acidentes, doenças e diversos distúrbios relacionados ao trabalho. Caracteriza essa situação como um verdadeiro problema de saúde pública, agravado não apenas pela complexidade atual das exposições aos riscos inerentes aos serviços de saúde, mas, sobretudo, pela ausência de cuidados com quem tem a responsabilidade de atuar a favor do cuidado com a saúde da população.

O capítulo 22, "A Ergologia como Perspectiva de Análise: a saúde do trabalhador e o trabalho em saúde", apresenta essa área de conhecimento e seus fundamentos essenciais como uma importante contribuição que se propõe a ampliar os horizontes da ergonomia. A autora discute a noção de ergologia em seus vínculos com diversas áreas como psicologia, linguística, ergonomia, engenharia de produção, educação e saúde pública. Examina também estudos realizados no Brasil em setores de serviços e industriais, mostrando como a ergologia aporta um saber específico e importante com desdobramentos sobre a prática de atenção e prevenção.

Os autores de "Relações Sociais de Gênero e Divisão Sexual do Trabalho: uma convocação teórico-analítica para estudos sobre a saúde das trabalhadoras da educação" analisam as especificidades da saúde e do trabalho docente na ótica das relações sociais de gênero e da divisão sexual do trabalho. Apresentam alguns estudos relativos à saúde desses profissionais, agrupando-os segundo o tipo de abordagem com a finalidade de identificar 
os que incorporam nas suas análises a perspectiva de gênero e assinalar alguns de seus limites e possibilidades.

No último capítulo, "Relação de Serviço, Telemarketing e Saúde: algumas aproximações”, a autora discute as principais características desse setor, assinalando a grande tensão entre o consumidor e o trabalhador inscrito na interseção da racionalidade industrial e de serviços. Aponta como uma especificidade as diferenças nas relações de gênero presentes na organização do trabalho dessa modalidade de serviço, em que se encontra maior concentração de mulheres. Ressalta, assim, a importância dessa dimensão sexuada para a compreensão das especificidades que interferem nas condições de trabalho e nas modalidades de sofrimento e adoecimento. As LER e outras patologias relativas a esse tipo de atividade apresentariam, portanto, essa conformação feminina resultante de uma estratégia centrada na divisão sexual do trabalho.

Finalizando esta apresentação, destacamos que os textos mostram avanços na reflexão teórica e empírica na área de saúde do trabalhador ao se comparar as contribuições deste livro à produção anterior. Mas também é preciso dizer, fazendo coro com os autores que compõem a obra, que há lacunas importantes na construção do conhecimento que só serão superadas por meio da intensificação da articulação entre as análises teóricas, as propostas políticas e as ações de intervenção, conforme tem sido a tradição desse campo. Mencionamos, ao terminar, uma síntese das principais contribuições:

- O trabalho é tratado em toda a sua plenitude, para além do âmbito do trabalho industrial, superando assim alguns focos de crítica sobre a concepção do campo da saúde do trabalhador. São discutidas novas e variadas formas de organização do trabalho e suas repercussões como objeto de interesse pertinente ao campo. Nesse contexto, a relação entre saúde, trabalho e ambiente emerge sob várias vertentes como novo objeto do campo. Assim, a relação do processo de trabalho com a saúde é ampliada para além da atividade em si, indicando uma perspectiva de ação múltipla e transversal, que inclui os impactos na sustentabilidade socioambiental. Os textos sobre saúde do trabalhador e ambiente, sobre vigilância em saúde do trabalhador e sobre política de saúde do trabalhador são alguns exemplos desse enfoque.

- Na abordagem da saúde dos trabalhadores do setor de serviços, iniciouse uma reflexão - que precisa ter continuidade - sobre as características específicas dos processos de trabalho desse setor, para servir de referência nas análises dos problemas hoje conhecidos e dos emergentes. 
- As análises realizadas das políticas e estratégias institucionais em saúde do trabalhador, embora tenham um caráter avaliativo e propositivo, demonstram a necessidade de se intensificarem os processos de acompanhamento das situações concretas quanto às evidências epidemiológicas, às orientações e às diretrizes sobre os rumos e sobre como atuar no âmbito do SUS. Surge como desafio a necessidade de se aumentar a capacidade de realização de diagnósticos contextualizados e circunstanciados sobre a implantação das políticas de saúde do trabalhador no Brasil, superando distanciamentos entre instâncias da academia e executivas, assim como entre as organizações.

- Quanto aos acidentes de trabalho, temática recorrente do campo da saúde do trabalhador, as reflexões mostram a necessidade de se ampliar a compreensão teórica e prática sobre os quadros de agravos e mortes. Sobretudo, ressalta-se a urgência de incluir as questões novas trazidas pela ampliação do setor serviço, com as particularidades de funcionamento e as formas de adoecimento de seus trabalhadores. $\mathrm{O}$ tratamento dado à problemática do assédio moral permite elucidar o entendimento de uma forma pouco estudada de violência no trabalho, mas que sempre esteve presente em diversos cenários.

- O debate sobre as relações entre saúde mental e trabalho - demanda crescente e indispensável para os profissionais que lidam com a saúde do trabalhador - é ampliado do ponto de vista teórico e metodológico. Expressam-se, inclusive, divergências inerentes às abordagens doutrinárias sobre questões complexas como subjetividade, sofrimento, estresse e linguagem. Porém, todas as contribuições estão centradas na perspectiva de se encontrarem imersões novas ou renovadas que fortaleçam o campo e aprimorem a prática.

Em síntese, Saúde do Trabalhador na Sociedade Brasileira Contemporânea convida o leitor para um diálogo em torno das principais questões do campo da saúde do trabalhador, que são tratadas com a profundidade necessária no estágio de conhecimento atual. As reflexões e as lacunas temáticas apontadas formam uma agenda para o debate e a pesquisa. Espera-se, portanto, que o leitor possa se apropriar da variedade de aportes trazidos para compreensão do universo e das práticas em saúde do trabalhador, de forma a interagir com os autores e contribuir para o avanço e o aprimoramento do campo. 


\section{InTRODUÇÃO}

\section{CAMPO DA SAÚDE DO TRABALHADOR: \\ TRAJETÓRIA, CONFIGURAÇÃO E tranSFORMAÇÕES}

Carlos Minayo Gomez

Apresento aqui sucinta reflexão sobre o marco conceitual e de práticas que configuram o denominado campo de saúde do trabalhador à luz das transformações do mundo do trabalho que vêm ocorrendo nas últimas décadas. Tenho como objetivo oferecer subsídios para estimular um debate que leve em consideração a trajetória dessa construção social em sua abrangência, com o intuito de extrair algumas questões que possam ser aprofundadas. Realizo uma síntese dos pontos convergentes entre os vários autores que caracterizam o campo, antecipando que, do meu ponto de vista, não existem divergências substantivas entre eles, mas diferenças de ênfases nos aspectos observados. A tarefa hoje é pensar os desdobramentos dessas formulações.

Considerei as terminologias que os vários atores (estudiosos, gestores e profissionais de saúde, assessores e membros de organizações de trabalhadores) adotam em suas respectivas abordagens - como é o caso das expressões 'saúde do trabalhador' e 'paradigma de saúde do trabalhador' - com certo grau de similaridade à de 'campo de saúde do trabalhador'. Conforme as perspectivas aqui assinaladas, discutem-se a seguir os seguintes aspectos:

- o processo histórico que orientou a formulação teórica e prática do campo de saúde do trabalhador;

- as principais características identificadoras do campo;

- os limites e impasses desse 'objeto histórico' que se desenvolve no campo da saúde coletiva e em referência ao mundo do trabalho; e

- a constituição da saúde do trabalhador como campo de estudo. 


\section{Trajetória}

O campo da saúde do trabalhador tem sua origem em uma conjuntura política de organização e de lutas pela redemocratização do país - sobretudo a partir da década de 1980 - em que vários atores, situados em espaços e lugares sociais diferentes, confluem no questionamento das concepções e das políticas públicas de saúde até então vigentes. Entre os antecedentes suficientemente reconhecidos que exerceram significativa influência na gênese social desse campo, encontram-se:

- o avanço da produção acadêmica em setores da medicina preventiva e social e da saúde pública, que, apoiada na medicina social latino-americana, ampliou o quadro interpretativo do processo saúde-doença, incluindo-se aí a dimensão de 'classe' e a categoria 'trabalho' entre os determinantes sociais;

- o movimento pela Reforma Sanitária brasileira, inspirado em várias iniciativas mundiais voltadas para a universalização e a promoção da saúde, dentre as quais a experiência italiana, que contribuiu significativamente para a institucionalização da área de saúde do trabalhador;

- o fortalecimento do movimento dos trabalhadores pela conquista de direitos elementares de cidadania e pela consolidação do direito à livre organização, movimento esse que promoveu uma ampliação das reivindicações trabalhistas, introduzindo nelas questões relacionadas à saúde e, mais ainda, demandando serviços de atenção à saúde na rede pública - cabendo aí destacar o importante papel exercido pelo Departamento Intersindical de Estudos e Pesquisas de Saúde e dos Ambientes de Trabalho (Diesat);

- a realização da I Conferência Nacional de Saúde dos Trabalhadores, cujas resoluções contribuíram para o entendimento e a definição das competências do Sistema Único de Saúde (SUS) em relação à saúde do trabalhador, na Lei Orgânica de Saúde;

- a criação dos Programas de Saúde do Trabalhador (Pimenta \& Capistrano, 1988; Costa et al., 1989; Dias, 1994) e Centros de Referência em Saúde do Trabalhador, com graus diversos de participação de representantes dos trabalhadores na formulação e no desenvolvimento das ações, seguindo o curso mundial de constituir, de forma participativa, serviços de saúde no trabalho como política pública, em consonância com a posição da Organização Internacional do Trabalho (Lacaz, 2007). 


\section{Configuração do Campo}

O discurso da saúde do trabalhador emerge, do ponto de vista acadêmico, político e institucional na saúde coletiva, em contraposição à base conceitual e prática das concepções hegemônicas sobre a relação trabalho-saúde da medicina do trabalho (MT) e da saúde ocupacional (SO). Como parte integrante do campo da saúde coletiva, propõe-se a ultrapassar as articulações simplificadas e reducionistas entre causa e efeito de ambas as concepções que são sustentadas por uma visão monocausal, entre a doença e um agente específico; ou multicausal, entre a doença e um grupo de fatores de risco (físicos, químicos, biológicos, mecânicos), presentes no ambiente de trabalho (Mendes \& Dias, 1991; Lacaz, 1996).

Em princípio, a identidade do campo de saúde do trabalhador tem como referência a abordagem da saúde ocupacional, ao mesmo tempo que busca superá-la, na medida em que esta última - fundada na história natural da doença - orienta-se apenas por práticas e conhecimentos da clínica, da medicina preventiva e da epidemiologia clássica. Do ponto de vista disciplinar e profissional, a saúde ocupacional abrange fundamentalmente as áreas de medicina e de engenharia de segurança, restringindo-se à dimensão contratual das empresas (Lacaz, 2007). A saúde do trabalhador agrega, além dessas, um amplo espectro de disciplinas. Como campo de saber próprio da saúde coletiva, está composta pelo tripé epidemiologia, administração e planejamento em saúde e ciências sociais em saúde, ao que se somam disciplinas auxiliares como demografia, estatística, ecologia, geografia, antropologia, economia, sociologia, história e ciências políticas, toxicologia, engenharia de produção e ergonomia, entre outras.

Ao superar a visão da saúde ocupacional, a saúde do trabalhador se situa na perspectiva da 'saúde como direito', conforme a tendência internacional e a que foi plasmada no SUS, de universalização dos direitos fundamentais (Vasconcellos, 2007). Essa perspectiva transcende o marco do direito previdenciário-trabalhista. De forma bem abrangente, pode-se dizer que o objeto da saúde do trabalhador é o processo de saúde e doença dos grupos humanos, em sua relação com o trabalho (Mendes \& Dias, 1991). E em uma perspectiva muito pouco contemplada, essa abordagem busca, em última instância, colocar em destaque o lado humano do trabalho e sua capacidade protetora contra agravos à saúde dos trabalhadores (Lacaz, 2007).

No âmbito da 'produção de conhecimentos', o campo da saúde do trabalhador tem, como marco definidor, a compreensão dos vários níveis de com- 
plexidade das relações entre o trabalho e a saúde e, como conceito nucleador, o processo de trabalho (Laurell \& Noriega, 1989; Mendes \& Dias, 1991; Lacaz, 1996; Minayo-Gomez \& Thedim-Costa, 1997). Esse conceito, extraído da economia política (Marx, 1978), na sua acepção marxista - entendido como o cenário primário da exploração e da confrontação de classe -, quando adotado em toda a sua extensão teórica tem um elevado poder explicativo da gênese dos agravos à saúde em coletivos diferenciados de trabalhadores.

As potencialidades da análise dos processos de trabalho, no entanto, vêm condicionadas à adoção do tratamento interdisciplinar requerido para estabelecer e articular dois planos. O primeiro contempla o contorno social, econômico, político e cultural, definidor das relações travadas nos espaços de trabalho e das condições de reprodução dos trabalhadores; e o segundo se refere a determinadas características dos processos de trabalho com potencial de repercussão na saúde, inclusive a subjetividade dos trabalhadores (Minayo-Gomez \& Thedim-Costa, 1997). Para detectar essas características, temos algumas noções e conceitos mediadores, como 'risco', 'carga de trabalho', 'exigências' ou 'requerimentos', que dizem respeito às condições materiais ou a componentes mais qualitativos derivados da organização do trabalho. A aplicação desse conjunto de conceitos e noções mediadoras possibilita diversas formas de tratamento para identificar situações geradoras de efeitos potenciais ou reais sobre a saúde de grupos/categorias/ setores, configurando perfis epidemiológicos diferenciados. A conformação desses agrupamentos, em suas homogeneidades e diferenciações internas, vem condicionada à adoção de estratégias que devem combinar abordagens quantitativas e qualitativas.

É preciso ressaltar, entretanto, que o conceito de processo de trabalho foi elaborado originalmente para interpretar o modo de acumulação de capital no trabalho produtivo industrial-fabril. Surge associado à conformação do operariado industrial urbano, e esse viés transparece tanto na concepção e prática do campo saúde do trabalhador como na medicina do trabalho e na saúde ocupacional. Atualmente, embora o setor secundário seja regido pela mesma racionalidade técnica e organizacional e pelo mesmo processo de valorização econômica, esse modelo tornou-se muito mais complexo. Vem também sofrendo profundas transformações decorrentes da nova lógica produtiva que redundam em mudanças na composição da força de trabalho, como é o caso da introdução de novos padrões de terceirização, subcontratação e precarização do trabalho. 
Para a compreensão dos problemas de saúde e da especificidade das principais ações de vigilância em outros setores econômicos, esse instrumental analítico requer adequações para se ajustar às mais variadas situações vividas por enormes contingentes de trabalhadores. A grande heterogeneidade da área de serviços, por exemplo, desafia nossa capacidade explicativa. Podem-se constatar nessa área algumas características análogas às existentes no processo de trabalho industrial. Porém, existem atributos de alta significância muito próprios do setor em torno da interação entre trabalhadores e clientes/usuários/destinatários/consumidores. Adequações semelhantes cabem também no estudo de outros segmentos que não implicam formalmente o tipo de trabalho assalariado (Minayo-Gomez \& Lacaz, 2005).

Contrariamente aos marcos da saúde ocupacional, em que os trabalhadores são vistos como pacientes ou como objetos da intervenção profissional, na visão da saúde do trabalhador eles constituem-se em sujeitos políticos coletivos, depositários de um saber emanado da experiência e agentes essenciais de ações transformadoras. A incorporação desse saber é decisiva, tanto no âmbito da produção de conhecimentos como no desenvolvimento das práticas de atenção à saúde.

Como campo de intervenção e de práticas na esfera da saúde pública, a saúde do trabalhador tem por base os princípios do SUS que propugnam acesso universal, integralidade da atenção, com ênfase em ações de prevenção e de promoção, descentralização e participação social. É de acordo com essas premissas que a Rede Nacional de Atenção Integral à Saúde do Trabalhador (Renast) tem a responsabilidade pela inserção de ações de saúde do trabalhador na atenção básica e pela implementação de ações de vigilância e promoção em saúde do trabalhador, bem como pela instituição de serviços de saúde do trabalhador de retaguarda, de média e alta complexidades.

Em síntese, o campo da saúde do trabalhador compreende um corpo de práticas teóricas interdisciplinares - técnicas, sociais, políticas, humanas -, multiprofissionais e interinstitucionais no âmbito da saúde coletiva. Diversos atores, situados em lugares sociais distintos e informados por uma perspectiva comum de produção de saúde, desenvolvem ações com vistas à promoção da saúde, sempre no âmbito de atuação das políticas públicas de saúde.

Atualmente, temos de chamar a atenção em nossa área para a relevância da discussão ambiental e incorporá-la de forma integrada na formulação do campo de saúde do trabalhador. Essa necessidade vem sendo sentida e apontada em todas as áreas de conhecimento e intervenção, pois a questão 
ambiental, desde o final dos anos 70, progressivamente passou a ser tratada de forma transversal em todas as áreas científicas, técnicas e de práticas sociais. Em países como o Canadá, o tema vem sendo pensado teoricamente e traduzido em ações concretas, fazendo parte do próprio conceito ampliado de saúde. Tratado com base em abordagens ecossistêmicas, o conceito ampliado de saúde, que sempre englobou questões biológicas e biomédicas, passou a incluir definitivamente a questão social e o ambiente desde o chamado modelo Lalonde (1996).

A perspectiva ecossistêmica que vem se universalizando tem como princípios: 1) compreender os problemas em seu contexto e complexidade, mas atuar localmente; 2) envolver na solução dos problemas todos os atores sociais (população, governantes, gestores, empresários, profissionais, trabalhadores e técnicos); 3) usar a ciência e a tecnologia como estratégia de mudanças; 4) trabalhar com o conceito de participação social e 'fortalecimento' dos sujeitos; 5) contemplar os papéis diferenciados de homens, mulheres, crianças e idosos na construção social da mudança; 6) adotar uma perspectiva inter e transdisciplinar, em que 'fragmentos disciplinares' são acionados e postos em cooperação visando à qualidade de vida e ao ambiente saudável. Ora, todos esses princípios não só condizem com a filosofia da área de saúde do trabalhador como a enriquecem.

Considerando o propósito deste texto, de fornecer subsídios para um debate a fim de aprofundar as premissas básicas que definem o campo de saúde do trabalhador, apresento, a seguir, alguns questionamentos suscitados pelas contradições entre a fundamentação político-ideológica e sua tradução na prática de atuação no mundo do trabalho - o que ocorre no terreno da produção científica e na formulação das políticas públicas em seu escopo, metas e objetivos e nas propostas de ação, bem como no caráter da mobilização, da organização e das propostas do chamado 'controle social'.

\section{A Saúde do Trabalhador É um Campo?}

As premissas que, do ponto de vista teórico, deveriam pautar a produção científica no campo de saúde do trabalhador já estão definidas e, em grande parte, foram sintetizadas anteriormente. Da mesma forma, é consensual considerar que esse tema se insere no amplo espectro de teorias e práticas do campo da saúde coletiva e nos marcos institucionais do SUS, dando-se particular ênfase à participação dos trabalhadores como sujeitos coletivos. 
No entanto, em que sentido podemos afirmar que uma área tem consistência prático-teórica e de atuação dos agentes implicados para conformar um campo? Na concepção clássica de Bourdieu (1996: 50), campo é

um conjunto de forças cujas necessidades se impõem aos agentes que nesse campo se encontram envolvidos; e como uma arena de lutas, no interior da qual os agentes se enfrentam, com meios e fins diferenciados conforme sua posição na estrutura de forças, contribuindo assim para a conservação ou transformação da estrutura.

Portanto, talvez seja indicado, na atual conjuntura, nos referirmos a 'campo de relações saúde-trabalho' e entendermos que dentro dele estaria a saúde do trabalhador como proposta da saúde coletiva. Esse campo seria composto por um coletivo desigual, estruturalmente determinado por conflitos e embates de concepções e práticas condicionadas pelos recursos que agentes e instituições possuem (Bourdieu, 1996). Nele estariam também a medicina do trabalho e todas as abordagens que, em sentido amplo, contemplam a saúde ocupacional, e a abordagem de saúde do trabalhador faria a superação dialética das duas outras formas de pensamento e de práticas, algumas vezes rompendo com os modelos anteriores, e outras vezes contendo-os e ultrapassando-os. Expressão dos embates desse campo mais amplo seriam as tensões dos agentes da área de saúde do trabalhador com as corporações profissionais da medicina do trabalho e da engenharia de segurança, assim como seus conflitos com setores do trabalho e da previdência social. Esses embates, na prática, ocorrem principalmente nas ações de vigilância a partir do SUS.

Continuando a pensar dentro dos marcos concebidos por Bourdieu, campo se configura como uma construção coletiva e cria habitus. Esses 'hábitos', construídos como um conjunto socializado de práticas e de práticas teóricas, se transformam em um corpo estruturante e estruturado, composto por disposições adquiridas, individual e coletivamente. Sua internalização ocorre por meio de esquemas mentais e corporais que influenciam as percepções, a compreensão das coisas e as ações.

Nesse sentido, cabe perguntar até que ponto conseguimos criar um habitus, ou seja, um grau de coesão teórica e de práxis em saúde do trabalhador na formulação e implementação de políticas, nas ações de vigilância, na produção de conhecimentos, na visão teórica, nas demandas da prática, nas propostas de transformação e de luta e no controle social exercido por coletivos de trabalhadores. Poderíamos, por exemplo, afirmar hoje que profissionais, 
pesquisadores e trabalhadores que atuam na chamada área de saúde do trabalhador compartilham um mesmo paradigma - definido pelo próprio Kuhn (1978) como os princípios teóricos e conceituais com que os membros de uma mesma área estão de acordo - a ponto de formar uma comunidade de pessoas com um mesmo estilo de trabalho? Será que todos aderimos a um estilo de trabalho consensualizado e mais eficiente de praticar ciência em nossa área e de resolver problemas concretos? Será que, quando verbalizamos que o nosso é um campo 'em construção', não queremos dizer que estamos pouco institucionalizados, com limitado acordo entre os pares (pesquisadores, gestores e profissionais de saúde e trabalhadores) sobre conceitos e categorias estruturantes, com peculiares fragilidades metodológicas e pouca repercussão em relação às demandas relevantes da saúde dos trabalhadores?

Proponho que reflitamos sobre algumas conquistas que hoje podemos celebrar, mas também sobre as sérias limitações que dificultam nossa comunicação como cientistas e com o nosso espaço de práticas:

1) Do ponto de vista acadêmico, existe uma vasta e crescente produção científica sobre temas próprios da relação trabalho-saúde desenvolvida por pesquisadores de diversas áreas do conhecimento e de variadas instituições universitárias, mas que também inclui profissionais que atuam nos serviços. Essa pluralidade de estudos e investigações tem um indiscutível valor, pois trouxe e traz conhecimentos importantes que podem ser apropriados para a atuação nas práticas de prevenção, de promoção e de atendimento nos serviços. No entanto, nesse mesmo assunto, algumas lacunas precisam ser assinaladas:

- em muitas produções científicas, existe uma falta de precisão conceitual sobre o caráter da associação entre o trabalho e o processo saúde-doença;

- em grande parte delas, são abordadas questões pontuais e unidisciplinares, ou os objetos de estudo são fundados em premissas que apenas tangenciam a concepção de saúde do trabalhador;

- boa parte dos estudos tem caráter fundamentalmente descritivo e trata os trabalhadores apenas como objetos de pesquisa ou se restringem a análises fenomenológicas ou tecnicistas;

- muitos trabalhos acadêmicos estão comprometidos pela repetição de discursos de conotação ideológica que encobrem contradições e conflitos conceituais e metodológicos e apresentam sínteses simplificadoras, 
perdendo a riqueza de aportes que a articulação entre a teoria e a prática poderia trazer.

2) Do ângulo da saúde pública, a área de saúde do trabalhador no espaço institucional do SUS vem apresentando um contínuo crescimento nos últimos anos, particularmente no nível assistencial, chegando com grande capilaridade a todos os estados, embora com diferenças regionais. As grandes diretrizes da política nacional e marcos regulatórios de suas atribuições foram estabelecidos. Porém, inexiste um diagnóstico de base sobre a situação de saúde dos trabalhadores brasileiros que possa fundamentar planos de ação viáveis e de acordo com o quadro real de necessidades. Certamente, dada a complexidade da atual conjuntura, qualquer análise dos agravos à saúde dos trabalhadores será parcial e incompleta. Mas seria preciso enfatizar o imenso contingente socialmente desprotegido, no qual trabalhadores do setor terciário da economia assumem lugar qualitativa e quantitativamente preponderante.

3) Falta-nos construir políticas integradas, intersetoriais e capazes de orientar linhas de ação e formas de implementação.

4) Existem poucas avaliações efetivas e adequadas das ações, tendo em vista as necessidades reais da saúde dos trabalhadores.

5) Sempre houve um entrosamento bastante razoável entre formuladores de políticas, gestores, profissionais de saúde, representantes dos trabalhadores e pesquisadores na área de saúde do trabalhador. Porém, faltam rumos e demanda qualificada por parte dos responsáveis pelas políticas e gestores. Desses últimos, seria importante exigir a efetivação de um processo de indução que incite as universidades e, principalmente, suas pós-graduações a darem uma contribuição mais articulada e efetiva e a trabalharem em rede ou de forma interinstitucional, em uma perspectiva propositiva e eficaz para os trabalhadores.

6) Continua faltando, também no plano governamental, uma consciência clara da situação da classe trabalhadora que redunde em decisão conjunta por parte dos ministérios da Saúde, do Trabalho e da Previdência Social, com a parceria do Ministério de Ciência e Tecnologia, por meio de suas agências de fomento, de abertura de editais visando a impulsionar censos específicos, pesquisas contextualizadas e interdisciplinares e estudos de problemas cruciais ainda pouco abordados. Frequentemente são apontadas 
as necessidades, e nesse sentido procede afirmar que a incapacidade da saúde pública de resolver muitos problemas não é fruto da incapacidade de revelá-los, e sim da pouca vontade política de escrutiná-los e tratá-los (Vasconcellos \& Pignati, 2006).

Por todos os pontos aqui relacionados, considero que, em nossa área, a produção dos saberes e práticas ainda está bastante fragmentada, carente de fundamentos consensualizados e articulados com a realidade dos trabalhadores. Frequentemente, os marcos teóricos dos estudos flutuam entre os princípios da saúde coletiva e as práticas da medicina do trabalho e da saúde ocupacional. Não há uma verdadeira comunidade teórico-prática, com conceitos, categorias e planos de ação acordados, trabalhando com um único paradigma.

É claro que os problemas da área não se limitam apenas ao campo acadêmico ou de gestão. Esses dois aspectos são apenas parte de uma grande fragilidade política dos atores que deveriam ser os pilares das demandas e das proposições: os trabalhadores organizados como sujeitos coletivos impulsionadores das políticas nos seus diversos níveis. Os motivos para essa situação são muitos, mas destacamos que a nova configuração do mundo do trabalho não facilita a participação.

No sentido de fragilização do movimento dos trabalhadores, é importante assinalar que o chamado 'controle social' passou a ocorrer muito mais nas ações institucionais, tanto do Estado como das empresas, do que no protagonismo de ação e na definição de frentes de atuação. No caso do setor saúde, o controle sobre ações institucionais vem tomando o tempo e as energias do movimento dos trabalhadores que, no início da construção do SUS, era proativo e propositivo. Portanto, ao mesmo tempo que constatamos a presença legitimada da representação dos trabalhadores nos conselhos de saúde, nas comissões interinstitucionais de saúde do trabalhador e nos conselhos gestores, avaliamos que sua participação fica bastante diluída. $O$ peso que essas instâncias conferem às negociações tripartites acaba por valorizar mais a forma do que a importância dos processos que estão em jogo, e assim o papel dos trabalhadores fica subsumido às funções dos técnicos de saúde. Eu diria, para provocar, que há um excesso de 'tripartitismo', reduzida participação e excesso de 'participacionismo'.

Assim, com base nos tópicos abordados aqui, ainda continuo pensando que a saúde do trabalhador "é uma meta, um horizonte, uma vontade que entrelaça trabalhadores, profissionais de serviços, técnicos e pesquisadores 
sob premissas nem sempre explicitadas e consensualizadas" (Minayo-Gomez \& Thedim-Costa, 1997: 24).

No caso da participação da área acadêmica nas transformações em favor da saúde do trabalhador, faltam propósitos implícitos ou explícitos para que os produtos do conhecimento científico produzam consequências benéficas e constituam subsídios para a elaboração de políticas públicas. Se saúde do trabalhador é um campo aberto e em construção - e eu creio que assim seja -, precisamos investir o melhor de nós mesmos no aprofundamento teórico, no encontro de todos os atores e em planos de ação que promovam maior consenso - o que permitirá que nossa construção avance e seja sólida.

\section{REFERÊNCIAS}

BOURDIEU, P. Razões Práticas: sobre a teoria da ação. Campinas: Papirus, 1996.

COSTA, D. F. et al. Programa de Saúde dos Trabalhadores: a experiência da Zona Norte uma alternativa em saúde pública. São Paulo: Hucitec, 1989.

DIAS, E. C. A Atenção à Saúde dos Trabalhadores no Setor Saúde (SUS) no Brasil: realidade, fantasia ou utopia, 1994. Tese de Doutorado, Campinas: Faculdade de Ciências Médicas, Universidade Estadual de Campinas.

KHUN, T. S. A Estrutura das Revoluções Científicas. 2. ed. São Paulo: Perspectiva, 1978.

LACAZ, F. A. C. Saúde do Trabalhador: um estudo sobre as formações discursivas da academia, dos serviços e do movimento sindical, 1996. Tese de Doutorado, Campinas: Faculdade de Ciências Médicas, Universidade Estadual de Campinas.

LACAZ, F. A. C. O campo saúde do trabalhador: resgatando conhecimentos e práticas sobre as relações trabalho-saúde. Cadernos de Saúde Pública, 23(4): 757-766, 2007.

LALONDE, M. El concepto de campo de salud: una perspectiva canadiense. In: OPAS (Organización Panamericana de la Salud). Promoción de la Salud: una antología. Washington, D. C.: Opas, 1996. (Publicación científica n. 537)

LAURELL, A. C. \& NORIEGA, M. Processo de Produção e Saúde: o desgaste operário. São Paulo: Hucitec, 1989.

MARX, K. O Capital. Livro I, capítulo VI (inédito). São Paulo: Ciências Humanas, 1978.

MENDES, R. \& DIAS, E. C. Da medicina do trabalho à saúde do trabalhador. Revista de Saúde Pública, 25: 341-349, 1991.

MINAYO-GOMEZ, C. \& THEDIM-COSTA, S. M. F. A construção do campo da saúde do trabalhador: percurso e dilemas. Cadernos de Saúde Pública, 13(supl. 2): 21-32, 1997.

PIMENTA, A. L. \& CAPISTRANO FILHO, D. Saúde do Trabalhador. São Paulo: Hucitec, 1988. 
VASCONCELLOS, L. C. F. Saúde, Trabalho e Desenvolvimento Sustentável: apontamentos para uma política de Estado, 2007. Tese de Doutorado, Rio de Janeiro: Escola Nacional de Saúde Pública Sergio Arouca, Fundação Oswaldo Cruz.

VASCONCELLOS, L. C. F. \& PIGNATI, W. A. Medicina do trabalho: subciência ou subserviência? Uma abordagem epistemológica. Ciência E Saúde Coletiva, 11(4): 1.105-1.115, 2006. 


\section{Parte I}

\section{Politicas e Estratégias de Vigilância e Prevenção}





\section{Politica Nacional de Saúde do Trabalhador: AMPLIAÇÃO DO OBJETO EM DIREÇ̃̃O A UMA POĹIIICA DE ESTADO}

Luiz Carlos Fadel de Vasconcellos Jorge Mesquita Huet Machado

Desde que o campo da saúde do trabalhador foi inscrito no sistema de saúde brasileiro, do ponto de vista ideológico e normativo como atribuição de saúde pública, o Estado brasileiro vem sendo chamado a uma responsabilidade de traçar políticas para a área. A partir do marco temporal de 1990, ano em que as leis orgânicas da saúde foram promulgadas, ocorreram muitas iniciativas no sentido de traçar uma política nacional, cujos resultados foram insuficientes como plano de ação consistente do Estado brasileiro. Pouco se fez na direção da intersetorialidade, praticamente não se constituiu uma vigilância sanitária dos processos de trabalho e persistem as inconsistências das informações.

Mesmo tendo-se um razoável diagnóstico dos obstáculos para a implementação da política, as soluções propostas vêm trilhando caminhos erráticos e periféricos, e nenhuma delas é priorizada na agenda de projetos para o país.

O campo da saúde do trabalhador foi acolhido parcialmente pela saúde pública e vive um permanente desafio para o seu desenvolvimento técnicooperacional por dentro das práticas de saúde em geral. $\mathrm{O}$ fato se observa na questão assistencial, em todos os níveis da atenção, na formação e educação permanente dos profissionais de saúde, na questão das vigilâncias e no tratamento das informações, nos debates intergestores e da gestão participativa, enfim, na condução de políticas locais e programáticas.

Um dos principais dilemas na configuração de uma política nacional é o enfrentamento da blindagem política, reproduzida pelo sistema de saúde brasileiro, no sentido de não considerar a centralidade da categoria trabalho nos determinantes sociais dos agravos da população em geral. 
Nesse contexto, o campo de produção de conhecimentos em saúde tem uma responsabilidade compartida, pelo desafio mal enfrentado de dar relevância à categoria trabalho como central em saúde pública, considerando que a maior parte da produção acadêmica sobre saúde do trabalhador tem um foco predominante na análise de enfermidades relacionadas ao trabalho (Mendes, 2003; Minayo-Gomez \& Thedim-Costa, 2003; Freitas, 2005; Santana, 2006), e não na chamada enfática ao trabalho como determinante social relevante.

A par de uma explícita marginalidade no tocante à formulação das políticas públicas, a área de saúde do trabalhador se perpetua numa "equívoca fragmentação da área, intra e extrassetorialmente ao setor saúde, propriamente dito. Cultura de fragmentos, pois bem" (Vasconcellos, 2007: 18).

A trajetória tateante de constituição dessa política propiciou a conjugação de forças sociais e institucionais que, em algumas ocasiões, provocaram o Estado para uma definição política e um posicionamento mais claro e mais resolutivo em relação à área, sempre buscando o horizonte de uma Política Nacional de Saúde do Trabalhador (PNST) no âmbito do Sistema Único de Saúde (SUS). Foi o caso da 2a Conferência Nacional de Saúde do Trabalhador (CNST), ocorrida em março de 1994, com o tema incisivo: "Construindo uma política de saúde do trabalhador”. O momento da 2a CNST foi o clímax de uma grande mobilização de representantes institucionais e sindicais, no esforço suprassetorial de consolidar e provocar o desencadeamento de ações concretas no âmbito do SUS. Mas continuou faltando a definição de uma política mais determinante (Vasconcellos, 2007).

$\mathrm{Na} 3{ }^{a}$ CNST, realizada em novembro de 2005, mais uma vez o temário do evento reportou-se à estruturação de uma política de Estado, já agora apontando para sua incorporação nas questões do desenvolvimento sustentável, condizente com os rumos das políticas globalizantes. Todavia, suas recomendações continuam sem receber acolhida no próprio Ministério da Saúde como pauta de sua agenda política. Novamente, reitera-se a marginalização do campo e o seu não reconhecimento como eixo estruturador de políticas de saúde no contexto dos processos produtivos e do desenvolvimento.

O desafio de se refletir sobre a formulação de uma PNST, compreendida a necessidade de se analisarem carências, avanços e tendências, metodologicamente deverá bem localizar o ponto de concepção do qual se parte. Nesse sentido, observamos a necessidade de se resgatar um conceito ideológico e político da saúde do trabalhador, perdido em uma confusa malha de marcos conceituais, em que persistem, de um lado, visões técnico e medicocêntricas; 
de outro, resistências corporativas e institucionais ao ingresso do trabalhador como sujeito da construção do campo.

Para ser conceitualmente fiel ao ideário contra-hegemônico da saúde do trabalhador, não há lugar, sequer aproximado, para uma política nacional que se diga de saúde do trabalhador sem a confluência de duas construções que se complementam: uma, a de uma nova forma de construir a política pública com o trabalhador-objeto da política como sujeito da construção e não como reivindicante ou acompanhante dela; e outra, a de uma nova forma de produzir conhecimentos, especialmente na academia, na mesma linha de consideração do trabalhador-sujeito. As tentativas brasileiras nesse sentido são tímidas e incipientes.

Conceitos perdidos, tanto o do próprio campo da saúde do trabalhador em sua origem político-ideológica, quanto o de sua abrangência em direção ao ambiente externo aos sistemas de trabalho stricto sensu, são razões da crise de paradigma no estado da arte e no estado de suas práticas. Recuperar conceitos é ponto de partida para a política.

Em sua origem na Itália dos anos 60 , a saúde do trabalhador pressupunha no caminho da política "o processo saúde-doença como emergente estrutural das condições de trabalho e das condições sociais gerais vinculadas ao trabalho"; "a incapacidade teórica do modelo médico de analisar a problemática da saúde dos trabalhadores"; e que "a solução mais significativa para a crise da saúde é dada pelo movimento operário que reivindica a unidade de ação e luta em torno da relação política e saúde” (Basaglia et al., 1980: 14, 16, 28). Berlinguer (1983: 22-23) complementa:

Com relação às atividades dos poderes locais, passou-se da inércia frente à saúde operária (...) aos inquéritos conduzidos com a participação dos trabalhadores e dos especialistas, à criação de serviços municipais e provinciais de medicina preventiva, às propostas de leis regionais (...) para tornar mais eficazes as intervenções sanitárias nos lugares de trabalho. (...) propôs-se um modelo de proteção sanitária experimentado nas fábricas, com sua carga viva de participação popular, como ponto de referência para a regulação total da relação homem-ambiente e para a administração dos serviços sanitários.

O mesmo Berlinguer revela a face paradigmática da saúde do trabalhador, chamando a atenção para algumas inter-relações entre ciência e trabalho e homem-ambiente que estão ainda ausentes no debate e na construção teórica do desenvolvimento sustentável. 
Creio que se os nossos filósofos (...) estivessem mais atentos à evolução da relação entre capital e trabalho, entre ciência e sociedade (...) poderiam ser retiradas das lutas pela saúde conduzidas na Itália, nesses anos, algumas indicações interpretativas de valor internacional para argumentos antigos que hoje suscitam debates apaixonados: a democracia como participação de massa; a relação ciência-trabalho e ciência-poder; os valores humanos na tecnologia moderna; a relação homem-ambiente. (Berlinguer, 1983: 23-24)

Assim, o paradigma da saúde do trabalhador, como campo técnico e político de mudança das relações entre saúde e trabalho, recupera-se na produção de conhecimentos vinculados ao espectro da saúde pública, em uma profunda revisão do modelo médico tradicional e na ruptura com a hegemonia médica na condução de suas práticas. Significa subordinar, na PNST, a saúde ocupacional - incluídas a medicina do trabalho e a engenharia de segurança -, a ela reservando a regulação técnica e normativa do contrato de trabalho estabelecido entre patrões e empregados.

A saúde do trabalhador transcende o direito trabalhista, previdenciário e os demais direitos limitantes por efeitos específicos de contratos. (...) invoca o direito à saúde no seu espectro irrestrito da cidadania plena, típica dos direitos civis, econômicos, sociais e humanos fundamentais, a que os demais "direitos" estão subordinados. (...) arvora a si, desse modo, a égide sobre as relações saúde-trabalho no Estado democrático de direito. (Vasconcellos, 2007: 162)

Nesse contexto, é construído o campo da saúde do trabalhador na vinculação permanente entre ação de saúde e ação política, com os trabalhadores como sujeitos e protagonistas da ação político-institucional, inclusive na construção de conhecimentos e dos instrumentos de intervenção. E, por fim, o conceito de saúde do trabalhador se reencontra na sua ampliação em direção ao cenário do desenvolvimento sustentável, cuja base estrutural para a concretização da política tem como palco o SUS, em uma perspectiva efetivamente sistêmica que vai além do setor saúde.

\section{SUS como Palco Sistêmico de uma PNST}

A possibilidade de efetivação de uma PNST depende, essencialmente, de uma profunda revisão do significado político-estrutural do SUS como instância articuladora e sistêmica do aparelho de Estado brasileiro no interesse da saúde.

A percepção objetiva e subjetiva do sistema de saúde, pautada na mídia, determinada pelo campo político e jurídico e fortemente enraizada no imaginário 
simbólico da população, como um conjunto de serviços de saúde capazes de tão somente resolver os problemas assistenciais da doença, concorre para a manutenção de um comportamento político-institucional não sistêmico do SUS.

Entendemos que a uma concepção sistêmica do SUS agregam-se categorias subjacentes que lhe dão movimento: inter e transdisciplinaridade, intra e intersetorialidade, transversalidade e transposição de limites com a transposição da gestão do sistema. Ou seja, no caminho de construção de uma PNST, o SUS deve ir além da intersetorialidade, transetorializando, transpondo os limites que impedem a criação de novos objetos estruturais para a implementação da política. Pode-se compreender transetorializar no sentido de se estar ao mesmo tempo entre, através e além dos setores e das disciplinas (Nicolescu, 1997, 1998).

Para tentar resolver os problemas que apresentam a interdisciplinaridade como processo de recomposição do saber fracionado, postula-se a 'transdisciplina' como a solução final: um conhecimento holístico e integrador, sem falhas nem vazios; um conhecimento reunificador que transcende o propósito de estabelecer pontes interdisciplinares entre ilhotas científicas isoladas (Leff, 2000).

Utilizando o conceito de transdisciplinaridade, pensar o SUS em uma perspectiva transetorial significa romper com a cultura reducionista de cada setor isoladamente na formulação e implementação de seus objetos. Significa reorganizar o aparelho de Estado e colocá-lo permeável à saúde nos objetos de interesse da política pública, com capacidade de introjetar suas estruturas nas respostas executivas em que haja afinidades e identidades comuns. Significa também romper com a cultura de fragmentos que, nos primórdios da construção do SUS, originou o princípio regente do sistema: a unicidade.

Em síntese, uma política de Estado centrada nas relações saúde-trabalho, cuja extensão natural de sua operacionalização recai na dimensão dos processos produtivos, do desenvolvimento e de sua sustentabilidade, implica a transversalidade da categoria trabalho, a transetorialidade articulando estruturas do Estado e a necessária transposição dos limites da gestão do SUS, em direção a uma transição para o 'trans'.

A perspectiva de transição para o 'trans', especialmente no caso da transetorialidade, com base na transposição da gestão, implica a compreensão de que as políticas, os planos e as ações decorrentes da saúde como estrutura sistêmica do Estado tornem-se capazes de serem introjetados em todas as esferas de decisão das políticas, com a condução (ao menos compartilhada) do SUS e utilizando a capilaridade estrutural do sistema como instâncias efetoras. Em 
última instância, a transição para o 'trans' culmina com a transformação do SUS em sistema (Vasconcellos, 2007).

Desse modo, não há como se pensar uma PNST sem ampliar o olhar sobre o horizonte das relações saúde-trabalho e sem ter como esteio da sua operacionalização um SUS efetivamente sistêmico, interferindo nas múltiplas faces das políticas públicas de interesse da saúde. "Uma Política Nacional de Saúde que quer ser eficiente e eficaz deve partir de uma concepção ampla da questão saúde que permita o redimensionamento das políticas e ações específicas nos diferentes âmbitos do poder em que se fizer necessário” (Tambellini, 1988: 8).

O SUS como ponto de partida para redirecionar o modelo de atenção à saúde em sua relação com o trabalho, a produção, o consumo, o meio ambiente e o desenvolvimento pauta-se na sua missão político-estrutural de dar resposta às grandes questões de saúde do país, especialmente por essa vocação sistêmica não implementada. Os pressupostos da unicidade e da integralidade não foram efetivamente incorporados.

A constituição da Comissão Nacional sobre Determinantes Sociais da Saúde, por decreto presidencial de 13 de março de 2006 (Brasil, 2007), ao reconhecer o que a Constituição Federal já assinalava, em termos de garantia da saúde "mediante políticas sociais e econômicas", 1 e o que a Lei Orgânica da Saúde, desde 1990, considerava como fatores condicionantes e determinantes da saúde, ${ }^{2}$ é uma primeira aproximação com a vocação sistêmica do SUS, na direção de buscar políticas transetoriais.

Entretanto, é curioso que o decreto que cria a comissão e estabelece seus objetivos não faça qualquer menção ao SUS, ao seu papel no desenrolar da política e à sua responsabilidade de disponibilizar estruturas e ações nesse processo. A expressão 'Sistema Único de Saúde' sequer é mencionada no ato presidencial.

Parece haver uma crise de identidade do SUS, velada e intocada, no que diz respeito ao seu papel contra-hegemônico ao modelo hospitalocêntrico, e que foi um de seus pilares de formulação.

1 "Art. 196. A saúde é direito de todos e dever do Estado, garantido mediante políticas sociais e econômicas que visem à redução do risco de doença e de outros agravos e ao acesso universal e igualitário às ações e serviços para sua promoção, proteção e recuperação" (Brasil, 1988).

2 "Art. 3․ A saúde tem como fatores determinantes e condicionantes, entre outros, a alimentação, a moradia, o saneamento básico, o meio ambiente, o trabalho, a renda, a educação, o transporte, o lazer e o acesso aos bens e serviços essenciais; os níveis de saúde da população expressam a organização social e econômica do País.

Parágrafo único. Dizem respeito também à saúde as ações que, por força do disposto no artigo anterior, se destinam a garantir às pessoas e à coletividade condições de bem-estar físico, mental e social" (Brasil, 1990). 
Um emblema do que seria essa crise de identidade do SUS como sistema agregador de políticas públicas no interesse da saúde é dado pela análise de uma de suas missões: "Art. 16. À direção nacional do Sistema Único da Saúde (SUS) compete: I - formular, avaliar e apoiar políticas de alimentação e nutrição", com base na atribuição de atuar na vigilância nutricional e na orientação alimentar (Brasil, 1990).

A despeito dessa 'antiga' formulação, ao SUS não coube o protagonismo do que é o carro-chefe das políticas sociais do governo brasileiro: o Programa Fome Zero, cujo caráter intersetorial da política, envolvendo diversas estruturas do aparelho de Estado, confirma a marginalização do sistema de saúde como estrutura sistêmica.

É evidente que a complexidade de uma política de combate à fome, com base na compensação econômica, exige o envolvimento de grande parte das estruturas do Estado, ultrapassando os limites de cada uma delas, isoladamente. O que é incompreensível é a destituição do SUS como parte essencial na condução de uma política social, fundamentalmente com foco na saúde (Vasconcellos, 2007).

Outros empreendimentos com a estatura de política de Estado podem ser invocados para ilustrar a marginalização do SUS e o não reconhecimento de sua capacidade estrutural sistêmica. A Política Nacional de Ordenamento Territorial, que agrega centenas de planos e programas de governo em territórios distintos, ordenados de forma sistêmica para melhor articular as diversas políticas setoriais, reserva ao SUS tão somente a disponibilização de hospitais, especialmente filantrópicos (Brasil, 2006a). E mais recentemente, no Programa de Aceleração do Crescimento - PAC (Brasil, 2007), cujos megainvestimentos, especialmente em infraestrutura, serão aplicados em numerosas regiões do território nacional, pode-se antever a nula participação do SUS no programa. Em nenhum dos documentos oficiais sobre o programa observa-se algum cuidado com o planejamento de saúde de cada um dos territórios - o impacto epidemiológico, as cargas migratórias, a capacidade de se atender a novas demandas, a construção de indicadores, o monitoramento do processo e a busca por um melhor padrão de saúde da população, concomitantemente ao crescimento planejado.

Estamos, assim, diante de um grande desafio no sentido de pautar o SUS na agenda do governo, não só para reconduzir o sistema à sua aspiração original de aparelho do Estado brasileiro a fim de mudar a face sanitária do país, como também para colocar sua capilaridade estrutural à disposição das grandes mudanças necessárias na ordem social. 
Nesse contexto, uma PNST com capacidade para determinar rumos distintos ao campo não se viabiliza sem uma profunda revisão do papel do SUS, cujo modelo de foco assistencial na saúde do trabalhador afasta-se do centro nervoso em que se produzem os agravos à saúde.

\section{Desenho da Atual Politica: estrutura e processo}

A par de várias iniciativas no campo da saúde do trabalhador, ao longo do período em que a lei n. 8.080/90 está em vigor, poucas são as inovações que possam indicar mudanças substanciais da PNST. Mantêm-se como características: a formulação normativa pluri-institucional e desarticulada; a execução de ações também pluri-institucionais e desarticuladas; a exclusão de grandes contingentes de trabalhadores do alcance da política tradicional; a manutenção de informações oficiais sem caráter epidemiológico; a formação de quadros com base no recorte medicocêntrico; e, entre outras variáveis, a manutenção do sujeito trabalhador como corpo-objeto.

Além disso, as tímidas tentativas de entrada do SUS no campo das relações saúde-trabalho como instância responsável e agregadora, ao não ostentar de forma incisiva a chancela de uma política de saúde pública do Estado brasileiro, acrescentaram questões que mais ocasionaram problemas para a sua implementação do que solucionaram antigos problemas. Por exemplo, agregaram-se situações de conflito na esfera da vigilância em saúde do trabalhador, especialmente com o Ministério do Trabalho, em decorrência de vários fatores, mas principalmente pela omissão da Agência Nacional de Vigilância Sanitária (Anvisa), a que os gestores do SUS se reportam para justificar sua não operacionalização. Aprofundaram-se, ainda, os nichos de saúde do trabalhador, com a implementação da Rede Nacional de Atenção Integral à Saúde do Trabalhador (Renast), ${ }^{3}$ cuja esperada intenção de dar organicidade à área no SUS vai desvirtuando seu rumo e mantendo o campo na marginalidade institucional, como conjunto de polos assistenciais paralelos à rede instalada.

3 Instituída pela portaria do Ministério da Saúde n. 1.679, de 19 de setembro de 2002, a Renast articula os três níveis de gestão: o Ministério da Saúde, a Secretaria de Saúde dos estados e do Distrito Federal e a Secretaria de Saúde dos municípios. Segundo o próprio Ministério da Saúde, a Renast deve ser compreendida como uma ferramenta estratégica no sentido da construção, no âmbito do SUS, de uma efetiva política de Estado na área do atendimento à saúde do trabalhador. A Renast financia a criação e/ou o incentivo dos Centros de Referência em Saúde do Trabalhador, definidos como polos irradiadores, em uma determinada região, da cultura da saúde do trabalhador, assumindo a função de suporte técnico e científico junto aos profissionais de todos os serviços da rede do SUS, orientando-os nas suas práticas de atenção. 
Essas consequências, entre outras, subsistem pela continuidade de uma estrutura xifópaga com duas vertentes de condução da política nacional, que correm paralelas: "uma contratual-previdenciária, já consolidada, de forte caráter normativo fiscal e reparador financeiro dos danos; e uma epidemiológicosanitária, em fase de construção, de forte caráter universalista e vinculada ao controle social" (Vasconcellos, 2007: 96).

Embora tenham ocorrido alguns avanços no campo da saúde do trabalhador, especialmente no da produção de conhecimentos, a rigor não se superou a fragmentação estrutural que tantos têm noticiado há anos (Oliveira \& Vasconcellos, 1992; Brasil, 1993; Dias, 1994; Minayo-Gomez \& Thedim-Costa, 1997; Silva et al., 2001; Corrêa et al., 2004; CUT, 2002).

O nível de articulação entre as estruturas do aparelho de Estado - Coordenação Geral de Saúde do Trabalhador (CGSAT)/Ministério da Saúde; Centro de Estudos de Saúde do Trabalhador e Ecologia Humana/Escola Nacional de Saúde Pública Sergio Arouca/Fundação Oswaldo Cruz (Cesteh/Ensp/Fiocruz); Superintendências Regionais de Trabalho e Emprego (SRTE); Fundação Jorge Duprat de Figueiredo de Segurança e Medicina do Trabalho (Fundacentro); Instituto Nacional do Seguro Social (INSS); universidades; Rede Nacional de Atenção Integral à Saúde do Trabalhador/Centro de Referência em Saúde do Trabalhador (Renast/Cerest) - é baixíssimo, inexistindo na maioria dos casos. Atribuições superpõem-se, dispersam-se recursos e somam-se as omissões.

Essa estruturação reflete o quanto o Estado brasileiro, no nível da macropolítica, deixou 'correr solto' o enigma da saúde do trabalhador. Algo deixou de ser feito. Seriam tantas as razões:

Não podemos transformar a Saúde do Trabalhador em guetos (...) via Centros de Referência em Saúde do Trabalhador (...). O nosso desafio é que cada trabalhador de saúde, cada serviço de saúde nas suas ações faça Saúde do Trabalhador e se tenha Unidades realmente de referência nas áreas de assistência e vigilância, de apoio e diagnóstico e de capacitação de recursos humanos. (Jaeger, 2001: 7)

E, ainda, é importante lembrar que:

apesar de (...) experiências inovadoras, a área ainda não logrou atingir de fato a integralidade da atenção. E aqui inicia o primeiro nó crítico, que considero fundamental, que é a questão do modelo assistencial. Tal modelo foi construído, principalmente, centrado na criação e funcionamento de centros de referência, ou unidades de referência, que tornaram-se quase "ilhas autônomas", marginais ao restante do sistema (...) não consideram 
ainda o trabalho como um determinante do processo saúde-doença. (Nobre, 2001: 105-106)

As bancadas de trabalhadores dentro dos conselhos estão discutindo uma série de coisas fundamentais e indispensáveis em política de saúde e estratégia de saúde. Mas as políticas específicas de saúde do trabalhador precisam ser um pouco tiradas a saca-rolha, ainda. (Santos, 2001: 83)

Uma das dificuldades de se decifrar o enigma da saúde do trabalhador deve-se à complexidade da área e à natureza transdisciplinar do seu objeto, configurando o que Machado (2004) assinala como uma "crise no campo dos saberes".

Do lado acadêmico, a perplexidade é visível pela falta de uma base conceitual que harmonize as ações transversais, sendo este um dos elementos fundamentais para a superação da crise de perplexidade institucional, de formulação, de resistência e de representatividade. A formulação interdisciplinar, resultante do entendimento da saúde do trabalhador por vários atores sociais, não tem dado conta desse conflito. A construção conceitual da área vem se pautando por hierarquizações que não correspondem aos papéis possíveis de serem desempenhados pelas instituições isoladamente (Machado, 2004).

A rigor, nossa avaliação é de que a estruturação da área, no período SUS, não foi consentida como a política de saúde inovadora que a Reforma Sanitária idealizava. Todos os avanços no processo de constituição da área, por dentro do sistema de saúde, consignaram-se de modo um tanto errático, elaborados entre o terceiro e o quarto escalões da gestão do sistema. Colocando seus abnegados técnicos - profissionais de saúde - e representantes do controle social, defensores de uma política mais proativa, em uma posição de luta permanente contra o descaso com a área, a saúde do trabalhador no SUS segue como um processo de construção de desfecho pouco alvissareiro.

A Renast ruma, cada vez mais, por caminhos assistenciais (Andrade \& Kassawara, 2004; Brasil, 2006b), confirmando temores quanto à sua estruturação original e configurando uma política programática focal de baixo alcance (Vasconcellos, 2007).

Em relação ao processo de vigilância em saúde do trabalhador (Visat), os avanços, ao longo dos últimos anos, tais como o controle da silicose na construção naval (Miranda, 1997) e o controle da exposição ao benzeno (Machado et al., 2003), ainda constituem soluções direcionadas para problemas pontuais. De certo modo, revelam a incapacidade da vigilância em saúde do trabalhador 
de olhar globalmente para os processos produtivos. Na maioria das vezes, a solução de problemas da relação saúde-trabalho, embora legítima e necessária, origina-se casualmente no encontro entre a demanda e a oportunidade, por mecanismos que não se configuram em políticas mais perenes. Seja por interesse pessoal do pesquisador-interventor sobre um determinado tema; pela direcionalidade de pesquisas-intervenção pelos aparelhos formadores, em razão de interesses acadêmicos e/ou facilitadores das agências de financiamento; por demandas trazidas por trabalhadores mais organizados e com maior capacidade de reivindicação, participação e luta; por menor potencial de geração de conflitos para chegar às soluções direcionadas; pela presença nos serviços de vigilância de profissionais 'especialistas' em determinados temas; por situações de emergência para determinados agravos com maior visibilidade epidemiológica e/ou social; ou ainda pela facilidade de intervenção em setores historicamente mais permeáveis a eventuais mudanças (Vasconcellos, 2007), as iniciativas têm baixa reprodutibilidade, baixa difusão e dificuldade de abrangência. A ausência de uma PNST é sua sentença.

é perceptível um intenso crescimento da área (...). Porém, quando comparada com as práticas de assistência ainda é possível considerar a vigilância como uma prática incipiente, que vem ocupando um espaço periférico e mal definido dentro dos modelos de atenção à saúde no Brasil. (Ribeiro et al., 2001: 130)

Sem desmerecer o avanço sobre o controle de algumas enfermidades relacionadas ao trabalho, a desvinculação de uma vigilância em saúde, na linha de uma efetiva política de Estado, impede que ocorram transformações mais perenes do processo saúde-trabalho-doença.

a implementação desta prática articulada ainda é emergente. (...) O cotidiano das práticas de fiscalização, salvo ações isoladas, ainda reproduz o modelo centralizador, punitivo e isolado do Ministério do Trabalho (...). A grande maioria dos Serviços de Saúde do Trabalhador ainda não viabiliza a prática interdisciplinar, pluriinstitucional e articulada com o controle social (...). A Vigilância em Saúde do Trabalhador se insere nas práticas de um Estado que pode ser modificado a qualquer momento pela sociedade, dependendo da correlação de forças entre o capital e o trabalho. (Ribeiro et al., 2001: 130-132)

São muitos os nós críticos para a implementação da Visat no Brasil. Pesquisa realizada no início desta década constatou: necessidade de treinamento e capacitação; carência de recursos materiais; problemas na definição 
de fluxos e de indicadores de avaliação de impacto das ações; necessidade de integração dos níveis de gestão do SUS; necessidade de legislação municipal pertinente; reconhecimento por parte do empresariado que resiste à atuação; baixa consciência sanitária dos trabalhadores; dificuldades de parceria com sindicatos de trabalhadores; inexistência de organização sindical no local de trabalho; pouco envolvimento dos gestores municipais; falta de investimento específico (Lacaz, Machado \& Porto, 2002).

Em síntese, a estrutura do campo da saúde do trabalhador e o processo dinâmico de suas ações no universo das práticas de saúde ainda exibem uma face incipiente, do ponto de vista de uma política pública articulada e bem elaborada que a complexidade e a relevância do campo exigem. Há mesmo um descompasso entre o formulado constitucionalmente e o instituído como política de Estado.

Cuando la Constituyente del 88 selló un salto delante de los derechos sociales al consignar la responsabilidad del Estado en la atención de la salud de los/as trabajadores/as y del medio ambiente, estaba colocándose a la altura de los cuerpos jurídicos más avanzados y señalando la responsabilidad del Sistema Nacional de Salud de ocuparse de la protección del trabajo y de la promoción de condiciones saludables en el mismo, no sólo en los espacios convencionales de trabajo industrial, sino en todos los ámbitos donde se ejerce trabajo humano, formal o informal, del espacio público o privado, del ámbito doméstico o extradoméstico, en fin, de toda la población que trabaja (...). (Breilh, 2001: 32)

\section{Conteúdos para uma outra Política}

Em um contexto político-econômico globalizado, intensamente dinâmico e sujeito a oscilações conjunturais que subordinam o Brasil a regras de mercado cada vez mais hegemônicas nas relações internacionais, a ótica da saúde do trabalhador tende a perder terreno como política de saúde. Nesse cenário, para se pensar uma PNST a partir do SUS, é preciso avançar para estratégias mais condizentes com preocupações hoje plenamente assumidas pelo mercado - como é o caso do desenvolvimento sustentável. Assim, supomos que as relações saúde-trabalho, como política de saúde, encontrem brechas significativas de entrada nas políticas de Estado direcionadas para as relações saúde-produção-desenvolvimento. Esse parece ser o grande desafio atual do campo da saúde do trabalhador.

No Plano Diretor da Reforma do Aparelho de Estado, coordenada pelo ministro Bresser Pereira, realizada no primeiro governo Fernando Henrique 
Cardoso (1995-1999), a inclusão da "fiscalização de normas sanitárias" como atividade exclusiva do Estado (Brasil, 1995) sinaliza para alguns aspectos. Em primeiro lugar, corrobora a compreensão de que é possível, mediante a utilização de normas sanitárias e mecanismos de vigilância (portanto, no campo da saúde pública), estabelecer políticas mais sólidas de intervenção sobre os fatores determinantes de adoecimento e morte localizados nos processos produtivos. Em segundo lugar, indica que essa política de vigilância pode ser consolidada mesmo em um contexto de reforma neoliberal do Estado brasileiro, que o governo Lula claramente veio mantendo em sua agenda, nos moldes propostos por Bresser Pereira. $\mathrm{O}$ fato situa a vigilância em saúde do trabalhador como ponto estratégico de avanço, desde que marcada pela chancela do desenvolvimento sustentável e com a remodelação metodológica necessária para enfrentar novos desafios.

$\mathrm{Na}$ verdade, a natureza política da saúde do trabalhador já era prevista em seus primórdios:

há (...) dois elementos políticos novos. O primeiro é que os trabalhadores, defendendo na fábrica a sua saúde, defendem também a saúde da comunidade (...) conscientes desta nova relação entre a "condição operária" e a condição humana em geral, fogem das tendências corporativas e assumem (...) sua função de vanguarda e de libertação. O segundo (...), de que a biosfera tem uma unidade mundial, e que qualquer perturbação do equilíbrio adquire uma dimensão planetária. Tudo isto cria uma nova base objetiva para o internacionalismo, sublinha a exigência de acelerar em todos os países o movimento de libertação dos homens, impõe a associação da ação política com a iniciativa técnico-científica, sugere formas de ligação mais profundas das lutas nos diferentes países. (Berlinguer, 1978: 72)

Tambellini e Câmara (1998: 52) reafirmam a superação do paradigma clássico naturalista da saúde:

pensar o acontecimento e o conceito/a realidade e sua explicação levou à configuração de novas possibilidades de intervenção técnica no campo da saúde (...) a Saúde do Trabalhador e a Saúde Ambiental, intrinsecamente unidas, como as dimensões técnicas da intervenção do campo de preocupações Produção/Ambiente/Saúde.

Os nítidos contornos de uma desfocalização da relação saúde-trabalho do mundo da saúde pública e do desenvolvimento sustentável, tanto no campo político quanto no da produção de saberes, são os obstáculos a serem vencidos 
na construção de uma política nacional centrada em uma refocalização da saúde do trabalhador.

uma ausência de estratégias de atenção à saúde dos trabalhadores (...) pode ser caracterizada como uma estratégia de negação, estabelecida para resultar em ocultamento dos conflitos ambientais e de saúde resultantes do processo de desenvolvimento em curso (...). Se as políticas públicas fecham os olhos para estes problemas, o governo engendra sua exclusão das prioridades do setor saúde, e dificulta sua visibilidade para a sociedade: na mídia, na pauta de negociação entre trabalhadores e empregadores, entre os temas de pesquisas (...). O compromisso com um processo de desenvolvimento sustentável deveria significar (...) um intenso e profundo investimento no controle dos riscos ocupacionais e ambientais gerados pelas indústrias, iniciado na seleção dos ramos de atividade menos nocivos, no acompanhamento do projeto das instalações, no monitoramento da qualidade ambiental, na normatização e fiscalização, na preparação do setor saúde, trabalho e meio ambiente (...) da abertura de canais de democratização e de participação da sociedade civil nos processos decisórios. (Rigotto, 2004: 234-235)

Assim, a constituição de uma agenda de construção da PNST passa pela refocalização da relação saúde-trabalho no campo político e no da produção de conhecimentos. Algo semelhante ao ocorrido no movimento pela Reforma Sanitária, em que o conhecimento técnico-científico infiltrou o pensamento político, e a ação política deu a devida relevância a esse conhecimento. Pensar na centralidade do processo de produção como condicionante sanitário significa uma nova estruturação radical no campo das práticas.

Alguns dos pontos de uma possível agenda para a deflagração do processo de construção da política são imprescindíveis: a saúde pública como o seu campo de atuação, com o SUS como sistema efetor transetorial, sob comando único e universal quanto ao plano e à logística em cada esfera de governo local.

Entre as diversas iniciativas destaca-se, a priori, a transformação do modelo de intervenção do Estado sobre os riscos dos processos e ambientes de trabalho, colocando as vigilâncias sanitária e epidemiológica de todos os municípios brasileiros como primeira linha de enfrentamento dos danos à saúde do trabalhador, reservando às demais estruturas de governo - trabalho, previdência, meio ambiente e universidades - o apoio técnico-operacional, o treinamento e as ações de maior envergadura e complexidade. E, concomitantemente, na criação de planos estratégicos de ação baseados em uma política sintonizada com toda a estrutura do Estado, nas áreas do meio ambiente, planejamento, educação, indústria e comércio, transporte, agricultura e todas as demais 
capazes de inserir o tema na agenda dos compromissos nacionais e internacionais do Brasil, no marco da globalização econômica e do desenvolvimento sustentável (Brasil, 2002; Vasconcellos, 2007).

A vertente da produção de conhecimentos, da mesma forma estratégica para dar suporte técnico-científico ao desenvolvimento da política, empresta sua relevância na medida de mudanças e aprimoramentos de seus enfoques usuais, sintonizados com a nova ordem global que exige uma revisão de paradigmas. A produção científica também é essencial para o adequado embasamento das iniciativas de formação em saúde do trabalhador, sejam elas dirigidas a alunos de graduação e pós-graduação, sejam a profissionais de saúde, lideranças sindicais ou trabalhadores. A análise do cenário atual no mundo do trabalho e de suas perspectivas em um futuro próximo poderá facilitar bastante o esforço em definir prioridades para a saúde do trabalhador (Rêgo et al., 2001).

A pesquisa em saúde do trabalhador, via de regra, atua sobre campos territoriais delimitados, cujos eventuais resultados que geram transformação de processos e ambientes limitam-se aos mesmos campos territoriais. A incapacidade político-estrutural de valorizar a pesquisa como instrumento da transformação impede que a identificação de problemas de caráter singular, mas frutos de relações sociais e produtivas similares, dimensione agravos e problemas em outros processos diversos, outros momentos e outros territórios (Vasconcellos \& Ribeiro, 1995). Ou seja, a pesquisa perde o pragmatismo da reprodutibilidade e economia de tempo e recursos. Contribui para isso a formação medicocêntrica do pesquisador, cuja avaliação de preferência e relevância do objeto da pesquisa é mais da alçada da orientação acadêmica do que propriamente sua.

Na ampliação do campo de investigação e pesquisa da saúde do trabalhador, com a incorporação de variáveis relacionadas ao desenvolvimento sustentável, é imperioso pensar em metodologias capazes de imprimir um maior nível de articulação, mesmo porque outros campos do conhecimento serão requeridos. "Disciplinas utilizadas de forma esporádica em pesquisas no campo da saúde do trabalhador, como a economia, o direito e as ciências políticas, passarão a ser imprescindíveis em qualquer investigação na área das relações saúde, trabalho e desenvolvimento sustentável" (Vasconcellos, 2007: 233). A Figura 1 apresenta algumas variáveis no campo da produção de conhecimentos, na perspectiva de uma PNST. 
Figura 1 - Multiprojetos concêntricos de pesquisa nas relações saúde, trabalho e desenvolvimento sustentável no SUS

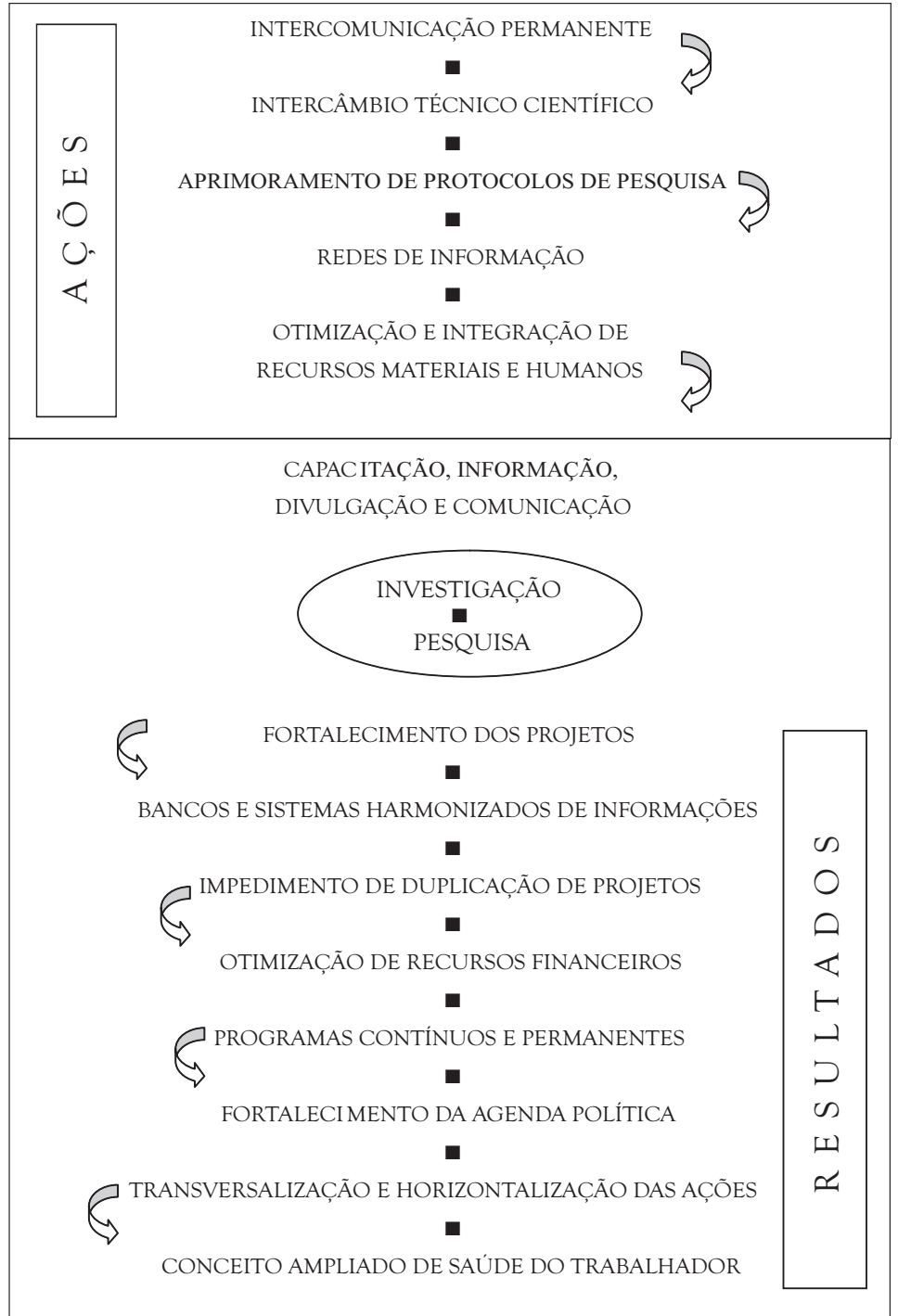

Fonte: Vasconcellos, 2007.

Quanto à vertente da formação de recursos humanos, tendências e consensos se referem a alguns pontos: importância do investimento em capacitação; estratégias adotadas em razão das peculiaridades regionais e da diversidade dos processos produtivos; contextos políticos e culturais; heterogeneidade 
dos serviços; e heterogeneidade da formação, relacionada às oportunidades e às singularidades dos que atuam na área (Rigotto et al., 2001). Em síntese, uma PNST deve creditar relevância ao processo de formação, considerando a necessidade de se definir o papel das instâncias do SUS e das instituições formadoras, calcada na lógica sistêmica da descentralização, e agregando conteúdos temáticos coerentes com a ampliação do objeto da saúde do trabalhador.

Nesse contexto, cabe

definir uma política nacional de capacitação, a partir das bases, de concepção descentralizada e acompanhar sua implantação; estabelecer as diretrizes estratégicas que considera fundamentais, como a questão da Globalização e da Reestruturação Produtiva e seus impactos sobre a saúde dos trabalhadores e a intervenção dos serviços; as inter-relações entre trabalho, meio ambiente e saúde; a interdisciplinaridade e o trabalho em equipe multiprofissional; a intersetorialidade, etc. (Rigotto et al., 2001: 145-146)

Outro ponto é o papel de excelência da Renast na elaboração, na execução e no acompanhamento da política, por se tratar da rede estrutural, por dentro do SUS, com capacidade instalada e linhas de financiamento bem estabelecidas. Para dar conta de se tornar instância estratégica na redefinição e elaboração de uma PNST, a Renast deveria ser alvo de uma remodelação de seus objetivos e meios. Sabendo-se que a solução para os problemas decorrentes do modelo Renast não está no nível de governabilidade da própria Renast, o nível de decisão será o da resolutividade na estrutura de gestão, não só do SUS como também na do próprio aparelho de Estado em seu todo, segundo as variáveis antes assinaladas.

Um eventual projeto de uma Renast revigorada deve partir de uma padronização estrutural para os centros de referência/Renast, em uma inserção capaz de dialogar com instâncias do planejamento estratégico dos três níveis de gestão do SUS.

Nas aproximações que faz o discurso teórico entre saúde/trabalho-produção/ consumo/meio ambiente e desenvolvimento sustentável, uma Renast revitalizada e condizente com uma política de Estado mais abrangente, que contemple essas variáveis, encontra-se na linha de um SUS sistêmico, em transição para o trans: transdisciplinar, transetorial, transversal e transpondo a gestão.

Como pontos de enfoque de atuação da Renast, no contexto de uma nova PNST, podem-se considerar: a ampliação do objeto para uma rede de atenção às relações saúde, trabalho e desenvolvimento sustentável, articulando organicamente na rede as variáveis antes implicadas; a ampliação das estruturas, 
especialmente daquelas relacionadas às instâncias de meio ambiente do SUS, situadas nas três esferas de gestão, em um novo lócus de planejamento com maior capacidade decisória; intrassetorialmente, a capacidade de estabelecer diretrizes conjuntas com a atenção básica, as vigilâncias e a rede assistencial; transetorialmente, a coordenação compartilhada com outras estruturas do Estado em nova instância de planejamento, pactuação e estabelecimento de diretrizes políticas, subordinando programaticamente estruturas efetoras do aparelho de Estado mais próximas dos objetos da política: saúde, trabalho, previdência, educação e meio ambiente, entre outras.

Além disso, algumas caixas de diálogo esparsas como o Grupo Executivo Interministerial de Saúde do Trabalhador (Geisat), as comissões intersetoriais de Saúde do Trabalhador (Cist), os grupos de trabalhos (GTs) da Associação Brasileira de Pós-Graduação em Saúde Coletiva (Abrasco) - GT de Saúde do Trabalhador e de Meio Ambiente -, a Comissão Tripartite Paritária Permanente (CTPP), as instâncias de controle social, entre outras, poderiam estar articuladas, elaborando conjuntamente o plano das políticas públicas. Nesse contexto, a Renast e seus centros, com seu papel redirecionado, poderiam servir como pontas de lança das políticas locais de saúde, trabalho e desenvolvimento sustentável em todo o país, inclusive servindo como campi avançados de pesquisa, formação e educação permanente para a área, em conjunto com as universidades.

Em síntese, uma Renast ampliada e remodelada seria uma instância de planejamento, gestão de informações e coordenação de ações diversas - capacitação, educação permanente, vigilância, articulação, comunicação etc. - em rede nacional, abarcando as interfaces saúde, trabalho, produção, ambiente, consumo e desenvolvimento sustentável, de modo transetorial integrado.

Como já se observou, a partir do Plano de Reforma do Estado a vigilância em saúde do trabalhador se tornou o lócus, talvez mais privilegiado, para desenvolver ações de uma política de Estado em saúde, trabalho e desenvolvimento sustentável. No entanto, no Brasil temos vigilâncias demais, cujo somatório tantas vezes resulta em nenhuma. Então, para uma nova política, uma nova vigilância.

A Visat, como a compreendemos, é parte intrínseca da vigilância em saúde e, se guarda especificidades da relação saúde-trabalho, transcende o objeto da saúde pública vertical e horizontalmente.

As distintas transcendências, com base na análise do modelo de vigilância em saúde, são desejadas na sua territorialização e distritalização (Mendes, 1993; 
Teixeira, Paim \& Vilasboas, 1998; Monken \& Barcellos, 2005), na revisão de suas práticas (Teixeira, 1999) e do seu marco conceitual (Sabroza, 2006), na sua constituição como rede (Santos \& Bittencourt, 2005), na consideração a territórios de exclusão e contextos vulneráveis (Porto, 2007) e, ainda, na integralização de todas as vigilâncias, entendendo-as como atenção básica no sentido da prevenção, da proteção, da promoção e da precaução em saúde (Augusto, 2005).

Mais perto do objeto da Visat, os desejos recaem na inclusão de outras variáveis em um novo paradigma, acrescentando-lhe maior abrangência e amplitude (Franco Netto \& Carneiro, 2002; Brasil, 2005; Barcellos \& Quitério, 2006), na observação de cadeias produtivas (Dias et al., 2002), na implicação de sujeitos sociais (Breilh, 2003) e na radicalização do processo participativo com ampliação do controle social no planejamento e no acompanhamento de ações (Brasil, 1998).

De há muito, a Visat vem sendo debatida e estudada por diversos pesquisadores (Santos et al., 1990; Lacaz, 1992, Wünsch Filho et al., 1993; Vasconcellos, 1994; Oliveira, 1994; Pinheiro, 1996; Machado, 1996; Santos, 2000; Lacaz, Machado \& Porto, 2002; Machado \& Porto, 2003; Pinheiro, Ribeiro \& Machado, 2005), analisando as interfaces entre a política, o método, as práticas e os conflitos da Visat. Na

situação atual, em termos gerais, poderíamos afirmar que o modelo de Vigilância em Saúde do Trabalhador brasileiro possui um caráter híbrido, calcado em experiências institucionalizadas e generalizadas de múltiplas facetas, repletas de ações voluntaristas e de personalismos, em contexto institucional desestabilizado. (Machado \& Porto, 2003: 129)

Sintonizada com a revisão do papel do SUS para um horizonte efetivamente sistêmico, em um contexto de ação sistêmica da vigilância em saúde em um dado território transetorial, ungido de ações transversais para fora dos equipamentos de saúde e garantido pela transposição da gestão, a vigilância em saúde do trabalhador poderia ser assumida como um braço técnico-operacional no teatro de operações do território político.

É nesse cenário de novos caminhos que uma Visat ampliada, algo como uma Vigilância dos Processos Produtivos (VPP), poderia se tornar mais agregadora e mais atualizada em seus parâmetros metodológicos. Na Figura 2, observamos uma síntese do componente de vigilância de uma nova PNST. 
Figura 2 - O SUS e uma nova vigilância em saúde: o sistema de vigilância dos processos produtivos e do desenvolvimento

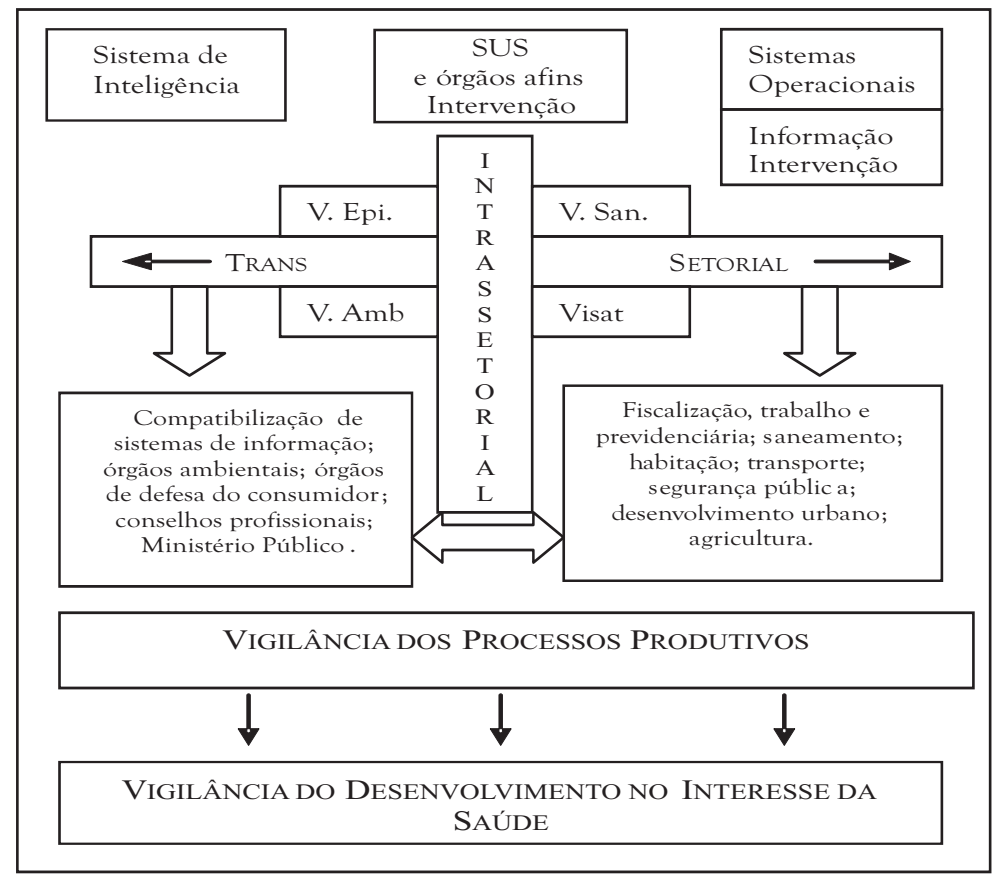

Fonte: Vasconcellos, 2007.

A operacionalização de uma VPP, agregando vigilâncias e fiscalizações em graus de complexidade da ação, contaria com o apoio técnico, estrutural e logístico dos Cerests/Renast, cujas estruturas estão disseminadas em rede por todo o território brasileiro. A potencialidade dessas estruturas é inusual no SUS como reserva técnica estratégica.

Nesse contexto, seriam parâmetros para sua adoção: o político-gerencial, dado pela decisão (decision-making) de assumir uma política de Estado na área de saúde, trabalho e desenvolvimento sustentável, utilizando a capacidade sistêmica do SUS; o teórico-metodológico, dado principalmente pela portaria n. 3.120/98, cujo objeto de vigilância seria ampliado da saúde do trabalhador para os processos produtivos, com as adaptações e agregações necessárias; o técnico-administrativo, dado pela adoção de níveis de complexidade da ação, utilizando a capacidade instalada das vigilâncias, da Renast, da atenção básica e dos órgãos afins fora do setor saúde propriamente dito (Vasconcellos, 2007). 


\section{CONCLUSÃO}

Uma PNST, com cara de política de Estado, passa pela remodelação de sua identidade, reafirmando a centralidade da categoria trabalho, sem dúvida, mas saindo da intimidade do mundo do trabalho para o mundo da produção e do desenvolvimento.

O grande desafio, em tudo semelhante ao da Reforma Sanitária, é como compatibilizar uma construção de saberes, ainda conservadora, com a luta dos trabalhadores pela saúde, hoje entorpecida, e com a gestão macropolítica, desde sempre insensível às relações saúde-trabalho.

Sem fórmulas ao alcance imediato das mãos, o primeiro esforço, na nossa alçada, é o da revisão de paradigmas fortemente consolidados na inteligência acadêmica.

O custo Brasil relacionado às doenças e mortes decorrentes do trabalho, da produção e do desenvolvimento constitui-se de perdas incalculáveis que a produção científica do mundo da saúde pública, da economia, do direito e das ciências sociais e políticas não tem sequer a dimensão aproximada. Alguns estudos iniciam essa discussão ainda limitados às estimativas de mortes por acidentes e ao somatório de anos perdidos (Machado, 1991; Santana et al., 2006).

A luta pela saúde, cuja marca registrada italiana foi adotada nas origens da saúde do trabalhador brasileira, por questões diversas e conhecidas, perdeu força e hoje se restringe a lutas pontuais. Por seu turno, a associação entre o saber técnico e o saber empírico dos trabalhadores e sua subjetividade, exercitado nos primórdios dos Programas de Saúde do Trabalhador dos anos 80, parece confinar-se, hoje, aos espaços de controle social, muitas vezes de modo cartorial.

Em revisão recente sobre o modelo operário italiano, Ángel Cárcoba Alonso (2007: 191) nos rememora:

Se establece una relación dialéctica entre el conocimiento experto y el conocimiento profano, basado en el principio de consenso entre ambos: "validación consensual". El criterio de aceptabilidad o no de determinadas situaciones de riesgo, así como las medidas preventivas a adoptar ha de ser consensuado. No se privilegia la opinión de un técnico sobre el grupo de trabajadores ni lo contrario. Era necesario el consenso.

Associar os saberes na construção de uma política nacional é um desafio que repousa mais em iniciativas da academia do que do movimento sindical e social. E são poucas essas iniciativas.

Quanto à gestão macropolítica, cuja insensibilidade a essas questões é notória, os poucos espaços de formulação nos poderes Executivo e Legislativo 
não têm sido palco de proposições criativas, capazes de gerar novas alternativas à constituição da política.

A relação saúde, produção e desenvolvimento não é incluída, por exemplo, nas políticas de investimento do Banco Nacional de Desenvolvimento Econômico e Social (BNDES). ${ }^{4}$ Dentre os seus objetivos sociais, é assinalada a expansão de serviços de saúde, associada ao desenvolvimento, reduzindo desigualdades regionais, por meio de projetos estruturantes, arranjos produtivos locais e projetos e atividades de natureza social, paradigmáticos, que possam vir a se tornar políticas públicas (BNDES, 2006).

Esse objetivo, adequado à perspectiva de um SUS sistêmico com responsabilidades mais diretas sobre as relações saúde, trabalho e desenvolvimento sustentável, carece de se desvincular da compreensão de que a expansão de serviços de saúde trata apenas de ampliar os serviços assistenciais e hospitalares.

Alguns dispositivos legais não são utilizados como instrumentos capazes de dar suporte jurídico a iniciativas políticas, mais por omissão do que por oportunidade. São casos emblemáticos: a lei n. 11.196, de 21/11/2005, que dispõe sobre incentivos fiscais para a inovação tecnológica; ${ }^{5}$ a lei n. 8.666, de 21/6/1993, que estabelece normas sobre licitações e contratos administrativos; e a lei n. 11.079, de 30/12/2004, que trata das parcerias público-privadas no âmbito da administração pública.

O Estatuto da Cidade, estabelecido pela lei n. 10.257, de 10/7/2001, que trata das diretrizes gerais da política urbana, não cita em momento algum a palavra saúde. A Lei dos Crimes Ambientais (lei n. 9.605, de 12/2/1998), não faz menção à saúde, ao trabalho, à produção e ao desenvolvimento.

A Política Nacional de Ordenamento Territorial (PNOT) e o festejado PAC, anotados na introdução deste texto, também são exemplos da irrelevância da saúde nas políticas de desenvolvimento. Nesse sentido, desde o advento do SUS, de Collor a Lula, não existe, a rigor, interlocução operacional e de planejamento entre as políticas públicas de produção e desenvolvimento e o sistema de saúde.

$\mathrm{O}$ fato se reveste de uma profunda gravidade, pois nos revela a incompreensão do SUS no seu contexto de origem. A meu ver, esse é o maior debate

4 O decreto n. 4.418, de 11 de outubro de 2002, que aprova o novo estatuto social do BNDES como empresa pública, estabelece em seu artigo 3 que o banco "é o principal instrumento de execução da política de investimento do Governo Federal e tem por objetivo primordial apoiar programas, projetos, obras e serviços que se relacionem com o desenvolvimento econômico e social do País".

$5 \mathrm{O}$ regulamento da atual lei é dado pelo decreto n. 5.798, de 7 de junho de 2006, aplicado tanto às medidas de inovação tecnológica quanto às atividades de pesquisa tecnológica. 
que podemos, os profissionais que vêm estudando o sistema de saúde, desencadear nos próximos tempos, se pensarmos em preservar a idéia de uma Reforma Sanitária em movimento. (Vasconcellos, 2007: 357)

Numerosas seriam as situações em que o Estado brasileiro poderia intervir e propor soluções, seguindo uma linha política de saúde, trabalho e desenvolvimento sustentável, houvera a sensibilidade e o compromisso com a mudança do quadro sanitário do país. Por exemplo, poderiam ser propostos sistemas integrados de gestão (Tor, 2006) e aplicadas medidas integralizadoras, como a inclusão de contrapartidas: nos dispositivos legais anteriormente descritos; nas certificações, do tipo Selo Verde; nos Termos de Ajustamento de Conduta pelos ministérios públicos; nos empréstimos do BNDES para os setores produtivos; na certificação de manejo florestal e cadeia de custódia, já consolidada nacional e internacionalmente; no Sistema Brasileiro de Certificação do Instituto Nacional de Metrologia, Normalização e Qualidade Industrial (Inmetro); no redimensionamento do seguro previdenciário do acidente de trabalho; nos critérios da Superintendência de Seguros Privados (Susep) para a regulamentação de prêmios de seguro das empresas do setor produtivo; na avaliação, no dimensionamento e no licenciamento em cadeias produtivas de setores economicamente estratégicos; na plataforma de apoio à inovação tecnológica para pequenas e médias empresas do Ministério da Ciência e Tecnologia; na concessão de microcrédito em setores específicos (Ministério do Desenvolvimento, Indústria e Comércio Exterior e Ministério da Fazenda); na inclusão de setores no Sistema Integrado de Pagamento de Impostos e Contribuições das Microempresas e das Empresas de Pequeno Porte (Simples); e, ainda, na criação de modalidades de incentivo, do tipo Empresa Saudável (Brasil, 2000; Oliveira et al., 2000).

Finalmente, considerando a crise global do emprego e do mercado de trabalho, diante das perspectivas de flexibilização trabalhista, é extemporâneo excluir a massa de trabalhadores do mercado informal em políticas públicas de saúde, trabalho e desenvolvimento.

As políticas de desenvolvimento sustentável, normalmente dirigidas ao trabalho formal, impõem o desafio de desenhar políticas que não subestimem a informalidade e sua importância nesse contexto, especialmente nos países com grande densidade de trabalho informal, como é o caso do Brasil (Briassoulis, 1999).

Assim, a precondição de um SUS sistêmico, transetorializado e que transponha a gestão em saúde, é ponto de partida para planejar e desenvolver políticas de Estado abrangentes, no campo da produção e do desenvolvimento com 
interesse hegemônico na saúde pública. E além, "estabelecendo mecanismos de inteligência sistêmica, revendo paradigmas do enfoque sanitário, redimensionando o teatro de operações do SUS, inserindo-o nas diversas arenas de conflito de interesse da saúde, com capacidade decisória no policy-making" (Vasconcellos, 2007: 384).

Com o andamento da reforma do Estado brasileiro, harmonizada às diretrizes do Banco Mundial de incentivo à globalização do mercado, o SUS, com sua relativa robustez às oscilações político-partidárias, sua extensa capilaridade e suas estruturas de controle social consolidadas, é uma boa trincheira para se contrapor à ideologia político-econômica que desvaloriza as relações saúdetrabalho-desenvolvimento.

Há uma zona de sombra entre ideologia, ciência e ação política, na qual se localizam teorizações sobre saúde do trabalhador que a mantêm desfocalizada do campo das políticas de desenvolvimento sustentável. Esse é um resgate imperioso.

Se saúde pública é, essencialmente, política pública, suas ciências agregadas não tangenciam a política, mas antes a alimentam e a impulsionam.

\section{REFERÊNCIAS}

ALONSO, A. C. La Salud no se Vende ni se Delega, se Defiende: el modelo obrero. Madrid: Ediciones GPS, 2007.

ANDRADE, E. T. \& KASSAWARA, M. E. Centro de Referência em Saúde do Trabalhador: variações sobre um modelo idealizado, 2004. Monografia (Curso de Especialização em Saúde do Trabalhador), Rio de Janeiro: Centro de Estudos de Saúde do Trabalhador e Ecologia Humana, Escola Nacional de Saúde Pública Sergio Arouca, Fundação Oswaldo Cruz.

AUGUSTO, L. G. S. O desafio da integração das vigilâncias no Brasil. Revista Brasileira de Vigilância Sanitária, 1(1): 75-78, 2005.

BARCELlOS, C. \& QUITÉRIO, L. A. D. Vigilância ambiental em saúde e sua implantação no Sistema Único de Saúde. Revista de Saúde Pública, 40(1): 170-177, 2006. BASAGLIA, F. et al. La Salud de los Trabajadores: aportes para una politica de salud. México: Editorial Nueva Imagen, 1980.

Berlinguer, G. Medicina e Política. São Paulo: Cebes, Hucitec, 1978.

BERLINGUER, G. A Saúde nas Fábricas. São Paulo: Cebes, Hucitec, 1983.

BNDES (Banco Nacional de Desenvolvimento Econômico e Social). Desenvolvimento Social: objetivos, 2006. Disponível em: <www.bndes.gov.br/SiteBNDES/export/ sites/default/bndes_pt/Galerias/Arquivos/empresa/download/Relat_Gestao_ FINAME_2006.pdf>. Acesso em: 15 dez. 2006. 
BRASIL. Constituição da República Federativa do Brasil, 1988. Disponível em: <www. planalto.gov.br/ccivil_03/Constituicao/Constituiçao.htm>. Acesso em: 5 set. 2007. BRASIL. Lei n. 8.080, de 19 de setembro de 1990. Dispõe sobre as condições para a promoção, proteção e recuperação da saúde, a organização e o funcionamento dos serviços correspondentes e dá outras providências. Diário Oficial da União, 20 set. 1990. Disponível em: <www.planalto.gov.br/ccivil_03/Leis/L8080.htm>. Acesso em: 14 out. 2010.

BRASIL. Comissão Interministerial de Saúde do Trabalhador. Relatório Final. Brasília: Ministério da Previdência Social, Ministério da Saúde, Ministério do Trabalho, 1993.

BRASIL. Presidência da República. Plano Diretor da Reforma do Aparelho do Estado. Brasília: Presidência da Câmara da Reforma do Estado, Ministério da Administração Federal e Reforma do Estado, 1995.

BRASIL. Ministério da Saúde. Portaria n. 3.120, de 1/7/1998. Aprova a Instrução Normativa de Vigilância em Saúde do Trabalhador no SUS. Brasília: Ministério da Saúde, 1998.

BRASIL. Ministério da Saúde. Empresa Saudável. Projeto desenvolvido em parceria com a Organização Pan-Americana da Saúde (Opas). Brasília: Área Técnica de Saúde do Trabalhador/Secretaria de Políticas de Saúde/Ministério da Saúde, 2000. (Mimeo.)

BRASIL. Ministério da Saúde. Saúde do Trabalhador para um Novo País. Documento encaminhado à equipe de transição do governo Lula. Brasília: Cosat, 2002. (Mimeo.)

BRASIL. Ministério da Saúde. Protocolo de Vigilância em Saúde do Trabalhador (Visat). Texto em discussão. Secretaria de Atenção à Saúde (SAS)/Departamento de Ações Programáticas Estratégicas (Dape)/Área Técnica de Saúde do Trabalhador. Brasília: Cosat, 2005. (Mimeo.)

BRASIL. Ministério da Integração Nacional. Política Nacional de Ordenamento Territorial (PNOT). (Versão preliminar para discussão). Recife, 2006a. Disponível em: 〈www.integracao.gov.br/desenvolvimentoregional/publicacoes/pnot.asp>. Acesso em: 12 nov. 2006.

BRASIL. Ministério da Saúde. Rede Nacional de Atenção Integral à Saúde do Trabalhador. Manual de Gestão e Gerenciamento. São Paulo: Hemeroteca Sindical Brasileira, 2006b.

BRASIL. Programa de Aceleração do Crescimento, 2007. Disponível em: <www. agenciabrasil.gov.br/noticias/2007/1/22/materia.2007-01-2.1909859633/view>. Acesso em: 6 set. 2007.

BRASIL. Comissão Nacional sobre Determinantes Sociais da Saúde, 2007. Disponível em: <www.cndss.fiocruz.br/pdf/home/relatorio.pdf>. Acesso em: 12 abr. 2008.

BREILH, J. Eficacia del poder, retroceso del derecho y degradación del trabajo: el escenario regresivo de la Salud Laboral en América Latina. Conferência de abertura. In: ENCONTRO NACIONAL DE SAÚDE DO TRABALHADOR: DESAFIO DA CONSTRUÇÃO DE UM MODELO ESTRATÉGICO. Série D, n. 10, 2001, Brasília. Anais... Brasília: Ministério da Saúde, 2001. 
BREILH, J. De la vigilancia convencional al monitoreo participativo. Ciência E̊ Saúde Coletiva, 8(4): 937-951, 2003.

BRIASSOULIS, H. Sustainable development and the informal sector: an uneasy relationship? Journal of Environment Eु Development, 8(3): 213-237, 1999.

CUT (Central Única dos Trabalhadores). Posição da CUT sobre a proposta de portaria (SAS) que institui a estruturação dos Centros de Referência em Saúde do Trabalhador na Rede Nacional de Atenção à Saúde do Trabalhador no SUS. São Paulo: CUT, 2002. (Mimeo.)

CORRÊA, M. J. M. et al. Política de atenção integral à saúde do trabalhador: a experiência do estado do Rio Grande do Sul. In: MERLO, A. R. C. (Org.) Saúde e Trabalho no Rio Grande do Sul: realidade, pesquisa e intervenção. Porto Alegre: Editora da UFRGS, 2004.

DIAS, E. C. A Atenção à Saúde dos Trabalhadores no Setor Saúde (SUS) no Brasil: realidade, fantasia ou utopia?, 1994. Tese de Doutorado, Campinas: Departamento de Medicina Preventiva e Social, Faculdade de Ciências Médicas, Universidade Estadual de Campinas.

DIAS, E. C. et al. Processo de trabalho e saúde dos trabalhadores na produção artesanal de carvão vegetal em Minas Gerais, Brasil. Cadernos de Saúde Pública, 18(1): 269-277, 2002.

FRANCO NETTO, G. \& CARNEIRO, F. Vigilância ambiental em saúde no Brasil. Ciência Eु Ambiente, 25: 47-58, 2002.

FREITAS, C. M. A produção científica sobre o ambiente na saúde coletiva. Cadernos de Saúde Pública, 21(3): 679-701, 2005.

JAEGER, M. L. Texto apresentado pela representante do Conselho Nacional de Secretários de Saúde (Conass). In: ENCONTRO NACIONAL DE SAÚDE DO TRABALHADOR: DESAFIO DA CONSTRUÇÃO DE UM MODELO ESTRATÉGICO, série D, n. 10, 2001, Brasília. Anais... Brasília: Ministério da Saúde, 2001.

LACAZ, F. A. C. Vigilância em saúde do trabalhador. Texto de apoio. Curso précongresso. In: CONGRESSO BRASILEIRO DE SAÚDE COLETIVA, 3, 1992, Porto Alegre. Anais... Porto Alegre: Abrasco, 1992.

LACAZ, F. A. C.; MACHADO, J. H. M. \& PORTO, M. F. S. Estudo da Situação e Tendências da Vigilância em Saúde do Trabalhador no Brasil: relatório final. Brasília: Opas, 2002.

LEFF, E. Complexidade, interdisciplinaridade e saber ambiental. In: PHILIPPI JR., A. et al. (Orgs.) Interdisciplinaridade em Ciências Ambientais. São Paulo: Signus, 2000.

MACHADO, J. M. H. A Epidemiologia dos Acidentes de Trabalho Registrados no Rio de Janeiro, 1991. Dissertação de Mestrado, Rio de Janeiro: Escola Nacional de Saúde Pública Sergio Arouca, Fundação Oswaldo Cruz.

MACHADO, J. M. H. A Heterogeneidade da Intervenção: alternativas e processos de vigilância em saúde do trabalhador, 1996. Tese de Doutorado, Rio de Janeiro: Escola Nacional de Saúde Pública Sergio Arouca, Fundação Oswaldo Cruz. 
MACHADO, J. M. H. Ação transversal intersetorial: entre o racional e o conjuntural. In: CONFERÊNCIA NACIONAL DE SAÚDE DO TRABALHADOR, 3, 2004, São Paulo. (Texto contribuição da Abrasco para o encontro preparatório da conferência).

MACHADO, J. M. H. \& PORTO, M. F. S. Promoção da saúde e intersetorialidade: a experiência da vigilância em saúde do trabalhador na construção de redes. Epidemiologia e Serviços de Saúde, 12(3): 121-130, 2003.

MACHADO, J. M. H. et al. Alternativas e processos de vigilância em saúde do trabalhador relacionados à exposição ao benzeno no Brasil. Ciência $\mathcal{G}$ Saúde Coletiva, 8(4): 913-921, 2003.

MENDES, E. V. (Org.) Distrito Sanitário: o processo social de mudança das práticas sanitárias do Sistema Único de Saúde. São Paulo, Rio de Janeiro: Hucitec, Abrasco, 1993.

MENDES, R. Produção científica brasileira sobre saúde e trabalho, publicada na forma de dissertações de mestrado e teses de doutorado, 1950-2002. Revista Brasileira de Medicina do Trabalho, 1(2): 87-118, 2003.

MINAYO-GOMEZ, C. \& THEDIM-COSTA, S. M. F. A construção do campo da saúde do trabalhador: percurso e dilemas. Cadernos de Saúde Pública, 13(supl. 2): 21-32, 1997.

MINAYO-GOMEZ, C. \& THEDIM-COSTA, S. M. F. Incorporação das ciências sociais na produção de conhecimentos sobre trabalho e saúde. Ciência Ė Saúde Coletiva, 8(1): 125-136, 2003.

MIRANDA, A. C. A Vigilância em Saúde na Indústria Naval: o caso dos trabalhadores em atividade de pintura em um estaleiro do Rio de Janeiro, 1997. Dissertação de Mestrado, Rio de Janeiro: Escola Nacional de Saúde Pública Sergio Arouca, Fundação Oswaldo Cruz. MONKEN, M. \& BARCELLOS, C. Vigilância em saúde e território utilizado: possibilidades teóricas e metodológicas. Cadernos de Saúde Pública, 21(3): 898-906, 2005.

NICOLESCU, B. Projeto Ciret-Unesco: evolução transdisciplinar da universidade. Congresso Internacional que Universidade para o Amanhã? Em busca de uma evolução transdisciplinar da Universidade. Locarno, Suíça, 1997. Disponível em: <http:// perso.club-internet.fr/nicol/ciret/locarno/locapor4.htm>. Acesso em: 26 out. 2006.

NICOLESCU, B. The transdisciplinary evolution of the university, condition for sustainable development. Bulletin Interactif $d u$ Centre International de Recherches et Études Transdisciplinaires (Ciret), 12, 1998. Disponível em: <http://nicol.club.fr/ciret/bulletin/ b12/b12.htm>. Acesso em: 27 out. 2006.

NOBRE, L. A prática atual de saúde do trabalhador: nós críticos. In: ENCONTRO NACIONAL DE SAÚDE DO TRABALHADOR: DESAFIO DA CONSTRUÇÃO DE UM MODELO ESTRATÉGICO, série D, n. 10, 2001, Brasília. Anais... Brasília: Ministério da Saúde, 2001.

OLIVEIRA, L. S. B. A Intervenção do Estado nos Ambientes de Trabalho: origens, evolução no Brasil e análise crítica da prática da Delegacia Regional do Trabalho do Rio de Janeiro na década de 1980, 1994. Dissertação de Mestrado, Rio de Janeiro: Escola Nacional de Saúde Pública Sergio Arouca, Fundação Oswaldo Cruz. 
OLIVEIRA, L. S. B. et al. Projeto Empresa Saudável: desenvolvimento do projeto. Brasília: Ministério da Saúde, 2000. (Mimeo.)

OLIVEIRA, M. H. B. \& VASCONCELLOS, L. C. F. Política de Saúde do Trabalhador no Brasil: muitas questões sem respostas. Cadernos de Saúde Pública, 8(2): 150-156, 1992. PINHEIRO, T. M. M. Vigilância em Saúde do Trabalhador no Sistema Único de Saúde: a vigilância do conflito e o conflito da vigilância, 1996. Tese de Doutorado, Campinas: Faculdade de Ciências Médicas, Universidade Estadual de Campinas.

PINHEIRO, T. M. M.; RIBEIRO, F. S. N. \& MACHADO, J. M. H. Vigilância em saúde do trabalhador. In: CONFERENCIA NACIONAL DE SAÚDE DO TRABALHADOR, 3, 2005, Brasília. Coletânea de Textos. Brasília: Conselho Nacional de Saúde/Ministério da Saúde, Ministério do Trabalho e Emprego, Ministério da Previdência Social, 2005.

PORTO, M. F. S. Uma Ecologia Política dos Riscos: princípios para integrarmos o local e o global na promoção da saúde e da justiça ambiental. Rio de Janeiro: Editora Fiocruz, 2007. RÊGO, M. A. et al. Investigação e pesquisa em saúde do trabalhador. In: ANAIS DO ENCONTRO NACIONAL DE SAÚDE DO TRABALHADOR: DESAFIO DA CONSTRUÇÃO DE UM MODELO ESTRATÉGICO, série D, n. 10, 2001, Brasília. Anais... Brasília: Ministério da Saúde, 2001.

RIBEIRO, F. S. N. et al. Vigilância em Saúde do Trabalhador: o que está por vir..., série D, n. 10, 2001, Brasília. Anais... Brasília: Ministério da Saúde, 2001.

RIGOTTO, R. M. O 'Progresso' Chegou: e agora? As tramas da (in)sustentabilidade e a sustentação simbólica do desenvolvimento, 2004. Tese de Doutorado, Fortaleza: Programa de Pós-Graduação em Ciências Sociais, Universidade Federal do Ceará.

RIGOTTO, R. M. et al. Capacitação em serviço, graduação e pós-graduação em saúde do trabalhador. In: ENCONTRO NACIONAL DE SAÚDE DO TRABALHADOR: DESAFIO DA CONSTRUÇÃO DE UM MODELO ESTRATÉGICO, série D, n. 10, 2001, Brasília. Anais... Brasília: Ministério da Saúde, 2001.

SABROZA, P. Vigilância em Saúde. Disponível em: <www.abrasco.org.br/grupos/ arquivos/20060718160725.pdf>. Acesso em: 23 out. 2006.

SANTANA, V. S. Saúde do trabalhador no Brasil: pesquisa na pós-graduação. Revista de Saúde Pública, 40(n. esp.): 101-111, 2006.

SANTANA, V. S. et al. Acidentes de trabalho: custos previdenciários e dias de trabalho perdidos. Revista de Saúde Pública [on-line], 40(6): 1.004-1.012, 2006.

SANTOS, A. \& BITTENCOURT, R. R. Perspectivas para a construção de uma nova consciência coletiva que conceba a vigilância sanitária como rede: Redevisa. Revista Brasileira de Vigilância Sanitária, 1(2): 133-140, 2005.

SANTOS, L. Saúde do Trabalhador: conflito de competência - União, estados e municípios interface Ministério do Trabalho e Emprego, Ministério da Saúde e Ministério da Previdência e Assistência Social. Brasília: Organização Pan-Americana da Saúde-Representação do Brasil, Organização Mundial da Saúde, 2000. 
SANTOS, N. R. Exposição do representante do Conselho Nacional de Saúde. In: ENCONTRO NACIONAL DE SAÚDE DO TRABALHADOR: DESAFIO DA CONSTRUÇÃO DE UM MODELO ESTRATÉGICO, série D, n. 10, 2001, Brasília. Anais... Brasília: Ministério da Saúde, 2001.

SANTOS, U. P. et al. Sistema de vigilância epidemiológica para acidentes de trabalho: experiência na zona Norte do município de São Paulo (Brasil). Revista de Saúde Pública, 24: 286-293, 1990.

SILVA, J. M. et al. Informação e comunicação em saúde do trabalhador. In: ENCONTRO NACIONAL DE SAÚDE DO TRABALHADOR: DESAFIO DA CONSTRUÇÃO DE UM MODELO ESTRATÉGICO, série D, n. 10, 2001, Brasília. Anais... Brasília: Ministério da Saúde, 2001.

TAMBELLINI, A. T. Avanços na formulação de uma Política Nacional de Saúde no Brasil: as atividades subordinadas à área das relações produção e saúde. In: CONFERÊNCIA NACIONAL DE SAÚDE DOS TRABALHADORES, 1, 1986, Brasília. Anais... Rio de Janeiro: Cesteh/Ensp/Fiocruz, 1988. (Mimeo.)

TAMBELLINI, A. T. \& CÂMARA, V. M. A temática saúde e ambiente no processo de desenvolvimento do campo da saúde coletiva: aspectos históricos, conceituais e metodológicos. Ciência E3 Saúde Coletiva, 3(2): 47-59, 1998.

TEIXEIRA, C. F. Epidemiologia e planejamento de saúde. Ciência E̊ Saúde Coletiva, 4(2): 287-303, 1999.

TEIXEIRA, C. F.; PAIM, J. S. \& VILASBOAS, A. L. SUS, modelos assistenciais e vigilância da saúde. Informe Epidemiológico do SUS, 7(2): 7-28, 1998.

TOR, D. Sistema Integrado Gestión Ambiental, Seguridad y Salud Ocupacional. Montevideo (Uruguay): Sociedad de Ecología Médica y Social, 2006. Disponível em: <www. ergonomia.cl/d_tor.html>. Acesso em: 14 dez. 2006.

VASCONCELLOS, L. C. F. Os Caminhos do Caminho: a municipalização como estratégia de consolidação da saúde do trabalhador no setor saúde, 1994. Dissertação de Mestrado, Rio de Janeiro: Escola Nacional de Saúde Pública Sergio Arouca, Fundação Oswaldo Cruz. VASCONCELLOS, L. C. F. Saúde, Trabalho e Desenvolvimento Sustentável: apontamentos para uma política de Estado, 2007. Tese de Doutorado, Rio de Janeiro: Escola Nacional de Saúde Pública Sergio Arouca, Fundação Oswaldo Cruz.

VASCONCELLOS, L. C. F. \& RIBEIRO, F. S. N. A Pesquisa Epidemiológica no Processo de Vigilância em Saúde do Trabalhador: panorama atual do estado do Rio de Janeiro. In: CONGRESSO BRASILEIRO DE EPIDEMIOLOGIA, III, 1995, Salavador. (Trabalho apresentado na Oficina de Trabalho de Saúde do Trabalhador).

WÜNSCH FILHO, V. et al. Sistema de informação para a ação: subsídios para a atuação prática dos Programas de Saúde dos Trabalhadores a nível local. Cadernos de Saúde Pública, 9(2): 136-148, 1993. 



\section{Perspectivas e Pressupostos da Vigilâncla eM Saúde do Trabalhador no Brasll}

Jorge Mesquita Huet Machado

A vigilância em saúde do trabalhador (Visat) pode ser considerada como um dos campos da vigilância em saúde cuja característica singular de intervenção é sua ação na transformação do trabalho no sentido da promoção da saúde. Tem como estratégia elementar a interdependência dos profissionais de saúde com os trabalhadores, com base nas possibilidades institucionais de regulação e proteção voltadas às relações técnicas e sociais do trabalho.

Os agravos relacionados ao trabalho representam, nessa perspectiva, uma situação a ser evitada e acolhida. Essa configuração epidemiológica torna estratégica e fundamental a intervenção de vigilância em saúde nos processos de trabalho.

Essa delimitação da natureza específica das ações de Visat estabelece para o Sistema Único de Saúde (SUS) uma perspectiva de intervenção no trabalho como um condicionante do perfil sanitário. Representa também uma ação essencial diante da configuração das relações sociais e das transformações ambientais decorrentes do processo produtivo como um todo e que em grande parte determinam a forma como se organizam os territórios.

A intervenção e a regulação exercidas pela Visat, ao direcionarem a transformação na maneira de trabalhar em um dado território, se constituem em uma força de organização e de construção dos lugares onde as pessoas vivem. Por essa via, a Visat ultrapassa a abrangência de sua ação para além dos trabalhadores diretamente expostos aos processos de trabalho - foco das ações -, configurando um condicionante socioambiental do processo saúde-doença. 


\section{Trajetória Histórica}

As práticas de Visat no Brasil se iniciam com as experiências dos programas de saúde do trabalhador desenvolvidos por escritórios regionais da Secretaria de Saúde do estado de São Paulo na década de 1980, em uma relação estreita com a reforma sanitária italiana, que estabelece os pressupostos da ação de saúde em torno de um território e uma relação forte com os movimentos dos trabalhadores. O principal interlocutor desse processo foi o senador Giovani Berlinguer, um sanitarista com um olhar particular da epidemiologia e da relação do processo saúde-doença com o trabalho. A influência da reforma sanitária italiana é ampla e inspirou a nossa reforma sanitária e o SUS no Brasil, configurando um movimento de construção da saúde coletiva em que a saúde do trabalhador é um dos temas.

Nesse contexto político e acadêmico, surgem ações de serviços comandados por sanitaristas envolvidos nesse movimento. São marcantes as ações desenvolvidas pelos programas de saúde do trabalhador de Santos (SP), que introduzem a vigilância epidemiológica de agravos relacionados ao trabalho e, posteriormente, o programa da Zona Norte, em que são realizadas ações de vigilância nos ambientes de trabalho (Costa et al., 1989). Até esse momento, as ações institucionais de saúde no âmbito dos ambientes de trabalho eram restritas ao Ministério do Trabalho e executadas por fiscais médicos e engenheiros das delegacias regionais do Trabalho.

As experiências dessa fase inicial tinham apoio do movimento dos trabalhadores e são inspiradoras do primeiro processo de disseminação nacional. Com as eleições de 1986, são instituídos, nas secretarias estaduais de Saúde no Rio de Janeiro, na Bahia, em Minas Gerais e no Rio Grande do Sul, serviços ambulatoriais e coordenações voltadas à Visat. Destaca-se, no Rio de Janeiro, as ações de formulação de estratégias e de execução de Visat no período de 1987 a 1994, embora houvesse uma discussão contínua de criação de centros de referência só estabelecidos ao final dessa década e em Volta Redonda (RJ).

Nesse período, foi estabelecido como estratégia de vigilância, na Coordenação de Saúde do Trabalhador da Secretaria de Estado de Saúde do Rio de Janeiro (CST/SES/RJ), o desenvolvimento de ações de vigilância por setor econômico, com foco em situações-problema, como a ocorrência de acidentes letais ou de surtos de casos de silicose na indústria naval ou o acompanhamento de processos nacionais de intervenção e vigilância, como as alterações hematológicas por exposição ao benzeno em polos industriais. Em termos de 
organização, foram constituídas câmaras técnicas interinstitucionais e com acompanhamento sindical relacionadas ao Conselho Estadual de Saúde do Trabalhador (Consest).

Em termos nacionais, o processo de disseminação de ações de saúde do trabalhador é influenciado pela I Conferência Nacional de Saúde do Trabalhador (CNST), em 1988, e se caracteriza pela expansão de serviços estaduais de saúde do trabalhador com uma regionalização ainda restrita ao estado de São Paulo e a poucos municípios de outros estados, como Rio de Janeiro, Minas Gerais e Bahia. Em 1994, com o movimento da II CNST, é evidenciada essa primeira disseminação de ações de saúde do trabalhador, porém sem ênfase na vigilância, e sim com uma concentração em ações assistenciais focada muitas vezes nas disputas de diagnóstico e de nexo causal com a previdência. É característico da II CNST o embate entre corporações dos setores da saúde e do trabalho, reproduzindo um conflito de competências bastante utilizado pelas empresas e por seus representantes legais no constrangimento de ações de vigilância realizadas pelas instâncias do SUS. Pode-se destacar também a disseminação de programas municipais de saúde do trabalhador com níveis de formalização e de propostas marcadas pela fragilidade institucional e heterogeneidade programática como realidade emergente.

A avaliação sistematizada por Dias (1994) revela alguns problemas desse período com respeito à estratégia assistencial centrada na atenção individual, à dificuldade de desenvolver ações intersetoriais, à precariedade das informações disponíveis e à pouca articulação com o controle social.

Em síntese, os problemas apontados se referem a uma falta de definição da vigilância em saúde do trabalhador como uma estratégia fundamental e à fragilidade do processo de informação e de participação dos trabalhadores, elementos fundamentais e estruturantes da concepção de saúde do trabalhador no âmbito da saúde coletiva.

Por encomenda da Comissão Interinstitucional de Saúde do Trabalhador (Cist), do Conselho Nacional de Saúde, foi realizada uma avaliação em 2002 sobre como estavam as ações de vigilância em saúde do trabalhador no Brasil. O resultado foi apresentado em relatório (Lacaz et al., 2003) que sistematiza os avanços e problemas encontrados, em que se destacam os seguintes pontos:

1) Há uma grande concentração de experiências em São Paulo, com uma proporção de $40 \%$ dos serviços, e em toda a região Sudeste (80\%); no restante do Brasil, com exceção da Bahia, as ações se limitam ao âmbito estadual, ou seja: a municipalização das ações se restringe ao Sudeste e à Bahia. 
2) A dimensão até esse período é restrita e localizada, considerando a simples presença no município de serviço de vigilância em saúde do trabalhador como indicativo de população coberta; por esse superestimado parâmetro, calcula-se que $77 \%$ da população não tinham acesso aos serviços de vigilância em saúde do trabalhador no Brasil.

3) Como problema central, há uma incipiente integração interna entre as instâncias das próprias secretarias.

4) O modelo participativo, interinstitucional, centrado em bases epidemiológicas e sociais, é em parte observado. Como destaque negativo, observou-se que a participação dos trabalhadores estava ausente em grande parte dos casos, seja na definição de objetivos, seja na identificação de demanda ou mesmo na gestão. Foram registrados apenas $30 \%$ dos serviços com mecanismo de controle social de sua gestão.

5) Há uma forte relação interinstitucional, e pode ser notada a existência de um marco regulatório satisfatório para execução das ações de vigilância, embora em boa parte apareça a utilização das normas regulamentadoras do Ministério do Trabalho e Emprego (MTE) como instrumento de intervenção, o que indica uma mimetização pelo SUS das ações de auditorias e fiscalizações realizadas pelas delegacias regionais do Trabalho.

O período de 2003 à atualidade é marcado por um incremento no número de Centros de Referência em Saúde do Trabalhador (Cerests), que passam a compor a Rede Nacional de Atenção à Saúde do Trabalhador (Renast), definida na portaria n. 2.437/2005 como polo articulador das ações de saúde do trabalhador em um determinado território, com dotação de recursos orçamentários específicos. Na prática, tem tido pouca eficiência em seus processos de articulação e vem funcionando como porta de entrada de demandas diversas.

Não há um modelo ou modelos de Renast no Brasil; fala-se em uma ênfase assistencial, pelo viés inerente aos serviços de saúde. Tampouco é resolvida essa questão, marcada por uma tentativa de aproximação com a atenção básica, em um processo recorrente de estabelecer uma racionalidade de portas de entradas no SUS. Seria fundamental que a Renast caminhasse para a superação da dicotomia entre assistência e vigilância e incorporasse em seu modelo estratégias de prevenção a agravos e de promoção da saúde (Minayo-Gómez \& Lacaz, 2005). Ressalva-se que, em alguns estados, a saúde do trabalhador se organiza na vigilância sanitária, como em Santa Catarina, ou permanece como atividade do Centro Estadual de Saúde do Trabalhador (Cesat), como 
na Bahia. Uma regra geral é a pouca disseminação de ações de vigilância dos ambientes e processos de trabalho, que deveriam ser integradas e algumas vezes são intensamente contestadas, provocando desgastes e até descontinuidade das ações, como no caso da Secretaria de Saúde do município de Porto Alegre (RS), que foi impedida judicialmente de exercer vigilância em saúde do trabalhador.

Em síntese, no cenário atual, há um protagonismo do SUS no campo institucional voltado à saúde do trabalhador, com a formulação de uma política clara de expansão das ações com a Renast e um reforço na relação com a vigilância em saúde, com a reorganização institucional do Ministério da Saúde, com a criação do Departamento de Saúde Ambiental e Saúde do Trabalhador na Secretaria de Vigilância em Saúde.

Entretanto, a qualidade e a avaliação do impacto dessa política ainda estão para acontecer, embora haja alguns indícios de que inicialmente o seu efeito seja fugaz, principalmente pelo baixo grau de formalidade das relações de trabalho dos profissionais envolvidos e pela dificuldade de gestão do orçamento, graças à pouca capacidade operacional dos Cerests estaduais e regionais, questões que estão em pauta para serem superadas.

Bem como no aspecto técnico, a capacidade de articulação prévia com as estruturas existentes tem sido também bastante variável, o que repercute diretamente na descontinuidade das ações de vigilância de intervenção nos locais de trabalho.

Em termos gerais, continua sendo verdade que a implantação de ações de vigilância em saúde do trabalhador desenvolvidas a partir do setor saúde no país pode ser definida como pouco articulada internamente no SUS. Em um processo desencadeado por grupos institucionais localizados - embora com a Renast passem a existir Cerests em todo o território nacional -, é mantida uma forte concentração na região Sudeste, especialmente em São Paulo, o que resulta em uma gama de experiências distintas.

As diferenças nas respostas observadas estão relacionadas às potencialidades regionais, que giram em torno da força e da qualidade da organização dos trabalhadores quanto às questões de saúde e, em termos institucionais, dependem das políticas regionais e da estrutura organizacional, da capacidade instalada, da qualidade dos profissionais envolvidos e de influências advindas das instituições acadêmicas (Lacaz et al., 2003; Machado, 1996).

A perspectiva desse momento é de que as ações de saúde do trabalhador amadureçam e se difundam, ao superar esse grau de informalidade e seus conflitos, consolidando-se calcadas na configuração do SUS em sua relação com o 
movimento social, com instituições relacionadas à previdência, ao trabalho e ao meio ambiente, setores empresariais, corporações técnicas e aparato formador técnico-científico, além de agências de regulação envolvidas mais proximamente na interação da saúde com o trabalho. Desse modo, configurariam uma ação transversal intrassetorial e interinstitucional.

\section{Fundamentos da Vigilância em Saúde do Trabalhador}

As ações de vigilância em saúde do trabalhador se caracterizam como processos sociais de intervenção em situações em que as condições de trabalho afetam a saúde de forma negativa, provocando acidentes ou desencadeando processos de adoecimento. Essas ações têm um conteúdo compartilhado pela sociedade, que determina as situações de trabalho que são passíveis de uma intervenção sanitária e em que contexto socioambiental é possível a ação da vigilância em saúde do trabalhador.

A Visat é uma tarefa desempenhada por atores múltiplos externos e internos aos âmbitos das empresas e das atividades específicas de determinado trabalho. Trata-se de uma tarefa exercida por várias instâncias que se ocupam do controle direto ou indireto da regulação do impacto na saúde dos processos de trabalho. As instituições de governo, por meio de seus órgãos executivos que fazem parte desse processo social, estão longe de ser os maiores protagonistas da determinação de situações de risco no trabalho.

A natureza técnica da intervenção de vigilância é compartilhada por várias disciplinas e objeto de disputa conceitual pela comunidade acadêmica, permeada por interesses empresariais, corporativos e dos trabalhadores, mediada por processos mais ou menos democráticos e em que o valor da saúde pode estar prevalecendo em graus distintos, definidos no processo de enfrentamento caso a caso em situações reguladas e acompanhadas pelas ações de vigilância. Mesmo diante dessa relativização de protagonismo social do processo de controle das condições de trabalho pelas instâncias de governo, é uma característica de sua ação a permanente estruturação e desestruturação institucional de suas instâncias voltadas para a regulação do trabalho. Esse processo pendular de construção e desconstrução do marco regulatório do Estado é condicionado pelos projetos de Estado com seus modelos sociais e de desenvolvimento, portanto, tornando-se objeto de construção social e de disputa permanente.

O modelo apresentado parte de uma dinâmica social, em que os conceitos e valores em jogo nesse processo fazem parte da estruturação contínua do Estado 
e da sociedade, que afetam em particular o direcionamento da evolução dos processos produtivos, de forma a promover ou não a saúde.

As ações de Visat se inserem no campo da reprodução social como política de saúde voltada diretamente aos trabalhadores com repercussões em toda a sociedade, mediante sua interação com o processo produtivo.

Em termos institucionais, a Visat deve ser incorporada como um tipo especial de prática de vigilância em saúde que integra dois tipos de atividades, essenciais às vigilâncias: a de produzir, analisar e difundir informações; e a de realizar uma intervenção sanitária preventiva. Esses dois blocos de atividades integradas incluem em seu escopo atividades de vigilância epidemiológica voltada ao registro e à intervenção nos agravos relacionados ao trabalho -, de vigilância sanitária de intervenção e regulação das atividades laborais e de vigilância ambiental - voltada para a intervenção nas situações de risco dos ambientes relacionados ao trabalho.

\section{CONCEITO}

As concepções de vigilância podem ser sintetizadas no entendimento de que "vigilância é informação para ação", conforme apresentado por Wünsch Filho, Setimi e Carmo (1992).

A informação deve ter um sentido amplo, para além das informações de morbidade e mortalidade de cunho estritamente epidemiológico. Trata-se do acúmulo de conhecimento sobre determinada situação, em que podem ser incluídos rumores e demandas sociais como fontes sistemáticas de priorização de ações. A informação é também um resultado que frequentemente extrapola as fronteiras dos territórios onde se localizam os casos e os problemas a serem enfrentados, certamente com repercussão no âmbito local e condicionados pelos filtros sociais com seus condicionantes institucionais e históricos locais.

A ação da vigilância é caracterizada por métodos e técnicas não rotineiras ao modelo de organização de serviços existentes nos sistemas de saúde. A ação de intervenção e regulação dos condicionantes ambientais e do trabalho é um objeto compartilhado por atores não tradicionais em relação aos serviços de saúde. Tal reflexão nos leva a enfatizar a prática interinstitucional e as atividades de campo, na rua, fora dos muros institucionais, longe dos consultórios, que resultam em análises coletivas e participativas dos processos de vigilância vivenciados. 
Portanto, vigilância é informação para ação, pressupondo que as ações de intervenção pertençam ao campo da vigilância. O conceito com esse complemento de ênfase nos coloca em uma posição de desafio em que os pressupostos a seguir permitem traçar um caminho a ser definido a cada objeto priorizado, a cada situação crítica em que pretendamos intervir, regular e negociar diretamente com atores institucionais intra e intersetoriais e com representantes de corporações e de grupos empresariais.

\section{Pressupostos da Atividade de Vigilância em Saúde do Trabalhador}

Os pressupostos aqui apresentados são os componentes da natureza das ações de vigilância em saúde do trabalhador. Configuram seu corpo teórico e conferem características de sua prática intrínseca ao campo da saúde do trabalhador e da saúde coletiva.

\section{A participação dos trabalhadores: a base social das ações}

É um componente fundamental e inerente às ações de saúde do trabalhador. Está presente na definição de prioridades por indução de demandas, na própria atividade de preparação e de execução de inspeções sanitárias, bem como na avaliação e no acompanhamento permanente dos casos e processos em vigilância.

Incorpora qualidade técnica ao processo por trazer o saber dos trabalhadores, contextualizando as observações técnicas e informações gerais sobre os processos de trabalhos e atividades e o próprio território como condicionante da atividade em foco. Produz um efeito de fortalecimento das ações sanitárias e dos acompanhamentos propostos pela vigilância, por representar força política de interesses voltada para a redução de riscos e agravos de saúde.

É estratégica na superação de entraves de relacionamento inter e intrainstitucionais e corporativos, pois se coloca em um patamar externo aos micropoderes existentes nas instituições e nas corporações; portanto, é em si um componente de facilitação para a realização de ações transversais e de costura de redes de vigilância.

Em síntese, não há vigilância em saúde do trabalhador sem a participação dos trabalhadores; entretanto, esse processo estruturante não cai do céu. Portanto, devem ser construídas as relações das práticas de vigilância em saúde do trabalhador com os trabalhadores e suas representações, em um processo de costura contínua de interesses mútuos, sem perder a direcionalidade dada pelo processo de promoção da saúde. 


\section{As bases epidemiológicas das ações}

Estabelecem critérios técnicos para priorizações e para os acompanhamentos das ações de vigilância e constituem as informações de saúde relacionadas aos casos.

O uso da epidemiologia na saúde do trabalhador deve ter como referência os seguintes aspectos centrais:

1) A epidemiologia é essencial à integração interdisciplinar, ao constituir-se em um instrumental de aglutinação de diversas abordagens de identificação das características do processo de trabalho e do processo saúde/doença, transformando-as em variáveis de exposição e efeito.

2) A epidemiologia, associada à observação do processo de trabalho, é fundamental para a qualificação das ações de vigilância, pois há relação direta da profundidade do entendimento qualitativo do processo de trabalho com a quantificação da exposição e com a especificidade dos grupos e estratos recortados nas análises epidemiológicas.

3) $\mathrm{Na}$ organização da informação e no processo de análise, os fundamentos da epidemiologia orientam a prática dos profissionais de saúde envolvidos no processo de vigilância em saúde do trabalhador.

Esses aspectos integram-se e formam o núcleo da investigação em saúde do trabalhador relacionado à identificação de situações de risco e à avaliação de impactos sobre a saúde provocados por procedimentos de gerenciamento de riscos ou mudanças tecnológicas. Dessa forma, constrói-se o agir epidemiológico em saúde do trabalhador, o que possibilita, pela clareza e pelo caráter incisivo de seus resultados, estabelecer diálogo interno, no setor saúde, e externo, principalmente com setores ligados às políticas social, de desenvolvimento, do trabalho e do meio ambiente (Machado, 1996).

A evidência epidemiológica, em razão de seu caráter científico e quantitativo, é também um fator de legitimação do processo de vigilância. Entretanto, as evidências tendem a ser tardias e, em eventos raros, às vezes nunca alcançadas. A ajuda da toxicologia e a aderência ao princípio da precaução são formas de superação dessas limitações dos métodos e análises epidemiológicas.

Assim, as análises de tendências epidemiológicas e de estimativas são formas de estabelecer cenários de impactos que instrumentam os processos de negociação e superam os limites dos estudos de casos de agravos à saúde. 


\section{A interdisciplinaridade, a transversalidade e as ações interinstitucionais}

O trabalho, pela sua natureza diversa e por seu significado social, é um conceito transdisciplinar, e toda ação que envolva o seu entendimento e que se volte para suas repercussões deve ter uma perspectiva transversal inter e intrassetorial. Embora possam existir e mesmo devam existir práticas disciplinares, institucionais e mesmo de algum ator institucional isolado, estas só se materializam em um processo de vigilância em saúde do trabalhador quando articuladas. No mínimo, uma ação de vigilância em saúde do trabalhador deve articular os componentes institucionais intrassetoriais das vigilâncias epidemiológica, sanitária e ambiental.

A vigilância em saúde do trabalhador é um processo que articula saberes e práticas de controle sanitário e se insere no campo da vigilância em saúde. Suas ações técnicas operacionais são mediadas pelas instâncias institucionais voltadas às vigilâncias sanitária, epidemiológica e ambiental, em sua relação com atividades produtivas, produtos e serviços de interesse sanitário, agravos e situações de risco ambiental, respectivamente. Portanto, a Visat é uma ação de vigilância em saúde transversal às vigilâncias específicas, devendo estar articulada a determinado território ou problema de saúde.

Tal ação implica uma constante integração de competências institucionais, no sentido da incorporação de atores sociais definidos segundo a natureza dos programas específicos, buscando o avanço em direção a práticas de caráter multiprofissional, interdisciplinar e intersetorial que configuram as ações de Visat, como se pode observar no esquema a seguir.

\begin{tabular}{|c|c|c|}
\hline \multicolumn{3}{|c|}{ VIGILÂNCIA EM SAÚde } \\
\hline $\begin{array}{c}\text { ViGILÂNCIA } \\
\text { EPIDEMIOLÓGICA }\end{array}$ & VIGILÂNCIA SANITÁRIA & ViGILÂNCIA AMBIENTAL \\
\hline \multicolumn{3}{|c|}{ VIGILÂNCIA EM SAÚdE DO TRABALHADOR } \\
\hline
\end{tabular}

\section{A articulação intrainstitucional}

A intrassetorialidade é o maior entrave a ser superado na área da saúde dos trabalhadores (Lacaz et al., 2003). Há uma necessidade de melhor articular as ações de Visat dentro do SUS, não só com as vigilâncias entre si, mas também com projetos relacionados aos objetos de outras políticas de saúde pública, como as relacionadas ao câncer, à violência urbana, à saúde mental e à saúde da 
família, entre outras. A potencialidade dessa articulação é ampla e se constitui em um embrião de transformação do modelo assistencial.

As estruturas institucionais trazem em si uma contradição ao se tornarem autorreprodutoras, voltadas para si mesmas por meio da construção de mecanismos corporativos, distanciados dos compromissos fundamentais da missão institucional geral de promoção da saúde. Convertem-se em instâncias de poder e de disputas institucionais marcadas por gestores e trabalhadores dispersos sem uma possível condução harmônica, dada a magnitude de setores, gerências, coordenações, departamentos, fóruns, comitês e mesmo de secretarias existentes. A missão de realizar uma ação coordenada em saúde do trabalhador passa por tantas instâncias que o processo de discussão corre o risco permanente de se tornar contínuo e restrito a si mesmo.

A construção possível das saídas desse movimento circular encarcerado em um labirinto tem sido operada pelos processos participativos, ainda que muito tênues, mas que, quando presentes, fazem o destravamento burocrático. Podese dizer que essa inércia é mais localizada no componente federal, seguindo a complexidade das estruturas das organizações públicas. Entretanto, dado o nível de tensão das negociações relacionadas à saúde dos trabalhadores, o nível federal de governo é contraditoriamente a instância de maior possibilidade de intervenção voltada para o interesse sanitário em questões que envolvem interesses econômicos; portanto, é imprescindível ao processo de Visat.

Os processos participativos que realizam integrações estruturais inter e intrainstitucionais partem da consolidação de comissões ligadas a uma instância de poder, seja do Executivo, do Legislativo ou do Judiciário, e pelo fato de estabelecerem a discussão baseada em problemas, refazem interações positivas entre instâncias externamente aos próprios órgãos. Há numerosos e positivos exemplos, como os fóruns do Ministério Público da Bahia e do Rio Grande do Norte, as comissões de Ambiente e Saúde das assembleias legislativas do Rio de Janeiro e de São Paulo, as comissões temáticas do MTE, como a Comissão Permanente do Benzeno, que promoveu um processo de articulação com comissões estaduais, ampliando assim a possibilidade de acompanhamento da restrição ao uso do benzeno no Brasil.

\section{0 caráter processual das ações}

As ações de vigilância em saúde do trabalhador, além de sistemáticas, estabelecem, em relação a cada caso, um processo específico, em que a dimensão temporal é construída de forma intrínseca a cada ação de vigilância. 
Essa é desencadeada em etapas, em um processo de aproximação sucessiva, com aprofundamento e abrangência cada vez maiores, ou seja: grupos de risco são inicialmente delimitados com base em informações gerenciais e por meio da articulação das ações de intervenção, investigação e dos serviços de atenção à saúde. São realizadas avaliações em que a heterogeneidade dos grupos homogêneos de risco é evidenciada e motiva novas estratificações. Paralelamente, estabelece-se um processo de negociação das melhorias das condições de trabalho, e as intervenções propostas nesse âmbito são avaliadas por indicadores sociais, tecnológicos e epidemiológicos. Levam-se em conta as condições tecnológicas da própria empresa, o estabelecimento de prazos e metas para as medidas a serem adotadas. Portanto, embora o período previsto para a intervenção seja virtualmente ilimitado, o estabelecimento de etapas com metas a serem cumpridas confere racionalidade e visibilidade ao processo de vigilância (Machado, 1996).

A natureza processual da vigilância permite, assim, um movimento de aprofundamento do conhecimento com a elaboração de estratégias de monitoramento, de discussão de alternativas tecnológicas e de mudanças na organização do trabalho, que são estruturantes dos serviços e da legitimização social da vigilância em saúde do trabalhador.

\section{A relação com 0 território}

O território como lugar, singular e histórico, se constitui ao mesmo tempo em objeto e condicionante das ações de vigilância em saúde do trabalhador. Em termos conceituais, o entendimento desse território como um espaço sociotécnico de produção de condicionantes à saúde segue a seguinte formulação: os conceitos de "conteúdo geográfico do cotidiano" e "dimensão espacial do cotidiano", desenvolvidos por Milton Santos, são os fundamentos do entendimento diferenciado das ações e as formas geográficas que podem formar, ou não, 'vulnerabilidades geoepidemiológicas', localizadas em situações do cotidiano e, assim, em espaços definidos (Monken, 2000).

As expressões sanitárias do lugar e suas vulnerabilidades constituem-se em objetos de observação e de intervenção no processo de vigilância em saúde em um contexto sanitário geral, e da vigilância em saúde do trabalhador em particular.

A construção do território cotidiano, além de estabelecer a organização dos processos de produção e de reprodução, condiciona a intensidade do impacto na saúde desses processos e em que sentido e velocidade ocorrem suas transformações. 
O local é também onde se organizam os movimentos sociais e onde se exerce a pressão sobre as condições de trabalho. Essa força local é também mediada pelas possibilidades de contatos e relações em rede, sejam elas institucionais, sejam comunitárias. A permeabilidade das mudanças no processo de trabalho está diretamente ligada à força social existente no território; portanto, é determinante do condicionamento político institucional e participativo da efetividade das ações de vigilância em saúde do trabalhador.

O território também deve ser visto em relação a outros territórios, avaliandose a porosidade com que se estabelecem seus contatos com as redes de condicionantes das situações encontradas em dado local. A relação local e global é contínua, de influência mútua e em permanente movimento.

\section{A relação com 0 processo de trabalho}

A ação da vigilância relacionada à atividade se conecta com o conceito fundamental do campo da saúde do trabalhador, que é o de processo de trabalho estabelecido por Marx, na sua obra O Capital, que o define como o momento de transformação da natureza pelo homem, que, ao mesmo tempo, se transforma. Essa transformação de si no contato com o processo de transformação da natureza define a possibilidade de situações potencialmente negativas para a saúde, relacionada a um desfecho de determinado tipo de agravo. Tal transformação é ainda mediada por condicionantes referentes a uma atividade laboral e a mecanismos de proteção, como a própria cultura do setor em relação à saúde e segurança no trabalho.

Cabe destacar que o objeto central de intervenção das ações de vigilância em saúde do trabalhador é o processo de trabalho e sua relação com a saúde.

A atividade de Visat deve estabelecer uma intervenção e negociação de controle e mudanças no processo de trabalho, em sua base tecnológica ou de organização de trabalho, o que virtualmente poderá eliminar o risco de acidentes e de adoecimento relacionados ao trabalho (Machado, 1996).

Essa ação de intervenção e regulação do processo de trabalho é o foco central das ações de vigilância em saúde do trabalhador. Tal ação deve ser o mais sistêmica possível, pois será mais preventiva e abrangente. As ações setoriais ou em um tipo de atividade, como o jateamento de areia, têm a capacidade de multiplicação da intervenção pelo número de locais que utilizam essa tecnologia ou forma de trabalho específica que foi modificada e teve reduzido seu potencial de geração de agravos. No caso do jateamento, seu banimento significou a possibilidade de redução dos casos de silicose 
nas indústrias naval e metalúrgica e em atividades de limpeza e pintura de superfícies metálicas em geral.

A síntese do modelo de Visat centrado na intervenção no processo de trabalho é operacionalizada pelo conceito de atividade que relaciona as situações de risco e agravos em um território.

\section{Prática multiprofissional e coletiva}

Para a realização das ações, as atividades de informação e ação em vigilância em saúde do trabalhador, em razão de sua complexidade e conflitos, não devem ser realizadas individualmente; e mais uma vez, diante da natureza transdisciplinar dos temas abordados nas atividades cotidianas dos vigilantes, é evidente que equipes multidisciplinares e mesmo o trabalho em equipe devam ser a rotina dos serviços envolvidos em tais ações. $\mathrm{O}$ apoio institucional e a qualidade da equipe são componentes decisivos na qualidade das ações.

Importa destacar que uma contribuição fundamental da abordagem de saúde é a construção de uma visão que traz como valor a preservação da saúde e a sua discussão diante de condicionantes, sejam eles de qualquer natureza.

Esse olhar da saúde coletiva preventivista é a moeda de troca do profissional de saúde diante do saber técnico do processo de trabalho; representa o olhar sanitarista e coletivo que decodifica a forma de transformação da saúde pelo processo de trabalho.

Nesse processo de construção do saber sanitário da Visat, a relação entre o saber técnico, com suas facetas disciplinares, e o saber operário se funde na construção objetiva e subjetiva do trabalho e das potenciais relações com as transformações corporais dos trabalhadores, em uma perspectiva de síntese que transcende as disciplinas envolvidas, buscando a construção de um saber multiprofissional e transdisciplinar.

\section{A heterogeneidade das ações}

Os métodos a serem utilizados para observação e registro nos processos de Visat são múltiplos e assim devem permanecer. Destacamos que, sempre que possível, deve ser incentivado o compartilhar de técnicas multidisciplinares, aplicadas por distintos profissionais e com a participação dos trabalhadores, pois traz em si princípios de transparência e de superação dos problemas corporativos. Entretanto, salientamos que cada método requer formação específica para sua aplicação, ou seja: as integrações metodológicas e as metodologias 
participativas devem utilizar ou mesmo se apoiar em técnicas que venham a ser usadas complementarmente ou até mesmo a ser definidas como essenciais em dado momento como parte das avaliações.

O método é definido pelo problema; não existe método adequado a todos os problemas. A heterogeneidade das ações de Visat é dada pela natureza múltipla, histórica e em permanente movimento de transformação do processo de trabalho.

Em síntese, a vigilância é compreendida como uma prática de saúde complexa, ampla, permeada por interesses múltiplos, por vezes conflitantes, inserida visceralmente na sociedade; uma prática de fortalecimento dos trabalhadores na luta pela saúde e não meramente uma prática neutra, padronizada e estritamente técnica (Pinheiro et al., 2005).

A flexibilidade da base técnica a ser aplicada é também parte estratégica da ação de Visat, pois possibilita a incorporação de parceiros institucionais múltiplos em um processo de construção em permanente busca de ampliação de seu espectro de intervenção nos condicionantes da saúde relacionados aos processos de trabalho.

\section{Contextos e questões organizacionais}

Algumas questões têm emergido dos debates recentes acerca da implantação da Renast e especialmente das ações de vigilância em saúde do trabalhador. A princípio, podemos notar uma falta de definição dos fundamentos das ações de Visat, que reflete a pouca organicidade interna setorial dos serviços de saúde do trabalhador. Os princípios gerais de vigilância não são ou são pouco apreendidos e aplicados, com raras exceções, como as ações desenvolvidas pelo Cesat/SES/BA e pela Coordenação de Saúde do Trabalhador, da Secretaria de Estado de Saúde do Rio de Janeiro (SES/RJ), em cooperação com a Fundação Oswaldo Cruz (Fiocruz), desde a implantação de suas ações ao final da década de 1980.

\section{Princípios Gerais de Vigilância em Saúde e as Práticas de Visat}

1) Ação contínua e de serviço, mesmo sendo ela um sistema de prontidão para emergências.

2) Ação baseada em evidências ou dados, com a necessidade de se criar um sistema de identificação, avaliação e registro de situações-problema. 
3) Estabelecimento de um programa de fundamentos e prescrições para as situações-problema a serem acompanhadas.

Esses princípios das ações de vigilância são fundamentais no processo de construção de uma consistência institucional e de inserção nas redes de atenção operadas no cotidiano do SUS.

É necessário considerar a discrepância de entendimento sobre o que é distinto do preconizado como fundamento estruturante no SUS e o que é considerado como heterogeneidade de estratégias de Visat.

Alguns problemas de concepção podem ser notados com base na avaliação das ações de Visat implantadas pelos Cerests (Lacaz et al., 2003). Por exemplo: a ênfase na definição das equipes segundo o modelo definido para os serviços de empresa, com a inclusão e a sobrevalorização da engenharia de segurança como disciplina organizadora do processo de vigilância, e o uso das normas do MTE como base técnica operacional.

Uma segunda questão é a definição da complexidade da ação institucional, que precisa estar relacionada à complexidade da situação-problema. Ou seja: uma vez que o objeto da intervenção necessite de uma abordagem de várias disciplinas e instituições, essas devem ser envolvidas no processo. Outra variável a se considerar na definição da complexidade do objeto da Visat são as relações de poder envolvidas e a possibilidade de uma ação articulada local e regionalmente por setor econômico ou por determinado tipo de atividade ou situação de risco. Se a ação se amplia no tempo e com repercussões externas ao caso, setorialmente ou até intersetorialmente, ela deve ser apoiada por instâncias estaduais, nacionais e de outras instituições que complementem a intervenção.

Uma consequência para essa questão é a articulação interna ao SUS, especialmente da vigilância no modelo assistencial, em suas bases operacionais, em que a atenção básica tem sido cenário de experiências focais da maior relevância. Um exemplo é a identificação de trabalho informal, penoso e de risco em populações acompanhadas pelo Programa de Saúde da Família em Campinas (SP) com apoio da Universidade Estadual de Campinas (Unicamp) e por alguns Cerests regionais de Minas Gerais. Várias iniciativas regionais têm construído na prática o processo de Visat no Brasil. Podemos destacar algumas, como os programas de vigilância de acidente de trabalho com ações sistêmicas de acompanhamento e intervenção em situações de risco, desenvolvidos pelo Cesat/SES/BA, em cooperação com a Universidade Federal 
da Bahia (Ufba), e pelos Cerests de Tocantins e de Alagoas, apresentados na 8a Mostra de Experiências Bem-Sucedidas em Epidemiologia, Prevenção e Controle de Doenças (Expoepi). São experiências que superaram a vigilância dos acidentes a partir do acesso à Comunicação de Acidentes de Trabalho, as CATs, que se difundiram na década de 1990.

Os processos nacionais e regionais de Visat estabelecidos com base em problemas de uso de substâncias carcinogênicas, como o caso do benzeno (Machado et al., 2003), do amianto e dos agrotóxicos, em que o SUS e os Cerests são coadjuvantes, se organizaram e continuam se organizando em torno desses problemas, em polos com maior intensidade conforme a organização institucional e dos trabalhadores e a possibilidade de articulação interinstitucional com o MTE e de apoio institucional acadêmico - como da Fundacentro, Fiocruz e grupos do campo de saúde coletiva no âmbito das universidades.

Vemos também como positivos os trabalhos de apoio ao Ministério Público como foco das ações de vigilância de serviços de Visat, em destaque as experiências de São Paulo e Bahia. Devemos ainda ressaltar a existência de casos que representam um potencial de atividade e resultados de delimitação do impacto sanitário e na própria organização dos serviços. Como exemplo, temos as contaminações químicas industriais (Rezende, 2005) e de postos de combustíveis, que vêm na prática articulando as vigilâncias ambiental e sanitária à saúde do trabalhador.

Uma questão emergente é a vigilância do agronegócio, em que as experiências de Mato Grosso e São Paulo são emblemáticas e deveriam ser disseminadas. Entretanto, refletem a integração e a tensão intrassetorial das ações desenvolvidas pelos Cerests e pela vigilância sanitária e a dificuldade da articulação entre os vários atores institucionais.

O cenário geral das iniciativas de Visat indica a falta de uma discussão nacional e a criação efetiva de fórum de acompanhamento de ações estratégicas de Visat.

No âmbito nacional, os fóruns hoje existentes não têm conseguido realizar esse acompanhamento. A Comissão Tripartite de Segurança e Saúde do Trabalhador, instituída em 2008, tem sua ação limitada pela impossibilidade de focalização consensual do processo de regulação e de fiscalização entre as partes envolvidas. A Cist, do Conselho Nacional de Saúde, se aproxima dessa perspectiva de fórum integrador, ao priorizar situações críticas, como o acompanhamento do setor sucroalcooleiro. 
Em outubro de 2008, com a definição no fórum de dirigentes da Renast referente à criação de um grupo para discussão das ações de Visat nos estados, surgiu uma perspectiva de encaminhamento dessa discussão. No entanto, fica a impressão de que há Cerests pautados por um modelo de centro de atenção à saúde do trabalhador isolado, com fracas relações com as redes de serviços do SUS, imersos em um mecanismo de autoisolamento, e outros à espera de orientações ou se tornando esferas burocráticas dissociadas das ações em um processo inercial de articulação com base em uma referência imediata e burocrática. Mesmo diante desses extremos, há um processo de amadurecimento e de integração e de avaliação da Renast, como uma rede articulada inter e intrainstitucionalmente, local e nacionalmente, em curso por interesse da Coordenação de Saúde do Trabalhador do Ministério da Saúde (Cosat/MS) da maioria dos estados e dos Cerests regionais.

\section{Considerações Finais}

O contexto do processo produtivo em dado território requer um olhar histórico do processo de desenvolvimento em sua relação com a saúde. Parte da constatação de que as forças decorrentes dos processos econômicos atraem populações, organizam espaços de moradia, de circulação e de serviços e condicionam padrões de consumo e desgaste ao estabelecer os modos de vida e trabalho no território de referência.

Assim, a vigilância em saúde do trabalhador transforma as atividades, com suas características de constante movimento, em que o processo de vigilância em saúde do trabalhador pode ser definido como um vetor institucional e determinante social de promoção da saúde relacionado ao modelo socioeconômico em dado território.

As ações de Visat se organizam de acordo com a complexidade da atividade, o objeto de sua ação, de forma mais ou menos transversal em relação aos setores institucionais de sua abrangência. Constituem-se em um processo de aproximação sucessiva e contínua de intervenção em uma situação-problema, formando redes de intervenção com a mesma complexidade da organização da situação de risco a ser enfrentada.

Devemos considerar a Visat inserida em um jogo de forças e contradições permanentes, cuja resultante aponta para a construção de ambientes saudáveis e de processos de desenvolvimento que consideram a sustentabilidade ecológica e social. 


\section{REFERÊNCIAS}

COSTA, D. et al. Programa de Saúde do Trabalhador, a Experiência da Zona Norte: uma alternativa em saúde pública. São Paulo: Hucitec, 1989.

DIAS, E. C. A Atenção à Saúde dos Trabalhadores no Setor Saúde (SUS), no Brasil: realidade, fantasia ou utopia?, 1994. Tese de Doutorado, Campinas: Universidade Estadual de Campinas.

LACAZ, F. A. et al. Estudo da Situação e Tendências da Vigilância em Saúde do Trabalhador no Brasil. Relatório final (convênio Abrasco-Opas). Brasília, 2003.

MACHADO, J. M. H. Alternativas e Processos de Vigilância em Saúde do Trabalhador: a heterogeneidade da intervenção, 1996. Tese de Doutorado, Rio de Janeiro: Escola Nacional de Saúde Pública Sergio Arouca, Fundação Oswaldo Cruz.

MACHADO, J. M. H. et al. Alternativas e processos de vigilância em saúde do trabalhador relacionados à exposição ao benzeno no Brasil. Ciência Ė Saúde Coletiva, 8(4): 913-921, 2003.

MINAYO-GOMEZ, C. M. \& LACAZ, F. A. C. Saúde do trabalhador: novas-velhas questões. Ciência $\mathcal{E}$ Saúde Coletiva, 10(4): 797-807, 2005.

MONKEN, M. Espaço e vigilância em saúde: uma perspectiva operacional para a territorialização em sistemas locais de saúde. In: CONGRESSO BRASILEIRO DE SAÚDE COLETIVA, 2000, Salvador. Anais... Salvador: Abrasco, 2000.

PINHEIRO, T. M. M. et al. A vigilância em saúde do trabalhador. In: CONFERÊNCIA NACIONAL DE SAÚDE DO TRABALHADOR, 3, 2005, Brasília. (Texto de apoio).

REZENDE, J. O Caso Shell, Cyanamide, Basf, Epidemiologia e Informação para o Resgate de uma Precaução Negada, 2005. Tese de Doutorado, Campinas: Universidade Estadual de Campinas.

WÜNSCH FILHO, V.; SETIMI, M. M. \& CARMO, J. C. Vigilância em saúde do trabalhador. In: CONGRESSO BRASILEIRO DE SAÚDE COLETIVA, 1992, Porto Alegre. Anais.... Porto Alegre: Abrasco, 1992. 



\section{Saúde do Trabalhador no SUS: Contexto, ESTRATÉGIAS E DESAFIOS}

Ana Paula Lopes dos Santos

Francisco Antonio de Castro Lacaz

\section{Contexto Histórico: os Programas de Saúde do Trabalhador}

No espaço da saúde pública, com a posse dos governadores eleitos diretamente em 1982, aumentaram os esforços para a condução de um movimento político-ideológico de criação dos Programas de Saúde dos Trabalhadores - PST (Lacaz, 1997), principalmente em São Paulo, Minas Gerais, Rio de Janeiro, Bahia e Rio Grande do Sul (Dias, 1994).

Os PST são uma tendência mundial, influenciada por organismos internacionais, como a Organização Internacional do Trabalho (OIT), a Organização Mundial da Saúde (OMS) e a Organização Pan-Americana da Saúde (Opas), que preconizavam ações de saúde ocupacional na rede de serviços de saúde pública desde a década de 1970, "quando a crise socioeconômica do sistema capitalista começava a atingir níveis alarmantes” (Freitas et al., 1986: 4).

Em São Paulo, a partir de 1984, são criados PST no município de São Paulo, nas regiões do litoral/Baixada Santista, Bauru, Vale do Ribeira, Campinas, Santos e no ABCD. ${ }^{1}$ Esses PST tinham em comum sua inclusão na programação de adultos; ênfase na história profissional; uso de instrumentos da vigilância epidemiológica e sanitária, para, confirmada a existência de casos de doenças, intervir sobre seu processo gerador, nos locais de trabalho; articulação interinstitucional e interlocução constante com o movimento sindical (Lacaz, 1996).

$1 \mathrm{ABCD}$ se refere à Região Metropolitana de São Paulo que envolve os municípios de Santo André, São Bernardo do Campo, São Caetano do Sul e Diadema. 
Frise-se que eram organizados todos eles na perspectiva de acoplar ações de assistência à saúde às ações de vigilância dos ambientes de trabalho, com ênfase na interlocução com o movimento social de trabalhadores e na atividade interinstitucional e multiprofissional, procurando sempre uma aproximação com a universidade. Tais experiências desenvolvem-se de maneira a avançar sobre o conhecimento das realidades de saúde e doença das populações trabalhadoras, constituindo-se em importante elemento de denúncia da morbi-mortalidade dessas populações. Esta abordagem preconizada pelos pressupostos da medicina social latino-americana e da saúde coletiva, com peso particularmente importante da determinação social do processo saúde-doença, assume que as relações entre trabalho e saúde são as mais privilegiadas para o estudo e a demonstração/comprovação dessa determinação (Lacaz, 1996).

Um dos indicadores da efetividade dos PST sobre o diagnóstico das doenças profissionais foi o desvelamento das doenças ocultas, evidenciando verdadeiras 'epidemias' delas, com o aumento, em termos tanto relativos como absolutos, do número de doenças profissionais registradas pelas estatísticas da previdência social, no período de 1985 a 1987 (Lacaz, 1992).

Contemporânea ao movimento da Reforma Sanitária, a estratégia de inserção da atenção à saúde dos trabalhadores na saúde pública obtém maior repercussão com a $8^{a}$ Conferência Nacional de Saúde, em 1986, que propõe a criação do Sistema Único de Saúde (SUS). Em dezembro desse mesmo ano acontece a I Conferência Nacional de Saúde do Trabalhador, na qual se ratifica tal proposição.

A prática acumulada nos PST, embasada na participação dos trabalhadores - em alguns casos na própria gestão, controle e avaliação, integralidade das ações de assistência e vigilância, e universalidade de acesso -, orienta a atenção à saúde dos trabalhadores como atribuição do SUS (Lacaz, 1992, 1996).

A consolidação, no âmbito legal, da atenção no SUS é garantida com sua inscrição na Constituição Federal de 1988 e na Lei Orgânica de Saúde - lei n. 8.080/90 (Brasil, 2005a). O Ministério da Saúde assume, desde então, o compromisso de reestruturar o modelo de atenção no Brasil partindo de um referencial de saúde como direito de cidadania, pressupondo a organização de serviços cada vez mais resolutivos, integrais e humanizados (Souza \& Carvalho, 2003).

A partir de 1998, com a publicação da Norma Operacional de Saúde do Trabalhador - portaria n. 3.908, de 30/10/98 (Brasil, 2005d) -, são estabelecidos os procedimentos para orientar e instrumentalizar as ações e os serviços no 
SUS. Esse aparato legal institucionaliza o direito à informação sobre a saúde, o controle social, a regionalização e a hierarquização das ações, bem como a utilização do critério epidemiológico e de avaliação de riscos no planejamento e avaliação das ações, visando ao estabelecimento de prioridades para a alocação de recursos e para o desenvolvimento de um conjunto de ações de vigilância e de assistência à saúde dos trabalhadores (Santos, 2001).

Os pressupostos básicos que norteiam essas ações são: a universalidade, a equidade e a integralidade das ações, contemplando seu planejamento e execução, na perspectiva de um movimento constante em direção à mudança do modelo assistencial para a atenção integral, articulando ações individuais e coletivas de vigilância da saúde (Portaria MS n. 3.908, de 30/10/1998).

\section{Os Centros de Referência em Saúde do Trabalhador}

No final da década de 1980, iniciam-se debates acerca das concepções de organização dos serviços de saúde no SUS (Minayo-Gomez \& Lacaz, 2005). Por um lado, defendia-se a criação de centros regionais de saúde do trabalhador, que seriam referência para a rede; por outro, acreditava-se que essa conformação contribuiria para a concentração das ações de saúde dos trabalhadores apenas nesses centros (Maeno \& Carmo, 2005).

A organização do processo de municipalização influencia esse debate, e "como alternativa para potencializar os escassos recursos disponíveis, facilitar o diálogo com o movimento social e capacitar profissionais para desenvolver as ações propostas” (Dias \& Hoefel, 2005: 819), são criados os Centros de Referência em Saúde do Trabalhador (CRST). São serviços específicos e especializados, de nível secundário, e que buscam incorporar maior densidade tecnológica em seu quadro de profissionais, de apoio diagnóstico e de vigilância (Lacaz, 1996). Esses serviços foram constituindo-se em importantes municípios do país, como São Paulo, Campinas, Santos, Porto Alegre, Belo Horizonte e Volta Redonda (Lacaz, Machado \& Porto, 2002; Minayo-Gomez \& Lacaz, 2005). No município de São Paulo, por exemplo, os CRSTs são caracterizados como "unidades especializadas, de modo a servir de retaguarda e constituíremse como centros articuladores das práticas de Saúde do Trabalhador na rede básica de saúde" (Spedo, 1998: 83, grifos nossos).

A estratégia de implantação dos CRSTs permitiu avanços setoriais, acúmulo de experiências e conhecimentos técnicos, mas tem contribuído para manter a área à margem das políticas de saúde do SUS, uma vez que esses centros têm 
sido excluídos do sistema como um todo (Hoefel et al., 2005), expressando a grande dificuldade de articulação intrassetorial, nos níveis básicos de atenção à saúde, nos níveis especializados e também nas instâncias de vigilância. Do ponto de vista da atuação intersetorial, essas ações podem se constituir em espaços de lutas corporativas, limitadas a avaliações pontuais e de baixa eficácia na implantação de mudanças nas condições e nos processos de trabalho (Machado, 1997).

Muitos problemas para a atenção à saúde dos trabalhadores na rede pública de saúde estão apontados, tais como: a persistência do modelo assistencial centrado na consulta médica individual em detrimento das ações coletivas; a insuficiência ou inexistência quantitativa e qualitativa das ações de promoção e proteção da saúde; a indefinição e/ou duplicidade de atribuições, no SUS e entre as instituições governamentais; a carência e o despreparo dos recursos humanos para a abordagem das questões de saúde dos trabalhadores; informações insuficientes, inacessíveis ou pouco ágeis; e as dificuldades para a implementação de uma real e efetiva participação dos trabalhadores (Dias, 1994).

Mesmo considerados como experiências válidas no momento de implantação, os CRSTs são hoje objeto de reavaliação, visto que a rede do SUS ainda permanece alheia à discussão da relação entre trabalho e saúde, de modo a adequar os procedimentos de assistência e demais ações decorrentes de uma doença ou acidente de trabalho, apresentando um impacto pequeno na intervenção sobre os ambientes e processos de trabalho (Lacaz, Machado $\&$ Porto, 2002).

Paradoxalmente, apesar do aparato legal, já referido, inexiste uma Política Nacional de Saúde do Trabalhador, com um quadro referencial de princípios norteadores, diretrizes, estratégias, metas e um corpo profissional técnicopolítico preparado, integrado e estável para garantir ações de promoção à saúde, prevenção e atenção aos problemas de saúde decorrentes do trabalho (Minayo-Gomez \& Lacaz, 2005).

Mesmo incorporada no organograma e nas práticas do Ministério da Saúde, dos estados e dos municípios, ao longo de sua história a saúde do trabalhador tem sido colocada ora no âmbito da estrutura da vigilância, ora na assistência ou em outras instâncias administrativas do SUS, dependendo do formato institucional vigente (Dias \& Hoefel, 2005). 


\section{A Rede Nacional de Atenção à Saúde do Trabalhador: ESTADO DA ARTE}

O Ministério da Saúde, a partir da Secretaria de Assistência à Saúde, publicou a portaria n. 1.679, de 19 de setembro de 2002 (Brasil, 2005c), criando a Rede Nacional de Atenção Integral à Saúde do Trabalhador (Renast), apontada como a principal estratégia do SUS para a promoção da atenção integral à saúde dos trabalhadores. Conceitualmente, "a Renast é uma rede nacional de informação e práticas de saúde, organizada com o propósito de implementar ações assistenciais, de vigilância e de promoção da saúde no SUS, na perspectiva de saúde do trabalhador" (Dias \& Hoefel, 2005: 822).

A criação e a expansão da rede de Centros de Referência em Saúde do Trabalhador, agora conhecidos pela sigla Cerests, foram as principais medidas estabelecidas por essa portaria. Por meio da organização das ações e serviços voltados para a atenção da saúde dos trabalhadores, pretende sua incorporação na rede de serviços de saúde pública (São Paulo/Cerest, 2005). Esses centros devem ser compreendidos como polos irradiadores, no âmbito de um determinado território, da relação do processo de trabalho com a saúde e devem assumir a função de suporte técnico e científico em saúde do trabalhador (Braga Jr., 2005).

Dentre as atribuições e ações a serem desenvolvidas pelos Cerests, vale apontar as tarefas de:

prover suporte técnico adequado às ações de assistência e vigilância em saúde do trabalhador; recolher, sistematizar e difundir informações de modo a viabilizar as ações de vigilância, facilitar os processos de capacitação e educação permanente para os profissionais e técnicos da rede SUS e o Controle Social. (Dias \& Hoefel, 2005: 822)

Além disso, a portaria sinalizava a implantação de 130 Cerests, sendo 27 estaduais e 103 regionais, no período de 2002 a 2004, assim como criava parâmetros mínimos para a composição da equipe desses centros e os valores dos recursos financeiros a serem repassados para os centros habilitados pela Renast.

Ao se referirem à Renast, Maeno e Carmo (2005) lembram que a portaria que a criou padece de um pecado de origem. Por ter sido gerada pela Secretaria de Atenção à Saúde (SAS), trata somente da assistência, sem dispor sobre a vigilância nos ambientes de trabalho, pilar fundamental para a prevenção de danos relacionados ao trabalho.

Três anos depois de sua criação, foi publicada a portaria n. 2.437, dispondo sobre a ampliação e o fortalecimento da Renast (Brasil, 2005f). Destaque-se que 
em 2009 foi publicada a portaria n. 2.728, de 11/11/2009, dispondo sobre a implementação da Renast, mediante: 1) estruturação da rede de Cerests; 2) inclusão das ações de saúde do trabalhador na atenção básica, por meio da definição de protocolos, estabelecimento de linhas de cuidado e outros instrumentos que favoreçam a integralidade; 3) implementação das ações de promoção e vigilância em saúde do trabalhador; 4) instituição e indicação de serviços de saúde do trabalhador de retaguarda, de média e alta complexidades já instalados, aqui chamados de Rede de Serviços-Sentinela em Saúde do Trabalhador; e 5) caracterização de municípios-sentinela em saúde do trabalhador. ${ }^{2}$

Os Cerests continuam sendo entendidos como unidades especializadas de retaguarda para as ações de saúde do trabalhador no SUS, envolvendo "ações de prevenção, promoção, diagnóstico, tratamento, reabilitação e vigilância em saúde dos trabalhadores urbanos e rurais, independentemente do vínculo empregatício e do tipo de inserção no mercado de trabalho” (Brasil, 2009).

Vale destacar também que o controle social dos serviços que compõem a Renast se dá mediante a participação de organizações de trabalhadores e empregadores, das Conferências de Saúde, dos Conselhos de Saúde e das Comissões Intersetoriais de Saúde do Trabalhador (Cist). Já no âmbito dos Cerests, o controle social previsto deve ser executado com a criação e a implementação dos conselhos gestores desses serviços (Silveira et al., 2005).

Atualmente, todos os estados do Brasil e o Distrito Federal possuem Cerests estaduais habilitados pela Renast. O estado de São Paulo tem o maior número deles, totalizando 42 centros habilitados. O Quadro 1 dá uma dimensão do processo de ampliação das estratégias dos Cerests em todo o país (Brasil, 2009).

2 Os municípios-sentinela são definidos com base em dados epidemiológicos, previdenciários e econômicos, que indiquem fatores de riscos significativos à saúde do trabalhador, oriundos de processos de trabalho em seus territórios (Portaria MS n. 2.728/2009). 
Quadro 1 - Distribuição dos Cerests habilitados e a serem habilitados

\begin{tabular}{|c|c|c|c|c|}
\hline Regiões/Estados & População & \begin{tabular}{|c|} 
Cerests \\
habilitados até \\
março/2009 \\
\end{tabular} & $\begin{array}{c}\text { Cerests a serem } \\
\text { habilitados }\end{array}$ & Total \\
\hline NORTE & 13.504 .612 & 15 & 4 & 19 \\
\hline Rondônia & 1.431 .776 & 2 & - & 2 \\
\hline Acre & 586.945 & 1 & 1 & 2 \\
\hline Amazonas & 2.961 .804 & 3 & - & 3 \\
\hline Roraima & 346.866 & 1 & 1 & 2 \\
\hline Amapá & 516.514 & 1 & 1 & 2 \\
\hline Pará & 6.453 .699 & 4 & 1 & 5 \\
\hline Tocantins & 1.207 .008 & 3 & 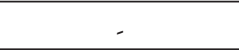 & 3 \\
\hline Nordeste & 48.845 .219 & 54 & 2 & 56 \\
\hline Maranhão & 5.803 .283 & 4 & 1 & 5 \\
\hline \begin{tabular}{|l|} 
Piauí \\
\end{tabular} & 2.898 .191 & 4 & 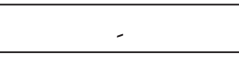 & 4 \\
\hline Ceará & 7.654 .540 & 8 & . & 8 \\
\hline Rio Grande do Norte & 2.852 .800 & 4 & - & 4 \\
\hline Paraíba & 3.494 .965 & 4 & - & 4 \\
\hline Pernambuco & 8.084 .722 & 9 & - & 9 \\
\hline Alagoas & 2.887 .526 & 3 & 1 & 4 \\
\hline \begin{tabular}{|l|} 
Sergipe \\
\end{tabular} & 1.846 .042 & 3 & - & 3 \\
\hline Bahia & 13.323 .150 & 15 & 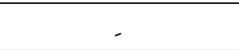 & 15 \\
\hline SUDESTE & 74.447 .443 & 72 & 10 & 82 \\
\hline Espírito Santo & 3.201 .712 & 3 & 2 & 5 \\
\hline Minas Gerais & 18.343 .518 & 17 & 2 & 19 \\
\hline Rio de Janeiro & 14.724 .479 & 10 & 6 & 16 \\
\hline São Paulo & 38.177 .734 & 42 & - & 42 \\
\hline SuL & 25.734 .111 & 23 & 6 & 29 \\
\hline Paraná & 9.797 .965 & 6 & 4 & 10 \\
\hline Santa Catarina & 5.527 .718 & 7 & 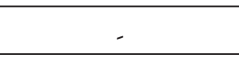 & 7 \\
\hline Rio Grande do Sul & 10.408 .428 & 10 & 2 & 12 \\
\hline Centro-Oeste & 13.238 .067 & 14 & - & 14 \\
\hline Mato Grosso & 2.000 .000 & 3 & - & 3 \\
\hline Mato Grosso do Sul & 2.140 .620 & 3 & - & 3 \\
\hline Goiás & 7.000 .000 & 5 & - & 5 \\
\hline \begin{tabular}{|l} 
Distrito Federal \\
\end{tabular} & 2.097 .447 & 3 & - & 3 \\
\hline Total & 174.632 .932 & 178 & 22 & 200 \\
\hline
\end{tabular}

Fonte: Portaria n. 2.728, Anexo IV (Brasil, 2009). 
No estado de São Paulo, foi criado o Grupo Estadual de Implantação e Acompanhamento da Renast (Geiar), vinculado à Comissão Intergestora Bipartite (CIB), com representação da Secretaria de Estado da Saúde e do Conselho de Secretários Municipais, tendo como convidados representantes do Conselho Estadual de Saúde (Maeno \& Carmo, 2005).

Na primeira fase de implantação, os Cerests (estadual e regionais) de São Paulo foram habilitados obedecendo aos seguintes critérios da Comissão Intergestora Regional (CIR): 1) sede de Diretoria Regional de Saúde (DIR) como critério de base geográfica, levando-se em conta a conveniência administrativa e buscando-se a pactuação geral por intermédio das CIR; 2) serviços já instalados; 3) demanda social; 4) interesse do gestor municipal em desempenhar o papel de referência regional; 5) articulação interinstitucional; e 6) acessibilidade (São Paulo, 2005).

Em 2009, a Renast contava com 178 Cerests habilitados e cerca de 400 unidades-sentinela. Os centros regionais receberam repasse de 30 mil reais mensais, enquanto os estaduais, 40 mil - o que totalizou cerca de 54 milhões por ano de investimento do Ministério da Saúde, distribuído entre os Cerests já consolidados, alguns com mais de vinte anos de existência, e também novos serviços criados pela Renast.

No que tange ao modelo de atenção, Dias e Hoefel (2005) afirmam que ao estar inserida no SUS, a Renast deve obedecer a seus princípios e qualificar essa atenção. Apesar da ponderação, foi proposto um modelo de atenção à saúde dos trabalhadores para a Renast (Brasil, 2006a), no qual a rede de cuidados assistenciais (atenção básica, urgência e emergência, média e alta complexidades) notificam os agravos à saúde relacionados ao trabalho, que são processados pelo sistema de informação. Na outra ponta da atenção, as ações de vigilância (sanitária, epidemiológica e ambiental) também podem gerar e alimentar o sistema de informação, assim como encaminhar os casos para notificação na rede de assistência. No sistema de informações, os casos notificados são processados e ganham a dimensão de um fenômeno coletivizado que desencadeará as diversas ações de saúde do trabalhador. Dessa forma, seria somente com a constatação do nexo causal do agravo ou doença com o trabalho e sua notificação no sistema de informação que os procedimentos de vigilância seriam desencadeados.

Nesse modelo, o primeiro passo para a articulação da atenção à saúde dos trabalhadores, na rede do SUS, é sua caracterização como agravos à saúde relacionados ao trabalho. A propósito da notificação desses agravos, existem 
alguns instrumentos em vigor. Entre eles, a lista das doenças (agravos) relacionadas ao trabalho, portaria n. 1.339, de 18/11/1999 (Brasil, 1999), publicada em cumprimento à determinação contida na Lei Orgânica de Saúde, e o livro Doenças Relacionadas ao Trabalho: manual de procedimentos para os serviços de saúde (Brasil, 2001). Essas publicações contêm cerca de duzentas entidades nosológicas reconhecidas como relacionadas ao trabalho -, entre elas, os transtornos mentais e do comportamento relacionados ao trabalho, caracterizados no Grupo V segundo a Classificação Internacional das Doenças (CID 10).

Outro instrumento pautado diz respeito à notificação compulsória - portaria GM/MS n. 777, de 28/4/2004 (Brasil, 2004) - que dispõe sobre os procedimentos técnicos para a notificação dos agravos à saúde dos trabalhadores em rede de serviços-sentinela específica, no SUS. A notificação desses eventos é objeto dos protocolos de notificação. Até hoje, dez protocolos foram publicados. ${ }^{3}$

A priorização do investimento nos Cerests apresenta-se como a estratégia política atual do Ministério da Saúde, no âmbito da saúde do trabalhador, desenvolvida com a institucionalização da Renast. $\mathrm{O}$ contexto contemporâneo em que essa estratégia é implantada demanda uma reflexão teórica e metodológica sobre as bases da atuação em saúde do trabalhador no SUS, inclusive sobre os pressupostos formulados por esse campo.

\section{Desafios e Perspectivas}

Diante desse quadro, destacamos algumas questões pertinentes quanto às possibilidades e dificuldades para a consolidação das ações de saúde dos trabalhadores na rede do SUS, já apresentadas em pesquisas anteriores (Lacaz, Machado \& Porto, 2002).

\section{Intrassetorialidade}

Um primeiro aspecto que merece destaque diz respeito à intrassetorialidade. Muitos Cerests já consolidados se tornaram porta de entrada dos trabalhadores com doenças ocupacionais ou acidentes do trabalho (Santos, 2001), isto é, não se constituem como unidade de referência em saúde do trabalhador,

3 Os protocolos publicados são: 1) anamnese ocupacional; 2) acidentes do trabalho fatais, graves e com crianças e adolescentes; 3) LER/Dort; 4) exposição ao chumbo metálico; 5) perda auditiva induzida por ruído; 6) pneumoconiose; 7) risco químico: benzeno; 8) câncer relacionado ao trabalho; 9) dermatoses ocupacionais; 10) materiais biológicos (Brasil, 2006b). 
de retaguarda técnica, para o manejo de problemas mais complexos e/ou especializados, mas sim um espaço que acolhe os trabalhadores que sofreram acidentes ou doenças ocupacionais. $\mathrm{O}$ enfoque sobre a assistência à saúde dos trabalhadores ainda constitui o foco das ações dos Cerests. Por isso, apesar das novas orientações, muitos continuam a se estruturar para promover o atendimento a esses trabalhadores, com equipamentos de fisioterapia e terapia ocupacional adquiridos com recursos da própria Renast. No entanto, esse modelo apresenta um impacto pequeno na intervenção sobre os ambientes e processos de trabalho nocivos à saúde (Lacaz, Machado \& Porto, 2002).

A construção da intrassetorialidade nas instâncias da atenção básica Programa de Saúde da Família (PSF), urgência e emergência -, média e alta complexidades, assim como a articulação das instâncias de vigilância em saúde do trabalhador - epidemiológica, sanitária e ambiental - constitui questão muito importante para superação do modelo assistencial dos Cerests. A própria portaria de 2009 prevê essa adequação pela inclusão das ações de saúde dos trabalhadores na rede básica e pela implementação das ações de vigilância e promoção em saúde. Romper a lógica assistencial ainda é um grande desafio para a própria estruturação da Renast e da atenção à saúde dos trabalhadores no SUS. As ações coletivas, no âmbito da vigilância, da promoção e proteção da saúde, mesmo que mais efetivas, estão em segundo plano, em decorrência de um modelo centrado na consulta médica e na abordagem individual do trabalhador.

Seria de suma importância que a Renast caminhasse para a superação da dicotomia entre assistência e vigilância e estimulasse a construção de estratégias de prevenção dos agravos e promoção da saúde (Minayo-Gomez \& Lacaz, 2005). Em 2007, a Coordenação de Saúde do Trabalhador (Cosat), do Ministério da Saúde, foi deslocada da Secretaria de Atenção à Saúde para a de Vigilância Sanitária (Brasil, 2007). Essa mudança na estrutura organizacional do Ministério da Saúde poderia representar um passo à frente na superação dessa lógica? De que forma?

\section{A Vigilância em Saúde do Trabalhador}

São muitas as concepções sobre a Vigilância em Saúde do Trabalhador (Visat). A mais limitada e mais frequentemente utilizada é a concepção de que ela se restringe às inspeções pontuais nos locais de trabalho, que seguiriam a lógica cartorial do Ministério do Trabalho e Emprego, mas apresentam baixa 
eficácia na implantação de efetivas mudanças nas condições de trabalho. Mesmo nessa perspectiva, "a entrada nas empresas para realização de investigações nos locais de trabalho é cercada de entraves e explicações relacionadas ao jogo de legitimação social do SUS como órgão fiscalizador dos locais de trabalho" (Machado, 1997: 36).

No entanto, quando a equipe de vigilância entra nesses locais, eles são apresentados pelas empresas com características menos danosas à saúde: máquinas perigosas são desligadas, o ritmo de trabalho é diminuído etc. (Sato et al., 2004). Em certos casos, a necessidade de interdição, observada pelas equipes de vigilância, gera contradições para os próprios trabalhadores, visto que a luta pela manutenção do emprego (Dias \& Hoefel, 2005) condiz com a submissão consciente a tais condições, o que parece indicar um fator adicional de sofrimento psíquico (Sato \& Bernardo, 2005).

$\mathrm{Na}$ instrução normativa de Visat, esta é conceituada como uma

atuação contínua e sistemática ao longo do tempo, no sentido de detectar, conhecer, pesquisar e analisar os fatores determinantes e condicionantes dos agravos à saúde relacionados aos processos e ambientes de trabalho, em seus aspectos tecnológico, social, organizacional e epidemiológico, com a finalidade de planejar, executar e avaliar intervenções sobre esses aspectos, de forma a eliminá-los ou controlá-los. (Brasil, 1998)

Entretanto, a Visat vem sendo construída por meio de uma gama de experiências distintas, desenvolvidas por grupos institucionais localizados em vários pontos do Brasil, com diferentes graus de organização, competências, atribuições, recursos e práticas de atuação. Interferir na forma como o trabalho está organizado em favor da saúde dos trabalhadores - como redução do ritmo de trabalho, aumento do número de trabalhadores, modificação do conteúdo das tarefas, mudança na dinâmica das relações interpessoais e da estrutura hierárquica - traz consequências para os interesses do capital (Sato et al., 2004) e demanda uma ação contínua e sistemática dos atores sociais envolvidos com a saúde do trabalhador. Por isso, mais do que nunca, a atuação intrassetorial, suas interfaces com as vigilâncias sanitária, epidemiológica e ambiental, e a articulação intersetorial dos Cerests com as instituições locais do trabalho e da previdência social devem ser estimuladas. Para tanto, o estabelecimento de critérios de prioridades para investigação, em torno de casos relevantes em que redes de intervenção intersetoriais possam ser construídas, mostra-se como estratégia real para provocar mudanças na relação do processo de trabalho com a saúde. 
No entanto, foi a realidade do trabalho urbano, regulamentado pela Consolidação das Leis do Trabalho (CLT), que de início assumiu o foco da Visat. Atualmente, a precarização das relações de trabalho e o crescimento do desemprego e do setor informal criam outras demandas em saúde do trabalhador e principalmente sobre as práticas de vigilância até então instituídas. Segundo essa lógica, mesmo que o termo 'vigilância em saúde do trabalhador' seja recorrente nas portarias e nos manuais de gerenciamento da Renast, sua concepção, suas formas de atuação e articulação não estão claramente delineadas para os Cerests. A construção e a publicação de protocolos de Visat auxiliariam na superação de algumas dificuldades nesse processo?

\section{Controle social e participação dos trabalhadores}

É importante destacar que, com o processo de desregulamentação das relações de trabalho, o SUS assume um papel diferenciado, como a única política pública de cobertura universal (Dias \& Hoefel, 2005). Assim, a clientela dos Cerests, antes encaminhada por sindicatos ou pela previdência social, passou a ser de trabalhadores do setor informal/precário ou de desempregados. Nesse sentido, torna-se premente para os Cerests a construção de abordagens para a investigação e a intervenção que considerem a configuração contemporânea do mundo do trabalho e, ao mesmo tempo, deem conta da inclusão e da participação dos trabalhadores.

Os mecanismos de controle social, como os Conselhos de Saúde do Trabalhador, previstos pela Renast, devem ser compostos com a participação de organizações de trabalhadores e empregadores e têm o papel de elaborar os planos de saúde dos Cerests. Essa forma de controle social é apenas uma parte da discussão sobre participação dos trabalhadores nas ações de saúde do trabalhador, visto que, na década de 1980, os PST tinham como atores sociais mais significativos as organizações sindicais, inclusive na própria gestão dos programas. A garantia da efetividade das ações em saúde do trabalhador só é possível com a participação dos trabalhadores em todo o processo de atenção, tanto para investigar a situação real de trabalho quanto para assegurar a implementação das mudanças sugeridas com base nessas avaliações (Sato et al., 2004). No entanto, a participação dos trabalhadores e dos sindicatos está fragilizada nesse cenário de desemprego estrutural e globalização neoliberal. Diante desse paradoxo, é de suma relevância a discussão dos mecanismos de controle social institucionalizados com a Renast. A representação dos trabalhadores nesses conselhos corresponde à realidade dos trabalhadores da região de abrangência? 
Qual o papel da representação dos empregadores nessas instâncias de controle social? Elas são de fato representativas do mundo do trabalho contemporâneo?

Se entendemos que o conhecimento e a participação dos trabalhadores são essenciais para a construção das ações em saúde do trabalhador, qual deveria ser o grau de compromisso, mobilização e envolvimento desses atores com relação ao planejamento, acompanhamento e avaliação das ações dos Cerests e da própria Renast?

\section{Mudança no perfil de morbidade dos trabalhadores}

No cenário contemporâneo, os modos de adoecer e morrer dos trabalhadores vêm se transformando e ganhando maior complexidade. Essa complexidade se traduz no aumento da prevalência das lesões por esforços repetitivos (LER) e "em formas de adoecimento mal caracterizadas como estresse, a fadiga física e mental e outras expressões de sofrimento relacionadas ao trabalho" (Dias \& Hoefel, 2005: 820). A evidência da problemática dessa relação, embora observada em algumas experiências dos Cerests como uma questão coletiva, ainda não passa necessariamente pelo diagnóstico e pela notificação. Na experiência do centro regional de Porto Alegre (RS), por exemplo,

a questão do adoecimento como expressão da exclusão, o isolamento social, a ruptura de vínculos, o sentimento de impotência individual e a culpabilidade pelo adoecimento, assim como os sintomas depressivos, já não apareciam como problemas intrapsíquicos isolados, mas como dramas coletivos. (Barfknecht et al., 2004: 321)

Em Campinas (SP), os problemas de saúde mental relacionados ao trabalho também se apresentam como uma questão secundária para os trabalhadores que buscam o Cerest (Sato \& Bernardo, 2005). As autoras observam uma baixa notificação desses problemas em relação ao total de atendimentos, em que a LER representa 70\% dos casos notificados. O mesmo ocorre nos Cerests de Santo Amaro e Sé, onde, na prática, os distúrbios psíquicos têm representado uma parcela pequena do atendimento desses serviços, devido às dificuldades inerentes ao reconhecimento dessa relação por parte dos profissionais de saúde, dos sindicatos e dos próprios trabalhadores (Glina et al., 2001).

Apesar dessa situação, as estatísticas do Instituto Nacional do Seguro Social (INSS), mesmo que limitadas aos trabalhadores regidos pela CLT, colocam os transtornos mentais entre as principais causas de concessão de benefício previdenciário: auxílio-doença, afastamento superior a quinze dias e aposentadorias por invalidez (Brasil, 2001). 
Os sindicatos de trabalhadores, mais atentos às questões de saúde no trabalho, relatam que os problemas de saúde mental e trabalho são cada vez mais observados, especialmente os fatores relacionados à organização do trabalho, como o ritmo acelerado, a pressão por produção, os constrangimentos cotidianos e a ameaça de desemprego (Sato \& Bernardo, 2005). No entanto, a organização do trabalho não se apresenta como fenômeno sobre o qual seja possível definir medidas objetivas, como se faz, por exemplo, em relação a produtos químicos e agentes físicos (Sato et al., 2004). Dessa forma, o número pouco significativo de diagnósticos não indica necessariamente sua baixa frequência na população trabalhadora, mas parece

mostrar a persistência da dificuldade por parte de todos os envolvidos - empresas, profissionais de saúde e peritos do INSS - em reconhecer o trabalho como causador de problemas de saúde mental, o que, conseqüentemente, reduz a busca de ajuda em serviços de referência, como os CRSTs. (Sato \& Bernardo, 2005: 872)

A 'invisibilidade' dos casos, sua interface com a subjetividade e a saúde mental do trabalhador e a dinâmica complexa do processo de organização do trabalho demandam análises de causalidade mais elaboradas, assim como respostas mais complexas dos Cerests, para lidar com essa realidade e intervir sobre ela. No entanto, como o modelo de atenção delineado pressupõe o estabelecimento da relação causal entre o dano e/ou doença e o trabalho (Jacques, 2003), à medida que persiste a lacuna na notificação de agravos à saúde mental, ${ }^{4}$ estes não ganham visibilidade coletiva e consequentemente não desencadeiam ações preventivas e de vigilância. Como superar essa lógica e intervir positivamente sobre o perfil de morbidade dos trabalhadores brasileiros?

\section{Abrangência regional e municipalização do SUS}

A organização dos Cerests por regiões constitui uma outra questão a ser analisada. Atualmente existem cerca de 150 Cerests de abrangência regional habilitados pela Renast. Frise-se que este número é elevado, considerando-se a massa crítica de pessoal capacitado, conforme apontaram Lacaz, Machado e Porto (2002) quando, segundo pesquisa para avaliar a situação da Visat no Brasil, observaram a existência de cerca de oitenta instâncias no país com capacidade para atuar em referência na área, o que dá origem aos 'Cerests

\footnotetext{
4 O protocolo de diagnóstico, acompanhamento e vigilância dos agravos à saúde mental relacionados ao trabalho, previsto na portaria n. 777, de 28/4/2004 (Brasil, 2004), ainda não foi publicado.
} 
de papel'. Alguns desses centros chegam a ter trinta municípios na sua área de abrangência, o que contradiz a organização municipalizada preconizada para o SUS. Além disso, é evidente a dificuldade de articulação dos serviços da rede do SUS com outras instâncias relacionadas à saúde do trabalhador, bem como com as organizações de trabalhadores em todos os municípios de abrangência dos Cerests. Por isso, apesar da organização regional, muitos têm limitado e priorizado sua atuação sobre o município sede, o que dificulta a inserção na rede do SUS e a cobertura do conjunto de trabalhadores da região. Os mecanismos de pactuação da gestão das ações em saúde do trabalhador constituem um elemento-chave para a construção de uma rede regionalizada e integrada. As diferenças regionais, as diversas concepções sobre a saúde do trabalhador, os diferentes interesses políticos influenciam fortemente a pactuação municipal da gestão regional dos Cerests. A Renast, como instância do Ministério da Saúde, poderia contribuir para os processos de pactuação dos procedimentos de assistência, vigilância e informação entre os municípios de abrangência desses centros de referência? Como?

\section{Pessoal envolvido em ações de saúde do trabalhador}

Outra questão importante refere-se à composição da equipe, à formação e à capacitação dos recursos humanos dos próprios Cerests. Até 2005, a Renast não cobria recursos para pagamento de pessoal, o que representava um grande entrave para a estruturação das equipes. Tal situação foi modificada com a portaria de ampliação da rede, cujo custeio do Ministério da Saúde passou a incluir o pagamento de pessoal.

No entanto, a falta de tradição, familiaridade e conhecimento dos profissionais de saúde sobre a determinação social do adoecimento e sobre a importância do conhecimento e participação dos trabalhadores leva à crônica incapacidade técnica para a intervenção sobre os processos de trabalho adoecedores. Superar essa lógica significa também dar visibilidade aos referenciais teóricos e às concepções do próprio campo, sem o qual o termo saúde do trabalhador é utilizado, mas se mantém o discurso hegemônico da medicina do trabalho e da saúde ocupacional.

Por isso, vale repensar a constituição das equipes mínimas de trabalho, na qual o médico do trabalho se torna figura central na articulação da rede, mantendo a perspectiva médico-assistencial-individual, da relação causal direta, em detrimento das ações de caráter coletivo. Para o estabelecimento da relação do trabalho e saúde, em toda a rede SUS, é de suma importância discutir a 
formação dos outros profissionais de saúde da rede. De que forma a articulação mais estreita da Renast com instituições de pesquisa e universidades poderia fornecer respostas e subsídios técnico-científicos para o enfrentamento dos problemas de formação de profissionais em saúde do trabalhador?

\section{Informação em saúde do trabalhador}

A partir da Renast, foram criados os serviços-sentinela, responsáveis pela notificação e por informações-base das ações de prevenção, vigilância e de intervenção articuladas pelos Cerests. A notificação compulsória dos acidentes e doenças relacionados ao trabalho no Sistema de Informação de Agravos de Notificação do SUS (Sinan NET) auxilia a organização dessas informações. No entanto, dadas as características próprias desse sistema, os dados gerados são processados internamente para o próprio SUS, mas não são objetos de divulgação externa.

O Observatório da Saúde do Trabalhador, produzido pelo Ministério da Saúde e pela Organização Pan-Americana da Saúde/Organização Mundial da Saúde (Opas/OMS) no Brasil, deveria propiciar o acesso a informações e análises dos dados da saúde dos trabalhadores. Hoje instalado no site da própria Opas, o observatório está desatualizado, sem informações precisas ou estatísticas recentes dos diagnósticos e medidas de intervenção decorrentes. Do mesmo modo, os dados sobre os Cerests no Brasil e da própria Renast ainda não constituem objeto desse portal ou mesmo do portal do próprio Ministério da Saúde. Na medida em que as informações processadas pelo SUS não ganham visibilidade social, as estatísticas da previdência social, mesmo que limitadas aos trabalhadores regidos pela CLT, ainda constituem a principal fonte de informações disponíveis ao público externo do SUS. Que mecanismos a Renast poderia fornecer para informar e discutir com os profissionais de saúde, trabalhadores em geral e universidades as questões atuais da saúde dos trabalhadores?

Obviamente, outras questões não abordadas neste capítulo, como a criação de indicadores de impacto das ações, de instrumentos e procedimentos de avaliação da qualidade da intervenção, aspectos relacionados ao financiamento, entre outras, atravessam a construção das práticas da saúde dos trabalhadores no SUS.

Fica, para nós, o desafio de analisar as estratégias adotadas e avaliar se o modelo proposto avança em direção a um modelo integrado, participativo e 
intersetorial. Nesse cenário adverso, o espraiamento de Cerests, a partir da Renast, poderia representar um importante papel na consolidação da atenção integral à saúde dos trabalhadores no SUS?

\section{REFERÊNCIAS}

BARFKNECHT, K. et al. A construção da saúde do trabalhador em Porto Alegre: processo de integração entre saúde do trabalhador e saúde mental. In: MERLO, A. R. C. (Org.) Saúde do Trabalhador do Rio Grande do Sul: realidade, pesquisa e intervenção. Porto Alegre: Editora da UFRGS, 2004.

BRAGA JR., D. A Gestão da Rede Nacional de Atenção Integral à Saúde do Trabalhador - Renast. In: BRASIL. Ministério da Saúde. 3a Conferência Nacional de Saúde do Trabalhador: "Trabalhar sim, adoecer não". Coletânea de textos. Brasília: Ministério da Saúde, 2005.

BRASIL. Ministério da Saúde. Portaria n. 1.339, de 18 de novembro de 1999. Institui a Lista de Doenças Relacionadas ao Trabalho. Disponível em: <www.saude.ba.gov. br/cesat/Legislacao/Portaria\%20Federal\%201.339.pdf>. Acesso em: 25 out. 2010.

BRASIL. Ministério da Saúde. Doenças Relacionadas ao Trabalho: manual de procedimentos para os serviços de saúde. Brasília: Ministério da Saúde, 2001.

BRASIL. Ministério da Saúde. Lei Orgânica da Saúde. Lei n. 8.080, de 19 de setembro de 1990. Dispõe sobre as condições para a promoção, proteção e recuperação da saúde, a organização e o funcionamento dos serviços correspondentes. In: MINISTÉRIO DA SAÚDE. Legislação em Saúde: caderno de legislação em saúde do trabalhador. 2. ed. Brasília: Ministério da Saúde, 2005a.

BRASIL. Ministério da Saúde. Portaria n. 3.120, de 1º de julho de 1998. Dispõe sobre a Instrução Normativa de Vigilância em Saúde do Trabalhador. In: MINISTÉRIO DA SAÚDE. Legislação em Saúde: caderno de legislação em saúde do trabalhador. 2. ed. Brasília: Ministério da Saúde, 2005b.

BRASIL. Ministério da Saúde. Portaria n. 1.679, de 19 de setembro de 2002. Dispõe sobre a Rede Nacional de Atenção Integral à Saúde dos trabalhadores - Renast. In: MINISTÉRIO DA SAÚDE. Legislação em Saúde: caderno de legislação em saúde do trabalhador. 2. ed. Brasília: Ministério da Saúde, 2005c.

BRASIL. Ministério da Saúde. Portaria n. 3.908, de 30 de outubro de 1998. Dispõe sobre a Norma Operacional de Saúde do Trabalhador. In: MINISTÉRIO DA SAÚDE. Legislação em Saúde: caderno de legislação em saúde do trabalhador. 2. ed. Brasília: Ministério da Saúde, 2005d.

BRASIL. Ministério da Saúde. Portaria n. 777, de 28 de abril de 2004. Dispõe sobre a notificação compulsória dos agravos relacionados ao trabalho. In: MINISTÉRIO DA SAÚDE. Legislação em Saúde: caderno de legislação em saúde do trabalhador. 2. ed. Brasília: Ministério da Saúde, 2005e. 
BRASIL. Ministério da Saúde. Portaria n. 2.437, de 7 de dezembro de 2005f. Dispõe sobre a ampliação da Renast. Disponível em: <www.renastonline.org/index. php?option=com_content $\&$ view $=$ article $\&$ id $=33$ : portaria- $n-0-2437-d e-0712-2005>$. Acesso em: 25 out. 2010.

BRASIL. Ministério da Saúde. Rede Nacional de Atenção Integral à Saúde do Trabalhador: manual de gestão e gerenciamento. Brasília: Ministério da Saúde, 2006a.

BRASIL. Ministério da Saúde. Protocolos de Atenção Diferenciada: saúde do trabalhador. Brasília: Ministério da Saúde, 2006b.

BRASIL. Ministério da Saúde. Portaria n. 1.956, de 14 de agosto de 2007. Dispõe sobre a coordenação das ações relativas à saúde do trabalhador no âmbito do Ministério da Saúde. Disponível em: <http://dtr2001.saude.gov.br/sas/PORTARIAS/Port2007/GM/ GM-1956.htm>. Acesso em: 25 out. 2010.

BRASIL. Ministério da Saúde. Portaria n. 2.728, de 11 de novembro de 2009. Dispõe sobre a Rede Nacional de Atenção Integral à Saúde do Trabalhador, Renast, e dá outras providências. Diário Oficial da União, 11 nov. 2009.

DIAS, E. C. A Atenção à Saúde dos Trabalhadores no Setor Saúde (SUS), no Brasil: realidade, fantasia, utopia?, 1994. Tese de Doutorado, Campinas: Universidade Estadual de Campinas.

DIAS, E. C. \& HOEFEL, M. G. O desafio de implementar as ações de saúde do trabalhador no SUS: a estratégia da Renast. Ciência $\mathcal{E}$ Saúde Coletiva, 10(4): 817-828, 2005.

FREITAS, C. U. et al. Saúde pública e ações de saúde do trabalhador: uma análise conceitual e perspectivas de operacionalização programática na rede básica da Secretaria de Estado da Saúde. Temas Instituto de Medicina Social e Criminalística. Sociedade, Direito, Saúde, 2(1): 3-10, 1986.

GLINA, D. et al. Saúde mental e trabalho: uma reflexão sobre o nexo com o trabalho e o diagnóstico com base na prática. Cadernos de Saúde Pública, 17(3): 607-616, 2001.

HOEFEL, M. G. et al. A atenção à Saúde do Trabalhador no SUS: a proposta de constituição da Renast. In: BRASIL. Ministério da Saúde. $3{ }^{\text {a }}$ Conferência Nacional de Saúde do Trabalhador: "Trabalhar sim, adoecer não". Coletânea de textos. Brasília: Ministério da Saúde, 2005.

JACQUES, M. G. C. Abordagens teórico-metodológicas em saúde/doença mental e trabalho. Psicologia Eु Sociedade, 15(1): 97-116, 2003.

LACAZ, F. A. C. O Programa de Saúde dos Trabalhadores da Secretaria de Estado de Saúde de São Paulo: a agonia de uma proposta. Saúde em Debate, 36: 41-47, 1992.

LACAZ, F. A. C. Saúde do Trabalhador: um estudo sobre as formações discursivas da academia, dos serviços e do movimento sindical, 1996. Tese de Doutorado, Campinas: Faculdade de Medicina, Universidade Estadual de Campinas.

LACAZ, F. A. C. Saúde dos trabalhadores: cenário e desafios. Cadernos de Saúde Pública, 13(2): 7-19, 1997. 
LACAZ, F. A. C.; MACHADO, J. M. H. \& PORTO, M. F. S. Estudo da Situação e Tendências da Vigilância em Saúde do Trabalhador no Brasil. Relatório de Pesquisa. Rio de Janeiro, 2002. (Mimeo)

MACHADO, J. M. H. Processo de vigilância em saúde do trabalhador. Cadernos de Saúde Pública, 13(2): 33-45, 1997.

MAENO, M. \& CARMO, J. C. A Saúde do Trabalhador no SUS: aprender com o passado, trabalhar o presente, construir o futuro. São Paulo: Hucitec, 2005.

MINAYO-GOMEZ, C. \& LACAZ, F. A. C. Saúde do trabalhador: novas e velhas questões. Ciência Eु Saúde Coletiva, 10(4): 797-807, 2005.

SANTOS, A. P. L. Entre o Imediatismo e o Planejamento: o desafio da construção da Vigilância em Saúde do Trabalhador no Centro de Referência em Saúde do Trabalhador do Espírito Santo, 2001. Dissertação de Mestrado, Rio de Janeiro: Cesteh/Ensp/Fiocruz. SATO, L. \& BERNARDO, M. H. Saúde mental e trabalho: os problemas que persistem. Ciência Eु Saúde Coletiva, 10(4): 869-878, 2005.

SATO, L. et al. Psychology and workers' health movement in the state of São Paulo. Journal of Health Psychology, 9(1): 121-130, 2004.

SÃO PAULO/CEREST (Secretaria de Estado da Saúde/Centro de Referência em Saúde do Trabalhador. Plano de Saúde do Trabalhador-SUS/SP. São Paulo: Rede de Saúde do Trabalhador-SUS-SP, 2005. (Mimeo.)

SILVEIRA, A. M. et al. O controle social no SUS e a Renast. In: BRASIL. Ministério da Saúde. $3^{\text {a }}$ Conferência Nacional de Saúde do Trabalhador: "Trabalhar sim, adoecer não”. Coletânea de textos. Brasília: Ministério da Saúde, 2005.

SOUZA, R. A. S. \& CARVAlHO, A. M. Programa de Saúde da Família: um olhar da psicologia. Estudos Psicologia (Natal), 8(3): 515-523, 2003.

SPEDO, S. M. Saúde do Trabalhador no Brasil: análise do Modelo de Atenção proposto para o Sistema Único de Saúde (SUS), 1998. Dissertação de Mestrado, Campinas: Faculdade de Ciências Médicas, Universidade Estadual de Campinas. 



\section{Desenvolvimento de Ações de Saúde do Trabalhador no SUS: a ESTRatéGIa da Rede Nacional de Atenção Integral à Saúde do Trabalhador (RenAst)}

\section{Elizabeth Costa Dias | Thais Lacerda e Silva Cláudia Vasques Chiavegatto | Juliana do Carmo Reis Augusto de Souza Campos}

A Rede Nacional de Atenção Integral à Saúde do Trabalhador (Renast), criada pela portaria GM/MS n. 1.679, de 19 de setembro de 2002 (Brasil, 2002), é a principal estratégia adotada pela área técnica do Ministério da Saúde, atual Coordenação Geral de Saúde do Trabalhador (CGSAT), da Secretaria de Vigilância em Saúde, para implementar o cuidado aos trabalhadores no Sistema Único de Saúde (SUS), considerando o papel do trabalho na determinação do processo saúde-doença.

A proposta da Renast surge em momento de grandes transformações no 'mundo do trabalho', no perfil produtivo e no perfil demográfico e epidemiológico dos trabalhadores, nas organizações sindicais e sociais, parceiros históricos do que se convencionou denominar 'movimento da saúde do trabalhador'. Além disso, no âmbito do SUS, em 2006, as Diretrizes Operacionais do Pacto pela Saúde, em suas três dimensões: pela Vida, em Defesa do SUS e de Gestão, reorientaram o cuidado à saúde no país (Brasil, 2006a).

Tantas mudanças dificultam a apreensão mais global da realidade e reforçam a necessidade da discussão sistemática e abrangente do tema. Com esse propósito, o Grupo de Trabalho (GT) de Saúde do Trabalhador da Associação Brasileira de Pós-Graduação em Saúde Coletiva (Abrasco) organizou, em 2007, o I Simpósio Brasileiro de Saúde do Trabalhador (Simbrast), favorecendo a análise de situação e a construção coletiva de alternativas para aperfeiçoamento do processo.

Este texto tem por objetivo contribuir para a reflexão sobre o processo de organização e desenvolvimento da Renast no Brasil, considerando os antece- 
dentes, os avanços e as dificuldades a serem superadas, tendo como referência as diretrizes para o modelo de atenção expressas no Pacto pela Saúde de 2006. Inicialmente, traça breve retrospectiva da construção de ações de saúde do trabalhador na rede de serviços de saúde no país até a criação da Renast, em 2002. Em seguida, descreve o processo de implementação da estratégia, caracterizando a situação em 2010, e os principais ganhos ou aspectos positivos e as dificuldades enfrentadas. Finalizando, são sugeridos pontos de uma agenda para a garantia da atenção integral à saúde do trabalhador no SUS.

\section{Aspectos histórico-CONCEItuals dO DESENVOLVIMENTO dE AÇÕES DE SAÚde DO TRABALHADOR NOS SERVIÇOS DE SAÚDE}

A implementação das ações de saúde do trabalhador na rede de serviços de saúde do SUS é um processo sociopolítico e técnico em construção. Ele tem início, no Brasil, no final dos anos 80 , na forma de ações isoladas, implementadas a partir de alianças solidárias entre as organizações e os sindicatos de trabalhadores e técnicos dos serviços públicos de saúde e de hospitais universitários, da fiscalização do Trabalho e da Previdência Social, em alguns estados e municípios brasileiros, conformando os Programas de Saúde do Trabalhador (PST).

O intenso processo de mobilização e reorganização social que culminou com o fim da ditadura militar - expresso, na saúde, no movimento pela Reforma Sanitária - permitiu que, no processo constituinte, a responsabilidade pelo cuidado da saúde dos trabalhadores fosse atribuída ao SUS.

A atribuição constitucional, regulamentada pela Lei Orgânica da Saúde, em 1990, impôs novo entendimento e novas práticas para a atenção integral à saúde dos trabalhadores no país (Brasil, 1988, 1990). Desde então, as ações de saúde do trabalhador na rede de serviços de saúde foram institucionalizadas nas três esferas de gestão do SUS: federal, estadual e municipal (Dias, 1994).

Considerando o princípio da universalidade de acesso, todos os trabalhadores, independentemente de sua localização, urbana ou rural, de sua forma de inserção no mercado de trabalho, formal ou informal, de seu vínculo empregatício, público ou privado, assalariado, autônomo, avulso, temporário, cooperativado, aprendiz, estagiário, doméstico, aposentado ou desempregado, têm direito ao cuidado à saúde provido pelo SUS. Rompeu-se, assim, ainda que parcialmente, a tradição brasileira de que apenas trabalhadores inseridos no setor formal de trabalho, registrados e contribuintes da previdência social 
dispunham de assistência médica, proteção trabalhista, traduzida na regulação e na inspeção das condições de trabalho e seguro de acidentes do trabalho, atribuições dos ministérios do Trabalho e da Previdência Social.

É importante ressaltar que a saúde do trabalhador nasce comprometida com a integralidade do cuidado da saúde, articulando as práticas de:

- Promoção da saúde: considera o trabalho como oportunidade de saúde, 'empoderando' os trabalhadores e desmistificando a visão de que o acidente e a doença são 'inerentes' ao seu desempenho.

- Vigilância à saúde: busca reconhecer as situações de risco e perigos gerados ou associados aos processos de trabalho para antecipar, prevenir, mudar.

- Assistência qualificada: reconhece o usuário como trabalhador inserido em uma situação particular de trabalho, para desenvolver ações integradas de promoção e proteção da saúde, de diagnóstico, tratamento e reabilitação.

Para a saúde do trabalhador, as ações de promoção, vigilância e assistência à saúde são indissociáveis, não importando o arranjo organizacional ou a 'caixinha' em que estão inseridas.

Um novo posicionamento surge da compreensão de que as questões de saúde do trabalhador e saúde ambiental têm determinantes comuns nos mesmos processos produtivos, responsáveis tanto pela degradação ambiental, traduzida na poluição do ar, da água e do solo, quanto pelos danos à saúde dos trabalhadores e da população moradora no entorno das unidades de produção. Isto tem aproximado as duas áreas, não somente no plano da organização institucional, mas também nas práticas de saúde, particularmente nas ações de vigilância.

Outra orientação importante para a atenção integral à saúde dos trabalhadores é a transversalidade das ações: intrassetoriais, no âmbito do próprio SUS, e interssetoriais, em articulação com outras instituições e aparelhos sociais que lidam com a questão, na esfera do Trabalho, da Previdência Social, do Meio Ambiente, da Educação, da Justiça do Trabalho, do Ministério Público, entre outros, em estreita parceria com as organizações dos trabalhadores.

Na perspectiva da articulação intrassetorial, o entendimento do trabalho como determinante do processo saúde-doença dos indivíduos e da coletividade e o reconhecimento do usuário como trabalhador devem permear as ações em todos os pontos de atenção da rede de saúde, desde a atenção primária, considerada, na atualidade, como ordenadora da rede de cuidado; os serviços 
especializados, incluindo a reabilitação; a atenção pré-hospitalar, de urgência e emergência e hospitalar; a rede de laboratórios e de apoio diagnóstico; a assistência farmacêutica; os setores responsáveis pela promoção e vigilância da saúde, os sistemas de informação e gestão da saúde, incluindo o planejamento, o acompanhamento, a regulação, avaliação e a auditoria.

Também é essencial a articulação com as ações das vigilâncias em saúde, em especial da vigilância ambiental; da gestão do trabalho e da educação na saúde; de gestão participativa; de ciência, tecnologia e insumos estratégicos; além da Agência Nacional de Vigilância Sanitária (Anvisa) e da Fundação Nacional de Saúde (Funasa).

Entre os fóruns estratégicos para a pactuação intrassetorial estão: o Conselho Nacional de Saúde (CNS); a Comissão Intersetorial de Saúde do Trabalhador (Cist); o Colegiado de Secretários do Ministério da Saúde; a Comissão Permanente de Saúde, Ambiente, Produção e Desenvolvimento Sustentável (Copesa); o Conselho Nacional de Secretários de Saúde (Conass) e o Conselho Nacional de Secretários Municipais de Saúde (Conasems).

A articulação intersetorial tem como interlocutores privilegiados os ministérios do Trabalho e Emprego, Previdência Social e Meio Ambiente. Outros fóruns de articulação intersetorial são: o Fórum Permanente de Erradicação do Trabalho Infantil; a Comissão Nacional de Segurança Química (Conasq); o Conselho Nacional de Direitos Humanos; a Comissão Técnica Nacional de Biossegurança (CTNBio), por exemplo.

A participação dos trabalhadores é considerada essencial em todas as fases do desenvolvimento das ações de saúde do trabalhador no SUS, entre elas a identificação dos fatores de risco presentes no trabalho e das repercussões sobre o processo saúde-doença, e para a transformação das condições geradoras de acidentes e doença. $\mathrm{O}$ crescimento das relações informais e precárias de trabalho exige a criação ou identificação de novas modalidades de representação dos trabalhadores, além das organizações sindicais tradicionais (Nehmy \& Dias, 2010; Silveira et al., 2005).

No desafio de fazer cumprir a lei e inserir as ações de saúde do trabalhador no SUS, são identificados alguns avanços e muitas dificuldades, entre os quais se destaca o despreparo dos profissionais de saúde para cuidar da saúde dos trabalhadores, considerando sua inserção nos processos produtivos, pela ausência da temática nos cursos de graduação e/ou nos processos de educação permanente em saúde. Outra dificuldade encontrada refere-se à superposição ou concorrência de algumas das atribuições mantidas no texto constitucional, 
fomentando conflitos entre os setores, particularmente quanto às ações de fiscalização dos ambientes e das condições de trabalho.

É preciso reconhecer que, vinte anos após a regulamentação da atribuição constitucional de que o SUS deve prover atenção integral à saúde dos trabalhadores, este objetivo ainda não foi plenamente cumprido. Ou seja, o SUS não incorporou, de forma efetiva, em suas concepções, paradigmas e ações, o lugar que o 'trabalho' ocupa na determinação do processo saúde/doença dos trabalhadores diretamente envolvidos nas atividades produtivas, da população em geral e nos impactos ambientais que essas atividades produzem (Hoefel, Dias \& Silva, 2005; Nehmy \& Dias, 2010).

O processo de reestruturação produtiva em curso no país, de forma mais evidente a partir dos anos 90, alterou substancialmente a configuração do trabalho e as relações de produção. Entre as consequências dessas mudanças para o trabalho, o modo de vida e as condições de saúde da população, dos trabalhadores em particular, podem ser identificados: o desemprego estrutural; a precarização do trabalho e o crescimento do setor informal, com perda de direitos trabalhistas e previdenciários historicamente conquistados pelos trabalhadores. O desemprego estrutural repercute na organização dos sindicatos, obrigando-os a deslocar o foco de atuação para a preservação de postos de trabalho, deixando em segundo plano as condições em que o trabalho é executado. As relações de solidariedade e cooperação no cotidiano de trabalho, essenciais para a saúde e a segurança dos trabalhadores, são substituídas pela competição predatória, socialmente valorizada e estimulada pelos meios de comunicação.

Essas mudanças se refletem no perfil de adoecimento dos trabalhadores, traduzidas no aumento da prevalência das doenças relacionadas ao trabalho. Além das tradicionais, como a silicose e as intoxicações pelos metais e solventes, surgiram as 'novas' doenças, como as lesões por esforços repetitivos (LER) ou distúrbios osteomusculares relacionados ao trabalho (Dort), por exemplo, que respondem por cerca de $80 \%$ dos casos atendidos nos serviços especializados, na atualidade, e outras formas de adoecimento mal caracterizadas, entre elas o estresse, a fadiga física e mental e outras expressões de sofrimento relacionadas ao trabalho (Brasil, 2004).

No final de 2002, oportunidade política surgida no âmbito da Secretaria de Assistência à Saúde, do Ministério da Saúde, permitiu a criação da Renast. Apesar das críticas ao processo de elaboração da portaria n. 1.679/02, em particular à ênfase dada às ações assistenciais, os profissionais de saúde e o 
movimento dos trabalhadores reconheceram na iniciativa a possibilidade de fortalecimento da saúde do trabalhador no SUS, em especial pelos recursos extrateto aportados para o financiamento das ações, vinculado ao Plano de Trabalho de Saúde do Trabalhador.

Nos termos da portaria, a organização da Renast tinha como eixo os Centros de Referência em Saúde do Trabalhador (Cerests), compreendidos como: "polos irradiadores, no âmbito de um determinado território, da cultura especializada subentendida na relação processo de trabalho/processo saúde/ doença, assumindo a função de suporte técnico e científico, deste campo do conhecimento". Em 2003, a Renast foi adotada como a principal estratégia de implementação da Política Nacional de Saúde do Trabalhador (PNST) para o SUS (Brasil, 2004).

Com base nas deliberações da $3^{a}$ Conferência Nacional de Saúde do Trabalhador, a portaria n. 2.437, de 5 de dezembro de 2005, ampliou a rede de Cerests e enfatizou a importância das ações de vigilância e o envolvimento da atenção básica de saúde. Além disto, propôs duas estratégias complementares: a rede de serviços de média e alta complexidades, denominada serviços-sentinelas e municípios-sentinela em saúde do trabalhador (Brasil, 2005).

A organização da rede sentinela de notificação deveria cobrir os 5.230 municípios brasileiros. O termo 'sentinela' é empregado na portaria n. 2.437/05, de modo distinto daquele utilizado pela epidemiologia para designar um evento ou problema de saúde em uma população ou comunidade. Ele nomeia a rede de serviços assistenciais de retaguarda, de média e alta complexidades, organizada de modo a garantir a geração de informação e viabilizar a vigilância da saúde. Assim, o serviço-sentinela é responsável pela notificação e informações que irão gerar as ações de prevenção, vigilância e de intervenção e mudanças em saúde do trabalhador. Em situações especiais, caracterizadas em razão da presença de fatores de risco para a saúde nos processos produtivos em um dado território, e por critérios epidemiológicos, previdenciários e socioeconômicos, além da presença efetiva do controle social, as ações de saúde do trabalhador poderiam ser organizadas, em nível local, em municípios-sentinela.

Uma questão chave para a saúde do trabalhador decorre da subnotificação ou mesmo da ausência de informação sobre os agravos à saúde relacionados ao trabalho, nos sistemas de informação do SUS, que dificulta a visibilidade social dos problemas e a inclusão nas agendas técnica e política dos gestores e dos conselhos estaduais e municipais de Saúde, alimentando o círculo vicioso (Lacaz \& Santos, 2010). 
A possibilidade de estabelecer a relação entre a exposição a fatores de risco para a saúde presentes nos ambientes e condições de trabalho, nas ações de vigilância da saúde e/ou da relação entre o agravo ou doença com a atividade desenvolvida pelo trabalhador, na rede assistencial, em especial nas abordagens individuais e coletivas, como visitas domiciliares, consultas e grupos operativos desenvolvidos no âmbito da atenção primária à saúde (APS), devem desencadear o registro nos sistemas de informação de saúde, permitindo coletivizar os fenômenos da exposição e/ou do adoecimento e promover mudanças nas condições e ambientes de trabalho geradoras de doença.

O Pacto pela Saúde publicado na portaria GM n. 399, de 22 de fevereiro de 2006, em suas três dimensões (pela Vida, em Defesa do SUS e de Gestão) acarretaram mudanças significativas para a organização e a gestão da saúde no país. O Pacto Pela Vida estabelece compromissos de atingir metas sanitárias entre os gestores do SUS, com base em prioridades; o componente em Defesa do SUS estabelece compromissos políticos com vistas a consolidar o processo da Reforma Sanitária brasileira, e o de Gestão define responsabilidades sanitárias de cada gestor municipal, estadual e federal para a gestão do SUS. Entre os desafios apresentados pelo pacto, destacam-se os ajustes no modelo de gestão capazes de superar a fragmentação das políticas e dos programas de saúde, por meio da organização de uma rede regionalizada e hierarquizada de ações e serviços e da qualificação da gestão (Brasil, 2006a).

Em 2009, a portaria n. 2.728 modificou a organização da Renast, redefinindo o papel do Cerest, adequando-os às diretrizes do Pacto pela Saúde de 2006. Considerando que a organização da atenção integral à saúde do trabalhador deve seguir a diretriz que coloca a APS como ordenadora do cuidado na rede de atenção, a nova portaria prescreve que o Cerest deve: "oferecer subsídio técnico para o SUS, nas ações de promoção, prevenção, vigilância, diagnóstico, tratamento e reabilitação em saúde dos trabalhadores urbanos e rurais" (Brasil, 2009a).

Entre 2002 e 2009 foram habilitados 198 Cerests, em todas as unidades da federação, como pode ser visualizado na Figura 1. 
Figura 1 - Distribuição geográfica dos Cerests estaduais, regionais e municipais. Brasil - 2009

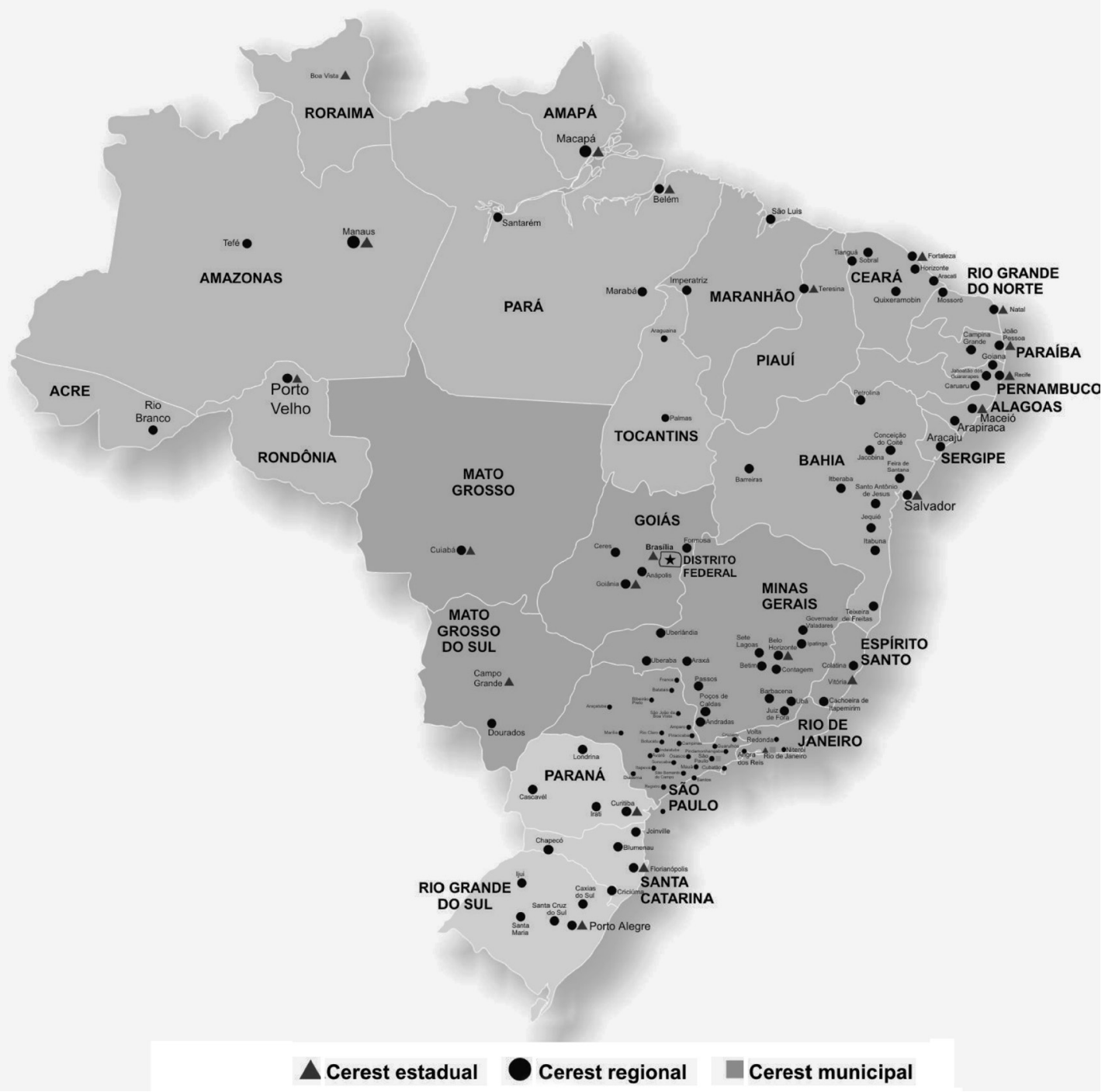

Fonte: Galdino (2010).

Apesar da ausência de estudos de avaliação, de âmbito nacional, sobre o processo de implantação da Renast e de seus impactos sobre a situação de saúde dos trabalhadores, algumas pesquisas regionais e ou estaduais têm identificado avanços importantes e dificuldades a serem superadas (Dias et al., 2010; Lacaz \& Santos, 2010; Dias \& Hoefel, 2005). 
Entre os avanços registrados podem ser apontados: a ampliação da visibilidade da área, facilitando a interlocução com os gestores; o acúmulo de experiência e saberes; a capacitação de técnicos, gestores e participantes do controle social do SUS, difundindo noções básicas sobre o tema (Quadro 1). Quadro 1 - Síntese dos principais avanços e desafios para a implantação da Renast no SUS

\section{Avanços}

Propiciou um fluxo contínuo de financiamento para as ações em saúde do trabalhador desenvolvidas pelos Cerests

Aumentou o número de Cerests, tendo sido implantados em todos os estados do Brasil e no Distrito Federal

Permitiu o acúmulo de experiências e conhecimento técnico

Permitiu o desenvolvimento de diversos processos de capacitação de técnicos, gestores e controle social

\section{DESAFIOS}

Acompanhamento sistemático dos problemas de execução financeira

Reforço das articulações intrassetoriais

Consolidação do papel do Cerest no apoio técnico e pedagógico para a atenção à saúde dos trabalhadores

Ruptura com a lógica do modelo da Renast, centrada na atuação dos Cerests

Inserção da temática saúde do trabalhador nos processos de educação permanente em saúde

Fomento da informação em saúde do trabalhador, tornando-a fidedigna e disponível em tempo real, para orientar o planejamento e gestão e o controle social

Estruturação da vigilância em saúde do trabalhador de modo articulado com as outras vigilâncias em saúde: epidemiológica, sanitária e ambiental

Fonte: Adaptado de Dias e Hoefel (2005), Lacaz e Santos (2010) e Dias et al. (2010).

Finalizando, pode-se dizer que a Renast não se consolidou como rede, permanecendo, na maioria das situações, restrita ao Cerest. Muitas vezes, a Renast é até mesmo considerada como sinônimo de Cerest, o que contribui de modo significativo para a confusão conceitual sobre o papel do Cerest e 
suas atribuições na rede SUS. Observa-se também que os critérios utilizados para credenciamento desses centros nem sempre seguem o modelo de regionalização do SUS nos estados, além das dificuldades para utilização dos recursos financeiros em âmbito regional, que são transferidos para o Fundo Municipal de Saúde (FMS) do município sede do Cerest.

\section{Pontos para uma Agenda de Trabalho na Construção da Saúde do TRABALHADOR NO SUS}

Considerando que, na atualidade, o SUS é, de fato, a única política pública de cobertura universal para o cuidado da saúde dos trabalhadores, é fundamental redefinir as práticas de saúde e a construção de um 'modelo' de atenção que considere essas questões e permita que, de fato, o SUS como um todo esteja mobilizado para suprir as necessidades dos trabalhadores. A pressão para que o SUS assuma o cuidado de um contingente crescente de trabalhadores aumenta, apesar da rede de serviços inadequada, despreparada e sobrecarregada, sobretudo no que se refere à atenção primária, em especial à estratégia de Saúde da Família.

A implementação das ações de saúde do trabalhador no SUS e a estratégia da Renast necessitam ser ajustadas às novas realidades do perfil produtivo e dos trabalhadores em seus aspectos demográficos e epidemiológicos.

Entre os desafios para o SUS, destaca-se o de desenvolver ações de saúde do trabalhador na APS, atual referência para o reordenamento da atenção à saúde. Ela constitui a porta de entrada nos serviços de saúde e deve assegurar atenção integral, com resolutividade e de modo coordenado com os níveis de maior incorporação tecnológica. A APS é apresentada como a melhor estratégia para otimizar a saúde da população e minimizar as desigualdades existentes entre os grupos populacionais, na direção da equidade. A organização das ações tem como referência uma base territorial e critérios epidemiológicos, priorizando os problemas mais comuns em uma dada comunidade, oferecendo serviços de prevenção, cura e reabilitação, visando maximizar a saúde e o bem-estar das pessoas (Brasil, 2006b; Starfield, 2002). Pode-se dizer que a inserção efetiva das ações de saúde do trabalhador no SUS, na atualidade, está diretamente relacionada à sua assimilação pela APS e suas estratégias.

Além dos argumentos de natureza conceitual e gerencial no âmbito do SUS, a defesa de que as ações de saúde do trabalhador sejam desenvolvidas a partir da APS considera, também, as repercussões dos processos de reestruturação 
produtiva sobre o crescimento do trabalho informal, familiar e em domicílio. Neste caso, apenas a APS tem a possibilidade de fazer chegar ações de saúde o mais próximo possível de onde as pessoas vivem e trabalham.

São possibilidades concretas de ações de saúde do trabalhador desenvolvidas na APS: o mapeamento das atividades produtivas em um dado território; o acolhimento dos trabalhadores, reconhecendo sua inserção particular no processo produtivo; a assistência ao trabalhador que considera a contribuição do trabalho na determinação dos processos saúde-doença; avaliação e manejo das situações de risco e perigos para a saúde presentes no trabalho pelas ações de vigilância, incorporando o saber do trabalhador.

Entretanto, para que a APS assuma e coordene o desenvolvimento de ações de saúde do trabalhador, não basta acrescentar mais uma atribuição às já sobrecarregadas equipes de trabalho. É importante que as tarefas sejam redefinidas e redimensionadas, as equipes capacitadas e garantidos os procedimentos de referência e contrarreferência adequados.

Embora não se tenha um distanciamento temporal que permita analisar a implementação da Renast no país, e não se conte com estudos de acompanhamento e avaliação desse trabalho - necessários e urgentes, que devem ser realizados em nível local e nacional -, a observação empírica e os registros de reuniões da área permitem identificar algumas questões a serem respondidas de modo a contribuir para a reflexão sobre o processo e aperfeiçoar a implantação da Política Nacional de Saúde do Trabalhador no país.

Apesar da baixa prioridade nas agendas dos governos, nas três esferas de gestão do SUS, é possível dizer que a Renast está implantada nas 27 unidades da federação (incluindo o Distrito Federal), com formatos e práticas diversas, dando continuidade ao processo de construção de uma atenção diferenciada aos trabalhadores brasileiros que contemple sua inserção nos processos produtivos iniciada nos anos 80 .

A possibilidade de contar com recursos extrateto, repassados aos municípios e destinados a apoiar as ações dos Cerests habilitados, é apontada pelos coordenadores e equipes técnicas como fator facilitador da interlocução com os gestores de saúde, ampliando a visibilidade do campo. Entretanto, esses recursos não são suficientes para cobrir os custos das ações e devem ser complementados pelos estados e municípios, o que raramente se observa. Também têm sido observadas dificuldades para utilização dos recursos, assim como o desvio de sua destinação para cobrir outras necessidades no âmbito do SUS. 
Outra questão importante se refere à falta de clareza do papel a ser desempenhado pelo Cerest. Uma explicação simples para essa dificuldade pode ser encontrada na história da conformação desses centros especializados e na fragmentação das 'caixinhas' que organizam o SUS nas três esferas de gestão, responsáveis pela dicotomia das ações de assistência e vigilância.

É importante lembrar que a indissociabilidade das ações assistenciais e de vigilância da saúde constitui pedra angular da saúde do trabalhador, nas suas dimensões técnicas, éticas e por exigência do movimento de trabalhadores. Porém, historicamente, os centros de referência foram organizados privilegiando, em alguns casos, as práticas assistenciais e, em outros, as ações de vigilância. No 'mundo real', poucos serviços desenvolvem de fato atenção integral. Apesar dos esforços e de avanços regionais, observa-se o privilegiamento da assistência em detrimento das ações de vigilância, prejudicando a integralidade das ações. Também as ações intersetoriais são pontuais.

A portaria que orienta a Renast retirou a ênfase nas ações assistenciais, mas contraditoriamente propôs uma equipe mínima de profissionais para os Cerests, sem explicitar claramente as ações e as responsabilidades de cada um. Esta falta da clareza do papel a ser cumprido dificulta a composição das equipes e os processos de capacitação dos profissionais. Além do despreparo dos profissionais, é reconhecida a insuficiência do saber técnico sobre os novos agravos à saúde gerados pela adoção de novas tecnologias e novas formas de gestão do trabalho.

Outro aspecto a ser destacado se refere à abrangência de atuação dos Cerests. A habilitação dos centros, que não considera os processos de regionalização de cada estado, gera conflitos e prejuízos para a garantia da integralidade da atenção. Apesar da organização regional da maioria dos Cerests, muitos deles acabam limitando sua atuação no município sede, colocando assim um desafio para a Renast na contribuição para os processos de pactuação dos procedimentos entre os municípios de abrangência dos Cerests (Dias et al., 2010; Lacaz \& Santos, 2010).

Outra dificuldade a ser superada não apenas pela Renast, mas pela área de saúde do trabalhador no seu conjunto, refere-se à participação do controle social. Apesar de ser um valor básico e histórico na construção da área, é nítida a desarticulação do movimento sindical e social na Renast, agravada pelas dificuldades de se incorporarem os trabalhadores do setor informal nas instâncias de controle social.

O controle social no SUS é a concretização do direito e dever da sociedade de participar do debate e da decisão sobre a formulação, a execução e a avaliação 
da política nacional de saúde. Nessa perspectiva, é essencial o fortalecimento dos conselhos gestores de saúde do trabalhador de modo articulado com a Cist, que são câmaras técnicas assessoras dos conselhos estaduais e municipais de Saúde. Um grande esforço tem sido feito para a preparação dos participantes do controle social para cumprir adequadamente essa tarefa.

Entre as atividades de educação popular em saúde do trabalhador, destacase a criação da Rede Escola, que pretende qualificar o controle social para a atuação na construção de políticas públicas de saúde, trabalho e meio ambiente.

A Rede Escola Continental busca o fortalecimento e o 'empoderamento' da sociedade civil em articulação com os diversos setores públicos para permitir o exercício da defesa dos interesses dos trabalhadores, que variam em razão dos diversos contextos e momentos históricos e que se efetivam por ações concretas que ressignificam e reconstroem formas de participação social no processo da consolidação da saúde como direito.

Outra dificuldade para a implementação da Renast decorre da ausência de um sistema ágil de informação, em tempo real, que alimente os procedimentos de planejamento e gestão das ações de saúde e do controle social. As informações, quando existem, se encontram dispersas e pouco contribuem para o planejamento das ações de saúde e aplicação dos recursos. A melhoria da notificação dos agravos e doenças relacionados ao trabalho é um desafio assumido, nacionalmente, com o objetivo de dar visibilidade às questões da saúde do trabalhador, permitindo que sejam incorporadas nas agendas técnica e política do SUS. Neste sentido, um dos objetos de discussão tem sido a necessidade de mudanças nas estratégias e parâmetros adotados que restringem a notificação compulsória à rede de serviços-sentinela (Santana \& Silva, 2009).

A integração intrassetorial na saúde é incipiente e descontínua. Alguns níveis de atenção, em particular a APS e os serviços de urgência, sempre atenderam trabalhadores; porém, não estão preparados para estabelecer a relação entre o agravo e o trabalho e adotar os procedimentos decorrentes adequados. Também não se observa, na grande maioria dos locais, a integração entre os procedimentos assistenciais e de vigilância da saúde, essencial para uma ação efetiva em saúde do trabalhador.

A portaria n. 3.252, de dezembro de 2009, acrescentou um novo desafio para a vigilância em saúde do trabalhador, ao incluíla no conjunto de ações da vigilância em saúde (Brasil, 2009b). Assumir a portaria n. 3.252 como norteadora das ações de vigilância em saúde do trabalhador significa pensar e agir de modo articulado com as vigilâncias epidemiológica, sanitária e ambiental, 
qualquer que seja o recorte territorial onde essas ações serão desenvolvidas: do território de atuação do Agente Comunitário de Saúde (ACS) - na atualidade a menor fração de território de trabalho no SUS - à área de abrangência da equipe de Saúde da Família, à unidade básica de saúde (UBS), ao município, à microrregião, à macro, ao nível estadual e nacional.

Os papéis das coordenações estaduais e municipais de saúde do trabalhador, no âmbito das secretarias estaduais e municipais de Saúde e dos Cerests, também necessitam ser mais bem definidos.

No plano nacional, apesar de avanços pontuais, como observado por ocasião da realização da $3^{\text {a }}$ Conferência Nacional de Saúde do Trabalhador, em 2005, de modo compartilhado pelos ministérios da Previdência Social, Trabalho e Saúde, a articulação intersetorial, técnico-institucional e política entre os órgãos de governo responsáveis pelas ações de saúde do trabalhador é frágil e descontínua e necessita ser melhorada.

Cabe ainda reiterar a importância de se adotarem, de forma sistemática, processos de avaliação da implementação da Renast, bem como a necessidade de construir indicadores de impacto que permitam conhecer a organização e o funcionamento da rede. A avaliação sistemática em saúde tem crescido em importância no âmbito do SUS, com o propósito de contribuir para o planejamento e a gestão das ações de saúde.

Finalizando, são formuladas questões que necessitam ser respondidas, por meio de um debate aberto e participativo entre os atores da área de saúde do trabalhador, para o qual o GT da Abrasco deve dar sua contribuição:

- Como garantir a atenção integral à saúde do trabalhador no novo modelo de cuidado que se desenha para o SUS, tendo a APS como eixo orientador e conformado nas redes de atenção?

- Qual o papel dos Cerests para o provimento das ações de saúde do trabalhador no SUS, considerando esse novo modelo de cuidado?

- Quais devem ser a composição e as atribuições dos profissionais das equipes dos Cerests?

- Como consolidar de fato o desenvolvimento de ações de saúde do trabalhador nas práticas dos profissionais que atuam na APS? Quais seriam as atribuições desses profissionais no cuidado à saúde dos trabalhadores?

- Como conseguir o controle social qualificado, garantindo a participação e a presença da representação dos trabalhadores do setor informal? 
- Como incorporar temas ambientais e a discussão dos impactos do modelo de desenvolvimento econômico sobre a saúde das populações, dos trabalhadores em particular, e sobre a degradação ambiental?

O movimento da saúde do trabalhador já tem uma história no SUS. Ele é marcado por avanços e recuos, mas principalmente pela defesa do direito que todos os trabalhadores têm de viver, produzir e partilhar da riqueza que constroem com seu trabalho. Para isto necessitam ter saúde.

\section{REFERÊNCIAS}

BRASIL. Constituição da República Federativa do Brasil. Diário Oficial da União, Brasília, 5 out. 1988. Disponível em: <www.planalto.gov.br/ccivil_03/constituicao/ constituiçao.htm>.

BRASIL. Lei Orgânica da Saúde. Lei n. 8.080, de 19 de setembro de 1990. Dispõe sobre as condições para a promoção, proteção e recuperação da saúde, a organização e o funcionamento dos serviços correspondentes e dá outras providências. Diário Oficial da União, Brasília, 20 set. 1990. Disponível em: <www.in.gov.br/imprensa/visualiza/ index.jsp?jornal=1\& pagina=1\& data=20/09/1990>.

BRASIL. Ministério da Saúde. Portaria n. 1.679, de 20 de setembro de 2002. Dispõe sobre a Rede Nacional de Atenção Integral à Saúde do Trabalhador - Renast, evidenciada durante a sua implantação. Diário Oficial da União, Brasília, 21 set. 2002.Disponível em: 〈http://dtr2001.saude.gov.br/sas/PORTARIAS/Port2002/Gm/GM-1679.htm〉.

BRASIL. Ministério da Saúde. Politica Nacional de Saúde do Trabalhador para o SUS. Brasília: Ministério da Saúde, 2004. Disponível em: <https://docs.google.com/ viewer?url=http://portal.saude.gov.br/portal/arquivos/pdf/insumos_portaria_ interministerial_800.pdf>.

BRASIL. Ministério da Saúde. Portaria n. 2.437, de 7 de dezembro de 2005. Dispõe sobre a ampliação e o fortalecimento da Rede Nacional de Atenção Integral à Saúde do Trabalhador-Renast no Sistema Único de Saúde - SUS e dá outras providências. Diário Oficial da União, Brasília, 8 dez. 2005. Disponível em: <http://dtr2001.saude. gov.br/sas/PORTARIAS/Port2005/GM/GM-2437.htm>.

BRASIL. Portaria n. 399, de 22 de fevereiro de 2006a. Divulga o Pacto pela Saúde 2006 - Consolidação do SUS e aprova Diretrizes Operacionais do referido Pacto. Diário Oficial da União, Brasília, 23 fev. 2006. Disponível em: <www.in.gov.br/imprensa/ visualiza/index.jsp?.jornal=1\& pagina $=43 \&$ data $=23 / 02 / 2006>$.

BRASIL. Portaria n. 648, de 28 de março de 2006b. Aprova a Política Nacional de Atenção Básica, estabelecendo a revisão de diretrizes e normas para a organização da Atenção Básica para o Programa Saúde da Família (PSF) e o Programa Agentes Comunitários de Saúde (PACS). Diário Oficial da União, Brasília, 29 mar. 2006. Disponível em: <www.in.gov.br/ imprensa/visualiza/index.jsp?jornal=1\&pagina=71\&data=29/03/2006>. 
BRASIL. Ministério da Saúde. Portaria n. 2.728, de 11 de novembro de 2009a. Dispõe sobre a Rede Nacional de Atenção Integral à Saúde do Trabalhador (Renast) e dá outras providências. Diário Oficial da União, Brasília, 12 nov. 2009. Disponível em: <https://docs.google.com/viewer?url=http://portal.saude.gov.br/portal/arquivos/ pdf/portaria_renast_2728.pdf>.

BRASIL. Portaria n. 3.252, de 22 de dezembro de 2009b. Aprova as diretrizes para execução e financiamento das ações de Vigilância em Saúde pela União, Estados, Distrito Federal e Municípios e dá outras providências. Diário Oficial da União, Brasília, 23 dez. 2009. Disponível em: <www.in.gov.br/imprensa/visualiza/index.jsp?jornal=1 \&pagina $=65 \&$ data $=23 / 12 / 2009>$.

DIAS, E. C. Atenção à Saúde dos Trabalhadores no Setor Saúde (SUS), no Brasil: realidade, fantasia ou utopia?, 1994. Tese de Doutorado, Campinas: Departamento de Medicina Preventiva e Social, Faculdade de Ciências Médicas, Universidade Estadual de Campinas.

DIAS, E. C. et al. Construção da Renast em Minas Gerais: a contribuição dos Centros de Referência em Saúde do Trabalhador (Cerest), 2002-2007. Revista Médica de Minas Gerais, 20(Supl.2): S66-S75; 2010.

DIAS, E. C. \& HOEFEL, M. G. O desafio de implementar as ações de saúde do trabalhador no SUS: a estratégia da Renast. Ciência Eु Saúde Coletiva, 10(4): 817-828, 2005.

GALDINO, A. Centros de Referência em Saúde do Trabalhador e as Notificações de Acidentes do Trabalho, 2010. Dissertação de Mestrado, Salvador: Instituto de Saúde Coletiva, Universidade Federal da Bahia.

HOEFEL, M. G.; DIAS, E. C. \& SILVA, J. M. A Atenção à Saúde do Trabalhador no SUS: a proposta de constituição da Renast. Brasília: Ministério da Saúde, 2005. Disponível em: <https://docs.google.com/viewer?url=http://www.saude.ba.gov.br/cesat/3aCNST/ DOCA>.

LACAZ, F. A. C. \& SANTOS, A. P. L. do. Saúde do trabalhador, hoje: re-visitando atores sociais. Revista Médica de Minas Gerais, 20(Supl. 2): S5-S12, 2010.

NEHMY, R. M. Q. \& DIAS, E.C. Os caminhos da saúde do trabalhador: para onde apontam os sinais? Revista Médica de Minas Gerais, 20(Supl. 2): S13-S23, 2010.

SANTANA, V. S. \& SILVA, J. M. da. Os 20 anos da saúde do trabalhador no Sistema Único de Saúde do Brasil: limites, avanços e desafios. In: MINISTÉRIO DA SAÚDE. Saúde Brasil 2008: 20 anos de Sistema Único de Saúde (SUS) no Brasil. Brasília, 2009.

SILVEIRA, A. M. et al. O Controle Social no SUS e a Renast. $3^{\text {a }}$ Conferência Nacional de Saúde do Trabalhador (Textos de Apoio). Brasília: Ministério da Saúde, 2005.

STARFIELD, B. Atenção Primária: equilibrio entre necessidades de saúde, serviços e tecnologia. Brasília: Unesco, 2002. 


\section{0 Trabalho em Saúde nos Referencials da Política Nacional de Humanização: construindo UMA METODOLOGIA DE ANÁLISE E INTERVENÇ̃̃o}

Maria Elizabeth Barros de Barros

Serafim Barbosa dos Santos Filho

Realizamos aqui uma revisão analítica do que foi produzido ao longo dos sete anos em que a Política Nacional de Humanização (PNH) ou HumanizaSUS vem se constituindo como política pública, de modo que essa revisão possa se configurar, como sugere a organização do I Simpósio Brasileiro de Saúde do Trabalhador (Simbrast), uma espécie de 'estado da arte' no âmbito da saúde do trabalhador e, em nosso caso, articulado aos referenciais conceituaismetodológicos da PNH. Buscamos construir vias para subsidiar gestores e formuladores de políticas, contribuindo de maneira mais articulada e efetiva para a implementação de ações de saúde do trabalhador, seguindo formulações de caráter propositivo, com a marca de uma política pública. O desafio se apresenta, principalmente, porque a passagem de uma política de governo a uma política pública não se faz com facilidade, nem está garantida. Construir políticas públicas na máquina do Estado exige um trabalho de conexão com as forças do coletivo, com os movimentos sociais, com as práticas concretas no cotidiano dos serviços de saúde (Benevides \& Passos, 2005). Assim, uma política de humanização só se efetiva quando se consegue sintonizar 'o que fazer' com o 'como fazer', o conceito com a prática, o conhecimento com a transformação da realidade.

A questão que tem nos movido, então, é: de que maneira tem sido abordado o trabalho nas práticas no campo da saúde do trabalhador? Como construir políticas públicas nesse campo que visem à produção e à promoção de saúde nos locais de trabalho?

Seguindo Brito (2004: 98), diríamos que a tradição no campo da saúde do trabalhador é construir "análises descritivas do processo de trabalho, 
privilegiando-se o trabalho abstrato, em sua forma desvitalizada e genérica, mesmo quando são feitas observações de campo". Para a autora, essa tendência seria contraditória em relação às propostas que buscam analisar o trabalho concreto - contraditória porque não reconhece a potência de aprendizagem do trabalho. Ao se desconsiderar o trabalho concreto, criador de valor de uso, essa direção de análise leva em conta, apenas, o modo de reprodução do capital, correndo-se o risco de se considerarem os trabalhadores como meros executores das tarefas que lhes são designadas e "vítimas passivas desse processo de constrangimento, subordinação e exploração” (Brito, 2004: 99), o que vai na contramão do proposto pelo campo nomeado no âmbito da saúde coletiva como saúde do trabalhador.

$\mathrm{Na} \mathrm{PNH}$, fizemos uma escolha: ter como referência conceitual-metodológica abordagens sobre o trabalho humano que partam da "compreensão de que a relação entre o trabalho e subjetividade não é centrada na luta contra o sofrimento, mas na atividade de trabalho como fonte permanente de recriação de novas formas de viver" (Osório da Silva, 2007: 77). São abordagens, portanto, que podem enriquecer a concepção de trabalho que adotamos nas nossas práticas nos serviços de saúde com base nos referenciais da PNH, sem desconsiderar a realidade perversa dos mundos do trabalho, marcada pela precarização do trabalho hoje. Buscamos uma direção de pesquisa-intervenção que tem como eixo principal a afirmação das possibilidades de vida, de uma relação inventiva e prazerosa com o trabalho, afirmando processo de trabalho, na direção apontada por Marx, como categoria privilegiada para as análises da relação saúde-trabalho, o que só se efetiva se partimos do intercâmbio com os trabalhadores, uma vez que não podemos conhecer a atividade de trabalho a priori, pois não se trata de abordar o trabalho apenas em sua generalidade e que é relativamente estável -, mas, principalmente, abordá-lo com o que se mostra enigmático, inesperado e que se expressa nas situações mais restritivas e difíceis (Brito, 2004).

Zarifian aponta alguns analisadores que poderíamos tomar como estratégicos para a compreensão (e avaliação) dessa concretude do trabalho cotidiano, o que nos interessa como objeto de análise-intervenção. Um desses analisadores seria o que o autor nomeia como 'eventos', entendidos como situações cotidianas "parcialmente imprevistas", que "alteram o desenrolar do sistema de produção"; "ações não previstas que devem ser enfrentadas na produção, em oposição ao conceito taylorista/fordista de tarefa, ou de trabalho prescrito, normatizado em suas ações" (Zarifian, 2001a, 2001b). 
Então, partindo desses referenciais, vamos trazer neste texto um pouco do que tem sido vivido e experimentado por um coletivo de pesquisadores do campo da saúde coletiva, que vêm se debruçando, se 'misturando', com as questões que os mundos do trabalho nos apresentam, na tentativa de contribuir para a formulação de políticas públicas para a saúde, tematizando o trabalho - partindo de abordagens que afirmam um conceito de trabalho como "atividade industriosa", ou seja, atividade que envolve sempre algo como um "debate de normas" (Schwartz, 2003), como criação. Essa noção implica, com base na herança de Canguilhem (1990), a tendência de cada um renormatizar seu 'meio de vida - trabalho'. A atividade industriosa definida como um debate de normas significa considerar que é por meio dessas normas que podemos encontrar, dentre outras, a dimensão da gestão, incluindo (e aqui ressaltando) a gestão do próprio fazer. Essas são as principais referências para nosso percurso na PNH, uma vez que, na direção espinozana, diríamos que não estamos alinhados com aquelas práticas que buscam a causa da impotência humana como um vício da natureza humana.

Conforme Campos (2007: 11), a humanização formulada pela PNH é uma estratégia política que tem funcionado "como um dispositivo valioso", na medida em que amplia a agenda para a política de saúde no Brasil. Uma política que vai na contramão de práticas tecnocráticas, estratégias que se efetivam por meio de portarias e regulações de diferentes ordens. Ao contrário, a PNH toca em temas importantes como a reorganização da clínica, a necessidade de um debate sobre as relações de poder em serviços de saúde, gestão participativa e na temática da saúde do trabalhador da saúde. Busca construir juntamente com os trabalhadores, de forma a fazer política e gestão de maneira interativa, valendo-se de 'apoio institucional', ${ }^{1}$ difusão e debates de novos conceitos, partindo das experiências vividas no chão dos serviços de saúde, em sentido contrário da tradição verticalista e autoritária, muito comum no âmbito da saúde pública.

Nesse contexto, a PNH enfrenta um primeiro desafio, que é o de atribuir outro sentido ao termo 'humanização', que não se identifica com o 'bom humano' ou com um 'homem ideal'. Trata-se de um novo posicionamento que afirma o homem comum, o ser humano na sua existência concreta, na sua diversidade normativa e nas mudanças que experimenta nos movimentos coletivos. Esse outro modo de apresentar o problema da humanização na saúde

$1 \mathrm{O}$ apoio institucional é uma das principais estratégias utilizadas no âmbito da PNH para aproximação dos serviços/coletivos de trabalho. Para aprofundamento do conceito de apoio institucional, ver Campos, (2003). 
implica a produção de formas outras de relação entre os sujeitos que constroem os cotidianos dos estabelecimentos de saúde, considerando esses sujeitos concretos e engajados nas práticas locais em que são capazes de transformar os processos de trabalho e se transformarem nesse processo.

A PNH, como política pública, visa a expressar os princípios do SUS em modos de operar nos diferentes equipamentos de saúde, propondo articulação das práticas que se atualizam nesses estabelecimentos, propiciando nas equipes trocas solidárias e comprometidas com a dupla tarefa de produção de saúde e produção de sujeitos (Campos, 1997, 1998, 2000, 2006, 2007). A PNH propõe uma transversalização nas/das numerosas instâncias do SUS, reafirmando e ampliando o exercício da descentralização e da autonomia da rede de serviços, de forma a integrar os processos de trabalho e as relações entre os diferentes profissionais (Brasil, 2006).

Assim, a PNH se constrói com base em alguns princípios, tais como a afirmação e ampliação da autonomia e do protagonismo dos sujeitos e coletivos que constituem o SUS e a corresponsabilidade nos processos de atenção e gestão em saúde. Pautados nesses princípios, definiram-se algumas diretrizes que afirmam que no processo de trabalho em saúde os estabelecimentos são espaços de valorização do potencial inventivo dos sujeitos que trabalham nos serviços. Os trabalhadores criam formas de agir, de se relacionar e de criar regras específicas de divisão do trabalho, criação que implica experimentação constante, evitando-se repetir a tarefa de forma mecânica, o que seria "invivível”, como nos diz Schwartz (2003).

Promover saúde nos locais de trabalho é aprimorar a capacidade de compreender e analisar o trabalho de forma a fazer circular a palavra, criando espaços de debates coletivos - em uma perspectiva de produção/relação de serviço, segundo as categorias analíticas utilizadas por Zarifian (2001a, 2001b). Este autor, ao problematizar o conceito de serviço, define-o como uma "relação ou produção de serviço", que estaria embasada ou sustentada numa organização em rede e organização em equipes, dinâmica na qual uma ação comunicativa assume importância central. Por essa via, a noção de serviço em Zarifian está sempre associada a uma transformação do processo de trabalho, que se dá na/por meio da própria interação entre os atores envolvidos. Em uma 'lógica de serviço' (contraposta às 'lógicas taylorista-fordista, fordista renovada ou japonesada'), importa o trabalho como aprendizagem e como espaço de desenvolvimento de competências, a partir das situações concretas do cotidiano, que aparecem como demandas e necessidades reais dos 'clientes', parceiros etc. 
Salerno (2001), também recorrendo a Zarifian, diz que a saúde é considerada um serviço típico porque mantém a essência de lidar diretamente com o cliente, envolve a relação direta, simultânea, do paciente e da equipe profissional e no conceito de relação de serviço (em qualquer setor produtivo). Assim, o ponto central é a coprodução entre produtor e cliente, o controle conjunto de operações, a emergência do usuário/destinatário/cliente como ator pertinente na gestão de muitas atividades.

No caso da saúde, nos modelos analíticos (e de intervenção) que nos interessa construir, é preciso demarcar a importância de se verem os próprios trabalhadores como clientes uns dos outros, em uma exigência permanente de cooperação mútua, de trocas e aprendizagens para enfrentamento das situaçõesdesafio, 'eventos' ('demandados' por eles mesmos, por usuários e por gestores). É nesse contexto que se localiza o conceito de competência de Zarifian (2001a, 2001b), como sendo o entendimento do processo e a capacidade de assumir iniciativa. E esse conceito traz embutida a ideia de uma forma diferente de se exercitar o trabalho e as relações nele implicadas/imanentes, abordagem que é muito cara à nossa matriz teórico-política de humanização, cuja ênfase está colocada em novos modos de fazer, de operar, de gerir o trabalho.

Nesse sentido é que queremos enfatizar a noção de 'competência de serviço' (competências que se desenvolvem no rastro das vivências) como em uma equação em que se associam ganho de competência-autonomiaprotagonismo-saúde. E queremos também enfatizar que isso se faz em rede. Na perspectiva da PNH, o trabalho em saúde parte de uma concepção de rede que sustenta todos esses princípios e diretrizes, rede que não se refere a uma justaposição de serviços ou ações, mas a uma política transversal no/do SUS, que se traduz em ações construídas coletivamente nas diversas práticas e instâncias de sua efetuação (Santos-Filho \& Barros, 2007). Pensar o trabalho em saúde na direção do HumanizaSUS é, portanto, afirmar a transversalidade como um aumento de comunicação entre os diferentes membros de cada grupo e entre os diferentes grupos que constituem as unidades de saúde. Falamos de uma comunicação transversal como uma dinâmica multivetorializada, em rede, na qual se expressam os processos de produção de saúde e subjetividade. Esse conceito de rede diz respeito a uma participação ativa e inventiva de atores, saberes e instituições, voltados para o enfrentamento de problemas que emergem nos cotidianos de trabalho (Santos-Filho, 2007a). Rede, portanto, como grupalidade atualizada como coletivo em agenciamento e transformação. 
A rede seria um dispositivo de conversa na direção da melhoria das condições de vida e saúde das populações (Teixeira, 2004). Os sujeitos que compõem essa rede são o efeito de um processo de produção de subjetividade sempre coletivo, histórico e determinado por múltiplos vetores: vetores-dobras inseparáveis do campo da saúde: sujeitos (desejos, necessidades, interesses), processos de trabalho (saberes), poder (modos de estabelecer as relações) e políticas públicas (coletivização dessas relações) (Barros \& Benevides, 2007).

É com esse entendimento que a PNH busca fomentar, nos atores que constroem essa rede, o exercício pleno de suas condições como trabalhadores protagonistas de análises compartilhadas e intervenções nos seus espaços de trabalho. Lança o desafio de convocá-los no seu potencial de criação próprio dos vivos para disparar novos modos de fazer e gerir o trabalho e, assim, transformar os mundos do trabalho. Porque, além de viabilizar ambientes seguros e saneados de trabalho, objetivamos superar posturas legalistas e assistencialistas e ir na direção de fomentar o envolvimento dos trabalhadores na construção de projetos, incentivando a multiplicação de diferentes movimentos e rodas, fortalecendo as redes (Santos-Filho, 2007a).

Estamos, assim, compreendendo o trabalho como o espaço concreto de invenção e reinvenção de regras e usos de si (Schwartz, 2003) e a gestão como função de quem está produzindo e conduzindo seu próprio fazer. Com esses referenciais e perseguindo os princípios que assinalamos, a PNH utiliza um 'método', ou seja, uma forma de conduzir análises e intervenções com espaços de trabalho, de forma a traçar um caminho no sentido da inclusão dos diferentes agentes implicados nos processos de trabalho. Um método que convoca gestores e trabalhadores no sentido da produção de autonomia, protagonismo e corresponsabilidade. Inclui, também, os analisadores sociais, ou seja, os fenômenos que desestabilizam os modos de trabalhar em curso, de forma a acolher e potencializar os processos de mudança - o que significa não desconsiderar os conflitos, tanto na esfera local como no âmbito das políticas governamentais, mas, ao contrário, usar a potência disruptiva desses conflitos, tomá-los como estratégia para as mudanças que desejamos nos locais de trabalho na busca de produção de saúde nos ambientes laborais.

Entendemos que o modo de operar do trabalhador se confunde com o próprio processo de criação de si. Trabalhar-gerir inclui, também, a criação de formas-subjetividades à deriva, "outramento", corpos rebeldes que desejam a experimentação e o múltiplo, ou seja, trabalhadores que no curso da atividade criam permanentemente na relação com os instrumentos de 
trabalho, reinventando-se como trabalhador incessantemente; é "prática de tateio". (Kastrup, 1999: 150)

Assim, quando nos referimos a modos de gestão, estamos falando das maneiras como se produzem realidades, de jeitos de se produzir em situação de trabalho. Nossa preocupação é entender as articulações entre processos de subjetivação, modos de gestão e produção de saúde engendrados nos diferentes locais de trabalho. As políticas públicas e as diferentes formas de organização do trabalho que elas atualizam têm decorrências importantíssimas na gestão do trabalho - portanto, nos processos de subjetivação. As experiências nas unidades de saúde que fortalecem a comunicação cotidiana e imprimem movimento e processualidade nesses locais, priorizando a circulação da fala, têm a produção criadora como tendência dominante. Os processos de subjetivação que perseguem a produção criadora não estão, apenas, a serviço da solução dos problemas apresentados nas situações de trabalho; são, antes de tudo, invenção de problemas, perturbação, rachadura do instituído, uma vez que, ao se defrontar com o inesperado, o sujeito é forçado a pensar e divergir de si mesmo. No entanto, quando a organização do trabalho está pautada prioritariamente por uma administração/gerência que não afirma os processos de gestão coparticipativos, tende a produzir subjetividades metástases (Neves, 1997). ${ }^{2}$

Ao perseguirmos a produção criadora nas unidades de saúde, temos utilizado a análise coletiva do trabalho como estratégia para abordagem do que o trabalho mobiliza e provoca. Ao se falar dos sentimentos experimentados, podem-se construir novas e mais potentes análises das situações vividas nos ambientes laborais.

Mas o que estamos afirmando quando dizemos que os modos de gestão engendram modos de subjetivação? Qual o conceito de subjetividade que subsidia nossas intervenções? Na nossa atualidade discursiva, encontramos diferentes abordagens sobre esses chamados 'aspectos subjetivos'. Indicamos uma distinção entre o que entendemos por subjetividade e as formas como ela é abordada nos diferentes saberes disciplinares. A noção que estamos utilizando busca referência em uma linhagem teórico-metodológica que afirma uma ontologia em ruptura com os substancialismos que consideram o ser como unidade fundada sobre si mesma e que partem de um indivíduo já constituído, sem capacidade de se 'defasar' em relação a si próprio. Concebemos a subjeti-

2 Subjetividades metástases são subjetividades amorfas, moldadas ao sabor dos interesses do capital e, portanto, com dificuldades de cultivar resistências às instituições, às técnicas de controle e à disciplinarização. 
vidade comprometida com a invenção de novas possibilidades de vida, o que nos distingue dos modos de compreensão do sujeito na tradição psicológica ou psicanalítica. No sentido empregado neste trabalho, "o sujeito não é um dado, nem um ponto de partida, uma essência, uma entidade estável com identidade fixa, mas resultado de um processo no qual emergem indivíduo psíquico e meio. A subjetivação é, portanto, sempre individual e coletiva, é individuação psicossocial" (Escóssia, 1999: 56).

Na maneira como buscamos abordar o problema da subjetividade e os modos de produção da existência no âmbito da $\mathrm{PNH}$, considera-se que os processos de subjetivação são múltiplos, heterogenéticos, e podem resistir às diferentes tentativas de modulações que visam à homogeneização das formas de existência dos trabalhadores. Conforme Rolnik (2002), é preciso criar alianças entre práticas que desertam ativamente a máquina de sobrecodificação e inventam outras cenas, colocando em rede sua sinergia e ativando sua potência de singularização; inserir-se no movimento de reativação da força de invenção a contrapelo de seu esvaziamento vital, da neutralização de seu poder crítico. Os modos de gestão do trabalho engendram, portanto, muitas possibilidades de subjetivação. Ao gerir seu trabalho, os humanos inventam formas de cooperação e uma certa relação a si $^{3}$ em um incessante processo de criação.

A criação implica experimentação constante, maneiras diferentes de fazer, evitando-se realizar a tarefa mecanicamente, em um processo de aprendizagem permanente, uma vez que se questionam as prescrições e se constroem outros modos de trabalhar para se dar conta de uma situação nova e imprevisível. Promover saúde nos locais de trabalho, nunca é demais afirmar, é aprimorar a capacidade de compreender e analisar o trabalho de forma a fazer circular a palavra, criando espaço para debates coletivos. Trata-se de compreender as situações nas quais os sujeitos trabalhadores afirmam sua capacidade de intervenção no processo de tomada de decisões no âmbito das organizações de saúde. Vale ressaltar: "a pessoa ou o grupo humano são decisivos, pois a transformação do uso de si mesmo é o elemento-chave para o sucesso do serviço, isto é, para a produção de resultados úteis" (Zarifian, 2001b: 107), utilidade que se define como correspondente à expectativa dos sujeitos envolvidos.

É necessário dizer que, como ponto de partida para orientar nossas intervenções, consideramos as atuais mazelas das situações de trabalho em saúde,

3 Gostaríamos de reafirmar que a ideia de 'si' aqui utilizada não se refere a processos de fechamento em uma interioridade ou a qualquer forma de intimismo, e sim à possibilidade sempre existente de diferir do que se cristalizou em nós. 
destacando sua precarização nos seus diferentes âmbitos (Santos-Filho, 2007b). Portanto, reafirmamos a complexidade e as limitações em se fortalecerem e potencializarem os espaços de trabalho como espaços 'vivos' (e 'saudáveis'), em uma conjuntura tão desfavorável quanto as atuais políticas institucionais de trabalho. Para Zarifian (2001a), seria incompatível o modelo de relação de serviço, que propõe redes de relações e competências, com a crescente política de precariedade própria do modelo de assalariamento flexível, com degradação das condições e relações sociais dos sujeitos, modelo que puxa para baixo as qualificações, a organização do trabalho, os salários, os níveis de consumo, as exigências da vida (Zarifian, 2001a, 2001b). Ao discutir os métodos de gestão e organização do trabalho no mundo atual, alguns autores enfatizam a permanência das lógicas tradicionais ligadas ao taylorismo-fordismo ou neofordismo, lógicas que são contrárias ao que se mencionou como produção/relação de serviço (Salerno, 2001; Zarifian, 2001a, 2001b), guiada pela integração e valorização de saberes e experiências no trabalho. Daí a complexidade dos desafios na configuração de políticas públicas em saúde do trabalhador no campo da saúde.

\section{Articulando Princípios, Diretrizes e Dispositivos no Âmbito da Saúde do Trabalhador na PNH: a cOgestão e o PFST}

No âmbito da PNH, as diretrizes que a orientam expressam o método da inclusão no sentido da cogestão e da valorização do trabalho que se atualizam por meio de dispositivos, em agenciamentos coletivos concretos. São utilizados vários dispositivos nas práticas de produção de saúde que envolvem coletivos e visam a promover mudanças nos modelos de atenção e de gestão (Benevides $\&$ Passos, 2005). Dentre eles, destacamos, para os fins deste texto, o Grupo de Trabalho de Humanização (GTH), o Colegiado Gestor, o Contrato de Gestão, o Programa de Formação em Saúde e Trabalho (PFST) e a Comunidade Ampliada de Pesquisa (CAP).

Entretanto, é importante afirmar que os dispositivos não se constituem em formas de funcionamento prescritivas, mas se constroem com base nas experiências singulares de cada unidade de saúde, que se efetivam por meio de uma análise sempre aberta dos processos de trabalho em curso, o que nos convoca a construir novas formas de produzir intervenções. Como política pública, a PNH é uma política aberta, em construção cotidiana pelos seus autores/atores. 
Assim, buscamos novas relações entre trabalhadores de saúde e aqueles que, também trabalhadores (apoiadores, pesquisadores), detêm conhecimentos específicos que possam permear e mediar diálogos cada vez mais efetivos entre todos os que povoam o cenário da saúde - diálogo desejado entre diferentes saberes e práticas que subsidiam e orientam o trabalho em equipes multiprofissionais. Essa concepção e esse método de aprender fazendo com e no próprio trabalho têm sido disponibilizados como oferta da $\mathrm{PNH}$, estimulando e apoiando processos de formação nos ambientes de trabalho por meio do apoio institucional.

Utilizamos o método de "apoiador institucional", proposto por Campos (2000: 29), "como uma função que transborda os limites de todas as denominações sugeridas pela Teoria Geral de Administração para papéis semelhantes”. Trata-se de uma relação dinâmica que se estabelece entre o apoiador institucional e a equipe apoiada: nem uma postura de passividade ou omissão (dos consultores), nem a pretensão de operar à revelia dos grupos e, muito menos, apenas a elaboração de pareceres ou planos e a imposição de protocolos ou normas às equipes. Segundo o autor, esse apoio à cogestão objetiva afirmar e atiçar a produção de coletivos organizados e ajuda a articular a produção de serviços, de instituições e dos próprios sujeitos. Campos indica a função do apoiador institucional como aquele que ajuda na gestão e organização de processos de trabalho, na construção de espaços coletivos onde os grupos analisam, definem tarefas e elaboram projetos de intervenção. $\mathrm{O}$ apoiador institucional compromete-se com as equipes às quais deve comunicar suas avaliações e seus achados. Nessa direção, contribui para a efetivação dos processos de cogestão no trabalho, devendo começar com a construção de um 'contrato', estabelecendo expectativas, objetivos, regras, métodos e o que mais for necessário.

Partimos, assim, no trabalho, dos relatos de trabalhadores que, com base nas situações vividas nos serviços de saúde, apontam, insistentemente, para a relação dor-desprazer-trabalho. Tal relação nos convoca a interrogá-la, colocá-la em análise, na medida em que se acompanham

as mudanças no modo de produção no contemporâneo caracterizado pela precarização das relações de trabalho, pela contínua perda dos direitos de proteção ao trabalhador, pelas instáveis formas de contratação, pelo baixo investimento em processos de educação permanente, pelos fracos vínculos que os trabalhadores estabelecem nos e com os seus espaços/processos de trabalho. (Barros \& Benevides, 2007: 61) 
No entanto, em vez de propor a busca de 'tratamentos'/soluções para o trabalhador em sua situação individual de adoecimento, ou reivindicações cada vez mais fragilmente organizadas orientadas para o conjunto de trabalhadores, propomos a radicalização do método da inclusão com o qual trabalhamos no HumanizaSUS. Trata-se, sim, de interferir nos processos de gestão do trabalho, trazer ao centro da cena não apenas o trabalhador (indivíduo) ou sua categoria (conjunto), mas as relações que ele estabelece com o processo produtivo, com os objetos de investimento em (e de) seu trabalho.

Seguindo os princípios da $\mathrm{PNH}$, consideramos a saúde do trabalhador de uma perspectiva transdisciplinar, que rompe os limites das disciplinas e faz-se cotidianamente com base nos diálogos com os diferentes regimes de saberes, de forma a produzir intercessão (que produz interferência) nos campos disciplinares. O eixo que privilegiamos é a valorização das demandas e dos conhecimentos advindos da experiência, considerando-se a participação dos trabalhadores como fecunda e indispensável e interferindo no modo como tem sido considerada essa participação, com seu saber advindo, sobretudo, da experiência (Osório da Silva, 2007).

Com base nesse referencial, os dispositivos que indicamos buscam disparar a análise dos processos de trabalho. São dispositivos que têm como eixo condutor a nucleação dos trabalhadores de forma a se produzir um debate entre o saber acadêmico e o saber da experiência. O PFST se nos apresenta com sua potência de problematizar as situações instituídas nos locais de trabalho de forma a interrogar os processos em curso. É nessa direção que compreendemos que não é possível ações no campo da saúde do trabalhador a não ser mediante uma sistemática de pesquisas, debates contínuos e ações cotidianas nos locais de trabalho. Ao colocar em diálogo os conhecimentos e análises científicas com as ações práticas de mudanças, como se espera no âmbito da saúde pública, a meta do PFST é construir um observatório sobre as relações entre saúde e trabalho nos equipamentos de saúde.

O PFST tem como eixo a democratização das relações de trabalho, redimensionando a tradição conceitual e metodológica pautada na saúde ocupacional, que privilegia intervenções pontuais sobre os riscos à saúde, atribuindo aos trabalhadores a responsabilidade e o ônus pelas doenças no trabalho. $\mathrm{O}$ programa visa a analisar as condições e a organização do trabalho de forma a instituir novos modos de ser trabalhador da saúde. Um sistema não funciona se as pessoas não consentirem em fazê-lo funcionar, dedicando-lhe modos de subjetividade. Ao se gerir trabalho, inventam-se formas de subjetivação, e é a 
dedicação dessas formas subjetivas, de modos de funcionamento singulares e imprevisíveis, que viabiliza o funcionamento dos sistemas. Modo de trabalhar/ modo de subjetivar, os trabalhadores são gestores de si e do mundo.

No entanto, a cooperação é o que viabiliza a construção no coletivo, quando as regras do trabalho são transformadas. É preciso correr o risco de se envolver em um debate coletivo, em que cada um mostra como trabalha e, ao mostrar, dá visibilidade também ao seu não saber. $O$ trabalho é também para um outro, uma relação com alguém, é cooperação que pressupõe um coletivo e é conflituosa, pois a capacidade de entrar em conflito é a base da cooperação.

É importante destacar que a regra do trabalho não é apenas técnica, mas, principalmente, saber como é possível trabalhar junto, afirmando a autonomia de cada um no trabalho, o que não significa qualquer espécie de individualismo. Trata-se, dessa forma, de uma regra ética e técnica, pois o mundo do trabalho é o mundo do conviver. Trabalhar não é apenas poder agir, mas conviver, estar junto. Então, como saber sobre o trabalho se não falando sobre ele, construindo o saber-fazer coletivo, construindo espaços de deliberação?

Os indivíduos se mobilizam para cooperar e esperam retribuições, como o salário, por exemplo, mas também outras retribuições importantes, pois eles não trabalham só por dinheiro; o reconhecimento, o olhar do outro é importante para a produção de saúde no trabalho.

Sofrimento, resistência, obstinação, situação de fracasso fazem parte do trabalho. Trabalho é aspecto central para a produção de subjetividade, pois o sujeito se transforma com o trabalho. Trabalhar é poder se transformar. Logo, adoecemos quando não conseguimos construir as regras no trabalho. Comentar, falar, defender seu trabalho é fundamental para que a cooperação possa existir. A capacidade de falar e de escutar é necessária para a cooperação e implica riscos.

Assim, as escolhas dessas ferramentas conceituais/metodológicas é, sobretudo, uma opção relacionada a uma concepção do humano como um ser em movimento, capaz de imprimir algo de singular naquilo de que participa e no qual também se produz, capaz de intervir em sua própria história. Assim, estamos afirmando uma concepção de trabalho como um processo coletivo e singular, de criação e recriação da história de um ofício, atividade de trabalho como processo de produção não só de coisas ou serviços, mas também de subjetividades (Osório da Silva, 2007). 
$\mathrm{Na}$ atividade realizada nas unidades de saúde está sempre presente um conflito. Na escolha de um caminho, quando um gesto é feito, outros modos de fazer foram deixados de lado, outras intenções tiveram menos força (Clot, 2006).

O trabalhador, por mais que participe de um processo de trabalho pautado em práticas verticalizadas, afirma sempre algo de sua capacidade de ação. Portanto, os dispositivos criados na PNH buscam fazer alianças com as possibilidades ilimitadas dos trabalhadores de criarem e recriarem suas próprias relações com o mundo, o que, reafirmamos, não significa ignorar a situação de precarização das relações de trabalho no contemporâneo. Tomamos a ampliação do poder de ação do trabalhador como principal objetivo do método de trabalho no HumanizaSUS - ampliação do poder de ação que exige a produção de novas formas-subjetividades, a produção de sujeitos capazes de construir estratégias para enfrentar as situações que se apresentam no concreto das experiências das unidades de saúde, confrontando-as com sua própria experiência, bem como com a de outros que desempenham as mesmas tarefas. Nessa perspectiva, o principal analista da atividade de trabalho é o próprio trabalhador, e não um especialista em análise do trabalho, que deve se oferecer apenas como um apoio ao deslocamento do trabalhador para o lugar de analista de sua atividade.

Estamos falando, portanto, de uma perspectiva de clínica do trabalho entendida como processo de mudança e que tem como motor a pergunta: como podemos conhecer o trabalho a partir de uma clínica do trabalho? Trabalho como atividade humana, trabalho vivo, o que é vivo no trabalho. $\mathrm{O}$ objetivo da PNH é investigar os efeitos do trabalho na saúde, uma vez que o mesmo trabalho pode inscrever-se como construção ou destruição da saúde. A saúde não é um estado de equilíbrio, é uma orientação de nossas ações, é um compromisso adquirido pela luta nos cotidianos de trabalho. Trabalhar é a experiência que se vive nos cotidianos de trabalho, é também fracassar, é resistir, suportar o sofrimento até que a via para superá-lo, a solução, se efetive. Sofrimento e resistência fazem parte do trabalho. É preciso fracassar para trabalhar e, a partir do sofrimento, ter a intuição para a resolução.

Não buscamos, no âmbito da PNH e por meio de seus dispositivos, a quantificação e a objetivação das práticas dos trabalhadores ou de seu sofrimento, pois o trabalho não é mensurável, o que não significa se renunciar à sua avaliação. Propomos uma avaliação que seja uma modalidade de reconhecimento do que o trabalhador faz para alcançar os objetivos definidos pela organização do trabalho, considerando seus métodos de ação. O que nos parece um equívoco 
é pensar que a avaliação pode ser objetiva e quantitativa, pois o resultado do trabalho não é o trabalho. Não há proporcionalidade entre o trabalho e seus resultados. O equívoco de frequentemente se confundir ou superpor 'avaliação' e 'medida', em sentido tradicional e reducionista, não serve como parâmetro (teórico-político-metodológico) para a análise do trabalho - sobretudo quando se lança mão de indicadores tradicionais (Santos-Filho, 2007b, 2007c). No entanto, salientamos que as diferentes dimensões das transformações do/no processo de trabalho - na ótica dos produtos e resultados, dos processos-meio, das relações, da autonomia dos sujeitos, dos usos de si mesmos etc. - podem ser trazidas à tona em termos analíticos, em um movimento avaliativo dinâmico, dialogado, coconstruído (Santos-Filho, 2007b, 2007c).

É preciso fazer a análise do trabalho em campo com base no que as pessoas têm a dizer do trabalho invisível, ou seja, da experiência do trabalho e não do seu resultado. Avaliar é, assim, conhecer o trabalho invisível e não seu resultado.

Entretanto, avaliar o trabalho renunciando à medida significa dizer que a avaliação pode se efetivar pelo ‘julgamento' do que é feito pelos/nos coletivos de trabalho, o que também significa a possibilidade de uma apreensão do trabalho na sua complexidade, para se aproximar da qualidade do trabalho desenvolvido. Uma perspectiva estética, portanto, de julgamento da beleza, que se viabiliza por meio de palavras que qualificam o trabalho pela via da arte.

Uma ênfase avaliativo-analítica nesses sentidos referidos implica e requer dar visibilidade à dinâmica de renovação das práticas, atos e atitudes nos processos e relações de trabalho, renovação/inovação que se dão simultaneamente à transformação dos próprios sujeitos, isso devendo ser então reconhecido como do âmbito dos processos/produtos do trabalho (Santos-Filho, 2007b, 2007c). Zarifian (2001a) abre caminhos para pensarmos a avaliação no/do trabalho em novos sentidos de utilidade, de eficiência, de eficácia, de estética, e o que interliga esses âmbitos avaliativos é a noção de pertinência, isto é, de significado do trabalho para os sujeitos em cena. ${ }^{4}$ A eficácia do sistema de saúde deve se basear no trabalho de cada um, na inteligência e na paixão dos trabalhadores quando interpretam as situações que se impõem, e não na obediência cega às ordens. São os trabalhadores que fazem o sistema funcionar, portanto.

4 Temos aprofundado essa discussão sobre avaliação, problematizando seus referenciais e ajustando-os ao campo de políticas complexas, cujas transformações nos processos de trabalho ocupam lugar de destaque (e de desafios). Além de algumas produções mencionadas neste texto (Santos-Filho, 2007b, 2007c), estamos explorando um diálogo que se pode estabelecer com os conceitos utilizados por Zarifian (2001a, 2001b), atrelando ou derivando alguns eixos avaliativos por dentro da noção de 'produção de serviço-trabalho-competência'. 
Com relação ao exposto, perguntamos: o que tem sido produzido no campo nomeado como saúde do trabalhador? Que práticas têm sido engendradas? São estas algumas das questões disparadoras que marcam as práticas da $\mathrm{PNH}$, uma vez que destacamos a importância da criação de dispositivos que buscam intervir nas situações de trabalho e que não limitam/compreendem o trabalho desenvolvido nas unidades de saúde ao trabalho abstrato. $\mathrm{O}$ aporte específico do que temos desenvolvido na PNH visa a problematizar os modelos de atenção à saúde e contribuir na formação dos trabalhadores para análise do seu cotidiano laboral, com vistas à promoção de saúde nos locais de trabalho. Criar espaços de trocas e debates entre conceitos científicos e a experiência dos trabalhadores e construir comunidades ampliadas de pesquisa que se consolidam no esforço coletivo são tarefas do apoiador institucional. Enfim, tornar as experiências no trabalho fontes de percepção e interpretação do que causa o adoecimento e/ou saúde e desencadear ações que possam alterar o curso de nocividade presente nos ambientes de trabalho, pois, ao produzir conhecimentos sobre eles, abre-se a possibilidade de transformação das situações de risco e/ou vulnerabilidade. É importante voltar aos referenciais abertos por Zarifian (2001b) para chamar a atenção para a relevância da interação com o 'cliente' (e seus pares), nesse processo de desafio contínuo para o trabalhador exercitar um aprendizado e a produção de conhecimento; para interagir com esse 'cliente', processo de aprendizagem e trocas permanentes que cabe em nossas matrizes referenciais equivalendo a um processo de 'ganho de saúde', isto é, estreitamente atrelado à autonomia.

Articulados na PNH, esses processos se efetivam por meio de dispositivos como os Grupos de Trabalho em Humanização $(\mathrm{GTH})^{5}$ e também por meio daqueles já instituídos na saúde do trabalhador, como os setores de recursos humanos e de pessoal (ou equivalentes), serviços especializados de segurança e medicina do trabalho, como os Serviços Especializados em Engenharia de Segurança e Medicina do Trabalho (SESMT), ou Comissões Internas de Prevenção de Acidentes (Cipas) e outras estratégias formal e informalmente constituídas (Brasil, 2006; Santos-Filho, 2007a).

5 O GTH é um dispositivo da PNH que se efetiva por meio do encontro de pessoas interessadas em discutir o serviço de saúde em que trabalham, ou que utilizam. Pretende discutir também as relações estabelecidas entre eles, e de que maneira esse serviço pode funcionar para melhorar o processo de trabalho e a qualidade da produção de saúde. Todos podem participar desse grupo, sejam profissionais da saúde, técnicos, funcionários, coordenadores e também usuários. Participam os interessados na construção de propostas para promover tanto ações humanizadoras, que melhorem o cuidado em saúde, quanto as inter-relações das equipes e a democratização institucional na unidade de prestação de serviço ou nos órgãos das várias instâncias do SUS (Brasil, 2006). 
Desse modo, a PNH, tomando como bases conceituais as perspectivas que tematizam o trabalho como atividade industriosa, vem acumulando experiências importantes no que se refere à incitação de mudanças e transformações nos ambientes de trabalho, assim como à educação permanente dos trabalhadores por meio da articulação de apoio institucional para o desenvolvimento de ações voltadas para as relações trabalho-saúde, implantação e acompanhamento do PFST e constituição de comissões de saúde nos serviços. A história da organização dos trabalhadores no movimento por mudanças nos locais de trabalho tem confirmado que essa prática é possível e obtém sucesso.

Em consonância com as diretrizes do HumanizaSUS, o PFST se apresenta como um dos esforços empreendidos para incitar a promoção de saúde no SUS. Seus postulados indicam uma indissociabilidade entre modelos de gestão e atenção em saúde, ou seja, simultaneamente ao trabalho realizado no atendimento aos usuários é preciso estar atento e desenvolver ações que visem à promoção de saúde nos ambientes laborais.

O referido programa parte da problematização e do intercâmbio entre saberes e experiências advindas das situações concretas de trabalho que emergem como fontes de avaliação da vida no trabalho, vislumbrando os momentos de criação, construção e aprendizagem no coletivo e, também, analisando os aspectos geradores de sofrimento, desgaste e adoecimento. Tem como método a participação de cada trabalhador, que deverá se tornar multiplicador do processo de formação. Cada um, do seu próprio jeito, apropria-se dos conceitos e saberes oferecidos pelos apoiadores institucionais, analisa sua realidade de trabalho e apresenta suas invenções nas diferentes rodas e espaços institucionais.

Assim, não nos interessa apenas associar saúde à manutenção de certas condições biológicas e ambientais; entendemos processos de produção de saúde como algo vinculado à potência do ser humano em atender ao desafio de criar e recriar normas que lhe permitam melhor lidar com um meio que a todo instante se transforma, apresentando sempre desafios com os quais se deve lidar.

Como nos diz Benevides (2007), na orelha do seu livro,

construir espaços democráticos de compartilhamento de saber-poder, tornar inseparável a atividade da gestão da atividade, aumentar o grau de transversalidade nas redes de trocas afetivo-comunicacionais entre os grupos, são modos de enfrentar a lógica de funcionamento instituído, baseada numa verticalização da gestão e que dificulta a apropriação de trabalho pelos trabalhadores. 
Insistimos em dizer que tais mudanças se operarão como efeito de lutas no e pelo trabalho, uma vez que, ainda conforme essa autora, não podemos descartar a especificidade do objeto do trabalho em saúde, que é a vida, o que nos apresenta imediatamente a tarefa de reposicioná-la como coisa pública sendo, ao mesmo tempo, singular.

Nessa direção, nosso foco está dirigido para o que falam os trabalhadores do seu trabalho como alguma coisa que os provoca, que aciona sua capacidade de criação, ou seja, considerar não o trabalho como tendo uma existência em si, mas a forma como os trabalhadores criam para si perspectivas diversas. Nosso olhar é para o modo como usam de si (Schwartz, 2003) para efetivar mudanças nos ambientes de trabalho - um olhar para essa luta que é vivida como um jogo em que se batalha sempre para ganhar e não para perder (Clot, 2006). O que não significa ignorar as dificuldades e os dramas vividos no cotidiano dos serviços, dramas vividos nas situações adversas de trabalho; é preciso analisá-los, pois não nos ajuda a simples denúncia dessas situações. Procuramos construir estratégias para fortalecer os coletivos de trabalho em seus movimentos para manter e ampliar suas ações. Como ressalta Clot (2006: 165), com base em Odonne, "a tarefa consiste, então, em inventar ou reinventar os instrumentos dessa ação, não mais iniciando pelo protesto contra as pressões ou as "negociando', mas pela via de sua superação concreta”. Essa é a direção da PNH.

\section{REFERÊNCIAS}

BARROS, M. E. B. \& BENEVIDES, R. D. Da dor ao prazer no trabalho. In: SANTOS-FILHO, S. B. \& BARROS, M. E. B. (Orgs.) Trabalhador da Saúde: muito prazer! Protagonismo dos trabalhadores na gestão do trabalho em saúde. Ijuí: Ed. Unijuí, 2007.

BENEVIDES, R. Apresentação. In: SANTOS-FILHO, S. B. \& BARROS, M. E. B (Orgs.) Trabalhador da Saúde: muito prazer! Protagonismo dos trabalhadores na gestão do trabalho em saúde. Ijuí: Ed. Unijuí, 2007.

BENEVIDES, R. \& PASSOS, E. A humanização como dimensão pública das políticas de saúde. Ciência E⿱ Saúde Coletiva, 10(3): 561-571, 2005.

BRASIL. Ministério da Saúde. Trabalho e Redes de Saúde: valorização dos trabalhadores da saúde. Brasília: Ministério da Saúde/Secretaria de Atenção à Saúde, 2006.

BRITO, J. Saúde do trabalhador: reflexões a partir da abordagem ergológica. In: FIGUEIREDO, M. et al. (Orgs.) Labirintos do Trabalho: interrogações e olhares sobre o trabalho vivo. Rio de Janeiro: DP\&A, 2004.

CAMPOS, G. W. S. Subjetividade e administração de pessoal: considerações sobre modos de gerenciar o trabalho em equipes e saúde. In: MEHRY, E. E. \& ONOCKO, R. (Orgs.) Agir em Saúde. São Paulo: Hucitec, 1997. 
CAMPOS, G. W. S. O anti-Taylor: sobre a invenção de um método para cogovernar instituições de saúde produzindo liberdade e compromisso. Cadernos de Saúde Pública, 14(4): 863-870, 1998.

CAMPOS, G. W. S. Um Método para Análise e Cogestão de Coletivos. São Paulo: Hucitec, 2000.

CAMPOS, G. W. S. Saúde Paidéia. São Paulo: Hucitec, 2003.

CAMPOS, G. W. S. Clínica e saúde coletiva compartilhadas: teoria Paidéia e reformulação ampliada do trabalho em saúde. In: CAMPOS, G. W. S. et al. (Orgs.) Tratado de Saúde Coletiva. São Paulo, Rio de Janeiro: Hucitec, Editora Fiocruz, 2006. CAMPOS, G. W. S. Prefácio. In: SANTOS-FILHO, S. B. \& BARROS, M. E. B. (Orgs.) Trabalhador da Saúde: muito prazer! Protagonismo dos trabalhadores na gestão do trabalho em saúde. Ijuí: Ed. Unijuí, 2007.

CANGUilHeM, G. O Normal e o Patológico. 5. ed. Rio de Janeiro: Forense Universitária, 1990.

CLOT, Y. Territoires du Travail. Paris: Avril, 2006.

ESCÓSSIA, L. Relação Homem-Técnica e Processo de Individuação. Aracaju: Fundação Oviêdo Teixeira, 1999.

KASTRUP, V. A Invenção de Si e do Mundo: uma introdução do tempo e do coletivo no estudo da cognição. Campinas: Papirus, 1999.

NEVES, C. E. A. B. Sociedade de controle, o neoliberalismo e os efeitos de subjetivação. Revista Saúde e Loucura, 6: 75-98, 1997.

OSÓRIO DA SILVA, C. As ações de saúde do trabalhador como dispositivo de intervenção nas relações de trabalho. In: BARROS, M. E. B. et al. (Orgs.) Psicologia e Saúde: desafios às políticas públicas no Brasil. Vitória: Edufes, 2007.

ROLNIK, S. A Vida na Berlinda. Disponível em: <http://pphp.uol.com.br/tropico/ html/textos/1338,1.shl>. Acesso em: 5 jun. 2002.

SALERNO, M. S. Relação de Serviço: produção e avaliação. São Paulo: Senac, 2001.

SANTOS-FILHO, S. B. Um olhar sobre o trabalho em saúde nos marcos teóricopolíticos da saúde do trabalhador e do HumanizaSUS: o contexto do trabalho no cotidiano dos serviços de saúde. In: SANTOS-FILHO, S. B. \& BARROS, M. E. B. (Orgs.) Trabalhador da Saúde: muito prazer! Protagonismo dos trabalhadores na gestão do trabalho em saúde. Ijuí: Ed. Unijuí, 2007a.

SANTOS-FILHO, S. B. Indicadores de valorização do trabalho e trabalhadores da saúde: construindo o conceito de valorização a partir de uma perspectiva analítica. In: SANTOS-FILHO, S. B. \& BARROS, M. E. B. (Orgs.) Trabalhador da Saúde: muito prazer! Protagonismo dos trabalhadores na gestão do trabalho em saúde. Ijuí: Ed. Unijuí, 2007b.

SANTOS-FILHO, S. B. Perspectivas da avaliação na Política Nacional de Humanização: aspectos conceituais e metodológicos. Ciência ES Saúde Coletiva, 12(4): 999-1.010, 2007c. 
SANTOS-FILHO, S. B. \& BARROS, M. E. B. A base político-metodológica em que se assenta um novo dispositivo de análise e intervenção no trabalho em saúde. In: SANTOS-FILHO, S. B. \& BARROS, M. E. B. (Orgs.) Trabalhador da Saúde: muito prazer! Protagonismo dos trabalhadores na gestão do trabalho em saúde. Ijuí: Ed. Unijuí, 2007.

SCHWARTZ, Y. Travail et gestion: niveaux, critéres, instances. Revue Performances Humaines et Technicque, (n. hors-série):10-20, 2003.

TEIXEIRA, R. R. As redes de trabalho afetivo e a contribuição da saúde para a emergência de uma outra concepção de público. In: RESEARCH CONFERENCE ON RETHINKING “THE PUBLIC" IN PUBLIC HEALTH: NEOLIBERALISM, STRUCTURAL VIOLENCE, AND EPIDEMICS OF INEQUALITY IN LATIN AMERICA. San Diego: Center for Iberian and Latin American Studies (CILAS), University of California, 2004.

ZARIFIAN, P. Objetivo, Competência: por uma nova lógica. São Paulo: Atlas, 2001a.

ZARIFIAN, P. Valor, organização e competência na produção de serviço: esboço de um modelo de produção de serviço. In: SALERNO, M. S. (Org.) Relação de Serviço: produção e avaliação. São Paulo: Senac, 2001 b. 



\title{
6. A Implantação de Políticas Públicas de Ergonomia na Saúde do Trabalhador: A EXPERIÊNCIA PARTIIIIPATIVA dO MINISTÉRIO dO TRABaLHO E EMPREGO
}

\author{
Paulo Antônio Barros Oliveira | Lys Esther Rocha \\ Airton Marinho da Silva | Carlos Alberto Diniz Silva \\ Maria de Lourdes Moure
}

\section{Breve Histórico}

As relações de trabalho e suas consequências para o trabalhador são tratadas no Brasil por um sistema complexo com a atuação de diferentes instituições, cada uma com atribuições definidas pela legislação. Uma de suas principais características é a intervenção do Estado na busca de soluções dos conflitos da relação entre capital e trabalho. No campo das relações coletivas, os pilares são a organização sindical e as negociações coletivas, por meio dos quais são determinadas as condições gerais de trabalho, inclusive salários. No campo das relações individuais, a característica preponderante é a existência de uma legislação bastante detalhada e rígida, com caráter protetivo (Coelho, 1996). No âmbito do trabalho, o Ministério do Trabalho e Emprego (MTE) é o órgão federal encarregado da fiscalização do cumprimento dos direitos trabalhistas. No âmbito da ergonomia, suas ações estão assentadas no que delimita a competência da União quanto à inspeção do trabalho, incluindo a Constituição Federal, o decreto-lei n. 5.452, de 1º de maio de 1943 (Consolidação das Leis do Trabalho - CLT), a lei n. 10.593/2002, a convenção 81 da Organização Internacional do Trabalho (OIT) e os decretos n. 95.461/1987 e n. 4.552/2002 (Regulamento da Inspeção do Trabalho).

Pressões tanto internacionais como internas contra as precárias condições de trabalho no Brasil, principalmente advindas do início da efervescência do movimento sindical de algumas categorias mais organizadas, e o início do processo de abertura política corroboraram para que em 1977 o capítulo V da CLT, que trata de saúde e segurança no trabalho, fosse alterado. Incluiu-se 
então uma normatização a mais que a anterior, incorporando, na seção XIV, alguns princípios de ergonomia, como artigos relacionados à prevenção da fadiga; ao peso máximo que o empregado pode remover individualmente; à obrigatoriedade da colocação de assentos que assegurem a postura correta do trabalhador quando a execução da tarefa exigir que se trabalhe sentado; bem como o fornecimento de assentos aos empregados para serem utilizados durante as pausas, quando o trabalho for executado em pé.

No Brasil, demorou o início da participação do movimento operário na definição das políticas públicas na área trabalhista e da saúde. No início do século XX, a atenção foi maior na luta pela redução da jornada de trabalho e pela diminuição dos acidentes no trabalho. A partir de 1930, o movimento sindical foi reorganizado pelo Estado, possibilitando o controle do operariado durante o processo de industrialização do país. As relações de trabalho estão disciplinadas pela Consolidação das Leis do Trabalho de 1943, tendo como característica a transformação dos sindicatos em entidades de direito público, com a perspectiva de atrelá-los ao Estado. Entre os princípios dessa legislação, está o da unicidade sindical, que consiste no monopólio da representação sindical, acompanhada do imposto sindical (ou contribuição sindical), que garante o funcionamento das entidades independentemente da filiação dos trabalhadores.

No final da década de 1970, cresceu o movimento pela autonomia dos sindicatos em relação ao Estado, cujo marco são as greves de 1978 em diferentes regiões do país, mas realizadas com maior grau de organização nas indústrias metalúrgicas do chamado ABC paulista, quando a elevação dos salários foi negociada diretamente em acordo coletivo. A estrutura corporativa dos sindicatos tem sido, aos poucos, modificada por meio de conquistas dos trabalhadores, como a formação das centrais sindicais, reconhecidas em março de 2008, de caráter nacional e não estruturadas por categorias profissionais. Nesse mesmo período, incrementaram-se as lutas sindicais por melhores condições de saúde no trabalho, dentro de uma proposta mais global de criação de um caminho por meio da negociação direta dessas condições de trabalho, que diminuísse o poder de controle do Estado e retirasse o caráter assistencialista dos sindicatos.

No campo da saúde, em 1983, a Organização Pan-Americana da Saúde (Opas) propôs a ampliação do conceito clássico da saúde ocupacional, passando a empregar o termo 'saúde dos trabalhadores'. Essa nova proposta, além de incluir o escopo da saúde ocupacional - que tradicionalmente abrangia apenas a identificação e o controle dos riscos profissionais nos ambientes do trabalho -, 
pretendia agregar a compreensão das relações entre atividade de trabalho e saúde, ou seja, uma visão estrutural da ocupação como determinante social desse processo. A saúde dos trabalhadores deveria contar com a atuação de diferentes instituições, com suas atribuições definidas pela legislação. Esse enfoque, mais amplo, propunha, entre outros aspectos, pelo menos dois avanços importantes para o processo de melhoria das condições de trabalho: a participação dos trabalhadores na resolução de seus problemas de saúde e segurança, e a inclusão na avaliação do ambiente de trabalho também de aspectos da organização do trabalho e da qualidade de vida.

Nesse mesmo período de meados da década de 1980, no âmbito de modificações políticas importantes que ocorriam em alguns estados da federação, as secretarias de Saúde desses estados criaram programas de saúde dos trabalhadores que propuseram ações interinstitucionais, compreendendo as atividades de assistência à saúde e vigilância dos ambientes de trabalho. Vários desses programas funcionam até os dias de hoje e deram origem à implementação da política setorial da saúde do trabalhador no Sistema Único de Saúde (SUS), servindo como campo de práticas para essa implementação.

No campo do trabalho, a norma brasileira que trata da ergonomia (NR-17) foi modificada em 1990 (Brasil, 1990), ao fim de um processo de tentativa de reformulação de todas as normas regulamentadoras (NR) no primeiro governo após o regime militar (a chamada Nova República). Essa importante alteração, que insere no texto legal brasileiro o item organização do trabalho, foi resultado de intensa dinâmica social e da detecção de uma 'epidemia' de tenossinovite ocupacional em digitadores. No transcurso dos anos 80 , o movimento dos trabalhadores de processamento de dados, aliado ao chamado 'novo sindicalismo', mobilizou-se nacionalmente e conseguiu o reconhecimento pela Previdência Social da relação existente entre as lesões por esforços repetitivos e o trabalho.

Nesse mesmo período, em plena fase da elaboração da nova Constituição, aumentou a demanda por fiscalização das empresas de processamento de dados com base em denúncias de trabalhadores, corroboradas por médicos e engenheiros do trabalho de sindicatos dos empregados de empresas de processamento de dados de diversos estados. A Associação Nacional de Profissionais de Processamento de Dados solicitou à Secretaria de Segurança e Saúde no Trabalho, em Brasília, a elaboração de uma norma para os profissionais de processamento de dados que limitasse a cadência de trabalho, proibisse o pagamento de prêmios de produtividade e estabelecesse critérios de conforto para os trabalhadores em relação ao mobiliário e ao ambiente de trabalho. 
Ao mesmo tempo, a Delegacia Regional do Trabalho de São Paulo elaborou um manual e um documento audiovisual sobre o trabalho com terminais de vídeo, que representava a tradução e a adaptação do texto Les Écrans de Visualisation: guide méthodologique pour médecin du travail (INRS, 1987). Esse material foi distribuído aos médicos e engenheiros das demais delegacias regionais do Trabalho do país. Em dezembro de 1989, foi realizado em São Paulo um seminário nacional que tratava de problemas relacionados ao trabalho com terminais de vídeo. Nesse evento, foi decidido que não deveria ser elaborada uma norma apenas para os profissionais de processamento de dados, já que as lesões por esforços repetitivos eram observadas também em outras atividades profissionais.

A redação final da NR-17, publicada na portaria n. 3.751, de 23/11/90, resultou de uma negociação tripartite com a participação de representantes dos empregadores, dos trabalhadores e do Ministério do Trabalho. Foi a primeira experiência de modificação de norma de Saúde e Segurança com base em uma negociação tripartite, princípio que, mais tarde, acabaria sendo firmado como regra geral para esses procedimentos. Foram especificadas recomendações para as atividades de processamento de dados e incluídos itens genéricos sobre mobiliário, ambiente de trabalho, equipamentos e organização de trabalho a serem utilizados também em negociações específicas para outras atividades profissionais. $\mathrm{O}$ enfoque da saúde dos trabalhadores é incorporado à NR-17, incluindo a organização do trabalho como aspecto a ser analisado na avaliação das condições de trabalho que podem, potencialmente, comprometer a saúde. Tal inclusão está mais de acordo com o que se entende por ergonomia: conjunto de conhecimentos científicos relativos ao homem e necessários à concepção de ferramentas, máquinas e dispositivos que possam ser utilizados com o máximo de conforto, segurança e eficiência (Wisner, 1987). A análise ergonômica do trabalho propõe a participação dos trabalhadores na avaliação das condições de trabalho e na validação dos seus resultados.

Assim, a fiscalização da segurança e da saúde do trabalhador pelo Ministério do Trabalho, que foi efetivamente instituída a partir da década de 1980, na estratégia de reforçar os mecanismos de acordo e negociação coletiva pelo processo tripartite, cria, no final de 1990, a Comissão Tripartite Paritária e Permanente (CTPP), para fins de consulta, diagnóstico, proposta técnica, validação e revisão de normas visando à melhoria contínua das situações de trabalho. A ratificação pelo Brasil da convenção n. 148 da OIT, que regulamenta a participação dos trabalhadores no acompanhamento das inspeções 
do trabalho e a implementação das negociações tripartites, dá novo impulso às tentativas de melhorias das condições de trabalho no país.

Como podemos ver, a participação dos trabalhadores no processo de diagnóstico, proposta técnica, validação e revisão de normas de saúde e segurança no trabalho é regulamentar no Brasil, mas tais condições não estão distribuídas igualmente em todo o território nacional. Até mesmo em regiões em que o movimento sindical é mais organizado, como no Sul e no Sudeste do país, sua atuação não está uniformemente distribuída: metalúrgicos, bancários, comerciários, telefônicos, petroleiros e petroquímicos costumam ser mais atuantes na defesa de questões relacionadas à saúde e segurança no trabalho; no Nordeste, essas ações lideradas pelos sindicatos têm sido mais pontuais.

Outro aspecto que interfere nesse quadro é o papel exercido pela própria empresa. Organizações com forte vinculação ao comércio exterior e que respondam a interesses de consumidores globalizados têm demonstrado maior flexibilidade à participação efetiva de seus trabalhadores nos processos de negociação e de implementação de medidas coletivas de proteção à saúde e segurança no trabalho, incluindo as de ergonomia.

Também o desempenho dos próprios auditores fiscais interfere nesse processo, não só pela distribuição não uniforme do conhecimento dentro da corporação, mas também devido à atuação mais ou menos diretiva e/ou coercitiva das gerências regionais desses órgãos, que acaba influindo no resultado final das ações de auditagem. Mesmo com a autonomia concedida pela legislação à auditoria fiscal, a conformação da estrutura física e operacional, além do fornecimento de condições de acesso às ferramentas modernas de auditoria e de inteligência investigativa, interfere na capacidade efetiva de regulação do Estado nessa e em outras áreas de interesses conflituosos.

\section{A Mudança na Politica do Ministério do Trabalho e Emprego}

Com a automação de base microeletrônica, surgem novas formas de organizar as atividades produtivas, com a utilização de novos métodos de gestão que exigem maior participação dos trabalhadores e de seus sindicatos. A introdução das novas tecnologias modifica as responsabilidades dos trabalhadores, os requisitos de qualificação, o conteúdo do trabalho, as cargas físicas e mentais e as relações sociais no trabalho. A perda do controle sobre a cadência de trabalho, com sua frequente intensificação, tem gerado um 
aumento de queixas de fadiga, estresse, doenças psicossomáticas e distúrbios osteomusculares relacionados ao trabalho.

O movimento sindical, com relação à luta pela saúde, vem estabelecendo frentes de trabalho com propostas de negociações coletivas para a construção de um processo de mudança nas relações de trabalho, na perspectiva de que a negociação direta viabilize melhorias nas condições de saúde e segurança no trabalho. Bonciani (1996) assinala algumas características dessas negociações:

- a participação dos diversos atores sociais, incluindo os representantes dos trabalhadores, dos empresários e do Estado, além de outras instituições não governamentais;

- o reconhecimento do princípio da negociação permanente com diálogo direto e entendimento entre as partes, com comissões que tenham a função explícita de acompanhar o cumprimento do acordo e negociar soluções para os conflitos que surgem;

- a busca de fortalecimento da representação dos trabalhadores no local de trabalho, inclusive com a valorização da Comissão Interna de Prevenção de Acidentes (Cipa);

- o incentivo ao desenvolvimento de atividades de formação dos trabalhadores;

- a redefinição do papel do Estado, reconhecendo os sindicatos patronais e dos trabalhadores como atores sociais que são capazes de dialogar e buscar o entendimento direto;

- a apresentação clara das cláusulas com descrições de medidas preventivas e corretivas, de forma a facilitar o seu entendimento pelo trabalhador e, ao mesmo tempo, permitir que o empregador saiba interpretar corretamente as medidas propostas.

No momento atual, as transformações dos processos de trabalho, devem ser buscados instrumentos que possibilitem aos próprios interessados (trabalhadores e empregadores) uma participação mais efetiva sobre as decisões que afetam o trabalho. As negociações coletivas são consideradas como um momento especial em que os trabalhadores podem obter melhorias das condições de trabalho. Assim, diante de um problema identificado no processo de produção ou pela repercussão na saúde dos trabalhadores, a análise ergonômica do trabalho permite conhecer melhor a situação, o que é importante para subsidiar a negociação coletiva que articularia as mudanças necessárias. 
Embora a nova redação da NR-17 tenha sido publicada em 1990, na época foi pouco utilizada pelos auditores fiscais do trabalho (AFT), apesar das grandes demandas sociais para resolução dos distúrbios osteomusculares relacionados ao trabalho, cuja incidência aumentava gradativamente em diferentes setores da produção. No início desse processo de mudanças, as modificações, do ponto de vista ergonômico, aconteceram principalmente nas atividades de processamento de dados e na discussão sobre conforto versus insalubridade no trabalho, até porque essas questões estavam inseridas em um processo histórico e social intenso.

Ao longo dos anos 90, o aumento do número de doenças ocupacionais relacionadas à organização do trabalho, notadamente a intensificação da cadência e a precarização das relações de emprego, aliado às pressões de diferentes setores (Ministério Público do Trabalho, Previdência Social, sindicatos) para que se incentivasse a fiscalização da aplicação da NR.17, levou o Ministério do Trabalho e Emprego (MTE) a implementar uma coordenação nacional das ações em ergonomia no âmbito de suas competências. O Departamento de Segurança e Saúde no Trabalho (DSST), da Secretaria de Inspeção do Trabalho (SIT), identificou a pouca utilização da NR.17 nas ações fiscais, em decorrência da falta de conhecimento técnico dos auditores sobre a matéria. Havia problemas e demandas, mas faltava competência específica em ergonomia na inspeção do trabalho para enfrentá-los.

Constatada a necessidade de atualização para auditores fiscais, desencadeou-se um processo de capacitação que envolveu um grupo de instrutores do próprio MTE (AFT e Fundacentro), articulado com a Associação Brasileira de Ergonomia (Abergo). Em 2000 e 2001, foram realizados 15 cursos de capacitação de 30 horas, aos quais compareceram aproximadamente 450 AFT (engenheiros e médicos do trabalho e técnicos de segurança) de todas as delegacias regionais do Trabalho, utilizando-se apostilas criadas especificamente para orientar a fiscalização quanto às exigências contidas na NR-17. Nesse processo, grupos de auditores realizaram intervenções em situações reais de trabalho que foram monitoradas pelos instrutores, e cujos resultados foram discutidos e avaliados em dois seminários ocorridos durante os congressos da Abergo de 2000 e 2001, em espaço especificamente delimitado para essas atividades (Oliveira et al., 2004a, 2004b).

Além dos conhecimentos discutidos, nesses cursos o MTE transmitiu aos AFT orientações gerais no sentido de que a análise ergonômica do trabalho não é, necessariamente, indicada para todas as empresas, nem para toda a empresa. Em tais cursos, foram enfatizados os seguintes pontos: 
- a necessidade da indicação precisa da análise ergonômica do trabalho para uma situação específica;

- a inclusão das recomendações nos relatórios e a verificação do cumprimento dessas medidas;

- a possibilidade de se privilegiar um cronograma de execução das modificações efetivas nos ambientes e organizações, com a participação dos trabalhadores, em vez da simples elaboração dos chamados laudos ou estudos ergonômicos;

- a necessidade de que os auditores façam notificações com demandas detalhadas e precisas, e de que os cronogramas de implementações dessas ações nas empresas sejam negociados coletivamente, devido às peculiaridades das transformações requeridas. Conforme a situação, o auditor deve fazer as exigências necessárias, prescindindo de análise ergonômica de terceiros, utilizando seus conhecimentos e as normas e notas técnicas existentes. Nessa lógica, um dos objetivos das capacitações foi possibilitar aos AFT a compreensão de que a reformulação da demanda faz parte do processo de construção social da ação ergonômica - e que mais importante do que simplesmente a realização de um laudo ergonômico é a implementação de ações que promovam transformações reais nas condições de trabalho. Para tanto, é imprescindivel compreender o trabalho antes de propor qualquer mudança (Brasil, 2002a).

Para qualificar esse processo de intervenção, de âmbito nacional, em março de 2001, o DSST criou a Comissão Nacional de Ergonomia (CNE), com o objetivo de assessorá-lo na qualificação e na coordenação das ações para a aplicação da NR-17. A CNE tinha, entre outras atribuições, a de coordenar as negociações sobre as melhorias das condições de trabalho e a de mapear as demandas nacionais referentes à aplicação da NR-17, assim como as empresas ou setores de atividade econômica de todo o território nacional que tenham problemas ergonômicos em comum. Ainda coube à CNE implementar a articulação do DSST com outras instâncias governamentais, representar o DSST onde solicitado, uniformizar, disseminar e implantar as melhorias acordadas nessas negociações e propor modificações em estudos e projetos que circulam por esse departamento e que têm interface com a ergonomia. As discussões setoriais, quando necessárias, têm caráter tripartite, contando com a representação dos trabalhadores e dos empregadores das categorias econômicas envolvidas. A partir de 2004, a administração federal não convocou mais a CNE e implementou parte das ações que vinham 
sendo realizadas através de grupos de trabalho tripartites especificamente constituídos, como veremos a seguir.

\section{Implementação de Ações Normativas}

A CNE participou de diversas atividades com o objetivo de orientar empregados, empregadores, auditores fiscais do trabalho, profissionais ligados à área e outros interessados na adoção de melhorias nos postos de trabalho. Um exemplo interessante foram os estudos e pareceres sobre a adoção de postura fixa de pé em diversos segmentos da economia nacional. A base da política implementada pela $\mathrm{CNE}$ consistiu no princípio reconhecido internacionalmente de que a postura mais adequada ao trabalhador é aquela que ele escolhe livremente e que pode ser modificada ao longo do tempo. A concepção dos postos de trabalho ou da tarefa deve favorecer a variação de postura, principalmente a alternância entre a sentada e em pé, estabelecendo que o tempo de manutenção de uma postura deve ser o mais breve possível, pois seus efeitos, nocivos ou não, dependem do tempo em que ela será mantida (Adams \& Hutton, 1988).

Todo esforço de manutenção postural leva a uma tensão muscular estática (isométrica) que pode ser nociva à saúde. De acordo com essa lógica, a CNE emitiu a primeira nota técnica, a de número NT 60/2001, na qual esclarece que a postura de trabalho adotada é função da atividade desenvolvida, das exigências da tarefa (visuais, emprego de forças, precisão dos movimentos etc.), dos espaços de trabalho e da ligação do trabalhador com máquinas e equipamentos de trabalho, como o acionamento de comandos, por exemplo. As amplitudes de movimentos dos segmentos corporais como os braços e a cabeça, assim como as exigências da tarefa em termos visuais, de peso ou esforços, influenciam na posição do tronco e no esforço postural, tanto no trabalho sentado como no trabalho em pé.

Conclui-se que qualquer postura, desde que mantida de maneira prolongada, é mal tolerada. A alternância de posturas deve ser sempre privilegiada, deve ficar à escolha do trabalhador. Ele é quem vai saber, diante da exigência momentânea da tarefa, qual é a melhor posição. Uma tarefa tem exigências variadas; por isso, nunca se pode afirmar de antemão qual é a melhor postura baseando-se apenas em critérios biomecânicos. Logo, não são os fisiologistas que têm a palavra final sobre o conforto. Um posto de trabalho, mesmo quando bem projetado do ponto de vista antropométrico, pode se revelar 
desconfortável se os fatores organizacionais, ambientais e sociais não forem levados em consideração.

\section{SUPERMERCADOS}

Os operadores de checkout, em especial de supermercados, têm apresentado distúrbios osteomusculares relacionados ao trabalho. Os Sindicatos dos Trabalhadores do Comércio de São Paulo e do Rio Grande do Sul e o Ministério Público do Trabalho iniciaram, em 1994, um conjunto de ações com médicos e engenheiros de segurança do trabalho das delegacias regionais do Trabalho para melhoria dessa situação. Bem mais tarde, outras regionais do MTE começaram a fiscalizar com maior ênfase essas condições de trabalho (Khouri, Amâncio \& Peres, 2001) e, no início dos anos 2000, já com a coordenação da CNE, e considerando-se que essa atividade ocorre em todo o Brasil, o DSST do MTE nomeou um grupo técnico em dezembro de 2002, envolvendo representantes dos empregadores, dos empregados e da sociedade civil, como a Universidade de São Paulo, para propor um anexo da NR-17, com o objetivo de estabelecer parâmetros e diretrizes mínimas para adequação das condições de trabalho dos operadores de checkout, visando à prevenção dos problemas de saúde e segurança a eles relacionados.

Os resultados desse grupo de trabalho foram apresentados em uma minuta que incluía itens como posto de trabalho, equipamentos, ambiente de trabalho, manipulação de mercadorias, organização do trabalho, aspectos psicossociais do trabalho e formação dos trabalhadores. Após a aprovação do texto pela Comissão Tripartite Paritária Permanente (CTPP), foi criado o Grupo Técnico Tripartite, que elaborou e aprovou por consenso a proposta de anexo da NR-17. Esse esforço culminou com a aprovação pela CTPP e a publicação na portaria n. 8, de 30/3/2007, do Anexo I da NR-17: Trabalho dos Operadores de Checkout. O anexo compreende as disposições transitórias, incluindo a implantação progressiva de alguns itens, com prazos de três, seis e doze meses para implementação, e prazo até dezembro de 2011 para cumprimento completo do Anexo I em todos os estabelecimentos.

Destacam-se os principais aspectos desse anexo quanto ao posto de trabalho: mobiliário com dimensões, distâncias e alturas que garantam movimentação adequada; equipamentos e ferramentas que evitem esforços extremos e acidentes; ambiente físico que permita trabalhar com o máximo conforto possível; e possibilidade de adequações e ajustes no conjunto do posto de trabalho. 
Com relação à manipulação de mercadorias, deverão ser tomadas medidas que impeçam o uso de força muscular excessiva, como tamanho compatível das embalagens, equipamento acessório, pessoal auxiliar etc.; medidas para evitar o ensacamento por parte do operador. Por exemplo: um ensacador para, no mínimo, cada três checkouts; ensacamento pelo cliente etc. No caso da pesagem de mercadorias, deverá ser realizada somente com a balança bem posicionada no posto de trabalho. A empresa deverá disponibilizar pessoal auxiliar, sempre que necessário, nos checkouts de pessoas idosas, deficientes, gestantes ou incapacitadas.

Quanto à organização do trabalho, o Anexo preconiza medidas para adequar o ritmo de trabalho. Por exemplo: pessoal de apoio, filas únicas, caixas especiais, pausas, rodízios entre operadores etc. É vedado sistema de avaliação de desempenho, para fins de remuneração ou premiação, com base no número de mercadorias registradas pelo operador. Também são proibidas ao operador tarefas de segurança patrimonial. Os aspectos psicossociais do trabalho compreendem a identificação adequada, escolhida pelo próprio trabalhador, e dispõem a vedação do uso de vestimentas, propagandas e maquiagem temática que causem constrangimento ou firam a dignidade pessoal.

No que concerne à formação e à informação dos trabalhadores, o treinamento engloba todos os envolvidos com o trabalho de checkout com conteúdo programático básico, com duração mínima de duas horas, anualmente, além de informar com antecedência mudanças a serem implementadas no processo de trabalho com a participação de integrantes da área técnica - Serviço Especializado em Engenharia de Segurança e Medicina do Trabalho (SESMT), coordenador do Programa de Controle Médico de Saúde Ocupacional (PCMSO) e Cipa.

\section{Teleatendimento/Telemarketing}

Os serviços de teleatendimento, considerados vitais para o desenvolvimento das empresas na nova estrutura da produção e da economia, tornaram-se viáveis graças à junção das tecnologias da telefonia e da informática. Tem sido constatado que uma regra no setor é a incorporação de princípios neotayloristas, baseados em formas de controle exacerbadas do tempo e das interações (Jackson Filho \& Assunção, 2006), trazendo prejuízos evidentes à saúde dos trabalhadores e a necessidade de intervenção pública por parte da fiscalização. Em razão das dificuldades encontradas pela auditoria fiscal do MTE para fazer com que as empresas operadoras de centrais de atendimento e de relaciona- 
mento com clientes implantassem as medidas técnicas preconizadas na NR-17, levando-se ainda em conta diversas demandas sindicais dos trabalhadores, a CNE discutiu em vários eventos e reuniões, desde 2002, o impacto das novas tecnologias sobre a atividade dos trabalhadores em contato telefônico.

Em reconhecimento aos agravos a que estão submetidos esses trabalhadores, demonstrados em farta literatura científica, e após ampla discussão interna na CNE, entendeu-se que era necessário o desenvolvimento de uma regulamentação específica para o setor, que envolvesse, segundo dados empresariais, a crescente cifra de pelo menos setecentos mil trabalhadores (ABT, 2005). Em outubro de 2004, a CNE elaborou nota técnica que ressaltava a imposição simultânea de intenso esforço mental, elevado esforço visual, exigências de grande responsabilidade acompanhada de falta de controle sobre o processo de trabalho, rigidez postural, sobrecarga estática de segmentos corporais, cobranças excessivas de desempenho com utilização de monitoramento eletrônico, gravação e escuta de diálogos e premiação por produção. Demonstrou-se que não vinham sendo feitas intervenções no campo da ergonomia que assegurassem o bem-estar dos operadores, sendo frequentes a realização de pausas insuficientes para descanso e conflitos diversos entre a tarefa a executar e as condições de trabalho oferecidas, gerando desgaste evidente para os operadores, refletido em altas taxas de absenteísmo e de rotatividade. Propuseram-se, então, detalhadas medidas técnicas relativas ao mobiliário e aos equipamentos dos postos de trabalho, ao ambiente, à organização, aos aspectos psicossociais do trabalho e aos programas de prevenção da saúde.

Em março de 2005, o DSST incluiu no endereço eletrônico do ministério a recomendação técnica DSST 01/2005, referente à Segurança e Saúde nas Atividades de Teleatendimento. $O$ texto baseou-se integralmente na nota técnica da CNE, já mencionada, e trouxe, além de positivo referencial fiscal para o setor e para os auditores fiscais, a manifestação contrária dos setores empresariais envolvidos. Como descrito em Peres e colaboradores (2006), a despeito de não ter sido publicada no Diário Oficial e de não apresentar efeito de norma impositiva, o texto teve ampla divulgação, inclusive em revistas especializadas, e gerou efeitos afirmativos, como referência para inspeções do MTE e acordos tripartites.

Entretanto, a movimentação empresarial contrária à forma de regulamentação, considerada unilateral, levou o MTE a incluir o tema nas discussões normativas tripartites e a formar grupo técnico para a elaboração de anexo à NR-17, específico sobre o teleatendimento. O grupo, formado por auditores fiscais do MTE, técnicos da Fundacentro e membros do Ministério Público 
do Trabalho, desenvolveu texto técnico, que em março de 2006 foi disponibilizado para consulta pública. Após o prazo regulamentar de sessenta dias e o recebimento de contribuições da sociedade ao texto original, foi instituído um Grupo de Trabalho Tripartite sobre Teleatendimento/Telemarketing, composto por representantes dos empresários, dos trabalhadores e do governo federal, incluindo auditores fiscais, representantes do Ministério Público do Trabalho e da Agência Nacional de Telecomunicações (Anatel). Durante os meses seguintes, a comissão se reuniu várias vezes e, obtido um consenso, elaborou um texto que veio a ser aprovado pela CTPP em março de 2007 e publicado na portaria n. 9, de 30/3/2007, como Anexo II da NR-17 - Trabalho em Teleatendimento/Telemarketing.

O conteúdo do anexo, de cumprimento obrigatório, é aplicável a todas as empresas com teleatendimento/telemarketing, no todo ou em setores, e tem capítulos detalhados destinados à melhoria de: 1) mobiliário; 2) equipamentos dos postos de trabalho; 3) condições ambientais de trabalho, incluindo condições acústicas e de climatização; 4) organização do trabalho, definindo tempo máximo efetivo de atividade em teleatendimento/telemarketing de seis horas diárias, além da instituição obrigatória de pausas em dois períodos de dez minutos e aumento do intervalo obrigatório para repouso e refeição para vinte minutos. Entre diversos itens relativos à organização do trabalho, são importantes a vedação de competição abusiva e a exposição pública de desempenho, entre outras formas de redução de carga cognitiva e emocional no teleatendimento. $O$ texto do Anexo II ainda apresenta diretrizes sobre capacitação dos trabalhadores; condições sanitárias de conforto; programas de saúde ocupacional e de prevenção de riscos ambientais, incluindo detalhamento de análises ergonômicas a serem realizadas nas empresas e facilitação do trabalho para pessoas com deficiência. Foram negociados prazos no grupo tripartite para a implementação, como correção de mobiliário em até cinco anos, mas praticamente todo o conteúdo do Anexo II está em vigor desde julho de 2007, permitindo ao MTE, às entidades sindicais dos trabalhadores, ao Ministério Público do Trabalho e à sociedade uma atuação mais efetiva e adequada sobre as condições de trabalho em teleatendimento (Peres et al., 2006).

\section{Outros Casos Relevantes}

Outros ramos de produção foram causas de preocupação da CNE. Entre esses, o do agronegócio vem se destacando. As empresas de abate e processa- 
mento de carnes empregam cerca de 170 mil trabalhadores em todo o país. A alta prevalência de distúrbios osteomusculares relacionados ao trabalho em sistemas de produção com as características existentes nesse ramo industrial vem sendo amplamente descrita na literatura. Segundo a Occupational Safety $\&$ Health Administration (Osha, 1997), 50\% das doenças e das lesões relacionadas ao trabalho em 1997 nas indústrias de aves eram distúrbios osteomusculares relacionados ao trabalho. No Brasil, segundo dados do Ministério da Previdência Social (Brasil, 2002b), as lesões por esforços repetitivos/distúrbios osteomusculares relacionados ao trabalho (LER/Dort) são a primeira causa de doenças relacionadas ao trabalho nas agroindústrias. Em 2000, por solicitação do Ministério Público do Trabalho, em razão do grande número de casos de Dort registrados no INSS na região oeste de Santa Catarina, foram efetuadas investigações pelo MTE em oito unidades das cinco empresas do setor ali situadas. Com base no diagnóstico, a CNE criou um grupo técnico específico com o objetivo de verificar se as condições de trabalho e de funcionamento das empresas eram semelhantes nas diferentes regiões do país; identificar o(s) setor(es) mais crítico(s) do ponto de vista de segurança e saúde; estabelecer os fatores determinantes (a organização do trabalho, as características da situação de trabalho, mobiliário e equipamentos utilizados etc.) para o adoecimento; e verificar o que as empresas estavam fazendo para alterar/melhorar as condições de trabalho e reduzir os casos de Dort.

Confirmou-se que a forma como é organizado o processo produtivo nessas empresas representa risco potencial à saúde e à segurança dos trabalhadores e que as melhorias implementadas pelas empresas têm sido insuficientes. Os trabalhadores continuam sujeitos a pressões de tempo, estresse, jornadas de trabalho prolongadas, tarefas fragmentadas, ritmo imposto, pressão de tempo, número e tempo insuficiente de pausas para repouso, com exposição ao frio, umidade, ruído, repetitividade, esforços estáticos, posturas inadequadas (por exemplo, o trabalho fixo em pé), entre outros fatores.

A atuação dos auditores fiscais nesse ramo de atividade pôde confirmar essa situação, o que justificou a preocupação da CNE e do DSST em desenvolver uma política nacional de fiscalização, com o objetivo de melhorar as condições de trabalho e reduzir os altos índices de agravos à saúde nesse setor. Foi elaborada minuta de nota técnica sobre o tema, mas o processo ficou sobrestado de 2003 até o início do ano de 2010. Nesse ano, o DSST criou um Grupo de Estudos Tripartite (GET) para reencaminhar formalmente as soluções normativas possíveis para esse ramo da economia. Caso o assunto 
evolua, o resultado do GET é levado à consulta pública e o produto fianal é encaminhado à CTPP para negociação e oficialização de uma nova norma.

Outra demanda emergente, que requereu uma ação coordenada em âmbito nacional desde 2002, foi a que trata da indústria de calçados. A CNE promoveu diversos eventos e esteve presente também em outros, no Rio Grande do Sul, na Bahia, em São Paulo e no Ceará sobre ergonomia e trabalho na indústria de calçados, com a participação de AFT, empregadores, trabalhadores e profissionais da área de segurança e saúde de empresas. Têm-se discutido diversos aspectos técnicos sobre a determinação de posturas fixas por parte das empresas, e a tentativa de se privilegiar a abordagem do design em postos de trabalho que permitam a alternância postural, com ênfase nos aspectos relativos à dinâmica e à complexidade do processo produtivo. Como nos demais casos, valoriza-se como imprescindível, na ação ergonômica, a participação dos trabalhadores no processo de formulação e projeto de postos de trabalho, o que, historicamente, não é usual na produção de calçados. Grupos de estudos tripartites foram criados, foram elaborados manuais para a produção de máquinas seguras para o setor de couro e calçados, e uma Comissão Tripartite Paritária se reúne para a definição de parâmetros de ergonomia para o setor.

Outro tema que tem sido tratado é a biomecânica do trabalho em pé e sentado. Indicou-se o trabalho na posição sentada quando as exigências da tarefa são de acuidade visual e a movimentação de peso é expressa em gramas (como ocorre, por exemplo, na atividade de costura). Reiterou-se a necessidade dos movimentos dos segmentos corporais durante o trabalho, assim como o formal e impositivo impedimento do trabalho fixo em pé. Têm sido valorizadas as experiências de intervenções tripartites, como as que ocorreram na região do município de Birigui, em São Paulo no final dos anos 90, que contam com a participação da auditoria fiscal do trabalho e de sindicatos patronais e de trabalhadores.

Foi também identificado, consensualmente, que os problemas nos ambientes na indústria do calçado, além das especificidades próprias das condições em cada um dos polos calçadistas, não se restringem ao trabalho em pé, mas existem diversos outros problemas envolvendo questões de segurança e saúde, exposição a produtos químicos e proteção de máquinas, incluindo as relativas à organização do trabalho.

Boas práticas e experiências bem-sucedidas também têm sido observadas em outras situações. Em uma delas, Lima Jr., Lopes-Vacarcel e Dias (2005) destacam a criação do núcleo de ergonomia nas atividades de fiscalização da construção civil, pela Delegacia Regional do Trabalho de São Paulo (DRT/SP). Em 2002, o núcleo de ergonomia do Programa Estadual da Construção 
Civil, em São Paulo, direcionou suas ações para fazer um diagnóstico a fim de identificar os fatores determinantes do risco de Dort por fase da obra e buscar em conjunto soluções e propostas de intervenção preventiva para a melhoria das condições de trabalho nos canteiros de obras. O setor vem apresentando maturidade para início da discussão dessa questão nas comissões regionais e na comissão nacional da construção, e são identificados com relativa frequência casos de boas práticas, principalmente no que diz respeito à movimentação manual de cargas nas fases de alvenaria e acabamento nas obras.

\section{Futuro a se Construir}

As mudanças nas situações de trabalho ocorridas nos últimos vinte anos nos diversos segmentos produtivos, atingindo um grande número de trabalhadores jovens, impuseram a necessidade de se priorizar a prevenção de doenças relacionadas ao trabalho, principalmente LER/Dort, por meio de abordagem coletiva a partir de 2005, incluindo-as como meta estratégica entre os programas de saúde e segurança nas Superintendências Regionais do Trabalho (Peres et al., 2000; Moure, 2006).

Nos últimos dois anos, a regional de São Paulo tem implementado ações coordenadas nas suas subdelegacias, atuais gerências regionais, da capital e do interior, com a participação de representantes de trabalhadores, empregadores e demais parceiros. $\mathrm{O}$ balanço das ações nos primeiros anos desse projeto estratégico referente à prevenção das LER/Dort identifica ações em três cenários muito distintos: supermercados, bancos e processamento de dados (Moure, 2005). No final desta década, houve o início de trabalho conjunto mais fortemente no setor do comércio. Foram realizadas ações fiscais tripartites bem-sucedidas, como no setor de supermercados, focadas nos operadores de checkout e repositores, em que a demanda principal do movimento sindical foi relacionada principalmente às questões de organização do trabalho (ausência de pausas, desrespeito à jornada de trabalho legal, postura principal de trabalho em pé e não limitação de peso máximo de levantamento individual). Em 2007, incluiu-se formalmente no planejamento o teleatendimento, e como as LER/Dort atingem os mais diversos segmentos produtivos, foram recebidas demandas crescentes. Como encaminhamento natural, foi proposta a criação de Comissão de Ergonomia Regional, no início do segundo semestre daquele ano, para subsidiar a implementação da NR-17 e suas atualizações.

Por último, cabe-nos destacar que, em termos de políticas públicas em ergonomia, na acepção correta da palavra, estamos agora em um período de quase 
ausência em âmbito nacional. Há uma desarticulação dos diferentes órgãos públicos com interface na área, como os ministérios do Trabalho e Emprego, da Educação, da Saúde, da Agricultura, da Ciência e Tecnologia, incluindo Comércio Exterior e Relações Internacionais. Não podemos falar em políticas públicas sem pensar na pequena e na microempresa, as que mais empregam em nosso país. Mas também não é possível manterem-se de fora, por mais tempo, as áreas de ponta (em tecnologia), como as indústrias de petróleo, de aviação e siderurgia, entre outras. Nessas, as empresas já vêm adotando medidas para solucionar os problemas por elas identificados ou priorizados, mas em termos de construção do país que queremos ainda são insuficientes.

Práticas institucionais (mentalidades, identidades) não se mudam rapidamente nem universalmente. A fiscalização na área de segurança e saúde do trabalhador tem passado por transformações, inicialmente centrada em pessoas, posteriormente em grupos de trabalho e, atualmente, com a organização de programas que se caracterizam por um planejamento baseado nas realidades locais, na participação ativa de todos os envolvidos e na interlocução com a sociedade. Temos que pensar a ergonomia para o Brasil no contexto da globalização, mas construindo os mecanismos de regulação necessários para começarmos a produzir com qualidade e sem adoecimento. Caminhos para a transformação que privilegiem, no mínimo, o trabalho integrado, o respeito às formas de contratação dispostas na legislação e as boas condições de trabalho.

Assim, espera-se contribuir gradualmente para a criação de uma cultura de geração de emprego em condições de trabalho adequadas, em que todos possam produzir de forma digna, o empregador integre as questões de saúde e segurança à produção, considerando-as como investimento que agrega valor ao seu produto, e que os trabalhadores tenham sua saúde preservada e encontrem satisfação em seu trabalho.

\section{ReferênCIAS}

ABT (Associação Brasileira de Telesserviços). Página de abertura. Disponível em: <www.abt.org.br>. Acesso em: 10 set. 2005.

ADAMS, M. A. \& HUTTON, W. C. The effect of posture on the role of apophyseal joints in resisting intervertebral compressive forces. The Journal of Bone and Joint Surgery, 62B: 358-362, 1988.

BONCIANI, M. (Org.) Saúde, Ambiente e Contrato Coletivo de Trabalho: experiências em negociação coletiva. São Paulo: LTr, 1996. 
BRASIL. Ministério do Trabalho. Portaria n. 3.751, 23 nov. 1990. Altera a Norma Regulamentadora 17-Ergonomia. Diário Oficial da União, Brasília, 1990.

BRASIL. Ministério do Trabalho. Manual de Aplicação da Norma Regulamentadora n. 17. 2. ed. Brasília: MTE; SIT, 2002a. Disponível em: <www.mte.gov.br/Temas/ SegSau/Publicacoes/default.asp>.

BRASIL. Ministério da Previdência Social. Boletim Estatístico da Previdência Social. Brasília, 2002b.

COELHO, E. A. Sistema atual de relações de trabalho no Brasil. In: BONCIANI, M. (Org.) Saúde, Ambiente e Contrato Coletivo de Trabalho: experiências em negociação coletiva. São Paulo: LTr, 1996.

INRS (Institut National de Recherche en Sécurité). Les Écrans de Visualisation: guide méthodologique pour médecin du travail. Paris, 1987.

JACKSON FILHO, J. M. \& ASSUNÇÃO, A. A. Trabalho em teleatendimento e problemas de saúde. Revista Brasileira de Saúde Ocupacional, 31(114): 4-6, 2006.

KHOURI, M. A.; AMÂNCIO, V. M. \& PERES, C. C. Ergonomia de concepção como meta de auditoria do trabalho: estudo do posto de caixa de um supermercado de Fortaleza. CONGRESSO BRASILEIRO DE ERGONOMIA, 2001, Recife. Anais... Recife: Abergo, 2001.

LIMA JR., J.; LOPES-VACARCEL, A. \& DIAS, L. A. Segurança e Saúde no Trabalho da Construção: experiência brasileira e panorama internacional. Brasília: Safework/OIT, 2005.

MOURE M. L. Aspectos Ergonômicos na Movimentação Manual de Cargas: boas práticas. Apostila do curso pré-congresso 23-26 out. 2005. (V Congresso Nacional sobre Condições e Meio Ambiente do Trabalho na Indústria da Construção - CMATIC e do III Seminário sobre Condições e Meio Ambiente do Trabalho na Indústria da Construção nos Países do Mercosul).

MOURE, M. L. Labour inspection: the Brazilian experience. Labour Education, 140. 141(840): 36-41, 2006.

OliveIRA, P. A. B. et al. Comissão Nacional de Ergonomia e Políticas Públicas: a implementação e procedimentos auxiliares à NR-17 (os casos da indústria de calçados, abate e processamento de carnes, telemarketing e check-out de supermercados. CONGRESSO BRASILEIRO DE ERGONOMIA, 12, 2004, Recife. Anais... Recife: Abergo, 2004a.

OlIVEIRA, P. A. B. et al. Políticas públicas em ergonomia em países em desenvolvimento e a experiência da Comissão Nacional de Ergonomia do Ministério do Trabalho. CONGRESO DE LA UNIÓN LATINOAMERICANA DE ERGONOMIA, 1, 2004, Santiago, Chile. Anais... Santiago: Sociedad Chilena de Ergonomia, 2004b. PERES, C. C. et al. Uma construção social: o anexo da norma brasileira de ergonomia para o trabalho dos operadores de telemarketing. Revista Brasileira de Saúde Ocupacional, 31(114): 35-46, 2006.

WISNER, A. Por Dentro do Trabalho: ergonomia: método E̊ técnica. São Paulo: FTD, Oboré, 1987. 


\title{
7. Saúde, Trabalho, Ambiente e Território: CONTRIBUIÇÕES té́RICAS E PROPOSTAS DE OPERACIONALIZAÇÃ̃O
}

\author{
Maurício Monken | Christovam Barcellos \\ Marcelo Firpo de Souza Porto
}

\section{Território como Categoria Síntese de Fenômenos Socials, Ambientals e SAnitários}

Vivemos em um mundo complexo, extremamente confuso e, em consequência, difícil de ser compreendido. No entanto, no plano teórico, abre-se a possibilidade de produção de um novo discurso que ganha relevância devido ao fato de que, pela primeira vez na história do homem, podemos evidenciar uma "universalidade empírica", conforme expressão de Milton Santos (1999). As novas tecnologias de informação e comunicação (TICs) e as atuações em redes sociais conectam de diferentes formas a existência humana, e essa universalidade empírica deixa de ser apenas mera elaboração abstrata para resultar da experiência ordinária de cada ser humano, fazendo com que a explicação do acontecer possa ser feita com base em categorias de uma história concreta, permitindo-se conhecer as possibilidades existentes no lugar e escrever uma nova história. Este é um desafio central de nosso tempo.

Nos estudos sobre saúde pública, categorias de cunho geográfico como espaço, território e lugar vêm sendo progressivamente incorporadas, sem muita preocupação com a definição 'original' da ciência de procedência, e dessa forma são gerados conflitos lógicos entre as muitas acepções ou conteúdos teóricos que a eles subjazem. Nem por isso, pesquisadores provenientes de diferentes e antes distantes saberes deixam de incorporar com relativa naturalidade o repertório teórico e conceitual, os procedimentos e recursos tecnológicos, na investigação em território, trabalho, ambiente e saúde. 
O campo da saúde pública tem usado cada vez mais esses conceitos originalmente geográficos. Porém, só recentemente tais conceitos vêm sendo discutidos em articulação com os temas da promoção e vigilância da saúde (Teixeira, Paim \& Villasbôas, 1998; Costa \& Teixeira, 1999; Czeresnia \& Ribeiro, 2000; Monken \& Barcellos, 2005), assim como da saúde ambiental em sua relação com o desenvolvimento (Freitas \& Porto, 2006) e da ecologia política e justiça ambiental (Porto, 2007).

Esse interesse decorre do fato de que a promoção da saúde coletiva analisa, como uma de suas questões centrais, os condicionantes ou determinantes históricos e sociais dos fenômenos de saúde em populações e lugares concretos. Tais análises podem envolver diferentes escalas espaciais, desde o nível mais local - como o domicílio, o local de trabalho e o bairro - até o mais global, como o município, o estado, o país, o continente ou mesmo o planeta. Também as escalas temporais podem variar bastante, fornecendo os quadros evolutivos de um passado mais remoto ou recente até a situação presente, ou ainda a projeção de cenários futuros de curto, médio ou longo prazos, segundo as forças e tendências que conformam potencialidades e possibilidades de desenvolvimento. Mas, do ponto de vista da saúde pública e dos serviços de saúde, todas as escalas e análises devem realizar as mediações com populações e territórios singulares, com suas histórias, seu presente e possibilidades futuras, permitindo ações de prevenção e promoção no âmbito de abrangência desejado, seja o bairro, seja o município, o estado ou o país.

Por sua vez, a chamada intersetorialidade das ações de saúde, um tema central para a promoção da saúde, torna-se mais evidente quando discutimos as múltiplas territorialidades - e frequentemente as numerosas lacunas e contradições - definidas e abrangidas pelos vários níveis de governo. Isso se dá quando analisamos espacialmente os distintos limites administrativos, por exemplo, bairros, distritos, municípios, estados e nações; ou quando analisamos recortes espaciais dos vários setores de governo, como saúde, educação, meio ambiente, segurança pública ou transportes, dentre outros. A territorialização, nesse sentido, adquire o sentido de operacionalizar a integração de ações de governo, ou ao menos de permitir a visualização das diferentes ações sobre uma mesma base territorial.

Conforme veremos a seguir, discutir o território implica considerar as relações de poder e os projetos de desenvolvimento que os vários atores sociais e econômicos elaboram e materializam ao usarem os espaços para numerosos fins, e é por isso que o geógrafo Milton Santos (1994) se refere ao território 
como território usado. Por fim, espaço e território são categorias que facilitam o entendimento integrado de questões ambientais e sociais cada vez mais importantes em um mundo globalizado com enormes desafios em termos de (in)justiça social e (in)sustentabilidade ambiental.

\section{Entendendo o Território e as Várias Territorialidades}

A mais antiga e tradicional concepção de território o define como uma delimitação de poder, e por isso um recorte do espaço, usado para a dominação e a apropriação de recursos. O território é, portanto, "um espaço onde se projetou um trabalho, seja energia e informação, e que, por conseqüência, revela relações marcadas pelo poder" (Raffestin, 1993: 144). Para Sack (1986: 1), "a territorialidade em seres humanos é melhor compreendida como uma estratégia espacial para afetar, influenciar ou controlar recursos e pessoas, pelo controle de uma área; e, como territorialidade, pode ser ativada e desativada".

Segundo essa abordagem, cada grupo social, classe ou instituição pode 'territorializar-se' por meio de processos de caráter mais funcional (econômicopolítico) ou mais simbólico (político-cultural) na relação que desenvolvem com os 'seus' espaços, dependendo da dinâmica de poder e das estratégias que estão em jogo (Sack, 1986). No mundo moderno, esse poder é exercido não só pelo Estado, mas também por atores sociais com interesses por vezes conflituosos. Por exemplo, uma fábrica pode ter por objetivo produzir com baixos custos, enquanto moradores e ambientalistas podem ter como objetivos centrais a defesa de sua saúde e dos ecossistemas afetados pela poluição fabril. Portanto, nesse território se expressam a produção, o consumo e a interação humana, daí sua conotação de identidade e subjetividade coletiva.

Os territórios, portanto, têm vida, expressa pelas histórias de pessoas e lugares, pela cultura, pelos movimentos sociais e ações políticas, mas também pelos ecossistemas, pelos rios e paisagens, muitas vezes degradadas, que dele fazem parte. Os eventos de saúde e os cuidados a eles associados são apenas uma das dinâmicas que compõem uma complexa rede de interações, interesses e projetos de uso que fazem parte do território.

Em diversos casos, como os distritos sanitários ou as áreas de abrangência de postos de saúde, os territórios são estabelecidos pela prática da saúde pública. O desenho desses territórios pode mudar de acordo com critérios técnicos, gerenciais e/ou políticos. Mesmo nesse caso, alguns critérios geográficos são seguidos para se estabelecerem os limites dos territórios. Em vários municípios, 
foram criadas subdivisões de territórios de saúde, como os distritos sanitários. Cada distrito contém diversas áreas de abrangência, e o município é coberto por territórios que são hierárquicos e complementares, embora as muitas territorialidades de que falamos antes frequentemente não dialoguem entre si. Além disso, cada área de abrangência possui (ou contém) apenas um centro de saúde. Isso quer dizer que qualquer evento de saúde importante para a vigilância dispõe, em princípio, de um centro de saúde correspondente. Esse desenho de territórios permite organizar o trabalho dentro do município, de modo que os gestores possam planejar ações e a população saiba quais recursos de saúde pode e deve usar.

As divisões territoriais normalmente adotadas correspondem a algumas escalas territoriais apropriadas pela população em geral, e relacionadas aos diferentes níveis de gestão governamental:

- Local - pequenas áreas como o município, área de abrangência de um serviço de saúde, um distrito, com características singulares, de gestão, administrativas e de estilos de vida.

- Estadual - território com limites político-administrativos, incluindo aspectos territoriais ampliados (econômicos, ecológicos e culturais).

- Regional - o território de vários municípios, estados ou parte deles, compondo regiões de saúde.

- Nacional (o Estado-nação) - o território é definido com base no conceito de soberania relativa aos aspectos políticos, econômicos, sociais, culturais e dos recursos naturais.

- Global - os interesses políticos e econômicos da ordem internacional substituem o território da identidade, da singularidade e da produção e reprodução da vida, criando outros territórios com limites opacos e incertos. Processos como a globalização e os riscos ecológicos globais, intensificados nas últimas décadas, assim como a internacionalização de redes sociais que articulam o local ao global, vêm acelerando as discussões sobre o papel do nível global.

As escalas apresentadas, na realidade, estão justapostas e imbricadas em uma teia de relações e inter-relações político-sociais e econômicas, que ora as aproxima, ora as distancia, criando e recriando, sistematicamente, novos territórios, novas escalas, novos lugares, mas também novos desafios para o setor saúde. 
Segundo Milton Santos (1994), o espaço geográfico é formado por um sistema de objetos e ações. Esses objetos são pontos fixos no território, como as casas, as indústrias, as estradas e as florestas. Mas nesses objetos são realizadas atividades humanas de produção ou de moradia, lazer etc. Os objetos se inserem em um sistema mais amplo, o sistema de objetos, como um aeroporto, uma estação de estrada de ferro ou um shopping center. Cada objeto é, em si mesmo, um sistema. Um supermercado ou um shopping center seriam incapazes de existir se não fossem servidos por vias rápidas, estacionamentos adequados e acessíveis, sistemas de transporte públicos com horários regulares e se, no seu próprio interior, as atividades não tivessem uma coordenação. Esse é caso também dos grandes edifícios, tão comuns hoje nas grandes e médias cidades, dos armazéns, dos silos etc. Os portos, as redes rodoviária e ferroviária são exemplos de objetos complexos e sistêmicos nos quais circulam mercadorias e pessoas e que, portanto, são vitais para a vigilância e o controle de circulação de agentes patogênicos (vírus, bactérias, substâncias tóxicas etc.) responsáveis pela produção de diversas doenças.

Portanto, em resumo, podemos dizer que o território tem as seguintes características:

- sempre tem limites que podem ser político-administrativos;

- contém as relações entre seus habitantes;

- é uma construção social em permanente mudança;

- é relativamente homogêneo internamente, com uma identidade que vai depender da história de sua construção;

- e o mais importante: ele é portador de poder. Nele se constroem e se exercitam os poderes de atuação tanto do governo como de seus habitantes.

Para gerir os territórios, os setores de governo e empresas costumam demarcá-los para fins administrativos, isto é, para organizar o seu trabalho. Esse é o caso da manutenção de telefones, da distribuição de energia ou de processos eleitorais. O setor saúde também tem suas divisões territoriais regionais ou locais. No Sistema Único de Saúde (SUS), a organização territorial corresponde aos diferentes níveis de governo: federal, estadual e municipal. Isto significa que, em geral, os limites da atuação dos profissionais de saúde são o próprio território do governo - por exemplo: os técnicos que trabalham em uma secretaria municipal de Saúde atuam nos limites do seu município. Para promover alguma ação que transcenda esses limites, é preciso se articular 
com os municípios vizinhos (secretarias municipais de Saúde) ou recorrer aos níveis estadual (secretaria estadual de Saúde) ou federal (Ministério da Saúde).

\section{O Território e a Saúde Pública}

O aumento do interesse pelo território na saúde é um fenômeno recente e partiu principalmente dos gestores de saúde e estudiosos em administração dos serviços e dos próprios trabalhadores desses serviços. Os sistemas de saúde se organizam sobre uma base territorial, o que significa que a distribuição espacial dos serviços segue uma lógica de delimitação de áreas de abrangência, as quais devem ser coerentes com os três níveis de atenção: primário, secundário e terciário.

As diretrizes estratégicas do SUS (lei n. 8.080) têm uma forte relação com a definição do território. $\bigcirc$ município representa o nível inferior do sistema em que é exercido o poder de decisão sobre a política de saúde no processo de descentralização, porém revestido de grande importância por atuar diretamente com as populações e os territórios onde vivem, circulam e muitas vezes trabalham. Neste nível, as práticas de saúde avançam para a integração das ações curativas, promocionais e preventivas, de forma que as intervenções sobre os problemas sejam também sobre as condições de vida das populações. A organização desses serviços segue os princípios da regionalização e hierarquização, delimitando uma base territorial, ou seja, uma área de atuação das unidades de saúde, da equipe de saúde da família ou um distrito sanitário.

É nesse sentido que Mendes (1999) recupera o conceito de território no livro Distrito Sanitário: o processo social de mudanças das práticas sanitárias do Sistema Único de Saúde, reunindo artigos de diversos autores que reafirmam a importância da categoria território para a implementação de uma reforma democrática na saúde. A democracia e o controle social têm muito a ver com o nível local, pois nele as populações e as forças sociais interagem mais diretamente com os profissionais e gestores do sistema de saúde.

A organização da atenção à saúde é baseada em critérios como espaço territorial, área de abrangência de unidade de saúde, adscrição de clientela, referência e contrarreferência. Em um primeiro momento do processo de territorialização das ações de saúde, o objetivo é compreender a dinâmica da população, as relações sociais e econômicas, as condições ambientais - incluindo os ambientes de trabalho, moradia e circulação -, as relações de poder, os espaços políticos e culturais de expressão das forças sociais e comunitárias, o 
mapeamento de fontes e situações de risco e vulnerabilidades, bem como os processos de produção da saúde ou da doença das populações, como resultante da interação dessas diversas dimensões. Em um segundo momento, essas ações visam a criar as condições necessárias para vigiar, regular, controlar e organizar os problemas e necessidades de saúde que surgem no território, com sua população intervindo sobre eles.

Segundo Unglert, a base territorial é um dos princípios organizativoassistenciais mais importantes do sistema de saúde. Ela considera que o estabelecimento dessa base territorial é um passo básico para a caracterização da população e de seus problemas de saúde, bem como o dimensionamento do impacto do sistema sobre os níveis de saúde dessa população e, também, para a criação de uma relação de responsabilidade entre os serviços de saúde e sua população adscrita (Unglert, 1999).

O território também constitui uma importante abordagem para análise de situação de saúde. Ele delimita uma população concreta que apresenta particularidades no seu modo de vida (e de trabalho) e seu perfil epidemiológico. O 'lugar', ao lado das 'pessoas' e do 'tempo', é uma das três principais dimensões de análise de fenômenos de saúde, em particular pela epidemiologia. Essa categorização é meramente didática, uma vez que pessoas, tempo e lugares interagem e se modificam ao longo de certa trajetória histórica dos territórios.

Diversos autores têm alertado para a crise da chamada 'epidemiologia dos fatores de risco', centrada nos indivíduos e seus distúrbios de saúde como unidades de observação, isolados de seu contexto histórico, social e territorial. Essa linha de trabalho frequentemente desconsidera as interações entre indivíduos, ambientes e as condições coletivas que emergem dessas relações (Castellanos, 1990). Tais relações são necessariamente coletivas e têm expressão espacial, embora muitas vezes de difícil apreensão (Barcellos \& Machado, 1998). Portanto, a análise de situação de saúde deve procurar identificar condições de vida e situações de risco desse coletivo, mais do que listar problemas dos indivíduos que compõem essas populações.

Segundo Possas (1989), a população é a dimensão concreta em que se expressam os determinantes da distribuição dos riscos da morbi-mortalidade, sendo, portanto, o objeto de análise epidemiológica. Para tanto, é necessário definir princípios de recorte desse objeto, mediante critérios epidemiológicos obtidos com base nas condições concretas de vida e trabalho que determinam níveis diferenciados de exposição a riscos. 
Bairros, cidades e países são territórios com organizações internas próprias e ao mesmo tempo interdependentes. Espaço e território podem ser considerados categorias síntese e de convergência cada vez mais importantes para entendermos melhor os problemas de saúde e na organização e atuação do SUS, em que se manifestam diversos processos envolvidos nas condições de vida das populações. O espaço geográfico é complexo, constituído por um sistema de objetos e ações com numerosas articulações verticais e horizontais (Santos, 1999). As verticais envolvem relações com os níveis mais globais em que um dado território se insere, enquanto as horizontais expressam as relações e inter-relações internas ao próprio território, com suas populações, forças sociais, características e paisagens ambientais, sendo, portanto, mais singulares. O território abriga uma grande diversidade de subpopulações, processos de trabalho, equipamentos técnicos públicos e privados (como moradias e vias de transporte), enfim, redes sociotécnicas ou sistemas sociotécnico-ambientais com composições, organizações, estruturas físicas, processos de trabalho e interesses diversificados.

Sistemas sociotécnico-ambientais (STAs) são unidades específicas de análise relevantes para entendermos a relação entre os riscos ambientais e a saúde das populações em territórios concretos, pois neles interagem pessoas, sistemas técnicos e ambientes (Porto, 2007). A definição do sistema sociotécnicoambiental a que estamos nos referindo dependerá do referencial adotado, do tipo de problema e da escala espacial e sempre envolverá a relação dos sistemas técnicos com as pessoas em dado território.

Podemos falar de STAs relacionados a setores produtivos, cadeias produtivas, processos de trabalho, tecnologias de fabricação, empresas ou locais de trabalho perigosos, ou ainda sistemas técnicos relacionados à infraestrutura urbana, como estruturas construtivas, redes de água e eletricidade, rodovias, dentre outros. Tais STAs existem e/ou interferem nos lugares, como residências, locais de trabalho, bairros, cidades ou regiões onde atuam riscos como a poluição química atmosférica (Porto, 2007).

Muitas vezes, diversos perigos localizam-se em um mesmo espaço, pois resultam da existência de vários STAs em dado território, com a presença de sinergias que podem tornar tais espaços ainda mais perigosos e os problemas de saúde relacionados ao ambiente mais complexos e incertos.

Portanto, ao mapearmos os problemas de saúde, trabalho e ambiente em dado território, existem várias possibilidades de analisar uma dada realidade. Podemos nos ocupar dos perigos gerados em um STA específico, como uma 
fábrica, uma residência, uma via de trânsito, um rio poluído ou que transborda causando enchentes, ou mapeando e inter-relacionando os vários perigos decorrentes dos vários STAs e situações de risco existentes em dado território. À medida que ampliamos as escalas espaciais (territórios mais amplos) e temporais (análises históricas retrospectivas mais longas, ou então cenários futuros prospectivos) nas análises territoriais, estas se tornam mais abrangentes, porém mais complexas (Figura 1).

Figura 1 - Dos riscos localizados aos riscos globais

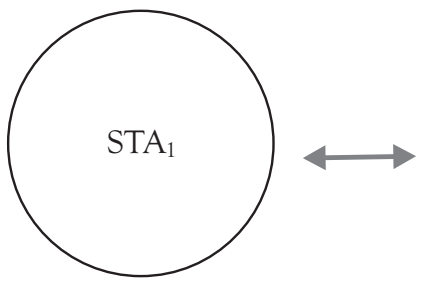

Locais e territórios demarcados

Sistema de suporte à vida

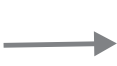

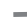

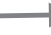

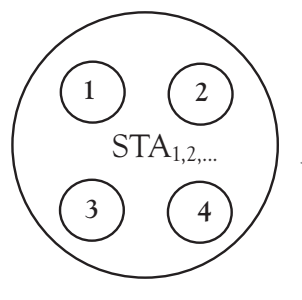

Território ampliado

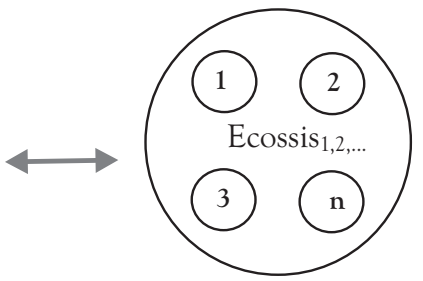

Território global
Ecossistemas regionais/globais
Sist. de suporte à vida Ecossistema restrito

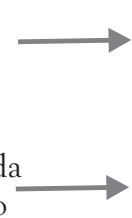

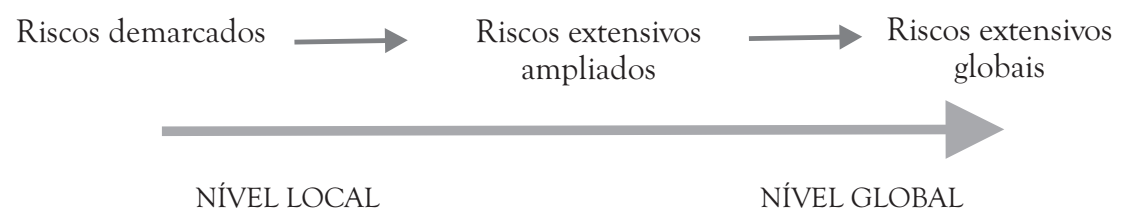

Fonte: Porto. (2007).

\section{O Território e as VIGLLÂNCIAS}

As diversas expressões da vigilância (epidemiológica, sanitária, ambiental e de saúde do trabalhador) são utilizadas não para vigiar pessoas e lugares, mas para controlar contextos e produzir saúde (Paim, 2003). Por isso mesmo, se utilizam da categoria território como um dos elementos estruturantes de suas ações e de sua materialidade junto aos serviços de saúde e à população.

Em se tratando da organização dos serviços de saúde para a vigilância da saúde do trabalhador, a escolha da população de referência determina de que 
forma a relação saúde e trabalho torna-se objeto de sua intervenção, em que podemos destacar duas vertentes (Machado, 2005):

1) Considerar apenas o trabalho da população residente na região. Essa vertente abstrai a vigilância ao local de trabalho como pertinente à práxis sanitária e leva em consideração somente a história ocupacional referida pelo usuário da Unidade de Saúde Local (USL);

2) Considerar o trabalho efetivamente exercido na região. A população de referência, nesse caso, consiste na fração residente que trabalha na região, acrescida dos trabalhadores fixos e móveis da região.

Segundo Machado (2005), o foco central dessa discussão é se as ações de uma USL se referem a um espaço geográfico em que se leva em consideração a mobilidade populacional ou, no sentido restrito tradicional das USL, se considera apenas o espaço residencial como de intervenção sanitária.

Um dos primeiros problemas a serem enfrentados pela vigilância em saúde do trabalhador, segundo uma lógica territorial, é reconhecer esse território: os seus 'limites' e os 'atores' políticos atuantes. Mas, ao contrário dos animais, as relações de poder não são tão claras, e existem diversas pessoas e instituições participando e compartilhando esse poder, muitas vezes de forma conflituosa. Em um mesmo bairro, por exemplo, convivem os moradores, as associações, os setores da Prefeitura, as empresas, os partidos políticos. Cada um desses atores tem seus interesses e formas de representação política, e muitas vezes tais interesses entram em conflito.

Na prática de vigilância, diversos problemas dizem respeito ao território. Em primeiro lugar, como já foi comentado, esse território é a base da organização do trabalho do setor saúde. Essa é a sua área de atuação. Mas isso também quer dizer que todo o 'conteúdo' desse território é de interesse para a vigilância. Cabe aos profissionais de saúde pública levantar as principais atividades humanas aí existentes de interesse. Esse processo é chamado de "reconhecimento" do território (Monken \& Barcellos, 2005), sendo resultante não somente da listagem das atividades, mas também do reconhecimento das relações entre a população, as atividades econômicas e o ambiente.

Territorializar as análises é fundamental para operacionalizarmos a junção entre a saúde do trabalhador, a saúde ambiental e a vigilância à saúde como um todo. Significa ampliar nossa visão clássica sobre os processos produtivos e os riscos que afetam a saúde dos trabalhadores, entendendo as cadeias de produção e os sistemas sociotécnicos que fazem parte do território ou o in- 
fluenciam, bem como as várias formas de uso e redes que o compõem. Nessa perspectiva, é necessário ampliar a análise dos problemas de saúde pública que precisam ser investigados pela vigilância em saúde em um município.

Existem casos no nível local que integram todas as vigilâncias. Imaginemos, por exemplo, que em um pequeno município que fabrica queijo, as condições de trabalho, assim como a qualidade do produto e do ambiente sejam investigadas. É provável que toda a cadeia de produção esteja contida na área de atuação do agente local da vigilância, isto é, o seu território. Além disso, a pequena indústria é um lugar de convergência das diferentes matérias-primas, dos trabalhadores e de desenvolvimento de tecnologia. Em muitos casos, também o consumo desses produtos é local. Assim, se houver um problema de contaminação do produto no ambiente de trabalho, é muito mais fácil rastreá-lo e tomar providências, como é possível observar na Figura 2.

Figura 2 - Redes locais de produção

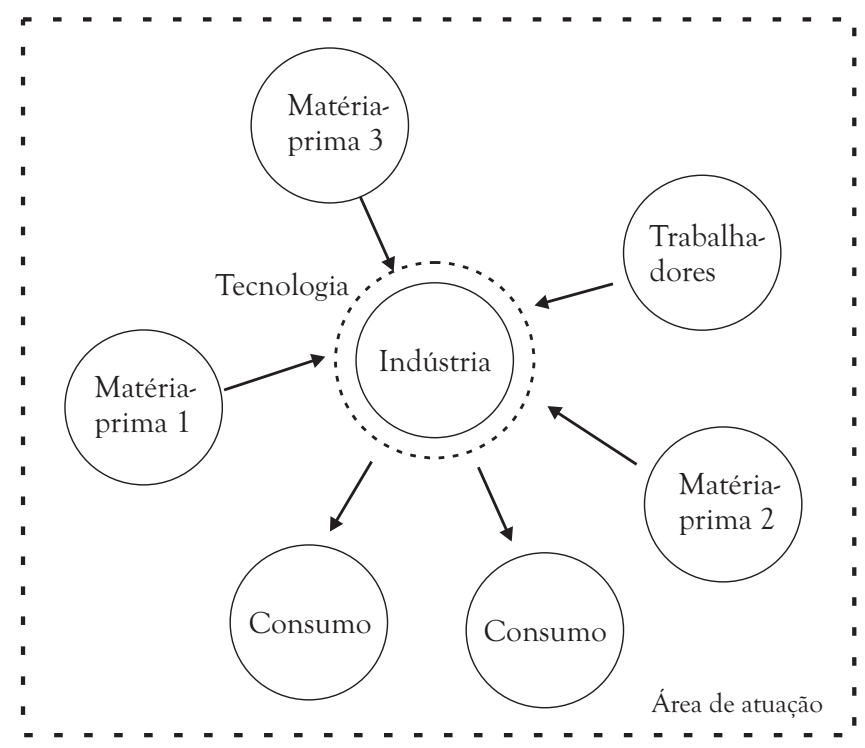

No entanto, existem outros casos em que a cadeia de produção ultrapassa os limites da área de atuação do profissional de vigilância, como em uma indústria de medicamentos. Neste caso, o trabalho da vigilância torna-se bem mais complexo, já que as matérias-primas de medicamentos podem vir de várias partes do Brasil ou do mundo. Os trabalhadores em geral são locais, mas muitas vezes moram em áreas distantes do trabalho. $\mathrm{O}$ consumo pode ser feito tanto na região local como em lugares muito distantes do mundo, caso 
a fábrica exporte seus medicamentos. Além disso, a própria base tecnológica pode ser importada. Por isso, a indústria não é autônoma e depende de desenvolvimento e pesquisa que se fazem muito longe da indústria, em outros países e em universidades ou centros de pesquisa. Esse caso é bastante comum no trabalho de vigilância de regiões metropolitanas. Precisamos pensar em como seguir essa trilha que liga a base tecnológica, produção e consumo e que acontece em diferentes pontos do planeta. As articulações técnicas e políticas devem ser muito mais intensas para se trabalhar com esse tipo de problema. A Figura 3 esquematiza essa situação.

Figura 3 - Redes ampliadas de produção

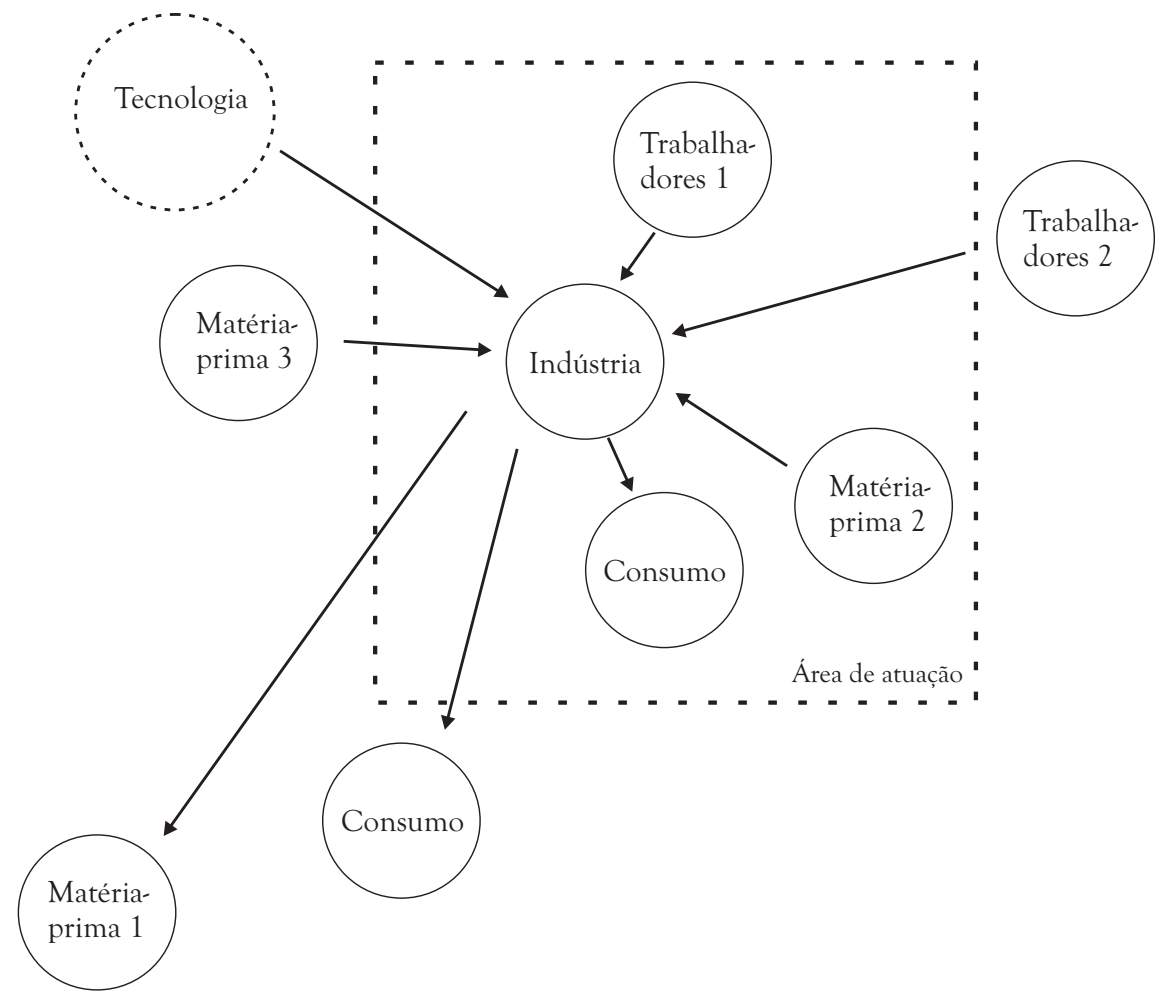

Todos esses lugares, de produção e de consumo, são pontos fixos, podendo ser colocados em um mapa para entender onde se encontram possíveis fontes de riscos ou perigos (como fábricas, postos de gasolina, vias de trânsito mais perigosas, lugares de enchentes, depósitos oficiais ou clandestinos de lixo etc.) e vulnerabilidades do sistema. A vulnerabilidade pode ser entendida como um conceito mais amplo do que risco, pois o contextualiza dentro de uma 
realidade socioambiental e nos permite compreender territórios e populações que se encontram especialmente mais fragilizados diante da exposição a certas situações de risco.

Para Blaikie e colaboradores (1996: 30), provenientes do campo de estudos sobre desastres, a vulnerabilidade pode ser definida como a redução da "capacidade de antecipar, sobreviver, resistir e recuperar-se dos impactos" decorrentes de certos eventos de risco, como os desastres tecnológicos (por exemplo: explosões, incêndios e contaminações em plantas nucleares e químicas) ou 'naturais' (como terremotos, ciclones, vulcões e inundações).

Para Porto (2007), a análise de vulnerabilidade busca articular, em um enfoque transdisciplinar, o entendimento das contribuições dos processos biológicos, geofísicos e tecnológicos aos processos socioeconômicos e políticos que estão por detrás do ciclo de geração-exposição-efeitos de certos grupos populacionais submetidos a situações e eventos de risco particulares, em escalas espaciais e temporais variáveis.

Em um território, cada um desses pontos está conectado com o outro, por isso eles formam um sistema ou uma cadeia de produção. Para Milton Santos (1994: 45), "o território é na verdade uma superposição de sistemas de engenharia [em que se incluem as redes técnicas] diferentemente datados, e usados, hoje, segundo tempos diversos". Toda essa rede cria e viabiliza um fluxo de pessoas e de mercadorias, e a vigilância deve estar atenta principalmente para a circulação de produtos em seu território de atuação. Muitas vezes, nos territórios existem empresas (indústrias e serviços) que têm fluxos específicos de mercadorias, de trabalhadores e de consumidores que precisam ser controlados, como o transporte de produtos tóxicos.

Portanto, para a constituição de uma base organizativa dos processos de trabalho nos sistemas locais de saúde em direção a essa nova prática, é importante o reconhecimento dos territórios e seus contextos de uso, pois estes materializam diferentemente as interações humanas, os problemas de saúde e as ações sustentadas na intersetorialidade. Cabe à vigilância em saúde exercer o papel organizativo dos processos de trabalho em saúde mediante operações intersetoriais, articuladas por diferentes ações de intervenção (promoção, prevenção, recuperação) fincada em seus três pilares estratégicos: os problemas de saúde, o território e a prática intersetorial (Teixeira, Paim \& Villasbôas, 1998). Com base nesse raciocínio, o conceito de espaço, do qual se origina a noção de território, pode exercer importante papel na organização das práticas de vigilância em saúde. 
A identificação de problemas de saúde no território deve, portanto, suplantar a listagem de agravos prevalentes e evidenciáveis por meio de notificações, para abordar e contemplar a compreensão das vulnerabilidades e dos determinantes. O ponto de partida desse processo é a territorialização do sistema de saúde, isto é, o reconhecimento e o esquadrinhamento do território do município segundo a lógica de relações entre condições de vida, saúde e acesso às ações e serviços de saúde, o que implica um processo de coleta e sistematização de dados demográficos, socioeconômicos, político-culturais, epidemiológicos e sanitários.

A identificação e a localização dos objetos, seus usos pela população e sua importância para os fluxos das pessoas e de matérias são de grande relevância para o conhecimento da dinâmica social, seus hábitos e costumes. As vulnerabilidades de saúde são originadas das interações de grupos humanos em determinados espaços geográficos.

Segundo Machado (1997), o trabalho de vigilância da saúde do trabalhador deve superar a fragmentação das ações, procurando categorias integradoras e operacionais. Para este autor, as bases dessa integração são:

1) Territorial, em consonância com os pressupostos do distrito sanitário, mas em articulação com a compreensão e o diálogo com as diversas territorialidades existentes que nele interferem, sejam setores de governo (educação, meio ambiente, segurança pública etc.), sejam redes produtivas e sociais presentes.

2) Ramo de atividade econômica, envolvendo tanto as cadeias produtivas e processos de trabalho como a base de organização dos trabalhadores e dos sindicatos atuantes.

3) Riscos existentes no território, partindo-se dos processos de trabalho e dos problemas de saúde do trabalhador, ampliando para os diversos riscos ambientais que, em razão de sua exposição, podem gerar efeitos à saúde das populações que habitam e circulam no território.

4) Agravos, entendendo-os como os principais problemas de saúde das populações que demandam serviços de saúde. Análises epidemiológicas descritivas e discussões com as populações e trabalhadores do território geram importantes bases de atuação em saúde ambiental e do trabalhador.

É necessário ressaltar que a maior parte dos dados de saúde, bem como de outros setores, reproduz uma organização territorial. Os territórios políticoadministrativos são, na maior parte das vezes, utilizados como estratégia para 
a coleta e a organização de dados sobre ambiente e saúde, mas deve-se manter claro que os processos sociais e ambientais transcendem esses limites. Por exemplo: podemos falar da qualidade do ar de um bairro, mas sabemos que o ar não é do bairro. Ele circula na atmosfera e tem fontes de contaminação espalhadas em diversas áreas das cidades e regiões. Porém, para atuar sobre o problema da qualidade do ar, devemos também pensar no bairro. Incorporar um dado do ambiente, contínuo, a um território, fragmentado, permite "pensar a implementação da política ambiental, que na verdade nada mais é que a internalização do vetor ambiental nas várias políticas territoriais" (Moraes, 1994: 25). Como o território é resultado da organização da sociedade, incorporar dados ambientais a esse território permite colocar sobre uma base comum fatores que são da natureza exterior e interior dessa sociedade. Além disso, pelo fato de o território ter um caráter de identidade e de organização da população, referir-se à qualidade ambiental de um determinado território promove uma politização da questão ambiental.

Voltamos, portanto, ao problema inicial da delimitação dos territórios e dos poderes instituídos dentro deles. A ideia de que esses territórios são fechados e autônomos é completamente artificial. Mas essa territorialização serve, antes de mais nada, para organizar as práticas de trabalho de vigilância. Precisamos atuar sobre esse território e, ao mesmo tempo, reconhecer que ele tem um conteúdo social, político e ambiental e que tem uma população que pode sofrer consequências, para a nossa saúde, dos processos de produção e consumo. Além disso, no entanto, precisamos lembrar que esses territórios estão ligados por redes em que pessoas, informações, energia e materiais circulam cada vez com mais intensidade e velocidade.

\section{Território, Conflitos e Poder Local}

Como o território é ocupado por uma população heterogênea, formada por atores sociais e interesses muitas vezes antagônicos, espera-se que esse território seja um palco de conflitos entre projetos. Os conflitos socioambientais se materializam por meio de interesses e ações contrapostas que distintos atores sociais desenvolvem no território. Essas ações surgem porque entre esses atores existem diferentes percepções, projetos de desenvolvimento e usos do território. Para a ecologia política, os conflitos socioambientais decorrem de diferentes sentidos de desenvolvimento e de formas de poder que concentram e dividem os espaços em centros e periferias. São, portanto, conflitos que envolvem lógicas 
distributivas, pois muitas das riquezas geradas pelo trabalho e pelos recursos naturais do lugar são apropriadas por elites que frequentemente moram nos centros de poder distantes das periferias (Porto \& Martinez-Alier, 2007). Por isso, esses conflitos podem ser locais ou alcançar maior magnitude, quando interesses pertinentes a outros atores são atingidos (Chavez, 2002). A relação local-global, a territorialização das análises de problemas de saúde e ambiente e a produção integrada e compartilhada de conhecimentos e ações por meio de redes sociotécnicas, dentre outros fatores, representam mais do que avanços técnicos decorrentes de um 'natural' progresso do conhecimento científico. Trata-se de uma necessidade simultaneamente epistemológica e política em face dos atuais desafios de um capitalismo crescentemente globalizado que desterritorializa e aliena o local e suas populações diante das alternativas de desenvolvimento.

Segundo Bertha Becker (1991), a modernização conservadora, em que o Estado negocia com os grupos dominantes o apoio ao seu projeto de modernização de 'cima para baixo' em troca da manutenção dos privilégios desses grupos, sustentada na política territorial, é marca específica da formação social brasileira. Esse modelo de desenvolvimento se caracteriza pela concentração de poder em determinados lugares, promovendo a desterritorialização, o desenraizamento social e a volatização dos lugares. Do conflito entre a malha programada e o espaço vivido, emergem novas territorialidades e problemas ambientais (Becker, 1991). Quando "a modernidade se instala em focos isolados", ao mesmo tempo "emergem a oposição organizada e as novas territorialidades mais significativas, como o novo sindicalismo, os movimentos sociais e as ONGs, que representam projetos alternativos da sociedade em busca da justiça social" (Becker, 1995: 4).

Para Acselrad (2010), a atual mobilidade do capital tem sido peça-chave para entendermos as desigualdades regionais e injustiças socioambientais em um mundo cada vez mais globalizado. Ao introduzir o conceito de "chantagem locacional”, o autor chama a atenção do crescente poder de um capital que se globalizou enquanto seus movimentos sociais de resistência ainda permanecem restritos às fronteiras regionais.

Segundo Porto (2007), atualmente, se um país ou estado da federação, no exemplo da guerra fiscal existente no Brasil, tem um movimento social avançado que exige mais e melhores condições de produção, trabalho e controle da poluição, uma empresa pode ameaçar se transferir para outras regiões que oferecem 'vantagens competitivas' baseadas justamente na ausência dessas exigências. 
O processo de desindustrialização, de desregulação e fragmentação do Estado se estende sobre as ações de saúde do trabalhador e afeta a capacidade de mobilização diante de projetos de desenvolvimento que se apropriam dos recursos existentes nos territórios e concentram renda e poder, ao mesmo tempo que atingem a saúde e a integridade dos trabalhadores, dos seus habitantes e dos ecossistemas. Unir as frações dessas populações, que são vítimas de um modelo de desenvolvimento marcado pela injustiça ambiental, é o maior desafio (Porto, 2005). Cabe repensar a inserção dos trabalhadores no mundo econômico e a própria organização das atividades de saúde do trabalhador. Como identificado por Gómez e Lacaz (2005), a formação dos técnicos em saúde do trabalhador e as estratégias de negociação carregam uma grande identidade com a indústria. Segundo os autores:

além da necessidade de se efetuarem ajustes e adaptações na aplicação do conceito de "processo de trabalho" para o entendimento de determinadas realidades nas novas situações de produção, enfrentamos o desafio de construir novos conceitos e categorias capazes de dar conta da compreensão do amplo e majoritário universo de trabalhadores sem vínculos formais e desempregados. (Gómez \& Lacaz, 2005: 800)

Durante os anos 70 e 80, observou-se um avanço dos movimentos sociais urbanos, acompanhados no Brasil por uma retomada das organizações populares de bairros (Castells, 1979; Souza, 2006). Segundo autores marxistas, se o território é conformado pela estrutura de classes, precisa abarcar o ponto vulnerável e se concentrar nele: a produção do espaço, a estrutura territorial de exploração e dominação, a reprodução espacialmente controlada do sistema como um todo (Soja, 1993). A eficácia desses movimentos dependeria da sua capacidade em espacializar e territorializar as suas lutas. "Somente aqueles que têm capacidade de espacializar conscientemente as suas lutas podem ultrapassar essa crise-prova que se dá hoje em todas as escalas" (Martin, 1997: 14).

No início do século XXI, observa-se a regressão desses movimentos, vista por alguns autores como uma derrota ante a globalização e a fluidez do capital. Outros autores, ao contrário, argumentam que os movimentos sociais urbanos foram internalizados e pulverizados de tal forma que fazem parte do cotidiano das cidades. Segundo Souza (2006: 106),

a mudança social não deve ser confundida com o assalto ao Palácio de Inverno (...). Autênticos movimentos sociais (...) podem, de toda sorte, a longo prazo e por efeito cumulativo complexo, provocar alterações dignas de nota, rupturas. Assim, uma luta pontual e, em si, temática e socialmente 
limitada - ativismo de bairro, o movimento regionalista (...) - pode polinizar outras lutas e ajudar a instaurar uma sinergia transformadora; ademais, ela pode permitir aos atores uma ampliação de sua margem de manobra contra os efeitos mais alienantes do processo de globalização hoje em curso - o que, dialeticamente, pode vir a ser um fator sustentador de um avanço da consciência crítica dos atores e do seu potencial de combate.

Por sua vez, os movimentos socioterritoriais do campo indicam que a luta pela reforma agrária consiste nuclearmente em uma luta pela apropriação do território, pelo direito de seu uso - o que vem conduzindo os movimentos sociais, em especial o Movimento dos Trabalhadores Rurais Sem Terra (MST), a perceber as implicações entre as reivindicações locais e suas repercussões globais, levando inclusive o movimento a incorporar bandeiras de luta que estão diretamente associadas à questão ambiental e à biotecnologia, como os transgênicos e os agrotóxicos, dentre outras questões.

A saúde do trabalhador, estabelecida como estratégia de integração entre atenção e vigilância da saúde, pode se beneficiar da abordagem territorial, não só como forma de organização das suas atividades, mas principalmente como meio de superação da fragmentação do saber e do agir em saúde, contribuindo para a democratização da sociedade. Para isso, precisamos ampliar e articular nossas análises, entendendo problemas de saúde do trabalhador em relação a processos produtivos e populações em territórios concretos, cujos problemas mais amplos de saúde e ambiente nos remetem a diferentes usos e escalas. A crítica ao atual modelo de desenvolvimento e a construção de alternativas tornam-se, então, fundamentais para integrarmos nossas análises e definirmos possíveis alianças com movimentos sociais e setores de governos em torno de políticas públicas que apontem para sociedades ambientalmente sustentáveis e socialmente justas.

\section{REFERÊNCIAS}

ACSELRAD, H. Ambientalização das lutas sociais: o caso do movimento por justiça ambiental. Estudos Avançados, 24(68): 103-119, 2010.

BARCELLOS, C. \& MACHADO, J. H. M. A organização espacial condiciona as relações entre ambiente e saúde: o exemplo da exposição ao mercúrio em uma fábrica de lâmpadas fluorescentes. Ciência Ë Saúde Coletiva, 3(2): 103-113, 1998.

BECKER, B. Modernidade e integração do território no Brasil: da integração nacional à integração competitiva. Espaço $\mathcal{E}$ Debates, 32(1): 47-56, 1991.

BLAIKIE, P. et al. Vulnerabilidad: el entorno social, politico y económico de los desastres. Bogotá: Tercer Mundo Editores, 1996. 
CASTELLANOS, P. L. Avances metodológicos en epidemiologia. In: CONGRESSO BRASILEIRO DE EPIDEMIOLOGIA E DESIGUALDADE SOCIAL, 1, Desafios do final do século, 1990, Campinas. Anais... Campinas: Abrasco, 1990.

CASTELLS, M. La Cuestión Urbana. Barcelona: Siglo XXI, 1979.

CHAVEZ, B. V. Conflictos Ambientales: la internacionalización de la defensa de las comunidades contra instalaciones contaminantes. Guadalajara: Ed. Universidad de Guadalajara, 2002.

COSTA, M. C. N. \& TEIXEIRA, M. G. L. C. A concepção de "espaço" na investigação epidemiológica. Cadernos de Saúde Pública, 15(2): 271-279, 1999.

CZERESNIA, D. \& RIBEIRO, A. M. O conceito de espaço em epidemiologia: uma interpretação histórica e epistemológica. Cadernos de Saúde Pública, 16(3): 595-605, 2000.

FREITAS, C. M. \& PORTO, M. F. Saúde, Ambiente e Sustentabilidade. Rio de Janeiro: Editora Fiocruz, 2006.

GÓMEZ, C. M. \& LACAZ, F. A. C. Saúde do trabalhador: novas-velhas questões. Ciência Ë Saúde Coletiva, 10(4): 797-807, 2005.

MACHADO, J. M. H. Processo de vigilância em saúde do trabalhador. Cadernos de Saúde Pública, 13(supl.2): 33-45, 1997.

MACHADO, J. M. H. A propósito da vigilância em saúde do trabalhador. Ciência $\mathfrak{E}$ Saúde Coletiva, 10(4): 987-992, 2005.

MARTIN, J.Y. A geograficidade dos movimentos socioespaciais. Caderno Prudentino de Geografia, 19/20: 26-41, 1997.

MENDES, E. V. (Org.) Distrito Sanitário: o processo social de mudanças das práticas sanitárias do Sistema Único de Saúde. São Paulo, Rio de Janeiro: Hucitec, Abrasco, 1999.

MONKEN, M. \& BARCELLOS, C. Vigilância em saúde e território utilizado: possibilidades teóricas e metodológicas. Cadernos de Saúde Pública, 21(3): 898-906, 2005.

MORAES, A. C. R. Meio Ambiente e Ciências Humanas. São Paulo: Hucitec, 1994.

PAIM, J. S. Modelos de atenção e vigilância da saúde. In: ROUQUAYROL, M. Z. \& ALMEIDA FILHO, N. de (Orgs.). Epidemiologia Ë Saúde. 6. ed. Rio de Janeiro: Medsi, 2003.

PORTO, M. F. S. Saúde do trabalhador e o desafio ambiental: contribuições do enfoque ecossocial, da ecologia política e do movimento pela justiça ambiental. Ciência ES Saúde Coletiva, 10(4): 829-839, 2005.

PORTO, M. F. S. Uma Ecologia Política dos Riscos: princípios para a promoção da saúde e da justiça ambiental. Rio de Janeiro: Editora Fiocruz, 2007.

PORTO, M. P. \& MARTINEZ-ALIER, J. Ecologia política, economia ecológica e saúde coletiva: interfaces para a sustentabilidade do desenvolvimento e para a promoção da saúde. Cadernos de Saúde Pública, 23(suppl. 4): S503-S512, 2007.

POSSAS, C. Epidemiologia e Sociedade. São Paulo: Hucitec, 1989. 
RAFFESTIN, C. Por uma Geografia do Poder. São Paulo: Ática, 1993.

SACK, R. D. Human Territoriality. Cambridge: Cambridge University Press, 1986.

SANTOS, M. Técnica, Espaço e Tempo: globalização e meio técnico-científico informacional. São Paulo: Hucitec, 1994.

SANTOS, M. A Natureza do Espaço: técnica e tempo, razão e emoção. São Paulo: Hucitec, 1999.

SOJA, E. Geografias Pós-Modernas: a reafirmação do espaço na teoria social crítica. Rio de Janeiro: Jorge Zahar, 1993.

SOUZA, M. L. O território: sobre espaço e poder, autonomia e desenvolvimento. In: CASTRO, I.; GOMES, P. C. C. \& CORRÊA, R. L. (Orgs.) Geografia: conceitos e temas. Rio de Janeiro: Bertrand Brasil, 2006.

TEIXEIRA, C. F.; PAIM, J. S. \& VILLASBÔAS, A. L. SUS, modelos assistenciais e vigilância da saúde. Informe Epidemiológico do SUS, 7(2): 7-28, 1998.

UNGLERT, C. V. S. Territorialização em saúde. In: MENDES, E. V. (Org.) Distrito Sanitário: o processo social de mudanças das práticas sanitárias do Sistema Único de Saúde. São Paulo, Rio de Janeiro: Hucitec, Abrasco, 1999. 


\section{Prevenção da Exposição ao Benzeno no Brasil: análise com base na experiência em São Paulo}

Danilo Fernandes Costa

0 benzeno tem importância significativa do ponto de vista ambiental e do trabalho por causa dos agravos à saúde que provoca, sendo objeto de discussão em boa parte do mundo na atualidade. Os riscos do benzeno são conhecidos há muito tempo e vêm sendo objeto de tratamentos diversos, nacional e internacionalmente. Os elementos centrais da importância dessa substância estão ligados à sua toxicidade e à difusão de sua utilização em razão de sua presença no petróleo, grande produção nas indústrias petroquímicas, uso como matéria-prima nas indústrias químicas, subproduto na coqueificação do carvão e presença no condensado de gás natural. Embora seja hematotóxico e cancerígeno, tem vasta utilização nas cadeias de extração e refino de petróleo e na produção de aço devido à sua presença nas matérias-primas desses processos. Trata-se de questão complexa e intricada, pois, ao mesmo tempo que se conhecem cada vez mais as características tóxicas desse produto, sua presença e sua utilização são partes de processos essenciais no mundo em que vivemos, não havendo no momento perspectivas de mudança significativa nessas cadeias produtivas (Brasil, 2006).

A discussão sobre o benzeno está inserida na 'questão química', envolvendo aspectos ambientais, de saúde da população e dos trabalhadores e até mesmo de sobrevivência da humanidade, que se tornaram pauta permanente da discussão pública no momento atual. O desenvolvimento tecnológico e das matrizes energéticas do século XX teve participação fundamental das substâncias químicas, e o aumento de sua utilização industrial nas mais diversas atividades fez com que se constituíssem em parte indispensável de praticamente todas as atividades humanas, sejam elas industriais, sejam comerciais ou domésticas. 
A indústria química é a terceira maior atividade industrial no mundo hoje, empregando dez milhões de pessoas em todo o planeta e movimentando vendas globais em torno de 1,481 bilhão de euros em 2002 (Schorling, 2004).

Os primeiros relatos de doenças relacionadas à exposição a benzeno datam do século XIX, quando foram identificados casos de intoxicação aguda e aplasia de medula na Europa. A expansão do uso industrial do benzeno no início do século XX se ampliou ainda mais após a Primeira Guerra, com uma elevação do número de achados de casos de doenças em geral referidos como intoxicação por benzeno. Esse conhecimento vem se reafirmando ao longo dos anos, sendo hoje a discussão central os efeitos do benzeno em baixas concentrações, em razão das mudanças do padrão de exposição que ocorreram nas últimas décadas. Tais mudanças começaram na década de 1930, a partir da identificação da carcinogenicidade do benzeno. Ainda em 1939, vários pesquisadores propuseram a substituição do benzeno por outros solventes. Apesar disso, a American Conference of Governmental Industrial Hygienists (ACGIH) recomendou em 1946 um limite de 100 ppm (partes por milhão) para exposição a benzeno nos locais de trabalho, revendo este valor no ano seguinte para 50 ppm e depois para 35 ppm, em 1948 (Infante, 2002; Snyder, 2002).

Ao período do pós-guerra, 1945-1970, corresponde um aumento extraordinário da utilização do petróleo. Nesses 'anos dourados' de grande expansão da produção industrial e do consumo em boa parte do planeta, o petróleo se tornou a principal base material, como combustível e como matéria-prima, para a indústria petroquímica e suas cadeias produtivas principais: indústrias químicas, de borracha e plásticos. É um período histórico em que há grande desenvolvimento tecnológico junto com uma valorização significativa do trabalho e dos trabalhadores, com um aumento correspondente da preocupação com a implantação de medidas de prevenção de riscos nas atividades laborais e proteção dos trabalhadores, em particular na Europa, nos Estados Unidos e na União Soviética (Yergin, 1992; Hobsbawm, 1996).

Nesse período, aumentam os estudos que relacionam a exposição ao benzeno com leucemia, em que se destacam os realizados na Itália por Vigliani e Forni e na Turquia por Aksoy. Na Itália, já a partir dos anos 20, em razão de exposições a altíssimas concentrações, haviam sido identificadas verdadeiras epidemias de intoxicações por benzeno. A partir dos anos 50, diversos estudos nesses dois países identificaram a ocorrência de casos de intoxicação e câncer. Essas populações continuaram a ser investigadas nos anos 70 e 80, e esses resultados constituem os primeiros estudos epidemiológicos que com- 
provaram a relação entre benzeno e leucemia (Bartolucci, Alessandro \& Saia, 1995; Aksoy, 1987).

Eram padrões de exposição quase sempre bastante elevados que ao longo do tempo foram diminuindo, sem que tivessem sido identificados patamares de concentrações ambientais em que não se encontrassem agravos à saúde. No começo dos anos 70, foi publicada uma série de estudos epidemiológicos nos Estados Unidos, demonstrando excesso de leucemias em trabalhadores expostos a baixas concentrações ambientais de benzeno. Em 1977, Infante, Rinsky e colaboradores publicaram os resultados do primeiro estudo de coorte de trabalhadores expostos especificamente a benzeno, identificando um risco cinco a dez vezes mais elevado desses trabalhadores de desenvolverem leucemia com exposição em níveis correlatos com os vários limites existentes no período de 1940 a 1971. Com base nesse estudo e em outros dados da literatura, o Departamento do Trabalho dos Estados Unidos (Occupational Safety \& Health Administration - OSHA) estabeleceu um limite de exposição de 1 ppm. Este limite foi contestado pelas empresas, tendo sido suspenso pela Suprema Corte Americana até 1987, quando foi aceita a argumentação levantada pela OSHA para justificar a diminuição do limite (Aksoy, 1987; Infante, 2002).

A discussão, no entanto, não se encerrou; não foi possível chegar a conclusões consensuais. Foram numerosos os estudos promovidos pelos defensores dos diversos pontos de vista conflitantes quanto à possível concentração ambiental que permitiria uma exposição sem danos a benzeno. $O$ foco já era, então, a relação benzeno e câncer, particularmente as leucemias, pelos diversos fatores de incerteza que permeiam essas investigações e pela exposição em si, que superou os marcos da discussão ocupacional, sendo hoje tratada também como uma questão ambiental. Assim, apesar dos muitos avanços, persistem questões não resolvidas. A tendência de priorizar os estudos sobre benzeno e leucemia iniciada nos anos 50 se consolida nos anos 70 e passa a ser a principal questão tratada nos estudos feitos desde então, sendo os principais nos Estados Unidos e, posteriormente, na China, onde se desenvolvem atualmente os principais estudos sobre benzeno no mundo, com uma coorte de 74 mil trabalhadores que vêm sendo seguidos desde os anos 70 e numerosos estudos pontuais - entre os quais se destaca o artigo publicado na revista Science, em 2004, por Lan e colaboradores, comprovando a ocorrência de alterações hematológicas em trabalhadores expostos a menos de 1 ppm (Hayes et al., 2001; Lan et al., 2004).

No Brasil, as primeiras iniciativas de controle da exposição ao benzeno remontam à década de 1930, quando foram feitas as primeiras legislações res- 
tritivas ao trabalho de mulheres em atividades perigosas e insalubres, em 1932. Posteriormente, em 1939, o trabalho com benzeno passou a ser considerado atividade perigosa e insalubre. Em 1943, foi proibido o trabalho de menores com benzeno e seus homólogos. Após um intervalo de trinta anos, em 1973 é concedida aposentadoria especial de 25 anos aos expostos a benzeno. Ainda nessa década, diversos casos graves de exposição a benzeno com intoxicação e morte foram relatados, tendo sido produzidos vários estudos sobre exposição a benzeno, presença de benzeno em solventes e aplasia de medula relacionada com exposição a benzeno. Em 1978, o benzeno foi colocado na norma regulamentadora n. 15 do Ministério do Trabalho, que tratava de agentes insalubres, com um limite de tolerância estabelecido em 8 ppm-MPT (partes por milhão-média ponderada pelo tempo). Este limite foi estabelecido com base na adaptação da tabela de limites de tolerância da ACGIH. Já naquela época, a OSHA havia proposto redução para 1 ppm (Wakamatsu \& Fernícola, 1980; Novaes, 1992; Carvalho et al., 1995; Freitas \& Arcuri, 1996).

No final dessa década e no começo da seguinte, houve uma grande valorização da importância do benzeno, provocada principalmente por estudos que mostravam sua presença em solventes diversos comercializados para o público. Alguns dos produtos analisados chegavam a ter em sua composição mais de 90\% dessa substância (Novaes \& Gruenzner, 1981). A gravidade da situação provocou uma ação inédita e inovadora: mediante ampla articulação social, envolvendo o Ministério do Trabalho, o Ministério da Saúde, empresas da indústria do petróleo e o Conselho Nacional do Petróleo, os dois ministérios publicaram em 1982 uma portaria conjunta (portaria interministerial n. 3, de 28 de abril de 1982, MTb-MS), proibindo a presença de benzeno em solventes, sendo aceita contaminação de no máximo 1\% desta substância em produtos acabados. Essa portaria constitui um marco regulatório fundamental na história da luta contra a exposição a benzeno em nosso país. Com base nos estudos e ações existentes, vários movimentos foram desencadeados no ano de 1983, em relação ao risco de exposição ao benzeno em instâncias governamentais e no movimento sindical, no bojo das ações pela redemocratização do país em curso naquele período (Lianza \& Zidam, 2003; Novaes, 1992).

Na Baixada Santista, no início da década de 1980, estudos mostraram alterações hematológicas na população de Cubatão e em trabalhadores da região (Naoum, Mourão \& Ruiz, 1984). Desde 1979, trabalhadores da Companhia Siderúrgica Paulista (Cosipa) expostos ao benzeno tiveram identificadas alterações hematológicas quantitativas com redução de leucócitos 
em consequência da redução de neutrófilos decorrentes de exposição a benzeno (Ruiz et al., 1993). Em curto período de tempo, centenas de casos foram identificados, chegando a 929 trabalhadores intoxicados em 1985. Foi criada então uma comissão interinstitucional com participação dos setores envolvidos - trabalhadores, empregadores e poder público - com o objetivo de discutir três aspectos fundamentais em questão: o acompanhamento clínico-ocupacional dos casos, inclusive o diagnóstico, com o estabelecimento de valores de referência para tomada de decisão quanto à identificação dos casos e à conduta a ser tomada em relação aos trabalhadores; a necessidade de implementação de mudanças no processo do ponto de vista tecnológico e de proteção dos trabalhadores; e as estratégias de avaliação do risco de exposição a benzeno e sua operacionalização. Já naquela época se desenhava um modelo de intervenção nos ambientes de trabalho com base em três eixos: mudanças tecnológicas e de processo no ambiente de trabalho, investigação da situação de saúde dos trabalhadores e criação de mecanismos colegiados de participação (Costa, 1996a).

Além dessa experiência, outros casos significativos foram identificados nesse período, em particular em São Paulo, como o caso da Fábrica de BHC das Indústrias Químicas Matarazzo, interditada em 1985 pelo Ministério do Trabalho, em razão da contaminação de 34 dos 60 trabalhadores da empresa - com a ocorrência de uma morte por leucemia mieloide aguda - e das altas concentrações ambientais de benzeno lá encontradas, acima de 1.000 ppm. A situação era similar àquela registrada na década de 1970 em nosso país e, internacionalmente, em décadas anteriores ou mesmo em passado mais remoto. Havia, portanto, diferenças importantes nos padrões de exposição a benzeno em relação aos países desenvolvidos que permanecem até hoje (Freitas \& Arcuri, 1996; Costa, 1996a).

Da segunda metade da década de 1980 até o início da década de 1990, diversas situações de exposição e contaminação por benzeno foram identificadas, gerando a identificação de 3.331 casos de intoxicação conforme levantamento feito em 1993, que indicava ainda provável subnotificação e sub-registro de doenças e da mortalidade por benzenismo. $\mathrm{O}$ desvelamento desse grave quadro, com a emergência de situações epidêmicas em regiões que tinham núcleos de saúde do trabalhador que desenvolviam ações efetivas de investigação de casos, não foi seguido por nenhum trabalho de acompanhamento clínico e epidemiológico, apesar da possibilidade de agravamento da situação de saúde desses trabalhadores. 
Na segunda metade da década de 1990, houve um aumento desse subregistro, com uma diminuição do achado de casos a praticamente zero, com exceção de algumas ações como a dos trabalhadores metalúrgicos, petroleiros e petroquímicos, que continuaram a busca de casos de benzenismo, muitos deles ficando restritos aos serviços que fizeram o diagnóstico, em razão da resistência da Previdência Social em reconhecer essas doenças. Não há levantamento dos casos de intoxicação ou morte entre 1993 e 2008, mas há fortes evidências de subnotificação, já que a diminuição significativa de notificações e registros não correspondeu à melhora das condições de trabalho nesse período que permitisse a ausência de casos. Tal situação foi identificada como de grave silêncio epidemiológico, significando o velamento da situação real de doenças ainda em curso (Costa, 1996b; Machado et al., 2003).

Em 1993, o Ministério do Trabalho constituiu grupo multidisciplinar e interinstitucional para fazer diagnóstico da situação de exposição ao benzeno no Brasil, com a finalidade de subsidiar tecnicamente a revisão da legislação trabalhista a esse respeito. Com base nas constatações e propostas do estudo, em 1994 o Ministério do Trabalho enquadrou o benzeno na categoria das substâncias cancerígenas, retirando os limites de tolerância ambientais e biológicos, passando a não reconhecer mais limite seguro para exposição a essa substância. A regulamentação dessa portaria ocorreu após 18 meses de discussão, com grande participação social e a formação de um grupo tripartite com representantes do poder público, trabalhadores e empresas que elaboraram acordo e legislação publicada em dezembro de 1995 (Brasil, 1995).

São pontos importantes do acordo e da legislação: proibição do uso do benzeno, admitindo como exceções as empresas que o produzem ou o utilizem, em situações em que ele não possa ser substituído; obrigação de cadastramento dessas empresas; o conceito de Valor de Referência Tecnológico (VRT), superando o conceito de limites de tolerância, que permitiu assumir postura de precaução em que não existe exposição segura para o benzeno, conforme reconhecido pela legislação alemã em que esse conceito se baseou; o Programa de Prevenção da Exposição Ocupacional ao Benzeno, principal instrumento técnico de prevenção que inclui as instruções normativas de monitoramento ambiental e vigilância da saúde, que deve expressar o consolidado das ações realizadas pela empresa para prevenir a contaminação dos trabalhadores; os Grupos de Trabalhadores do Benzeno (GTBs), escolhidos por seus pares entre os eleitos para as Comissões Internas de Prevenção de Acidentes (Cipas), que instituem a vigilância ao benzeno como uma prioridade de ação para as 
comissões das empresas cadastradas e estabelecem a possibilidade de exercício do controle da exposição pelos próprios expostos. Foi criada também uma Comissão Nacional Permanente do Benzeno, organizando uma instância de negociação e acompanhamento da implementação do acordo e da legislação, responsável também por complementar as lacunas não resolvidas até então. Posteriormente, foram criadas instâncias regionais para cumprir esse papel localmente (Freitas \& Arcuri, 1996; Machado et al., 2003).

$\mathrm{O}$ acordo e a legislação estão ainda em vigor e constituíram a base legal e negociada das numerosas ações de prevenção desenvolvidas no país nos últimos 15 anos, tendo sido complementados em diversos aspectos, alguns deles comentados aqui. A pergunta condutora deste trabalho é avaliar se as políticas públicas de prevenção da exposição ao benzeno estabelecidas no Brasil são bem-sucedidas e se os instrumentos criados para sua implementação são adequados, se estão sendo aplicados e se podem ou devem ser modificados. Para tanto, procuramos identificar os principais aspectos atuais da situação de exposição ao benzeno, dimensionando o problema no país, e analisar sua relação com os eixos de intervenção e conceitos técnico-científicos que dão base ao acordo e à legislação, avaliando assim sua capacidade de tornar efetivas essas políticas.

\section{Metodologia}

Foi feito diagnóstico da situação de prevenção da exposição a benzeno no Brasil com base na identificação dos principais elementos que compõem o quadro técnico-científico, político e administrativo existentes no país relacionados com a prevenção da exposição ao benzeno. Para tanto, realizou-se um levantamento dos principais aspectos históricos e institucionais entre 1982 e 2006 que contribuíram para a definição da situação naquele momento, tendo como base revisão da produção técnico-científica sobre o assunto em nosso país, ampliada com a inclusão de produtos identificados como relevantes que extrapolam o âmbito acadêmico e que expressam pontos de vista representantes de diferentes segmentos sociais. Boa parte desse material está registrado no Repertório Brasileiro do Benzeno, publicado pelo Ministério da Saúde, que compila experiências de vigilância da saúde aos riscos do benzeno no país (Brasil, 2005).

Esses elementos identificados foram avaliados com base em análise de intervenção realizada em empresa localizada no estado de São Paulo, a pedido 
do Ministério Público do Trabalho (MPT), em que se investigou a situação de saúde dos trabalhadores da empresa com risco de exposição a benzeno, priorizando um grupo de trabalhadores que apresentavam alterações hematológicas persistentes e restrição à exposição ao benzeno - sem, no entanto, ter sido caracterizada doença ocupacional (intoxicação crônica por benzeno) pela empresa e estando a maior parte desse grupo em atividade na área industrial da empresa.

\section{Resultados}

\section{Aspectos atuais da exposição ao benzeno no Brasil}

A política de restrição da utilização do benzeno no Brasil - iniciada na década de 1930 e que tem como principal marco histórico a proibição de sua comercialização em produtos acabados, no ano de 1982 - a partir da legislação de 1995 praticamente limitou seu uso a atividades industriais muito específicas e setorizadas, o que se consolidou com a portaria MS/MTE n. 775, de 2004, que diminuiu o percentual de concentração desse produto aceita como contaminação. Apesar dessas restrições, ainda é possível encontrar benzeno em diversos produtos como a gasolina e misturas de solventes. As atividades em que se encontra benzeno no Brasil atualmente podem ser divididas em três categorias. A situação de exposição e contaminação dos trabalhadores e da população é particular a cada uma delas (Brasil, 2005).

Na primeira categoria, estão as atividades industriais em que são permitidos a produção, a utilização, o armazenamento e o transporte de benzeno. Envolvem: as cinco indústrias siderúrgicas integradas do Brasil, em que há produção de coque; a indústria de extração e refino de petróleo em todas as suas etapas; a indústria petroquímica produtora de benzeno; as indústrias químicas de segunda geração que utilizam benzeno; as empresas de armazenamento e transporte de produtos químicos que transportam ou armazenam benzeno (Brasil, 1995).

As cinco indústrias siderúrgicas em que há coquerias e utilização do gás de coqueria como fonte energética são: Companhia Siderúrgica Paulista (Cosipa), em Cubatão-São Paulo; Companhia Siderúrgica Tubarão (CST), no Espírito Santo; Companhia Siderúrgica Nacional (CSN), em Volta Redonda-RJ; Usiminas, em Ipatinga-MG; e Açominas, em Ouro Branco-MG. Dessas empresas, são mais conhecidos os casos na Cosipa, onde foram diagnosticados dois mil casos de intoxicação por benzeno até 1993 e ainda hoje há a suspeita de ocorrência 
de algumas centenas de casos novos, sendo uma parte significativa deles em trabalhadores terceirizados. Na CSN, diagnosticaram-se cerca de quinhentos casos até 1993 e continua sendo palco de discussão sobre a contaminação por benzeno no município de Volta Redonda, com denúncias de casos novos entre trabalhadores e a população, sem que haja informações qualificadas e atualizadas sobre esse quadro, sendo ainda ponto importante do debate ambiental que ocorre na região. Na CST, a investigação de casos de intoxicação, além dos casos já estabelecidos, tem sido feita de forma limitada e sob enorme pressão da empresa, que se recusa a reconhecer os casos.

No caso da indústria do petróleo, em particular as refinarias da Petrobras, a política de ocultamento das doenças e do não reconhecimento dos direitos dos trabalhadores chegou ao extremo da negação do nexo causal no caso de operador, com exposição importante e comprovada a benzeno, que faleceu em razão de uma leucemia mieloide aguda em 5 de outubro de 2004. Há evidências de existirem centenas de casos não reconhecidos nas refinarias da Petrobras, portanto sem os direitos e a proteção necessários decorrentes dessa situação (Brasil, 2005). Os trabalhadores terceirizados são mais frequentemente expostos às atividades de risco. $\mathrm{O}$ caso de dois trabalhadores intoxicados no Paraná em 2002, durante o combate a um dos principais entre os numerosos vazamentos de produtos derivados do petróleo provocados pela Petrobras, expressa a gravidade dessa situação. A portaria n. 776, de Vigilância da Saúde dos Trabalhadores Expostos ao Benzeno, e o Protocolo de Vigilância de Riscos Químicos: Módulo Benzenismo, ambos do Ministério da Saúde, são esforços importantes visando à superação desse quadro.

Na segunda categoria das atividades em que se encontra benzeno no Brasil, estão aquelas em que há utilização de solventes e suas misturas - envolvem as indústrias gráficas, de calçados, couros, borracha, colas, tintas e vernizes. A legislação não permite a adição do benzeno nos solventes e suas misturas; no entanto, aceita-o como contaminante. Mesmo estando em quantidades reduzidas, não significa a inexistência de risco, sendo ainda possível encontrar produtos fora das especificações, com concentrações maiores do que é permitido pela portaria conjunta n. 775 do Ministério do Trabalho e do Ministério da Saúde: 0,1\% a partir de dezembro de 2007 (Brasil, 2006).

A terceira categoria inclui a gasolina automotiva, que tem concentração máxima permitida de benzeno de $1 \%$ e 1,5\%, dependendo do seu tipo, pela legislação da Agência Nacional do Petróleo (ANP). Assim, trabalhadores de postos de gasolina e de oficinas mecânicas constituem grupos de risco impor- 
tantes e pouco acompanhados em nosso país. A adulteração de combustíveis, problema grave e frequente, é muitas vezes feita com adição de mistura de solventes recuperados, o que potencializa em muito a possibilidade de se encontrarem concentrações bem mais elevadas de benzeno nos combustíveis, havendo relatos da ANP de achado de até 8\% de benzeno em gasolinas adulteradas (Brasil, 2005).

Não se pode esquecer que essas atividades, bem como toda combustão incompleta de substâncias orgânicas, têm efeito importante na contaminação ambiental que atinge a população como um todo. Há um esforço importante em praticamente todo o mundo pela diminuição da emissão de benzeno na atmosfera, focado principalmente na diminuição das emissões industriais e dos veículos automotivos.

Até o início da década de 1970, os relatos internacionais de achados de danos provocados por benzeno se relacionavam com níveis de exposição bastante elevados, que resultavam em casuísticas mais numerosas envolvendo principalmente alterações hematotóxicas, muitas delas típicas de intoxicações crônicas, mas que muitas vezes se desenvolviam de forma acelerada devido à intensidade da exposição. Na década de 1920, foram estimadas exposições de 200 a 1.000 ppm por Hogan e Schrader, ou ainda de 90 ppm ou mais por Greenburg (apud Infante, 2002). Estudos na Turquia nos anos 1960 e 1970 estimavam exposições de 210 a 650 ppm na indústria de calçados, época em que foi proibida a presença de benzeno em solventes nesse país. No Brasil, o problema é identificado, particularmente no estado de São Paulo, apenas no início da década de 1970, com padrões de exposição e morbidade semelhantes aos identificados e modificados algumas décadas antes nos Estados Unidos e posteriormente na Itália e na Turquia - mostrando uma defasagem nos tipos de processos produtivos típicos das transferências de tecnologias atrasadas dos países desenvolvidos para os do Terceiro Mundo, fenômeno que persiste até os dias de hoje (Aksoy, 1987; Bartolucci, Alessandro \& Saia, 1995; Wakamatsu \& Fernícola, 1980).

\section{Vigilância da exposição ao benzeno}

A vigilância da exposição ao benzeno tem sido feita com base no acordo e legislação de 1995 e seus desdobramentos, sendo referência para numerosas ações envolvendo trabalhadores, órgãos públicos e empresas. Seus principais pontos são: 1) o reconhecimento oficial do benzeno como cancerígeno; 2) a consolidação da restrição de sua utilização; 3) o estabelecimento de estratégias e formas de vigilância em que a participação tem papel fundamental. 
Com base no Repertório Brasileiro do Benzeno, que compila a experiência das ações contra a contaminação por benzeno no Brasil e serve como apoio para a discussão e difusão desse movimento, foram identificados elementos para analisar os principais avanços e desafios atuais. A experiência desses últimos anos tem se concentrado na discussão e na intervenção nas atividades industriais em que a presença de benzeno é notória e substantiva. Nesses setores (siderurgia, refino de petróleo e petroquímica/química de segunda geração), vem se desenvolvendo atuação com caráter multidisciplinar, interinstitucional e marcadamente participativo, privilegiando a articulação dos trabalhadores com os serviços públicos e, ao mesmo tempo, estabelecendo mecanismos permanentes de interlocução com as empresas.

Alguns princípios fundamentais têm norteado essas ações: 1) a defesa do direito de saber que têm todos os trabalhadores expostos a riscos de qualquer natureza em seu trabalho, além do dever de informar que cabe às empresas e, em especial, aos funcionários com responsabilidade direta sobre essas situações: diretores, gerentes, engenheiros de segurança e processos e médicos do trabalho; 2) o direito dos trabalhadores de recusa ao trabalho em atividades que possam provocar danos à sua saúde; 3) a necessidade de técnicos do serviço público das mais diversas instituições atuarem em conjunto com trabalhadores e seus representantes.

Desde 1997 - ano em que foram realizados o primeiro curso sobre riscos da exposição ao benzeno para trabalhadores petroleiros e a primeira oficina nacional de técnicos do serviço público, sindicalistas e trabalhadores das empresas onde foram definidas as estratégias iniciais de ação conjunta têm ocorrido numerosas atividades de formação envolvendo trabalhadores, sindicalistas, técnicos e mesmo representantes das empresas. Entre as principais atividades de formação, destacamos os cursos para GTBs, que em algumas regiões do país, em particular no estado de São Paulo, estão institucionalizados como uma prática desenvolvida pelo poder público, e os cursos para técnicos do serviço público que formaram diversos grupos estaduais e municipais de acompanhamento da implementação do acordo e da legislação do benzeno.

É possível identificar que os locais e categorias em que há mais participação e mobilização são em geral aqueles nos quais ocorreram as melhores experiências de formação. Também devem ser valorizadas as numerosas atividades de divulgação e discussão públicas em encontros, oficinas, palestras, seminários, inclusive internacionais, que consolidaram conceitos 
e avaliações dessa experiência nacional e propiciaram a troca e a difusão de informações e a criação de uma visão mais homogênea e compartilhada da aplicação dessas estratégias.

Assim, onde essas atividades têm tido maior repercussão podem ser identificadas mobilizações e intervenções por modificações nas empresas, além de denúncias e disputas pelo diagnóstico e reconhecimento de doenças relacionadas à exposição ao benzeno. Ao mesmo tempo, em boa parte em consequência dessas atividades de formação e discussão, vem se ampliando a criação de instâncias colegiadas de acompanhamento da implantação do acordo e da legislação em âmbitos nacional, estadual e regional, como a Comissão Nacional Permanente do Benzeno e as comissões estaduais e regionais. Essas comissões, também de forma heterogênea, têm contado com a participação expressiva de trabalhadores e técnicos do serviço público, estabelecendo assim redes de controle.

De forma mais autônoma, trabalhadores e técnicos do serviço público vêm privilegiando, não sem contradições, a organização de redes horizontais para a troca de informações e experiências e para a viabilização de suas articulações e ações. Não obstante esse esforço, ainda é possível separar os setores envolvidos por suas cadeias produtivas. Assim, são os petroleiros os mais mobilizados e organizados, e é no setor siderúrgico que as dificuldades de intervenção são maiores, chamando a atenção o desmonte ocorrido no movimento dos trabalhadores siderúrgicos atingidos pela contaminação pelo benzeno, pioneiro na década de 1980 nesse tipo de organização. Químicos e petroquímicos participam num grau intermediário, relacionado à manutenção de sua força de organização dentro das empresas e de um patamar mais elevado de direitos de representação e cidadania conquistados historicamente, mas claramente com menor poder de mobilização, coerente com a diminuição global da capacidade de resistência dos trabalhadores ante as violências contra sua organização na década de 1990 .

As principais questões que vêm sendo tratadas por esses grupos giram em torno de alguns conceitos centrais que dão base às ações desenvolvidas:

1) A importância da restrição do uso e circulação do benzeno e o controle sobre sua produção; o conceito de não exposição a benzeno, que fundamenta o Valor de Referência Tecnológico (VRT), parâmetro para as concentrações ambientais máximas aceitas que se contrapõe ao funesto limite de tolerância, ainda presente no imaginário de muitos serviços de empresa. O VRT não é um limite de exposição, não exclui risco à saúde e deve ser a base para os programas de melhoria contínua. 
2) As mudanças tecnológicas nos processos produtivos como principal alternativa de proteção aos trabalhadores nos ambientes de trabalho.

3) A necessidade de monitoramento da saúde dos trabalhadores de forma permanente, sistemática e buscando identificar alterações da forma mais precoce possível.

4) A importância da avaliação de riscos com participação do trabalhador e apoiada em rigoroso levantamento qualitativo, que deve sempre nortear as medições, as quais têm caráter complementar.

5) A necessidade de ações com caráter multidisciplinar e interinstitucional, em que a contribuição dos trabalhadores e suas representações constituem parte essencial, não apenas do ponto de vista da participação, mas também da produção de conhecimento e realização das atividades de vigilância como protagonistas desse processo.

\section{Relato de caso}

O sindicato dos petroleiros apresentou denúncia ao MPT quanto à existência de casos de intoxicação por benzeno em empresa que não os admitiam, e os trabalhadores continuavam expostos, correndo risco de ter agravamento potencialmente ainda maior desses quadros. O MPT constituiu um procedimento preparatório e organizou grupo técnico para dar encaminhamento ao trabalho. O grupo fez levantamento por meio de entrevistas com esses trabalhadores, discussões coletivas com a participação dos trabalhadores e do sindicato, análise de documentos produzidos pela empresa e verificações in loco na empresa. O resultado da investigação mostrou uma situação grave de exposição a benzeno em todas as áreas da empresa e contaminação de trabalhadores, confirmando a ocorrência de intoxicação por benzeno nos casos investigados e identificando falhas severas no sistema de vigilância da saúde aplicados na empresa, entre outros problemas graves.

O levantamento feito no grupo de trabalhadores, ao apontar para a consistência da suspeita da ocorrência de numerosos casos de intoxicação por benzeno sem que o acompanhamento da saúde dos trabalhadores na empresa fosse adequado e confiável, fundamentou a necessidade de se ampliar o trabalho para se verificar a situação do conjunto de trabalhadores da refinaria em relação ao monitoramento feito pela série histórica de hemogramas. Para tanto, foi proposta uma revisão das séries históricas de todos os trabalhadores e um aprofundamento da investigação diagnóstica do grupo de 15 trabalhadores 
caracterizados como casos de intoxicação em dezembro de 2004 e que foram afastados da refinaria em janeiro de 2005. O estudo realizado confirmou a precariedade da vigilância à saúde dos trabalhadores da empresa, tendo também confirmado o diagnóstico dos 15 casos de intoxicação.

\section{Discussão e Conclusões}

Os achados sobre a toxicidade e a carcinogenicidade do benzeno foram sendo feitos ao longo dos anos, quase sempre correlacionados aos padrões de exposição existentes que variaram nesses períodos, assim como variaram os cenários em que ocorria exposição. Apesar da diminuição do número de estudos realizados nos países centrais, Estados Unidos e Europa principalmente, e da mudança de sua orientação, priorizando a pesquisa de riscos a baixas concentrações e os aspectos ambientais dessa questão, é razoável supor que haja diferença nos padrões de exposição daqueles países em relação ao Brasil. Assim, é possível identificar em nosso país ocorrências de agravos com uma diferença de dez anos ou mais em relação àqueles países, sugerindo um aparecimento tardio, correspondente ao desenvolvimento industrial também tardio, típico da relação entre aqueles países e os países em desenvolvimento.

No caso particular do benzeno, deve ser considerada ainda a reestruturação produtiva relacionada com o processo de globalização que atinge todos os países. As cadeias produtivas do petróleo e do aço, em que há presença significativa de benzeno, se deslocam para os países periféricos de forma cada vez mais significativa, puxadas pela China, que se tornou a 'fábrica do mundo' e ocupa um lugar decisivo hoje na produção de bens materiais e tecnologia. Acompanhando esse crescimento, o aumento potencial da capacidade produtiva dessas cadeias no Brasil já está em andamento, tornando praticamente inexorável nossa convivência com essa substância a longo prazo e aumentando ainda mais a importância de se enfrentarem as questões postas pela necessidade de prevenirmos a exposição ao benzeno.

A restrição da produção e da utilização do benzeno no Brasil para apenas alguns tipos de empresas vem se mostrando correta e bem-sucedida, tendo sido estabelecido um acompanhamento desse grupo de empresas por meio do controle da compra e da venda do produto - o que permite a suposição de que a eventual existência de empresas fora do grupo cadastrado que estejam usando essa substância ocorra de forma marginal, além de evidentemente ilegal, o que permitiria ações de intervenção com boas probabilidades de sucesso. 
Esse grupo de empresas, no entanto, não é homogêneo, havendo grandes diferenças entre os setores: siderurgia; refinarias; petroquímicas e químicas de segunda geração; armazenamento e transporte.

Na siderurgia, é possível identificar um grande desgaste das organizações sindicais e das discussões sobre saúde do trabalhador, particularmente na segunda metade da década de 1990, quando logo após o processo de privatização houve grande inflexão da produção de aço no mundo, repercutindo de forma negativa nessas empresas, em especial na Cosipa, emblemática dessa discussão no Brasil e no mundo, pois há pouca valorização da exposição a benzeno na atividade siderúrgica, tendo a experiência brasileira um caráter pioneiro nesse e em outros aspectos. Sintomaticamente, em meados de 2007, três mortes de trabalhadores ligados à Cosipa exemplificaram os vários ciclos de adoecimento e morte associados a essa atividade e pouco identificados em nosso país: um trabalhador, afastado na década de 1980 e aposentado na década de 1990, foi diagnosticado com uma leucemia mieloide aguda que teve evolução rápida e fatal. Outro trabalhador, com diagnóstico de leucemia linfoide crônica diagnosticada em 1997, após dez anos de sobrevida, também faleceu. Finalmente, um jovem trabalhador de empresa terceirizada, que teve diagnosticada leucemia linfoide crônica em 2004, foi afastado e transplantado, retornou à empresa após a alta, tendo recidiva com óbito em menos de seis meses.

O setor siderúrgico é, no momento, um dos possíveis carros-chefe da ampliação da produção industrial em curso no Brasil, havendo a expectativa de que nosso parque industrial nesse setor aumente em até duas vezes e meia, em um período de aproximadamente dez anos, sua capacidade produtiva constituída ao longo de sessenta anos. Do ponto de vista da saúde do trabalhador, há pouca perspectiva de enfrentamento dessas questões. A questão ambiental é, no entanto, muito significativa pelo impacto das indústrias eletrointensivas e com grande potencial de contaminação, sendo este um caminho importante para a discussão necessária sobre um crescimento que não seja predatório para o ambiente e as comunidades, inclusive a dos trabalhadores dessas indústrias.

O setor do petróleo chama a atenção pelo seu envolvimento na discussão apenas nos últimos anos, participação que pode ser atribuída à presença dos trabalhadores desse setor na Comissão Nacional do Benzeno e ao desenvolvimento de numerosas ações de formação e intervenção nos locais de trabalho mediante articulações entre técnicos do poder público e representantes de trabalhadores. Não foram encontrados registros de ações sobre o benzeno no setor antes de 1997, e não houve sequer participação da Petrobras no proces- 
so de negociação ocorrido em 1994/95. Trata-se de uma situação singular, pois, internacionalmente, a participação da indústria do petróleo é bastante significativa, sendo possível encontrar nessas empresas numerosos trabalhos técnico-científicos, assim como a organização e a participação em eventos, muitas vezes por meio de órgãos próprios de pesquisa tecnológica e científica, outras em associação com universidades.

Na maior parte dos países há presença de benzeno na gasolina em níveis iguais ou superiores a $1 \%$, sendo a discussão da toxicidade do benzeno em baixas concentrações, em produtos e no ambiente, fundamental para essas corporações. Assim, a participação da Petrobras expressa esse avanço, conseguido desde 1995, ao mesmo tempo que permite constatar a ocorrência de numerosas situações de risco ainda existentes nas atividades industriais ligadas a esse setor e, não menos importante, as múltiplas questões ambientais a ele relacionadas.

No setor petroquímico e químico de segunda geração, é possível identificar maior capacidade de diálogo, sendo neste setor que a discussão sobre boas práticas, sistemática que vem sendo implementada nas ações de vigilância, mais tem avançado. O setor de armazenamento tem sido acompanhado há relativamente pouco tempo, mas é possível, no entanto, diferenciar a estrutura de armazenamento que faz parte diretamente da indústria de refino de petróleo daquela que armazena e distribui combustíveis, não incluída na legislação, e daquela que armazena benzeno e misturas com grande concentração dessa substância, geralmente para exportação. $\mathrm{O}$ acompanhamento da situação do setor de transporte é ainda incipiente no estado de São Paulo. O fato de as atividades de vigilância da saúde estarem concentradas nos setores industriais aqui relacionados expressa uma limitação importante do alcance do acordo e da legislação referentes ao benzeno, que são voltados essencialmente para o núcleo dessas cadeias produtivas, envolvidas na discussão desde o seu início, porém pouco capazes de responder às necessidades de intervenção nos seus campos periféricos - como a distribuição e venda de combustíveis e a recuperação de solventes, áreas em que não há praticamente nenhum tipo de ação de vigilância.

A questão da doença é um fator mobilizador importante, embora haja muita dificuldade para se fazer o diagnóstico, particularmente das alterações hematológicas relacionadas com a exposição ao benzeno. Essas dificuldades se agravam em razão dos problemas de acolhimento do trabalhador intoxicado, que enfrenta grande resistência da empresa e da previdência social para o reconhecimento de seu quadro clínico, sendo também com frequência 
discriminado principalmente quando se identifica grande número de casos com potencial de impacto importante nos processos produtivos e na vida das comunidades envolvidas.

A experiência brasileira de luta contra a exposição ao benzeno e suas consequências é extremamente rica e, em muitos casos, exemplar. Destaca-se a importância da produção técnico-científica como base das ações, o que pode ser identificado já nos anos 70 e que teve momentos marcantes no início das décadas de 1980 e 1990. É também significativa a combinação dessa produção com situações institucionais favoráveis, em geral decorrentes da abertura de espaços na sociedade, quase sempre vinculada aos movimentos sociais e às situações políticas.

Apesar de muitos limites e desafios - sendo um dos principais a dificuldade de envolver trabalhadores terceirizados e os ramos de atividade menos organizados que não estão contemplados diretamente no acordo e na legislação, como os frentistas de postos de gasolina e os trabalhadores em oficinas mecânicas -, a experiência brasileira de luta contra a exposição ao benzeno é um exemplo bem-sucedido de vigilância da saúde em que as estratégias de articulação entre trabalhadores e serviço público - com a preservação da autonomia de cada setor, a priorização das atividades de formação e a opção por formas participativas de atuação - ajudam a entender e enfrentar os desafios da luta em defesa da saúde do trabalhador no Brasil.

A despeito dos avanços conseguidos na prevenção dos agravos à saúde decorrentes do benzeno, vários aspectos ainda precisam ser modificados, o que pode ser exemplificado na empresa estudada em São Paulo.

\section{REFERÊNCIAS}

AKSOY, M. Benzene Carcinogenicity. Boca Raton: CRC, 1987.

BARTOLUCCI, G. B.; ALESSANDRO, G. \& SAIA, B. Evoluzione storica della patologia professionale da benzene. In: MINOYA, C.; APOSTOLI, P. \& BARTOLUCCI, G. B. Il Benzene: tossicologia, ambiente di vita e di lavoro. Milano: Morgan Edizioni Tecniche, 1995.

BRASIL. Ministério do Trabalho e Emprego. Secretaria de Segurança e Saúde no Trabalho. Acordo e Legislação sobre o Benzeno. São Paulo: Fundacentro/MTE, 1995.

BRASIL. Ministério da Saúde. Repertório Brasileiro do Benzeno. Fundação Osvaldo Cruz, 2005. CD-ROM.

BRASIL. Ministério da Saúde. Risco Quimico: atenção à saúde dos trabalhadores expostos a benzeno. Série A. Normas e Manuais Técnicos. Brasilia: Ministério da Saúde, 2006. 
CARVAlHO, A. B. et al. Benzeno: subsídios técnicos à Secretaria de Segurança e Saúde no Trabalho (SSST/MTb). 2. ed. São Paulo: Fundacentro, 1995.

COSTA, D. Benzeno: uma negociação exemplar em saúde, ambiente e contrato coletivo de trabalho, experiências em negociação coletiva. In: BONCIANI, M. (Org.) Saúde, Ambiente e Contrato Coletivo de Trabalho. São Paulo: LTr, 1996a.

COSTA, D. Relatório da Análise de Hemogramas dos Trabalhadores da Coqueria e Carboquimicos da Cosipa em Repertório Brasileiro do Benzeno. Rio de Janeiro: Fundação Osvaldo Cruz/Ministério da Saúde, 1996b. CD-ROM.

FREITAS, N. \& ARCURI, A. O benzeno e a saúde dos trabalhadores: a luta histórica e a negociação tripartite. In: BONCIANI, M. (Org.) Saúde, Ambiente e Contrato Coletivo de Trabalho. São Paulo: LTr, 1996.

INFANTE, P. F. Benzene: an historical perspective on American and European occupational setting. In: EUROPEAN ENVIRONMENT AGENCY. Late Lessons from Early Warnings: the precautionary principle 1896-2000. Copenhagen: European Environment Agency, 2002. (Environment Issue Report 22)

HAYES, R. et al. Benzene and lymphohematopoietic malignancies in humans. American Journal of Industrial Medicine, 40: 117-126, 2001.

HOBSBAWM, E. Era dos Extremos: o breve século XXI, 1914-1991. São Paulo: Companhia das Letras, 1996.

LAN, Q. et al. Hematotoxicity in workers exposed to low level of benzene. Science, 306: 1.774-1.776, 2004.

LIANZA, S. \& ZIDAM, L. Relatório de Formação em Saúde e Segurança no Brasil. São Paulo: CUT, 2003. (Mimeo.)

MACHADO, J. M. H. et al. Alternativas e processos de vigilância em saúde do trabalhador relacionados à exposição ao benzeno no Brasil. Ciência Ė Saúde Coletiva, 8(4): 913-921, 2003.

NAOUM, P. C.; MOURÃO, C. A. \& RUIZ, M. A. Alterações hematológicas induzidas por poluição industrial em moradores e industriários de Cubatão, SP. Revista de Saúde Pública, 18(4): 271-277, 1984.

NOVAES, T. C. P. Bases Metodológicas para Abordagem da Exposição Ocupacional ao Benzeno, 1992. Dissertação de Mestrado, São Paulo: Instituto de Química, Universidade de São Paulo.

NOVAES, T. C. P. \& GRUENZNER, G. Determinação dos teores de benzeno em solventes orgânicos industriais comercializados no Brasil e propostas para prevenção do risco potencial de benzolismo. Revista Brasileira de Saúde Ocupacional, 9(36): 66-70, 1981.

RUIZ, M. A. et al. Alterações hematológicas em pacientes expostos cronicamente ao benzeno. Revista de Saúde Pública, 27(2): 145-151, 1993.

SCHORLING, I. Reach: the only planet guide to the secrets of chemicals policy in the EU - what happened and why? 2004. Disponível em: <hesa.etui-rehs.org/uk/newsevents/ files/reach1sw.pdf>. Acesso em: 4 nov. 2010. 
SNYDER, R. Benzene and leukemia. Critical Reviews in Toxicology, 32(3): 155-210, 2002.

WAKAMATSU, C. \& FERNÍCOLA, N. Intoxicação profissional por benzeno em medicina do trabalho e doenças profissionais. In: MENDES, R. (Org.) Medicina do Trabalho-Doenças Ocupacionais. São Paulo: Sarvier, 1980.

YERGIN, D. O Petróleo: uma história de ganância, dinheiro e poder. São Paulo: Scritta, 1992. 



\section{Parte II}

Acidentes e Agravos 



\section{Acidentes de Trabalho e a Repolitização da Agenda da Saúde do Trabalhador}

Ildeberto Muniz de Almeida

\section{Enfraquecimento Técnico e Politico da Prevenção de Acidentes}

0 s primeiros estudos que mostraram a desarticulação e a pulverização de responsabilidades institucionais em saúde do trabalhador (ST) no Brasil ocorreram há mais de duas décadas. No entanto, apesar da existência de comissão assessora específica para a área junto ao Conselho Nacional de Saúde, da realização de conferências nacionais de ST e de diversas tentativas de superação dos problemas identificados, continuamos, na prática, sem uma Política Nacional de Saúde do Trabalhador e sem um ator político que consiga dar vida e dinamizar a construção de um projeto para a área orientado, estrategicamente, em consonância com os princípios e com a definição de ST incorporada na Lei do Sistema Único de Saúde (SUS) (Lacaz, 1996; Minayo-Gomez \& Thedim-Costa, 1997; Minayo-Gomez \& Lacaz, 2005; Mendes \& Dias, 1991).

Uma das principais manifestações desse quadro continua aparecendo na relação esquizofrênica entre as áreas de ST dos ministérios da Saúde, do Trabalho e Emprego e da Previdência Social. Nesse campo, reinam a desarticulação, a diferença de linguagens, o distanciamento de propósitos e, por vezes, até manifestações de hostilidade. Uma das piores consequências dessa falta de norte político para sua implementação talvez seja a impossibilidade de abertura de diálogo entre segmentos dessas três áreas, inclusive entre aqueles (segmentos) mais bem intencionados e que mais se beneficiariam com esse diálogo.

A inexistência, até hoje, de proposta especifica referente à prevenção de acidentes do trabalho contemplando interesses estratégicos dessas três áreas de governo é um dos reflexos desse quadro. Considerando a importância já 
assumida pelas mortes e mutilações relacionadas ao trabalho, dentro e fora do espaço das empresas, poder-se-ia ampliar essa ideia para a articulação de atores ligados ao trânsito e também à segurança pública.

Mais grave ainda, talvez, seja a falta de voz dessas áreas nas escolhas estratégicas de política econômica do governo. Aqui, a posição caudatária das áreas de políticas sociais é mostrada em seu formato mais duro. O episódio dos transgênicos mostra que em nome de objetivos 'estratégicos' de curto prazo o governo joga na lata do lixo o princípio da precaução. Por sua vez, as mortes por exaustão no corte da cana-de-açúcar e a substituição de áreas de plantação de alimentos por cana-de-açúcar ou outra monocultura revelam que informações e preocupações manifestadas por grande número de cientistas do país - e de fora dele - sobre impactos potenciais de condições de trabalho são desconsideradas em decisões de governo. As críticas esboçadas às escolhas governamentais de incentivo à expansão do programa do álcool combustível foram destratadas em declarações do presidente da República.

As discussões sobre a agenda da área de ST para os próximos anos continuam sendo realizadas de forma pulverizada entre instituições que não dialogam entre si nem com a área econômica do governo - e ainda desconsiderando cenários possíveis para a inserção do país na economia internacional e suas implicações para a área de ST e ambiente.

Não bastassem essas dificuldades, a forma como se dão a implantação e o desenvolvimento de ações denominadas de ST no SUS, em particular quando alimentam a ideia de enclausuramento da área em guetos institucionais, ainda enseja cenas de ciúme, de incertezas na condução política, de conflitos e resistências entre atores do próprio campo da saúde.

A construção da ST no SUS parece viver um momento que exige parada para reflexão e elaboração de nova agenda. Como desafio maior, merece destaque a necessidade de repolitização da atuação no campo e na área em um período em que se somam enfraquecimento da presença política dos trabalhadores organizados nos padrões tradicionais do sindicalismo e emergência de pluralismo de formas de organizações e movimentos sociais em defesa de múltiplas agendas de temas que, em grande parte, têm raízes no modelo de 'desenvolvimento' vigente e que, em última instância, poderiam facilitar o diálogo e a ampliação de alianças com atores inseridos prioritariamente no campo da ST.

Considerando esse cenário como pano de fundo da situação atual, este capítulo defende a ideia de que o problema dos acidentes do trabalho não 
vem sendo tratado de modo que explore o potencial que permite revelar como caminho para a repolitização da agenda da área.

\section{Acidentes do Trabalho e Repolitização da Atuação em Saúde do Trabalhador}

A diversidade de escolhas estratégicas e práticas gerenciais encontradas nas origens e consequências proximais e distais de acidentes permite que esses eventos sejam usados como um dos caminhos para a repolitização da agenda de ST.

Iniciando pelas consequências dos acidentes, têm-se as mortes, as mutilações incluindo amputações, as lesões incapacitantes de modo permanente ou temporário, em especial com duração superior a trintas dias, e outras que, em sua quase totalidade, são reconhecidas como facilmente preveníveis e representam fontes potenciais de denúncias, protestos sociais e outras formas de mobilização e ação política. $\mathrm{O}$ mesmo se pode dizer de prejuízos ao meio ambiente e bens materiais, em especial quando de larga monta, como em acidentes ampliados ou maiores. Quando o impacto de acidente extrapola os 'muros' ou as fronteiras do processo produtivo ou a atividade que o gera e atinge populações externas, transeuntes, passageiros, moradores abastecidos pela água contaminada etc., essas reações podem ganhar força, embora, em muitos casos, ensejem reações de alcance limitado - ou seja, sem questionar as condições de geração do perigo e da exposição conforme recomendado na abordagem da vigilância em saúde (Machado, 2005; Paim, 1999; Porto, 2007).

A possibilidade da amplificação dos impactos desses eventos em situações de omissão e fragilidade do poder público, em especial diante do poder de grandes corporações, deve ser tema da agenda da área.

A desproteção social das vítimas de acidentes e de seus familiares, a fragilidade das políticas públicas afins e as respostas de diferentes atores a esse problema é um dos temas centrais do livro Trabalhar Mata, lançado na Itália (Rovelli, 2008), que relaciona esse fenômeno com o crescimento e a disseminação de diferentes formas de precarização do trabalho naquele país. No Brasil, estudos e denúncias que explorem impactos da difusão de práticas semelhantes são ainda incipientes.

As diversas consequências de acidentes precisam ganhar visibilidade pública, tanto nos casos localizados como em sua dimensão coletiva, e podem ser vistas como possíveis caminhos para a politização das respostas dadas a esses problemas. 


\section{[3] Perplexidade e Passividade}

Quais os reflexos dessa situação para os interessados na prevenção de acidentes? Dada a desmobilização e a desarticulação dos movimentos de trabalhadores que, em tese, seriam os maiores beneficiados com ações de prevenção, parece urgente que as instituições públicas que atuam nesse campo construam pacto de entendimento e parem de agir como se o inimigo morasse no ministério ao lado.

A organização do I Simpósio Brasileiro de Saúde do Trabalhador (Simbrast) pode ser vista como ponto de partida para a retomada de reflexões e elaboração de nova agenda para a ST. Nesse simpósio, a identificação de leque de cenários mais prováveis foi apenas esboçada e precisa ser retomada. As reflexões e sugestões discutidas no evento podem contribuir nessa tarefa.

Novas e velhas questões persistem à espera de enfrentamento. Como avaliar a adequação do arcabouço jurídico existente sem ideia clara sobre as atividades e os riscos emergentes? Como implementar os suportes técnico, material e de formação necessários sem identificar o que tende a ser o trabalho e seus respectivos riscos no território em questão? Como organizar as respostas de emergência indicadas para os diferentes cenários? Etc. etc. (Minayo-Gomez \& Lacaz, 2005).

Por sua magnitude e gravidade, seria de se esperar que os acidentes de trabalho não só fossem visualizados como problema de saúde pública a exigir urgente resposta na forma de políticas públicas, mas que também ensejassem a criação de movimento social pela prevenção que denunciasse a maioria das ocorrências como socialmente inaceitáveis e alavancasse iniciativas de mudanças políticas e culturais em constante defesa da atualização de agenda de prevenção dinamizada por setores de fora do governo.

Não é por falta de exemplos e de denúncias que não temos entre nós esse movimento social pela prevenção. Apesar do número crescente de estudos e alertas mundiais sobre impactos negativos da precarização do trabalho, não existem, no Brasil, iniciativas de políticas públicas ou ações organizadas de atores sociais envolvidos que revelem como se deu e se dá esse processo no país; ou que possam ser descritas como respostas visando a minimizar ou controlar seus impactos.

Algumas tímidas ações podem ser apontadas no âmbito jurídico-institucional, como a emissão de portarias ministeriais cuja implementação esbarra em fortes restrições de ordem política, em decisões já tomadas no 'núcleo duro' 
de governo de incentivo a políticas de eliminação ou flexibilização de direitos trabalhistas, de incentivo à precarização, de inserção do país na economia mundial em moldes subalternos, de redução do 'custo Brasil', de rendição a projetos de expansão de monoculturas etc.

Nesse contexto, a resposta atual da área de ST no âmbito governamental parece restringir-se ou consolar-se com estratégia que associa expansão ilusória da presença da área em espaços do SUS com incorporação burocrática de ações de medicina do trabalho e saúde ocupacional desenvolvidas, em sua maioria, de forma pontual e sem perspectiva estratégica em consonância com o projeto de ST. Honrosas exceções ilustram situações em que, nos novos serviços da área, surgem iniciativas orientadas por conceitos como vigilância em saúde do trabalhador e esforços visando a substituir as práticas de atenção centradas em demandas espontâneas por outras informadas pela noção de risco e prioridades definidas com a participação de segmentos organizados da sociedade.

O tema dos acidentes do trabalho parece surgir como um daqueles em que explorações adicionais dessas questões e sugestões de ações estrategicamente orientadas podem ser desenvolvidas com facilidade. Afinal, quantos dos novos serviços oferecem ações relacionadas a esses acidentes que sejam diferentes da mera elaboração de bancos de dados de notificações e eventual análise de casos isolados, abordados de modo pontual? Os dados já existentes, ou facilmente obtidos, sobre acidentes graves e fatais permitiriam que todos esses serviços já tivessem definido prioridades de prevenção e estivessem realizando ações programáticas, articulando diferentes atores sociais, ampliando e qualificando as atividades realizadas. As muitas iniciativas de formação de profissionais desses novos serviços podem ser aproveitadas para estimular o aprimoramento do diagnóstico dessa realidade.

Tal situação tem outras consequências não menos graves. Uma delas é o fato de que o poder público torna-se refém dos acontecimentos, e sua incapacidade ganha contornos evidentes diante do primeiro desastre. Outra não parece ser a situação nos casos da queda de avião no aeroporto de Congonhas e do colapso na estação Pinheiros do metrô em São Paulo. ${ }^{1}$

Outra implicação aparente desse quadro é o fato de boas iniciativas desenvolvidas no âmbito específico de cada uma das instituições citadas tenderem

1 Em 17 de julho de 2007, no aeroporto de Congonhas, São Paulo, um Airbus A320 ultrapassou o final da pista durante o pouso e chocou-se contra depósito de cargas da própria empresa, matando as 187 pessoas que estavam a bordo e outras 12 que estavam no solo. No dia 12 de janeiro de 2007, o túnel no sentido Faria Lima sofreu colapso matando sete pessoas, a maioria transeuntes. 
ao isolamento e, eventualmente, ao enfraquecimento ou evolução limitada por constrangimentos que poderiam ser mais bem enfrentados com a conjugação de esforços e a ajuda de recursos cognitivos, materiais, técnicos, políticos etc. disponíveis em outra área de governo.

Pensar a repolitização da agenda da ST significa repensar situações como as aqui citadas. Afinal, será que tais acidentes deveriam ensejar algum tipo de ação preventiva ou reativa por parte daqueles que atuam na área de ST ou devem ser vistos como algo que não nos dizem respeito? Estamos preparados para intervir nesses tipos de situações? O que fazer?

\section{A Situação Atual}

\section{De que adoecem² e morrem os trabalhadores brasileiros?}

A pergunta é antiga, mas permanece atual. Diversos estudos mostram que, com os sistemas de informação disponíveis atualmente, os serviços de saúde do país não têm resposta para essa questão, a não ser de modo parcial, mesmo quando adotam definição restrita para o termo 'trabalhadores' usado na pergunta (Binder \& Cordeiro, 2003).

De acordo com estudos epidemiológicos, nos grandes centros urbanos, as mortes ou mutilações por acidente mais frequentemente relacionadas ao trabalho ocorrem em vias públicas, fora do espaço das empresas, e geralmente envolvem trânsito ou violência. Os casos que acontecem dentro das empresas são decorrentes predominantemente de quedas em altura, choques elétricos, soterramentos e máquinas (Binder \& Almeida, 2002; Santana, Nobre \& Waldvogel, 2005; Waldvogel, 2002; Wünsch-Filho, 1999).

Estudos também indicam os ramos de atividade ou ocupações com maior número de vítimas fatais e que, em geral, deveriam representar alvos prioritários das intervenções preventivas desencadeadas pelos organismos do Estado. No entanto, na esfera nacional não se evidenciam iniciativas políticas desenhadas estrategicamente com foco na prevenção de acidentes desses grupos. No âmbito do Ministério do Trabalho e Emprego (MTE), na esfera nacional, embora tenha sido desativado ${ }^{3}$ grupo de trabalho que atuava na prevenção de acidentes graves e fatais, persistem ações isoladas de análises de acidentes graves e fatais e, apesar de aparentemente bastante enfraquecido nos últimos anos, mantém-se o grupo que lida com o tema dos acidentes ampliados.

2 Neste texto não se discute o tema das doenças relacionadas ao trabalho.

3 Em agosto de 2008, houve iniciativa de reativação dessas atividades. 
No âmbito da saúde, com base nas informações existentes, o governo brasileiro propôs a portaria MS n. 777/2004, que torna compulsória a notificação em rede de serviços predefinida dos acidentes do trabalho fatais ou com mutilações ou com exposição a materiais biológicos ou, ainda, com crianças e adolescentes.

Aparentemente, o deslocamento de acidentes do trabalho graves para o espaço das ruas reflete mudanças ocorridas na sociedade, como o aumento do número de atividades que funcionam ininterruptamente ('sociedade 24 horas'), a precarização de formas de emprego, o crescimento de atividades de serviços envolvendo o uso de motocicletas, a ocupação desordenada de espaços urbanos, entre outras (Santana \& Loomis, 2004; Waldvogel, 2002). Até o momento, são praticamente inexistentes ações de governo direcionadas para a prevenção desses tipos de acidentes.

Por sua vez, a persistência de mortes e mutilações no espaço interno de empresas parece refletir outra face da nossa realidade: a persistência de situações de trabalho degradadas, caracterizadas por desrespeito aberto a exigências de segurança firmadas na legislação do país, condição essa facilitada por contexto de fragilidade político-institucional de atores do campo da vigilância e/ou da auditoria de segurança, assim como do próprio movimento de trabalhadores expostos aos riscos em questão. Por isso mesmo, no Brasil, justifica-se a abordagem desses acidentes como formas de violência (Cohn et al., 1985).

\section{Acidentes que se repetem}

Como essa situação se manifesta entre nós? De um lado, com denúncias de acidentes que 'se repetem', ou seja, elevada frequência de acidentes que apresentam características assemelhadas em alguns ramos de atividades. Aderbal China (2007), em estudo sobre acidentes com soterramentos, explorou questão aparentemente paradoxal: por que os acidentes continuam acontecendo se suas supostas causas técnicas já estão identificadas nos diferentes lugares há mais de dez anos?

O autor mostrou que os achados de análises desse tipo de acidentes em diferentes países, incluindo Estados Unidos, Canadá e empresa de saneamento do estado mais desenvolvido do Brasil, apontam como principais causas o desrespeito às normas e medidas de prevenção preconizadas na legislação.

Exemplos assemelhados podem ser apresentados para outros acidentes, e em todos os casos é fácil mostrar que a persistência desses eventos não é problema de natureza técnica, ligado à inexistência ou desconhecimento das 
proteções indicadas. $\mathrm{O}$ desafio apresentado à área de ST para enfrentar esses problemas é político e dificilmente será superado enquanto a correlação de forças atual não for alterada - em especial, com o fortalecimento das forças que defendem interesses dos trabalhadores e dos cidadãos em geral e com a revitalização e o 'empoderamento' dos setores de governo encarregados da implementação dessa política. Enquanto isso não ocorre, esse enfrentamento pode ser auxiliado por mudanças na formação das equipes encarregadas das análises desses acidentes, de modo a estimulá-las a não interromper seus trabalhos sem explorar as razões associadas à não utilização das proteções.

Os impactos do trabalho sobre a saúde das populações expostas têm suas origens nas formas assumidas pela presença e inserção das atividades de trabalho no território em questão. Em outras palavras, dependem da racionalidade econômica global predominante no território e implementada em cada empreendimento, das tecnologias, das práticas gerenciais escolhidas para a aquisição de matérias-primas, políticas de manutenção, gestão de segurança e de tempos de produção, além de outras escolhas dos gestores do processo. Assim é que em contextos de despolitização, de fragilização da ação sindical de trabalhadores e do aparato regulador do Estado, novas tecnologias mais seguras e mais produtivas serão escolhidas ou não, de acordo com razões de mercado. Tal situação explica por que, em muitos setores, persistem baixas taxas de incorporação de inovações tecnológicas e uso extensivo de mão-de-obra mal remunerada - obviamente com sua tradução em termos de acidentalidade e demais impactos.

Um dos principais desafios dos serviços de ST no tocante ao tema dos acidentes é o da superação das análises que não exploram as mediações existentes entre as manifestações finais ou desfechos desses eventos e seus determinantes. Além de dar visibilidade às origens proximais e distais dos acidentes, é preciso incentivar movimentos de prevenção que abordem essa dimensão. Essa segunda tarefa parece ainda mais difícil do que a primeira, em contextos políticos de exacerbação de propostas baseadas na perspectiva neoliberal e de desmobilização de trabalhadores organizados.

Os esforços em defesa da ampliação do perímetro das intervenções públicas em casos de acidentes encontram obstáculo na forma predominante de abordagem sobre os acidentes/eventos de grande visibilidade instantânea na mídia, em especial aqueles ocorridos em espaços externos às empresas, como os acidentes de trânsito, os casos relacionados com a violência urbana cotidiana e até casos envolvendo sistemas de maior incorporação tecnológica e interações mediadas 
por instrumentos técnicos entre múltiplos atores sociais. Como regra geral, o que se evidencia é o reforço da cultura de atribuição de culpa, da ocultação das origens estruturais, latentes ou incubadas desses acidentes, substituídas na imprensa, cotidianamente, por avaliações superficiais de responsabilidades civis individualizadas, traduzidas pelas palavras 'negligência', 'imperícia', 'imprudência', sempre imputadas às vítimas ou a trabalhadores com ínfimo poder de alterar as condicionantes ou os constrangimentos que os obrigavam a fazer como fizeram (Almeida, 2006; Vilela, Iguti \& Almeida, 2004).

A culpa é sempre do 'mais fraco', retratado como se detivesse poder ou controle total de decidir o caminho a seguir para não chegar ao acidente. Uma vez acontecido o acidente, a explicação está pronta: ele decorre de irresponsabilidade, negligência ou imprudência da vítima. Esquecem-se o traçado e a manutenção das estradas, os projetos dos veículos que desprezam itens de segurança como airbags ou freios ABS, considerados um 'luxo' para veículos brasileiros, vendidos aqui por um preço muito mais alto do que os similares com todos os dispositivos de segurança comercializados em outros países. Esquece-se que os controladores de voo não têm poder para decidir em que alocar recursos: em equipamentos de segurança ou no luxo de terminais de passageiros? Ou na contratação de mais controladores? Esses profissionais também não conseguem definir jornadas de trabalho adequadas à complexidade cognitiva de seu trabalho. Assistimos, diariamente, à repetição da velha cantilena nos jornais: "a culpa pelo acidente é de alguém que foi negligente e imprudente".

Esse massacre da mídia incentiva a criação de uma sociedade pouco crítica, que aceita passivamente conclusões precoces, parciais, incompletas. Alimenta e reforça a visão de que a segurança depende exclusivamente da atenção e do cuidado de cada um, em vez de alimentar demandas que visem a alterar o cenário de sociedade que convive em todo o seu entorno - estradas, ruas, trabalhos, produtos, diversões, brinquedos, comércio - com nível de risco já inaceitável na maioria dos países.

Um ponto de partida para politizar e dar consequência à discussão desse tema exige de profissionais e das instituições afins esforços especiais para destruir e substituir a prática de atribuição de culpa. Do ponto vista prático, na situação atual esse esforço parece exigir a revisão dos termos da norma regulamentadora NR-01 do MTE, ${ }^{4}$ assim como da Norma Brasileira de Acidentes

4 Em 4 de março de 2009, a portaria SIT n. 84/09 do MTE alterou a redação da NR-01, retirando de seu texto a expressão 'ato inseguro'. 
do Trabalho, da Associação Brasileira de Normas Técnicas (ABNT), retirando delas as referências à ideia de 'atos inseguros' como causas de acidentes. A persistência dessa noção só contribui para a inibição da prevenção e a construção da culpa das vítimas.

A seguir, apresentam-se alguns aspectos relacionados com as questões aqui abordadas, procurando mostrá-las como desafios que agregam dimensões técnicas e políticas. A intenção é associar reflexões ou pontos já destacados na literatura recente com outros derivados de situações correntes na vida dos serviços que atuam no campo da ST.

\section{Pontos para uma Agenda de Discussão sobre Acidentes do Trabalho}

Acidentes de trabalho são eventos caracterizados por múltiplas dimensões. Estudos destacam pelos menos três: 1) a dramática ou vivencial; 2) a jurídica; e 3) a sociotécnica.

1) A DimENSÃo DRAMÁtICA OU VIVENCIAL explora vivências ou dramas associados às consequências desses eventos. Nela estão incluídos estudos que abordam impactos econômicos; sociais (consequências para a vida pessoal e familiar); ambientais (contaminações diversas); sobre patrimônios histórico-culturais e de saúde (física e psíquica), entre outros impactos causados pelos acidentes.

A emergência dos acidentes de dimensões catastróficas (acidentes maiores ou ampliados) traz à luz a necessidade de discutir o tema das respostas de emergência e sua eficiência. A emergência desses acidentes também dá nova ênfase à discussão de problemas ambientais e das dificuldades envolvidas em seu controle. Acidentes como o de Chernobyl são apontados como responsáveis por verdadeiro 'choque antropológico' e, ao mesmo tempo, evidenciam a emergência de riscos cuja avaliação também passa a depender da ciência e da tecnologia. Ou seja, trazem desafios ao desenho metodológico hegemônico em estudos sobre percepção de riscos, em especial às abordagens psicométricas baseadas exclusivamente na percepção sensitiva (dependente do uso dos órgãos dos sentidos).

Embora uma das consequências dessa crítica seja a emergência de visão tecnicista que defende a ideia de transferência dessas avaliações a pequenos grupos de 'especialistas' no assunto em questão, esse processo também marca a emergência de outras abordagens de percepção, como as centradas em enfoques antropológico e cultural e sociológico (Dwyer, 2006; Freitas \& Minayo-Gomez, 1996-1997; Kouabenan, 1998; Llory, 1999; Perrow, 1999). 
A abordagem desse tipo de acidentes começa seja com a aplicação da chamada Análise Interdisciplinar e Participativa de Acidentes (Aipa), desenvolvida por pesquisadores da Escola Nacional de Saúde Pública Sergio Arouca (Ensp), seja com estudos de caso que utilizam novas propostas de abordagens sociotécnicas de acidentes que também são usadas na exploração das outras dimensões citadas dos acidentes (Johnson \& Almeida, 2008; Pignati, Machado \& Cabral, 2007; Strausz, Machado \& Brickus, 2007).

Estudos de recorte epidemiológico exploram aspectos parciais dessa situação como, por exemplo, o impacto em vítimas de sexo feminino ou em crianças e adolescentes; ou ainda tipos de serviços assistenciais demandados pelas vítimas etc.

Nessa dimensão, também aparecem estudos que exploram impactos na vida familiar das vítimas no pós-acidente, como, por exemplo, a via-crúcis da busca de assistência de saúde e disputa por acesso a benefícios e direitos sociais; e consequências advindas da mudança da condição de provedor para a de dependente (em praticamente todos os sentidos) (Hirano, Redko \& Ferraz, 1990). Em alguns locais do país, surgiram mobilizações sindicais defendendo espaços para inclusão social de vítimas de acidentes, às vezes em associação com movimentos que cobram respeito à legislação que trata da inserção de deficientes no mercado de trabalho. Esses aspectos continuam como temas a serem estudados na maioria dos estados do país e apontam para a necessidade da oferta, na rede de serviços de saúde do SUS, de ações de busca ativa de impactos de saúde de instalação tardia em vítimas de acidentes do trabalho.

2) A DimENSÃo JURÍDICA também ganha destaque em acidentes de dimensões catastróficas, como os casos recentes de contaminação ambiental e da aviação comercial. Ela refere-se, sobretudo, à exploração de consequências jurídicas desses eventos em termos de responsabilidade tanto civil quanto criminal.

Atualmente, o encaminhamento de acontecimentos nessa esfera inclui a organização de associações civis de familiares de vítimas e discussões políticas sobre o arcabouço jurídico relativo às atividades envolvidas, como se viu na Comissão Parlamentar de Inquérito (CPI) do apagão aéreo. Nos casos dos recentes acidentes aéreos, essa dimensão apareceu com destaque nas ações de atores políticos, em especial de integrantes da própria CPI, autoridades do governo federal e autoridades policiais presentes nas discussões a partir 
de iniciativas do próprio presidente da República. Esses acontecimentos recolocaram na ordem do dia discussões relacionadas à culpabilização de trabalhadores, em especial pilotos e/ou controladores de voo, mas ao mesmo tempo escancararam para a sociedade brasileira aspectos socioestruturais associados à fragilidade da gestão do sistema de segurança de voo no país. As implicações dos acontecimentos no funcionamento e na segurança do setor aéreo, mas não só para este setor, ganham destaque como possíveis assuntos para futuros estudos.

3) A DIMENSÃO SOCIOTÉCNICA refere-se à exploração das razões que explicam o que aconteceu ou aspectos do processo causal dos acidentes.

No caso de acidentes industriais, diversos estudos revelam aspectos da construção social da culpa, sobretudo nas análises realizadas no âmbito das empresas, mas também em serviços de polícia técnica (Cohn et al., 1985; Vilela, Iguti \& Almeida, 2004). As denúncias enfatizam a fragilidade técnica dessas 'investigações' e o uso político e ideológico de seus resultados por parte de representantes de empresas.

Nos casos de acidentes de dimensões catastróficas, tanto pelos danos materiais quanto pelo número de vítimas que provocam, chama a atenção a fragilidade técnica e política do aparato governamental envolvido na condução das análises. O controle de informações por parte das empresas é, em muitos aspectos, quase absoluto.

Além disso, é gritante a insuficiência seja do aparelhamento técnico necessário à condução de análises em casos como o do desabamento do túnel da futura estação Pinheiros do metrô de São Paulo, seja da prévia articulação interinstitucional capaz de viabilizar e agilizar o acionamento de recursos necessários à condução das análises. Nesse acidente, em particular, as primeiras informações mostram que a gestão de segurança adotada pelo consórcio beirava o ridículo, desconsiderando solenemente lições indicadas em numerosas análises de eventos anteriores ocorridos com uso da técnica de construção New Austrian Tunnelling Method (NATM) - que era usada na estação afetada - e já recomendadas inclusive em documentos formais da Associação Internacional de Construtores de Túneis.

O mesmo desconhecimento pode ser apontado na legislação do país que não incorpora mecanismo de cobranças de atualização progressiva da gestão de segurança desse tipo de obra/atividade, com ênfase em aspectos consensuais e de amplo reconhecimento na comunidade científica. 
Outro aspecto que merece destaque é a existência de análises conduzidas no âmbito de empresas que procuram 'naturalizar' essas ocorrências, ${ }^{5}$ às vezes apresentando descrições detalhadas de aspectos técnicos dos processos envolvidos nos acidentes. Como se explicaria a presença desses componentes e eventos técnicos no sistema? "Ah! Eles simplesmente estavam lá.” Além de seu viés ideológico, essas abordagens suscitam questionamento sobre até que ponto essas iniciativas estariam vinculadas a tentativas de defesas corporativas de monopólios ou de 'cartórios' de especialistas técnicos que tendem a se apresentar como donos do saber e únicos capazes de explicar, desde que bem pagos, esses tipos de eventos.

Em diversos países, com a influência de múltiplos fatores, como a introdução de tecnologias mais confiáveis e seguras, de medidas de engenharia de segurança consignadas em legislações, de aperfeiçoamento de práticas de gestão de segurança, de lutas de trabalhadores organizados contra mortes e mutilações no trabalho, entre outros, surgem novos desafios ao desenho de estudos epidemiológicos. Um aspecto destacado em diversas atividades (aviação, nuclear, transportes de produtos perigosos etc.) é uma acentuada redução nas taxas de acidentes fatais, que permanecem relativamente estáveis (curvas assintóticas) por períodos de até 25 anos (Amalberti, 1996; Rassmussen, 1997). Nesses sistemas, a ocorrência de novos acidentes/eventos negativos não afeta os indicadores desses eventos. Assim, os diagramas de controle pouco informam, seja em relação à chance de novos desastres, seja à capacidade dessas organizações de lidar com eventos adversos futuros. Em outras palavras, mesmo os resultados de análises de acidentes bem desenhadas, aprofundadas, com colaboração de múltiplos olhares teóricos, pouco ou nada contribuem em termos de mudanças na acidentalidade futura.

No Brasil, ainda são praticamente inexistentes estudos que explorem o comportamento da acidentalidade em sistemas que lidam com tecnologias consideradas perigosas, embora, até a emergência de acidentes com naves de companhias aéreas comerciais brasileiras, os indicadores de segurança do setor fossem apontados como equivalentes aos da maioria dos países de melhor desempenho no mundo. Assim, nossa realidade de segurança é vista como um mosaico em que, ao lado de sistemas que tendem à alta confiabilidade e

5 Nesse sentido, a explicação apresentada pelo Consórcio Via Amarela para o acidente da estação Pinheiros do metrô de São Paulo é uma 'pérola'. Ela associa tentativa absurda de reduzir o acidente ao momento específico do colapso do túnel, com explicação centrada na noção de inusitada combinação de características geológicas apresentadas como 'absolutamente imprevisiveis' com agressões abertas à conclusão do laudo dos técnicos do Instituto de Pesquisas Tecnológicas. 
segurança, convivem outros caracterizados por elevada acidentalidade e gestão de segurança marcadas por abordagens que atribuem acidentes e incidentes a características pessoais dos trabalhadores, em especial daqueles do 'chão de fábrica'.

$\mathrm{Na}$ primeira década de 2000, os acordos firmados para a prevenção de acidentes em máquinas injetoras de plástico e prensas e similares ensejaram expectativas otimistas associadas, sobretudo, a aspectos dos seus processos participativos de elaboração, alcance de suas áreas de cobertura e grande número de atores mobilizados em torno de sua implementação em diferentes estados do país. Esses acordos abrem novas possibilidades para estudos comparativos explorando aspectos de impactos dessas negociações na acidentalidade (pré e pós) e, ao mesmo tempo, de seu aperfeiçoamento por meio de conclusões de análises de acidentes de trabalho ocorridos em máquinas com todas as proteções definidas nessas normas.

Também é crescente o número de estudos de casos e iniciativas de discussões que aportam contribuições da abordagem sociotécnica, da engenharia de sistemas, da sociologia, da antropologia, da ergonomia, da psicologia cognitiva e de sua articulação em olhares de inspiração multiprofissionais, inter e até transdisciplinares.

Como consequência, surgem também novas propostas de técnicas de análises inspiradas em críticas já desenvolvidas às abordagens anteriores e em críticas às suas insuficiências como ferramentas de investigação de acidentes típicos da sociedade moderna, marcada pela incorporação de novas tecnologias automáticas e informatizadas e também por novas formas de organização do trabalho (Amalberti, 1996; Dwyer, 2006; Llory, 1999; Perrow, 1999; Rassmussen, 1997). Ensaios de utilização dessas novas abordagens ainda parecem concentrados em estudos desenvolvidos por pesquisadores ligados a universidades, por vezes em associação com profissionais de serviços de ST (Centros de Referência em Saúde do Trabalhador - Cerests - ou representações do MTE) (Almeida \& Binder, 2004; Oliveira, 1997). Aparentemente, as áreas nuclear e da aviação caminham em paralelo, com maior número de profissionais que também adotam novas técnicas e conceitos dos campos de conhecimento citados anteriormente (Cardoso \& Cukierman, 2007).

No Brasil, nos anos 2000 surgem exemplos promissores de aplicação da Aipa por pesquisadores da Ensp (Pignati, Machado \& Cabral, 2007; Strausz, Machado \& Brickus, 2007). O mesmo se dá com contribuições da ergonomia da atividade que passam a ser usadas em diversas escolas de engenharia de produção (Diniz, Assunção \& Lima, 2005; Lima, 2007). Pesquisadores isolados 
ensaiam aplicações de mapas verticais e de conceitos de autores como James Reason, Michel Llory e Erik Hollnagel, entre outros.

Esses estudos tendem a revelar a vulnerabilidade das sociedades contemporâneas em face dos denominados riscos tecnológicos ambientais, ao mesmo tempo que, com a ajuda de contribuições das ciências sociais, da ergonomia e de enfoques sociotécnicos, lançam importantes questionamentos a limites dos enfoques de risco usados no âmbito da engenharia, da epidemiologia, da higiene ocupacional, da toxicologia, enfim, das vertentes que se apegam a definições de perigo e risco como fenômenos exclusivamente técnicos, ou seja, centrados na noção de liberação de fluxo de energia potencial presente no sistema.

No Brasil, entre os desdobramentos desse processo, pode-se destacar o início de processo de aproximação e colaboração entre universidades e instituições de pesquisa e profissionais que atuam em serviços públicos de segurança e saúde no trabalho, notadamente os Cerests e representações estaduais e locais do MTE. Apesar de sua natureza ainda incipiente, essa aproximação tem resultado em iniciativas de formação e de pesquisa, em particular com o ingresso de parcela de profissionais desses serviços em programas de pós-graduação. A maioria dos exemplos dessa colaboração se dá em universidades dos estados da Bahia, de Minas Gerais, Rio de Janeiro, Rio Grande do Sul e São Paulo.

Além da contribuição oferecida na difusão de novos olhares sobre a segurança e a saúde no trabalho, em alguns casos essas experiências parecem assumir o formato de veredas abertas para colaborações de formato permanente, de modo que já é possível identificar a emergência de embriões de polos de formação em outros estados e serviços. Aparentemente, esse movimento de aproximação entre serviços e universidades é benéfico para todos os envolvidos. Será que a colaboração externa qualifica e diferencia aspectos da ação desenvolvida pelos profissionais e dos seus serviços de origem? A natureza incipiente desse processo e a ausência de estudos sobre o tema ainda não permitem responder a essa questão.

O conjunto de aspectos aqui abordados precisa ser explorado na perspectiva da repolitização da agenda do movimento em defesa da ST no Brasil. As três dimensões citadas suscitam exemplos de temas de interesse comum de múltiplos atores a serem chamados ao debate. Além disso, cada um desses aspectos pode ser visto como tema para estudos e debates que devem ensejar elenco de reivindicações que contemplem a perspectiva recomendada na abordagem da vigilância em saúde, que ensejem propostas de ação elaboradas com enfoque 
estratégico. Enfim, capaz de estimular a mobilização de atores que possam dinamizar movimentos sociais em defesa da agenda proposta.

\section{Comentários Finais}

Acidentes do trabalho são um dos temas da agenda do campo da ST no Brasil. No âmbito do setor público, onde quer que se discuta a implantação de serviço ou a oferta de ações de ST surge elenco de atividades relacionado a ideias como, entre outras, a de criação ou aprimoramento de sistema de informação de agravos relacionados ao trabalho; a inexistência de fontes de informação sobre agravos que acometem população não vinculada ao seguro de acidentes do trabalho; a possibilidade de acesso aos dados de comunicações de acidentes do trabalho; a existência ou não de equipes preparadas para criação e gerenciamento de banco de dados dessas informações, de condução de análises de casos selecionados como os definidos na portaria MS n. 777; a existência de dificuldades afins à estruturação de mecanismos de aprendizagem organizacional; a existência ou não de condições para a formalização de intervenções preventivas e de realização dos enfrentamentos daí decorrentes, com equipes de segurança do trabalho das empresas de origem dos casos.

A primeira seção deste capítulo destaca o enfraquecimento técnico e político da prevenção de acidentes em nosso país. Porém, simultaneamente, cita a existência de boas iniciativas dispersas por instituições e regiões do país. Retomando este último aspecto, é possível afirmar que, nos serviços e instâncias que desenvolvem análises de acidentes e intervenções baseadas em seus achados, é crescente o número de experiências que se deparam com enfrentamentos que denunciam limites das abordagens tecnicistas e de atribuição de culpa, que cada vez mais desvelam cenários que explicitam as relações entre decisões estratégicas, escolhas organizacionais relativas à racionalidade econômica predominante na gestão da produção/atividade fim da empresa e as origens de acidentes nesses sistemas e atividades.

Também já é possível evidenciar que, em número crescente desses serviços, as intervenções desencadeadas visando à prevenção de acidentes revelam embriões de modo de agir estratégico, caracterizado pela ampliação do escopo da negociação para todo o conjunto de atividades semelhantes (Diniz, Assunção \& Lima, 2005; Pignati, Machado \& Cabral, 2007; Strausz, Machado $\&$ Brickus, 2007). Como exemplos, é possível apontar casos nos quais, em 
vez de proteção da máquina envolvida em acidente, negociou-se programa de prevenção de todos os tipos de máquinas da empresa ou até para todas as empresas daquele setor de atividade. Experiências como a das máquinas injetoras de plástico e a da Convenção Coletiva de Melhoria das Condições de Trabalho em Prensas e Equipamentos Similares, Injetoras de Plástico e Tratamento Galvânico de Superfícies têm sido usadas como referências de parâmetros mínimos de exigências a serem solicitadas em negociações, assim como exemplo de caminhos ou processos de construção social de acordos específicos da segurança de máquinas.

Em outros casos, com base em denúncias de epidemias de acidentes graves e fatais, como nas mortes na extração do mármore e granito na região de Cachoeiro do Itapemirim, no Espírito Santo, evoluiu-se até a elaboração de norma nacional que passa a regulamentar a atividade simultaneamente à construção de processo social que deu visibilidade aos impactos daquele trabalho sobre a saúde dos trabalhadores e criou condições para o acompanhamento da intervenção. Nesse tipo de acordo, é importante desvelar o formato assumido pela cadeia produtiva no nível local, explicitando o papel - geralmente encoberto - dos grandes empresários beneficiários da extração dos minérios que tentam 'lavar as mãos' em face do seu não envolvimento direto com a extração que, deliberadamente, eles pulverizam entre pequenos produtores.

No estado de Minas Gerais, numa empresa 'terceira', ou seja, contratada para produzir peças para outra do setor automobilístico, houve acidente em prensa dotada de todos os dispositivos de proteção citados na convenção coletiva de prevenção, cuja análise mostrou como fator causal preponderante a forma de gerenciamento do just in time adotada pela empresa fabricante de veículos que contratava os serviços da terceira em questão. $\bigcirc$ tempo disponível pela contratada para fabricar as peças solicitadas era de 24 horas contadas a partir do recebimento do pedido. Esse fato, associado ao volume de pedidos que exigia uso de $100 \%$ da capacidade instalada da contratada, a levou a suspender a programação de manutenção das máquinas, o que acabou contribuindo para que o tempo necessário para funcionamento dos freios da máquina ficasse maior do que aquele necessário para a descida de seu punção (martelo) superior.

Nesse tipo de situação, a fragilidade do poder público fica evidente quando seus agentes tentam obter acordo que envolva todos os atores, em especial solicitando mudanças nas decisões adotadas pela contratante do serviço. 
Entre os cenários possíveis para o futuro próximo, um deles é a persistência dessa situação atual de intervenções isoladas, politicamente enfraquecidas e dificilmente conhecidas mesmo entre os demais atores da ST. Aqui, os desfechos possíveis serão mantidos como extremamente dependentes das estratégias locais de condução e do protagonismo já assumido, ou não, por trabalhadores organizados ou equipes de serviços de ST ou representações locais do MTE. Nos últimos anos, também têm assumido papel de grande importância as representações dos Ministérios Públicos do Trabalho ou da União. Embora esse apoio tenha sido de grande importância na construção da ST, em muitos locais o principal problema dessa estratégia é o limitado alcance de suas áreas de cobertura.

Outro elemento que caracteriza algumas dessas experiências é a capacidade de articulação dos serviços de origem com setores da universidade ou organismos de pesquisa, que ajudam a construir desenhos de intervenções diferenciados em termos de qualidade e alcance. Em alguns casos, essa estratégia tem ajudado inclusive financeiramente na estruturação de determinadas áreas de serviço. Entretanto, tal cooperação continuaria se dando de modo eventual e articulado caso a caso.

Outro cenário é o de aprofundamento da perspectiva estratégica adotada nessas abordagens, ampliando seu alcance para áreas de cobertura cada vez mais amplas. Tal aprofundamento significa incentivar a criação de redes de apoio a serem acionadas em experiências desse tipo, visando, de um lado, a superar a situação de isolamento que predomina atualmente e, de outro, a possibilitar a rápida avaliação e identificação das situações com maior potencial de ensejarem negociações de maior impacto e alcance político - seja pelo número de participantes, seja pela inexistência de regulamentação para a atividade, seja pela maior facilidade de identificação e mobilização dos atores a serem envolvidos na negociação etc. Os serviços criariam estruturas de apoio a ser oferecido sistematicamente nesses casos. Tal intervenção seria acompanhada de modo a fornecer rápido feedback sobre o andamento das intervenções.

Assim, é importante buscar acordos ou desenhar ações que abranjam toda a cadeia produtiva envolvida na atividade, ou os territórios de municípios de grandes dimensões, estados e até todo o território nacional, em especial viabilizando formas de compartilhamento de informações e de exploração dos achados de análises, de modo a alimentar aprofundamento das análises, trocas de experiências e identificação de subsídios para o aprimoramento e melhoria contínua dos termos das negociações firmadas. 
Tal atitude também significa não só incentivar estudos que explorem os impactos dos acordos firmados como associar nesses acordos mecanismos que: 1) explicitem orientações sobre cuidados a serem adotados na implantação das medidas preconizadas (de modo a minimizar acidentes atribuídos a falhas na implantação de dispositivos recomendados); 2) sejam especialmente desenhados para a exploração aprofundada de acidentes que aconteçam em sistemas dotados de todas as proteções definidas (de modo a agilizar a identificação de aspectos não contemplados nessas negociações e incentivar sua colocação na ordem do dia das instâncias encarregadas do acompanhamento da implementação das negociações).

É preciso não perder de vista a importância política das iniciativas que resultam em acordos que atendem a interesses de todos os envolvidos e resultem em impactos de melhoria da situação de ST. Nesse sentido, vale registrar que tais experiências, em especial quando construídas com intencionalidade e como produtos de escolhas como as aqui defendidas, podem assumir características estruturantes da área de ST.

Um dos problemas que ainda persistem em muitas áreas é a falta de atores encarregados de pensar estrategicamente elenco de alvos principais de ação para a área de ST, em termos não apenas de agravos ou impactos de saúde ou ambientais, evidenciados ou potenciais, mas também da identificação de atores políticos presentes no processo e a serem efetivamente envolvidos em tentativas de construções de movimentos sociais pela prevenção.

No contexto atual de enfraquecimento político da área, não parece haver condições para a criação desse tipo de movimentos na dimensão nacional, como parte de iniciativa política que priorize todos, ou a maioria, dos alvos que o limitado conhecimento que já temos permite - o que se dá principalmente por duas razões.

A primeira delas é a atual fragilidade da área de segurança e saúde do trabalho do MTE, que a partir do ano 2000 não desenvolve nenhum projeto nacional de caráter estratégico. E, pior ainda, esvaziou grupos de trabalho e embriões de organismos que ali existiam em condições de fazê-lo. Por isso mesmo, no âmbito geral, essa área sobreviveu de algumas poucas iniciativas de resistência de técnicos envolvidos em processos de revisão de normas anteriormente deflagrados, ou de manutenção de pontes construídas com segmentos de movimento de trabalhadores que ainda demandam intervenções da área, ou outras ações isoladas de cunho equivalente. Paralelamente, observa-se a influência de lógica burocrática, que incentiva acompanhamento 'contábil' 
de ações fiscalizadoras, muitas delas alheias ao campo da segurança e saúde do trabalho e desvinculadas de objetivos estratégicos formulados mediante diretrizes políticas da área.

A segunda razão refere-se ao desenho estratégico da atuação do SUS no setor, priorizando a estratégia da Rede Nacional de Atenção Integral à Saúde do Trabalhador (Renast) - em outras palavras, a descentralização que enfatiza a estruturação de serviços assistenciais e, eventualmente, de vigilância com alcance localizado. Na estrutura de nível federal e mesmo estadual do setor saúde não existem, na prática, atores que cumpram os papéis de dinamizadores da construção de negociações sociais em torno de exigências de mudanças nas características de processos de produção, da organização do trabalho ou de subsistemas técnicos de trabalho como os que foram discutidos neste capítulo.

Enquanto persistir esse vácuo, essa inexistência do ator capaz de dedicar esforços ao trabalho de dar vida ao grande movimento social de que necessitamos pela prevenção de acidentes, as estratégias possíveis para a melhoria da situação tendem a assumir formatos de alcance restrito, tanto para determinados tipos de dispositivos técnicos (máquinas) quanto para proteções específicas ou de eliminação de agravos em certo tipo de trabalho em setor de atividade específico.

Alguns acidentes são facilmente identificados como pontos de partida para processos como os defendidos neste texto. A título de exemplo, vale citar o naufrágio da Plataforma P36, as rupturas de barragens de rejeitos em Minas Gerais, os vazamentos de petróleo na baía de Guanabara e em outras localidades do país, os acidentes com os veículos lançadores de foguete na plataforma de Alcântara (MA), as colisões de trens em Minas Gerais, São Paulo e no Rio de Janeiro, a colisão entre os aviões Gol e Legacy, os dois casos envolvendo aviões da TAM em São Paulo (capital), o colapso da estação Pinheiros no metrô e os repetidos casos de quedas de grua em diferentes localidades. ${ }^{6}$

6 A plataforma P-36 da Petrobras naufragou no dia 20/3/2001, cinco dias após três explosões que mataram 11 operários. As barragens de rejeitos de Macacos (2001), Rio Pomba (2003), Miraí (2006 e 2007), todas no estado de Minas Gerais, romperam nos anos indicados, despejando bilhões de litros de resíduos tóxicos e afetando a vida de 100.000 pessoas. No centro de lançamento de Alcântara, em 22/8/2003, explodiu o foguete VLS-1-V03, matando 21 técnicos civis. No dia 28/7/2000, uma colisão de trens na estação Perus, em São Paulo, matou nove pessoas e feriu mais de cem. Em 29/9/2006, um Boeing 737, da Gol, com 154 pessoas a bordo chocou-se contra um Learjet de fabricação nacional. Em 12/1/2007, o túnel da estação de metrô Pinheiros (SP) desmoronou, matando sete pessoas. Em 8/9/2010, na avenida Paralela, em Salvador, uma grua que estava sendo desmontada caiu e matou três trabalhadores. No dia 25/6/2007, em São Paulo, a queda de hastes de uma grua da construtora WTorre matou quatro operários e feriu um (ver também a nota 1). 
Defende-se aqui a ideia de que os acidentes representam fonte permanente de eventos a serem explorados nessa perspectiva. Exemplos de intervenções públicas como a do Chemical Safety Board, nos Estados Unidos, devem ser seguidos, em especial no que tange à divulgação pública dos resultados das análises, inclusive na Internet, e com a ajuda de ferramentas técnicas, como filmes de reconstrução dos acidentes e materiais jornalísticos de apresentação dos principais resultados obtidos.

Os casos que associam impactos extramuros do local de trabalho têm especial apelo, mas as atividades responsáveis pela maioria dos eventos graves e fatais em locais de trabalho precisam ter visibilidade social e servir de base a movimentos específicos pela prevenção que ponham fim à ideia de que mortes no trabalho, mesmo no 'varejo', são aceitáveis.

\section{REFERÊNCIAS}

ALMEIDA, I. M. Trajetória da análise de acidentes: o paradigma tradicional e os primórdios da ampliação da análise. Interface, 10(19): 185-202, 2006.

ALMEIDA, I. M. \& BINDER, M. C. P. Armadilhas cognitivas: o caso das omissões na gênese dos acidentes de trabalho. Cadernos de Saúde Pública, 20(5): 1373-1378, set-out, 2004.

AMAlBERTI, R. La Conduite des Sistèmes à Risques. Paris: Presses Universitaires de France, 1996. (Collection Le Travail Humain)

BINDER, M. C. P. \& ALMEIDA, I. M. Acidentes do trabalho: acaso ou descaso. In: MENDES, R. (Org.) Patologia do Trabalho. 2. ed. São Paulo: Atheneu, 2002. v. 1.

BINDER, M. C. P. \& CORDEIRO, R. Sub-registro de acidentes do trabalho em localidade do estado de São Paulo, 1997. Revista de Saúde Pública, 37(4): 409-416, 2003.

CARDOSO, V. A. F. \& CUKIERMAN, H. L. A abordagem sociotécnica na investigação e na prevenção de acidentes aéreos: o caso do voo RG-254. Revista Brasileira de Saúde Ocupacional, 32(115): 79-98, 2007.

CHINA, A. A. Limites da Abordagem Tradicional de Acidentes: o caso do soterramento em valas, 2007. Dissertação de Mestrado, Botucatu (SP): Universidade Estadual Paulista Júlio de Mesquita Filho, 2007.

COHN, A. et al. Acidentes do Trabalho: uma forma de violência. São Paulo: Brasiliense, Centro de Estudos de Cultura Contemporânea, 1985.

DINIZ, E. P. H.; ASSUNÇÃO, A. A. \& LIMA, F. P. A. Prevenção de acidentes: o reconhecimento das estratégias operatórias dos motociclistas profissionais como base para a negociação de acordo coletivo. Ciência Eु Saúde Coletiva, 10(4): 905-916, 2005.

DWYER, T. Vida e Morte no Trabalho. São Paulo: Multiação, Editora Unicamp, 2006. 
FREITAS, C. M. de \& MINAYO-GOMEZ, C. Análise de riscos tecnológicos na perspectiva das ciências sociais. História, Ciências, Saúde - Manguinhos, 3(3): 485-504, nov. 1996/fev 1997.

HIRANO, S.; REDKO, C. P. \& FERRAZ, V. R. T. A cidadania do trabalhador acidentado: (re)conhecimento do direito aos direitos sociais. Tempo Social: Revista de Sociologia da USP, 2: 127-150, 1990.

JOHNSON, C. W. \& ALMEIDA, I. M. An investigation into the loss of the Brazilian space programme's launch vehicle VLS-1 V03. Safety Science, 46(10): 38-53, 2008.

KOUABENAN, D. R. Beliefs and the perception of risks and accidents. Risk Analysis, 18: 243-252, 1998.

LACAZ, F. A. C. Saúde do Trabalhador: um estudo sobre as formações discursivas da academia, dos serviços e do movimento sindical, 1996. Tese de Doutorado, Campinas (SP): Faculdade de Ciências Médicas, Universidade Estadual de Campinas.

LIMA, M. E. A. Contribuições da clínica da atividade para o campo da segurança no trabalho. Revista Brasileira de Saúde Ocupacional, 32(115): 99-107, 2007.

LLORY, M. Acidentes Industriais: o custo do silêncio. Rio de Janeiro: Multimais, 1999.

MACHADO, J. M. H. A propósito da vigilância em saúde do trabalhador. Ciência $\mathbb{E}$ Saúde Coletiva, 10(4): 987-992, 2005.

MENDES, R. \& DIAS, E. C. Da medicina do trabalho à saúde do trabalhador. Revista de Saúde Pública, 25(5): 341-349, 1991.

MINAYO-GOMEZ, C. \& LACAZ, F. A. C. Novas-velhas questões. Ciência Ë Saúde Coletiva, 10(4): 797-807, 2005.

MINAYO-GOMEZ, C. \& THEDIM-COSTA, S. M. F. A construção do campo da saúde do trabalhador: percurso e dilemas. Cadernos de Saúde Pública, 13(Supl. 2): 21-32, 1997.

OlIVEIRA, F. A Construção Social dos Discursos sobre o Acidente de Trabalho, 1997. Dissertação de Mestrado, São Paulo: Instituto de Psicologia, Universidade de São Paulo. PAIM, J. S. Políticas de descentralização e atenção primária à saúde. In: ROUQUAYROL, M. Z. (Org.) Epidemiologia e Saúde. 5. ed. Rio de Janeiro: Medsi, 1999.

PERROW, C. Normal Accidents. New Jersey: Princeton University Press, 1999.

PIGNATI, W. A.; MACHADO, J. M. H. \& CABRAL, J. F. Acidente rural ampliado: o caso das "chuvas" de agrotóxicos sobre a cidade de Lucas do Rio Verde-MT. Ciência Eु Saúde Coletiva, 12(1): 105-114, 2007.

PORTO, M. F. S. Uma Ecologia Política dos Riscos. Rio de Janeiro: Editora Fiocruz, 2007.

RASMUSSEN, J. Risk management in a dynamic society: a modelling problem. Safety Science, 27(2/3): 183-213, 1997.

ROVELLI, M. Lavorare Uccide. Milano: BUR Futuropassato, 2008.

SANTANA, V. S. \& LOOMIS, D. Informal jobs and non-fatal occupational injuries. The Annals of Occupational Hygiene, 48(2): 147-157, 2004. 
STRAUSZ, M. C.; MACHADO, J. M. H. \& BRICKUS, L. S. R. Análise de um acidente por contaminação fúngica em uma biblioteca pública no município do Rio de Janeiro. Revista Brasileira de Saúde Ocupacional, 32(115): 69-78, 2007.

VILELA, R. A. G.; IGUTI, A. M. \& ALMEIDA, I. M. Culpa da vítima: um modelo para perpetuar a impunidade nos acidentes do trabalho. Cadernos de Saúde Pública, 20(2): 570-579, 2004

WALDVOGEL, B. C. Acidentes do Trabalho: os casos fatais - a questão da identificação e da mensuração. Belo Horizonte: Segrac, 2002. (Coleção Prodat Estudos e Análises) WÜNSCH-FILHO, V. Reestruturação produtiva e acidentes de trabalho no Brasil. Cadernos de Saúde Pública, 15(1): 41-51, 1999. 



\section{Quantos Acidentes do Trabalho Ocorrem no Brasil? Proposta de Integração de reglistros ADMINISTRATIVOS}

Bernadette Cunha Waldvogel

\section{Dados sobre Acidentes e Doenças do Trabalho}

Responder a esta questão não é tarefa simples para estudiosos e responsáveis pelas medidas de saúde e segurança do trabalho em nosso país. As fontes de dados existentes fornecem cifras distintas que revelam panoramas parciais e, muitas vezes, desencontrados.

A análise atual, abrangente e comparativa da questão acidentária no Brasil requer informações completas, atualizadas e fidedignas sobre a ocorrência de acidentes e doenças a que os trabalhadores estão sujeitos no exercício de sua profissão. Tal estudo é necessário para o melhor entendimento dessa problemática, para orientação de medidas que minimizem esses eventos e para elaboração de políticas direcionadas à classe trabalhadora, tantas vezes vítima de acidentes e doenças laborais.

O amplo debate entre setores do governo envolvidos com as questões de saúde do trabalhador motivou a convocação da 3a Conferência Nacional de Saúde do Trabalhador, ocorrida em Brasília em junho de 2005, organizada pelos ministérios da Previdência Social, da Saúde e do Trabalho e Emprego, com a perspectiva de aprofundar o diálogo sobre tais questões com toda a sociedade (Brasil, 2005).

$\mathrm{Na}$ realidade brasileira, não há carência de sistemas que seriam, em tese, suficientes para gerar informações necessárias para o acompanhamento das ocorrências de acidentes e doenças do trabalho. Na prática, os sistemas de informações mostram-se parciais, não se relacionam entre si e não cobrem a totalidade dos trabalhadores. 
Existem, no Brasil, pelo menos quatro grandes sistemas de informação, implantados e em funcionamento, com dados sobre acidentes e doenças do trabalho, que são padronizados em todo o território nacional:

1) Dataprev, gerenciado pelo Ministério da Previdência Social, com registros das Comunicações de Acidentes do Trabalho;

2) Sistema de Informações sobre Mortalidade, gerenciado pelo Ministério da Saúde, com registros das declarações de óbito;

3) Sistema de Informações Hospitalares, também gerenciado pelo Ministério da Saúde, com registros de Autorização de Internação Hospitalar;

4) Relação Anual das Informações Sociais, gerenciado pelo Ministério do Trabalho e Emprego, com dados sobre movimentação dos empregados com contrato formal de trabalho.

Esses quatro sistemas são alimentados por registros administrativos. Cada um desses registros foi concebido para cumprir uma função distinta, de modo que nem todos podem ser diretamente transformados em bases estatísticas. Entretanto, como eles contam com preciosas informações sobre a saúde do trabalhador, sua utilização oferece importantes subsídios para compreender a questão acidentária.

Com base na revisão bibliográfica realizada no artigo de Santana, Nobre e Waldvogel (2005) e nas bibliotecas virtuais Scielo, Lilacs, Claves e LIS, foi possível constatar que, de modo geral, as experiências e os estudos realizados com dados de acidentes e doenças do trabalho restringem-se às fontes de dados aqui mencionadas (Conceição, 2003; Correa \& Assunção, 2003; Freitas, 2005; Hennington et al., 2004; Lee, 1999; Oliveira \& Mendes, 1997; Pepe, 2002; Teixeira, 2005; Waldvogel, 2001, 2002, 2003). Encontram-se, também, estudos com dados de pesquisas amostrais desenhadas especialmente para esse fim (Almeida \& Binder, 2000; Binder \& Cordeiro, 2003; Montagner et al., 2001; Santana et al., 2003) e experiências locais de sistemas de vigilância em saúde do trabalhador (Andreotti, 2007; Cordeiro et al., 2005; Cortez, 2001; Facchini et al., 2005; Hennington \& Monteiro, 2006).

Este capítulo propõe-se discutir a alternativa de construção de base integrada de dados de acidentes e doenças do trabalho, com base na vinculação das quatro fontes de dados: Dataprev, SIM, SIH e Rais. Essa integração representa a otimização dos registros administrativos já existentes, fazendo com que os ministérios gerenciadores dos sistemas somem esforços, a fim de relacionar as informações que se encontram dispersas. 
O tratamento conjunto dos quatro registros administrativos aqui mencionados, de acordo com as bases de microdados de cada um dos sistemas, poder-se-ia constituir em 'ensaio' para formação de um Sistema Nacional de Monitoramento de Acidentes e Doenças do Trabalho. O procedimento permitiria elaborar uma base de dados mais completa, reduzindo a subnotificação de casos e de óbitos e abrindo novas perspectivas de análise.

Com a racionalização do uso dos sistemas existentes e o aprimoramento de sua cobertura e qualidade, talvez não sejam necessários novos sistemas de informação. Poder-se-ia aproveitar um conjunto de variáveis relevantes em cada um deles, para compor um sistema de monitoramento capaz de suprir as informações necessárias para o acompanhamento preciso e o estudo aprofundado da questão acidentária.

Descrevem-se aqui os quatro sistemas e seus respectivos registros administrativos, mostrando-se suas vantagens e limitações. Relata-se exemplo de vinculação de bases de dados, elaborada em parceria entre a Fundação Seade e a Fundacentro, em 2000, em que o banco de dados resultante permitiu avaliar e dimensionar os acidentes fatais do trabalho ocorridos em todo o estado de São Paulo, de 1997 a 1999. Em seguida, apresenta-se síntese dos dados sobre acidentes do trabalho disponíveis em cada sistema, entre 2000 e 2005, para o estado de São Paulo e o Brasil, permitindo comparar os diferentes valores existentes. Por último, comenta-se a relevância de construção de base integrada com esses dados.

\section{Os Principals Sistemas de Informação e os Respectivos Registros Administrativos}

\section{Dataprev: Comunicação de Acidente do Trabalho}

A Comunicação de Acidente do Trabalho (CAT), expedida pelo Instituto Nacional do Seguro Social (INSS), do Ministério da Previdência Social, constitui um registro administrativo que deve ser preenchido pela empresa sempre que o trabalhador sofre acidente a serviço desta, ou no trajeto entre sua residência e o local de trabalho.

No caso de morte do trabalhador vítima de acidente laboral, ou para aqueles casos em que se constate necessidade de indenização judicial, abre-se processo de acidente do trabalho no INSS, mediante encaminhamento, feito geralmente pelos dependentes do segurado, da documentação de tal ocorrência. 
Essa fonte contém tanto informações pessoais do acidentado quanto as circunstâncias do acidente, tais como local da ocorrência, condição de o acidentado estar ou não a serviço da empresa, data e horário do acidente. Existem, também, dados sobre a empresa onde o trabalhador exercia sua atividade, permitindo caracterizar o risco de acidente associado ao tipo de empresa.

A principal limitação dessa fonte refere-se a sua restrição à parcela da força de trabalho contribuinte do INSS, principalmente a classe trabalhadora inserida no mercado formal, excluindo os funcionários públicos, aqueles sem dependentes aptos a receber os benefícios decorrentes da morte por acidente do trabalho e, principalmente, os trabalhadores do setor informal.

O sistema de informação do INSS, cujos dados encontram-se disponíveis no Dataprev (www.dataprev.gov.br), tem como finalidade o processamento de benefícios aos acidentados, aos dependentes e àqueles acometidos por doenças do trabalho. Sua utilização para estudos mais detalhados é limitada, pois os dados divulgados referem-se, de modo geral, a totais de casos de acidentes do trabalho, sem maior caracterização dos eventos. Assim, o acesso a esse detalhamento só é possível por intermédio de levantamentos específicos em agências e postos do INSS espalhados pelo território nacional, ou por tabulações especiais solicitadas a este órgão. Vale ressaltar que, atualmente, as empresas enviam informações sobre acidentes do trabalho via Internet, o que teoricamente facilitaria sua disponibilização.

\section{Sistema de Informações sobre Mortalidade: declaração de óbito}

A declaração de óbito (DO), instrumento utilizado para registrar todas as mortes ocorridas no Brasil, é um registro administrativo expedido pelo Ministério da Saúde e segue o mesmo padrão em todo o território nacional. Mediante a DO assinada por um médico, que atesta a causa do falecimento, o óbito é registrado em cartório.

As secretarias de Saúde dos municípios brasileiros coletam uma via da DO e alimentam o Sistema de Informação sobre Mortalidade (SIM), enviando regularmente seus arquivos municipais às secretarias estaduais de Saúde e ao Ministério da Saúde, que coordena, processa e disponibiliza tais informações para o total do país. Como os dados são produzidos em cada secretaria municipal de Saúde, eles estão sujeitos a problemas estruturais ou conjunturais, que podem afetar a qualidade e a cobertura das informações em cada unidade da federação, interferindo no processamento do conjunto do sistema. 
É preciso considerar, também, a existência de diferenciados níveis de sub-registro de óbito nos estados, acrescida da ocorrência de mortes sem assistência médica e sem causa de morte definida, que ainda persistem em nosso país e enfraquecem os estudos epidemiológicos em determinadas regiões brasileiras.

As informações do SIM podem ser acessadas na página do Datasus na Internet (www.datasus.gov.br), que disponibiliza o aplicativo Tabwin, permitindo ao usuário realizar suas próprias tabulações. Uma das principais vantagens da DO para estudos da mortalidade por acidentes do trabalho consiste na diversidade de informações sobre o trabalhador falecido. Esta declaração contém ainda importantes informações epidemiológicas, como as causas de morte e o tipo de causa externa de morte, além de campo específico para notificar se o óbito ocorreu ou não devido a acidente do trabalho, ou se este fato é ignorado. Outra vantagem é que abrange todos os trabalhadores, independentemente de o vínculo empregatício ser formal ou informal, ou da condição de contribuinte ou não do INSS.

Quanto às desvantagens na utilização da DO como fonte de dados para esses estudos, a principal consiste no inadequado preenchimento do campo que indica se a morte resultou de acidente do trabalho, interferindo na identificação e na quantificação dos casos fatais desse tipo de acidente. Tal fato ocorre principalmente pelo desconhecimento do profissional médico sobre as circunstâncias exatas da morte, ou pelo fato de este não querer se comprometer com tal declaração.

Além disso, não há registro mais específico sobre o local onde ocorreu o acidente do trabalho nem se o trabalhador estava a serviço da empresa no momento do acidente. Também não é possível identificar as doenças ocupacionais, pois o campo de acidente do trabalho na DO é preenchido tão somente no caso de causa externa de morte.

Outro fator limitante diz respeito às regras de codificação para alimentar o SIM, que não consideram o homicídio como tipo de violência compatível com acidente do trabalho, embora na legislação acidentária essa causa de morte seja identificada como tal. Esse fato interfere, ainda mais, na subenumeração dos casos fatais de acidentes do trabalho. Com as evidências apresentadas em diversos trabalhos que atestam a importância desse tipo de causa de morte como risco à saúde do trabalhador, o Ministério da Saúde se propôs a alterar tais regras. 


\section{Sistema de Informações Hospitalares: Autorização para Internação Hospitalar}

O Sistema de Informações Hospitalares (SIH) destina-se a auxiliar a operacionalização, o controle e a gestão do atendimento hospitalar do Sistema Único de Saúde (SUS), pelas secretarias municipais e estaduais de Saúde. Ele é gerenciado pela Secretaria de Atenção à Saúde (SAS), do Ministério da Saúde, e suas informações encontram-se disponíveis na página do Datasus (dados agregados e bancos de microdados que podem ser baixados), cobrindo cerca de $70 \%$ das internações realizadas no país. Semelhante ao SIM, suas informações podem ser acessadas por intermédio do tabulador Tabwin (www. datasus.gov.br).

Alimentam o SIH informações da Autorização de Internação Hospitalar (AIH), contemplando dados de identificação do paciente, dos procedimentos realizados e do diagnóstico principal e secundário, que são organizados segundo a Classificação Internacional de Doenças (CID). Assim, embora tenha sido criado com objetivo gerencial e de controle dos custos hospitalares, o sistema contém informações importantes, cada vez mais utilizadas em estudos epidemiológicos. É possível, também, conhecer casos de internação em consequência de circunstâncias de trabalho, representando importante subsídio para avaliações e tomadas de decisão na área de vigilância epidemiológica.

Como vantagem para estudos de saúde do trabalhador, o sistema identifica a internação como decorrente de acidente do trabalho e a respectiva causa de internação. Em tese, haveria informação sobre todos os trabalhadores acidentados, independentemente de seu vínculo empregatício.

As principais desvantagens decorrem da própria finalidade para a qual o sistema foi criado, cobrindo apenas indivíduos atendidos pelo SUS, ficando fora de sua base os trabalhadores que procuram assistência médica particular ou conveniada, e do fato de a internação de muitos deles acontecer sem uma associação explícita com o trabalho. Na verdade, essa fonte apenas informaria casos de acidentes graves, que necessitaram de internação hospitalar, e os casos mais leves não fariam parte dessas estatísticas.

Outra limitação da AIH é que uma mesma pessoa pode apresentar repetidas internações, com complicações posteriores que até resultem em óbito, o que pode inclusive ocorrer em outro estabelecimento hospitalar. Isso acarreta múltiplas contagens de uma mesma ocorrência, interferindo no dimensionamento do número de indivíduos internados. 
Não há cobrança diferenciada para internações decorrentes de acidentes do trabalho, o que não motiva o estabelecimento hospitalar a registrar essa característica entre todos os demais quesitos a que está obrigado a preencher. Este seria mais um fator para a existência de subnotificação importante dessa fonte para estudos sobre acidentes do trabalho.

\section{Relação Anual de Informações Sociais}

A Relação Anual de Informações Sociais (Rais) consiste em base de informações estatísticas para subsidiar a elaboração de políticas de emprego e salários e de estudos sobre mercado de trabalho. É gerenciada pelo Ministério do Trabalho e Emprego e contém registro permanente de admissões e desligamentos dos empregados segundo o regime da Consolidação das Leis do Trabalho (CLT), dos trabalhadores com contrato temporário de trabalho sem carteira assinada e de funcionários públicos. Tem periodicidade anual e representa um censo do mercado formal brasileiro (www.mte.gov.br).

Essa fonte apresenta, como grande vantagem para estudos de acidentes do trabalho, dados relativos aos desligamentos de trabalhadores, que estão desagregados em aposentadoria e falecimento, sendo ainda discriminados em acidente ou doença do trabalho. A partir de 2003, passou-se a detalhar também se o acidente foi típico ou de trajeto. Tais dados aparecem por unidade da federação e por município.

As empresas, quando alimentam a Rais, informam diversas características de seus empregados, como salário e função que exercem, além de dados pessoais. Tais dados podem ser cruzados com as características das empresas, representando importante subsídio para estudos sobre saúde do trabalhador.

Uma limitação dessa fonte reside na falta de detalhes sobre a causa da morte ou a invalidez permanente. Nos estudos regionalizados, o fato de as informações sobre empregados referirem-se ao município em que a sede da empresa encontra-se instalada, e não ao local de residência ou de trabalho do empregado, pode acarretar distorções sobre tais ocorrências.

Outra desvantagem é cobrir apenas trabalhadores com vínculo formal de trabalho, ignorando os trabalhadores do mercado informal, que representam parcela expressiva da população economicamente ativa (PEA) ocupada.

As bases de dados da Rais são acessadas em CD-ROM distribuído anualmente pelo Ministério do Trabalho e Emprego, que disponibiliza ainda um tabulador próprio para realizar consultas nessas bases. 


\section{Exemplo de Integração de Bases de Dados: casos fatals no estado de São Paulo}

Com o propósito de exemplificar o potencial de aprimoramento resultante do tratamento conjunto de diferentes bases de dados, apresentam-se o projeto desenvolvido em parceira entre a Fundação Seade e a Fundacentro, em 2000, e os resultados descritos no trabalho de Waldvogel (2003).

A fim de resgatar a riqueza de informações sobre casos fatais de acidentes do trabalho em duas fontes de registro administrativo - DO e CAT - e tentar superar limitações específicas de cada uma delas, o projeto aqui mencionado aplicou metodologia de vinculação de fontes de dados para identificar e quantificar casos fatais de acidentes do trabalho ocorridos no estado de São Paulo entre 1997 e 1999.

Nesse período, as bases de mortalidade processadas pela Fundação Seade, com base nas informações contidas nas DO e no registro civil, não dispunham de variáveis de identificação, como nome do falecido e nome da mãe, necessárias para aplicação da metodologia de vinculação de bases de dados. Em contrapartida, as comunicações de acidentes do trabalho ainda não estavam informatizadas no INSS, inexistindo mais detalhes sobre casos fatais, além de não haver variáveis de identificação.

Fez-se necessário, então, resgatar todas as DO arquivadas na Fundação Seade cujo campo de acidente do trabalho estivesse preenchido com 'sim', para relacionar as variáveis de identificação. Também foi realizada pesquisa em todas as agências e postos do INSS no estado de São Paulo, coletando dados sobre os casos fatais de acidentes nos processos arquivados em cada unidade.

A metodologia de vinculação de bases de dados adotada nessa experiência procurou maximizar a utilização dos registros administrativos, compatibilizando suas informações, enriquecendo o detalhamento dos dados e ampliando o universo de casos fatais.

Um importante ganho com esse procedimento foi a possibilidade de conhecer casos de acidentes presentes em apenas uma das fontes, o que permitiu identificar os casos que, apesar de notificados pelo médico como acidentes do trabalho na DO, não resultaram em abertura de processo no INSS.

Os casos notificados na DO como acidente do trabalho e que não constam da base do INSS referem-se, de modo geral, à população trabalhadora não coberta pelo INSS, aos trabalhadores contribuintes sem dependentes aptos a requerer benefício a esse órgão ou àqueles cujos dependentes residam fora do 
estado de São Paulo. A parcela da população assim estimada representa uma aproximação dos acidentes fatais ocorridos com trabalhadores do mercado informal.

A pesquisa identificou 1.999 casos fatais nos processos de acidentes do trabalho do INSS e 2.177 casos nas DO do acervo da Fundação Seade, no estado de São Paulo, entre 1997 e 1999, indicando média anual, respectivamente, de 666 e 726 casos fatais.

Além dos totais distintos, existe sensível diferença no perfil da população trabalhadora revelada com base em cada fonte, sendo apenas a distribuição por sexo idêntica, com participação majoritariamente masculina (95,5\%). Quanto à distribuição etária, observa-se que os dados do INSS mostram maior frequência de casos fatais entre 30 e 39 anos, enquanto a população revelada pela DO é mais jovem, com pico entre 20 e 34 anos. Nessa segunda fonte também se verifica maior participação de acidentados com mais de 55 anos, em comparação com a primeira. Em relação à composição por estado civil, encontra-se maior diferença nos dados do INSS: $61,5 \%$ de casados e 28,4\% de solteiros, ao passo que nas DO ela foi menor: $51,9 \%$ de casados e $36,7 \%$ de solteiros.

Esses resultados indicam diferenças importantes nos perfis da população acidentada no estado de São Paulo, reveladas com base na análise isolada de cada fonte de registro administrativo. Tal constatação realça a necessidade de análise conjunta das fontes, considerando-se a integração de seus dados, para se contar com panorama mais abrangente da população trabalhadora vítima desses acidentes.

Aplicando-se a metodologia de vinculação de bases de dados, foi possível identificar 530 casos comuns às duas fontes. Após incorporar os casos presentes em apenas uma delas, a base integrada totalizou 3.646 casos fatais de acidentes do trabalho, no estado de São Paulo, entre 1997 e 1999, indicando que, a cada ano, 1.215 trabalhadores foram vítimas fatais de acidentes relacionados ao trabalho - ou seja, a cada dia ocorreram cerca de 3,3 mortes por acidentes laborais. Na Figura 1, descreve-se o resultado desse procedimento. 
Figura 1 - Composição da base integrada CAT/DO de acidentes do trabalho. Estado de São Paulo - 1997-1999

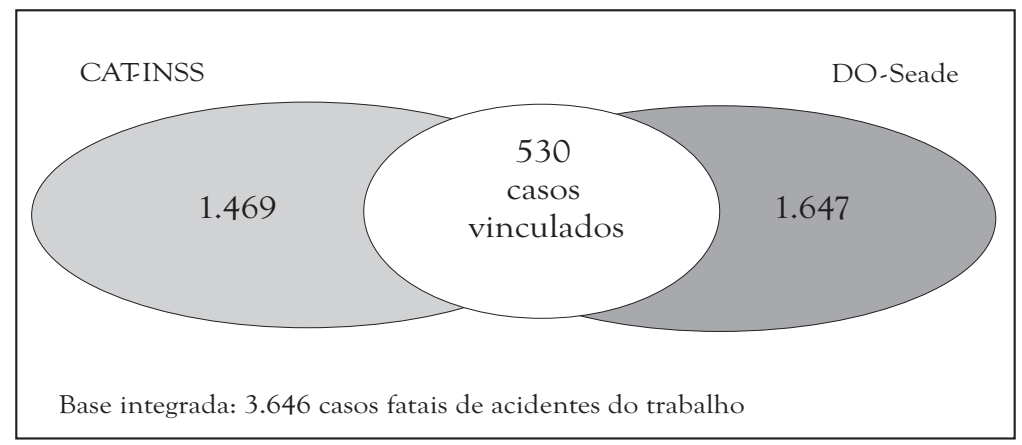

Fonte: Fundação Seade/Fundacentro (2000).

Como primeiro resultado, tem-se a estimativa do grau de cobertura dos casos fatais de acidentes do trabalho para cada fonte. As DO cobriram 59,7\% do universo de casos da base integrada, enquanto as CATs responderam por $54,8 \%$ desse total. Conclui-se, então, que as duas fontes de dados mostraramse insuficientes para identificar e dimensionar adequadamente os casos fatais de acidentes do trabalho quando utilizadas de forma isolada. $O$ tratamento conjunto ampliou esse universo e permitiu análises mais abrangentes da questão acidentária.

Vale dizer que o total de casos fatais identificados no levantamento de dados em agências e postos do INSS resultou em contingente distinto daquele apresentado nos Anuários Estatísticos da Previdência Social. Nessas estatísticas, o volume divulgado refere-se a casos comunicados e liquidados pelo INSS em determinado ano. O processo é considerado liquidado quando sua avaliação se encerra administrativa e tecnicamente no INSS, quando se define nexo causal entre acidente e trabalho, o que pode interferir no intervalo de variação entre a entrada e a decisão final do processo. Outro fator de diferenciação decorre do fato de o volume apresentado nos anuários referir-se ao total de benefícios gerados por tais acidentes, e um único caso pode gerar mais de um benefício. Além disso, o município ou estado adotado é o de entrada do processo, e não o da ocorrência do acidente ou da residência do segurado.

Segundo o Anuário de 1999, no estado de São Paulo foram liquidados 2.935 casos fatais de acidentes do trabalho, entre 1997 e 1999. A comparação com os dados da pesquisa realizada em 2000 mostra que eles correspondem a $68,1 \%$ do número publicado no referido Anuário. 
Esse porcentual é semelhante ao estimado por Gawryszewski e colaboradores (1998) para o estado de São Paulo em 1995. Analisando a distribuição dos óbitos segundo o ano de ocorrência do acidente, esses autores detectaram apenas 66,8\% desses casos como ocorridos e liquidados em 1995.

Em compensação, na base do SIM foram encontrados 1.724 óbitos por acidentes do trabalho ocorridos entre 1997 e 1999. O valor inferior em relação à pesquisa direta nas $\mathrm{DO}$ decorre, principalmente, da existência de homicídios como causa de morte de acidentes do trabalho, que não estão presentes no SIM, conforme regra de codificação mencionada anteriormente.

\section{Síntese dos Dados Relativos aos Quatro Sistemas de Informação}

Para ilustrar os quatro sistemas de informação aqui considerados, elaborouse a Tabela $1 \mathrm{com}$ os totais relativos a acidentes do trabalho, invalidez permanente e óbitos, ocorridos entre 2000 e 2005, respectivamente para o Brasil e o estado de São Paulo. Estes dados foram coletados em cada sistema de informação, para ilustrar as diferenças existentes entre eles. Dependendo do sistema considerado, o dimensionamento dos eventos é distinto, indicando suas fragilidades e limitações.

Tabela 1 - Acidentes do trabalho, óbitos e invalidez. Brasil e estado de São Paulo 2000-2005

\begin{tabular}{|c|c|c|c|c|c|c|c|c|}
\hline & & \multicolumn{3}{|c|}{ Dataprev } & \multicolumn{2}{|r|}{$\mathrm{SIH}$} & \multicolumn{2}{|r|}{ Rais } \\
\hline & Ano & $\begin{array}{l}\text { Acidentes do } \\
\text { trabalho (1) }\end{array}$ & Óbitos $_{(2)}$ & $\begin{array}{c}\text { Invalidez } \\
\text { permanente (2) }\end{array}$ & Óbitos & $\begin{array}{l}\text { Acidentes do } \\
\text { trabalho }\end{array}$ & Óbitos & $\begin{array}{l}\text { Aposentadoria } \\
\text { por invalidez }\end{array}$ \\
\hline & 2000 & 363.868 & 3.094 & 15.317 & 2.422 & 48.251 & 1.447 & 5.447 \\
\hline - & 2001 & 340.251 & 2.753 & 12.038 & 2.517 & 47.213 & 2.074 & 5.666 \\
\hline$\cdot \bar{\infty}$ & 2002 & 393.071 & 2.968 & 15.259 & 2.799 & 35.805 & 1.775 & 6.402 \\
\hline$\sigma$ & 2003 & 399.077 & 2.674 & 13.416 & 2.841 & - & 1.848 & 6.297 \\
\hline$\overline{0}$ & 2004 & 465.700 & 2.839 & 12.913 & 3.011 & 23.900 & 2.094 & 6.094 \\
\hline & 2005 & 491.711 & 2.708 & 13.614 & 2.740 & - & 1.898 & 8.138 \\
\hline & TOTAL & 2.453 .678 & 17.036 & 82.557 & 16.330 & - & 11.136 & 38.044 \\
\hline & 2000 & 147.567 & 722 & 5.799 & 541 & 12.364 & 669 & 1.366 \\
\hline 0 & 2001 & 133.936 & 750 & 4.206 & 524 & 11.211 & 1.271 & 1.205 \\
\hline$=$ & 2002 & 154.767 & 815 & 4.805 & 544 & 9.103 & 849 & 1.784 \\
\hline$\tilde{\sigma}$ & 2003 & 151.121 & 665 & 4.737 & 593 & - & 815 & 1.979 \\
\hline 0 & 2004 & 173.412 & 677 & 4.460 & 570 & 2.869 & 803 & 1.961 \\
\hline $1 \pi$ & 2005 & 181.705 & 670 & 4.860 & 553 & - & 627 & 2.388 \\
\hline$\infty$ & TOTAL & 942.508 & 4.299 & 28.867 & 3.325 & - & 5.034 & 10.683 \\
\hline
\end{tabular}

(1) Acidentes registrados. (2) Acidentes liquidados.

Fonte: Dataprev, (2007); Datasus, (2007); Brasil, (2007). 
Constata-se que apenas no sistema do Dataprev e do SIH existem dados para o total de acidentes do trabalho. Apesar de todas as restrições inerentes à primeira base, que abrange apenas trabalhadores contribuintes do INSS, ela ainda cobre um volume maior quando comparada ao SIH, que apresenta número bem mais reduzido de casos com esse caráter de internação, tornando-o insuficiente para quantificar esses eventos. Interessante observar certa incoerência na série histórica apresentada, em que os valores diminuem expressivamente sem motivo aparente para tal. Mas o SIH não deve ser totalmente descartado, já que informa justamente os casos de acidentes mais graves, que necessitaram de internação em hospitais, ainda que seus dados se refiram apenas aos atendimentos do SUS.

Apesar de seu potencial para servir a esse propósito, no SIH e também no SIM os dados são subnotificados, o que decorre, mais uma vez, do fato de instituições de saúde e médicos não estarem devidamente sensibilizados quanto à importância de classificar a internação e a morte como consequência de atividade profissional. São necessárias campanhas de conscientização sobre a utilidade dos registros administrativos, preenchidos pelos profissionais de saúde, como instrumento essencial para orientação de medidas de prevenção e redução dos acidentes do trabalho.

Os dados de invalidez decorrente de acidente do trabalho são refletidos em duas fontes: Dataprev e Rais. Observa-se ordem de grandeza muito distinta para esses eventos, sendo o total informado pelo Dataprev 2,2 vezes maior do que aquele presente na Rais, tanto no Brasil quanto no estado de São Paulo.

Em relação aos casos fatais de acidentes do trabalho, em tese os quatro sistemas deveriam conter tais informações, mas não é possível considerar o $\mathrm{SIH}$ neste grupo. As demais fontes apresentam resultados diversos, nas duas áreas estudadas. Para o total do Brasil, o Dataprev exibe maior cifra: 17.036 óbitos registrados, entre 2000 e 2005, enquanto no SIM constam 16.330 casos. Na Rais, o volume é menor, com 11.136 desligamentos em razão de acidentes do trabalho fatais.

Avaliação semelhante para o estado de São Paulo revela situação diversa. A Rais foi o sistema a informar maior número de casos fatais (5.034), seguida do Dataprev (4.118) e, por último, do SIM (3.325). Aqui valem algumas observações. $\mathrm{O}$ fato de a sede da empresa prestar informações sobre desligamentos de seus empregados pode acarretar diferenças se o trabalhador reside em estado distinto. Também no Dataprev, a residência pode ser a dos beneficiários e não aquela do trabalhador, como ocorre no SIM. 
Um ponto a favor dos dados da Rais relaciona-se à cobertura dos trabalhadores do setor público, os quais não aparecem no Dataprev, que compreende os trabalhadores do mercado formal regidos pela CLT. Em tese, no SIM estariam todos os trabalhadores, independentemente de seu vínculo empregatício.

Os dados aqui apresentados mostram a dificuldade de análise e algumas possibilidades de erro quando os sistemas de informação são considerados isoladamente nos estudos sobre acidentes do trabalho.

\section{Proposta de Elaboração de Base Integrada de Acidentes do Trabalho}

A breve avaliação realizada no item anterior, com a síntese dos dados existentes sobre acidente, invalidez permanente e mortes associadas ao trabalho, indica que não é possível saber com precisão a verdadeira ordem de grandeza desses eventos. Dependendo da fonte de dados utilizada, o dimensionamento desses eventos é distinto.

A informação mais enfraquecida é o total de acidentes do trabalho, disponível somente na base do Dataprev, com a limitação bastante conhecida de cobrir apenas trabalhadores contribuintes do INSS. Além disso, este órgão costuma ser acionado somente quando o trabalhador necessita de afastamento superior a 15 dias. Apesar da obrigatoriedade do preenchimento da CAT sempre que há acidente do trabalho, independentemente da gravidade, sabe-se que isso não acontece. A AIH, que poderia ser bom instrumento para quantificar acidentes do trabalho mais graves que levam à internação hospitalar, cumpre parcialmente esse papel, como demonstraram os dados apresentados. Por esses motivos, a quantificação mais próxima da realidade do total de acidentes do trabalho é feita por meio de estimativas, muitas vezes resultantes de pesquisas amostrais.

Como ilustração, apresentam-se alguns resultados do trabalho de Montagner e colaboradores (2001), com base em pesquisa domiciliar por amostra representativa da população do estado de São Paulo, realizada em projeto de parceria entre a Fundação Seade e a Fundacentro (2000). A pesquisa revelou que $6,5 \%$ da população economicamente ativa, com experiência de trabalho nos 12 meses anteriores ao levantamento, diz ter sofrido acidente do trabalho, o que permitiu estimar em 884 mil o número de acidentes ocorridos no estado de São Paulo em 2001. Na referida pesquisa, 84,7\% dos eventos resultaram em afastamento inferior a 15 dias e 52,2\% corresponderam a empregado do setor público e a assalariado de empresa privada com carteira assinada.

O trabalho de Santana e colaboradores (2003), de acordo com dados de inquérito de base comunitária conduzido em amostra aleatória de 
habitantes de Salvador (BA), estimou incidência anual de acidentes do trabalho em $5,8 \%$.

Os resultados encontrados são bem superiores às estatísticas da previdência, embora se refiram a universos de certa forma distintos. Enquanto nas pesquisas domiciliares há o relato de todos os acidentes do trabalho, inclusive aqueles que não implicaram afastamento, nas estatísticas oficiais aparecem principalmente os casos de maior gravidade, que realmente afastaram o indivíduo de suas funções. Deve-se considerar, além disso, a elevada parcela de trabalhadores sem vínculo formal, que não faz parte das estatísticas oficiais.

Já para os casos de invalidez permanente por acidente do trabalho, existem duas fontes nacionais com volume considerável de casos para tal evento: Dataprev e Rais. Para esses, é possível testar a alternativa de vincular as duas fontes, de forma a aprimorar a capacidade de entendimento das ocorrências e o mecanismo de seu registro.

$\mathrm{Na}$ Rais, desligamentos em razão de aposentadoria por invalidez, discriminada em acidente ou doença do trabalho, indicam o desfecho quando o trabalhador não tem mais condições para exercer suas atividades profissionais anteriores. Essa fonte cobre todos os trabalhadores com contrato de trabalho, mesmo aqueles que não têm carteira assinada, e os funcionários públicos, mas seu registro não permite conhecer o momento exato nem as circunstâncias do acidente, embora conte com informações relevantes, como salário e cargo que o empregado exercia, além de informações sobre a empresa. Na CAT, existem mais informações sobre o acidente, como hora, local, circunstâncias, causa da doença e dados sobre a empresa.

O tratamento conjunto das duas fontes permitiria aprimorar o conhecimento sobre invalidez permanente decorrente de acidente do trabalho, cuja gravidade impede o trabalhador de retornar à função anteriormente exercida. Esse procedimento permite realizar controles de qualidade das informações comuns, complementar as variáveis disponíveis e aumentar o número de casos informados. Contudo, o banco integrado ainda não incluiria aqueles casos de invalidez permanente relativos aos empregados sem vínculo formalizado de trabalho. Para essa parcela, a AIH corretamente preenchida poderia ser uma alternativa, considerando-se que os casos de invalidez permanente necessitam de cuidados médicos mais especializados, inclusive de internação hospitalar.

Quanto aos casos fatais de acidente do trabalho, esse é o evento com maior potencial de aprimoramento com a metodologia de vinculação de fontes de dados, já que deveria estar presente nas quatro fontes de dados. No Brasil, a apre- 
sentação da DO e o correspondente registro civil são obrigatórios para realizar um sepultamento. Se o trabalhador acidentado for contribuinte do INSS, seus dependentes abrirão processo neste órgão, com apresentação do registro civil do respectivo óbito e de uma CAT para requerer benefícios correspondentes. As empresas, por sua vez, se tiverem contrato formal de trabalho com o acidentado, deverão informar seu desligamento na Rais, no final do ano. Caso o trabalhador tenha procurado assistência médica em hospital do SUS por ocasião do acidente do trabalho e tenha falecido, este evento pode também aparecer no SIH.

A integração dessas fontes de dados representa importante mecanismo para ampliar a cobertura do evento mais grave do acidente do trabalho, que é a morte do trabalhador. A análise conjunta dos três sistemas com maior potencial para integração das bases de dados - Dataprev, SIM e Rais - ampliaria o universo de casos fatais e permitiria estudo mais completo e detalhado da mortalidade por acidentes laborais no país.

É verdade que ainda ficariam fora desse universo os casos fatais que, mesmo decorrentes de acidente do trabalho, não são corretamente notificados nos registros administrativos considerados, mas certamente a vinculação das bases melhoraria muito a estimativa da ordem de grandeza dessas ocorrências e representaria importante subsídio para orientar medidas de prevenção e reduzir os acidentes do trabalho de maior gravidade.

A técnica de vinculação de bases de dados considera que tais fontes contemplem variáveis de identificação, de modo a permitir a formação de pares com os casos comuns e a consistência de informações. Outra importante vantagem dessa metodologia reside na incorporação, na base integrada final, dos casos presentes em apenas uma das bases, resultando em base de dados mais completa e de melhor qualidade.

Essa metodologia permite, também, avaliar diferenciais de mortalidade por acidentes do trabalho para as duas parcelas da população acidentada correspondentes aos mercados formal e informal. Diversos estudos têm mostrado que características como incidência, perfil da população, tipo de acidente e causas de morte, entre outras, são bastante diferenciadas para esses dois conjuntos de trabalhadores (Waldvogel, 1993, 2001; Santana et al., 2003).

\section{Considerações Finais}

Um sistema de monitoramento de acidentes e doenças do trabalho, organizado com base no relacionamento de diferentes fontes de dados exis- 
tentes, representa importante esforço para otimizar informações atualmente disponíveis de forma fragmentada, auxiliando na resposta à pergunta sobre quantos trabalhadores se acidentam no exercício de sua profissão no país, nos dias de hoje.

Se os sistemas Dataprev, SIM, SIH e Rais estivessem integrados, as bases de dados cobririam universo mais amplo de trabalhadores acidentados, representando contribuição relevante para todos os programas relacionados a essa problemática.

Cada sistema tem suas limitações, mesmo de acordo com seus objetivos específicos, mas o tratamento conjunto procura reduzi-las, sendo fundamental para a organização de um sistema abrangente de monitoramento de acidentes do trabalho, que contemple uma seleção das informações mais relevantes disponíveis em cada sistema.

O formato como tais sistemas estão configurados, contendo variáveis de identificação, tem grande potencial para aplicação de mecanismos de integração de microdados e cruzamento de variáveis. Eles contêm informações coincidentes e outras complementares. Além das variáveis de identificação, existem outras que são comuns a dois ou mais sistemas. As variáveis específicas de determinado sistema poderão ser consideradas como informações complementares, devendo ser selecionadas aquelas que acrescentem elementos fundamentais para o objetivo aqui proposto.

Todo novo sistema de informação que for criado com abrangência nacional e contemplar variáveis relacionadas a essa problemática poderá ser incorporado ao sistema de monitoramento, como acontece com o Sistema Nacional de Agravos de Notificação (Sinan) para os casos de acidentes do trabalho, proposto pelo Ministério da Saúde.

O banco integrado resultante será estatisticamente preciso para fins de monitoramento, permitindo que análises realizadas nos órgãos centrais utilizem bases de dados mais completas e detalhadas sobre a questão acidentária no país. Diferentemente, no nível local ou em estudos específicos, sempre será necessário o acompanhamento de cada indivíduo isoladamente, sendo importante a manutenção de sistemas de vigilância e de informação em diversas localidades, que devem manter seu andamento e objetivo particular.

O caráter centralizador dos órgãos gerenciadores desses sistemas consiste em uma das principais dificuldades para o acesso aos microdados necessários a esse tipo de procedimento. Muitas vezes tal conduta é necessária para os objetivos específicos, além da questão de sigilo que envolve a manipulação de 
dados individualizados. A execução da alternativa metodológica aqui apresentada só será possível com a participação ativa e efetiva de cada órgão gestor responsável pela produção desses sistemas de informação.

É importante, também, haver uma concentração de esforços para melhorar a cobertura e a qualidade dos dados assim produzidos de forma isolada, aprimorando, cada vez mais, os sistemas de dados, aumentando o poder da base integrada e gerando subsídios confiáveis para acompanhamento e estudo dos acidentes e doenças do trabalho no Brasil.

\section{REFERÊNCIAS}

ALMEIDA, I. M. \& BINDER, M. C. P. Metodologia de análise de acidentes: investigação de acidentes do trabalho. In: MET-SIT-DSNT-FUNDACENTRO. Combate aos Acidentes Fatais Decorrentes do Trabalho. São Paulo: MET-SIT-DSNT-Fundacentro, 2000.

ANDREOTTI, M. Sistema de Vigilância de Acidentes do Trabalho (Sivat). São Paulo: Secretaria Municipal de Saúde do Município de São Paulo, 2007. Disponível em: <http://portal.prefeitura.sp.gov.br/secretaria/saude〉. Acesso em: jun. 2007.

BINDER, M. C. P. \& CORDEIRO, R. Sub-registro de acidentes do trabalho em localidade do estado de São Paulo, 1997. Revista de Saúde Pública, 37(4): 409-416, 2003.

BRASIL. Ministério da Saúde, Ministério da Previdência Social, Ministério do Trabalho e Emprego. $3^{a}$ Conferência Nacional de Saúde do Trabalhador - $3^{a}$ CNST. Coletânea de Textos. Brasília: MS, MPS, MTE, 2005.

CONCEIC̣ÃO, P. S. A. Internações por acidentes do trabalho, Bahia, 1998 a 2000. In: BAHIA. Secretaria de Estado da Saúde. Superintendência de Vigilância e Proteção da Saúde. Saúde do Trabalhador na Bahia: construindo a informação. Salvador, 2003.

CORDEIRO, R. et al. O sistema de vigilância de acidentes do trabalho de Piracicaba, SP, Brasil. Cadernos de Saúde Pública, 15(2): 1.574-1.583, 2005.

CORREA, P. R. L. \& ASSUNÇÃO, A. A. A subnotificação de mortes por acidentes do trabalho: estudo de três bancos de dados. Epidemiologia e Serviços de Saúde, 12(4): 177-187, 2003.

CORTEZ, S. A. E. Acidente do Trabalho: ainda uma realidade a ser desvendada, Ribeirão Preto/SP, 2001. Dissertação de Mestrado, Ribeirão Preto (SP): Faculdade de Medicina de Ribeirão Preto, Universidade de São Paulo.

DATAPREV. Ministério da Previdência e Assistência Social. Instituto Nacional do Seguro Social. Anuário Estatístico da Previdência Social. Brasília: Ministério da Previdência e Assistência Social, 2007.

FACCHINI, L. A. et al. Sistema de informação em saúde do trabalhador: desafios e perspectivas para o SUS. Ciência Ë Saúde Coletiva, 10(4): 857-867, 2005. 
FREITAS, R. M. Os Registros de Acidentes do Trabalho no Meio Rural Paulista: as culturas sucroalcooleira e de frutas cítricas entre 1997 e 1999, 2005. Dissertação de Mestrado, São Paulo: Faculdade de Saúde Pública, Universidade de São Paulo.

FUNDAÇÃO SEADE/FUNDACENTRO. Mortalidade por Acidentes do Trabalho. Relatório final. São Paulo: Fundação Seade, Fundacentro, 2000.

GAWRYSZEWSKI, M. et al. Acidentes do Trabalho Fatais: estudo sobre acidentes do trabalho fatais no estado de São Paulo em 1995. São Paulo: Ministério do Trabalho e Emprego, Delegacia Regional do Trabalho no Estado de São Paulo, 1998.

HENNINGTON, H. \& MONTEIRO, M. O perfil epidemiológico dos acidentes do trabalho no Vale dos Sinos e o sistema de vigilância em saúde do trabalhador. História, Ciências, Saúde - Manguinhos, 13(4): 865, 2006.

HENNINGTON, H. et al. Trabalho, violência e morte em Campinas, SP, Brasil. Cadernos de Saúde Pública, 20(2): 610-617, 2004.

LEE, J. B. Mortalidade por Acidentes do Trabalho em Curitiba, 1998: uma análise critica das declarações de óbito, 1999. Tese de Doutorado, Curitiba: Universidade Federal do Paraná.

MONTAGNER, P. et al. Acidentes do trabalho no estado de São Paulo: a importância da pesquisa domiciliar. In: ENCONTRO NACIONAL DA ASSOCIAÇÃO BRASILEIRA DE ESTUdOS DO TRABAlHO, 4, 2001, São Paulo. Anais... São Paulo: Abet, 2001.

OLIVEIRA, P. A. B. \& MENDES, J. M. Acidentes do trabalho: violência urbana e morte em Porto Alegre, RS, Brasil. Cadernos de Saúde Pública, 13(supl. 2): 73-83, 1997. PEPE, C. C. C. A Estratégia para Superar a Desinformação: um estudo sobre os acidentes do trabalho fatais no Rio de Janeiro, 2002. Dissertação de Mestrado, Rio de Janeiro: Escola Nacional de Saúde Pública Sergio Arouca, Fundação Oswaldo Cruz.

SANTANA, V. S.; NOBRE, L. \& WALDVOGEL, B. C. Acidentes do trabalho no Brasil entre 1994 e 2004: uma revisão. Ciência Eु Saúde Coletiva, 10(4): 841-855, 2005.

SANTANA, V. S. et al. Acidentes de trabalho não fatais: diferenças de gênero e tipo de contrato de trabalho. Cadernos de Saúde Pública, 19(2): 481-493, 2003.

TEIXEIRA, M. L. P. Acidentes e Doenças do Trabalho de Profissionais do Setor Transporte: análise dos motoristas no estado de São Paulo, 1998 a 1999, 2005. Dissertação de Mestrado, São Paulo: Faculdade de Saúde Pública, Universidade de São Paulo.

WALDVOGEL, B. C. Mortes precoces de trabalhadores em São Paulo. São Paulo em Perspectiva, 7(2): 124-132, 1993.

WALDVOGEL, B. C. Acidentes do trabalho: vida ativa interrompida. In: CARVALHO NETO, A. \& SALIM, C. A. (Orgs.) Novos Desafios em Saúde e Segurança no Trabalho. Belo Horizonte: PUC, Fundacentro, 2001.

WALDVOGEL, B. C. Acidentes do trabalho, os casos fatais: a questão da identificação e da mensuração. Coleção de Estudos e Análises, 1(1): 9-192, 2002.

WALDVOGEL, B. C. A população trabalhadora paulista e os acidentes do trabalho. São Paulo em Perspectiva, 17(2): 42-53, 2003. 


\title{
II. 0 Agronegócio e seus Impactos na Saúde dos Trabalhadores e da Populaģão do Estado de Mato Grosso
}

\author{
Wanderlei Antonio Pignati \\ Jorge Mesquita Huet Machado
}

\section{Agronegócio e o Processo Saúde-Produção-Doença}

0 processo de desenvolvimento econômico tem sido apontado como um dos principais determinantes da degradação ambiental e da mudança dos perfis de saúde da população humana. Suas transformações no espaço social são reflexos das atividades produtivas realizadas historicamente nas sociedades e estão distribuídas diferentemente entre países, regiões, áreas metropolitanas ou rurais (Leff, 2001; Breilh, 2006; Laurell, 1983; Rigotto, 2003; Câmara et al., 2003; Tambellini \& Câmara, 1998).

O processo de ocupação da Amazônia foi iniciado no século XVIII por migrantes, caboclos, garimpeiros e posseiros (ocupantes de pequenas áreas sem titulação de posse), que inscreviam suas lutas nesse espaço social, modificando as 'coisas' da floresta por meio do uso da terra, induzindo um processo de trabalho com objetivos de sobrevivência e/ou melhoria da qualidade de vida.

A partir da década de 1970, intensificou-se a ocupação da região por grandes agropecuaristas, madeireiros, mineradores, construtores de estradas/hidrelétricas e empresas colonizadoras públicas e privadas (Oliveira, 2005; Picoli, 2004). Daquele período em diante, Mato Grosso assistiu a uma intensificação das atividades produtivas baseadas nas monoculturas extensivas e no extrativismo de madeiras florestais, colocando-o, no século XXI, como o maior produtor brasileiro agrícola e pecuário e o segundo maior produtor de madeira serrada e laminada do Brasil (Delgado, 2001; IBGE, 2007; Seplan-MT, 2007).

Esse processo agroindustrial-florestal ganhou a expressão de 'agronegócio' e entrou de vez no vocabulário cotidiano brasileiro, que o relaciona com a agro- 
pecuária que 'dá certo', na qual a produção com alta tecnologia traz riquezas e modernidade. Além disso, esse marketing é vendido como 'salvação do país', pelo equilíbrio das contas públicas e pelo fornecimento de alimentos, madeira e biocombustível para o mundo (Schlesinger, 2005; Oliveira, 2005). Porém, ele tem trazido benefícios financeiros para poucos (grandes empresas) e gerado impactos negativos na saúde e no ambiente que ultrapassam os limites dos desmatamentos e das fazendas agropecuárias, os quais devem ser compreendidos como expressão das relações capital-trabalho e das tecnologias empregadas, visando a lucros imediatos e à máxima exploração dos bens naturais (Porto, 2000; Oliveira, 2005; Miranda et al., 2007).

Entretanto, o gerenciamento das situações de riscos à saúde-ambiente tem sido considerado como um problema de aplicação de normas legais e de conclusões relevantes da ciência quantitativa. A crença dos pesquisadores em que a objetividade científica pode fornecer todas as evidências para a tomada de decisão sobre questões de riscos à saúde tem-se modificado diante das situações de alta complexidade e incertezas geradas pelos processos produtivos do mundo moderno. Tal situação tem levado a se buscarem práticas de vigilância de enfoque qualitativo/participativo e aplicação do princípio da precaução sobre os possíveis prejuízos de riscos ainda não explicados por relações de causa-efeito e com possibilidades de agravos/danos futuros (Augusto, Florêncio $\&$ Carneiro, 2001; Augusto \& Freitas, 1988; Funtowich \& De Marchi, 2000; Tambellini \& Câmara, 1998).

Na busca por modelos teóricos para se verificarem os impactos dos processos produtivos, coloca-se o espaço social como uma categoria de análise, no sentido de se compreenderem as transformações no ambiente social, inclusive as provocadas pela agroindústria. Esse objeto de estudo deve ser ampliado para além da categoria trabalho, devendo incorporar elementos e formas processuais do modo de produção e sua conexão aos processos históricos e ecológico-sociais em que se situam, pois é dessa dinâmica de construção do espaço social que emergem as situações de risco à saúde (Câmara et al., 2003; Tambellini \& Câmara, 1998; Mattos \& Machado, 2002; Breilh, 2003).

Com essa abordagem ecológico-social se produziram trabalhos científicos que analisaram o processo saúde-doença nos diferentes espaços e tempos como a diferenciação do perfil epidemiológico dos acidentes de trabalho ocorridos na zona rural paulista (Teixeira \& Freitas, 2003) ou na gaúcha (Faria et al., 2000) ou o estudo de Wünsch Filho (1999), que correlacionou o produto interno bruto (PIB) nacional com a incidência de acidentes de trabalho. Outros 
analisaram as relações sociotécnicas de intoxicações agudas por agrotóxicos agrícolas (Silva et al., 2005; Peres et al., 2005) ou correlacionaram regiões de maior consumo de agrotóxicos em monoculturas com maior incidência de intoxicações e suicídios (Pires, Caldas \& Recena, 2005a, 2005b). Algumas pesquisas analisaram ainda o trabalho no espaço rural com aumento da incidência de acidentes com animais peçonhentos (França et al., 2003; Sinitox, 2007¹).

Também há exemplos como o estudo de consumo de agrotóxico em 11 estados brasileiros (incluindo Mato Grosso) e sua correlação com alguns tipos de neoplasias e teratogêneses (Koifman, 2002), bem como a pesquisa de Stopelli e Crestana (2005), que verificou que os trabalhadores da zona rural paulista estavam quase duas vezes mais propensos a desenvolver câncer do que aqueles que moravam e trabalhavam no centro da cidade. Devem ser citadas ainda as revisões bibliográficas de Cocco (2002), Grisólia (2005), Meyer et al. (2003) e Peres e Moreira (2003), que evidenciaram as correlações das poluições ambientais por agrotóxicos com casos de intoxicações agudas, de neoplasias, de teratogêneses e de distúrbios endócrinos e neurológicos.

Outros trabalhos com esse foco, realizados em Mato Grosso, também evidenciaram que o processo produtivo do agronegócio criou várias situações de riscos, como os 'acidentes rurais ampliados', no caso das derivas de pulverizações de agrotóxicos nas lavouras que atingiram as zonas urbanas de cidades do interior do estado (Pignati, Machado \& Cabral, 2007). Há ainda o estudo das madeireiras, em que se verificou o aumento do grau de precarização das condições de trabalho, de salário e de saúde quanto mais elas se distanciavam do centro das cidades (Pignati \& Machado, 2005).

Nesses trabalhos citados, notou-se que, apesar de mostrarem correlações dos agravos com as atividades econômicas, a maioria se restringiu a analisar uma única modalidade de agravo à saúde, não se considerando as inter-relações tecnológicas e sociais das várias etapas do agronegócio, nem se referindo ao sistema de vigilância e promoção de saúde.

Entende-se que, para se estudar a relação do agronegócio com vários agravos à saúde, com enfoque ecológico e social, as investigações devem conter a análise do processo produtivo, dos insumos, da tecnologia empregada e do sistema de vigilância à saúde para, com base nesses fatores sociotécnicos de riscos, inferirem-se os eventos de riscos dos trabalhadores, da população e do ambiente nas várias e diferenciadas regiões.

1 Sinitox (Sistema Nacional de Informação Tóxico-Farmacológica). Base de dados disponível em: <www. cict.fiocruz.br/intoxicaçõeshumanas>. Acesso em: 25 abr. 2007. 


\section{Metodologia}

Para compreendermos o processo saúde-produção-doença, construímos um estudo quali-quantitativo, focado nas relações do processo agrícola-florestalindustrial, do seu volume de produção (e insumos), do perfil epidemiológico de morbi-mortalidade e das práticas de vigilância à saúde.

Foram coletados e distribuídos dados numa série histórica (1998 a 2005) do volume da produção agrícola, pecuária, madeira/lenha e insumos (agrotóxicos, fertilizante e calcário) utilizados no processo produtivo agropecuário de Mato Grosso (IBGE, 2007; Seplan-MT, 2006; INPM, 2006; Indea-MT, 2006).

Pela complexidade da relação saúde-produção-doença, selecionou-se, através de análise estatística de tendência, os agravos à saúde que tiveram importante incremento naquele período, ou seja, os acidentes de trabalho, as intoxicações por agrotóxicos, os acidentes com animais peçonhentos, as malformações congênitas e as neoplasias. Eles também têm sido analisados como os mais sensíveis às situações de riscos e/ou das condições de trabalho e que provavelmente foram 'induzidos' pelo processo produtivo do agronegócio, como descritos na introdução deste capítulo. Os dados foram obtidos de registros de morbi-mortalidade: 1) de internação hospitalar (Datasus, 2007); de mortalidade e morbidade por capítulo da Classificação Internacional de Doenças (CID-10) e residência dos agravados (Datasus, 2007); 2) das Comunicações de Acidentes de Trabalho (CATs), notificadas ao MPS (Brasil, 2007a); 3) das Notificações de Agravos do Sinan-MT (2007); 4) dos dados demográficos do IBGE (2007); e 5) dos dados de empregos registrados no MTE (Brasil, 2007b).

Os dados dos eventos de riscos à saúde humana, os volumes e tipos de produção agrícola, pecuária e florestal, assim como de insumos agropecuários, foram relacionados em suas séries históricas (1988-2005), implicando uma matriz de produção agropecuária e de agravos à saúde dos trabalhadores e da população do interior do estado e de Cuiabá/Várzea Grande. A relação entre esses dados foi verificada em análise estatística de correlação de produção versus eventos de riscos e por análise de séries temporais, referenciadas em Moretin e Toloi (2004) e Draper e Smith (1998). Suas análises foram subsidiadas nos estudos de Câmara et al. (2003), Medronho (2003), Rouquariol e Almeida Filho (2003) e outros citados na seção inicial deste capítulo.

No complemento qualitativo da pesquisa, foram coletados dados de documentos de avaliações de vigilância em saúde da Secretaria de Estado de Saúde, de vigilância à sanidade animal e vegetal do Instituto de Defesa Agropecuária 
(Indea), da Secretaria Estadual de Agricultura, de vigilância no trabalho da Delegacia Regional do Trabalho e Emprego (DRTE) e do controle social da saúde (Conselho Estadual de Saúde, sindicatos e seminários). Analisaram-se as informações com base na "hermenêutica dialética" proposta por Minayo (2002), em que o objeto de estudo é a práxis social, com reconhecimento da historicidade dos processos sociais que são os fatores de causação dos eventos de riscos, reforçando a interpretação quali-quantitativa sugerida por Minayo e Sanches (1993), Tambellini e Câmara (1998), Laurell (1983) e Augusto, Florêncio e Carneiro (2001).

Para Freitas (2004), Funtowich e de Marchi (2000), Mattos e Machado (2002), Guivant (2000) e Machado (1996), nos estudos de problemas sociossanitários complexos devem ser consideradas duas dimensões: uma que inclui mecanismos mensuráveis como morbi-mortalidades, indicadores biológicos e ambientais; e a outra que tem propriedade qualitativa e inclui os domínios técnico, econômico, social, pessoal (consciência e conhecimento) e as práxis estatal, patronal e popular de vigilância à saúde dos processos de desenvolvimento de uma sociedade. Inter-relações criadas no espaço social agropecuário, como a de produção-saúde-agravos e de vigilância-produção-controle social, devem se comportar como uma rede de processos críticos para a saúde humana, que serão analisados neste trabalho.

Considerou-se que os processos produtivos localizados na floresta, no cerrado, no Pantanal e/ou nos municípios do 'interior do estado' formam o espaço agropecuário onde se desenvolve o agronegócio e que abrange todo o território mato-grossense, com exceção de Cuiabá e Várzea Grande. Esses dois municípios, apesar de possuírem um terço da população estadual de 2,8 milhões de habitantes, produziram apenas $0,1 \%$ dos produtos agropecuários em 2005. O 'interior do estado', com dois terços da população estadual e 139 municípios, concentrou 99,9\% da produção agrícola/florestal e 95\% das indústrias que beneficiam os cereais, cana, algodão, carnes, couro e madeira (IBGE, 2007; Seplan-MT, 2007). Observa-se que essa população tem como base econômica a agropecuária/agroindústria e o desmatamento/indústria madeireira, e que seu modo de vida deve ser diretamente influenciado pelos impactos/danos/agravos desse tipo de desenvolvimento, como nos indicam Druk e Franco (1997) ou Câmara et al. (2003), em que as situações de riscos presentes nos ambientes de trabalho modificam também o padrão de saúde da população em geral, visto que grande contingente desta é constituído pela própria população de trabalhadores - e também porque o processo de pro- 
dução pode alterar as condições ambientais, vale dizer ecológico-sociais, que influenciam a saúde de distintos grupos humanos.

O pressuposto deste estudo foi o de que os impactos do processo produtivo do agronegócio na saúde humana estão relacionados com a quantidade de hectares plantados e insumos (agrotóxicos), a forma de organização desse processo e as intervenções sindical, popular e estatal na vigilância e no controle social da saúde. O objetivo foi verificar as correlações desses fatores sociotécnicos com situações específicas de saúde-doença no estado de Mato Grosso.

Os dados foram coletados com autorização por escrito das instituições referidas, sob orientação do Comitê de Ética na Pesquisa da Escola Nacional de Saúde Pública Sergio Arouca da Fundação Oswaldo Cruz (Ensp/Fiocruz), parecer n. 83/2005.

\section{Matriz de Produção Agropecuária e de Agravos à Saúde}

Ao se caracterizar o processo produtivo agroindustrial-florestal predominante no interior de Mato Grosso, observou-se que se trata de um processo crítico para a saúde-ambiente e que foi subdividido em etapas interligadas, que podem ocorrer de maneira sequencial ou todas ao mesmo tempo, numa determinada região. Ele contempla as etapas de desmatamento, indústria da madeira, agricultura, pecuária, transporte, armazenamento, agroindústria, produção de sementes e de calcário agrícola. Tal processo é dependente da cadeia de insumos (combustíveis, agrotóxicos, fertilizantes, calcário), de máquinas agrícolas, caminhões e silos.

Esse processo, baseado nas transformações da natureza e coordenado pelo agronegócio, causa várias situações de riscos que induzem eventos de riscos que se externalizam em acidentes de trabalho e outros agravos à saúde, como descritos no início deste capítulo, e que serão analisados a seguir. Os dados demográficos, de produção, de insumos e de agravos à saúde estão listados na Tabela 1, com a finalidade de se verificarem correlações estatísticas e se visualizarem relações sociotécnicas a serem analisadas. 
Tabela 1 - Matriz de produção agropecuária e de agravos à saúde. Mato Grosso 1998-2005

\begin{tabular}{|c|c|c|c|c|c|c|c|c|}
\hline Grupos & 1998 & 1999 & 2000 & 2001 & 2002 & 2003 & 2004 & 2005 \\
\hline \multicolumn{9}{|l|}{ DemogrÁficos (em milhões) } \\
\hline $\begin{array}{l}\text { População - Cuiabá/Várzea } \\
\text { Grande }\end{array}$ & 0,66 & 0,67 & 0,70 & 0,71 & 0,73 & 0,74 & 0,75 & 0,78 \\
\hline $\begin{array}{l}\text { População - interior de Mato } \\
\text { Grosso }\end{array}$ & 1,68 & 1,71 & 1,81 & 1,85 & 1,88 & 1,91 & 1,94 & 2,02 \\
\hline $\begin{array}{l}\text { Trabalhadores - Cuiabá/ } \\
\text { Várzea Grande }\end{array}$ & 0,12 & 0,13 & 0,14 & 0,14 & 0,16 & 0,16 & 0,19 & 0,21 \\
\hline Trabalhadores - interior & 0,16 & 0,16 & 0,18 & 0,20 & 0,22 & 0,25 & 0,28 & 0,28 \\
\hline $\begin{array}{l}\text { Nascidos vivos - Cuiabá/ } \\
\text { Várzea Grande }\end{array}$ & 0,01 & 0,01 & 0,01 & 0,01 & 0,01 & 0,01 & 0,01 & 0,01 \\
\hline Nascidos vivos - interior & 0,03 & 0,03 & 0,04 & 0,03 & 0,03 & 0,04 & 0,04 & 0,04 \\
\hline \multicolumn{9}{|l|}{$\begin{array}{l}\text { PRODUÇÃO AGROPECUÁRIA-FLORESTAL } \\
\text { (interior de MT) }\end{array}$} \\
\hline $\begin{array}{l}\text { Lavouras temporárias } \\
\text { (milhões ha) }\end{array}$ & 3,75 & 4,17 & 4,61 & 4,78 & 5,61 & 6,38 & 7,83 & 8,80 \\
\hline $\begin{array}{l}\text { Produção agrícola temporária } \\
\text { (milhões t) }\end{array}$ & 20,59 & 21,34 & 21,67 & 25,29 & 29,30 & 33,55 & 36,84 & 40,43 \\
\hline $\begin{array}{l}\text { Lavouras permanentes } \\
\text { (milhões ha) }\end{array}$ & 0,05 & 0,06 & 0,06 & 0,11 & 0,09 & 0,09 & 0,06 & 0,06 \\
\hline $\begin{array}{l}\text { Produção agrícola } \\
\text { permanente (milhões t) }\end{array}$ & 0,04 & 0,06 & 0,08 & 0,14 & 0,15 & 0,08 & 0,07 & 0,07 \\
\hline $\begin{array}{l}\text { Gado bovino (milhões de } \\
\text { cabeças) }\end{array}$ & 16,75 & 17,24 & 18,92 & 19,92 & 22,18 & 24,61 & 25,92 & 27,38 \\
\hline Madeira (milhões de $\mathrm{m}^{3}$ ) & 2,58 & 2,64 & 2,60 & 2,73 & 2,87 & 2,45 & 2,09 & 1,78 \\
\hline Lenha (milhões de $\mathrm{m}^{3}$ ) & 2,05 & 2,06 & 2,02 & 1,97 & 2,01 & 2,19 & 2,40 & 2,62 \\
\hline Calcário agrícola (milhões t) & 3,28 & 3,13 & 4,06 & 3,83 & 4,82 & 6,15 & 5,73 & 6,41 \\
\hline \multicolumn{9}{|l|}{ INSUMOS AGRÍCOLAS (interior de MT) } \\
\hline Sementes (mil t) & 191 & 196 & 197 & 205 & 252 & 262 & 313 & 352 \\
\hline Fertilizantes químicos (mil t) & 938 & 1.043 & 1.152 & 1.195 & 1.403 & 1.594 & 1.959 & 2.201 \\
\hline Agrotóxicos (mil t) & 32 & 35 & 39 & 41 & 48 & 54 & 67 & 75 \\
\hline Calcário agrícola (mil t) & 1.877 & 2.085 & 2.304 & 2.391 & 2.806 & 3.188 & 3.917 & 4.402 \\
\hline \multicolumn{9}{|l|}{$\begin{array}{l}\text { ACIDENTES DE TRABALHO E ÓBITOS } \\
\text { (números) }\end{array}$} \\
\hline Cuiabá - Várzea Grande & 847 & 877 & 985 & 1021 & 1184 & 1389 & 1608 & 1789 \\
\hline Interior de Mato Grosso & 2.684 & 2.779 & 3.120 & 3.231 & 3.749 & 4.396 & 5.273 & 5.228 \\
\hline $\begin{array}{l}\text { Óbitos - Cuiabá/Várzea } \\
\text { Grande }\end{array}$ & 26 & 28 & 19 & 21 & 29 & 23 & 25 & 27 \\
\hline Óbitos - interior & 106 & 110 & 77 & 82 & 97 & 118 & 122 & 113 \\
\hline
\end{tabular}


Tabela 1 - Matriz de produção agropecuária e de agravos à saúde. Mato Grosso 1998-2005 (cont.)

\begin{tabular}{|c|c|c|c|c|c|c|c|c|}
\hline Grupos & 1998 & 1999 & 2000 & 2001 & 2002 & 2003 & 2004 & 2005 \\
\hline \multicolumn{9}{|l|}{ OUTROS AGRAVOS (números) } \\
\hline $\begin{array}{l}\text { Intoxicações por agrotóxicos } \\
\text { - Cuiabá/Várzea Grande }\end{array}$ & 1 & 0 & 1 & 0 & 1 & 0 & 4 & 1 \\
\hline $\begin{array}{l}\text { Intoxicações por agrotóxicos } \\
\text { - interior }\end{array}$ & 33 & 34 & 50 & 56 & 78 & 107 & 118 & 102 \\
\hline $\begin{array}{l}\text { Acid. por animais } \\
\text { peçonhentos - Cuiabá/ } \\
\text { Várzea Grande }\end{array}$ & 0 & 3 & 1 & 0 & 46 & 61 & 42 & 65 \\
\hline $\begin{array}{l}\text { Acid. por animais } \\
\text { peçonhentos - interior }\end{array}$ & 61 & 102 & 145 & 207 & 487 & 639 & 582 & 655 \\
\hline $\begin{array}{l}\text { Internações por neoplasia } \\
\text { - Cuiabá/Várzea Grande }\end{array}$ & 1.260 & 1.502 & 1.938 & 1.472 & 3.040 & 3.553 & 3.253 & 3.422 \\
\hline $\begin{array}{l}\text { Internações por neoplasia } \\
\text { - interior }\end{array}$ & 1.895 & 1.819 & 2.075 & 1.942 & 3.692 & 4.392 & 4.554 & 5.675 \\
\hline $\begin{array}{l}\text { Internações por } \\
\text { malformações - Cuiabá/ } \\
\text { Várzea Grande }\end{array}$ & 153 & 189 & 243 & 166 & 456 & 518 & 401 & 314 \\
\hline $\begin{array}{l}\text { Internações por } \\
\text { malformações - interior }\end{array}$ & 225 & 236 & 240 & 247 & 677 & 761 & 780 & 600 \\
\hline $\begin{array}{l}\text { Óbitos por neoplasias - } \\
\text { Cuiabá - Várzea Grande }\end{array}$ & 354 & 411 & 447 & 446 & 400 & 470 & 548 & 552 \\
\hline $\begin{array}{l}\text { Óbitos por neoplasias - } \\
\text { interior }\end{array}$ & 577 & 713 & 771 & 765 & 849 & 951 & 972 & 1.022 \\
\hline $\begin{array}{l}\text { Óbitos por malformações } \\
\text { - Cuiabá/Várzea Grande }\end{array}$ & 39 & 52 & 69 & 61 & 61 & 71 & 61 & 63 \\
\hline $\begin{array}{l}\text { Óbitos por malformações } \\
\text { - interior }\end{array}$ & 120 & 123 & 152 & 127 & 136 & 135 & 170 & 154 \\
\hline
\end{tabular}

Fonte: Datasus (2007), Brasil (2007a, 2007b), IBGE (2007), Sinan-MT (2007).

Os dados da Tabela 1 mostram que houve uma duplicação, em oito anos, da área cultivada, da produção das lavouras temporárias (soja, milho, arroz, feijão, algodão e cana-de-açúcar) e de insumos citados, enquanto o número de bovinos cresceu em 64\%. A extração de madeira em toras aumentou em 12\% entre 1988 e 2002 e diminuiu em 40\% em 2005; a produção de lenha, usada principalmente para secagem de cereais após a colheita, aumentou em 
$28 \%$, enquanto a produção de calcário, para correção do solo para plantio, apresentou aumento de $100 \%$.

A produção agrícola (temporária) ocupou na safra de 2005 uma área de 8,8 milhões de hectares; a pecuária bovina foi manejada em cerca de 13,7 milhões de hectares de pastagem (referência de dois bois/hectare) e a agricultura permanente (café, coco, seringueiras, cítricos e frutas) ocupou cerca de $60 \mathrm{mil}$ hectares. Para manter aquele ritmo de produção, tem se desmatado entre $2 \%$ e 3\% da floresta/cerrado por ano, sendo que as regiões de maior produção (Rondonópolis, Sinop, Tangará da Serra, Diamantino, Alta Floresta, Pontes Lacerda e Cáceres) já destruíram entre 70\% e 80\% de seu ambiente natural, levando Mato Grosso a ser, nos últimos anos, o vice-campeão nacional de desmatamentos e queimadas do Brasil (Seplan-MT, 2006; Inpe, 2006).

Como a maioria dessa produção agrícola é dependente de alta tecnologia e de agroquímicos, utilizaram-se em 2005 cerca de 75 mil toneladas de agrotóxicos (produto comercial) ou consumo médio de $8,5 \mathrm{~kg}$ de agrotóxicos por hectare de lavoura temporária (Indea-MT, 2006); porém, deveríamos acrescentar os adquiridos sem receituário agronômico e os contrabandeados. Essa tecnologia tornou Mato Grosso o maior consumidor nacional desses tóxicos (inseticida, herbicida, fungicida e outros), perfazendo 19\% de todo o consumo brasileiro (Sindag, 2007).

Para aumentar a produtividade das várias culturas temporárias, houve a necessidade de se corrigir a qualidade dos solos, acrescentando-se nestes, em média, $250 \mathrm{~kg}$ de fertilizantes químicos $(\mathrm{N}+\mathrm{P}+\mathrm{K})$ por hectare/ano. Além disso, utilizou-se para a correção de acidez dos solos mato-grossenses, em média, uma tonelada de calcário agrícola/hectare a cada dois anos (Vale et al., 2001; Embrapa, 2002).

Esse tipo de manejo, aliado ao uso e 'abuso' de insumos e alta tecnologia agropecuária, contribuiu para aumentar a produtividade por hectare e a produção anual ao longo dos anos analisados. Entretanto, os responsáveis pela 'boa colheita agrícola' foram os trabalhadores que venderam e despenderam suas forças de trabalho e que, em conjunto com suas famílias e população do 'interior', realizaram um 'esforço produtivo' crescente nesse período.

Tal 'esforço produtivo' agropecuário foi definido, neste trabalho, como o volume ou número absoluto anual de determinada produção agropecuária ou florestal de uma região e sua relação com a respectiva população que contribuiu direta ou indiretamente na cadeia produtiva - nesse caso, a população do interior do estado. 
Com os dados da Tabela 1, calculou-se o indicador de 'esforço produtivo' por habitante do interior do estado e verificou-se que este foi, em 1988, de 2,24 hectares plantados/habitante ou 12 toneladas/habitante adicionadas do manejo de 10 bovinos/habitante e da retirada/beneficiamento de $1,53 \mathrm{~m}^{3}$ de madeira/habitante. Esses indicadores de esforço produtivo aumentaram linearmente até 2005, quando passaram para 4,36 hectares/habitante ou 20 toneladas/habitante e manejo de 14 bovinos/habitante. $O$ indicador de retirada/beneficiamento de madeira manteve-se estável até 2003, caindo para $0,88 \mathrm{~m}^{3}$ de madeira/habitante em 2005. Outros indicadores de 'esforços produtivos' (calcário agrícola e lenha) e de demandas de insumos/habitante (agrotóxicos, fertilizante e calcário) devem ser calculados para compor o somatório de esforços/habitante nesse processo de produção. A demanda de agrotóxicos (produto comercial) por habitante do 'interior' foi de $19 \mathrm{~kg} /$ habitante em 1998, passando para 37 kg/habitante em 2005.

Esses indicadores (Gráfico 1) apresentaram curvas ascendentes de esforços produtivos/habitante e de demanda de agrotóxicos/habitante, significando que aumentou a carga ou o peso do processo produtivo e crítico para a saúde de cada habitante do interior ou de cada município/região que apresentou esse comportamento no período. Tal situação pode ter significado aumento das situações de riscos, que se externalizaram por meio do incremento de alguns eventos de riscos à saúde humana nesse espaço social relacionado à cadeia produtiva do agronegócio, cuja análise se encontra a seguir.

\section{Situação Sanitária (Crítica) do ‘Interior’ de Mato Grosso}

$\mathrm{Na}$ análise dos indicadores de acidentes de trabalho, de intoxicações agudas por agrotóxico agrícola, de acidentes com animais peçonhentos, neoplasias e malformações congênitas, verificou-se que as incidências de todos eles aumentaram no período analisado, em curvas ascendentes relativamente paralelas com as curvas de esforços produtivos/habitante e de demanda de agrotóxicos/ habitante (Gráfico 1). 
Gráfico 1 - Correlações dos indicadores de produção e agravos à saúde. Interior de Mato Grosso - 1998-2005

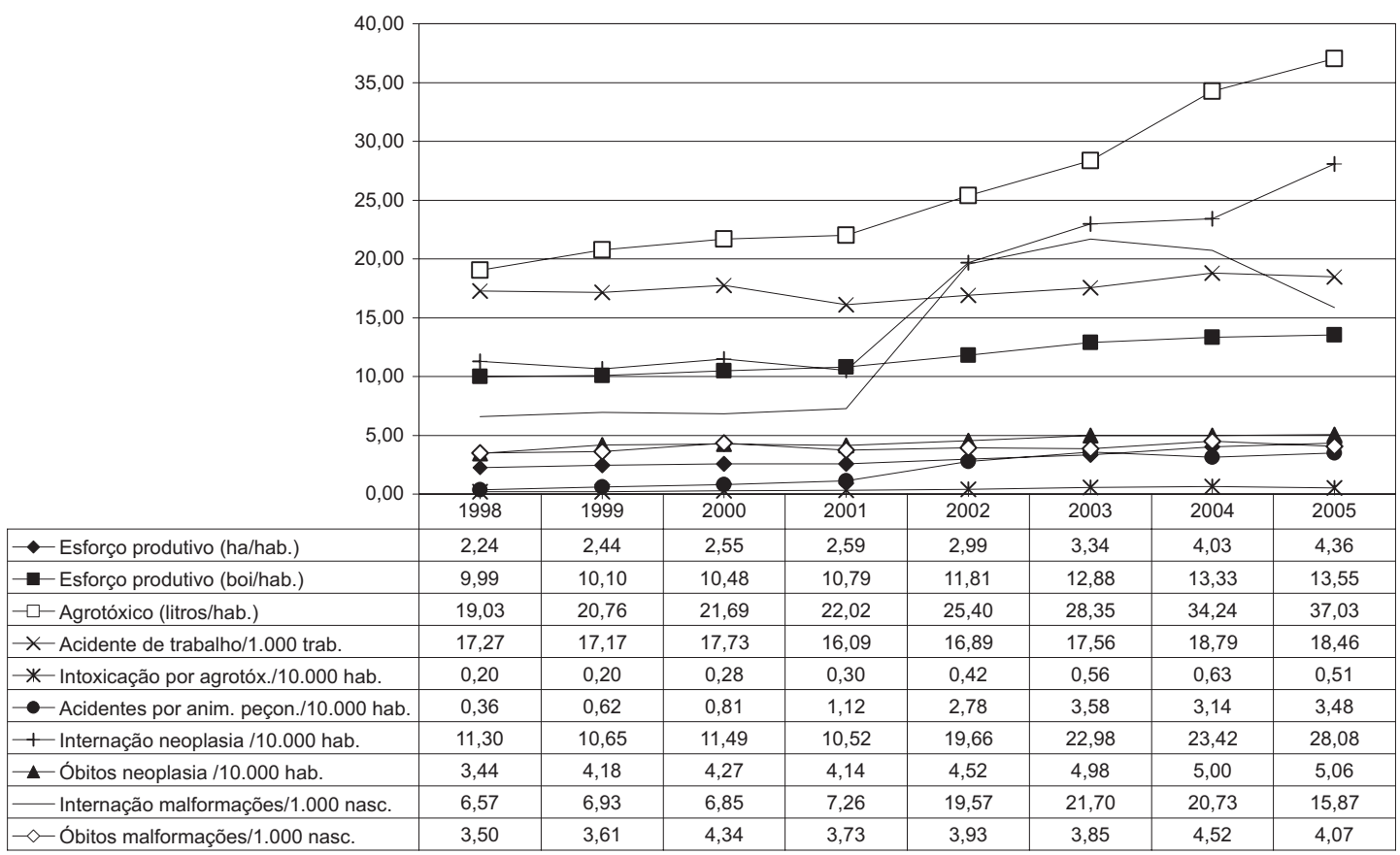

Fontes: Datasus (2007), Indea-MT (2006), Brasil (2007a, 2007b), IBGE (2007), Sinan-MT (2007).

$\mathrm{Na}$ análise estatística dos indicadores de cada série temporal (Moretin \& Toloi, 2004), todas as curvas se ajustaram, com intervalo de confiança de 95\%, em um único padrão de curva, ou seja, todas elas acompanharam, em correlação linear, as curvas de 'esforço produtivo' no período analisado (19982005). Essas observações indicam que quanto maior foram as quantidades de hectares plantados ou de manejo de bovinos por habitantes, maiores as incidências dos agravos dos trabalhadores, da população e dos nascidos vivos do interior de Mato Grosso.

Quando os indicadores foram analisados pela técnica de regressão linear (Draper \& Smith, 1998), verificou-se que os esforços produtivos e a demanda de agrotóxicos, quando pareados com as incidências de agravos e internações, apresentaram correlações positivas, com coeficientes de determinação variando de $32,2 \%\left(\mathrm{R}^{2}\right)$ a 94,2\% $\left(\mathrm{R}^{2}\right)$, descritos na Tabela 2. Cabe observar que a maioria dos coeficientes de correlação se concentrou na faixa de $76 \%$ a 94\%. Além disso, a adequação de todas as equações de regressão foi verificada pela análise residual, sendo adequada em todos os casos. 
Tabela 2 - Resumo das análises de regressão dos indicadores dos esforços produtivos e demanda de agrotóxicos com os agravos e internações. Interior de Mato Grosso - 1998-2005

\begin{tabular}{l|c|c|c}
\hline \multirow{2}{*}{ Variáveis independentes } & \multicolumn{3}{|c}{$\mathrm{R}^{2}$} \\
\cline { 2 - 4 } & $\begin{array}{c}\text { Esforço } \\
\text { produtivo } \\
\text { (ha/hab.) }\end{array}$ & $\begin{array}{c}\text { Esforço } \\
\text { produtivo } \\
\text { (boi/hab.) }\end{array}$ & $\begin{array}{c}\text { Agrotóxico } \\
\text { (litros/hab.) }\end{array}$ \\
\hline $\begin{array}{l}\text { Acidentes de } \\
\text { trabalho/1.000 trab. }\end{array}$ & 55,7 & 42,8 & 55,8 \\
\hline $\begin{array}{l}\text { Intoxicações por agrotóx./ } \\
10.000 \text { hab. }\end{array}$ & 78,8 & 93,2 & 78,7 \\
\hline $\begin{array}{l}\text { Acidentes por anim. } \\
\text { peçonhento/10.000 hab. }\end{array}$ & 77,5 & 93,5 & 77,4 \\
\hline $\begin{array}{l}\text { Internações por } \\
\text { neoplasias/10.000 hab. }\end{array}$ & 89,5 & 94,2 & 89,4 \\
\hline $\begin{array}{l}\text { Óbitos por } \\
\text { neoplasias/10.000 hab. }\end{array}$ & 78,8 & 85,1 & 78,8 \\
\hline $\begin{array}{l}\text { Internações por } \\
\text { malformações/1.000 nasc. } \\
\text { vivos }\end{array}$ & 55,2 & 76,3 & 55,1 \\
\hline $\begin{array}{l}\text { Óbitos por } \\
\text { malformações/1.000 nasc. } \\
\text { vivos }\end{array}$ & 36,9 & 32,2 & 37,0 \\
\hline
\end{tabular}

Por meio dos coeficientes de determinação (R2), a análise dos dados indicou que existe uma correlação positiva significante entre as incidências dos agravos (casos e óbitos) e internações hospitalares específicas com os 'esforços produtivos' agropecuários e demanda de agrotóxicos no 'interior' do estado de Mato Grosso no período analisado.

Quando se compararam os indicadores de agravos mostrados na Tabela 1 com os nacionais coletados nas mesmas fontes de dados, verificou-se que em Mato Grosso, no período de 1998 a 2005, a mortalidade por neoplasia por 100.000 habitantes passou de 41,5 para 57,1 (em curva ascendente), com aumento de $37 \%$, enquanto no Brasil esse indicador aumentou 14\%, de 68,4 para 78,6 (em curva ascendente). Nesse período, a mortalidade por 1.000 
nascidos vivos por malformações congênitas em Mato Grosso passou de 2,7 para 4,4 (em curva ascendente), com aumento de $62 \%$, sendo que no Brasil passou de 2,9 para 3,4 (em curva ascendente), com elevação de 17\%. Portanto, esses índices aumentaram mais rápido em Mato Grosso do que na média brasileira, ou cresceram na mesma proporção que a produção agropecuária desse estado (Tabela 1 e Gráfico 1). Tal situação sanitária indica a presença de situações específicas de riscos vinculados ao processo produtivo agropecuário dependente de agrotóxicos, dos quais parte deles é cancerígena, teratogênica ou mutagênica (Koifman, 2002; Stopelli \& Crestana, 2005; Cocco, 2002; Grisólia, 2005; Meyer et al., 2003; Meyer, Sarcinelli \& Moreira, 1999).

Além dessas correlações, quando se analisaram as séries temporais do número de internações hospitalares descritas na Tabela 1 observou-se que houve um incremento abrupto, passando de 3.414 em 2001 para 6.732 internações por neoplasias em 2002, e de 413 internações por malformações congênitas em 2001 para 1.133 em 2002 - sendo que a partir de 2002 seus patamares se mantiveram. Esse aumento súbito de casos pode estar relacionado a várias causas, entre elas o real acréscimo desses dois agravos devido ao 'uso e abuso' de agrotóxicos e/ou ampliação da oferta de leitos hospitalares para esses grupos de patologias. No caso das malformações congênitas, pode ter havido uma introdução abrupta de volume expressivo de novos poluentes teratogênicos no ambiente. No caso das neoplasias, isto pode significar as externalidades das exposições humanas após décadas do início das pulverizações por agrotóxicos cancerígenos nas lavouras e no combate de vetores de doenças infectoparasitárias, e/ou aumento das neoplasias agudas induzidas pela mesma causa.

A hipótese de novo poluente ambiental surgiu após se analisarem relatórios de consumo de agrotóxicos coletados pelo Indea-MT (2006), nos quais se observou aumento súbito e expressivo de consumo de fungicidas (cancerígenos/ teratogênicos?) para combater a 'nova praga da lavoura mato-grossense', a ferrugem asiática (Phokopsora pachyrhizi) da plantação de soja a partir de 2001 e/ou o aumento significativo de utilização de dessecantes para a colheita da soja transgênica com herbicidas mais tóxicos (cancerígenos/teratogênicos?) a partir da safra de 2003. Tal situação pode ter induzido situações de riscos (poluições ambientais e exposições humanas) e eventos de riscos à saúde nos municípios e/ou regiões em que ocorreu aquela fitopatologia e/ou porque se plantou soja transgênica e foi feito o manejo conforme descrito. 


\section{Acidentes de Trabalho em Mato Grosso: $70 \%$ estão relacionados aos PROCESSOS PRODUTIVOS DO AGRONEGÓCIO}

Para complementar os estudos da relação saúde-produção-agravos, foram analisados os acidentes de trabalho (ATs) ocorridos em Mato Grosso, de 2002 a 2005, distribuídos pela Classificação Nacional de Atividades Econômicas (CNAE). São mostrados na Tabela 3 os números somatórios dos quatros anos de trabalhadores por atividade econômica, de casos de ATs, de incapacidades permanentes e de óbitos, sendo que suas incidências foram calculadas pela média das incidências anuais de ATs notificadas pela CAT no sistema do MPS (Brasil, 2007a), tendo como denominador os número de empregos registrados pelo MTE (Brasil, 2007b).

Tabela 3 - Distribuição do número e incidências dos acidentes de trabalho segundo a CNAE. Mato Grosso - 2002-2005

\begin{tabular}{|c|c|c|c|c|c|c|c|c|}
\hline CNAE & $\begin{array}{l}\text { Total de } \\
\text { trabalha- } \\
\text { dores }\end{array}$ & $\begin{array}{l}\text { Acidentes } \\
\text { de } \\
\text { trabalho }\end{array}$ & $\begin{array}{l}\text { Percen- } \\
\text { tual por } \\
\text { grupo }\end{array}$ & $\begin{array}{l}\text { Incapa- } \\
\text { cidade } \\
\text { perma- } \\
\text { nente }\end{array}$ & Óbitos & $\begin{array}{l}\text { Incidên- } \\
\text { cia* }^{*}\end{array}$ & $\begin{array}{l}\text { Mortali- } \\
\text { dade }^{* *}\end{array}$ & $\begin{array}{l}\text { Letali- } \\
\text { dade }^{* * *}\end{array}$ \\
\hline & $\mathrm{n}^{\circ}$ & $\mathrm{n}^{\circ}$ & $\%$ & $\mathrm{n}^{\circ}$ & $\mathrm{n}^{\circ}$ & (média) & (média) & (média) \\
\hline Agricultura, pecuária & 221.939 & 4.967 & 20,2 & 141 & 128 & 22,3 & 58,1 & 26,2 \\
\hline $\begin{array}{l}\text { Silvicultura, exploração } \\
\text { florestal e pesca }\end{array}$ & 14.326 & 222 & 0,9 & 5 & 4 & 15,2 & 29,9 & 21,5 \\
\hline Extrativismo mineral & 5.517 & 233 & 0,9 & 5 & 5 & 40,8 & 103,5 & 26,2 \\
\hline $\begin{array}{l}\text { Abate e preparação de } \\
\text { animais (frigorifico) }\end{array}$ & 62.785 & 2.564 & 10,4 & 32 & 12 & 40,2 & 18,5 & 4,8 \\
\hline $\begin{array}{l}\text { Processamento de cereais, } \\
\text { óleos vegetais, laticínios } \\
\text { e ração }\end{array}$ & 19.887 & 721 & 2,9 & 16 & 11 & 35,4 & 57,4 & 19,0 \\
\hline $\begin{array}{l}\text { Fabricação de açúcar e } \\
\text { álcool }\end{array}$ & 18.878 & 1.008 & 4,1 & 19 & 4 & 52,7 & 20,6 & 4,6 \\
\hline $\begin{array}{l}\text { Beneficiamento de } \\
\text { algodão }\end{array}$ & 2.205 & 165 & 0,7 & 10 & 1 & 78,8 & 41,5 & 5,4 \\
\hline $\begin{array}{l}\text { Fabricação de bebidas, } \\
\text { biscoitos e massas }\end{array}$ & 12.749 & 491 & 2,0 & 12 & 2 & 38,3 & 15,7 & 4,3 \\
\hline $\begin{array}{l}\text { Tecelagem, fiação e } \\
\text { confecção }\end{array}$ & 6.023 & 40 & 0,2 & 0 & 1 & 6,2 & 19,0 & 22,7 \\
\hline $\begin{array}{l}\text { Curtimento de couro e } \\
\text { artefatos }\end{array}$ & 5.029 & 116 & 0,5 & 7 & 1 & 22,5 & 16,2 & 5,8 \\
\hline Indústria da madeira & 81.513 & 2.757 & 11,2 & 102 & 67 & 34,0 & 82,6 & 24,5 \\
\hline
\end{tabular}


Tabela 3 - Distribuição do número e incidências dos acidentes de trabalho segundo a CNAE. Mato Grosso - 2002-2005 (cont.)

\begin{tabular}{|c|c|c|c|c|c|c|c|c|}
\hline CNAE & $\begin{array}{l}\text { Total de } \\
\text { trabalha- } \\
\text { dores }\end{array}$ & $\begin{array}{l}\text { Acidentes } \\
\text { de } \\
\text { trabalho }\end{array}$ & $\begin{array}{l}\text { Percen- } \\
\text { tual por } \\
\text { grupo }\end{array}$ & $\begin{array}{l}\text { Incapa- } \\
\text { cidade } \\
\text { perma- } \\
\text { nente }\end{array}$ & Óbitos & $\begin{array}{l}\text { Incidên- } \\
\text { cia* }^{*}\end{array}$ & $\begin{array}{l}\text { Mortali- } \\
\text { dade }^{* *}\end{array}$ & $\begin{array}{l}\text { Letali- } \\
\text { dade*** }\end{array}$ \\
\hline & $\mathrm{n}^{\circ}$ & $\mathrm{n}^{\mathrm{o}}$ & $\%$ & $\mathrm{n}^{\circ}$ & $\mathrm{n}^{\circ}$ & (média) & (média) & (média) \\
\hline $\begin{array}{l}\text { Indústria gráfica e } \\
\text { reprodução em discos/ } \\
\text { fitas }\end{array}$ & 6.680 & 58 & 0,2 & 5 & 0 & 8,7 & 0,0 & 0,0 \\
\hline $\begin{array}{l}\text { Indústria química, vidro e } \\
\text { borracha }\end{array}$ & 9.899 & 190 & 0,8 & 2 & 3 & 19,1 & 32,3 & 16,8 \\
\hline $\begin{array}{l}\text { Fabricação de cimento e } \\
\text { artef. de cimento }\end{array}$ & 5.730 & 205 & 0,8 & 8 & 5 & 35,6 & 84,0 & 32,8 \\
\hline Cerâmicas & 8.184 & 141 & 0,6 & 9 & 1 & 17,3 & 12,2 & 7,4 \\
\hline $\begin{array}{l}\text { Metalurgia, fabricação } \\
\text { de máquinas e equip. } \\
\text { elétricos }\end{array}$ & 13.360 & 362 & 1,5 & 14 & 4 & 27,2 & 27,9 & 10,4 \\
\hline $\begin{array}{l}\text { Fabricação de reboque, } \\
\text { carrocerias, retífica e } \\
\text { sucatas }\end{array}$ & 2.728 & 53 & 0,2 & 5 & 0 & 19,2 & 0,0 & 0,0 \\
\hline $\begin{array}{l}\text { Fabric. de móveis de } \\
\text { madeira e metal, colchões }\end{array}$ & 6.321 & 125 & 0,5 & 0 & 1 & 19,8 & 14,1 & 6,9 \\
\hline $\begin{array}{l}\text { Fabric. de produtos } \\
\text { diversos (lapidação de } \\
\text { pedra, brinquedos, } \\
\text { escovas etc.) }\end{array}$ & 822 & 29 & 0,1 & 0 & 1 & 36,3 & 133,0 & 25,0 \\
\hline $\begin{array}{l}\text { Produção e distrib. de } \\
\text { eletric. e água e limpeza } \\
\text { urbana }\end{array}$ & 13.489 & 462 & 1,9 & 10 & 5 & 34,4 & 38,3 & 10,6 \\
\hline Construção civil e pesada & 54.574 & 1.426 & 5,8 & 41 & 39 & 26,3 & 71,1 & 27,8 \\
\hline $\begin{array}{l}\text { Comércio e reparação de } \\
\text { veículos }\end{array}$ & 89.050 & 937 & 3,8 & 24 & 29 & 10,4 & 32,9 & 32,3 \\
\hline Comércio atacadista & 59.665 & 789 & 3,2 & 16 & 23 & 13,2 & 39,3 & 30,6 \\
\hline Comércio varejista & 234.129 & 1.827 & 7,4 & 45 & 47 & 7,7 & 20,6 & 28,0 \\
\hline $\begin{array}{l}\text { Alojamento e } \\
\text { alimentação (hotel e } \\
\text { restaurante) }\end{array}$ & 36.783 & 217 & 0,9 & 10 & 7 & 5,9 & 18,2 & 30,6 \\
\hline $\begin{array}{l}\text { Transporte passageiro } \\
\text { terrestre, aéreo, marítimo } \\
\text { e ag. viagem }\end{array}$ & 32.242 & 435 & 1,8 & 19 & 17 & 13,5 & 51,0 & 37,6 \\
\hline $\begin{array}{l}\text { Transporte de cargas } \\
\text { rodoviário }\end{array}$ & 24.414 & 493 & 2,0 & 17 & 46 & 19,9 & 192,2 & 99,1 \\
\hline
\end{tabular}


Tabela 3 - Distribuição do número e incidências dos acidentes de trabalho segundo a CNAE. Mato Grosso - 2002-2005 (cont.)

\begin{tabular}{|c|c|c|c|c|c|c|c|c|}
\hline CNAE & $\begin{array}{l}\text { Total de } \\
\text { trabalha- } \\
\text { dores }\end{array}$ & $\begin{array}{l}\text { Acidentes } \\
\text { de } \\
\text { trabalho }\end{array}$ & $\begin{array}{l}\text { Percen- } \\
\text { tual por } \\
\text { grupo }\end{array}$ & $\begin{array}{l}\text { Incapa- } \\
\text { cidade } \\
\text { perma- } \\
\text { nente }\end{array}$ & Óbitos & $\begin{array}{l}\text { Incidên- } \\
\text { cia* }^{*}\end{array}$ & $\begin{array}{l}\text { Mortali- } \\
\text { dade** }^{* *}\end{array}$ & $\begin{array}{l}\text { Letali- } \\
\text { dade }^{* * *}\end{array}$ \\
\hline & $\mathrm{n}^{\mathrm{o}}$ & $\mathrm{n}^{\mathrm{o}}$ & $\%$ & $\mathrm{n}^{\circ}$ & $\mathrm{n}^{\circ}$ & (média) & (média) & (média) \\
\hline $\begin{array}{l}\text { Armazenagem, carga e } \\
\text { descarga }\end{array}$ & 6.988 & 133 & 0,5 & 1 & 10 & 18,9 & 139,9 & 63,5 \\
\hline $\begin{array}{l}\text { Correios e } \\
\text { telecomunicação }\end{array}$ & 9.978 & 251 & 1,0 & 3 & 6 & 27,4 & 69,2 & 24,4 \\
\hline $\begin{array}{l}\text { Intermediação financeira } \\
\text { (banco, seguros, previd.) }\end{array}$ & 23.540 & 124 & 0,5 & 9 & 2 & 5,2 & 8,5 & 25,3 \\
\hline $\begin{array}{l}\text { Ativid. imobil. e aluguéis } \\
\text { (resid., veículos e máq.) }\end{array}$ & 14.610 & 94 & 0,4 & 6 & 3 & 6,3 & 19,9 & 29,9 \\
\hline $\begin{array}{l}\text { Atividade de informática } \\
\text { e conexas }\end{array}$ & 20.930 & 54 & 0,2 & 0 & 1 & 3,6 & 3,8 & 41,7 \\
\hline $\begin{array}{l}\text { Atividades jurídica, } \\
\text { contábil, arquit., } \\
\text { engenharia, public. e } \\
\text { pesquisa }\end{array}$ & 14.797 & 106 & 0,4 & 6 & 4 & 7,1 & 25,5 & 32,0 \\
\hline $\begin{array}{l}\text { Prestação de serviços a } \\
\text { empresas (terceirização) }\end{array}$ & 61.124 & 773 & 3,1 & 13 & 25 & 12,7 & 42,4 & 34,3 \\
\hline Administração pública & 418.476 & 165 & 0,7 & 10 & 7 & 0,4 & 1,6 & 34,8 \\
\hline Educação & 34.019 & 83 & 0,3 & 3 & 3 & 2,4 & 8,3 & 37,2 \\
\hline Saúde e serviços sociais & 45.978 & 559 & 2,3 & 9 & 1 & 12,1 & 2,0 & 1,2 \\
\hline $\begin{array}{l}\text { Atividades assoc., recreat., } \\
\text { cult., desport., TV e rádio }\end{array}$ & 51.591 & 767 & 3,1 & 15 & 8 & 15,4 & 16,4 & 10,3 \\
\hline $\begin{array}{l}\text { Serviços pessoais } \\
\text { (lavanderia, cabeleireiro, } \\
\text { funerária) }\end{array}$ & 5.177 & 58 & 0,2 & 0 & 4 & 11,1 & 79,7 & 74,1 \\
\hline Serviços domésticos & 892 & 17 & 0,1 & 0 & 3 & 19,1 & 354,1 & 166,7 \\
\hline Ignorado & 0 & 398 & 1,6 & 138 & 21 & 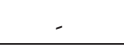 & 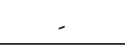 & 52,9 \\
\hline Total & 1.757 .021 & 24.615 & 100,0 & 787 & 562 & 14,0 & 32,2 & 23,2 \\
\hline
\end{tabular}

Obs: ${ }^{*}$ por 1.000 trabalhadores; ${ }^{* *}$ por 100.000 trabalhadores; ${ }^{* * *}$ por 1.000 acidentes.

Fonte: Brasil (2007a, 2007b).

Como os dados de CAT referem-se apenas aos trabalhadores com vínculo empregatício formal, eles podem representar menos de 10\% dos ATs totais ocorridos em Mato Grosso. Segundo Silva (2000) e Cristófolli (2005), naquele estado notificaram-se por meios das CATs apenas $11 \%$ dos acidentes ocorri- 
dos em Cuiabá/Várzea Grande e 5\% dos ocorridos no 'interior do estado'. No Brasil, a média de notificação era de 20\% dos ATs, segundo Machado e Gómez (1995), Wünsch Filho (1999) e em revisão de Santana, Nobre e Waldvogel (2005).

Em Mato Grosso, os ATs vinculados diretamente ao agronegócio, conforme descritos na Tabela 3, incluem os ocorridos na agropecuária (20,2\%), nas indústrias da madeira (11,2\%), nos frigoríficos de bovinos, suínos e aves (10,4\%), na fabricação de açúcar e álcool (4,1\%), no processamento de cereais, leite e rações $(2,9 \%)$, no beneficiamento de algodão $(0,7 \%)$, nos curtumes de couros bovinos $(0,5 \%)$ e no extrativismo/silvicultura/pesca $(0,9 \%)$, os quais somam 50,9\% do total dos ATs do período. Além disso, dos seis setores da CNAE que apresentaram maior número de acidentes, quatro estavam vinculados diretamente à cadeia produtiva da agropecuária. Ou seja: em primeiro lugar aparece o setor agropecuário; em seguida (segundo lugar), a indústria madeireira; em terceiro, o setor de frigoríficos; em quarto, o comércio varejista; em quinto, a construção civil/pesada; e em sexto, as usinas de açúcar e álcool.

Quando se acrescenta àquele percentual de 50,9\% parcelas dos acidentes também ligados à agropecuária, como os de transporte de cargas rodoviário, armazenamento/carga/descarga de cereais, comércio atacadista, reparação de veículos de carga e máquinas agrícolas, construção civil pesada (pontes e estradas) e extrativismo mineral (calcário agrícola), pode-se inferir que em torno de $70 \%$ dos ATs registrados pelas CATs em Mato Grosso estão vinculados ao agronegócio. A distribuição dos números de ATs fatais e com incapacidade permanente mostrou ser semelhante à descrição anterior.

Quanto à média das incidências dos ATs, notou-se que a agropecuária ocupa o $15^{\circ}$ lugar entre os 41 setores analisados, porém a maior incidência foi no setor de beneficiamento de algodão, aparecendo em segundo lugar o de usinas de açúcar/álcool; em terceiro, o de extrativismo mineral (ouro, diamante, brita e calcário); em quarto, o de frigoríficos; em quinto, o setor de fábricas de bebidas/biscoitos/massas; em sexto, o setor de fábrica de cimento e seus artefatos; em sétimo, o processamento de cereais; e em oitavo, o da indústria madeireira. Porém, os maiores números em relação a uso/gastos com serviços de saúde/previdência e prejuízos na economia local/regional estão localizados naqueles setores que mais induzem casos de ATs, de incapacidades e de acidentes com óbitos, ou seja, os ligados ao agronegócio.

Se retornarmos aos dados de ATs da Tabela 1 e do Gráfico 1 e compararmos com dados nacionais, expressos nos Anuários Estatísticos de Acidentes 
de Trabalho (Brasil, 2007a), pode-se verificar que, no período de 1998 a 2005 no Brasil, o número absoluto e a incidência dos ATs notificados pelas CATs vieram diminuindo até 2003, com pequeno aumento em 2004 e 2005, enquanto os de Mato Grosso vêm aumentando numa curva ascendente, passando de 3.531 acidentes em 1998 para 7.017 em 2005, e a incidência de ATs passou de 12,8 para 15,2 acidentes/1.000 trabalhadores, também em curva ascendente. Além disso, a mortalidade por ATs, mesmo diminuindo de 48 para 30 óbitos/100 mil trabalhadores, tornou Mato Grosso campeão nacional de mortes por acidente de trabalho; mesmo com sua letalidade passando de 37 para 20 mortes/ 1.000 acidentes, o estado tornou-se vice-campeão nacional desse máximo agravo à saúde dos trabalhadores.

Além disso, pelas incidências de ATs anuais, de 1998 a 2005, calculadas com os dados da Tabela 1 , verificou-se que esse indicador de agravos ocorridos no 'interior' é cerca de 2,5 vezes maior que os de Cuiabá/Várzea Grande ou o dobro disso, visto que o percentual de notificação de ATs no interior de Mato Grosso é metade em relação àquele da capital (Silva, 2000; Cristófolli, 2005). Tal resultado indica que há cinco vezes mais situações de riscos na agropecuária e/ou que há um menosprezo do agronegócio à promoção da saúde-segurança no trabalho.

\section{Vigilância da Saúde-Ambiente ou da Saúde do Agronegócio?}

Para complementarmos a análise da matriz de produção agropecuária e de agravos, indo além da dimensão quantitativa ou de produção versus morbimortalidade já analisada, ampliou-se para a dimensão social, requerida pela complexidade dos problemas sanitários do 'interior', e realizaram-se estudos da relação de vigilância-produção-controle social, como se nomeou neste capítulo.

O espaço agropecuário se constrói de maneira semelhante a outros espaços desse sistema capitalista, ou seja, com conflitos sociais, que têm como grupos de interesses os empresários do agronegócio, a população, os trabalhadores, o Estado, os grupos organizados, a mídia local/nacional e os pesquisadores, entre outros, que se relacionam como uma rede social e de vigilância à saúde, conforme indicam Machado e Porto (2003). Porém, o Estado, que deveria mediar/regular ou controlar os conflitos e riscos para conformar uma sociedade que busca o desenvolvimento sustentável (democrático, igualitário, eficiente e saudável), como não é neutro, vem atuando a favor da classe patronal há décadas (Oliveira, 2005; Picoli, 2005; Breilh, 2003; Miranda et al., 2007). 
As explicitações das observações anteriores são frequentes no Brasil; como exemplo, citam-se os 'tratoraços' (passeatas com tratores agrícolas) na Esplanada dos Ministérios em Brasília em 2002 e 2005, realizados e coordenados pelos grandes fazendeiros de Mato Grosso e de outras regiões agroprodutoras (Acuado, 2005). Isto resultou em favorecimento público dos governos federal e estadual, em forma de subsídios agrícolas, refinanciamentos privilegiados, perdão de impostos/dívidas e flexibilizações das legislações de biossegurança e dos agrotóxicos que ampliam os danos à saúde e ao ambiente.

Entretanto, os pequenos agricultores não dispõem daquelas 'facilidades', pois trabalham em regime familiar e/ou são posseiros, produzem para a subsistência e, quando necessitam de financiamentos para insumos ou custeio agrícola, a maioria tem suas solicitações negadas pelas instituições bancárias. Além disso, suas produções terão de ser vendidas aos patrões do agronegócio, sujeitando-se aos seus preços e prazos de comercialização (Picoli, 2005; Teófilo, 2001). Suas pequenas propriedades estão circundadas pelas grandes fazendas e sujeitas às poluições ambientais por agrotóxicos, como ocorreu em Lucas do Rio Verde (MT), onde as derivas de pulverizações de agrotóxicos, frequentes no estado, destruíram as plantações de 65 chácaras em 2006, causando grande impacto sanitário e ambiental (Pignati, Machado \& Cabral, 2007).

Além disso, Mato Grosso ocupa o segundo lugar brasileiro em conflitos agrários e em práticas de trabalho semelhante a escravo nas grandes fazendas de seu interior (Brasil, 2007c); também fazem parte do seu cotidiano o movimento popular dos 'sem-terras' e as prisões ou expulsões de posseiros e quilombolas (Picoli, 2005). Quanto aos índios, buscando melhorar a qualidade de suas vidas, perambulam pelas cidades 'mendigando' por serviços de saúde/educação ou por políticas públicas que respeitem sua soberania e cidadania, além de procurarem meios de barrar as degradações de seu ambiente provocadas por madeireiras, mineradoras e fazendas circunvizinhas de seus parques nacionais (Oliveira, 2005; Picoli, 2005).

Quanto ao sistema público responsável pela vigilância sanitária (no sentido amplo de saúde), este vem privilegiando a saúde agropecuária em detrimento da saúde humana. Em Mato Grosso, por exemplo, a vigilância sanitária animal/vegetal, coordenada e executada pelo Indea, possuía em 20061.238 funcionários, 242 veículos e escritórios de apoio técnico aos agropecuaristas em todos os municípios do estado, além das secretarias municipais de Agricultura. Consta ainda, nos relatórios de atividades do Indea, que a maioria das atividades teve como objetivos controlar a febre aftosa, ferrugem da soja, 
bicudo-do-algodão, cigarrinha-do-pasto e outras pragas da lavoura, além de fiscalizar, por meio das normas legais, a utilização de agrotóxicos e a devolução de suas embalagens vazias. Relataram-se também exames laboratoriais de animais/plantas doentes e/ou suspeitas e classificação de cereais e madeiras para a comercialização. Isto mostra uma das dimensões de gastos de recursos públicos voltados para controlar doenças de plantas e animais que são propriedades privadas dos agropecuaristas.

A Secretaria de Estado de Saúde (SES), que implantou no 'interior do estado' uma estrutura de 15 escritórios regionais de saúde, tinha, em 2006, 18 veículos e 183 funcionários para, entre outras atividades, executar a vigilância à saúde (de média e alta complexidades) e dar suporte técnico às vigilâncias municipais que não haviam implantado como rotina a vigilância em saúde ambiental e do trabalhador nos seus serviços (SES, 2006a). Além disso, as atividades da SES, específicas de vigilância em saúde dos trabalhadores, estavam implantadas em apenas um Centro de Referência Estadual em Saúde dos Trabalhadores (Cerest), que contava com oito técnicos e um veículo para dar suporte a todo o estado. Apesar de Mato Grosso executar modelo de desenvolvimento 'agroquímico dependente', o sistema de vigilância sanitária e ambiental da SES continua monitorando/fiscalizando apenas a qualidade dos alimentos e água potável, sem incluir nas análises laboratoriais os resíduos de agrotóxicos, fertilizantes químicos e metais pesados. Portanto, é a aplicação da política do 'Estado mínimo' para os serviços de vigilância à saúde humana e ambiental (públicas) e do 'Estado máximo' para controlar e/ou vigiar a saúde de plantas e animais (privadas). Ou seja: há privilégios públicos para o 'SUS da soja e do boi' em detrimento do SUS para a saúde humana e ambiental de Mato Grosso.

As fiscalizações em segurança e medicina nos ambientes de trabalho realizadas pela Delegacia Regional do Trabalho e Emprego (DRTE-MT) durante 2005 foram executadas por apenas três engenheiros e dois médicos do trabalho, apoiados por doze técnicos e oito veículos para todo o estado de Mato Grosso (141 municípios em 0,97 milhão de quilômetros quadrados). Além disso, das 2.811 fiscalizações realizadas naquele ano, apenas 161 foram em madeireiras, 104 foram em fazendas agropecuárias, 44 em usinas de açúcar/álcool, 16 em frigoríficos; as restantes (89\%) foram realizadas nas sedes de alguns municípios com foco nos setores de comércio, serviços, construção civil e indústrias urbanas. Portanto, não se priorizou o setor produtivo agropecuário predominante no estado (DRTE/MT, 2006). 
Quanto à organização dos trabalhadores rurais e sua participação na relação vigilância-produção-controle social, cita-se o relatório de pesquisa "Vigilância em saúde dos trabalhadores rurais de Mato Grosso - 2006", realizado pelo Instituto de Saúde Coletiva da Universidade Federal de Mato Grosso (ISC/ UFMT), Federação dos Trabalhadores da Agricultura (Fetagri) e Cerest, no qual se verificou que, dos 38 sindicatos de trabalhadores rurais pesquisados dentre os 81 existentes no estado, 70\% apresentavam índice de sindicalização de sua base sindical em torno de 3\% (Pignati, 2006). Observou-se ainda que as maiores reclamações dos sindicalizados aos diretores sindicais foram o não cumprimento dos contratos de trabalho (formal e informal), excesso de trabalho além das 44 horas semanais, ATs, intoxicações por agrotóxicos e pouca assistência à saúde-doença. Além disso, a maioria (96\%) não praticou ações e não acionou nenhuma entidade estatal no sentido de controlar/eliminar os riscos à saúde dos trabalhadores. A maioria das entrevistas, decodificadas e anotadas no relatório, pode ser resumida na fala de um presidente: "Não ganhamos nenhuma causa na Justiça do Trabalho, é muito difícil; pra todos os lados existe gente do patrão ou quem defenda essa beleza de agricultura de Mato Grosso".

A organização sindical dos trabalhadores nas indústrias madeireiras do estado de Mato Grosso mostrou-se semelhante à caracterização dos rurais, pois de acordo com Pignati e Machado (2005), que analisaram este setor produtivo do agronegócio, $8 \%$ dos operários das 1.389 indústrias madeireiras pesquisadas eram sindicalizados, e quanto mais as madeireiras se afastavam das sedes dos municípios 'em direção ao mato', mais esse índice se reduzia, enquanto aumentava o nível de precarização das condições de trabalho e saúde dos trabalhadores.

Observou-se ainda, em outro documento, que o Conselho Estadual de Saúde (CES) de Mato Grosso foi caracterizado como "controle social burocrático e controlado pelo Estado para atender aos interesses do agronegócio”, descrito por Silva (2007: 8), que analisou suas atividades de formulação de políticas de saúde e controle de sua execução. Como exemplo dessa caracterização, citou-se que este conselho decidiu, em reunião do dia 3/5/2006, priorizar para 2007 as seguintes ações: 1) implantar o Centro de Vigilância Ambiental a Produtos Tóxicos (Civitox); 2) implantar o Programa de Análises de Resíduos de Agrotóxicos em Alimentos (PARA); 3) cumprir a portaria MS/Anvisa n. 518/2004 (qualidade da água potável); e 4) realizar esforços interinstitucionais para evitar novos acidentes sanitário-ambientais causados por derivas 
de pulverizações de agrotóxicos (Mato Grosso, 2006a). Porém, constatou-se na análise da Programação Anual Pactuada de Saúde da Secretaria Estadual de Saúde para 2007 (SES, 2006a) e da Lei Orçamentária Estadual de 2007 (Mato Grosso, 2006b) que aquelas atividades aprovadas pelos conselheiros não constavam nos documentos.

Considera-se que esses desequilíbrios da vigilância-produção-controle social foram reflexo da realidade de desorganização dos trabalhadores e do papel do Estado como estruturante do neoliberalismo, contribuindo com o capital na ampliação da exploração dos recursos naturais e da força de trabalho, sendo determinantes das situações de riscos à saúde-ambiente induzidos pelo desenvolvimento econômico de Mato Grosso.

\section{Considerações Finals}

Com base na análise de inter-relações criadas no espaço social do 'interior do estado' de Mato Grosso, ou seja, a de produção-saúde-agravos e vigilânciaprodução-controle social, mostra-se que essas ações complexas formaram uma rede de processos críticos para a saúde-ambiente que promoveram os agravos específicos e internações hospitalares analisados neste estudo e provavelmente outros não investigados (danos ambientais).

O indicador de 'esforço produtivo', que relaciona o quantitativo de produção agropecuária ou florestal de uma região com a sua respectiva população que contribui na execução das etapas da cadeia produtiva agroindustrial-florestal, foi um importante instrumento de análise nesta pesquisa. Ele permitiu visualizar a correlação produção-agravo e indicar que sua relação vai além dos trabalhadores, atingindo a população regional na qual se desenvolve o agronegócio. Tal verificação nos indica que esse modelo de desenvolvimento econômico deverá ser tratado como problema de saúde pública pelas implicações diretas de seus agravos à saúde-ambiente e dos custos sanitários, previdenciários e sociais que são arcados/financiados com recursos públicos.

Os desequilíbrios da relação de vigilância-produção-controle social nos indicaram a dinâmica social e econômica imposta por esse setor do neoliberalismo em Mato Grosso e que podem ser considerados como reflexos dos seguintes fatores: 1) forças de poder político - originadas na desorganização sindical dos trabalhadores e dos privilégios de políticas públicas concedidas pelo Estado às instituições do agronegócio; 2) injustiça social - no sentido de desigualdade de direitos humanos; e 3) injustiça ambiental - rápida ex- 
ploração dos recursos naturais para aumentar a produtividade agropecuária com prejuízo socioambiental para a maioria da população. Eles podem ser apontados como as causas básicas das situações de riscos à saúde-ambiente induzidos pelo desenvolvimento agroindustrial-florestal.

Com a análise do processo produtivo do agronegócio, por meio da matriz de produção agropecuária e de agravos à saúde, se contribuiu para mostrar que esta metodologia pode ser útil, como estratégia, para o estabelecimento de agendas políticas e de saúde pública, tais como: 1) cálculo do esforço produtivo por habitante para se estimar a carga de trabalho e os efeitos na saúde dos trabalhadores e da população de determinada região e/ou município; 2) produção de dados estimativos dos efeitos das monoculturas e do uso intensivo de agrotóxicos e fertilizantes químicos sobre a saúde humana e ambiental; 3) cálculo dos custos sanitários, previdenciários, sociais e econômicos decorrentes desse modelo agropecuário; 4) construção de cenários comparativos de alternativas a esse modelo de desenvolvimento que baixem o nível de poluição e de agravos relacionados; e 5) necessidade de construção de políticas públicas intersetoriais e multidisciplinares entre as instituições responsáveis pela saúde pública, agricultura, meio ambiente, trabalho e universidades.

Há necessidade de aprofundar essas sugestões e colocar em debate as estratégias para mudar a situação sociossanitária das regiões brasileiras em que se desenvolve o agronegócio, não permitindo que somente os responsáveis pela 'boa colheita agrícola', ou seja, os trabalhadores, suas famílias e população do 'interior', arquem com o ônus sociossanitário advindo desse processo.

Entende-se a necessidade urgente de implantação imediata do sistema de vigilância ambiental e de saúde do trabalhador em todos os municípios brasileiros, articulados de forma intersetorial e coordenados pelo SUS; implementação do movimento popular de difusão de informações sobre o 'uso e abuso’ dos agrotóxicos e seus agravos agudos e crônicos à saúde e ambiente; implantação imediata de novas medidas de regulação e controle que impeçam a produção e/ou importação de agrotóxicos extremamente tóxicos e/ou com potencial carcinogênico/teratogênico/mutagênico; proibição imediata de pulverização por avião agrícola de todos os tipos/classes de agrotóxicos; ampliação da participação da saúde coletiva nos movimentos sociais que lutam pela justiça socioambiental. 


\section{REFERÊNCIAS}

ACUADO, Governo volta a ceder a ruralistas. Folha de S.Paulo, 30 jun. 2005. p. B1. AUGUSTO, L. G. \& FREITAS, C. M. Princípio da precaução no uso de indicadores de riscos químicos ambientais em saúde do trabalhador. Ciência $\mathcal{E}$ Saúde Coletiva, 3(2): 85-95, 1988.

AUGUSTO, L. G.; FLORÊNCIO, L. \& CARNEIRO, R. M. (Orgs.) Pesquisa(ação) em Saúde Ambiental: contexto - complexidade - compromisso social. Recife: Ed. Universitária UFPE, 2001.

BRASIL. Ministério da Previdência Social. Sistema de Comunicação de Acidentes de Trabalho (CAT): banco de dados por estado e municípios, 2002-2005. Disponível em: <www.mps.gov.br>. Acesso em: abr. 2007a.

BRASIL. Ministério do Trabalho e Emprego. Cadastro Geral de Empregados e Desempregados (Caged/Rais). Brasília: MTE, 2007b. Disponível em: <www.mte.gov. br>. Acesso em: abril de 2007b.

BRASIL. Ministério do Trabalho e Emprego. Portaria MTE n. 540/2004. Lista de infratores que exploravam trabalhadores na condição análoga a escravo. Brasília: MTE, 2007b. Disponível em: 〈www.mte.gov.br/trab_escravo/lista_25_01.pdf〉. Acesso em: abr. 2007c. BREILH, J. De la vigilancia convencional al monitoreo participativo. Ciência Ë Saúde Coletiva, 8(4): 937-951, 2003.

BREILH, J. Epidemiologia Crítica: ciência emancipadora e interculturalidade. Rio de Janeiro: Editora Fiocruz, 2006.

CÂMARA, V. M. et al. Saúde ambiental e saúde do trabalhador: epidemiologia das relações entre a produção, o ambiente e a saúde. In: ROUQUARIOL, M. Z. \& ALMEIDA FILHO, N. (Orgs.) Epidemiologia EF Saúde. Rio de Janeiro: Medsi, 2003.

COCCO, P. On the rumors about the silent spring: review of the scientific evidence linking occupational and environmental pesticide exposure to endocrine disruption health effects. Cadernos de Saúde Pública, 18(2): 379-402, 2002.

CRISTÓFOLLI, D. R. A Vigilância à Saúde e as Subnotificações dos Acidentes de Trabalho no Estado de Mato Grosso, 2005. Monografia (especialização), Cuiabá: ISC, Universidade Federal de Mato Grosso, 2005.

DATASUS (Sistema de Informática do SUS). Dados de Mortalidade e Morbidade por Estado, Classificados pela CID-10. Brasília: Datasus, 2007. Disponível em: <www.datasus. gov.br>. Acesso em: 22 mar. 2007.

DELGADO, G. C. Expansão e modernização do setor agropecuário no pós-guerra: um estudo da reflexão agrária. Estudos Avançados, 15(43): 157-172, 2001.

DRAPER, N. R. \& SMITH, H. Applied Regression Analysis. New York: John Wiley \& Sons, 1998.

DRTE/MT (Delegacia Regional do Trabalho e Emprego do Mato Grosso). Relatório Anual de Fiscalização em Segurança e Medicina do Trabalho. Cuiabá: DRTE, 2006. 
DRUCK, G. \& FRANCO, T. A degradação do trabalho e os riscos industriais no contexto da globalização produtiva e das políticas neoliberais. In: FRANCO, T. (Org.) Trabalho, Riscos Industriais e Meio Ambiente: rumo ao desenvolvimento sustentável? Salvador: EdUFBA, 1997.

EMBRAPA (Empresa Brasileira de Produtividade Agrícola). Série Técnica de Adubação no Cerrado Brasileiro. Brasília: Embrapa, 2002.

FARIA, N. et al. Processo de produção rural e saúde na serra gaúcha: um estudo descritivo. Cadernos de Saúde Pública, 16(1): 115-128, 2000.

FRANÇA, F. O. S. et al. Acidentes e doenças do trabalho provocados por animais peçonhentos. In: MENDES, R. (Org.) Patologia do Trabalho. São Paulo: Atheneu, 2003.

FREITAS, C. M. Ciência para a sustentabilidade e a justiça ambiental. In: ACSELRAD, H.; HERCULANO, S. \& PÁDUA, J. A. Justiça Ambiental e Cidadania. Rio de Janeiro: Relume Dumará, 2004.

FUNTOWICH, S. \& DE MARCHI, B. Ciencia posnormal, complejidad reflexiva y sustentabilidad. In: LEFF, E. (Org.) La Complejidad Ambiental. México: Siglo XXI, 2000.

GRISÓLIA, K. C. Agrotóxicos: mutações, reprodução e câncer. Brasília: Editora UnB, 2005.

GUIVANT J. S. Reflexidade na sociedade de risco: conflitos entre leigos e peritos sobre os agrotóxicos. In: HERCULANO, S.; PORTO, M. F. S. \& FREITAS, C. M. (Orgs.) Qualidade de Vida Eु Riscos Ambientais. Niterói: EdUFF, 2000.

IBGE (Instituto Brasileiro de Geografia e Estatísticas). Brasil: série histórica de área plantada; série histórica de produção agrícola - safras 1998 a 2005. Brasília: IBGE, 2007. Disponível em: <www.mapa.gov.br> e <www.sidra.ibge.gov.br>. Acesso em: mar. 2007.

INDEA-MT (Instituto de Defesa Agropecuária de Mato Grosso). Sistema de Informação de Agrotóxico. Relatório de Consumo de Agrotóxicos em Mato Grosso. Cuiabá: Indea-MT, 2006.

INDEA-MT (Instituto de Defesa Agropecuária de Mato Grosso). Relatório de Atividades (estatísticas e resultados). Cuiabá: Indea, 2007. Disponível em: 〈www.indea.mt.gov.br〉. Acesso em: 13 abr. 2007.

INPE (Instituto Nacional de Pesquisas Espaciais). Estimativas Anuais do Desflorestamento desde 1988. Projeto Prodes: monitoramento da floresta Amazônica brasileira por satélite, 2006. Disponível em: <www.obt.inpe.br/prodes/prodes_1988_2005.htm>. Acesso em: 25 out. 2006.

INPM (Instituto Nacional de Produção Mineral). Série Histórica de Produção Mineral do Mato Grosso: 1998 a 2005. Cuiabá: DNPM-MT, 2006.

KOIFMAN, S. Human reproductive system disturbances and pesticide exposure in Brazil. Cadernos de Saúde Pública, 18(2): 435-445, 2002.

LAURELL, A. C. A saúde-doença como processo social. In: NUNES, E. D. (Org.) Medicina Social: aspectos históricos e teóricos. Rio de Janeiro: Global, 1983.

LEFF, E. Saber Ambiental: sustentabilidade, racionalidade, complexidade, poder. Petrópolis: Vozes, 2001. 
MACHADO, J. H. M. O Processo de Vigilância em Saúde do Trabalhador, 1996. Tese de doutorado, Rio de Janeiro: Escola Nacional de Saúde Pública Sergio Arouca, Fundação Oswaldo Cruz.

MACHADO, J. H. M. \& GOMEZ, C. M. Acidentes de trabalho: concepções e dados. In: MINAYO, M. C. (Org.) Os Muitos Brasis: saúde e população na década de 80. São Paulo: Hucitec, 1995.

MACHADO, J. H. M. \& PORTO, M. F. S. Promoção da saúde e intersetorialidade: a experiência da vigilância em saúde do trabalhador na construção de redes. Epidemiologia e Serviços de Saúde, 12(3): 121-131, 2003.

MATO GROSSO. Conselho Estadual de Saúde. Ata da reunião dos conselheiros do dia 3 de maio de 2006. Cuiabá: CES-MT, 2006a.

MATO GROSSO. Lei n. 867/2006. Estima a receita e fixa a despesa do estado de Mato Grosso para o exercício financeiro de 2007. Diário Oficial de Mato Grosso, 29 dez. 2006b.

MATTOS, L. \& MACHADO, J. M. H. O mundo do trabalho e sua relação com a saúde e o ambiente. In: II SEMINÁRIO NACIONAL DE SAÚDE AMBIENTE. Rio de Janeiro: Fiocruz, 2002. (Série Fiocruz: Eventos Científicos, 4)

MEDRONHO, R. A. Estudos ecológicos. In: MEDRONHO, R. A. (Org.) Epidemiologia. São Paulo: Atheneu, 2003.

MEYER, A.; SARCINELli, P. N. \& MOREIRA, J. C. Estarão alguns grupos populacionais brasileiros sujeitos à ação de disruptores endócrinos? Cadernos de Saúde Pública, 15(4): 845-850, 1999.

MEYER, A. et al. Cancer mortality among agricultural workers in serrana region, State of Rio de Janeiro, Brasil. Environmental Research, 93(3): 264-271, 2003.

MINAYO, M. C. Hermenêutica-dialética como caminho do pensamento social. In: MINAYO, M. C. \& DESLANDES, S. F. (Orgs.) Caminhos do Pensamento: epistemologia e métodos. Rio de Janeiro: Editora Fiocruz, 2002.

MINAYO, M. C. \& SANCHES, O. Quantitativo-qualitativo: oposição ou complementaridade? Cadernos de Saúde Pública, 9(3): 239-262, 1993.

MIRANDA, A. C. et al. Neoliberalismo, uso de agrotóxicos e a crise da soberania nacional. Ciência Eु Saúde Coletiva, 12(1): 7-14, 2007.

MORETIN, P. A. \& TOLOI, C. M. C. Análise de Séries Temporais. 2. ed. São Paulo: Edgar Blucher, 2004.

OLIVEIRA, A. U. BR-163 Cuiabá-Santarém: geopolítica, grilagem, violência e mundialização. In: TORRES, M. (Org.) Amazônia Revelada: os descaminhos ao longo da BR-163. Brasília: CNPq, 2005.

PERES, F. \& MOREIRA, J. C. (Orgs.) É Veneno ou Remédio? Agrotóxicos, saúde e ambiente. Rio de Janeiro: Editora Fiocruz, 2003.

PERES, F. et al. Desafios ao estudo da contaminação humana e ambiental por agrotóxicos. Ciência E⿱ Saúde Coletiva, 10(supl. out/dez): 27-37, 2005. 
PICOLI, F. Amazônia: a ilusão da terra prometida. Sinop, MT: Editora Fiorelo, 2004.

PICOLI, F. Amazônia e o Capital: uma abordagem do pensamento hegemônico e do alargamento da fronteira. Sinop, MT: Amazônia Editora, 2005.

PIGNATI, W. A. Vigilância em Saúde dos Trabalhadores Rurais de Mato Grosso - 2006. (Convênio ISC-UFMT, Fetagri-MT e Cerest-MT). Relatório de pesquisa. Cuiabá: ISC/UFMT, 2006.

PIGNATI, W. A. \& MACHADO, J. M. H. Riscos e agravos à saúde e à vida dos trabalhadores das indústrias madeireiras de Mato Grosso. Ciência Eु Saúde Coletiva, 10(4): 961-973, 2005.

PIGNATI, W. A.; MACHADO, J. M. H. \& CABRAL, F. M. Acidentes rurais ampliados: o caso das "chuvas" de agrotóxicos sobre a cidade de Lucas do Rio Verde, MT. Ciência Ë Saúde Coletiva, 12(1): 105-114, 2007.

PIRES, D. X.; CALDAS, E. D. \& RECENA, M. C. Intoxicações provocadas por agrotóxicos de uso agrícola na microrregião de Dourados, MS-Brasil, 1992-2002. Cadernos de Saúde Pública, 21(3): 804-814, 2005a.

PIRES, D. X.; CALDAS, E. D. \& RECENA, M. C. Uso de agrotóxicos e suicídios no estado de Mato Grosso do Sul. Cadernos de Saúde Pública, 21(2): 598-605, 2005b.

PORTO, M. F. S. Considerações sobre a dinâmica de regulação dos riscos industriais e a vulnerabilidade da sociedade brasileira. In: HERCULANO, S.; PORTO, M. F. S. \& FREITAS, C. M. (Orgs.) Qualidade de Vida Eु Riscos Ambientais. Niterói: EdUFF, 2000.

RIGOTTO, R. M. Saúde ambiental \& saúde dos trabalhadores: uma aproximação promissora entre o verde e o vermelho. Revista Brasileira de Epidemiologia, 6(4): 388-403, 2003.

ROUQUARIOL, M. Z. \& ALMEIDA FILHO, N. Epidemiologia Ė Saúde. 6. ed. Rio de Janeiro: Medsi, 2003.

SANTANA, V.; NOBRE, L. \& WALDVOGEL, B. C. Acidentes de trabalho no Brasil entre 1994 e 2004: uma revisão. Ciência $\mathcal{E}$ Saúde Coletiva, 10(4): 841-855, 2005.

SCHLESINGER, S. Que Agronegócio É esse? Por que a agricultura e a pecuária crescem sem beneficiar a população brasileira. Rio de Janeiro: Fase, 2005.

SEPLAN-MT (Secretaria de Planejamento do Estado de Mato Grosso). Anuário Estatístico. Cuiabá: Seplan-MT, 2006. Disponível em: <www.seplan.mt.gov.br/ anuarioestatistico>. Acesso em: fev. 2007.

SES-MT (Secretaria Estadual de Saúde de Mato Grosso). Programação Anual Pactuada de Saúde do Estado de Mato Grosso para 2007. Cuiabá: SES-MT, 2006 a.

SES-MT (Secretaria Estadual de Saúde de Mato Grosso). Relatório de Gestão (2003/2005) Apresentado ao Conselho Estadual de Saúde. Cuiabá: SES, 2006b.

SILVA, C. A. As Subnotificações de Acidentes de Trabalho em Cuiabá/Várzea Grande-MT, 2000. Monografia (especialização), Cuiabá: ISC, Universidade Federal de Mato Grosso. SILVA, I. F. (Coord). Seminário Estadual de Pacto de Gestão e Controle Social da Saúde em Mato Grosso. Relatório de Pesquisa. Departamento de Serviço Social da UFMT. Cuiabá: DSS/UFMT, 2007. 
SILVA, J. M. et al. Agrotóxico e trabalho: uma combinação perigosa para a saúde do trabalhador rural. Ciência Ė Saúde Coletiva, 10(4): 891-904, 2005.

SINAN-MT (Sistema de Informação de Agravos de Notificação da SES de Mato Grosso). Banco de Dados de Intoxicação por Agrotóxicos Agrícolas. Disponível em <www. saude.mt.gov.br/sinan>. Acesso em: fev. 2007.

SINDAG (Sindicato das Indústrias de Defensivos Agrícolas). Seminário Nacional Sobre Agrotóxicos, Saúde e Ambiente, 2005, Olinda. Brasília: Ministério da Saúde, 2007.

STOPELLI, I. M. B. S. \& CRESTANA, S. Pesticide exposure and cancer among rural workers from Bariri, São Paulo State, Brazil. Environmental Internacional, 31: 731-738, 2005.

TAMBELlini, A. T. \& CÂMARA, V. M. A temática saúde e ambiente no processo de desenvolvimento do campo da saúde coletiva: aspectos históricos, conceituais e metodológicos. Ciência E⿱ Saúde Coletiva, 3(2): 47-59, 1998.

TEIXEIRA, M. L. P. \& FREITAS, R. M. V. Acidentes do trabalho rural no interior paulista. São Paulo em Perspectiva, 17(2): 81-92, 2003.

TEÓFILO, E. (Org.) A Economia da Reforma Agrária: evidências internacionais. Brasília: Ministério do Desenvolvimento Agrário, 2001.

VALE, F. R. et al. Manejo de Fertilidade do Solo. Lavras, MG: Editora UFLA/Faepe, 2001. WÜNSCH FILHO, V. Reestruturação produtiva e acidentes de trabalho no Brasil. Cadernos de Saúde Pública, 15(1): 41-51, 1999. 


\section{Movimentos de Assepsia Social: a doença do TRABALHO FORA DE ALCANCE}

Marilene Affonso Romualdo Verthein

Carlos Minayo Gomez

A luta pela saúde como um direito tomou a cena nas relações do trabalho quando os trabalhadores do início do século XX reivindicaram formas de regulamentação da vida no espaço das instituições, em que subjetividades produtoras de homens-máquinas capturavam memória, inteligência, sensibilidade, inconscientes.

A função do trabalho na Idade Média prescrevia uma estratégia de domínio do corpo pelas disciplinas, almejando maior aproximação com a espiritualidade; todavia, no âmbito do capitalismo, o trabalho, também instituído por estratégias de controle, foi indicador fundamental para o delineamento da sociedade disciplinar, cujo nicho pautava-se no discernimento entre o normal produtivo e o anormal improdutivo. Precursores como Tuke, na Inglaterra, e Pinel, na França, organizaram as condições de possibilidades dessas formas de se estar no mundo: o medo, que deveria incutir culpa e responsabilidade; o trabalho, criando o hábito da regularidade, da atenção e da obrigação; o outro, produzindo a autocontenção; a infantilização, indicando a necessidade de proteção; o julgamento perpétuo, codificando a sanidade; e, ainda, a imposição do biopoder como estratégia normativa do social.

Assim, a tomada do corpo como instrumento pela racionalidade no mundo do trabalho ficaria marcada nessa relação entre medicina, pedagogia e técnicas políticas de intervenção. As discussões apresentadas no livro Ciência e Tecnologia Hoje (Witkowski, 1997) são elucidativas quanto à atualidade da questão. Sabe-se dos avanços incomparáveis da medicina, e as curvas de mortalidade e morbidade refletem esses avanços - mas ao mesmo tempo, paradoxalmente, diria Brisset (1997), a distância sanitária entre as diferentes 
regiões é marcante e demanda um caráter ético e de evolução dos direitos de acesso às práticas sanitárias.

Veltz (1997: 38) afirma a mudança radical das relações de trabalho atuais, em que "a tarefa só existe como elo de uma rede de cooperações, cuja geometria é variável e que só pode funcionar com atores que tenham um grau elevado de autonomia”. Mas que, concretamente, estabelece-se com distorções.

Há também, na medicina atual, segundo Sendrail (1981), um estado de ser portador que permite um novo deslocamento na prática do sujeito submetido às regras do controle médico. É a criação de uma medicina preventiva que utiliza em grande escala uma tecnologia sofisticada, colocando "a história cultural dos males entre o domínio do mal latente" (Sendrail, 1981: 432), o que traria a ideia dos exames complementares como uma terapia, em que o sujeito não seria apenas frágil, mas, acima de tudo, não portaria nele a sensibilidade capaz de informar sobre a iminência de uma doença. Assim, para esse autor, a história dos males é revista na racionalidade atual, pois se torna uma história tecnológica dos males.

Nessa perspectiva, na prática laboral cotidiana tende-se a instituir a doença do trabalho como um problema pessoal e subjetivo. $\mathrm{O}$ adoecer adere-se ao enfoque da produção da culpa, já bastante visto e revisto, quando se transfere ao trabalhador a responsabilidade pelas adversidades das condições de trabalho. Frequentemente, os trabalhadores passam a tomar como verdade que, se não redobrarem a vigilância e a atenção e não aguçarem os sentidos no exercício das suas tarefas, 'fatalmente' poderão adoecer, com 'certeza', por serem 'emocionalmente frágeis' ou por estarem 'desadaptados', desajustados ou estressados.

Nesse percurso de volatilização da relação entre o trabalho e o processo de adoecer, vamos discutir as seguintes questões: que subjetividades estão sendo produzidas? Que armadilhas de captura e de silêncio são elaboradas? Tomaremos como base de análise dados de pesquisas sobre distúrbios osteomusculares relacionados ao trabalho, denominação atual das lesões por esforços repetitivos, aos quais faremos referência com a sigla LER/Dort.

\section{Mapeando as Pesquisas das LeR/Dort}

Podemos imaginar que vários segmentos contribuíram com uma interlocução permanente e com diferentes perspectivas para a construção da formação histórica sobre as lesões por esforços repetitivos. Embora não tenhamos a 
pretensão de apresentar uma totalidade dos encaminhamentos sobre o tema, podemos indicar algumas trilhas que se destacaram, outras que trouxeram rupturas e outras que permaneceram.

As denominações inglesas WRUED (work-related upper extremity musculoskeletal disorders) ou WMSD (work-related musculo-skeletal disorders of the upper limbs) marcam a abordagem ergonômica e epidemiológica dos fatores de risco, resultando no interesse pela etiologia da dor, pela relação entre o trabalho repetitivo e a doença profissional.

Segundo relatório da Occupational Safety \& Health Administration (OSHA, 2000), vários países, entre eles França, Alemanha, Itália, Suécia, Portugal, Espanha, Holanda e Inglaterra, uniram-se em campanha para prevenir as doenças osteomusculares por meio da transferência de informações técnicas, científicas e econômicas, uma vez que o problema tem sofrido um agravamento, afetando milhões de trabalhadores europeus. A abordagem do problema envolve avaliação dos riscos, vigilância médica, socialização das informações, sistemas de trabalho ergonômico e prevenção de fadiga.

É importante observarmos que a maioria das pesquisas publicadas no Brasil também focaliza essa trilha ergonômica e psicossocial. No XII Congresso Nacional de Prevenção de Acidentes do Trabalho, Campana e Lopes Neto (1973) já apresentaram casos de tenossinovite em lavadeiras e engomadeiras, sugerindo intervenções ergonômicas. No V Congresso Nacional de Profissionais de Processamento de Dados realizado em Belo Horizonte (MG), em 1984, Cardoso, Tavares e Castro (1984) abordaram a tenossinovite como uma doença profissional dos digitadores, utilizando metodologia de cunho epidemiológico e ergonômico na investigação dos dados.

Esse encontro ampliou a discussão e o número de publicações sobre o tema, como pode ser constatado em Maciel (1985), ao considerar os riscos apresentados pelo trabalho de digitação, e em Porto, Machado e Brito (1989), ao pesquisarem as LER e as doenças da coluna visando à construção de uma metodologia de investigação e prevenção de doenças osteoarticulares. Na mesma trilha, aprofundando os estudos sobre a dimensão psicossociopolítica nas LER/ Dort, estão, entre outros, as pesquisas de Sato e colaboradores (1993), Assunção e Rocha (1994), Codo e Almeida (1995), Merlo (1999) e Borges (1999); ressaltando a análise da história do reconhecimento dessas doenças e a análise das LER/Dort como forma de violência do trabalho, o estudo de Ribeiro (1997); problematizando as relações de saber/poder nas estratégias de descaracterização do nexo entre trabalho e adoecimento, o de Verthein e Minayo Gomez (2001). 
Em outra direção, as pesquisas da Austrália, realizadas no período de 1986 a 1992, abriram o campo de possibilidade das mudanças ocorridas nesse processo diagnóstico. Novo percurso de análise das LER/Dort toma corpo com a introdução dos referenciais da degenerescência, da cronicidade e da neuropsiquiatria, mais tarde influenciando as pesquisas do Canadá, dos Estados Unidos, da Inglaterra, da Alemanha e do Brasil, no que tange ao posicionamento do Instituto Nacional do Seguro Social (INSS). No rol das pesquisas publicadas no Medline, podemos ter uma ideia da expansão dessa trilha. Estudos de autores ingleses, desenvolvidos no Centro de Reumatologia Australiano, por exemplo, passam a abordar questões sobre histeria e neurose reumática. Spence e colaboradores (1995) estudaram trabalhadores com dor crônica e cervicobraquialgia, questionando o nexo de tais doenças com o trabalho.

A discussão da possibilidade de uma doença do trabalho ser diagnosticada como reumática ou psíquica passa a trazer novos rumos no encaminhamento das LER/Dort. Pode-se observar esse novo direcionamento em autores como Awerbuch (1996, 1999), Champion e colaboradores (1992), desenvolvendo pesquisa na Austrália, que analisaram diagnósticos de fibromialgia e outras doenças ditas crônicas e inespecíficas, levando à discussão os quadros diagnosticados anteriormente como tenossinovite e síndrome do túnel do carpo.

Nessa discussão, D’Auria (1993) afirma, em seu texto sobre medicina ocupacional denominado "Caos, controvérsia e consistência", que não só os diagnósticos das LER/Dort como doenças do trabalho são colocados em questão, mas toda a sintomatologia dos pacientes é considerada inconsistente. Alguns textos publicados na Alemanha também estudam os sintomas das LER/Dort e sua reincidência como casos de neuropatia. Por exemplo, As'ad, Iossifidis e Sutaria (1995) questionam a veracidade da síndrome do túnel do carpo como doença do trabalho.

Nota-se, no quadro argumentativo das discussões, que a preocupação com os custos das indenizações pagas aos trabalhadores lesionados torna-se mais aguçada. No Canadá, Houpt (1987), Miller e Topliss (1988) passam a analisar a experiência australiana quando se deparam com o crescimento estatístico das LER/Dort naquele país e com seus custos decorrentes. Na Suécia, Malmivaara e colaboradores (1995) ressaltam os custos e os aspectos crônicos e degenerativos das lesões osteomusculares. 
Nos Estados Unidos, as pesquisas também mantiveram essa referência diagnóstica, analisando os casos de LER/Dort como mialgias, dores crônicas e tendinites degenerativas. Alguns autores, como Zimmerman e Clark (1992), continuavam a afirmar que os traumas acumulativos foram responsáveis pelo desenvolvimento de neuropatias ocupacionais. Mas outros, tais como Schottland e colaboradores (1991), mais radicais, por estarem "levando em conta a recente falsa epidemia australiana de RSI" (Schottland et al., 1991: 627), consideraram que, embora o estresse e os movimentos repetitivos no local de trabalho causem traumas cumulativos e possam ser fatores de síndrome do túnel do carpo, essa associação era, no entanto, pouco evidente nas indústrias americanas.

Com a apresentação esquemática dessas pesquisas, queremos ressaltar que uma ruptura na análise das LER/Dort foi possível quando ocorreu a separação entre esse processo de adoecimento e o trabalho. $\mathrm{O}$ questionamento deixa de ser o nexo da doença com o trabalho e passa a configurar a composição do doente no âmbito do falso e do verdadeiro. Podemos observar que esse movimento cria um deslocamento no eixo de referência na rede discursiva à medida que permite fixá-la na construção de um sujeito mórbido.

As referências em relação às LER/Dort, no entanto, não são homogêneas; as influências são as mais diversificadas e, como elas, os encaminhamentos apresentam diferentes abordagens de análise de acordo com o país de origem dos pesquisadores. Ireland (1988, 1998), da Austrália, discute os aspectos físicos e psicológicos das LER/Dort enfatizando os segundos; Bystrom e Hall (1995), da Suécia, questionam a veracidade da doença profissional; e Takami e colaboradores (1991), do Japão, estudam as relações entre a sobrecarga de trabalho e as lesões apresentadas.

As pesquisas da Nova Zelândia sobre LER, registradas no período de 1988 a 1994, também são diversificadas. Baseiam-se no estudo anatomofisiológico e psicofisiológico; e mesmo as alterações, tais como a osteoartrite, são analisadas por Hess e colaboradores (1989) como decorrentes de traumas cumulativos decorrentes do trabalho.

Essa diversidade traz um dado positivo ao proporcionar a busca de uma interdisciplinaridade, enriquecendo assim, com novos rumos, tais abordagens. Na República Tcheca, o estudo de Kovarik e colaboradores (1989) enfatiza a cooperação entre neurologistas, ortopedistas, fisiologistas e especialistas em higiene do trabalho. Nessas abordagens, os aspectos neurológicos foram analisados em relação ao trabalho e não tratados como problemas individuais. 
É com base nesse múltiplo cenário que questionamos a separação entre trabalho e processo de adoecimento, afirmando juntamente com SeligmannSilva (1994) que, em um contexto no qual recessão e reestruturação de produção coincidem, os processos de degradação da saúde são aguçados pelas situações desfavoráveis de trabalho. Especificamente no caso das LER/Dort, problematizamos a recusa do nexo como um dispositivo político de exclusão; nesse caso, estamos lidando não apenas com as evidências do nexo da doença com o trabalho - o corpo lesado, as formas de violência -, mas também com as ramificações dos seus vínculos na história da saúde do trabalhador. Privilegiamos não o espaço de busca da sua afirmação/negação, mas práticas cotidianas que põem em movimento sua construção/desconstrução. Nesse âmbito, torna-se importante analisarmos o espaço da subjetividade e o espaço político e social que as atravessam.

\section{A Prática Discursiva do Nexo Produzindo Subjetividade}

Entendemos a subjetividade como construção exteriorizada de formas de pensar, agir e sentir (Guattari, 1992). Assinalamos a doença não como um conceito nosológico instituído pela biologia médica, mas como uma gama de relações intersubjetivas que podem ser estabelecidas entre profissionais de saúde e trabalhadores pacientes ou não. A doença, nessa perspectiva, é inseparável das relações que os sujeitos mantêm com o corpo, dos sistemas materiais - acesso à saúde, condições de qualidade de vida -, dos sistemas sociais e culturais envolvidos e articulados na relação de instituir e destituir sentidos, interesses, afetos.

Para a análise, entenderemos o nexo do trabalho com a doença como um dispositivo-rede, isto é, como pontos arbitrários em que as práticas e os discursos circulam e produzem formas de saber, de poder, de afetar e de ser afetado.

Aliamo-nos a Foucault (1994) ao afirmar que, em diferentes contextos institucionais, existem processos e técnicas que são utilizados para agir sobre os indivíduos tomados individualmente ou em grupo, objetivando transformar os seres humanos em sujeitos racionais e morais. Registra o autor que, a partir do século XIX, o sujeito tornou-se objeto de conhecimento pela prática da medicina social e psiquiátrica, da pedagogia e da penalidade, mas também objeto de conhecimento por si mesmo, quando foi levado a se analisar, a se decifrar, a se reconhecer em um domínio de saber possível. Trata-se da subjetividade que se entende como a maneira segundo a qual o sujeito faz a experiência dele mesmo no jogo de verdade. 
Podemos considerar, aproximando-nos desse enfoque foucaultiano, que, no estudo sobre as redes discursivas da recusa do nexo, os aspectos psicológicos ou psicopatológicos de uma pretensa personalidade fixa de quem adoece tornaram-se fundamentais para expressarem a subjetividade do trabalhador, à medida que eram articulados com elementos de culpabilização, de punição e de conscientização e delineavam o domínio de saber possível do território da doença do trabalho.

Os discursos dos médicos e dos trabalhadores, nessa rede discursiva mais ampla, são efeitos de formações e desconstruções de sentidos que resultam das alianças e das exclusões. As redes são produtos das histórias de vida que se articulam e criam outras histórias, nas quais o corpo não é só um corpo orgânico, visível para o médico, mas uma conjugação das condições de trabalho, da história dos indivíduos, das condições de saúde, das histórias sobre a saúde e o trabalho, sobre a saúde e o trabalhador. O corpo do médico, também um dispositivo, expressa multiplicidades, ao circular e produzir formas de saber e poder entre os enunciados sobre a medicina, a doença do trabalho, a saúde do trabalhador, os custos e a previdência.

Dessa forma, as práticas envolvendo as LER/Dort, problematizadas em razão de uma "economia política da verdade" (Foucault, 1986: 13), relacionam discurso, verdade, poder e estratégias, nos auxiliando a colocar a problematização do nexo como pertinente. Assim, as construções sociais legitimam e sancionam os campos de visibilidade dos enunciados construídos como 'verdadeiros' em uma sociedade. Diz o autor, definindo o enquadramento dessa economia:

Cada sociedade tem seu regime de verdade, sua política geral de verdade, isto é, os tipos de discurso que ela acolhe e faz funcionar como verdadeiros; os mecanismos e as instâncias que permitem distinguir os enunciados verdadeiros ou falsos; a maneira como sanciona uns e outros; as técnicas e os procedimentos que são valorizados para a obtenção da verdade; o estatuto daqueles que têm o encargo de dizer o que funciona como verdadeiro. (Foucault, 1986: 12)

Nessa linha de análise, a fala sobre o trabalho tem uma materialidade de produção não só do fazer, mas do pensar e do sentir que, no entender de Guattari e Rolnik (1986), são produções de subjetividades e de territórios existenciais, marcando que não há sujeitos sem o campo virtual de articulações que o 'produzem'. Para esses autores, há uma produção econômica e uma produção de subjetividade concomitante no mundo capitalista contemporâneo; 
assim, o aprendizado do ser trabalhador é 'maquinado' na fábrica, mas também na rua, na casa, na cidade e na mídia. Por isso a subjetividade é 'maquínica', é 'fabricada'. As intervenções colocariam em análise os enunciados, as falas (re)produzidas e seus efeitos na vida dos trabalhadores.

Os enunciados das políticas públicas da saúde, a partir da década de 1970, enfatizam não um Estado-providência de redes de benefícios contra as adversidades do trabalho, mas o combate à inflação do déficit público na emergência de um Estado neoliberal (Paiva, 2000), traduzindo o bem-estar como fardo burocrático. Assim,

fala-se em globalização e flexibilidade, principalmente, das perspectivas utilitaristas que apontam o fardo burocrático do Welfare State como limite para a eficiência e a inovação. (...) A noção de saúde/doença, neste contexto, pode perder sua dimensão interativa para se transformar em mero problema individual. (Paiva, 2000: 22)

Para Guattari (1992), a noção de responsabilidade individuada é tardia, assim como as noções interiorizadas de culpabilidade, uma vez que a ordem social instala sistemas de hierarquia, sistemas de escala de valor e disciplinarização, abrindo o campo de valorização em que diferentes indivíduos e camadas sociais terão de se situar. Aceita-se essa ideia de ordem como comprometida com a vida social organizada, e impõem-se naturalizações cotidianamente.

De acordo com esse autor, a subjetividade, como é uma produção essencialmente social, oscila entre dois extremos: uma relação de alienação e opressão, na qual o indivíduo se submete à subjetividade tal como a recebe; e uma relação de expressão e criação, na qual o indivíduo se apropria dos componentes da subjetividade produzindo singularizações. Ele recusa a ideia de que uma sociedade seja o somatório de subjetividades individuadas, colocando-a no cruzamento de determinações coletivas de várias espécies, não só sociais, econômicas, tecnológicas, linguísticas e culturais. "Se você é mulher, de tal idade e de tal classe, é preciso que você se conforme a tais limites. Se você não estiver dentro desses tais limites, ou você é delinquente ou você é louca” (Guattari \& Rolnik, 1986: 43).

A redefinição das relações entre o espaço construído, territórios existenciais e dos sistemas maquínicos não será mais uma questão da qualidade do bemestar, mas a instauração de práticas e realidades sociais singulares da vida como tal. Dessa forma, a saúde não é um problema entre outros; é um problema no cruzamento-rede das questões sociais, culturais, econômicas, tecnológicas. Assim, as naturalizações da saúde como questão geopolítica produzem um 
mapa que orienta sentidos, em que a exclusão da doença, permanecendo sem sentido, enche de significado a saúde que atende a excelência de figuras glamorosas mediadas pelo capital.

Essas naturalizações da saúde envolveram variáveis negociadas por segmentos sociais de interesses diferentes, ressaltando, no caso das LER/Dort, a questão do nexo entre o trabalho e a doença como uma articulação paradoxal entre capitalização e doença. Tal fato tem levado, sistematicamente, a previdência social, ao longo da sua história, a criar estratégias de ação para negar doenças do trabalho.

São práticas históricas que, ao longo dos anos, vêm cunhando lugares vazios de significados (Bauman, 2001), porque não se acredita que possam tê-lo; nas quais a questão de negociar diferenças no processo de adoecimento foge às classificações cabais. A dificuldade para o reconhecimento do nexo das doenças do trabalho traduz esse estranhamento. Segundo Ribeiro (1997), a previdência social brasileira costuma subestimar as ocorrências mórbidas provocadas pelo trabalho, por razões econômico-financeiras, mas também políticas.

Portarias e normas técnicas sobre as LER são efeitos dessas práticas. Em 1987, foi emitida a portaria ministerial da previdência social n. 4.062, regulamentando a tenossinovite como doença do trabalho, e em 1990 a portaria n. 3.751, reeditando a norma regulamentar n. 17, sobre os aspectos ergonômicos da digitação. Em 1991, com revisão em 1993 e em 1997, surge uma norma técnica para avaliação da incapacidade das LER. As revisões foram acompanhadas e discutidas por diferentes segmentos sociais: sindicatos, trabalhadores, profissionais de saúde.

Se, de um lado, os discursos são encaminhados para negar as LER/Dort pela via da neuropsiquiatria, de outro, essa mesma via não é um impedimento para o nexo. A lei n. 8.213/91, Regulamento da Previdência Social, revisada pelo decreto n. 3.081/99, resolução INSS n. 10/99, aprova os Protocolos Médicos para Benefícios por Incapacidade, no Anexo II, Grupo 13, "das doenças osteomusculares”. Expõe, entre elas, a dor articular, a síndrome cervicobraquial, mialgias, tenossinovite etc. - o que prova que não há um impedimento legal no reconhecimento das doenças osteomusculares se essas doenças forem produzidas pelo trabalho, mesmo daquelas associadas às doenças reconhecidas pela reumatologia e pela neurologia.

Entretanto, a historiografia das relações entre saúde e trabalho mostranos, quando referendado o corpo, que a lógica de capitalização da saúde tem eximido o trabalho das suas relações com os processos de adoecimento 
dos trabalhadores e assim, muitas vezes, naturalizado que o trabalho e suas condições adversas não afetam o corpo e pressupõe a saúde como ausência de doença ou disposição para o trabalho. Além disso, podemos observar que alguns diagnósticos neuropsiquiátricos servem muito mais à disciplinarização e ao controle da mão de obra dita saudável do que à análise diferencial. Nesses casos, tais diagnósticos compõem-se na referência de personalidades neuróticas, histéricas, borderline, de condições gerais de saúde crônicas e degenerativas, levando a discriminações e preconceitos.

Podemos considerar vários estudos que, na aliança entre subjetividade e trabalho, buscam parâmetros para fortalecer o nexo entre a doença e o trabalho, construindo com rigor o campo da saúde mental do trabalho. Esses estudos abarcariam, entre outros, a psicopatologia do trabalho (Dejours, 1987) e a psicodinâmica (Dejours et al., 1994). Estes autores, utilizando categorias de identidade psíquica, analisam no primeiro enfoque o sofrimento psíquico e os mecanismos de defesa e, no segundo, a dinâmica intersubjetiva da atividade realizada. Desse modo, o reconhecimento do indivíduo pelo grupo revitaliza a saúde e proporciona o fundamento da reconstrução do sentido do sofrimento no trabalho. A psicologia social do trabalho, em outro arcabouço teórico, vai utilizar a categoria de identidade social para definir o grupo homogêneo e analisar a sujeição e as resistências dos trabalhadores aos impactos das novas tecnologias. O sofrimento é determinado pelas estruturas laborais, isto é, situações ansiogênicas e estressantes mostram os aspectos psicossociais que caracterizam o risco. Nesse caso, o esgotamento físico e emocional, advindo das condições de trabalho, poderia desenvolver imagens negativas e atitudes desfavoráveis em relação a ele. A ergonomia integra em seus estudos cargas cognitivas, físicas e psicoafetivas ou emocionais.

Essas condições de sofrimento são aguçadas pela situação de indefinição político-econômica que atravessa o país: maior oferta de mão de obra do que de emprego; salários achatados pelas sucessivas crises econômicas; interesses na monetarização da saúde; sucateamento da rede de saúde pública e negação sistemática da doença do trabalho.

$\mathrm{Na}$ vinculação entre saúde/trabalho e corpo/doente, apresenta-se ainda uma questão: até que ponto esse modo de subjetivação desenha uma armadilha em forma de prescrição e aprisiona o sujeito na ficção da ideia de um trabalho sem corpo e de uma saúde sem doença? Qual o (não) lugar da instituição do sujeito-portador no processo de adoecimento nas organizações? 


\section{Armadilhas de Captura e de Silêncio}

Na historiografia do trabalho, apreendemos que o corpo foi espaço de intervenções estratégicas de controle que, a partir do século XIX, formata o corpo útil para a produção e a consumação de uma sociedade disciplinar. As disciplinas, ao delinearem as construções enunciativas históricas entre saúde/ trabalho e corpo/doença, mapeiam as leituras possíveis para um corpo inscrito no registro da inutilidade.

Em trabalho anterior (Verthein \& Minayo-Gomez, 2001), discutimos o encaminhamento do INSS/RJ, enfatizando as armadilhas da psiquiatrização das LER/Dort. Notou-se que as estratégias de negar reiteradamente o nexo deixavam muitas dúvidas quanto a sua própria referência de enunciado sobre o 'sujeito-portador-segurado' e, principalmente, quanto à sua constituição mórbida vinculada a um perfil de 'natureza' que articulava ansiedade, tensão, obsessividade e histeria e, ao mesmo tempo, fingimento e simulação. Essa rede discursiva para negar o nexo reportava historiografias do corpo útil/inútil para o trabalho; dos diagnósticos securitários e custos agenciados; das questões da divisão sexual do trabalho, mostrando a complexidade do processo em discussão.

Nesse registro do inútil nas histórias das LER/Dort, o corpo do trabalhador era espaço dicotomizado: capaz ou incapaz; doente ou saudável; ligado ao bem ou ao mal. Territórios tão totais e homogêneos que pareciam desconcentrar toda a lógica e nos quais esta parecia não caber. Os discursos sobre o corpo que adoecia no trabalho precisavam cada vez mais de regulagens, de disciplinas, de controles. O saudável cristalizava o ser no ter-a-capacidade-requerida-para-otrabalho. Assim, o processo de adoecimento como um estigma reterritorializase, marcando rigorosamente no próprio corpo a desregulagem, o descontrole, a inutilidade e a incapacidade. Em tal registro, nos deparamos com as buscas de uma personalidade totalizada, predisposta, marcada para a inutilidade, quando os diagnósticos são aliados ao referencial da neuropsiquiatrização.

As falas dos pacientes a seguir indicam essa construção de morbidade individuada:

Fui ao médico e ele falou: o que você tem é um sistema nervoso muito forte, e deu lá um nome estranho que está causando isso em você e mandou eu procurar um psiquiatra. (Bancária, 40 anos, 17 anos na função)

Faço fisioterapia e tomo cortisona. Sinto dor e dormência. Já não tenho tato. Os médicos dizem apenas que eu sou lerda porque estou nervosa. (Bancária, 45 anos, 20 anos na função) 
As bifurcações entre o estudo da doença dos 'nervos' e o da 'natureza' das mulheres nos remetem, nessa teia de discursos sobre o nexo das LER/Dort, às divisões sexuais do trabalho, já que não só em nossa pesquisa, mas em muitas outras, era comum encontrar um grande contingente de mulheres lesionadas que, na história dos males, eram descritas como simuladoras e dadas a 'pitis'.

Assim, comportamentos são reconhecidos e são qualificados ou desqualificados nessas incursões da codificação do que se chama historicamente de 'natureza feminina', partindo do acontecimento do projeto de higienização e educação emocional da mulher que vingou, na busca de uma sociedade progressista, no século XIX. Ressaltamos, nesse percurso, como os mecanismos de poder dos discursos neuropsiquiátricos sobre as mulheres são, ainda hoje, investidos, utilizados e ampliados por técnicas atuais de capturas e de silêncio. Tais conjuntos, como dispositivos de poder, servem ao propósito de desencadear as formas de sujeição de homens e mulheres nas relações de trabalho, e nesse processo esbarram com movimentos de resistência. Em tal relação de poder, é fundamental entender as alianças entre mulher, doença e predisposição; as lógicas de sua construção histórica marcadas na sociedade produtiva por necessidades respondidas por médicos, pedagogos, higienistas e outros profissionais; e quais os discursos legitimados como verdadeiros. Especificamente no caso das LER/Dort, tomaram-se identidades fixas de parâmetros úteis/inúteis e fúteis para fixar, no enredo do trabalho, doenças ditas 'de mulheres', com base no entendimento da captura do feminino como corpo instável e fragilizado pelas emoções.

Recorrendo a Foucault (1986), cabe ressaltar que não podemos nos deixar levar pela facilidade das evidências. As decisões não são tão técnicas, pois há muito tempo que a luta pela saúde no trabalho é uma luta política. E se é uma luta política, serve a alguns interesses. A constituição de sua rede discursiva torna-se um investimento de poder que registra, analisa, julga e direciona o que considera normal e psicopatológico. Entramos em outro registro: não é mais o corpo que adoece, que é ou não capaz ou incapaz, mas o normal/produtivo e o psicopatológico/improdutivo ou, envolvido por uma historiografia mais moralizadora, até mesmo de face degenerada. Dessa forma, a produção de saber assinala espaços pedagógicos e morais que, no agenciamento trabalho e saúde, ultrapassa muito as abordagens terapêuticas, positivando a rede de economia dos discursos de subjetividades descartáveis no trabalho.

Na prática, diversos corpos são citados na negação do nexo: o corpo incapaz, o improdutivo, o inútil, mas também o simulador, aquele codificado como o 
que 'finge-se de doente para não trabalhar'. É preciso outro registro para nos afastar das armadilhas de captura e de silêncio que pretendem nos alocar em um mundo homogêneo e uníssono ante as LER/Dort: ficou doente, é predisposto ou está fingindo. $\mathrm{O}$ espaço de subjetividade delineado pelos discursos dessa rede instituinte de verdade apresenta o sujeito constituído por uma natureza que traz em si a possibilidade do adoecimento por distúrbios psíquicos. Assim, a dor e o sofrimento expressos pelos portadores das LER/Dort, nas entrevistas do INSS/RJ, são sinais codificados como sintomas orgânicos de fundo emocional. Nesse caminho de análise, o trabalho pode agir como elemento disparador da doença, mas o que está em jogo é o entendimento de uma natureza subjetiva que se predispõe ao adoecimento.

Inicialmente, a banalização da repetitividade, depois, os aspectos contingenciais do esforço, que embora relacionados com o trabalho são creditados a uma neutralidade técnica e descartados como elementos pertinentes ao processo de adoecimento das LER/Dort, e, finalmente, os filtros da assepsia e da culpabilização, reafirmados pelos limites do território moral do comportamento, dos gestos, da sensibilidade e das paixões. Nessa lógica, estranhamente, se o trabalhador é afetado pelo que realiza e age com paixão, sua possibilidade de adoecer aumenta. No entanto, o seu adoecimento é concebido como efeito de pura paixão.

Nessa produção de silêncio da doença do trabalho, vamos problematizar a necessidade do uso do corpo para provar que se está verdadeiramente doente e, principalmente, as dissociações entre o processo de adoecimento e a história de vida e trabalho de quem adoece.

\section{Os Encaminhamentos da Proposta de uma Inversão da Leitura do Nexo}

Atendendo às antigas reivindicações dos trabalhadores e de profissionais de saúde, foi criado pela resolução n. 1.236, do Conselho Nacional de Previdência Social (CNPS), publicado em 10 de maio de 2004, o Nexo Técnico Epidemiológico Previdenciário (NTEP), propondo a presunção do nexo acidentário (B91) como política básica da análise das doenças profissionais e do trabalho.

O NTEP, ao (pre)assumir o nexo, traz uma nova lógica às conhecidas polêmicas referentes às indenizações aos trabalhadores acidentados, principalmente por barrar o privilégio de uma racionalidade economicista, que deixava a cargo dos acidentados uma imagem de réu, posto que deveriam, percorrendo 
uma via crucis, provar inocência. Tornou-se conhecido o NTEP como a lei que permite a inversão do ônus da prova.

Essa lei cria uma nova referência para a análise do nexo, no Ministério da Previdência Social, ao utilizar, como dado primário de critério epidemiológico, a articulação entre o Código Internacional de Doenças (CID) e o Código Nacional de Atividade Econômica (CNAE) de cada empresa.

Essa inversão do ônus da prova amplia a complexidade das ações em saúde do trabalhador, colocando em xeque de forma contundente articulações de produções subjetivas, políticas e econômicas de relações sociais, frequentemente combatidas, das quais ressaltamos a banalização do corpo como máquina, expressa no dia a dia de trabalho, e as frequentes cobranças de ônus individuais, sistematizadas nas estratégias de culpabilização dos trabalhadores pelos agravos. Fatos evidenciados, como vimos, nos estudos das LER/Dort.

Ao inverter o ônus da prova, essa lei revitaliza leis anteriores, editadas, mas nem sempre respeitadas, que explicitavam a necessária construção de indicadores de insalubridade e periculosidade para resguardar a vida dos trabalhadores. Essa instrução do decreto de 2007 reforça o decreto n. 3.048, de 1999, artigo 152, que definia a necessária comprovação dos ambientes de trabalho, com exposição de metodologia e procedimentos adotados nas mensurações para fins de requisição do direito ou não à aposentadoria especial. Atualmente, serve também para provar se há, ou não, nexo entre o processo de adoecimento e o trabalho, requisitando, de forma cada vez mais sofisticada e elaborada por especialistas vinculados à organização, a apresentação dos documentos: Programa de Prevenção de Riscos Ambientais (PPRA), Programa de Gerenciamento de Riscos (PGR), Programa de Controle Médico de Saúde Ocupacional (PCMSO), Laudo Técnico de Condições Ambientais do Trabalho (LTCAT), Perfil Profissiográfico Previdenciário (PPP) e Comunicação de Acidente do Trabalho (CAT).

Esse cruzamento de dados - CID/CNAE - é um indicador estatístico, pois permite a visibilidade dos ramos de atividade econômica que apresentam patologias acima da média da população em geral, servindo, em plano paralelo, para o mapeamento dos fatores de risco, independentemente de a CAT ser ou não emitida pelo empregador. Ressaltamos, no entanto, a importância da manutenção da CAT como documento da história dos agravos.

Nesse caso, a ênfase da análise está na efetiva condição de trabalho que, sucateada, coloca o trabalhador em processo de risco iminente ou adoecimento. Os dados de registro das condições laborais são fundamentais para garantir 
a eficácia do NTEP como indicador de saúde para intervir nos problemas de subnotificação, assim como para estabelecer estratégias de prevenção e promoção de saúde e garantia dos direitos trabalhistas.

Devemos, no entanto, considerar a complexidade do assunto e atentarmos para as suas várias composições e encaminhamentos, na medida em que o NTEP é tomado como parâmetro para o procedimento das normas em saúde do trabalhador. Um dado dessa complexidade pode ser observado na normatização de uma estatística que relativiza os custos ou negocia as conhecidas formas de barganha por adicionais de insalubridade e periculosidade. Outrossim, também ressaltamos que o presente estudo está delimitado no âmbito do mercado formal e não abrange o funcionalismo público, que não obedece aos procedimentos de nexo e CAT, nem os artesãos formais.

Assim, podemos ponderar sobre alguns encaminhamentos no caso das LER/Dort:

1) As CAT não são preenchidas corretamente, os diagnósticos não são citados e não há como cruzar CID/CNAE e distingui-los como indicadores estatísticos, embora os casos ocorram.

2) As subnotificações e a ausência de estatísticas sistemáticas sobre LER/Dort, principalmente por sua construção em doenças 'subjetivas' sem relação com o trabalho, levam ao encaminhamento individualizado, separando-as cada vez mais da origem de seu processo de adoecimento.

3) A atitude do trabalhador de esconder a própria doença para não correr o risco de perder o emprego e/ou de ser hostilizado por estar doente é um mecanismo cada vez mais usual nas formas de trabalho atuais, que estão cada vez mais precárias e tensas.

4) O descrédito na doença e nos adoecidos cristaliza sua exclusão dos locais de trabalho, levando à banalização do mal, como denomina Dejours (2007) em seu texto sobre a banalização da injustiça social.

O NTEP passa a apresentar uma prova, não só numérica ou estatística, mas de mapeamento de dados, ao solicitar várias entradas para o sistema de registro, fazendo da responsabilidade social um dado de realidade em saúde do trabalhador. A epidemiologia entra como mais um agenciador ao congregar políticas e ações preventivas, tornando a afirmação da exposição parte inalienável desse sistema de análise, pois comprova que o trabalhador permanece, muitas vezes, exposto a condições lesivas à saúde. 
A relação é estabelecida entre vários fatores e condições adversas à saúde e a frequência com que essas correlações determinam o processo de adoecimento e a incapacidade. Todavia, está presa ao monitoramento das estatísticas e estas a um complexo mosaico de articulações entre trabalho e subjetividade, que se estende por múltiplas leituras que, necessariamente, demandam a participação dos trabalhadores nos processos de avaliação dos riscos e exposição, assim como das efetivas ações de prevenção e promoção da saúde.

A luta pela saúde, hoje, está cada vez mais complexa. Não pode prescindir da luta pelo reconhecimento da doença no cotidiano de trabalho, no enquadramento do diagnóstico e do seu nexo como afirmação de resistência ante as escalas reticentes de exploração física e psíquica dos trabalhadores.

\section{As Assepsias: a doença do trabalho fOra do alcance}

Falar em movimentos de assepsia social - a doença do trabalho fora de alcance ou fora do olhar - é problematizar o ver como somente aquilo em que se deve crer. Para Certeau (1994), são formas de controle que agem sobre o sujeito, construindo um jogo de perda da credibilidade. As filosofias empresariais, os deveres e os direitos dos empregados como formas ritualizadas são construções para serem percebidas e lidas e deglutidas como credos. Essa articulação tem para esse autor

o duplo e estranho poder de mudar o ver num crer, e de fabricar real com aparências. Dupla inversão. (...) a modernidade, outrora nascida de uma vontade observadora que lutava contra a credulidade e se fundava num contrato entre a vista e o real, transforma agora essa relação, deixa ver precisamente o que deve crer. (Certeau, 1994: 288)

Ao lidarmos com as subnotificações das estatísticas, com os modelos de resumos compulsórios e com os quadros simétricos das epidemiologias em doença do trabalho, percebemos que muitos espaços instituídos no trabalho contemporâneo sofreram uma análise geopolítica, forjando campos de credulidade das potências produtivas e invisibilidade das precarizações do trabalho. Esses espaços precarizados moldam sua presença em uma sobra da reestruturação da modernidade, uma forma de assepsia que, permitindo a biossegregação dos espaços de produção e consumo, asseguram em sua constante mutação a liquidez, a flexibilidade, a maleabilidade e a eficácia, que são elementos de composição da história do nexo, em todas as suas formas já apresentadas: causal, técnica, epidemiológica. 
Um dado desta complexidade pode ser observado no padrão custo, em que se agenciam as abordagens da empresa e da previdência nos casos de acidente, como assinala a resolução n. 1.269, de 2006, a respeito dessa preocupação:

Parte deste custo-segurança no trabalho afeta negativamente a competitividade das empresas, pois ele aumenta o preço da mão de obra, o que se reflete no preço dos produtos. Por outro lado, o incremento das despesas públicas com previdência, reabilitação profissional e saúde reduz a disponibilidade de recursos orçamentários para outras áreas ou induz o aumento da carga tributária sobre a sociedade. (Brasil, 2006)

Percebe-se de imediato, por um lado, que as questões de segurança e higiene do trabalho, via penalizações, são possíveis de serem cobradas como redutores ou não; por outro lado, as despesas públicas com previdência, reabilitação profissional e saúde são fortes indícios da necessária afirmação das mudanças nas condições nocivas à integridade do trabalhador, como também de grandes custos previdenciários que as reformas tentam, de maneira neoliberal, descartar. Esse é um ponto importante para a discussão dos movimentos de assepsia, visto que muitas ações não ocorrem em razão da perversidade dos ambientes de trabalho, mas sim da relativização dos custos ou da negociação da saúde do trabalhador pelo menor preço.

A concentração de forças do INSS, nessa relação de poder na rede do reconhecimento das doenças do trabalho, evidencia polêmicas e ambivalências que muitas vezes se refletem nas próprias leis, nos decretos e nos regulamentos que lhe são adicionados, nas ordens de serviço e orientações de procedimentos internos. Assim podemos, finalmente, ponderar sobre algumas experiências:

1) Os dados informados pela empresa para o Cadastro Nacional de Informações Sociais (CNIS) procedem, mas não pertencem à organização como um todo; assim, muitas vezes, o trabalhador adoece, e não ficam provadas as sucateadas condições de trabalho. É sabido, pela literatura, que muitos canteiros de obra ganham o certificado da International Organization for Standardization (ISO) para a matriz, mas que são abertos vários canteiros pela mesma construtora, os quais não são avaliados.

2) O grau de incapacidade do segurado, ao servir de parâmetro para o diagnóstico de uma doença do trabalho, torna necessária a associação dicotomizada entre trabalho/saúde e corpo incapaz/doença. Essa doença tida como incapacidade ou inaptidão reforça o discurso do necessário treinamento individual ante as adversidades de um meio sucateado que tem sido mantido 
em nome de um desenvolvimento produtivo e lucrativo, mas consumido por preços bem diferentes. A grande questão, em um momento em que o trabalho é tão escasso e as formas de trabalhar tão precarizadas, é sabermos qual o valor da vida. Torna-se mister problematizar a vida que se discute em saúde do trabalhador, porque alguns trabalhos, mesmo com todo o avanço tecnológico, permanecem matando lentamente, ou até abruptamente.

3) No Brasil, podemos relacionar algumas ações que, cotidianamente, a despeito das leis, facilitam os danos à saúde. São ações que envolveram as LER, em passado recente, mas que são históricas em nossa cultura sobre trabalho: o investimento em treinamentos individuais, sem a preocupação devida com a renovação e manutenção dos equipamentos, muitas vezes pela opção de reduzir gastos com segurança; as demissões frequentes de trabalhadores que adoecem, para evitar que as doenças sejam associadas ao trabalho; a atitude do médico de não preencher a CAT corretamente, não citar diagnósticos e ser evasivo quanto às doenças que acometem os trabalhadores; o hábito da subnotificação e da ausência de estatísticas sistemáticas sobre acidentes e doenças do trabalho nas empresas, nos postos de saúde, no INSS, facilitando a sua volatilização; a atitude do trabalhador de esconder a própria doença para não correr o risco de perder o emprego e/ou de ser hostilizado por estar doente.

O nexo é um fato complexo; não se determina por uma lei, mas por um mosaico de ações que, na atualidade, com as ampliações das fronteiras mais aguçadas, coloca todos em situação de avaliação, a cada movimento. O mercado, efetivado pela globalização da economia, impõe novas investidas em saúde para garantir parcerias, mas a eficiência e a eficácia em saúde do trabalhador só serão efetivas se impulsionadas pelo movimento coletivo dos trabalhadores, engajados pela transformação das condições degradadas de trabalho.

\section{REFERÊNCIAS}

AS'AD, S.; IOSSIFIDIS, A. \& SUTARIA, P. D. Aneurysm of the superficial palmar arch: a case report. International Orthopaedics, 16(6): 403-404, 1995.

ASSUNÇÃO, A. \& ROCHA, L. E. Agora... até namorar fica difícil: uma história de lesões por esforços repetitivos. In: BUSCHINELLI, J. T. et al. (Orgs.) Isto É Trabalho de Gente? Vida, doença e trabalho no Brasil. Petrópolis: Vozes, 1994.

AWERBUCH, M. Repetitive strain injury: a 10 years follow-up. Medical Journal of Australia, 164(4): 252, 1996. 
AWERBUCH, M. Non-specific arm pain. Lancet, 354(9.189): 1.557-1.558, 1999.

BAUMAN, Z. Modernidade Líquida. Rio de Janeiro: Jorge Zahar, 2001.

BORGES, L. H. Sociabilidade, Sofrimento Psíquico e Lesões por Esforços Repetitivos em Processos de Trabalho Repetitivos: estudo de caixas bancários, 1999. Tese de Doutorado, Rio de Janeiro: Universidade Federal do Rio de Janeiro.

BRASIL. Ministério da Previdência Social. Conselho Nacional da Previdência Social Resolução n. 1.269, 15 fev. 2006. Diário Oficial da União, Brasília, 21 fev. 2006.

BRISSET, C. Saúde: os paradoxos de uma medicina técnica. In: WITKOWSKI, N. (Org.) Ciência e Tecnologia Hoje. São Paulo: Ensaio, 1997.

BYSTROM, S. \& HALL, C. Clinical disorders and pressure-pain threshold of the forearm and hand among automobile assembly line workers. Journal of Hand Surgery: British volume, 20(6): 782-790, 1995.

CAMPANA, C. L. \& LOPES NETO, L. A consideração da tenossinovite do punho como doença profissional: nossa casuística. In: CONGRESSO NACIONAL DE PREVENÇÃO DE ACIDENTES DO TRABALHO, 12, 1973, Brasília. Anais... Brasília: Fundacentro, 1973.

CARDOSO, A. J.; TAVARES, J. A. \& CASTRO, C. A. Tenossinovite: uma doença profissional dos digitadores. Porto Alegre: Sindicato dos Trabalhadores em Processamento de Dados/RS, 1984.

CERTEAU, M. A Invenção do Cotidiano: artes de fazer. Petrópolis: Vozes, 1994.

CHAMPION, G. D. et al. In search of the pathogenesis of refractory cervicobrachial pain syndrome: a deconstruction of the RSI phenomenon. Medical Journal of Australia, 156(6): 432-436, 1992.

CODO, W. \& ALMEIDA, M. C. C. G. (Orgs.) LER: diagnóstico, tratamento e prevenção - uma abordagem interdisciplinar. Petrópolis: Vozes, 1995.

D'AURIA, D. Chaos, controversy and consistency. Occupational Medicine, 43(3): 115-116, 1993.

DEJOURS, C. Loucura do Trabalho. São Paulo: Oboré, 1987.

DEJOURS, C. A Banalização da Injustiça Social. Rio de Janeiro: Editora FGV, 2007.

DEJOURS, C. et al. Psicodinâmica do Trabalho. São Paulo: Atlas, 1994.

FOUCAUlT, M. Microfísica do Poder. Rio de Janeiro: Graal, 1986.

FOUCAUlT, M. O Nascimento da Clínica. Rio de Janeiro: Forense Universitária, 1994.

GUATTARI, F. Da produção de subjetividade. In: PARENTE, A. (Org.) Imagem Máquina. Rio de Janeiro: Editora 34, 1992.

GUATTARI, F. \& ROLNIK, S. Micropolítica: cartografias do desejo. Petrópolis: Vozes, 1986.

HESS, G. P. et al. Prevention and treatment of overuse tendon injuries. Sports Medicine, 8: 371-384, 1989.

HOUPT, J. B. Repetitive strain syndrome: an Australian experience. Journal of Rheumatology, 14(4): 855, 1987. 
IRELAND, D. C. Psychological and physical aspects of occupational arm pain. Journal of Hand Surgery: British volume, 13(1): 5-10, 1988.

IRELAND, D. C. Australian repetition strain injury phenomenon. Clinical Orthopaedics and Related Research, 351: 63-73, 1998.

KOVARIK, J. et al. Personal experience with strain-indiced diseases-neurologic aspects. Ceskoslovenská Neurologie a Neurochirurgie, 52(5): 327-332, 1989.

MACIEL, R. Considerações gerais sobre o trabalho de digitação. Revista Brasileira de Saúde Ocupacional, 50(13): 37-40, 1985.

MALMIVAARA, A. et al. Rheumatoid factor and HLA antigens in wrist tenosynovitis and humeral epicondylitis. Scandinavian Journal of Rheumatology, 24(3):154-156, 1995.

MERLO, A. C. R. A Informática no Brasil: prazer e sofrimento no trabalho. Porto Alegre: Universidade Federal do Rio Grande do Sul, 1999.

MILLER, M. H. \& TOPLISS, D. J. Chronic upper limb pain syndrome (repetitive strain injury) in the Australian workforce. Journal of Rheumatology, 15(11): 1.705-1.712, 1988.

OSHA (Occupational Safety \& Health Administration). Relatório da Semana Europeia para a Segurança e Saúde no Trabalho, 2000. Disponível em: <http: //osha.eu.int/pt/ publications>.

PAIVA, C. H. A. Solidariedade, política e poder: o desafio às políticas sociais. Physis, 10(2): 9-26, 2000.

PORTO, M. F. S.; MACHADO, J. M. H. \& BRITO, J. Saúde e processamento de dados. Cadernos de Engenharia de Produção, 5(13): 14-32, 1989.

RIBEIRO, H. P. Lesões por esforços repetitivos (LER): uma doença emblemática. Cadernos de Saúde Pública, 13(2): 85-93, 1997.

SATO, L. et al. Atividades em grupo com portadores de LER e achados sobre a dimensão psicossocial. Revista Brasileira de Saúde Ocupacional, 79(21): 49-62, 1993.

SCHOTTLAND, J. R. et al. Median nerve latencies in poultry processing workers: an approach to resolving the role of industrial accumulative trauma in the development of carpal tunnel syndrome. Journal of Occupational Medicine, 33(5): 627-631, 1991.

SELIGMANN-SILVA, E. Desgaste Mental no Trabalho Dominado. Rio de Janeiro: Cortez, Editora da UFRJ, 1994.

SENDRAIL, M. Histoire Culturelle de la Maladie. Paris: Privat, 1981.

SPENCE, S. H. et al. Effect of EMG biofeedback compared to applied relaxation training with chronic, upper extremity cumulative trauma disorders. Pain, 63(2): 199-206, 1995.

TAKAMI, H. et al. Rupture of the extensor digitorum communis tendons caused by occupational overuse. Journal of Hand Surgery, 16(1): 70-71, 1991.

VELTZ, P. O trabalho comunicação. In WITKOWSKI, N. (Org.) Ciência e Tecnologia Hoje. São Paulo: Ensaio, 1997. 
VERTHEIN, M. A. R. \& MINAYO-GOMEZ, C. As armadilhas: bases discursivas da neuropsiquiatrização das LER. Ciência EO Saúde Coletiva, 6(2): 457-470, 2001.

WITKOWSKI, N. (Org.) Ciência e Tecnologia Hoje. São Paulo: Ensaio, 1997.

ZIMMERMAN, N. B. \& CLARK, G. L. Neuropathy in the workplace. Hand Clinics, 8(2): 255-262, 1992. 



\section{Parte III}

Subjetividade e Trabalho 



\section{0 Trabalho e as Redes}

Francis Sodré

Nos últimos anos, muito se produziu sobre a categoria trabalho em seus referenciais sociológicos, passando por discussões clássicas para defini-lo como central, interligado aos estudos que formam um campo de intervenção da saúde pública. $\mathrm{O}$ fato é que a categoria passou por modificações não do conceito em si, mas nas formas das suas expressões para o campo da saúde do trabalhador. Não se abandonaram com isto as clássicas teses marxistas; ao contrário, elas foram retomadas em sua raiz. Podemos talvez afirmar que os novos estudos apontam para a centralidade de um outro tipo de trabalho, um trabalho imaterial.

Foi nos Grundrisses que Marx desenvolveu uma importante vertente de análise por meio da categoria general intellect. Essas teses sustentam que o fato de o trabalho vivo ter sido objetivado nas máquinas reduzira o tempo de trabalho necessário como fator de criação. O tempo do trabalho se tornaria apenas necessário à pura repetição maquínica, e com o desenvolvimento industrial ele cessaria de ser a base da produção da riqueza, dependente cada vez mais da ciência e da tecnologia empregadas no desenvolvimento de engenharias e nas formas como se processa a cooperação produtiva.

O saber social geral, ou trabalho científico geral e inteligência coletiva, é que determinaria então a fonte de produtividade do capital. Esta tese de Marx, largamente estudada pelo operaísta Paolo Virno, se concretizaria no contexto do pós-fordismo, uma vez que é na economia informacional que sobressai a produção realizada por meio das atitudes mais genéricas da mente, como a linguagem, a disposição para a aprendizagem, a memória, a capacidade de abstração e correlação e o desejo de autorreflexão. Assim, a categoria general 
intellect se expressa na produção contemporânea como uma 'intelectualidade de massa'.

A intelectualidade de massa em sua totalidade é trabalho complexo, mas irredutivel a trabalho simples. A complexidade e também a irredutibilidade derivam do fato que essa força de trabalho mobiliza, no cumprimento de suas tarefas, competências linguístico-cognitivas unicamente humanas. Essa intelectualidade é, assim, a soma de todas as atitudes físicas e intelectuais existentes na corporeidade - competências ou faculdades que fazem com que as obrigações do indivíduo estejam sempre marcadas por uma elevada taxa de sociabilidade e inteligência. $O$ que não é redutível a trabalho simples é a qualidade cooperativa das operações concretas executadas pela intelectualidade de massa (Virno, 2008).

Falamos de uma nova subjetividade produzida pelo trabalho. Uma subjetividade política, coletiva, visto que o produto do trabalho não é mais individual, nem isolado. Ao contrário, mostra-se como uma combinação de atividades sociais que se apresentam como produtoras, algo que está colocado nos Grundrisse por Marx. A crise da grande indústria faz com que se dependa menos do tempo de trabalho e mais da potência da força de trabalho posta a produzir. E também da ciência, da tecnologia; da aplicação dessa ciência à produção. Ou seja, não é o trabalho imediato calculado pelo tempo gasto na produção, mas a apropriação da produtividade em geral. O indivíduo social é então o pilar de sustentação da produção de valor do capitalismo pós-fordista.

Será um indivíduo social e coletivo que determinará o valor da produção, pois sendo o trabalho organizado em formas comunicativas e linguísticas, e o saber algo cooperativo, a produção dependerá sempre mais da unidade de conexões e de relações sociais que constituem este trabalho linguístico e intelectual; isto é, produto que somente pode ser derivado de um indivíduo coletivo (Negri, 2003a).

O trabalho imaterial - como general intellect - consiste assim no valor de uso do trabalho vivo, envolvendo habilidades intelectuais, manuais e empresariais em atividades de coordenação, gestão, de pesquisa e de inovação (Cocco, 2002). Negri e Hardt (2001) complementam essa definição ao conceituar o trabalho imaterial como uma produção que não resulta em bens duráveis e materiais, mas em informação (produção de conhecimento), serviços (produção de relações) e afeto. O trabalho imaterial é então, como afirma Cocco (2002), uma recomposição do trabalho manual e do intelectual, mas ultrapassando essas duas visões. 


\section{Trabalho e Valor}

No campo da saúde do trabalhador, construiu-se durante toda a década de 1990 um referencial que tinha como principal aporte o referencial acumulado pela sociologia do trabalho - uma sociologia baseada nas evidências do emprego fabril, dependente das máquinas e de ritmos de trabalho intensificados pelo uso do tempo de acordo com o ritmo das máquinas. No entanto, hoje o tempo de trabalho torna-se algo supérfluo, pois a criação da riqueza é independente da quantidade de tempo empregado na sua produção - o que faz dessa relação não mais uma simples relação de subordinação ao capital; ao contrário, ela independe do tempo de trabalho imposto, porque se torna impossível distinguir o tempo livre do tempo de trabalho, ou o tempo produtivo do tempo de lazer. $\mathrm{O}$ trabalho se inseriu em todos os tempos da vida.

Assim, as formas de vida, nas suas expressões coletivas e cooperativas, se constituem como fonte de inovação. O que é produtivo, então, é o jogo das relações sociais. Existe um excedente de relações sociais durante todos os processos de trabalho da atualidade. É esse excedente que gera novas formas e estilos de vida. E até mesmo a capacidade constante de geração desse excedente é um ato criativo, base do trabalho imaterial. Para irmos mais longe, pode-se ainda afirmar que se rompe com a divisão entre trabalho material e trabalho intelectual; um está contido em outro, e ambos produzem de forma a serem um só.

(...) os processos de trabalho ultrapassaram os muros da fábrica e atingiram toda a sociedade. (...) A sociedade como um todo é agora permeada pelo regime de fábrica, ou seja, pelas regras específicas das relações de produção capitalistas. Sob essa luz, toda uma série de distinções marxianas deve ser revista e reconsiderada. Por exemplo, na sociedade fábrica, a distinção conceitual tradicional entre trabalho produtivo e improdutivo e a distinção entre produção e reprodução, que em outros períodos possuíam uma validade dúbia, deveriam hoje ser consideradas definitivamente ultrapassadas. (Negri \& Hardt, 2004: 22)

Existe um conceito metodológico por trás de toda essa discussão, pois revela a transformação do trabalho em atividade cognitiva e caracterizada por um excedente externo de valorização. Se o saber, o intelecto é posto em produção, a produtividade desse trabalho determinará um aumento de riqueza e também de mais conhecimento (Negri, 2003b). Dessa forma, a atualidade tem uma equação simples para entender a crise da fábrica e a fuga do trabalho 
de dentro das paredes fabris: 'conhecimento gera mais conhecimento' - uma fórmula que se aplica a muitos campos de saber da sociedade capitalista atual; um sistema já denominado de capitalismo do conhecimento ou da informação. A característica fundamental do novo capitalismo é essa constante geração de mais valor em rede, pois o trabalho tornou-se mais cognitivo por ser mais coletivo e ativador de redes sociais.

As máquinas tornaram-se próteses humanas. Não se concebe uma inovação qualquer ou mesmo um processo de trabalho sem o uso de máquinas e equipamentos. Do mais simples operário ou artesão ao mais qualificado dos intelectuais, em tudo há relações humanas capazes de agregar valor e gerar mais conhecimento. $\mathrm{O}$ novo trabalho produtivo é composto pelo conhecimento. Contudo, também pelo afeto, pelas relações que podem ser livres ou servis, mas que se joga de forma completa dentro desse tecido social difuso. O trabalho baseado em relações sociais, flexibilidade temporal e mobilidade espacial torna-se característico das novas peculiaridades que nosso tempo conhece. $\mathrm{O}$ trabalho imaterial é trabalho abstrato em sua mais alta expressão (Negri, 2003b).

Por se fazer necessário o uso do saber acumulado, o saber coletivamente acumulado, a sociedade do conhecimento é posta a trabalhar de forma incessante, sem turnos nem jornadas, como ditavam os preceitos da administração científica. Negri nos diz que o corpo pode ser colocado a trabalhar, mas desta vez é a alma do trabalhador que é posta ao trabalho. O corpo e a máquina são apenas suportes. E a alma se cansa como um corpo.

Não há liberdade suficiente para a alma, não há salário suficiente para o corpo, e por isso o trabalho (que é cada vez mais alma e cada vez mais sublima o corpo), nós o experimentamos como separação e exílio. É uma nova experiência de exploração a que vivemos. Mas é também uma nova experiência de constituição ontológica, ou melhor, de metamorfose. (Negri, 2001:11)

\section{a Vida como Produção do Valor e como Valor da Produção}

A ferramenta do trabalho, assim, é a própria vida e tudo o que pertence ao 'sentir'. A vida é posta em produção e tudo o que essencialmente compõe os elementos de comunicação - linguagem e afeto. Uma vida individual não poderia ser produtiva, pois a linguagem se torna essencial na produção desse processo. A linguagem se exprime por meio das potências de viver, o que po- 
deria chamar-se de afeto. $\mathrm{O}$ afeto torna-se uma das expressões da ferramenta de trabalho, em linguagens que são tanto racionais quanto afetivas. Tudo isso tem importante consequência na definição dos sujeitos. Todos os que têm potências vitais estão no interior desse processo. Essas potências apresentam-se na forma de linguagem e afeto (Negri, 2001).

Negri chega a dizer que existe um 'devir-mulher' no trabalho para dotá-lo de uma realidade que se tornou impossível ser imaginada sem passar pela produção de subjetividade e, portanto, da reprodução geral dos pensamentos vitais. As mulheres sempre estiveram no centro da produção de subjetividade, ou seja, reproduzindo aspectos essenciais à vida. Viveram a confusão do tempo de trabalho com o tempo da vida. O 'devir-mulher' do trabalho não significa afirmar que o trabalho do atual capitalismo é algo restrito somente às mulheres ou que somente elas viverão esse processo; mas significa reconhecer que a transformação que estamos discutindo é transgressora e se dá na reprodução geral da riqueza por meio dos processos de produção do saber, de comunicação, de linguagem e de afeto. O diferencial é que as mulheres sempre foram excluídas da capacidade da produção de valor econômico e agora assistem a uma mudança conceitual e prática do trabalho que requer a feminização dos homens e uma masculinização das mulheres (Negri, 2001).

A possibilidade de medir a exploração desapareceu definitivamente até mesmo porque a medida de valor se tornou ineficaz; "quanto mais a economia política se cala sobre o valor da força de trabalho, mais o valor da força de trabalho aumenta e intervém em um campo global, biopolítico" (Negri, 2001: 59). A dinâmica mostra-se paradoxal à proporção que o trabalho encontra seu valor no afeto, definido como potência de agir. $\mathrm{O}$ valor reside ainda mais no afeto, no trabalho vivo que se autonomiza da relação de capital e se exprime como potência de autovalorização. Assim, a teoria do valor marxista perde sua referência ao sujeito, mesmo como base de mediação ou do comando (Negri, 2001).

Assim, o trabalho imaterial produz imediatamente relações sociais e assume uma forma social de manifestação baseada na colaboração de relações afetivas; por isso só pode ser realizado em comum, cada vez mais inventando redes de cooperação por meio das quais possa produzir. Nesse sentido, o afeto ocupa posição central para o trabalho imaterial, um afeto que sempre se manifestou no feminino por meio de expressões como o trabalho familiar, doméstico, assistencial, materno ou educador. $O$ trabalho que se apresenta na forma desse 'devir mulher' envolve a produção de afetos, relações, comunicação, 
cooperação, envolvimento com comunidades. "O trabalho afetivo constitui-se em uma produção biopolítica na medida em que produz diretamente relações sociais e formas de vida" (Negri \& Hardt, 2005: 152). Expressa-se no trabalho de todos os profissionais que atuam com os serviços, com a comunicação, relacionamentos, mas também representa-se pelo trabalho do operário ou mesmo de um pedreiro que hoje não mais se sustenta por apenas saber 'subir paredes com tijolos', mas precisa agregar ao seu objeto de trabalho conhecimentos sobre luz, sombra, cor ou ventilação. Não basta mais ao operário conhecer o simples funcionamento das máquinas com suas teclas óbvias de on e off, mas saber consertá-las, agregar conhecimentos sobre seu funcionamento e incorporá-las como parte de um processo complexo, sempre complementado por mais tecnologias e mais robóticas.

O trabalho afetivo também se expressa dentre os que operam o cuidado e se manifesta na forma de escuta e acolhimento, como os enfermeiros, assistentes sociais, fisioterapeutas, psicólogos, nutricionistas ou médicos - o que demonstra que quando a produção afetiva torna-se parte do trabalho assalariado pode ser vivida de forma extremamente alienante: "estou vendendo minha capacidade de estabelecer relações humanas, algo extremamente íntimo" (Hardt \& Negri, 2005: 153). Por isso o conceito de alienação marxista nunca foi adequado para entender a exploração entre os trabalhadores de 'chão de fábrica', mas sim para ser aplicado no entendimento da exploração dos trabalhadores que produzem produtos imateriais. Aqui o trabalho não é compreendido como trabalho, pois produz afeto, assim como também produz conhecimentos e simbolismos. A alienação se constitui como um fator conceitual, útil somente para entender a exploração sobre ele (Hardt \& Negri, 2005).

O conceito de trabalho imaterial não prevê a utopia de uma nova economia, mas prevê que sua hegemonia tende a efetivamente mudar as condições de trabalho. Por exemplo: qual o tempo necessário para a realização desse trabalho? Não se sabe, pois não se consegue mensurar. Qual o local de produção? Também não se sabe, pois nunca se conseguirá mensurar algo que se estende por todo o tempo da vida. Na fábrica, assim como no hospital, os operários trabalham exclusivamente enquanto estão em seus locais de produção durante as horas passadas dentro desses locais. No entanto, quando o seu trabalho objetiva resolver um problema, criar uma ideia, uma relação, uma linguagem, o tempo de trabalho tende a se expandir por todo o tempo da vida. As ideias nascem no escritório, no consultório, mas também em casa, na conversa com os amigos ou mesmo em relacionamentos pessoais que hoje utilizamos como 'rede'. 
Os economistas que estudam a crise do fordismo o caracterizam como um modelo que sustenta relações de trabalho flexíveis, móveis e precárias. 'Flexíveis' porque os trabalhadores devem se adaptar a diferentes tarefas, que raramente se repetem - o novo sempre está por vir; 'móveis' porque mudam constantemente de empregos; e 'precárias' pois não existem novas formas de contratação em massa que assegurem a estabilidade em longo prazo (Hardt \& Negri, 2005). Ou seja, no pós-fordismo as estratégias são voltadas para mercados especializados - algo que acompanha a especialização das ciências e dos saberes na sociedade do conhecimento.

As redes tecnológicas existem e determinam ainda boa parte da produção, mas a apropriação do trabalho coletivo e a captura do valor pela circulação das redes sociais produzem comunicação, relações sociais e cooperação. A diferença do trabalho imaterial é que os produtos são imediatamente comuns: relações afetivas ou informação, por exemplo. No entanto, em contrapartida, a tentativa do comando é transformar toda a sociedade em estatísticas que as fórmulas não conseguem capturar. Esse é o devir biopolítico da produção (Hardt \& Negri, 2005).

Qual o produto gerado no atendimento de um assistente social? Qual o valor econômico agregado ao trabalho do hacker que produz novas tecnologias? Qual a diferença na riqueza produzida entre o vendedor de aparelhos celulares em shopping centers e o camelô com clientela fixa de seus DVDs pirateados? Algo que as estatísticas não conseguem capturar, pois o produto é a informação, o conhecimento, vínculo e relações sociais permeadas por numerosas mediações. Os produtos produzidos nunca são frutos do trabalho de um somente, mas de um coletivo. A linguagem, por exemplo, depende da capacidade de inovar em ambientes diferenciados, sempre em mutação ou com base em práticas e hábitos vividos. O trabalhador da economia imaterial, na execução de numerosas tarefas e funções, demonstra a capacidade de produzir vários tipos de enunciados, e o seu poder de falar é baseado em uma 'política do comum', pois toda a produção de linguagem é compartilhada, coletiva. $\mathrm{O}$ ato da fala é, portanto, político, pois é conduzido em comum, em diálogo, em comunicação (Hardt \& Negri, 2005). A produção é atualmente uma produção biopolítica em si.

Existe um diferencial entre 'biopoder' e 'biopolítica' nos formatos como aparecem na literatura produzida por Foucault. Para melhor explicar, por biopolítica entende-se a emergência de subjetividade, "uma abertura ontológica da liberação de processos que caminham em todas as direções” (Negri, 2003b: 107). 
Dentro desses processos inicia-se a discussão de produção de subjetividades. A biopolítica se apresenta nos espaços nos quais se desenvolvem relações, lutas e produções de poder.

Por biopoder, "entende-se quando o Estado exerce comando sobre a vida por meio de suas tecnologias e por meio de seus dispositivos de poder. $\mathrm{O}$ biopoder é a mais alta caracterização da modernização capitalista das relações sociais" (Negri, 2003b: 107). Por isso a produção do capitalismo atual é biopolítica: o produto é o próprio ato. Nas ideias de Deleuze e Guattari, a biopolítica surge do conjunto do trabalho efetivo, do trabalho de relações; imaterial, portanto. A flexibilidade temporal e a mobilidade espacial do trabalho tornam-se elementos característicos da forma de trabalho que o nosso tempo conhece (Negri, 2003b). Podemos afirmar que "a produção biopolítica é incomensurável", pois não pode ser quantificada em unidades fixas de tempo, e ainda porque é sempre excessiva na produção de valor que o capital pode e consegue extrair. Seu excedente é também incomensurável, "pois o capital não pode nunca capturar toda a vida” (Hardt \& Negri, 2005: 195).

A crise do fordismo deve-se ao fato de que produzir significa, antes, produção de subjetividade. Como aponta Negri (2003b), a produção de riqueza depende cada vez mais de conhecimentos, pois a produção de subjetividade é a reprodução social de processos vitais ricos em relações intelectuais e valores afetivos. Por isso, o fordismo-taylorismo não foi capaz de aglutinar, com sua economia baseada na força-repetição, fatores que potencializassem a produtividade social, porque a produtividade (a riqueza) é resultado somente do tempo de trabalho aplicado à produção. Por isso, dos anos 70 em diante, todo o desenvolvimento econômico passou a ser empurrado para a imaterialidade (o que os economistas chamam de "serviços e informação") como principal fator produtivo da sociedade, o que propiciou a construção de novos arranjos e hierarquias produtivos.

Para Virno (2008), o principal marco que inaugura a fase pós-fordista é a emergência das lutas dos trabalhadores precários (os sem contrato de trabalho ou os temporários) da Itália, em 1977. Era uma força de trabalho escolarizada, precária, móvel, que recusava a ética do trabalho e se opunha frontalmente às tradições e à cultura da esquerda histórica. E que também era estigmatizada pelos burocratas e intelectuais do Welfare como 'parasitas', por querer ter acesso ao sistema de proteção social sem passar pela relação de assalariamento na produção.

Por volta de 1976, sobretudo em 1977, é a própria universidade, como 'máquina' de produção em massa de uma força de trabalho intelectual, poli- 
valente e flexível, destinada a alimentar um modo de produção cada vez mais sofisticado, automatizado e flexível, que se torna o epicentro de conflitos sociais de tipo novo. Assim, o movimento italiano, que já tinha chegado a níveis de enraizamento social desconhecidos pelos outros grandes países europeus, experimentou, nesse mesmo ano, uma nova explosão generalizada - ponto culminante de um ciclo de lutas iniciado no final dos anos 60 e, também, ponto de ruptura e antecipação social das novas condições das lutas na crise do fordismo. O movimento de 1977 tanto superou efetivamente nossos instrumentos teóricos de análise como desdobrou a crise do 'político' que o havia precedido com a interpretação das lutas do 'operaísmo' italiano, não como protesto dos marginalizados e dos excluídos, mas de sujeitos centrais no novo modo de produção, representando uma antecipação teórica considerável (Virno, 2008).

Ao ver desencadear esse ciclo de lutas dos precários contra o Estado, o capital fez acelerar ainda mais sua 'contrarreforma' iniciada em meados dos 70 , quando começa a construir um novo conceito de capital. Até porque era necessário, como as grandes empresas anunciavam, capitalizar a revolução que se iniciou no Maio de 1968 e que contaminou várias regiões do mundo, inclusive no Brasil, nas chamadas greves do $\mathrm{ABC}$ paulista ou nas lutas democráticas pela queda da ditadura. Nos anos 70 e 80 , a contrarreforma - chamada, já na época, de 'reestruturação produtiva capitalista' - foi um revide, primeiramente à recusa do trabalho repetitivo e disciplinar. Assim, ampliou-se um longo processo de automação, informatização e robótica nas plantas fabris, diminuindo o número de funcionários, ampliando a produtividade e reduzindo a força sindical na atuação social dos funcionários que sobraram.

A contrarreforma também reagia à tendência de recusa do emprego estável, evidenciada, na Europa, por setores inteiros das forças de trabalho que saíam dos polos de industrialização metropolitana para desenvolver microatividades industriais (formais e informais) nos territórios. Esta contrarreforma solucionou essa recusa com a adoção de processos de terceirização, integrando a indústria a setores colaterais, difuso em vastos espaços territoriais. Essa operação forçava a proletarização ainda maior dos desempregados, ao mesmo tempo que retirava o conflito de dentro da fábrica para transferi-lo para as empresas terceirizadas - em particular, o levante de piquetes, greves e sabotagens.

Foi por causa das constantes rebeliões em massa dos trabalhadores que a reestruturação produtiva fez acelerar o processo de integração transnacional, que produziu um deslocamento das indústrias (ou de vários setores delas) 
para países emergentes, diluindo e negociando o efeito da crise no tempo e no espaço. Em boa parte, essa 'desterritorialização' do capital só foi possível graças à informatização do social, que possibilitou a integração produtiva no que tange à aceleração das relações não só entre empresas como entre produção e consumo.

Por sua vez, essa reestruturação produtiva acabou também por provar uma dupla crise do Welfare. A primeira reside no fato de que se a própria relação salarial passa a ser abandonada como principal fator de regulação para a produtividade social, o Welfare perde o seu papel de regulador e se torna alvo também das novas subjetividades políticas, à medida que essa forma-Estado protegia somente aqueles que se mantinham na relação salarial (Cocco, 2000).

Toda uma gama de precários (aqueles regidos com contratos temporários ou os 'sem contratos') passa a assumir o lema 'ter direitos aos direitos' e se articula em torno dele. Ao provocar a transnacionalização das empresas, o capital também ultrapassa a relação de dependência com o Welfare, forçando, inclusive, o financiamento de políticos (como Thatcher na Inglaterra e Reagan nos EUA) que iriam interpretar a crise política como crise do Estado, o que provocaria a emergência de projetos neoliberais dos anos 80 na Europa e nos EUA, chegando aos anos 90 nos países do Sul. Assim, o capital traduziu muito cedo aquilo que se tornou o epicentro das lutas sociais, principalmente na Itália, nos finais dos anos 70 e no início dos 80 . Em síntese, o capital interpretou que para ser produtivo era determinante o acesso a mínimos sociais - como o acesso incondicional a serviços e infraestruturas básicas: telecomunicações, habitação, educação, saúde, saneamento básico ou ainda transportes. Nesse sentido, acusa o Welfare State de ser uma máquina pesada que não protege todo o tecido social, e passa a propor o Estado neoliberal como estrutura alternativa para a aceleração da oferta desses mínimos sociais por meio de empresas privatizadas - flexíveis e leves. Telefone para todo mundo, saúde para todo mundo, educação para todo mundo, mas por meio do pagamento por esses serviços. Este foi um momento de intensas quebras de monopólios estatais e desregulamentação de vários setores econômicos e sociais, como as telecomunicações e o mercado de saúde.

Paralelamente ao desenvolvimento do Estado-empresa (como chamou Negri o Estado neoliberal), o capitalismo experimentou um conjunto de modelos produtivos pós-fordistas cuja principal característica é a dimensão social desses paradigmas. Suas forças residem exatamente no poder de captura de um conjunto de valores que se hospedam no terreno da reprodução social. 
O paradigma pós-fordista é, antes de tudo, um paradigma social e qualificase pela integração produtiva dos consumidores como produtores, ${ }^{1}$ pois eles participam da produção, desde o momento da concepção, em dois níveis: pela integração em tempo real dos comportamentos de consumo e pela proliferação disseminada dos atos criativos. Dessa forma, passa-se a discutir cada vez menos política industrial para se pensar a política econômica do território, isto é, uma política capaz de valorizar as interdependências entre indústria e redes de cooperação fabris e dinâmicas sociais (Cocco, 2000).

O modelo mais bem acabado em termos da incorporação do social à produtividade industrial foi o toyotismo, implantado pela fábrica da Toyota no Japão. Uma primeira novidade desse modelo foi a inversão do dispositivo lucrativo fordista: em vez de produzir para depois vender, passa a vender primeiro para depois produzir. Isso exige, é claro, uma profunda integração da produção ao consumo, o que o regime toyotista solucionou com a estratégia do just in time: o estoque é recomposto de acordo com os fluxos imediatos do consumo, isto é, só se repõe (logo, só se produz) aquilo que se está vendendo. Nesse modelo, o planejamento da produção se comunica com os mercados constante e imediatamente. As fábricas mantêm estoque zero, e as mercadorias são produzidas na medida exata, de acordo com a demanda atual dos mercados existentes. Esse modelo envolve, portanto, não apenas um feedback mais rápido, mas também uma inversão da relação, porque, pelo menos em tese, a decisão de produção vem, de fato, depois da decisão do mercado, e como reação a ela (Negri \& Hardt, 2001).

Essa estrutura de gestão de fluxos de consumo passa a requisitar também uma nova figura do trabalho, cuja qualidade reside na polivalência (para se adaptar às mudanças de padrões de trabalho exigidas pelas alterações nos padrões de consumo); na cooperação e no relacionamento (para expressar opiniões, gostos e informações sobre aquilo que estava a produzir para as sempre efêmeras demandas de consumo).

É necessário, então, que os trabalhadores entendam aquilo que fazem; mas, ainda, todo o processo e todo o sistema de fabricação precisa (em princípio)

1 Essa dinâmica é perceptível nos serviços. Como se compra um automóvel novo hoje em dia? Ao ir à loja, o consumidor praticamente 'cria' o seu próprio carro ao fazer composições e rearranjos que são necessários para utilizá-lo. Pode-se praticamente montar o produto visto apenas por um computador nas revendedoras. O mesmo se aplica à compra de roupas, calçados, serviços telefônicos... A criação imputada pelo consumidor do produto que quer consumir é parte do processo de inovação já calculado pela esfera da produção. Depende-se cada vez menos da produção e cada vez mais do consumo. Antes mesmo da criação de um determinado produto, ele já foi consumido. 
tornar-se um todo inteligível do qual assumem a responsabilidade e do qual se tornam e se sentem senhores. Devem refletir sobre os meios de incrementar e racionalizar a concepção; devem propor as possíveis melhorias nos procedimentos e na organização do sistema. Para tanto, precisam discutir entre si, entrar em acordo, saber exprimir-se e saber escutar, prontos continuamente a questionar, a aprender, a evoluir (Gorz, 2004).

O que se depreende disso então é que os primeiros modelos pós-fordistas assumem como núcleo da sua produtividade a produção de subjetividade, isto é, um trabalho cujo aspecto manual é uma aplicação material de uma atividade cada vez mais imaterial, intelectual, cognitiva, "de reflexão, de concerto, de troca de informações, de partilha de observações e de saberes" (Gorz, 2004: 41).

Ora, quando as capacidades comunicacionais, relacionais, cooperativas, criativas, passam a fazer parte da força de trabalho, estas capacidades, que implicam a autonomia do sujeito, não podem por essência ser comandadas; elas existirão e serão desenvolvidas não sob ordens, mas em virtude de iniciativas vindas do sujeito. A dominação do capital não pode exercer-se diretamente sobre o trabalho vivo por coerções hierárquicas. Ela só pode exercer-se por vias indiretas: deve deslocar-se da fábrica e tomar a forma de um condicionamento que conduz o sujeito a aceitar ou a escolher, ele próprio, exatamente o que trata de ser imposto a ele (Gorz, 2004).

A 'contrarreforma' capitalista produziu uma derrota no movimento sindical, principalmente. Mas essa vitória do poder modificou profundamente todo o velho sistema de comando. Daí que a emergência desse novo capital abriu uma série de linhas de fuga e novos planos de resistência, de luta. A contrarreforma foi, portanto, incompleta, porque a nova qualidade do trabalho (relacional, cooperativa, expressiva, informacional), exigida na produção de mercadorias, marca o deslocamento para um processo de expropriação nunca visto; no entanto, é também uma grandiosa possibilidade de autonomia do trabalho, pois pela primeira vez o valor não é produzido unicamente com um comando capitalista. Ao contrário, a produção do capital se encontra dentro do trabalho, visto que o principal instrumento da produção, a força inventiva do cérebro, escapa ao tempo inteiro de um enclousure do comando. O capital, assim, se transforma em uma máquina cada vez mais sofisticada de captura do social (das redes de conhecimentos, das subjetividades, dos estilos, das modas, dos gostos, das preferências) e empurra a produção para uma economia baseada na informação.

O capital torna-se produtivo somente na medida em que capta valores preconstituídos do trabalho social. Aqui, então, a razão do comando se organiza 
como ameaça de bloquear a informação, como interrupção dos processos cognitivos; em suma, o capital parasitário é aquele que extrai o valor, sobretudo da interrupção dos movimentos de conhecimento, de cooperação, de linguagem. Para viver e reproduzir-se, o capitalismo é obrigado a chantagear a sociedade e bloquear os processos sociais de produção toda vez que eles apresentem excedente que possam colocar em xeque o seu poder de comando (Negri, 2003a).

A passagem, de vez, para a economia da informação em que o domínio da reprodução (circulação, consumo, troca) hegemoniza a produção acontecerá com a intensificação do processo industrial informacionalizado e com o advento das 'superestradas' da informação (information superhighways). No primeiro caso, o uso abusivo das novas tecnologias da comunicação e da informação permitiu uma intensa descentralização da produção, dispersando fábricas e esvaziando as cidades fabris. Com os avanços das telecomunicações e das tecnologias da informação, ${ }^{2}$ todo o controle e comunicação passam a ser feitos a distância, reduzindo custos de distribuição, administração e de transporte. "Diferentes instalações podem ser coordenadas para a produção simultânea de uma única mercadoria, com fábricas espalhadas em diversos lugares" (Negri \& Hardt, 2001: 317).

Esse novo plano econômico da economia informacional é, para muitos autores contemporâneos, a concretização de uma substituição da linha de montagem para a rede como estrutura principal da organização da produção. $\mathrm{O}$ advento das redes altera assim as formas de cooperação e comunicação dentro de cada ambiente de trabalho e entre os lugares da produção.

As redes não funcionam como as infraestruturas rodoviárias que sustentaram o desenvolvimento fordista. As infovias não são um espaço de circulação de produtos produzidos pela indústria ou pelo setor terciário, mas são o próprio espaço de produção de relações de serviços, isto é, de bens imateriais nos quais produção e reprodução coincidem.

A produção em rede então será cada vez mais determinada pelo paradigma imaterial, já que o computador em rede é literalmente uma caixa vazia. Se não houver nele criação de usos e interatividades entre seus sujeitos, não há como

2 No final da década de 1980, já haviam sido instalados mais de cinco mil servidores de rede, um embrião daquilo que mais tarde se chamaria Internet, conectando empresas, instituições públicas e universidades. O próprio mercado via aparecer uma convergência das indústrias eletrônica, de informática, de telecomunicações e de mídia, o que possibilitou um rápido avanço das chamadas tecnologias virtuais e das redes telemáticas em todos os campos do tecido social. A marca dessas tecnologias era a de elas servirem como dispositivos de promoção da interatividade entre produção e consumo, fazendo com que ambos fossem um único processo. 
ativar essas redes, que perdem funcionalidade e utilidade. "A performance da ferramenta técnica depende da inteligência, da criatividade e da capacidade de invenção do trabalho vivo que se apresenta como trabalho imediatamente cooperativo" (Corsini, 2004: 22). Acrescenta-se a isso o fato de as redes (cuja Internet se tornou a mais utilizada) terem sido uma criação não somente do governo dos EUA, mas de uma multiplicidade de sujeitos que produziram invenções que as tornam até hoje um lugar democrático, não hierárquico e não centralizado. A implantação das information superhighways transferiu a captura do valor de dentro da fábrica para todo o tecido social, em uma gigantesca economia da interatividade. A nomenclatura 'nova economia' só é um termo que explicita o sintoma do deslocamento para a hegemonia do trabalho imaterial nas formas de produção contemporânea.

\section{A 'Saúde em Rede' nas 'Redes da Saúde’}

O campo da saúde do trabalhador compreende uma proposta que se norteou conceitualmente pelo resgate de categorias marxistas como o 'processo de trabalho' para explicar as relações sociais de produção existentes entre o capital e o trabalho. Em seu surgimento, baseou-se fundamentalmente em uma sociedade urbano-industrial. Em suas primeiras definições como campo, considerou o trabalho como organizador da vida social, mas, igualmente, espaço de resistência e do fazer histórico. Sua meta era que os trabalhadores assumissem o papel de sujeitos capazes de pensar e de se pensarem, produzindo uma experiência própria, no conjunto das representações da sociedade.

Esse campo de saberes se consolidou como prática por meio dos Programas de Saúde do Trabalhador (PST) e dos Centros de Referência em Saúde do Trabalhador (Cerests) no Brasil. A política se municipalizou, as universidades formaram recursos humanos com olhar sensível às determinações do trabalho sobre a saúde e, juntas, modificaram radicalmente o perfil das estatísticas sobre doenças profissionais e acidentes de trabalho. Alcançaram a produção de dados estatísticos que permitiram estudos epidemiológicos de maior abrangência, chegando a promover mudanças no seu campo de estudos sobre o ambiente.

Novos conceitos foram incorporados no final da década de 1990. Um deles foi o de promoção à saúde, que visava a direcionar o enfoque das ações assistenciais no campo da saúde coletiva e do trabalhador - algo que favoreceu a formulação de políticas públicas intersetoriais que propagavam a intenção de estimular a criação de ambientes e estilos de vida saudáveis, circunscritos a um 
movimento dos 'municípios saudáveis' e da discussão teórica e metodológica sobre a vigilância em saúde.

Os Cerests foram (e são) parte da base de modificação do perfil de morbimortalidade de muitas organizações de trabalhadores. Associaram-se a órgãos do Ministério do Trabalho e Emprego (MTE), como a Fundacentro e as Delegacias Regionais do Trabalho (DRTs); criaram parcerias sólidas com os sindicatos na detecção de doenças ocupacionais e no registro de acidentes de trabalho e fecharam um ciclo histórico necessário após as lutas sociais da década de 1980, pois deram visibilidade a adoecimentos e mortes que ficavam à margem das políticas sociais, chegando ainda a modificar a visão sobre seguro social para a previdência estatal.

Tudo isso só foi alcançado porque as bases sociais da década de 1980 foram solidificadas na década seguinte - mesmo porque proporcionaram ao profissional da saúde se repensar como trabalhador, despertando discussões dentro das categorias profissionais da própria área da saúde. $O$ trabalhador do Sistema Único de Saúde (SUS) também se viu dentro do debate. E a Saúde começou a produzir reflexões sobre sua saúde.

Essa contaminação foi algo universal. Tornou-se um fenômeno na América do Sul e gerou uma grande publicação de pesquisas sobre o tema - o que refletia a eficiência do processo formador desses serviços de saúde. Ou seja, a rede da saúde pública já estava conectada em quase todos os seus 'nós'. Tudo aquilo que o sanitarismo produzira juntamente com os sindicatos e os movimentos sociais no Brasil tinha gerado um excedente, uma 'mais-valia' na saúde. Talvez um excedente que gerasse o grande interesse do Estado em novamente acionar seu poder de captura sobre as inovações produzidas pelos movimentos: não bastava à saúde atuar em rede e ver nela o poder 'constituinte' de seus atores e movimentos; era preciso instituir a rede, capturar seus fluxos e mapear os seus atores. Os anos 2000 foram marcados pela constituição de um espaço consolidado pela saúde do trabalhador justamente no seu momento avaliativo. Ou melhor, a revisão de campo conceitual é demarcada pelo momento exato de sua captura.

Na década de 1990, os atores sociais se ramificaram e se difundiram em âmbito de Estado. Estavam na previdência, na assistência, na saúde, no trabalho e até na educação. Os aliados à formação de uma política pública de saúde voltada para o trabalhador e seu ambiente estavam sob a guarda da formação de um novo corpo de Estado. A luta instituinte da saúde passou a instituída; afirmou-se como um biopoder, agindo de uma forma que não gerou 
novas parcerias produtivas, não somou novos atores e não criou arranjos que permitissem que a política da saúde fosse interdependente de outras políticas sociais. Caminhou timidamente em direção às discussões sobre ambiente; sem metodologias claras e sem ferramentas para se impor como uma política sobre a vida.

Toda a multiplicidade agregada durante a década de 1990 transformouse em um poder centralizado no "imperialismo sanitário" parafraseando a expressão de Camargo Jr. (2010) - aquele que tudo pode e que tudo resolve por meio do discurso de defesa da saúde pública. Porém, não se pautou pelos novos arranjos sociais que sinalizavam uma mutação das classes trabalhadoras; deixou-se enganar por uma relação fabril que apontava como principal fonte geradora de renda uma indústria que não existe mais: detentora da "classe operária” e de sua “organização de classe”. Nas palavras de Tronti (1972) “a classe existe porque luta e não luta porque existe".

Também data da década de 1990 no Brasil o ápice do neoliberalismo. Por vezes, isso nos leva a inferir que a saúde do trabalhador no campo da saúde coletiva estava nesse momento ainda pautada em um discurso de proteção ao trabalhador fabril, operário talvez. Enquanto isso, a reestruturação produtiva e o neoliberalismo já estavam com suas bases prontas para a formação de todo um 'precariado' composto não apenas por operários, mas também por trabalhadores do setor de serviços, desempregados, trabalhadores do setor informal etc. em uma virada histórica para uma economia especulativa. Daí que o campo da saúde do trabalhador se afirma dentro das instituições do Estado em um momento em que o próprio Estado já tinha evidências da centralidade do trabalho imaterial na economia.

Por isso, nessa mesma época tornou-se recorrente o discurso da "economia que não cresce”, não porque o poder econômico do Estado não se ampliava, mas porque os índices, escalas e parâmetros deveriam ser revistos. Na realidade, a produtividade não mostra crescimento porque seu indicador não muda. Ou seja, a produção continua a ser medida pelos tradicionais padrões de cunho industrial; por isso a produtividade aparenta a estagnação. A definição de medida de valor é sempre a mesma, isto é, a quantidade de produto por hora de trabalho. Este raciocínio desenvolvido por Cocco (2000) nos traz elucidações importantes sobre um discurso derrotista que se quer manter baseado em uma linha de análise saudosista do fordismo - mudam-se as formas de produção mas não se alteram os seus indicadores ou suas formas de mensurar essa produção. Isto porque a quantidade de valor agora embutida nos produ- 
tos com o trabalho torna-se incomensurável. Ou seja, chegamos a patamares incalculáveis de exploração.

As novas lutas sociais mostram-se articuladas em rede, e parte das articulações mundiais de várias outras lutas, independentemente de suas causas, são antes de tudo lutas do trabalho que não defendem novos direitos, mas sim mais democracia: a representação de muitos, por muitos, através da voz de muitos. Os atuais espaços de discussão caracterizam-se pela polifonia dos atores e pela multiplicidade das arenas.

Daí a necessidade em se repensar a rede das redes da saúde. Quando avaliamos a Rede Nacional de Atenção Integral à Saúde do Trabalhador (Renast), por exemplo, cabe o questionamento se esta rede instituída se propõe a ser polifônica. E também se ela se caracteriza por ser democrática, ou seja, composta por multiplicidades. Até que ponto a Renast não se formou por meio de experiências constituintes e porventura não se tornou um poder constituído? Solidificado em uma estrutura de Estado sem disseminação ou irradiação dos movimentos que a formaram?

A América do Sul atualmente experimenta uma nova fase política após anos de regimes de governos ditatoriais vivenciados em série por quase todos os seus países. Hoje se recompõe por meio de uma virada à esquerda harmonizada por todos os Estados que experimentam pela primeira vez governos populares eleitos democraticamente. A saúde já viveu sua democratização no Brasil através da consolidação da política do SUS. Deu um salto qualitativo quando incorporou o trabalho como categoria a ser pensada pela saúde, apontando para intervenções sobre o ambiente. Agora cabe à saúde do trabalhador verificar se suas ações têm sido por mais democracia. As novas lutas sociais são pela radicalização da democracia. E as redes constituídas pela saúde pública devem estar atentas a essas novas formas de resistência, pois onde há resistência, há poder.

\section{REFERÊNCIAS}

CAMARGO JR., K. Das necessidades em saúde às demandas socialmente construídas. In: PINHEIRO, R. \& MATTOS, R. (Orgs.) Construção Social da Demanda. 2. ed. Rio de Janeiro: IMS/Uerj/Cepesc, 2010.

COCCO, G. Trabalho e Cidadania: produção e direitos na era da globalização. São Paulo: Cortez, 2000.

COCCO, G. Entre a universalização da guerra e universalização dos direitos. In: PACHECO, A. \& VAZ, P. (Orgs.) Vozes no Milênio: para pensar a globalização. Rio de Janeiro: Museu da República, 2002. 
CORSINI, L. As migrações e o trabalho da resistência. Lugar Comum: Estudos de mídia, cultura e democracia, 19-20: 185-196, jan. 2004.

GORZ, A. Misérias do Presente, Riqueza do Possivel. São Paulo: Annablume, 2004.

HARDT \& NEGRI, A. Império. São Paulo: Record, 2001.

HARDT \& NEGRI, A. Multidão. Rio de Janeiro: Record, 2005.

NEGRI, A. Exílio. São Paulo: Iluminuras, 2001.

NEGRI, A. La Forma-Estado. Madrid: Akaal, 2003a.

NEGRI, A. 5 Lições sobre o Império. Rio de Janeiro: DP\&A, 2003 b.

NEGRI, A. De Volta: abecedário biopolítico. Rio de Janeiro: Record, 2006.

NEGRI, A. \& HARDT, M. O Trabalho de Dioniso: para crítica ao Estado pós-moderno. Juiz de Fora: Editora UFJF, Pazulin, 2004.

TRONTI, M. Operários e Capital. 2. ed. Porto: Edições Afrontamento, 1972.

VIRNO, P. Virtuosismo e Revolução. Rio de Janeiro: Civilização Brasileira, 2008. 


\section{Produção de Conhecimento sobre a Triade Saúde, Trabalho e Subjetilidade}

Silvana Mendes Lima

0 presente estudo traça um panorama e faz uma análise do estado da arte da produção de conhecimentos na área da saúde do trabalhador e sua intercessão com os estudos da subjetividade. Justifica-se pela carência de pesquisas não somente que aprofundem as numerosas vertentes que comportam o tema, mas também que incluam a questão da subjetividade, por esta última ter se tornado matéria-prima essencial das relações de produção do capital, na sua forma atual.

É aspecto próprio das novas formas de produção do capital a destituição, diluição e exclusão daqueles que não são capazes de se inserir na dinâmica atual da modernização dos processos de trabalho baseados em ajustar, de modo polivalente e flexível, o trabalhador moderno. Nessa dinâmica, as empresas, de um modo geral, acabam funcionando como máquinas de vulnerabilizar e de excluir, tendo como efeito a desqualificação e a invalidação dos trabalhadores que estão envelhecendo e, em relação aos jovens, a redução das qualificações exigidas para a admissão, que acabam por "desmonetarizar uma força de trabalho antes mesmo que tenha começado a servir” (Castel, 1998: 527).

Mas se é fato que o capital se apropria em escala nunca vista das formas de trabalho e vida, instituindo modos próprios de subjetivar o trabalho na contemporaneidade, a subjetividade "é ela própria um capital de que cada um dispõe, virtualmente, com consequências políticas a determinar” (Pelbart, 2000: 37). Isso significa afirmar que os modos de subjetivar as formas de trabalho, próprias do nosso tempo, não existem de maneira uniforme nem total. Eles existem em uma série de outras maneiras de viver, de pensar, que, embora muitas vezes não apareçam ou apareçam como desviantes, são formas 
de resistir, transformar e alterar esses modos dominantes. Essas transformações se consolidam por meio das alianças pessoais, sociais e políticas que vão sendo constituídas no encontro e nos embates ante as formas de trabalho e vida.

Sobre esses embates, quando se acopla o tema da subjetividade e sua relação com a produção de conhecimento na área da saúde do trabalhador, verificamos uma pluralidade de olhares que esse tema tem suscitado na literatura. Para Araújo (2002), a discussão da subjetividade aparece referendada nos campos da saúde e do trabalho com base em abordagens teóricas diferenciadas. Nessas abordagens, a subjetividade comporta cinco perspectivas: sustentando um caráter psicodinâmico do trabalho; como oposição à objetividade; como dimensão da experiência; como dimensão clínica da organização; como invenção contínua de modos de estar na vida.

Além dessas diferentes perspectivas apontadas por Araújo, encontramse, igualmente, outras tentativas de sistematização e análise que vêm sendo operadas por diferentes campos de conhecimento e que trazem acepções próprias quanto às questões da saúde e do trabalho. Acepções essas que abarcam distintas compreensões sobre a noção de subjetividade e o que ela suscita.

Para fins deste estudo, foi realizado um primeiro mapeamento, que abrangeu resumos de artigos de revistas científicas, dissertações de mestrado e teses de doutorado, todos produzidos no Brasil, de 2000 a 2007. Entre as áreas de concentração em que foram produzidas, encontram-se: enfermagem, filosofia, sociologia, psicologia, engenharia, administração, fonoaudiologia, antropologia, saúde coletiva, economia, educação. Com relação aos artigos, um número considerável deles concentra-se na área de psicologia com incursões em outras áreas, tais como: engenharia, enfermagem, educação e saúde coletiva. No mais, aparecem alguns trabalhos da área de nutrição e fonoaudiologia.

Percebemos que a temática da subjetividade, quando referida aos campos da saúde e do trabalho, encontra-se mais associada aos estudos no âmbito da composição subjetividade, saúde mental e trabalho, ou ainda, subjetividade, sofrimento psíquico e trabalho - o que aponta, desde já, para a diversidade de arranjos, análises e metodologias que marcam, inevitavelmente, os estudos que referendam a saúde e a subjetividade de quem trabalha.

Este estudo constitui-se, inicialmente, em um mapeamento e análise dos trabalhos selecionados mediante um enfoque eminentemente qualitativo. Nosso esforço consistiu em buscar, com base nessa revisão, seus planos conceituais, dando visibilidade ao modo como eles produzem, repassam, recriam e atribuem sentidos e valores à tríade saúde, trabalho e subjetividade. Por 
conseguinte, do ponto de vista analítico, operamos uma inversão no caminho trilhado pela filosofia tradicional ou psicologia, com relação àquilo que se nomeia como a questão do sujeito e da intersubjetividade. A subjetividade aqui é concebida como produção, sendo composta de diversos elementos, de natureza interna e/ou externa (afetivos, familiares, do corpo, da mídia, da linguagem, do desejo, entre outros). Essa heterogeneidade de elementos, em constante processualidade, faz da subjetividade uma instância múltipla indissociável de práticas sociais concretas (Caiafa, 2000).

Assim, o que vem a seguir é um primeiro retrato sobre a produção de conhecimento no campo da saúde do trabalhador e a tríade saúde, trabalho e subjetividade. Importa-nos compreender como essa tríade é referida por alguns de seus autores e os sentidos, valores e embates daí derivados.

\section{Saúde do Trabalhador e as Noções de Subjetividade}

Um primeiro desafio presente nos resumos e estudos selecionados, para fins desta análise, é o modo como buscam dar visibilidade a uma "matéria-prima tão impalpável quanto incontornável a que chamamos subjetividade" (Pelbart, 2000: 35), ainda mais quando essa matéria é problematizada em razão de sua composição com a saúde e o trabalho.

Assim, a subjetividade ora é referida como uma espécie de entidade interiorizada que, ao sofrer as ações de determinadas formas de trabalho, torna-se uma subjetividade explorada e alienada; ora é concebida como algo que se perde, por exemplo, com a introdução da máquina no processo produtivo.

Há estudos, porém, que buscam compreender a organização subjetiva dos trabalhadores envolvidos em determinados processos de trabalho e outros voltados à busca dos sentidos, subjetivamente manifestos, em torno do trabalho ou de sua ausência. Nesse aspecto, a subjetividade permanece igualmente como uma entidade/unidade, mas que expressa a totalidade de um coletivo. O que se observa nessas análises é que, mesmo quando a noção de subjetividade é remetida a um coletivo, este último torna-se refém da ideia de unidade/ totalidade. Nas unidades que guardam suas identidades, um dos efeitos é a manutenção da cisão entre coletivo e individual, que, na composição saúde, trabalho e subjetividade, produz uma segunda cisão expressa entre modos de trabalhar e modos de subjetivar. Uma cisão histórica que se desdobra em tantas outras anunciadas entre o individual vs. o grupal; o objetivismo vs. o subjetivismo; o sujeito vs. o objeto. Nessa direção, segundo Araújo (2002), a 
tentativa de ultrapassar uma visão de subjetividade como oposição à objetividade é fruto da incorporação das ciências sociais nos estudos das relações e dos fenômenos saúde/doença, abrindo, portanto, novas perspectivas na área da saúde do trabalhador.

No entanto, embora essa guinada qualitativa da relação entre saúde, trabalho e subjetividade ganhe um novo fôlego, nota-se, em alguns dos estudos analisados, principalmente aqueles desenvolvidos no domínio da psicologia, uma visão dicotomizante - de um lado, as relações saúde e trabalho e, de outro, a subjetividade.

De acordo com Passos e Barros (2000), essa dicotomia remete ao advento da psicologia como campo. Buscando analisar as forças que o constituem, os autores afirmam que se parte da ideia de que o objeto próprio da psicologia seria o homem diante de sua própria contradição. Nesse sentido, a psicologia buscou e ainda busca, mediante procedimentos vários, tratar e analisar essa condição, demasiadamente humana, de um objeto caracterizado por uma tensão constituinte, "já que nele é impreciso o limite entre o normal e o patológico, o adaptado e o desadaptado, o corpo e o espírito" (Passos \& Barros, 2000: 77).

Portanto, a história dos estudos psicológicos é configurada por uma dispersão teórico-metodológica, cujo saber nunca se firmou em um campo coeso. São três as linhas evolutivas que andaram paralelas e concorreram na disputa pela preeminência nesse campo:

os estudos do sujeito do conhecimento evoluíram desde a segunda metade do século XIX, definindo uma vertente comprometida com o tema dos processos cognitivos. Contemporânea a esta linha evolutiva, outra se traça apoiada nas práticas clínicas e tendo como tema central o sujeito do desejo e do inconsciente. Por fim, sem forjar os seus próprios instrumentos com uma preocupação eminentemente utilitária, as psicotécnicas se desenvolveram voltadas para instituições como a escola, a fábrica, o hospital geral. (Passos \& Barros, 2000: 72)

Do ponto de vista epistemológico, o eixo de sustentação que se adota, diante desse estado de dispersão teórico-tecnológica, remete à especificidade da relação estabelecida entre sujeito e objeto de conhecimento. É, então, com base nessa relação, que se opera a distinção dos campos, que se determinam as fronteiras e que se demarcam as disciplinas.

Um aspecto relevante observado na leitura desses estudos se refere aos modos diferenciados de apropriação daquilo que eles nomeiam como o objeto de conhecimento: o trabalhador e as relações engendradas em seu território 
laboral, quando se tem como meta a promoção da saúde mediante a incorporação do tema da subjetividade.

Assim, essas formas de apropriação se realizam por meio de diferentes procedimentos quando se busca focar o objeto de conhecimento incorporando numerosos saberes. Uma é relativa ao movimento de disciplinas que se somam e tomam o objeto em sua natureza multifacetada, e que exige diferentes olhares (multidisciplinaridade); outra, mais frequente, busca uma zona de interseção entre as diferentes disciplinas para cada qual um objeto específico será designado (interdisciplinaridade). Em ambas as perspectivas, observa-se a manutenção das fronteiras disciplinares, assim como dos objetos e, notadamente, dos sujeitos desses saberes. Por último, há os estudos, mais raros, que se dirigem a uma perspectiva transdisciplinar em que

sujeito e objeto não são mais realidades previamente dadas, mas se produzem por efeito das práticas. Estas, sejam teóricas ou não, devem explicar as posições subjetivas e objetivas que tendem a se estabilizar como realidade. Nessa perspectiva, já não se pode mais admitir sujeitos determinando formas de conhecer objetos, nem objetos com suas bem marcadas linhas se dando a conhecer aos sujeitos. (Passos \& Barros, 2000: 74)

Esses procedimentos e formas de apropriação e condução dos estudos ganham maior complexidade quando se adentra o terreno arenoso da subjetividade e sua composição com a saúde e o trabalho. Assim, retomando os trabalhos consultados, dois textos são emblemáticos na tentativa de delimitação de abordagens teórico-metodológicas diferenciadas e da qual derivam estratégias de intervenção distintas.

Nos artigos de Borsoi (2007) e de Jaques (2003), as autoras assinalam quatro amplos conjuntos de modelos teóricos em saúde mental e trabalho: as teorias sobre o estresse, a corrente voltada para a psicodinâmica do trabalho, a abordagem epidemiológica e/ou diagnóstica e os estudos sobre subjetividade de trabalho. Destes modelos, podemos extrair dois eixos constitutivos. Um dos eixos menciona a importância de um diagnóstico dos sintomas de origem psíquica, analisando sua vinculação a situações de trabalho. No outro eixo, a ênfase não recai no diagnóstico de doenças ocupacionais, mas nas vivências dos trabalhadores em situações de trabalho produtoras de adoecimento. $\mathrm{O}$ que vale ressaltar é que cada uma das abordagens busca, a seu modo,

encontrar a relação entre trabalho e saúde mental, tentando apontar os nexos entre aspectos do trabalho e sofrimento psíquico. Pode-se notar que apesar das distâncias teórico-metodológicas existentes entre elas, há, pelo 
menos, um consenso: desencadeador, determinante ou constituinte, o trabalho pode ser considerado, de alguma maneira, motivo de sofrimento que muitas vezes limita o trabalhador, quando não o impede efetivamente de trabalhar. (Borsoi, 2007: 107)

Mais do que buscar um consenso quando se trata de trabalho, talvez possamos compreendê-lo à luz da afirmativa de que ele, o trabalho, é uma fonte inesgotável de paradoxos (Dejours, 2005).

De fato, a natureza paradoxal e complexa que a categoria trabalho abarca se traduz, historicamente, em um amplo leque de conceituações as mais diversas. Essa diversidade de acepções ganha feições específicas de acordo com as numerosas possibilidades, embates e confrontos presentes na relação que se estabelecem entre o trabalho e as formas de vida que ele engendra.

\section{Linhas Transversals de Análise na Composição Saúde, Trabalho e SUBJETIIIDADE}

Referindo-nos à composição saúde, trabalho e subjetividade, um dos desafios, próprio à produção de conhecimentos e às intervenções operadas nos espaços de trabalho, é que tais acepções acerca do trabalho e as modalidades e metodologias de intervenção daí derivadas sejam capazes de criar ressonâncias entre campos ou disciplinas que, predominantemente, foram sendo constituídos de modo cindido e estanque.

Se, como indica Brito (2004), o campo da saúde do trabalhador se constitui mais como uma perspectiva de estudo, atenção e intervenção sobre os problemas relativos à saúde dos trabalhadores, ele pode criar ações que escapam a esse modo cindido e estanque que vem predominando nas análises e intervenções próprias ao campo. Especialmente por se tratar de um campo que desenvolve ações práticas, segundo olhares de diferentes especialistas e trabalhadores. Nessa direção, nos questionamos acerca de como fundar uma intercessão entre esses diversos domínios, disciplinas ou especialidades, de modo que possam criar ressonâncias nas formas de produzir conhecimento, assim como nas metodologias de intervenção nos territórios de trabalho.

Quando falamos da noção de intercessão, é fundamental compreendê-la opondo-a radicalmente a uma outra noção, a de interseção. Esta última consiste, apenas, em compatibilizar dois domínios - por exemplo, o do trabalho e o da saúde - na constituição de um terceiro domínio, "que se espera estável, idêntico a si e para o qual se pode se definir um objeto próprio”. Quanto à 
primeira noção, "a relação que se estabelece entre os termos que se intercedem é de interferência, de intervenção através do atravessamento desestabilizador de um domínio qualquer (disciplinar, conceitual, artístico, sociopolítico, etc.) sobre outro" (Passos \& Barros, 2000: 77).

É nesse segundo sentido, inspirado na ideia de 'intercessor', que neste capítulo enfatizamos a ressonância entre as acepções de trabalho, saúde e subjetividade, assim como das ações práticas que tais acepções produzem em termos de mudanças significativas nas condições de trabalho, formando uma tríade cuja compreensão não pode ser apreendida senão no interior de uma certa intervenção ou operação (Deleuze, 1992).

A ideia de intercessor ganha relevância quando se trata de formas de intervenção no âmbito da saúde. Porém, vale ressaltar, uma acepção de saúde como a define Canguilhem (1990): saúde como um conceito vulgar, alheio ao campo do saber objetivo e que estaria ao alcance de todos. Nesta forma de pensar, a saúde não é propriedade de especialistas e, embora não possa prescindir desses saberes, deve incorporar como dimensão a experiência do corpo e suas referências de dor e prazer do ponto de vista de quem as vive.

O corpo, nessa acepção de saúde, resulta sempre de um campo de forças, dando-lhe um caráter de embate e necessidade de ultrapassagem. Esse caráter de embate é similar à perspectiva de saúde como um campo de luta, situada fora dos parâmetros de equilíbrio e conformidade ao meio. Assim, o caos, o desequilíbrio, o adoecer não são concebidos como defeitos, mas efeitos que emergem dos encontros dos corpos com as "infidelidades do meio", usando a expressão de Canguilhem (1990); o caos e suas linhas descontínuas como fazendo parte da vida, uma maneira de conceber e estar no mundo, uma das expressões em que a vida se manifesta.

Nos estudos em foco, identificamos, em suas linhas descontínuas, um esforço na direção de criar ressonâncias desestabilizadoras entre domínios diferenciados, preservando a natureza daquilo que eles compreendiam ser a singularidade de seus domínios de ação. Desse modo, encontramos, por exemplo, num dos artigos (Pereira \& Mishima, 2003), a problematização acerca da subjetividade como matéria para a reorganização do processo de trabalho da enfermagem. As autoras sugerem que a enfermagem retome o núcleo de competência que lhe cabe, além dos procedimentos técnicos, aquele concernente à ação cuidadora, detendo-se no doente e não na doença.

Em outro artigo, Ribeiro, Pires e Blank (2004) - teorizando sobre o processo de trabalho em saúde como instrumental para análise do trabalho no 
Programa Saúde da Família - buscam, igualmente, definir a especificidade ou a natureza do trabalho em saúde quando a definem como uma atividade laboral na esfera da produção não material, que se completa no ato de sua realização; portanto, seu produto é a própria realização da atividade. Em ambos os estudos, encontra-se, de algum modo, uma orientação teórico-metodológica-prática que, ao mesmo tempo que caotiza suas margens com outras disciplinas e áreas afins, está atenta à particularidade da natureza de seu trabalho. No caso do trabalho imaterial, principalmente aqueles circunscritos à área da saúde que demandam uma ação cuidadora, trata-se de um conjunto de atividades cujas ações não se restringem a executar tarefas, mas visam, sobretudo, a concebê-las, criá-las.

Ao ampliarmos essa análise, vemos que a condição do trabalho imaterial, assim como o seu conteúdo e resultado, consistem, eminentemente, na própria produção de subjetividade que atravessa todas as etapas do processo de trabalho. Nisso, conclui-se que o trabalho necessita da vida como nunca e que seu produto afeta a vida em uma escala sem precedentes. Urge, portanto, examinar os impasses e efeitos das formas que toma essa contínua apropriação da subjetividade e o que ela produz nos diferentes modos postos em funcionamento presentes nas relações de trabalho.

Esses impasses e efeitos tornam-se, igualmente, matéria-prima para a produção de conhecimentos no que se refere à composição saúde, trabalho e subjetividade e sua circunscrição ao campo da saúde do trabalhador. Vimos, inclusive, que tal circunscrição a um campo sofre a interseção de disciplinas e formas de intervenção que colocam em análise a própria noção de campo.

Por conseguinte, mais do que a ideia de campo, a saúde do trabalhador parece se configurar como um plano de constituição de saberes e práticas compostos de matérias heterogêneas e que produzem realidades diversas. Nesse plano, a produção de saúde consistiria, então, em considerar os componentes sociais, afetivos, econômicos que atravessam as formas de vida e trabalho atualmente, dada a intenção de suscitar uma saúde como potência de interferir no mundo ou, como diz Canguilhem (1990), capaz de inventar novas normas que abalem os traços e marcas, historicamente impressos no corpo do trabalhador e em sua relação com o trabalho em seu caráter coercitivo e excludente.

$\mathrm{O}$ que se inaugura com uma perspectiva de produção de saúde como potência de interferir no mundo são práticas de natureza transversal. Práticas conjugadas e traçadas em um espaço de revezamento entre saberes, corpos, perspectivas e métodos. Práticas que, em seu caráter dissidente, produzem, com base na composição saúde, trabalho e subjetividade, novas formas de 
sensibilidade que funcionam como processos criadores e de transformação e que entendemos como produtores de saúde.

\section{Considerações Finals}

Ao analisarmos os estudos que buscam congregar a tríade saúde, trabalho e subjetividade, nos deparamos com uma diversidade de orientações e de aportes teórico-metodológicos que o campo da saúde do trabalhador comporta. Essa diversidade, quando se busca focar o objeto de conhecimento incorporando numerosos saberes, se traduz em diferentes perspectivas e acepções nomeadas neste capítulo como: multidisciplinar, interdisciplinar e transdisciplinar.

Dentre essas acepções, constatamos visões, por vezes redutoras, acerca da problemática da subjetividade e sua composição com a saúde e o trabalho. Nelas, a subjetividade aparece como uma entidade interiorizada, estanque, que diz respeito apenas a um 'eu' que, ao sofrer ações engendradas nas formas de trabalho, torna-se matéria passiva, explorada. No entanto, há igualmente estudos que tentam ultrapassar essa lógica binária e estanque de conceber a subjetividade tomando-a como algo que é da ordem do inacabado e que, por isso, buscam desenvolver ações práticas, com base em olhares de diferentes especialistas, incluindo, principalmente, acepções e embates do trabalhador.

O que interessa nessas ações é o confronto com trajetórias, metodologias, afazeres que são sempre singulares, cujo efeito, quando privilegiamos uma perspectiva transversal nos modos de subjetivar a saúde e o trabalho, possa criar mediações produtoras de uma efetiva reapropriação da vida social e subjetiva. Para tanto, os conhecimentos produzidos teriam de trabalhar na direção de conhecimentos-ferramenta que funcionariam como operadores de realidade. Nesse sentido, os conhecimentos produzidos no interior de qualquer intervenção estariam cheios de força para produzir crise, desestabilizar. Teríamos, assim, conceitos-ferramenta forjando espaços-tempo de experimentação aptos a interferir e desestabilizar determinadas condições de trabalho, desatrelando e destituindo aquelas relações de trabalho pautadas no constrangimento e, por isso, produtoras de sofrimento. Tarefa árdua, mas necessária de ser exercida, em que os diferentes domínios, campos, disciplinas, conceitos e formas de intervenção seriam afetados pela particularidade de suas forças, as quais estabeleceriam uma relação de ressonância e/ou troca mútua, deixando-se perturbar tanto por suas diferenças quanto por uma interferência desestabili- 
zadora, aproveitando "a potência de diferir do outro para expressar sua própria diferença” (Passos \& Barros, 2000: 78).

Importa, então, retomando a tríade saúde, trabalho e subjetividade, que a relação entre esses diferentes domínios possa caotizar suas margens e limites, transformando-os em sistemas abertos, enfrentando, na sua composição, a moral dominante que tem estancado, agonizado e rivalizado, incessantemente, as múltiplas possibilidades de conceber e experimentar as formas de trabalho e vida.

\section{REFERÊNCIAS}

ARAÚJO, M. D. Alguns olhares sobre a subjetividade nas pesquisas em saúde do trabalhador. In: MACHADO, L. D.; LAVRADOR, M. C. C. \& BARROS, M. E. B. (Orgs.) Texturas da Psicologia: subjetividade e politica no contemporâneo. São Paulo: Casa do Psicólogo, 2002.

BORSOI, I. Da relação entre trabalho e saúde à relação entre trabalho e saúde mental. Psicologia $\mathcal{E}$ Sociedade, 19 (n. esp.): 103-111, 2007.

BRITO, J. Saúde do trabalhador: reflexões a partir da abordagem ergológica. In: FIGUEIREDO, M.; ATHAYDE, M. \& BRITO, J. (Orgs.) Labirintos do Trabalho: interrogações e olhares sobre o trabalho vivo. Rio de Janeiro: DP\&A, 2004.

CAIAFA, J. Nosso Século XXI: notas sobre arte, técnica e poderes. Rio de Janeiro: RelumeDumará, 2000.

CANGUILHEM, G. La Santé: concept vulgaire et question philosophique. Paris: Sables, 1990.

CASTEL, R. As Metamorfoses da Questão Social: uma crônica do salário. Petrópolis: Vozes, 1998.

DEJOURS, C. A Banalização da Injustiça Social. Rio de Janeiro: Fundação Getulio Vargas, 2005.

DELEUZE, G. Conversações. Rio de Janeiro: Editora 34, 1992.

JAQUES, M. G. C. Abordagens teórico-metodológicas em saúde/doença mental \& trabalho. Psicologia E⿱ Sociedade, 15(1): 92-116, 2003.

PASSOS, E. \& BARROS, R. B. A construção do plano da clínica e o conceito de transdisciplinaridade. Revista Psicologia: Teoria e Pesquisa, 16(1): 71-79, 2000.

PELBART, P. P. A Vertigem por um Fio: políticas da subjetividade contemporânea. São Paulo: Iluminuras, 2000.

PEREIRA, M. J. B. \& MISHIMA, S. M. Revisitando a prática assistencial: a subjetividade como matéria para a reorganização do processo de trabalho na enfermagem. Interface: Comunicação, Saúde, Educação, 7(12): 83-100, 2003.

RIBEIRO, E. M.; PIRES, D. \& BLANK, V. L. G. A teorização sobre o processo de trabalho em saúde como instrumental para análise do trabalho no Programa Saúde da Família. Cadernos de Saúde Pública, 20(2): 438-446, 2004. 


\section{Revisão de Abordagens Té́rico-Metodológicas sobre Saúde Mental e Trabalho}

Tânia Maria de Araújo

\section{A Constitulção do Campo}

0 campo da saúde mental e trabalho tem sido impulsionado pelos estudos que abordam o trabalho no processo de construção de subjetividade, a contribuição do trabalho nos processos de adoecimento psíquico, a caracterização de aspectos do trabalho mais diretamente associados à ocorrência de transtornos mentais ou situações de sofrimento psíquico. Outros aspectos, como satisfação e capacidade para o trabalho, também figuram na produção mais recente.

Para a constituição do campo da saúde mental e trabalho foi necessário, inicialmente, o estabelecimento de rupturas com os modelos dominantes de concepção dos processos de construção de identidade, individual e coletiva, e de estruturação do processo de determinação de saúde/saúde mental e doença. A primeira ruptura, bem caracterizada na produção existente, foi feita com concepções e teorias predominantes em determinadas abordagens em psicologia que desconhecem o trabalho como espaço estruturador da vida subjetiva de homens e mulheres, desenvolvendo a análise dos processos de adoecimento e sofrimento mental nos limites estreitos da família ou da sexualidade (Codo, Sampaio \& Hipomi, 1993).

O movimento crítico em oposição ao reducionismo na compreensão dos processos de saúde-doença mental, à fragmentação e às concepções teóricas incapazes de considerar a multiplicidade e complexidade na formação e estruturação do ser humano e de seu psiquismo impulsionou a elaboração de modelos mais amplos nesse campo e contribuíram para dar visibilidade às 
relações entre trabalho e saúde mental (Jacques, 2007). O trabalho foi, assim, trazido para o foco da discussão.

Embora haja certa divergência, como apontado por Lima (2004), no que se refere ao papel do trabalho, entendido por alguns autores como determinante (advogam que determinados tipos ou características do trabalho são estruturadores de adoecimento psíquico) ou como desencadeante (porta de entrada para o adoecimento), observa-se, na quase totalidade da produção, a discussão da importância de se trazer à cena a dimensão da vida no trabalho, explicitando a contraposição aos modelos nos quais o trabalho se encontra alijado da análise da subjetividade e dos processos relativos à saúde mental. Esse aspecto aglutina a maioria dos estudos revisados de um mesmo ponto de partida.

Nos modelos propostos, os percursos, concepções, pressupostos, as formas de avaliação, de diagnóstico e de intervenção são bastante diversos, embora muitas vezes complementares. Uma breve exposição sobre os aspectos que conformam as bases teórico-metodológicas das principais correntes e abordagens em saúde mental e trabalho encontra-se descrita a seguir.

\section{Principals Correntes Teóricas em Saúde Mental e Trabalho}

A análise da produção de textos sobre as principais abordagens em saúde mental e trabalho revela significativa diversidade taxonômica, com agrupamentos, distinções e classificações das correntes bem distintas. Apesar disso, algumas abordagens são claramente identificadas, com considerações sobre seus pressupostos, aplicabilidades e limites congruentes nas tentativas de classificação realizadas. Ao menos três modelos teóricos são claramente identificados como integrantes das abordagens predominantemente usadas nos estudos brasileiros: a teoria do estresse, a psicodinâmica do trabalho e o modelo de desgaste (embora este último seja nomeado com base em diferentes classificações). Outras delimitações são também propostas para se identificarem grupos de estudos emergentes ou para desagregar abordagens específicas surgidas no interior de uma linha maior - essas delimitações, embora úteis em alguns casos, apresentam contornos menos nítidos e poderiam ser classificadas em uma ou outra abordagem com base em elementos muito sutis.

Dentre o material produzido para discutir os aspectos teóricos e metodológicos das correntes de pensamento no campo, podem ser citados: Seligmann-Silva (1997), Jacques (2003), Neves, Seligman-Silva e Athayde (2004), Fernandes e 
colaboradores (2006) e Borsoi (2007). Há significativa confluência de posições acerca das proposições apresentadas nesses textos.

Seligmann-Silva (1997) distingue três correntes de pensamento no campo de saúde mental e trabalho: a corrente fundamentada na teoria do estresse, que reúne investigações sobre estresse e trabalho (work-stress); a corrente vinda das ciências sociais, que privilegia aspectos relacionados às relações de poder; e a corrente originária da teoria psicanalítica, que fundamentou os estudos da chamada psicodinâmica do trabalho.

Jacques (2003), considerando o referencial teórico, os aspectos metodológicos adotados e as concepções sobre a inter-relação entre trabalho e o processo saúde-doença mental, distingue quatro grandes grupos de abordagens nesse campo: teoria do estresse, psicodinâmica do trabalho, abordagem de base epidemiológica e/ou diagnóstica e pesquisas em subjetividade e trabalho. Na classificação proposta por Jacques, não há referência direta aos estudos fundamentados no modelo do desgaste (Laurell \& Noriega, 1989), modelo teórico que orientou uma dada tradição epidemiológica, derivada da epidemiologia social, na literatura sobre saúde e trabalho no Brasil.

A classificação proposta por Fernandes e colaboradores (2006) distingue cinco grupos de abordagem: a do desgaste, a da ergonomia e a das condições de vida e trabalho, além dos modelos já mencionados (estresse e psicodinâmica no trabalho).

Como se pode observar, embora haja diversidade na distinção de modelos teóricos e conceituais, há consenso na identificação de alguns modelos como influentes no campo, com destaque para a psicodinâmica do trabalho, a teoria do estresse e os estudos fundamentados nas ciências sociais.

A psicodinâmica do trabalho elege, como elementos centrais, a organização do trabalho e o sofrimento mental (Dejours, 1987; Dejours, Abdoucheli \& Jayet, 1994). Além disso, detém-se na análise das defesas que são coletivamente elaboradas pelos trabalhadores no enfrentamento das situações de sofrimento no cotidiano laboral. As abordagens qualitativas constituem as estratégias metodológicas comumente usadas e privilegiam o relato das vivências dos próprios trabalhadores: sua fala sobre o trabalho e as emoções, sentimentos e reações por ele desencadeados (Dejours, Abdoucheli \& Jayet, 1994).

O sofrimento psíquico foi tomado como categoria de análise para delimitar um campo de investigação diferenciado das abordagens que tomam, como objeto privilegiado de análise, a doença mental. $\bigcirc$ sofrimento corresponderia a uma vivência subjetiva intermediária entre a doença e a saúde, sendo experimentado, 
pelo trabalhador, por meio de sentimentos de insatisfação (com relação ao conteúdo ergonômico e ao conteúdo significativo do trabalho) e ansiedade.

Dentre as críticas mais relevantes apontadas com relação à abordagem da psicodinâmica, destacam-se a crítica com relação ao 'lugar' do trabalho na teoria proposta, fundada no modelo clínico da psicanálise, e aquela referente ao modelo metodológico adotado. Com relação ao papel do trabalho no adoecimento psíquico, não há, na proposição dejouriana, relação causal entre o trabalho e saúde mental. Na sua compreensão, as doenças mentais dependem, em última instância, das estruturas de personalidade, adquiridas muito antes da entrada dos indivíduos no mundo produtivo (Lima, 2004). Assim, o trabalho poderia se constituir em uma 'porta de entrada' do sofrimento e da doença mental, uma espécie de 'gatilho', mas não assumiria papel determinante no processo de adoecimento (Jacques, 2003). O trabalho poderia, a partir de determinadas características, estabelecer o momento de expressão do sofrimento, mas não a sua forma - esta, sim, decorrente da estrutura psíquica do indivíduo.

Outra crítica feita a essa abordagem diz respeito ao método. A ênfase no discurso dos trabalhadores, não raro, desconsidera as condições objetivas em que se realizam as atividades laborais. $\mathrm{O}$ trabalho é assim compreendido apenas por meio da sua vivência subjetiva, portanto, apenas parcialmente. Além disso, alguns aspectos na metodologia proposta são de difícil equacionamento em realidades como a brasileira, como a realização da pesquisa apenas segundo a demanda dos trabalhadores ou as entrevistas envolvendo o coletivo de trabalhadores.

Apesar dessas críticas, deve-se assinalar que essa abordagem vem tendo expressiva aceitação entre os pesquisadores brasileiros, ainda que algumas adaptações tenham sido feitas, como a realização do estudo na ausência de demanda por parte do coletivo de trabalhadores ou a substituição das entrevistas coletivas por entrevistas individuais, em que pesem as possíveis distorções que tais procedimentos possam implicar no método utilizado.

A teoria do estresse orientou os estudos pioneiros em saúde e trabalho e permanece como referência importante para boa parte da produção no campo da epidemiologia e da psicologia. Essa abordagem constituiu-se mediante a integração dos conhecimentos da psicofisiologia e da psicologia social, aplicados aos estudos de fadiga no trabalho. Entretanto, a complexidade dos fenômenos envolvidos na relação trabalho-saúde mental, abarcando enormidade de situações, que podem oscilar da saúde aos estados patológicos, revelou limitação dos estudos centrados na fadiga e conduziu à análise de novos elementos 
no interior dessa corrente. Nessa perspectiva, importantes contribuições vieram da abordagem psicossocial proposta por Gardell (1977, 1982). Os estudos de Frankenhaeuser e Gardell (1976) e de pesquisadores do Instituto Karolinska, em Estocolmo, buscaram novas categorias de fatores ambientais potencialmente capazes de produzir ou desencadear agravos à saúde. Para fins epidemiológicos, segundo Cassel (1974), o movimento de ampliação da perspectiva da teoria do estresse, incorporando novos elementos, promoveu a expansão do conceito de ambiente físico e microbiológico, originário de Seyle (1956), para o social. Esse campo de investigação desenvolveu-se amplamente e forneceu as bases teóricas para numerosas investigações sobre as fontes de estresse, insatisfação e de tensão no ambiente de trabalho.

$\mathrm{Na}$ tradição da psicologia, no Brasil, o estresse tem sido abordado, predominantemente, como variável resposta, buscando-se identificar os níveis de estresse vividos pelos indivíduos, como proposto na 'síndrome geral de adaptação', composta de três fases (alerta ou alarme, fase de adaptação ou resistência e fase de exaustão). Alguns instrumentos de avaliação de níveis de estresse foram adaptados para uso em estudos brasileiros (Lipp, 2000), com incorporação de uma quarta fase localizada entre as fases de resistência e exaustão, denominada de semiexaustão.

Nos estudos brasileiros ancorados na teoria do estresse, tanto na interpretação dos resultados como na proposição de intervenção, em geral são adotadas concepções cognitivo-comportamentais, ou seja: a abordagem adotada não incorpora, de modo mais orgânico, a análise da organização, do ambiente e do processo de trabalho, mantendo-se nos limites das medidas de intervenção voltadas ao gerenciamento individual do estresse, por meio de reestruturações dos comportamentos, práticas e hábitos individuais. $\mathrm{O}$ incremento nas estratégias de coping, por exemplo, ocupa destaque nessa perspectiva.

As principais críticas feitas a essa abordagem referem-se à pouca especificidade do termo e seu uso corrente para designar uma gama extremamente variada de situações: pode ser usado para designar um estressor, estratégias de coping ou resposta a situações de ameaças; pode ainda referir-se a estresse biológico, psicológico, social ou ambiental. Além disso, pode ser utilizada para descrever situações de irritação, ansiedade ou quadros graves de adoecimento mental. Essa inespecificidade, portanto, confere baixo poder para discriminar diferentes situações vivenciadas, dando-lhes contornos menos definidos.

Da necessidade de designar um campo específico de abordagem da teoria do estresse no mundo do trabalho, cunharam-se termos como estresse ocupa- 
cional ou síndromes específicas, como a síndrome de burnout (Borsoi, 2007). No Brasil, a síndrome de burnout, dentre aquelas ancoradas na abordagem do estresse, tem sido objeto de várias investigações, especialmente de educadores e profissionais de saúde. Essa síndrome é caracterizada como uma "reação à tensão emocional crônica gerada a partir do contato direto e excessivo com outros seres humanos, particularmente quando esses estão preocupados ou com problemas" (Vasques-Menezes, 2002: 201) e envolve três componentes: exaustão emocional, despersonalização e redução do envolvimento pessoal no trabalho. Apesar de os estudos sobre burnout incorporarem o trabalho como fator constitutivo do adoecimento psíquico, segundo Jacques (2003: 103) "o enfoque ainda dicotomiza a dimensão externa e interna do trabalho em que a natureza do trabalho se apresenta como fonte de tensão individualmente experimentada pelo trabalhador”. Mantém-se, assim, ainda presa a uma perspectiva centrada no indivíduo.

Outra ordem de críticas recai sobre a pouca importância dada à forma como o trabalho se estrutura, aos seus aspectos ambientais (condições concretas de trabalho) e organizacionais. Desse modo, as intervenções propostas apresentam limitações na sua abrangência e na sua capacidade de produzir alternativas e soluções para os problemas enfrentados em caráter mais duradouro, uma vez que, não raro, apenas a aparência ou as manifestações mais evidentes das situações são focalizadas e redesenhadas, sem interferência sistemática nas estruturas que produzem as condições desfavoráveis no ambiente laboral.

Observa-se ainda, nos artigos sobre modelos teóricos em saúde mental e trabalho, que a análise dos estudos derivados da teoria do estresse é feita tomando-se como base os modelos mais tradicionais dessa abordagem. Mesmo nos textos mais recentemente publicados (Jacques, 2003; Fernandes et al., 2006; Borsoi, 2007), não há referências a modelos oriundos da teoria do estresse com novos aportes teóricos e metodológicos, ou a novos modelos que buscaram superar limitações reconhecidas dessa abordagem, como a ênfase no referencial cognitivo-comportamental. Propostas que assumem causalidade sociológica, como o modelo demanda-controle, elaborado por Karasek (1979) e ampliado por Karasek e Theorell (1990) e Johnson (1989), por exemplo, não são mencionadas nos textos revisados, embora, nos últimos anos, respondam por um grupo crescente de estudos epidemiológicos de grupos ocupacionais no Brasil, especialmente na Bahia (Araújo et al., 2003a, 2003b; Reis et al., 2005; Nascimento Sobrinho et al., 2006; Porto et al., 2006; Araújo \& Karasek, 2008). 
Para estudos embasados nas ciências sociais, a discussão acerca dos transtornos psíquicos e trabalho liga-se, necessariamente, às dinâmicas das relações de dominação e, portanto, implicam abordagens que incorporam as relações de poder. Segundo tal corrente, os agravos à saúde mental decorrem de perdas geradas pelo desgaste mental. Tais perdas podem assumir múltiplas dimensões: serem concretas, simbólicas ou potenciais e, ainda, serem de natureza biológica, psíquica ou social - embora, geralmente, correspondam a articulações dessas três instâncias, mesmo quando o comprometimento mais palpável, representado pelas alterações orgânicas, não seja ainda visível (Clegg, 1993; Seligmann-Silva, 1994).

Adotando-se a classificação proposta por Jacques (2003), além das teorias aqui descritas, há as abordagens teórico-metodológica epidemiológica e/ou diagnóstica e a de subjetividade e trabalho.

A abordagem de orientação epidemiológica nas pesquisas de saúde mental e trabalho no Brasil surge na década de 1980, mas é a partir da década de 1990 que se observa aumento mais significativo de estudos nessa perspectiva. O incremento do uso de estudos epidemiológicos para análise das relações entre trabalho e saúde mental liga-se, em boa parte, ao crescimento do campo de saúde pública/saúde coletiva no Brasil, especialmente com a criação de cursos de pós-graduação stricto sensu - os quais passam a responder por parcela significativa da formação/qualificação de pesquisadores nas diversas áreas de atuação profissional (médicos, enfermeiros, psicólogos, assistentes sociais, fisioterapeutas) em saúde e trabalho, especialmente para os recém-criados serviços de atenção à saúde do trabalhador, nas diferentes esferas de governo.

O uso dos elementos teórico-metodológicos oriundos da epidemiologia social constituiu a primeira aproximação dessa tradição ao estudo das relações entre saúde mental e trabalho. Defende-se, nesse modelo, que as condições nas quais o trabalho é realizado determinam os modos de adoecimento (Laurell \& Noriega, 1989; Facchini, 1991). Nesta abordagem, o trabalho e seus elementos constituintes são estruturantes do conteúdo e da forma do sofrimento apresentado.

Tais estudos voltam-se para a investigação de categorias específicas de trabalhadores, no intuito de avaliar suas condições concretas de trabalho, as características das organizações e o perfil de adoecimento dos trabalhadores, buscando avaliar associações entre essas condições e as características laborais e o adoecimento observado. A produção nesse campo tem sido rica e encontra-se em marcante crescimento (Araújo, Graça \& Araújo, 2003). 
O uso de instrumentos padronizados de avaliação de características e de condições de trabalho e de adoecimento psíquico é característico nessa abordagem, utilizando-se aporte dos métodos quantitativos e das ferramentas epidemiológicas para a produção de evidências empíricas. Registra-se que boa parte dos estudos nessa perspectiva tem sido conduzida com base em demandas sindicais, portanto liga-se de modo significativo às lutas sindicais por melhores condições de trabalho.

Um dos problemas a serem registrados nessa abordagem é a multiplicidade de instrumentos de mensuração utilizados, o que dificulta a comparação entre os estudos. Além disso, a avaliação da relação entre trabalho e adoecimento psíquico nos limites apenas dos testes de significância estatística (na avaliação de associação entre variáveis), como se tem observado em dada tradição dos estudos identificados nessa vertente, muitas vezes não é capaz de identificar, satisfatoriamente, a complexidade e a inter-relação entre diferentes dimensões da vida no trabalho, levando muitas vezes a conclusões equivocadas ou apenas parciais.

Outra limitação apontada nesses tipos de estudos é o foco excessivo na doença, o que obscurece o olhar sobre a dimensão estruturante do trabalho, portadora de identidade e conformadora de subjetividade, ou a compreensão das formas de vida em movimento no trabalho, da plasticidade humana na cena laboral.

Para evitar as armadilhas reducionistas dos métodos baseados na quantificação, diversos autores têm defendido o emprego, simultâneo, de métodos quantitativos e qualitativos (Laurell \& Noriega, 1989; Lima, 2004), o que, de fato, tem-se mostrado uma alternativa muito promissora para investigar os eventos envolvendo trabalho e saúde mental.

Por fim, os estudos de subjetividade e trabalho analisam as relações entre saúde mental e trabalho com base nas experiências e vivências subjetivas dos trabalhadores. Seu objeto não se restringe apenas aos processos de adoecimento psíquico; assume-se, aqui, que o trabalho é o eixo central para a compreensão da subjetividade humana e que os indivíduos se constroem de acordo com uma dada contextualização histórica e cultural. Assim, concebe-se que o trabalho pode estabelecer formas específicas de sofrimento, considerando que este é, como mencionado, fundamental na constituição da subjetividade dos trabalhadores. Conformam interesse nesse enfoque as vivências, o cotidiano, os modos de vida; utilizam-se aportes teóricos de diversas disciplinas das ciências sociais.

Abordagens qualitativas são utilizadas nos estudos nessa vertente (Jacques, 2003). Observação, entrevistas individuais e coletivas e análises documentais constituem o arcabouço metodológico usado. 
Como mencionado, são muitas as propostas de classificação das abordagens teórico-metodológicas existentes em saúde mental e trabalho. Foram apontados aqui apenas os contornos de uma delas, aquela que, entendemos, cumpriu satisfatoriamente a tarefa de identificar as principais correntes de pensamento - os modelos que têm congregado, em torno de si, número expressivo de investigações e análises das relações entre trabalho e saúde.

A possibilidade de integração entre diferentes campos de conhecimento tem sido frequentemente discutida com base em contribuições de diferentes disciplinas. Seligmann-Silva $(1994,1997)$ destaca que convergências importantes entre essas correntes podem ser observadas, tais como a identificação de determinados fatores e situações de trabalho psicogênicos e repercussões clínicas e sociais que tais fatores e situações podem produzir. Ou seja, pode-se encontrar, na comparação de estudos dessas correntes teóricas, "a descrição de agravos cujas características clínicas são iguais ou muito semelhantes, embora venham recebendo denominações distintas e aderidas aos respectivos quadros teóricos de referência” (Seligmann-Silva, 1997: 97).

Duas questões devem ser salientadas nessa discussão. A primeira refere-se ao reconhecimento de que para o campo de saúde mental e trabalho convergem diferentes disciplinas e áreas de conhecimento, o que implica construção de um processo de interlocução e troca entre as diferentes disciplinas que o integram. A segunda questão diz respeito à própria aplicação dos resultados desses estudos. Quer a relação saúde mental e trabalho seja abordada pelo enfoque do estresse, quer seja pelo da psicodinâmica do trabalho ou das ciências sociais, o que parece ser merecedor de atenção é a ênfase recente aos fenômenos que antecedem a eclosão dos quadros patológicos, estejam eles rotulados como estresse, sofrimento mental ou desgaste. Tal ênfase oferece espaço extremamente relevante para a elaboração de ações preventivas, capazes de fortalecer os vínculos positivos que o trabalho possa estabelecer na vida dos indivíduos.

Assim, com base nessas considerações, vislumbra-se a possibilidade de que diferentes campos de conhecimento possam estabelecer interlocução efetiva, conformando métodos de investigação mais abrangentes e integradores. Uma vez apresentado o desafio da interdisciplinaridade como elemento central em trabalhos sobre saúde psíquica, os pontos de possíveis convergências podem ser ampliados à medida que os debates e as pesquisas entre esses campos forem intensificados. A busca de direção integradora firma-se como uma tendência identificada nos estudos mais recentes sobre saúde mental e trabalho. Como aponta Seligmann-Silva (1994), é preciso reconhecer que o campo da saúde 
mental é interdisciplinar; por isso são procedentes as tentativas de compatibilizar e mesmo integrar, caso seja possível, alguns referenciais teóricos e modelos de interpretação. Esse percurso pode ser alternativa fértil para se escapar das armadilhas reducionistas. Assim, a integração parece, de fato, possível, tanto para a compreensão dos fenômenos, quanto para a realização de observações e de análises em que abordagens distintas também possam convergir para revelar novos aspectos.

\section{Estudos em Saúde Mental e Trabalho: revisão da produção brasileira}

Para o levantamento da produção, tomou-se como referência a base de dados do Scientific Electronic Library Online (SciELO). O SciELO é resultante de um projeto de parceria da Fundação de Amparo à Pesquisa do Estado de São Paulo (Fapesp) com o Centro Latino-Americano e do Caribe de Informação em Ciências da Saúde (Bireme). Proporciona acesso a um número considerável de coleções de periódicos, tornando disponíveis resumos e textos completos dos artigos. $\mathrm{O}$ acesso, livre e gratuito, é feito no seguinte endereço eletrônico: <www.scielo.br>.

O levantamento bibliográfico foi inicialmente feito utilizando busca pelos termos selecionados. Após essa seleção, leram-se os resumos de todos os artigos identificados e selecionaram-se aqueles na área temática de interesse (saúde mental e trabalho). Em seguida, procedeu-se à classificação dos textos selecionados nessa segunda etapa de acordo com a abordagem teórico-metodológica adotada.

Para a pesquisa bibliográfica da produção brasileira na base de dados SciELO, utilizaram-se os seguintes termos: trabalho; saúde mental e trabalho; saúde do trabalhador; psicodinâmica do trabalho; subjetividade e trabalho; estresse ocupacional; epidemiologia. Realizou-se busca com cada um desses termos separadamente e de todas as possíveis combinações desses termos.

Na primeira etapa de busca foram identificados 120 artigos. Após leitura dos resumos e dos textos completos, quando necessário, foram selecionados e classificados 51 artigos. Tanto para a definição dos termos de busca quanto para a classificação dos artigos, foram consideradas as abordagens teóricometodológicas predominantes no campo de saúde mental já descritas aqui. A Tabela 1 sumariza a produção brasileira de acordo com o tipo de abordagem adotada, identificada na base de dados consultada - SciELO. 
Tabela 1 - Distribuição da produção bibliográfica em saúde mental e trabalho segundo tipo de abordagem - de 1990 a 2008

\begin{tabular}{l|c|c}
\hline TIPO DE ABORDAGEM & $\mathrm{n}$ & $\%$ \\
\hline Aspectos teóricos e conceituais & 5 & 9,8 \\
\hline Estresse ocupacional & 8 & 15,7 \\
\hline Psicodinâmica do trabalho & 13 & 25,5 \\
\hline Estudos epidemiológicos e/ou diagnósticos & 18 & 35,3 \\
\hline Estudos sobre desgaste & 1 & 2,0 \\
\hline Subjetividade e trabalho (estudos qualitativos) & 6 & 11,7 \\
\hline Total & 51 & 100,0 \\
\hline
\end{tabular}

Os estudos de abordagem epidemiológica e/ou de caráter diagnóstico representaram a maior proporção da produção identificada (respondendo por 35,3\% do total dos artigos), seguidos pelos estudos que utilizaram a abordagem da psicodinâmica do trabalho (25,5\% do total). Essas duas tradições de pesquisa foram responsáveis por $60,8 \%$ da produção brasileira na base de dados analisada.

Os estudos de análise teórico-metodológica responderam por um pequeno percentual da produção (cerca de 10\% do total); ainda assim, dentre os cinco artigos identificados nessa abordagem, dois foram elaborados em períodos diferentes (2003 e 2007), por uma mesma autora. Como se pode observar, a preocupação com a delimitação teórica, conceitual e metodológica é ainda incipiente, revelando que se trata de um campo ainda pouco analítico, que não privilegia a avaliação de seus conceitos e métodos como objeto de análise e crítica.

$\mathrm{Na}$ abordagem de estresse ocupacional, destacaram-se os estudos de validação de instrumento de pesquisa - escalas de estresse, satisfação e coping -, representando $50,0 \%$ da produção identificada (quatro dos oito artigos identificados), e os estudos de avaliação de burnout em grupos ocupacionais: policiais civis, professores (Moreno-Jimenez et al., 2002) e bancários (Paschoal \& Tamayo, 2005). Registrou-se apenas um estudo sobre aspectos teóricos e metodológicos.

Foi na psicodinâmica do trabalho que se observou o maior número de artigos voltados para análise de aspectos teóricos e conceituais (cinco dos 13 levantados). A utilização conjunta de aporte teórico e metodológico da psicodinâmica do trabalho e da ergonomia foi observada nos estudos realizados. 
Dentre as situações concretas de trabalho analisadas segundo a ótica dessa abordagem, citam-se aquelas vivenciadas por agentes de trânsito (Lancman et al., 2007), trabalhadores de hospital (Sznelwar et al., 2004), bancários (Palácios, Duarte \& Câmara, 2002), gestores (Brant \& Minayo-Gomez, 2004) e músicos (Assis \& Macedo, 2008). A análise de aspectos relacionados ao trabalho e gênero também foi discutida (Molinier, 2004).

Nos estudos que adotaram a abordagem epidemiológica e/ou diagnóstica, predominaram aqueles sobre condições e características do trabalho e sua relação com a morbidade psíquica, especialmente com os chamados transtornos mentais comuns em grupos ocupacionais específicos: professores (Reis et al., 2005; Porto et al. 2006; Gasparini, Barreto \& Assunção, 2006), agricultores (Faria et al., 1999), médicos (Nascimento-Sobrinho et al., 2006; Cabana et al., 2007), trabalhadoras de enfermagem (Araújo et al., 2003a), penitenciários (Fernandes et al., 2002) e trabalhadores informais (Ludermir, 2000). O SelfReporting Questionnaire (SRQ-20), instrumento de avaliação de transtornos mentais comuns desenvolvido pela Organização Mundial da Saúde (OMS), predominou entre os instrumentos utilizados (nove dos estudos realizados o adotaram). A análise de associação entre os aspectos psicossociais do trabalho e morbidade psíquica ganhou destaque nos anos mais recentes (Araújo et al., 2003c). Para a avaliação dos aspectos psicossociais do trabalho, vem sendo utilizado o Job Content Questionnaire (JCQ) (Karasek, 1985; Karasek \& Theorell, 1990). A avaliação de aspectos relativos à saúde mental e gênero, como trabalho doméstico e dupla jornada de trabalho, também é abordada nos estudos realizados.

Apenas um único artigo adotando o modelo de desgaste de Laurell e Noriega (1989) foi identificado (Carvalho \& Felli, 2006).

Os estudos da abordagem aqui denominada de subjetividade e trabalho (responsável por 11,7\% da produção) enfocaram a vivência do trabalho, suas características cotidianas, percepção de situações prazerosas e de sofrimento, mudanças nos processos e na organização do trabalho e seus impactos na vida dos trabalhadores (Avellar, Iglesias \& Valverde, 2007; Nardi \& Ramminger, 2007).

A revisão desenvolvida, embora se configure como um esforço inicial para identificar e classificar a produção existente no campo, rastreada na base de dados consultada, permitiu delimitar as principais abordagens do campo, corroborando as classificações elaboradas anteriormente (Seligmann-Silva, 1997; Jacques, 2003; Borsoi, 2007). Ressalta-se, no entanto, o caráter limitado da revisão realizada, uma vez que se restringiu a uma única base de dados. 
Estudos futuros devem ampliar o escopo do presente ensaio, incorporando análise de outras bases de dados existentes.

Finda essa primeira tarefa, de brevemente destacar elementos teóricos e metodológicos no campo e apresentar achados do levantamento bibliográfico realizado, cumpre-nos agora discutir alguns aspectos gerais sobre os limites e os desafios apresentados nesse momento. Em particular, interessa-nos explorar um pouco mais a contribuição dos estudos epidemiológicos à discussão, também no intuito de mostrar suas limitações e potencialidades.

\section{Avanços e Desafios para o Campo}

Um aspecto relevante a ser considerado no contexto atual da saúde mental e trabalho está intimamente ligado ao fortalecimento da perspectiva da saúde coletiva no modelo de atenção à saúde no Brasil, ainda que possamos identificar limitações significativas, muitas vezes frustrantes, na adoção desse paradigma nos serviços.

O reordenamento do sistema de saúde, a partir da consolidação da proposta do Sistema Único de Saúde (SUS), trouxe perspectivas novas para a estruturação do sistema da atenção à saúde dos trabalhadores. A estruturação de uma rede de atenção, em estados e municípios, abriu possibilidades novas para a atuação nesse campo. Entretanto, as demandas dos trabalhadores pelos serviços de atenção criados revelaram, rapidamente, a insuficiência das abordagens tradicionais para a avaliação de realidades complexas, multifacetadas, das organizações contemporâneas, envolvendo novos processos de trabalho (intensificação do trabalho e de suas formas de controle, elevação e diversificação das demandas laborais), mantendo-se as velhas e autoritárias formas de gerenciamento.

A confluência desses movimentos demarcou o lugar do sofrimento no trabalho, mesmo que sua possibilidade de expressão ainda se mantenha enclausurada pela queixa física, pela necessidade de algo palpável para nomear o processo de adoecimento vivenciado. Além disso, como apontam Sato, Lacaz e Bernardo (2006), a prática nas unidades de saúde da rede pública contribuiu para inserir, no âmbito de interesse da pesquisa em psicologia, um olhar para a saúde do trabalhador na perspectiva da saúde pública.

Cabe destacar também que as demandas sindicais permanecem muito relevantes para a incorporação e ampliação do olhar da psicologia na atuação em saúde do trabalhador. A trajetória das lutas sindicais para garantir a defesa 
da saúde dos trabalhadores foi sustentada por atuações técnicas diligentes e comprometidas que revelaram situações nocivas à saúde mental, descortinando um campo amplo de possibilidade de atuação e de intervenção. Em certo sentido, esse processo constituiu um estímulo substancial para a expansão das fronteiras da saúde mental no trabalho, ao tempo que deu novos contornos aos desafios do campo.

As práticas de atenção assentam-se, de modo relevante, em abordagens clínico-epidemiológicas, a partir do desenvolvimento de pesquisas voltadas à identificação de aspectos/características dos processos de trabalho associados ao sofrimento/doença mental. O modelo de desgaste (Laurell \& Noriega, 1989) e o método investigativo adotado, o modelo operário italiano (Odonne et al., 1986), com destaque para a sua perspectiva de 'pesquisa-ação', que advoga a incorporação dos trabalhadores aos processos de produção de conhecimento sobre saúde e trabalho, também são ferramentas disseminadas no campo.

Dentre as intervenções de caráter clínico, destaca-se a abordagem coletiva e multidisciplinar dos problemas, com a constituição de grupos de trabalhadores para coletivizar experiências, discutir, partilhar a vivência dos agravos e das doenças ocupacionais. Os grupos de acometidos por lesões por esforços repetitivos (LER) constituem experiências interessantes nessa perspectiva.

Apesar dos avanços obtidos com a incorporação dessas novas práticas, seja no âmbito da pesquisa/vigilância em saúde e trabalho, seja nos enfoques adotados na intervenção de problemas de saúde mental já diagnosticados, como destacam Sato, Lacaz e Bernardo (2006: 286), é importante também reconhecer as dificuldades e os limites postos nas ações de intervenção, especialmente quando atingem a organização do trabalho, uma vez que é exatamente "nesse âmbito que o conflito capital-trabalho se expressa com exuberância". Uma intervenção no modo como se organiza o trabalho, a favor da saúde dos trabalhadores, se contrapõe à lógica estabelecida no sistema capitalista de regulação das relações. Portanto, os limites para tais ações podem ser muito evidentes, uma vez que implica intervenção na dimensão das relações de poder, das relações entre classes. A alternativa para se avançar nessa direção envolve, necessariamente, a organização dos trabalhadores, a partir da mobilização de suas capacidades de impor mudanças concretas a seu favor. Assim, processos de construção, seja de investigação/monitoramento das condições de trabalho e de saúde, seja na conformação de práticas de atenção à saúde, precisam vincular-se aos próprios trabalhadores, atores da maior relevância em qualquer processo de mudança que se deseje estabelecer. 
Por um lado, como assinalado aqui, observa-se um crescente movimento na demarcação da relevância da saúde mental e do dimensionamento do adoecimento psíquico nas relações entre saúde e trabalho, oferecido por estudos e pesquisas, acadêmicas ou não, ou por atividades de vigilância; por outro, ainda assistimos à pouca visibilidade do problema nas estatísticas das doenças ocupacionais. As doenças mentais respondem por um número muito pequeno dos afastamentos por doenças ocupacionais, ainda que os estudos realizados com categorias de trabalhadores mostrem elevadas prevalências de transtornos mentais. Na Bahia, por exemplo, diversas pesquisas, desde a primeira metade da década de 1990, indicam as elevadas prevalências de transtornos mentais em professores, variando de 20,1\% a 55\% (Araújo et al., 2003b; Reis et al., 2005). Porto e colaboradores (2004), em levantamento das doenças ocupacionais dos atendimentos realizados a professores pelo Centro de Estudos da Saúde do Trabalhador (Cesat) de Salvador, Bahia, de 1991 a 2001, observaram inexistência de diagnóstico de doença mental, aparecendo como doenças mais frequentes as lesões por esforço repetitivo/distúrbios osteomusculares (LER/ Dort) e as doenças respiratórias. Ou seja, o adoecimento mental permanece alijado das estatísticas, mesmo quando já há produção científica significativa para destacar esse problema como relevante em um determinado grupo de trabalhadores.

A observação de Sato e Bernardo (2005: 873) de que "o que parece efetivamente autorizar o trabalhador a apresentar à assistência os problemas de saúde mental e trabalho atualmente é a LER" pode ser uma explicação alternativa para os achados de Porto e colaboradores (2004). Contudo, essa constatação corrobora o fato de que a doença mental e sua relação com o trabalho permanecem, no contexto brasileiro, invisíveis nas estatísticas existentes.

Portanto, um importante desafio é dar legitimidade ao processo de adoecimento mental, um 'lugar' próprio, legalmente reconhecido para sua existência. Obviamente, as dificuldades para se estabelecer tal legitimidade decorrem dos problemas conceituais, teóricos e metodológicos já discutidos, que não são simples, nem de solução fácil; iniciam-se mesmo na própria definição do que se entende por adoecimento psíquico e seguem pelos aspectos ou marcadores que assinalariam/indicariam tal adoecimento.

As dificuldades enfrentadas nesse âmbito têm repercussões bastante evidentes, constituindo entraves para garantir aos trabalhadores aporte técnico consistente e suficiente para o estabelecimento de direitos e benefícios em razão do adoecimento psíquico e para a adoção de medidas para proteger 
e preservar a saúde mental dos trabalhadores. Em última instância, essas limitações comprometem as mudanças efetivas na estruturas organizacionais e ambientais de trabalho.

Cabe também considerar a necessidade de se incorporarem, na análise e avaliação das relações entre trabalho e saúde mental, outros aspectos que não apenas a busca de legitimidade para a doença. Deve-se reconhecer o trabalho também como fonte de vida, de vias propiciadoras de satisfação e prazer, de modo a fortalecer as possibilidades de saúde no trabalho.

Outro aspecto que poderá contribuir para a superação dos limites atuais nesse campo refere-se ao incremento de investigações centradas na análise das exposições, mais do que nos desfechos, nos efeitos sobre a saúde. A análise das exposições poderá contribuir para a perspectiva de uma atuação sobre os determinantes, portanto, com maior potencial transformador.

Como se pode observar, os desafios não são poucos e crescem à medida que o campo se expande, merecendo de nós, que atuamos nessa frente, renovarmos nossos ânimos para os enfrentamentos que se fazem necessários, a começar pela possibilidade de abertura para novas perspectivas teóricas e metodológicas e para o trabalho coletivo, partilhado, construído na troca de dúvidas, dificuldades e reflexões sobre as diferentes experiências vividas.

\section{RefERÊNCIAS}

ARAÚJO, T. M.; GRAÇA, C. C. \& ARAÚJO, E. M. Estresse ocupacional e saúde: contribuições do modelo demanda-controle. Ciência Ė Saúde Coletiva, 8(4): 991-1.003, 2003.

ARAÚJO, T. M. \& KARASEK, R. Validity and reliability of the job content questionnaire in formal and informal jobs in Brazil. Scandinavian Journal of Work Environment Eु Health, Suppl. 6: 52-59, 2008.

ARAÚJO, T. M. et al. Aspectos psicossociais do trabalho e distúrbios psíquicos entre trabalhadoras de enfermagem. Revista de Saúde Pública, 37(4): 424-433, 2003 a.

ARAÚJO, T. M. et al. Saúde e trabalho: dando visibilidade aos processos de desgaste e adoecimento docente a partir de uma rede de produção coletiva. Educação em Revista, 37: 183-212, 2003b.

ASSIS, D. T. F. \& MACEDO, K. B. Psicodinâmica do trabalho dos músicos de uma banda de blues. Psicologia e Sociedade, 20(1): 117-124, 2008.

AVELLAR, L. Z.; IGLESIAS, A. \& VALVERDE, P. F. Sofrimento psíquico em trabalhadores de enfermagem em uma unidade de oncologia. Psicologia em Estudos, 12(3): 475-481, 2007. 
BORSOI, I. C. F. Da relação entre trabalho e saúde à relação entre trabalho e saúde mental. Psicologia e Sociedade, 19: 103-111, 2007.

BRANT, L. C. \& MINAYO-GOMEZ, C. A transformação do sofrimento em adoecimento: do nascimento da clínica à psicodinâmica do trabalho. Ciência E⿱ Saúde Coletiva, 9(1): 213-223, 2004.

CABANA, M. C. F. L. et al. Transtornos mentais comuns em médicos e seu cotidiano de trabalho. Jornal Brasileiro de Psiquiatria, 56(1): 33-40, 2007.

CARVALHO, M. B. \& FELLI, V. E. A. O trabalho de enfermagem psiquiátrica e os problemas de saúde dos trabalhadores. Revista Latino-Americana de Enfermagem, 14(1): 61-69, 2006.

CASSEL, J. Psychosocial processes and stress: theoretical formulation. International Journal of the Health Services, 4(3): 471-482, 1974.

CLEGG, S. O poder, linguagem e ação nas organizações. In: CHANLAT, J. F. (Org.) O Indivíduo nas Organizações: dimensões esquecidas. São Paulo: Atlas, 1993. v. 1.

CODO, W.; SAMPAIO, J. J. C. \& HIPOMI, A. H. Individuo, Trabalho e Sofrimento: uma abordagem interdisciplinar. Petrópolis: Vozes, 1993.

DEJOURS, C. A Loucura do Trabalho: estudo de psicopatologia do trabalho. São Paulo: Oboré, 1987.

DEJOURS, C.; ABDOUCHELI, E. \& JAYET, C. Contribuição da Escola Dejouriana à Análise da Relação Prazer, Sofrimento e Trabalho. São Paulo: Atlas, 1994.

FACCHINI, L. A. et al. Modelo operário e percepção de riscos ocupacionais e ambientais: uso exemplar de estudo descritivo. Revista de Saúde Pública, 25(5): 394 400, 1991.

FARIA, N. M. X. et al. Estudo transversal sobre saúde mental de agricultores da Serra Gaúcha (Brasil). Revista de Saúde Pública, 33(4): 391- 400, 1999.

FERNANDES, J. D.; MELO, C. M. M. \& GUSMÃO, M. C. C. M. Saúde mental e trabalho: significados e limites de modelos teóricos. Revista Latino-Americana de Enfermagem, 14(5): 803-811, 2006.

FERNANDES, R. C. P. et al. Trabalho e cárcere: um estudo com agentes penitenciários da Região Metropolitana de Salvador, Brasil. Cadernos de Saúde Pública, 18(3): 807816, 2002.

FRANKENHAEUSER, M. \& GARDELL, B. Underload and overload in working life: outline of a multidisciplinary work. Human Stress, 2: 34-46, 1976.

GARDELL, B. Autonomy and participation at work. Human Relations, 30: 515-533, 1977.

GARDELL, B. Worker participation and autonomy: a multilevel approach to democracy at workplace. International Journal of Health Services, 12: 527-558, 1982.

GASPARINI, S. M.; BARRETO, S. M. \& ASSUNÇÃO, A. A. Prevalência de transtornos mentais comuns em professores da rede municipal de Belo Horizonte, Minas Gerais, Brasil. Cadernos de Saúde Pública, 22(12): 2.679-2.691, 2006. 
JACQUES, M. G. Abordagens teórico-metodológicas em saúde/doença mental e trabalho. Psicologia e Sociedade, 15(1): 97-116, 2003.

JACQUES, M. G. O nexo causal em saúde/doença mental no trabalho: uma demanda para a psicologia. Psicologia Eु Sociedade, 19: 112-119, 2007.

JOHNSON, J. V. Control, collectivity and the psychosocial work environment. In: SAUTER, S. L.; HURREL JR., J. J. \& COOPER, C. L. (Eds.) Job Control and Worker Health. West Sussex: John Willey, 1989.

KARASEK, R. A. Job demand, job decision latitude, and mental strain: implications for job redesign. Administrative Science Quarterly, 24: 285-308, 1979.

KARASEK, R. A. Job Content Questionnaire and User's Guide. Lowell: University of Massachusetts, 1985.

KARASEK, R. A. \& THEORELL, T. Healthy Work-Stress, Productivity, and the Reconstruction of Working Life. New York: Basic Books, 1990.

LANCMAN, S. et al. O trabalho na rua e a exposição à violência no trabalho: um estudo com agentes de trânsito. Interface: comunicação, saúde, educação, 11(21): 79-92, 2007.

LAURELl, A. C. \& NORIEGA, M. Processo de Produção e Saúde: trabalho e desgaste. São Paulo: Hucitec, 1989.

LIMA, M. E. A. A relação entre distúrbio mental e trabalho: evidências epidemiológicas recentes. In: CODO, W. (Org.) O Trabalho Enlouquece?. Petrópolis: Vozes, 2004.

LIPP, M. Manual do Inventário de Sintomas de Stress para Adultos de Lipp. São Paulo: Casa do Psicólogo, 2000.

LUDERMIR, A. B. Inserção produtiva, gênero e saúde mental. Cadernos de Saúde Pública, 16(3): 647-659, 2000.

MOLINIER, P. Psicodinâmica do trabalho e relações sociais de sexo: um itinerário interdisciplinar - 1988-2002. Produção, 14(3): 45-57, 2004.

MORENO-JIMENEZ, B. et al. A avaliação do burnout em professores: comparação de instrumentos - CBP-R e MBI-ED. Psicologia em Estudos, 7(1): 11-19, 2002.

NARDI, H. C. \& RAMMINGER, T. Modos de subjetivação dos trabalhadores de saúde mental em tempos de reforma psiquiátrica. Physis, 17(2): 265-287, 2007.

NASCIMENTO SOBRINHO, C. L. et al. Condições de trabalho e saúde mental dos médicos de Salvador, Bahia, Brasil. Cadernos de Saúde Pública, 22(1): 131-140, 2006.

NEVES, M. Y.; SELIGMANN-SILVA, E. \& ATHAYDE, M. Saúde mental e trabalho: um campo em construção. In: ARAÚJO, A. et al. (Orgs.) Cenários do Trabalho: subjetividade, movimento e enigma. Rio de Janeiro: DP\&A, 2004.

ODDONE, I. et al. Ambiente de Trabalho: a luta dos trabalhadores pela saúde. São Paulo: Hucitec, 1986.

PALÁCIOS, M.; DUARTE, F. \& CÂMARA, V. M. Trabalho e sofrimento psíquico de caixas de agências bancárias na cidade do Rio de Janeiro. Cadernos de Saúde Pública, 18(3): 843-851, 2002. 
PASCHOAL, T. \& TAMAYO, A. Impacto dos valores laborais e da interferência família: trabalho no estresse ocupacional. Psicologia: teoria e pesquisa, 21(2): 173-180, 2005.

PORTO, L. A et al. Doenças ocupacionais em professores atendidos pelo Centro de Estudos da Saúde do Trabalhador (Cesat). Revista Baiana de Saúde Pública, 28(1): 33-49, 2004.

PORTO, L. A. et al. Associação entre distúrbios psíquicos e aspectos psicossociais do trabalho de professores. Revista de Saúde Pública, 40(5): 818-826, 2006.

REIS, E. J. F. B. et al. Trabalho e distúrbios psíquicos em professores da rede municipal de Vitória da Conquista, Bahia, Brasil. Cadernos de Saúde Pública, 21(5): 1.480-1.490, 2005.

SATO, L. \& BERNARDO, M. H. Saúde mental e trabalho: os problemas persistem. Ciência E̊ Saúde Coletiva, 10(4): 869-878, 2005.

SATO, L.; LACAZ, F. A. C. \& BERNARDO, M. H. Psicologia e saúde do trabalhador: práticas e investigações na saúde pública de São Paulo. Estudos de Psicologia, 11(3): 281-288, 2006.

SELIGMANN-SILVA, E. Desgaste Mental no Trabalho Dominado. Rio de Janeiro, São Paulo: Editora UFRJ, Cortez, 1994.

SELIGMANN-SILVA, E. Saúde mental e automação: a propósito de um estudo de caso no setor ferroviário. Cadernos de Saúde Pública, 13(2): 95-109, 1997.

SEYLE, H. The Stress of Life. New York: McGraw-Hill, 1956.

SILVEIRA, N.M. et al. Avaliação de burnout em uma amostra de policiais civis. Revista de Psiquiatria do Rio Grande do Sul, 27(2): 159-163, 2005.

SZNELWAR, L. I et al. Análise do trabalho e serviços de limpeza hospitalar: contribuições da ergonomia e da psicodinâmica do trabalho. Produção, 14(3): 45-57, 2004.

VASQUES-MENEZES, I. Saúde mental e trabalho: aplicações na prática clínica. In: JACQUES, M. G. \& CODO, W. (Orgs.) Saúde Mental e Trabalho: leituras. 2. ed. Petrópolis: Vozes, 2002. 



\section{Saúde 'Mental' e Trabalho: questões para DISCUSSÃO NO CAMPO DA SAÚdE DO TRABALHADOR}

Milton Athayde

Buscamos trazer para discussão neste capítulo questões que se encontram delineadas ${ }^{1}$ no campo que vem sendo designado na América Latina por saúde do trabalhador. Chamamos a atenção para o fato de que não nos dedicamos aqui às formas de adoecimentos e acidentes gerados pelo trabalho, como pode ser a expectativa, considerando-se a rubrica saúde mental e trabalho. $\mathrm{O}$ foco do texto está na interrogação sobre o 'mental' presente ao trabalhar, e em especial buscamos fazer considerações sobre a incorporação do trabalhador ao processo de pesquisa-intervenção nesse campo, pois entendemos que sua participação resiste como uma fragilidade persistente. Enfim, buscamos colocar em discussão como o corpo-si ${ }^{2}$ e a coprodução linguageira podem ser efetivamente contemplados nesses processos.

As condições de proveniência e emergência do campo saúde do trabalhador e a análise de seus desenvolvimentos, de seus impasses, vêm sendo satisfatoriamente tratadas na literatura. Destacamos os textos de Lacaz $(1983,1996)$, Mendes e Dias (1991), Minayo Gomez e Thedim Costa (1997), Minayo Gomez

1 Cabe ressaltar que, mesmo fora dessa configuração, fora dessa nomenclatura, encontramos também materiais importantes, a serem ainda rigorosa e cuidadosamente rastreados.

2 Preferimos essa noção provisória em relação à noção de 'subjetividade'. O "Glossário da ergologia” (Durrive \& Schwartz, 2008: 24) nos diz: "O trabalho não existe sem alguém que trabalha. É difícil nomear este sujeito porque isso subentenderia que ele se encontraria bem delimitado, definido. Ora, se a actividade é efectivamente conduzida por alguém em carne e osso, - ela inscreve-se em funcionamentos neurossensitivos de tal forma complexos que não se consegue dar a volta - esta actividade tem, além disso, prolongamentos que ultrapassam a pessoa física. São solicitados e mesmo incorporados, inscritos no corpo: o social, o psíquico, o institucional, as normas e os valores [do contexto e retrabalhados], a relação às instalações e aos produtos, aos tempos, aos homens, aos níveis de racionalidade, etc. (...) Este alguém que trabalha - este centro de arbitragens que governa a actividade - pode assim ser designado corpo-si ou corpo-pessoa". 
e Lacaz (2005). Outras questões têm sido incorporadas, como a do ambiente (Porto, 2005) e a de relações de gênero (Brito, 1997, 1999), sendo esta inclusive articulada com o "ponto de vista da atividade" (Brito, 2005). Ou seja, temos um legado que nos oferece as condições suficientes para um debate profícuo.

Nesse campo, teríamos uma subárea (para outros, uma temática) designada saúde mental e trabalho (ou $\mathrm{SM} \& \mathrm{~T}$ ). Inscreve-se nesta rubrica quem se situa de forma mais consistente no campo saúde do trabalhador. Não obstante, em nosso entendimento, o reconhecimento da riqueza dos textos que se assumem nessa rubrica não nos deve afastar das contribuições eventualmente presentes em outras linhagens, em outros campos. Se o conceito (e valor) de saúde, em suas diferentes acepções, tem um uso farto e fértil, a noção de 'mental' está eivada de problemas não resolvidos. Paradoxalmente, com frequência, o uso da expressão saúde mental se define mais pela ausência ou presença de doença mental. E a composição dos vocábulos (doença - mental) configura-se uma expressão pantanosa. Afinal, em que consiste doença? Será mesmo que a maior parte dos casos de 'estranhezas' encontrados pode mesmo ser definida como 'doença' mental? Muitas vezes não. ${ }^{3}$ Assim, no campo denominado saúde mental e atenção psicossocial, encontramos a utilização da expressão 'transtorno mental' (caindo a frequência do vocábulo 'loucura').

Quanto à sua localização no espaço de saber científico, poderíamos indagar se a melhor forma seria mesmo situar a SM\&T no interior - subárea - do campo saúde do trabalhador. Uma alternativa seria explorar as questões em foco com base nas relações entre os campos instituídos e denominados saúde do trabalhador e saúde mental e atenção psicossocial/estudos da subjetividade 4 - operando mais fecundamente neste 'entre', engendrando as questões pertinentes ao trabalho nesse espaço, repotencializando-o, 'rizomando', proliferando ao largo de binarizações, polibifurcando (Deleuze \& Guattari, 1980). Não se trataria, nesse caso, de se ficar paralisado ou debatendo-se entre dois campos instituídos, entendidos como entes, como duas totalidades instituídas.

3 Para muitos, como Basaglia, a chamada 'doença mental' é uma invenção da psiquiatria. Seu uso mais confunde que explica ou oferece vias de transformação.

4 Podemos sinalizar para os esforços de Pichon-Rivière e toda uma linhagem latino-americana, a partir da Argentina, para pensar os processos grupais, configurando o que este autor chamou de 'epistemologia convergente' (envolvendo microssociologia, psicanálise kleiniana, teoria da interação e comunicação, materialismo histórico). Essa noção de convergência, assim como a de interdisciplina - que também fundamenta seu esquema, denominado conceitual, referencial e operativo (Ecro) - têm passado por importantes críticas, na perspectiva ético-estético-política. A respeito, ver os importantes textos de Heliana Conde Rodrigues (2002) e Regina Benevides de Barros (2007). 
Entendemos que essas são dificuldades a serem discutidas, daí podendo tomar rumos frutíferos. No campo saúde do trabalhador, a emergência da questão da 'saúde mental' (ou da 'subjetividade', apresenta até aqui um quadro de desconfianças, bloqueios, especialmente no que tange à aceitação de que se trata de algo estratégico. Salvo engano, somente em 1994, na II Conferência de Saúde do Trabalhador, entre mais de uma dezena de temas tivemos um painel sobre saúde mental e trabalho (Sato, 1996). Em paralelo, no campo denominado saúde mental e atenção psicossocial, a questão trabalho sequer emergiu com vigor. ${ }^{5}$

Aqui também, damos como incorporado à nossa argumentação o patrimônio existente, com materiais que vêm de forma sistemática desde os anos 80 . Na América Latina, temos os textos de Matrajt $(1986,1994)$. No Brasil, temos em São Paulo, especialmente, os trabalhos pioneiros de Seligmann-Silva (1983, 1986, 1994, 1997), à frente desses desafios desde o movimento de criação do Departamento Intersindical de Estudos e Pesquisas de Saúde e dos Ambientes de Trabalho (Diesat), acompanhada entre outros por Sato $(1989,1996)$ e Sato e Bernardo (2005). No Rio de Janeiro, temos materiais de Silva Filho (1986, 1987). Estes são textos da maior importância, embora, muitas vezes, não tenham o devido reconhecimento.

Dentre os autores que têm escrito sobre o campo mais geral, Minayo Gomez e Thedim Costa (1997), ao falarem da exigência de sinergia entre saberes (tema que iremos explorar mais adiante), acabam chegando (via Laurell \& Noriega, 1989) à questão das cargas de trabalho, ou exigências psíquicas (Noriega, 1993). Minayo Gomez e Thedim Costa (1997:29) avançam com a ergonomia, entendendo que "um processo de investigação que objetive formular propostas de transformação requer um minucioso trabalho empírico que capte e potencialize o saber e os processos psíquicos mobilizados na atividade". Em seguida os autores dão mais um passo ao considerar que os postulados operados por Dejours "abrem novas perspectivas, desvelando na organização real do trabalho as estratégias adaptativas intersubjetivas, considerando-se que as manifestações patológicas do sofrimento são a expressão do fracasso dessa mobilização subjetiva" (1997: 29). Assim, temos aí, mesmo que tardiamente, um reconhecimento da relevância das questões 'psi' no trabalho.

5 Patinhando entre as oficinas de trabalho (e 'renda') e a proposta de economia solidária. 


\section{Vida, Saúde 'Mental', Trabalho: ignorâncias recíprocas e a necessária HUMILDADE EPISTEMOLÓGICA}

O viver ${ }^{6}$ e o trabalhar - considerando sua complexidade, ${ }^{7}$ o caráter sempre enigmático do real - extrapolam nossa capacidade de inteiramente compreendê-los. Diante de tais desafios, os humanos criaram, dentre outras formas de saber, a forma-ciência, limitada e parcial, mas de grande potência, explorada como força produtiva de capital. Ou seja, nessa cena de buscas e limitações, o campo da saúde do trabalhador - "um tema que ainda não atingiu a adolescência" (Lacaz, 1997: 8), ainda prenhe de "novas-velhas questões" (Minayo-Gomez \& Lacaz, 2005) - apresenta encaminhamentos ainda frágeis, especialmente quanto ao foco em saúde mental.

Entretanto, o risco talvez esteja mais em ignorar a fragilidade ou negá-la do que nela mesmo. É o que se percebe quando nos aproximamos de áreas nobres para a ciência (e o capital), nas quais coexistem muitas vezes noções e métodos oriundos de diferentes paradigmas teóricos e epistemológicos. O ecletismo e a coexistência de racionalidades contraditórias podem ser nocivos, sim, quando a comunidade científica se contenta com a situação, representando nesse caso um freio importante para a pesquisa. Entretanto, quando se entende que esse quadro pode estar traduzindo o reconhecimento de uma complexidade e dos limites de teorias e métodos disponíveis, em uma conjuntura científica e técnica dada, tal tipo de encaminhamento pode ser preferível ao dogmatismo. Podemos então entender que o mais fértil pode ser aceitar a complexidade presente no campo saúde do trabalhador (e da $\mathrm{SM} \& \mathrm{~T}$ ), assim como sua relativa dispersão como saber e formas de intervenção, especialmente no que tange à saúde 'mental', ${ }^{8}$ explorando com fertilidade essas características.

No referido texto de Minayo Gomez e Thedim Costa (1997: 27), assinala-se enfaticamente que "a referência central para o estudo dos condicionantes da saúde-doença é o processo de trabalho", cuja apropriação "possibilita reformular as concepções ainda hegemônicas que, ao estabelecerem articulações simplificadas entre causa e efeito, numa perspectiva uni ou multicausal, desconsideram a dimensão histórica do trabalho e da saúde/doença”. Também esse é nosso entendimento, mas ressaltando que o elemento que dá vida ao processo

6 Utilizamos aqui o substantivo deverbal ('o' viver), conforme Maturana (1991), e com ele entendemos o viver como "história de interações recorrentes".

7 Podemos encontrar em Stengers (1990), por exemplo, indicações para aprofundar essa perspectiva.

8 Quanto à complexidade no campo denominado saúde mental e atenção psicossocial, ver, por exemplo, Amarante (1996), especialmente o capítulo 1. 
de trabalho é a atividade humana, algo ainda explorado de forma insuficiente nesse campo. Na verdade, o foco costuma estar colocado exclusivamente nas relações sociais, que compõem o processo de produção, junto com o processo de trabalho. Ou nas ferramentas e formas de trabalhar, no desenvolvimento científico-tecnológico, em uma leitura reducionista de Marx, pois todos os elementos do processo de trabalho são fruto da atividade humana. A atividade acaba sendo desqualificada, limitada como força de trabalho incorporada pelo capital, dado que todo o processo de trabalho encontra-se então subordinado ao processo de valorização de capital.

\section{Para Além da 'Impactologia’ no Plano da Causalidade}

Temos incrustado em nossa cultura crítica um fardo composto de fatalismos e profetismos 9 - a 'impactologia': o determinismo simples de 'a' causando 'b'. Uma das formulações mais frequentes a partir dos anos 80 é o chamado impacto da reestruturação produtiva sobre a saúde mental dos trabalhadores, ou o trabalho capitalista gerando loucura ${ }^{10}$ etc. Ora, se denunciar a nocividade contida na vida cotidiana é absolutamente necessário, não se revela suficiente. Pior: se essa crítica se apresenta em um referencial que simplifica, torna-se um fardo que age na prática como obstáculo epistemológico para a busca de compreender-transformar.

Entendemos que a questão da causalidade está diretamente ligada à compreensão do viver, compreendendo o vivente como alguém que não está limitado à reação aos estímulos. Na linhagem de Canguilhem (1999, 2001), saúde é atividade (normativa), capacidade de produzir novas normas; o quadro que daí emerge é o de uma dinâmica, como a dialética marxista vem procurando dar conta. O cérebro (Berthoz, 1997) é um órgão de colocação de problemas, de antecipação, e não de pura resposta. $\mathrm{O}$ trabalhador, individual e coletivamente, em seu cotidiano, é não só capaz de detectar, interpretar e reagir, como também pode melhor apresentar os problemas e mesmo questionar o que seriam falsos problemas e inventar outros. Athayde (1996), por exemplo, denominou esse agenciamento criativo de "coletivo de rede".

9 E seu autoritarismo messiânico sobre a figura dos trabalhadores, tantas vezes professado em nome dos então denominados pobres e oprimidos.

10 É assim que o primeiro livro de Dejours (Travail, Usure Mentale: un essai de psychopathologie du travail, de 1980) foi publicado no Brasil, em 1987, com o título A Loucura do Trabalho. Talvez a alteração do título, embora distorça a tese defendida ao longo do texto, tenha sido um acerto de marketing, considerando a cultura aqui predominante entre os prováveis consumidores do livro. 
Denunciar a nocividade, como dissemos, é absolutamente necessário. Desde a inserção do Brasil no mercado capitalista, a força ideológica escravista persevera, combinando-se perversamente com o clientelismo, o mandonismo, o machismo e o populismo. Nessa formação social, pululam as possibilidades de adoecimentos e acidentes de trabalho. No interior desse campo de combates, a defesa dos trabalhadores, por meio da busca jurídico-política, para estabelecer um nexo causal muitas vezes se confunde com a polêmica científica. Quando a estratégia de produção científica subordina-se ideologicamente à luta político-sindical, os equívocos tomam a frente. Alguns chegam mesmo a considerar que determinadas abordagens - classificadas, por exemplo, como 'especulativas' - 'colaboram' com o capital. Duvidamos do êxito da empreitada, ela própria especulativa e acusatória.

Pode ser útil lembrar que essa busca de estabelecimento de nexo causal tem história. No Brasil, durante os preparativos da Constituinte, ao apresentar a hipótese de seu programa de investigação, Codo afirmava que "o trabalho teria função determinante, embora não exclusivo, nos distúrbios mentais". Naquele momento, propunha que as doenças mentais fossem consideradas doenças profissionais, enquadrando-as na lei n. 6.367, de 1976 (ou equivalente). Assinalava com lucidez que a importância do enquadramento legal não estaria no 'benefício' que o trabalhador então encontraria. Destacava que tal enquadramento "arranca a discussão e o diagnóstico do foro privado e o remete a uma instância pública, necessariamente política" (Codo, 1988: 21). Esse deslocamento teria, sim, efeitos, tanto para o trabalhador, a empresa e o Estado quanto para os profissionais de saúde mental.

Em seguida, esse autor nos lembrava que a disputa assumia a forma de comprovação sobre o nexo causal, ${ }^{11}$ estabelecendo-se um litígio, o que Codo nomeia como "farsa". Para ele, "quando estamos no território da saúde mental, são confusos e mal determinados os nexos causais de qualquer doença mental"; e em seguida: "talvez a postura mais correta seja a de eliminar o modelo simplista de mera atribuição causa-efeito, ou como querem alguns, partir, a priori, da múltipla causação, ao traçar a etiologia psicopatológica” (Codo, 1988: 24).

O próprio autor enfrenta a objeção a esse encaminhamento, pois se diria que desse modo se tornaria impossível o enquadramento legal. Ora, considerando-se a hipótese de que o trabalho seja apenas desencadeante, Codo lança mão da jurisprudência dos casos de cardiopatias: admite-se que as lesões cardíacas

11 Ou seja, que entre o evento - acidente ou doença - haja uma cadeia causal. 
geradas por traumatismo ou esforço físico violento e prolongado, em paciente predisposto, já afetado por moléstia cardíaca, podem ser consideradas acidentes de trabalho! Considerando-se outra hipótese, de que o trabalho seja apenas uma das causas, o mesmo autor lembra estar já consagrado o princípio da 'concausalidade': reconhece-se a existência de infortúnio mesmo que o acidente não tenha causa única. Assinala ainda que, na jurisprudência estabelecida, em caso de dúvida do nexo causal, a questão vinha-se resolvendo a favor do operário. Enfim, "mesmo a partir do Direito atual - que todos reconhecemos falho e esperamos aperfeiçoar com a Constituinte - é perfeitamente possível do ponto de vista jurídico o enquadramento das 'doenças mentais' como ‘doenças profissionais”' (Codo, 1988: 24).

Enfim, Codo considerava viável a luta nos termos por ele apresentados, naquele momento. Muitos poderão dizer: ora, mas não foi, nem é. Neste caso, poderíamos dizer que a discussão já está no plano jurídico-político, não no científico. Não caberia entrar em uma polêmica ferina e infecunda com as abordagens que 'atrapalhariam' o estabelecimento do nexo causal. Não se trata, portanto, de ausência de força científica, mas de fragilidade política. A melhor abordagem não é aquela que ajuda a sustentar o nexo cientificamente, ao preço de uma adesão ao positivismo, ao objetivismo, ao fetichismo da quantificação.

Jacques sinalizava que a edição da medida provisória n. 316, de 2006, pelo governo federal recolocava em cena a discussão acerca do nexo causal, pois "ela prevê o nexo técnico-epidemiológico e inverte o ônus da prova em alguns casos ao determinar o registro automático como doença relacionada ao trabalho de determinadas patologias, em função de altas incidências em determinados ambientes de trabalho" (Jacques, 2007: 112).

Segundo essa autora, "os vínculos entre o trabalho e o adoecimento psíquico vêm ganhando visibilidade crescente” (Jacques, 2007: 112), paralelamente ao crescente número de trabalhadores acometidos por agravos mentais. Assinala, ainda, a importância de psicólogos estarem atuando na direção de estabelecer o nexo causal, contribuindo para o diagnóstico e prescrição terapêuticos corretos, além de propiciarem ao trabalhador as garantias legais existentes.

Entretanto, Jacques (2007: 117) não se recusa a reconhecer que "os princípios que fundamentam o estabelecimento do nexo causal ainda se reportam a um modelo em que a ênfase recai na patologia”. Trata-se de um modelo em relação ao qual ela utiliza a análise de Vasques Menezes (2004) para criticar, afirmando que "a doença se sobrepõe ao paciente e este se apresenta como a-histórico", em que a necessidade de enquadrá-lo e classificá-lo "acaba por 
encobrir o sujeito e seu sofrimento, alienando-o de seu processo de adoecimento" (Jacques, 2007: 117). Conclui ela: "a relação de causalidade, mesmo que multicausal, que fundamenta o estabelecimento do vínculo entre saúde/ doença mental e trabalho não dá conta das relações de determinação das manifestações humanas" (Jacques, 2007: 118).

Se entendemos que esse tipo de encaminhamento apresenta tais limites, não se trata de ceder à inviabilidade e cair em paralisia, mas assumir o desafio da complexidade. Que fazer?

Na linhagem presente em Marx, perguntamos com Zarifian (1995): por que não explorar o campo de possíveis contido no próprio movimento do real, reforçando o que nesse curso seja indicador de transformações? Continuando com o autor, podemos ser mais precisos: um campo de possíveis está sempre presente, mesmo que no infinitesimal, em estado emergente, possíveis embora frágeis, mascarados pelas evidências dominantes; a transformação social reside no próprio movimento do real.

Esse entendimento implica que orientemos nossa busca para captar o que, no movimento do real, é indicador das transformações, dos modos de relações que não somente 'prefiguram', mas figuram uma outra sociedade/sociabilidade. Essa busca de captar a abertura para o devir (aquilo que rompe as cadeias do hábito, para constituição de novas formas, composições, fazendo desvios, bifurcando), dado o caráter sempre inacabado de sociedade, mostra-se muito mais importante que captar as regulações e as regras sociais que lhe correspondem (o que não é inútil detectar e compreender, é claro). Além disso, mais do que descrever o real (ou do que chegar a um quadro o mais exaustivo acerca dele), trata-se de identificar os possíveis (aqui entendidos como os pontos de tensão, os nós esquivos em que relações contraditórias se estabelecem, pois os nós - em suas estranhezas - são muito mais importantes que os laços).

Ou seja, diante das crises - e não só no plano econômico-financeiro, como na crise que temos hoje - é fértil perguntar: nesse contexto, que outras relações sociais, mesmo se minoritárias e dominadas, estão em vias de surgir, representativas de um devir 'diverso' (não 'anti' ou 'pós')? ${ }^{12}$ É desses possíveis, de sua abertura, que vem uma parte importante tanto do sofrimento patogênico quanto do potencial de revolta contra as relações dominantes. Ou seja, esse potencial, esse possível diverso já existe, está na própria constituição do real. Em nosso entendimento, essa deve ser a orientação para uma discussão metodológica.

12 Por exemplo, diverso do taylorismo, e não 'anti' ou 'pós'-taylorista. 


\section{Além do Esquematismo da Representação como Forma de Conhecimento}

Enquanto a episteme clássica estava fundada na semelhança, na episteme moderna o conhecimento deveria ser uma representação fiel da realidade, já dada, que seria independente do conhecedor. Nessa perspectiva, o cérebro extrairia (ou receberia passivamente desse mundo) as informações que o mundo já conteria, passando em seguida por um processamento (posteriormente visto como computacional), representando mentalmente aquelas informações. $O$ conhecer seria um espelho dos fatos, já dados.

A principal característica dessa concepção ('representacionista') é a separação sujeito/objeto, sendo a subjetividade descartada para não comprometer a pretendida exatidão, dada a imensa dificuldade para lidar com o subjetivo. Esta visão de que cada um de nós é separado do mundo, visto como objeto a ser explicado para dele 'beneficiar-se', opera uma prática de cunho extrativista, com efeitos éticos e societários de porte, em sua ação predatória sobre o meio. Ela vem sendo questionada desde o século passado por diversos grandes epistemólogos e cientistas, afastando-se do paradigma clássico, embora sem necessariamente buscar a construção de um novo paradigma. ${ }^{13}$ Com base na biologia, por exemplo, é o caso da obra de Maturana e Varela (2001), que apresentaram em 1984 a tese de que o próprio viver já é um processo de conhecimento, sendo então necessário entender esse processo para compreender o viver. Nessa ótica, o mundo não é anterior à nossa experiência, pois nele vivemos, dele fazemos parte, estamos todos de algum modo ligados, vivemos com outros seres e com eles compartilhamos o processo vital. No curso desse conviver, ao mesmo tempo que esse mundo nos constrói, nós o construímos. Aprendemos ao viver a vida e em seu devir vivemos aprendendo, em um processo incessante e interativo (e não passivo). Como enfatizam esses autores, não há por que levar em conta exclusivamente o observado; há, sim, que se considerar como o observador experiencia o que observa (Maturana \& Varela, 1990).

Assim, o conhecer não pode ser reduzido ao processamento de informações oriundas de um mundo exterior, a ser fragmentado e explorado cientificamente. Autonomia e dependência constroem-se mutuamente, em uma dinâmica circular: ao mesmo tempo que se relacionam com o meio e dependem de recursos externos, os viventes são autônomos, capazes de produzir seus próprios componentes ao interagir com o meio; vivendo 'no' conhecimento e conhecendo 'ao' viver. Observador e observado, vivente e mundo, cooperam

13 É o caso de Stengers (1990), para quem a questão da complexidade é 'prática'. 
na circularidade. Nessa mesma linhagem, com base na própria constituição do cérebro humano, é o que encontramos em Deleuze e Guattari (1980), com sua proposição do rizoma como 'paradigma'. ${ }^{14}$

É também nessa direção que em 1962 nos aponta Eco, desde o livro Obra Aberta. Embora sem querer forçar a relação entre o poético-literário e o científico, pode-se lançar mão dessa concepção para discutir metodologia e a tensão objetividade-subjetividade. Consideremos uma dada proposta para compreender-transformar no campo da saúde (mental) do trabalhador. Ela, na medida em que formulada e apresentada aos trabalhadores, pode ser tratada como um texto, uma obra em curso. Nesse caso, o profissional de saúde pode ser visto em diálogo com o protagonista da atividade de trabalho em análise, ambos produtores/consumidores/leitores de uma obra-proposta. Podem assim, ambos, fazer a gestão de um empreendimento de transformar o trabalho, uma vez que o trabalhador é, também ele - mesmo considerando-se as determinações que o subordinam relativamente - alguém ativo que desenvolve suas próprias ações.

Percebemos que qualquer proposta de pesquisa-intervenção (vista como uma 'obra') é, em alguma medida, aberta, admite mais de uma interpretação daquele a quem a proposta é apresentada (o protagonista da atividade de trabalho em foco). Daí pode-se esperar o engendramento de múltiplos sentidos, embora não qualquer sentido. Ou seja, entendemos que, ao tomar contato com uma proposta de ação nesse campo, o trabalhador dela faz uso, em um movimento em que, em alguma medida, recria a proposta na própria ação, ampliando seu universo de sentido. Trata-se então de um ato cooperativo, de uma relação dialética entre profissionais de saúde e protagonistas da atividade em foco.

Nessa mesma direção vai a produção de Certeau $(1994,1995)$, assim como a corrente britânica dos chamados estudos culturais. $\mathrm{O}$ trabalhador (individual e coletivo) pode ser visto como usuário ${ }^{15}$ da proposta apresentada, dela apropriando-se pelo seu uso. Desenvolvem-se formas de apropriação, de algum modo socializadas em rede pelos usuários, fluindo melhor quando em um movimento de "inovações ascendentes” ou “inovações horizontais' (Von Hippel, 2005).

É nessa perspectiva, segundo diferentes abordagens, que a busca de transformar pode ser pensada e posta em prática como coprodução, em uma 'relação

14 Um paradigma regido por seis princípios básicos: conexão, heterogeneidade, multiplicidade, ruptura a-significante, cartografia e decalcomania.

15 E não um utilizador, ou objeto da ação. Assinalamos que a figura do usuário ficou mais visível com as novas tecnologias, distinguindo-se da caracterização mercantil do consumidor ou da representação passiva do receptor. 
de serviço' (Zarifian, 2001b), envolvendo, para tal, competências pertinentes (Zarifian, 2001a, 2001c). Enfim, trata-se de um entendimento ainda a ser explorado.

Voltemos ao texto de Minayo Gomez e Thedim Costa (1997: 28), em que os autores reiteram o caráter interdisciplinar e multiprofissional do campo da saúde do trabalhador, pois que "nenhuma disciplina isolada consegue contemplar a abrangência da relação processo de trabalho-saúde em suas múltiplas e imbricadas dimensões". Apontam para um "princípio de cooperação”, enfatizando o necessário diálogo, incorporando o referencial de outras disciplinas e saberes. Tudo isso o Modelo Operário Italiano de luta pela saúde (MOI) estabeleceu, desenvolvendo experimentações extraordinárias (Oddone, Marri \& Gloria, 1986).

Esse 'modelo' (que continua sendo utilizado no sudeste da França, assessorado por Oddone), envolvendo o que se denominou uma 'comunidade científica ampliada', em seguida passou por uma análise rigorosa (Schwartz, 1988), estabelecendo-se com maior clareza na ergologia (Schwartz, 2000), com a proposição de um dispositivo dinâmico de três polos - o DD3P (Schwartz, 2004). Visa-se então a operar a sinergia não só entre disciplinas e abordagens, mas também entre diferentes saberes, para tal operando um terceiro polo (não assinalado no MOI), ético-epistêmico (no caso da Itália, naquela conjuntura, um polo operado pelo sindicato).

$\mathrm{Na}$ mesma direção das proposições do MOI (não delegação, validação consensual etc.), outra premissa metodológica é reiterada em Minayo Gomez e Thedim Costa (1997: 29), em que os autores assinalam que é imprescindivel a "interlocução com os próprios trabalhadores, depositários de um saber emanado da experiência e sujeitos essenciais quando se visa a uma ação transformadora". Em nosso entendimento, já nesse plano encontramos maior fragilidade, pois as características da interlocução, a produção linguageira que aí se desenvolve, as mediações necessárias não são facilmente formuláveis, correndo-se o risco de ficar nos princípios. Vamos, portanto, com a lupa sobre essa questão.

\section{Partir do Viver e da Saúde para Transformar os Transtornos e AdOECIMENTOS: UMA CAIXA de fERRAMENTAS teÓRICO-MEtOdOLÓGICAS}

Nossa lupa, nosso microscópio, nossa caixa de ferramentas teórico-metodológicas conta com algumas disciplinas e abordagens teórico-metodológicas em sinergia. 
A ergonomia da atividade (Guérin et al., 2001) representa um esforço exemplar. ${ }^{16}$ À diferença de outras abordagens, a ação ergonômica é global: partindo de uma demanda, passa por uma análise do trabalho (AET), mobilizando diferentes atores, chegando a recomendações de mudanças (ou "proposições discutíveis”, como prefere Daniellou, 2004), a serem acompanhadas por ergonomistas - quiçá operando-se um circuito virtuoso de 'melhorias'.

Mas no tipo de encaminhamento ergonômico que seguimos, entende-se que a efetividade das mudanças depende tanto da formação ${ }^{17}$ dos trabalhadores (aqueles que vão efetivamente operar a ação ergonômica) quanto do que aprendem os próprios especialistas nessa ação conjunta. Isso exige um tipo de dispositivo adequado. Aqui a ação ergonômica tem sido enriquecida pela perspectiva ergológica (Daniellou, 2004), seja com o alargamento do conceito de atividade (Schwartz, 2005), seja com o dispositivo dinâmico de três polos (Schwartz, 2000; Schwartz \& Durrive, 2010).

Na história da ergonomia na França, Wisner, considerando os determinantes geográficos e culturais da atividade de trabalho, criou uma outra abordagem, a antropotecnologia (Wisner, 1997). Tinha também clareza quanto à presença de sofrimento psíquico no trabalho; daí colaborou decisivamente para que junto à ergonomia caminhasse outra abordagem já em curso, a psicopatologia do trabalho, em seu caso tendo como interlocutor Dejours. Daniellou (2001), entre outros construtores da ergonomia da atividade, também reconhece a dívida com a psicodinâmica do trabalho (PDT) para seu maior desenvolvimento, especialmente para que ela não fosse tragada pelo cognitivismo.

A partir dos anos 80, no solo em que se constituiu a ergologia, sob influência do marxismo em psicologia do trabalho (incorporando as correntes russas da psicologia - com Vygotsky - e da linguística dialógica - com o círculo Bakhtin), alimentando-se com o MOI, ${ }^{18}$ deu-se, nos anos 90, a emergência da abordagem chamada clínica da atividade. Desenvolve-se com rigor um método indireto de aproximação (o que em ergonomia da atividade denomina-se confrontação), passando pela técnica chamada 'instruções ao sósia' (explorada pelo MOI), chegando às técnicas de autoconfrontação cruzada (Clot, 2006; Faïta, 2005; Faita \& Maggi, 2007). Trata-se de outra abordagem também

16 Schwartz (2004: 142) chega a sinalizar a possibilidade de que ela seja, hoje, "uma propedêutica da epistemologia".

17 Os próprios trabalhadores passam por uma formação em ergonomia para operarem a ação ergonômica. 18 Yves Clot (2006), que vem desenvolvendo a corrente denominada Clínica da Atividade, fez a apresentação e o posfácio da edição francesa do livro de Oddone, Re e Brianti (1981). 
reconhecida por Daniellou (2004), que agrega riqueza ao que a ergonomia da atividade busca desenvolver.

Quanto ao método pertinente ao trabalho de campo, iniciou-se um debate entre a ergonomia da atividade (método AET) e a psicodinâmica do trabalho (método enquete). Encontramos essa discussão na polêmica travada entre Daniellou e Molinier e publicada no número 7 da revista Travailler (2001). Na proposta metodológica da psicodinâmica do trabalho, tem-se a proposição de uma etapa, a pré-enquete. Há na literatura quase um vazio de considerações, tanto dos aficionados quanto dos críticos. A análise da oferta/demanda (uma etapa da AET) e a análise da implicação (quase sempre ausente nas diversas abordagens) merecem maior atenção, ambas podendo ser enriquecidas pelas abordagens da análise institucional (Lourau, 1975) e da esquizoanálise (Deleuze \& Guattari, 1973, 1980; Baremblitt, 1992). Entendemos que esse momento de pré-enquete tem relação com a etapa da análise global da AET, cabendo aí um conjunto de estudos sobre a realidade concreta de trabalho que muitos dizem ausente da proposta metodológica de Dejours.

Se pensarmos em um horizonte mais amplo de pesquisa-intervenção, a concepção que vimos desenvolvendo contempla o que classicamente se tem designado por triangulação (ou metodologia de convergência, validação convergente, métodos múltiplos). Quando se mostra pertinente, temos cruzado diferentes métodos e técnicas - por exemplo, mobilizando métodos de influência epidemiológica (ou de análise bioestatística) - dialogando inclusive com materiais de outros grupos. Nesse momento, estamos dando destaque a abordagens clínicas do trabalhar (Lhuilier, 2006; Clot \& Lhuilier, 2010).

Ao consideramos o trabalhar, a luta pela saúde, o permanente movimento e o caráter sempre enigmático (Schwartz, 2000; Dejours, 2005) que caracterizam a atividade humana, temos de indagar que métodos podem dar conta dessa complexidade. Como apreendê-la em sua dinâmica processual, seus fluxos? Como acompanhar o engendramento e operação da inteligência e sabedoria da prática, da competência, dos conhecimentos incorporados e desenvolvidos, se estes elementos (inteligência/sabedoria, competência, conhecimentos) são, muitas vezes, desconhecidos no plano da consciência pelo próprio trabalhador e quase nunca são verbalizados em uma entrevista clássica? Sabemos que, incorporados como 'informantes', os trabalhadores podem apenas repetir o discurso da hierarquia e descrever as tarefas prescritas, não permitindo a compreensão do trabalho efetivamente realizado, menos ainda do que eles experimentaram 
nesse processo. Que métodos permitem a expressão individual e coletiva dos conhecimentos sobre o trabalho, para pôr em palavras 'o que não se sabe' ou 'o que se sabe sem nunca haver podido dizer'? Entendemos que é preciso utilizar métodos indiretos.

No debate científico acerca do assunto, nos anos 80, apresentou-se como primeira dificuldade o chamado 'mutismo do trabalho': quando os trabalhadores falam, o fazem de forma variável e enigmática, gerando reservas sobre essa fala, composta de dois argumentos. Para Boutet (1993), existe uma não 'dizibilidade' do trabalho, uma dificuldade conceitual linguageira para colocar em palavras, dado o que seria uma falta social de produção discursiva a propósito do trabalho. Em sua forte singularidade, o trabalho não encontraria à sua disposição o ferramental semiótico necessário. Haveria uma vacuidade dos universos discursivos correspondentes. Isto porque, enquanto o trabalho prescrito está em relação direta com o linguageiro, o trabalho real estaria inadaptado à expressão da experiência do trabalho, que desborda o trabalho prescrito. A linguagem seria, portanto, inadaptada a esse dizer particular, deficitária em relação à complexidade do real.

Mas, para Faïta (2002), essa compreensão deve ser criticada, pois instala cada vez mais o trabalhador-ator-locutor em uma situação de exterioridade com relação à sua própria experiência, no mesmo movimento em que o analista mantém-se como o mestre do jogo, no trato com o trabalhador. Para esse autor, não existe transparência no discurso, sendo imprescindível instaurar as condições de interação (transação) na ação profissional, suscetível de fornecer modalidades de acesso (indireto) ao sentido/significação do trabalho. $\mathrm{O}$ desafio, nesse caso, está em criar as condições para uma fala autêntica sobre o trabalho, reintegrando o trabalhador em um debate que o implica como sujeito de sua própria experiência e de seu discurso.

Desde seus primeiros textos, a perspectiva dialógica de Bakhtin (2003) nos apresenta o conceito de extralocalidade ${ }^{19}$ ou exotopia (tradução mais frequente entre nós), ao analisar a criação artística. Aliamo-nos àqueles que entendem que se pode fazer uso desse conceito para compreender a atividade de trabalho e da pesquisa-intervenção.

Entre a compreensão que tem o trabalhador acerca de seu trabalho e o que outros podem ter existe sempre um hiato, uma diferença de lugares e de valores. Conforme Amorim (2003: 14), a tarefa do pesquisador é "tentar captar algo do modo como ele se vê, para depois assumir plenamente meu lugar

19 Na tradução de Guinsburg para outsideness (vnenaxodimost, em russo) no livro de Clark e Holquist (2004). 
exterior e dali configurar o que vejo do que ele vê". Para a autora, "exotopia significa desdobramento de olhares a partir de um lugar exterior", lugar (e cada um ocupa um lugar singular, que caracteriza a autoria, algo pelo qual cada um responde, se responsabiliza) que permite que se veja do trabalhador e seu trabalho algo que ele não vê.

O princípio dialógico que encontramos em Bakhtin sugere que o pesquisador nunca está livre para impor sua intenção, deve sempre mediá-la por meio das intenções dos outros, tendo que entrar em diálogo com o outro, a partir de onde seu ponto de vista deve emergir. Conforme Clark e Holquist (2004: 264), o conceito de extralocalidade (ou exotopia) “descreve uma posição que só pode ser conhecida por meio da mais complexa triangulação das relações interpessoais". No diálogo, todo enunciado tem uma segunda pessoa (seu destinatário), sendo o ato de fala moldado por sua compreensão responsiva. Mas na medida em que o autor não pode abandonar toda a responsabilidade do julgamento de sua obra à livre vontade dos destinatários mais próximos, pressupõe-se uma instância superior de compreensão da obra. Assim, cada ato de fala remete também, desde o início, a um fundo de compreensão-resposta, uma terceira pessoa que presencia de forma invisível o diálogo, antecipando, prevendo a compreensão do enunciado, interlocutor que Bakhtin (2003) denomina "destinatário superior". Essa terceira pessoa configura um momento constitutivo do enunciado completo.

O método indireto, o acesso ao enigmático da atividade de trabalho, demanda a criação de um meio de trabalho dito "extra-ordinário" (uma zona de desenvolvimento, ou um espaço potencial) que mobilize um coletivo - dispositivo que temos denominado comunidade ampliada de pesquisa (Brito \& Athayde, 2003), em que circula uma comunidade dialógica de pesquisa (França, 2007) - para investigar a atividade 'ordinária' de cada um e do(s) coletivo(s). Trata-se, então, de um trabalho de coanálise, associando os pesquisadores profissionais e os protagonistas da atividade de trabalho em foco (nesse caso, parceiros na coinvestigação/intervenção). $O$ objetivo é focalizar o como, e não somente o porquê da atividade de trabalho, seu desenvolvimento e não apenas seu funcionamento. Daí emergem questões pertinentes a importantes vetores, como o que Schwartz (2000) denomina corpo-si.

Nessa perspectiva, toma-se o humano 'de corpo inteiro', como um corpo-si, um corpo-atividade-potência. Uma corporeidade ao mesmo tempo fechada (nos limites da forma corpórea) e aberta (impulsionada para além, despregando-se de si, em uma dinâmica de criação dos limites de si). 
Trata-se então de um corpo (humano) que não é mudo, mas um vivente produtor de textos. Tendo o 'linguagear' tal nobreza para esse vivente, emerge em destaque a questão da produção de sentido.

Para Bakhtin, a língua é inseparável do fluxo da comunicação; ela não é transmitida, mas constituída na corrente da vida. Daí a busca dos 'constituintes' do sentido, em seu processo histórico. A atribuição de sentido a um objeto (a uma palavra) não é uma operação de etiquetagem, mas o produto de uma relação que cada indivíduo (locutor/interlocutor), a seu modo, constitui. Produção que implica uma grande parte de subjetividade, sendo o ponto de chegada de um processo (e não de um procedimento totalmente estabelecido). Então como podem ser operadas as escolhas que levam a esse tipo de procedimento? Para Bakhtin (1981), o sentido do enunciado é como uma "faísca elétrica" que só se produz quando há contato entre os dois polos opostos. Em qualquer momento do desenvolvimento do diálogo, existem quantidades enormes e ilimitadas de sentidos esquecidos, pois para o autor o sentido nunca está morto de um modo absoluto. Para Bakthin, há sempre uma lacuna a preencher pela imaginação de um ouvinte. A palavra quer ser ouvida, está em busca de compreensão, de maneira ilimitada.

Outro elemento é o 'transacional', ${ }^{20}$ pois o caráter linguageiro (e não o objeto técnico unificado que é a língua) possibilita a interação verbal, o conversar. Não se trata aqui apenas de um encontro de psiquismos individualizados, mas de uma relação de textos e contexto: o corpo-si, em sua singularidade, situado, em relação com o contexto histórico-social. Sua apreensão dialógica só pode se dar no fluxo da história (Jobim \& Souza, 1994).

Um terceiro elemento é o dialógico, pois a vida é dialógica por natureza. Como nos diz Bakhtin (1992), viver é participar de um diálogo com o corpo inteiro. Sendo a transação linguageira o centro organizador/formador da atividade dita 'mental', é essa expressão que organiza a atividade mental e modela/determina sua orientação. Assim, o conhecimento acerca do humano só pode ser dialógico.

20 O que, nas palavras de Bakhtin, aparece com o vocábulo interação, categoria básica da linguagem, cuja realidade fundamental é o seu caráter dialógico. Ele faz uma crítica ao que aponta como objetivismo abstrato (Saussure) e ao subjetivismo idealista (Humboldt), que reduzem a linguagem a um sistema abstrato de formas (separa língua/social de fala/individual, priorizando os elementos constituídos pelas formas normativas da língua, como se ela fosse registrada passivamente pelo humano; o que interessa é a relação de signo para signo, no interior de um sistema de signos) ou à enunciação monológica isolada (como criação individual, dicotomizando interior e exterior, privilegiando o interior), ambos criando obstáculos à apreensão da natureza real da linguagem como código ideológico (Jobim \& Souza, 1994). 
Quando desenvolvemos uma pesquisa-intervenção nos mundos do trabalho, é importante considerarmos que a enunciação (e a multiplicidade de vozes/personagens que aí se manifestam), o discurso, é já um diálogo (não existe o primeiro discurso). Toda enunciação/discurso faz parte de um processo de comunicação ininterrupto. Não há enunciado isolado; ele é um elo em uma cadeia discursiva. Logo, o que é dito encontra-se no universo do já dito.

É preciso levar em conta o linguageiro para compreender o que ocorre no trabalho, seus efeitos, sua dinâmica - seja considerando a linguagem sobre o trabalho, seja no trabalho, e mesmo a linguagem como trabalho (Lacoste, 1995). ${ }^{21}$ Afinal, a atividade de linguagem intervém na própria construção da atividade de trabalho (ou seja, ela faz parte da situação, é atividade na atividade), podendo mesmo ser o essencial da tarefa.

Trata-se, pois, de um duplo encaminhamento: 1) dar à linguagem uma dimensão de ação, considerá-la uma atividade (linguageira) na atividade (de trabalho); 2) considerar que pelas falas se manifesta um fazer material (a atividade de uma secretária ao telefone, por exemplo). Podemos então dizer com Boutet (1995) que existem três proposições acerca da atividade de linguagem em qualquer situação social, como na de trabalho. O processo de colocar em palavras tem uma função de descoberta (diz-se a outrem coisas que não se sabia ou ao menos não dessa forma, antes de enunciá-la), é uma operação 'material' e é um processo corporal.

Também Dejours (1987) considera como principal material de análise os comentários dos trabalhadores sobre seu próprio trabalho - antes, durante e após o trabalho realizado, no interior de uma cadeia dialógica. Assim, as atividades de linguagem de um trabalhador - conceito de atividade diferente do estabelecido pelos cognitivistas (Dejours, 1987) - fornecem uma via de acesso privilegiado ao conhecimento de sua atividade, em sua globalidade. A palavra não pertence exclusivamente ao que fala. O ouvinte, assim como todas as vozes que o antecederam, participa dessa produção. Ninguém é o primeiro a falar sobre o que está em jogo. Ao usar as palavras, já se está habitado por outras falas, múltiplas vozes participam do diálogo na vida (polifonia). Nos enunciados encontramos julgamentos (apreciativos) de valor, sendo a entoação (na fronteira entre o dito e o não dito) o modo como o socioafetivo pode ser detectado, como a relação entre as pessoas acontece, em sua singularidade.

21 Segundo Lacoste (1995), trata-se de uma distinção que apareceu na França via tradição oral, no meio dos ergonomistas, nos anos 80 . 
Na perspectiva ergológica, considera-se que o trabalho é 'encontro de encontros'; nele se situa um ponto de convergência/divergência de olhares múltiplos (por exemplo, expectativas da empresa em termos de funções e de missão, expectativas dos clientes/usuários, além das expectativas dos diferentes trabalhadores). Para expressar a confrontação entre o prescrito e o real, o trabalhador é entendido como o primeiro expert de seu trabalho. Mas temos aí uma opacidade, as palavras do discurso do trabalho não lhe vêm daí como por encanto, da forma que deveriam, para adequar-se ao modo de estruturação do discurso sobre o trabalho.

Sistematizando, do ponto de vista metodológico: após acordar um contrato psicológico em que os trabalhadores aceitam submeter sua própria atividade (assim com as condições e situações na qual ela se realiza) ao crivo da reflexão e a análise em comum (com os pesquisadores profissionais), é necessário criar situações em que os trabalhadores possam 'abrir espaços', 'abrir parênteses' (François, apud Faïta, 2007), escapando à contrainte da observação, do diálogo puramente desigual com o pesquisador. Não se trata de coletar, via verbalização, representações mentais do que se passou. Trata-se de não só compreender o funcionamento da atividade, mas acima de tudo contribuir para o seu desenvolvimento.

Para isso, o confronto deve envolver diferentes tipos de pares, especialistas práticos do trabalho em análise (os colegas de trabalho, agentes de um coletivo), assim como leigos/analistas profissionais (novos parceiros, compondo um novo coletivo). Quando na análise muda-se o tipo de endereçamento, o tipo de destinatário, ${ }^{22} \mathrm{o}$ quadro altera-se, modifica-se a própria análise. Dependendo das características do par - 'especialistas' daquela atividade ou 'leigos' -, são diferentes os acessos ao trabalho (particularmente em relação ao real da atividade). Nessa dinâmica de análise, há um reendereçamento das palavras do trabalhador, que não se voltam apenas para o seu objeto de trabalho, mas para sua própria atividade. Uma dinâmica se dá entre o que os trabalhadores fazem (em um coletivo de trabalho, no encontro entre diferentes coletivos de trabalho, em uma dada situação), o que eles dizem que fazem (diferentes endereçamentos, diferentes mobilizações de suas experiências), o que dizem daquilo que fazem, o que eles fazem daquilo que eles dizem (Clot, 2000).

$22 \mathrm{O}$ início de qualquer jogo dialógico entre interlocutores envolve o lançamento de uma 'ponte' em relação a outrem, construindo-se o sentido das palavras escolhidas para falar, pois o discurso é atividade e seus endereçamentos sucessivos à atividade dos outros. 
Esperamos que nosso texto sirva como instrumento para incentivar a discussão sobre o que existe de 'mental' tanto ao trabalhar quanto ao pesquisarintervir no campo da saúde do trabalhador. Quiçá contribua também como ferramenta metodológica para compreender-transformar o que se faz necessário nos mundos do trabalho contemporâneo.

\section{REFERÊNCIAS}

AMARANTE, P. O Homem e a Serpente: outras histórias para a loucura e a psiquiatria. Rio de Janeiro: Editora Fiocruz, 1996.

AMORIM, M. A contribuição de Mikhail Bakhtin: a tripla articulação ética, estética e epistemológica. In: FREITAS, M. T.; JOBIM e SOUZA, S. \& KRAMER, S. (Orgs.) Ciências Humanas e Pesquisa: leituras de Mikhail Bakhtin. São Paulo: Cortez, 2003.

ATHAYDE, M. Coletivos de Trabalho e Modernização: questões para a engenharia de produção, 1996. Tese de Doutorado, Rio de Janeiro: Coppe, Universidade Federal do Rio de Janeiro.

BAKHTIN, M. Marxismo e Filosofia da Linguagem. São Paulo: Hucitec, 1981.

BAKHTIN, M. Questões de Literatura e Estética. São Paulo: Unesp, Hucitec, 1992.

BAKHTIN, M. Estética da Criação Verbal. São Paulo: Martins Fontes, 2003.

BAREMBLITT, G. Compêndio de Análise Institucional e Outras Correntes. Rio de Janeiro: Rosa dos Tempos, 1992.

BARROS, R. B. Grupo: afirmação de um simulacro. Porto Alegre: Sulina, Ed. UFRGS, 2007.

BERTHOZ, A. Le Sens du Mouvement. Paris: O. Jacob, 1997.

BOUTET, J. Activité de langage et activité de travail. Futur Antérieur, 16: 53-62, 1993.

BOUTET, J. Le travail et son dire. In: BOUTET, J. (Dir.) Paroles au Travail. Paris: L'Harmattan, 1995.

BRITO, J. Uma proposta de vigilância em saúde do trabalhador com a ótica de gênero. Cadernos de Saúde Pública, 13(supl.2): 141-144, 1997.

BRITO, J. Saúde, Trabalho e Modos Sexuados de Viver. Rio de Janeiro: Editora Fiocruz, 1999.

BRITO, J. Trabalho e Saúde Coletiva: o ponto de vista da atividade e das relações de gênero. Ciência Eु Saúde Coletiva, 10(4): 879-890, 2005.

BRITO, J. \& ATHAYDE, M. Trabalho, educação e saúde: o ponto de vista enigmático da atividade. Trabalho, Educação e Saúde, 1(2): 239-265, 2003.

CLARK, K. \& HOLKIST, M. Mikhail Bakhtin. São Paulo: Perspectiva, 2004.

CANGUILHEM, G. Le Normal et le Pathologique. 8. ed. Paris: Quadrige, PUF, 1999.

CANGUilHeM, G. Meio e normas do homem no trabalho. Pro-posições, 12(2-3): 109-121, 2001. 
CERTEAU, M. A Invenção do Cotidiano. v. 1: Artes de fazer. Petrópolis: Vozes, 1994. CERTEAU, M. A Cultura no Plural. Campinas: Papirus, 1995.

CLOT, Y. Analyse psychologique du travail et singularité de l'action. In: BARBIER, J-M. (Org.) L'Analyse de la Singularité de l'Action. Paris: PUF, 2000.

CLOT, Y. A Função Psicológica do Trabalho. Petrópolis: Vozes, 2006.

CLOT, Y. \& FAÏTA, D. Genres et styles en analyse du travail: concepts et méthodes. Travailler, 4: 7-42, 2000.

CLOT, Y. \& LHUILIER, D. Travail et Santé: ouvertures cliniques. Paris: Erès, 2010.

CODO, W. Saúde mental e trabalho: uma urgência prática. Psicologia: ciência e profissão, 8(2): 20-24, 1988.

DANIELLOU, F. L'action en psychodynamique du travail: interrogations d'un ergonome. Travailler, 7: 119-130, 2001.

DANIELLOU, F. Introdução: questões epistemológicas acerca da ergonomia. In: DANIELLOU, F. (Org.) A Ergonomia em Busca de seus Princípios: debates epistemológicos. São Paulo: Edgard Blücher, 2004.

DEJOURS, C. A Loucura do Trabalho: estudo de psicopatologia do trabalho. São Paulo: Cortez, Oboré, 1987.

DEJOURS, C. O trabalho como enigma. In: LANCMAN, S. \& SZNELWAR, L. (Orgs.) Christophe Dejours: da psicopatologia à psicodinâmica do trabalho. Rio de Janeiro, Brasília: Fiocruz, Paralelo 15, 2005.

DELEUZE, G. \& GUATTARI, F. Capitalisme et Schizophrénie. t. 1: L'Anti-Edipe. Paris: Minuit, 1973.

DElEUZE, G. \& GUATTARI, F. Capitalisme et Schizophrénie. t. 2: Mille Plateaux. Paris: Minuit, 1980.

DURRIVE, L. \& SCHWARTZ, Y. Glossário da ergologia. Laboreal, 4(2): 23-28, 2008.

ECO, U. Obra Aberta: forma e indeterminação nas poéticas contemporâneas. 9. ed. São Paulo: Perspectiva, 2008.

FAÏTA, D. Análise das práticas linguageiras e situações de trabalho: uma renovação metodológica imposta pelo objeto. In: SOUZA e SILVA, M. C. \& FAÏTA, D. (Orgs.) Linguagem e Trabalho: construção de objetos de análise no Brasil e na França. São Paulo: Cortez, 2002.

FAÏTA, D. Análise Dialógica da Atividade Profissional. Rio de Janeiro: Imprinta Express, 2005.

FAÏTA, D. \& MAGGI, B. Un Débat en Analyse du Travail: deux méthodes en synergie dans l'étude d'une situation d'enseignement. Toulouse: Octarès, 2007.

FRANÇA, M. Uma Comunidade Dialógica de Pesquisa: atividade e discurso em guichê hospitalar. São Paulo: Educ, Fapesp, 2007.

GUÉRIN, F. et al. Compreender o Trabalho para Transformá-lo: a prática da ergonomia. São Paulo: Edgard Blücher, 2001. 
JACQUES, M. da G. O nexo causal em saúde/doença mental no trabalho: uma demanda para a psicologia. Psicologia $\mathcal{E}$ Sociedade, 19(ed. especial 1): 112-119, 2007. JOBIM, S. \& SOUZA, S. Infância e Linguagem: Bakhtin, Vygostsky e Benjamin. Campinas: Papirus, 1994.

LACAZ, F. Saúde no Trabalho, 1983. Dissertação de Mestrado, São Paulo: Faculdade de Medicina, Universidade de São Paulo.

LACAZ, F. Saúde do Trabalhador: um estudo sobre as formações discursivas da academia, dos serviços e do movimento sindical, 1996. Tese de Doutorado, Campinas: Faculdade de Ciências Médicas, Universidade Estadual de Campinas.

LACAZ, F. Saúde dos trabalhadores: cenários e desafios. Cadernos de Saúde Pública, 13(supl.2): 7-20, 1997.

LACOSTE M. Langage et travail: quelques perspectives. Sociologie du Travail (hors serie): 45-56, 1994.

LACOSTE, M. Parole, activité, situation. In: BOUTET, J. (Org.) Paroles au Travail. Paris: L'Harmattan, 1995.

LAURELL, A. C. \& NORIEGA, M. Processo de Produção e Saúde: trabalho e desgaste operário. São Paulo: Hucitec, 1989.

LHUILIER, D. Cliniques du Travail. Paris: Erès, 2006.

LOURAU, R. A Análise Institucional. Petrópolis: Vozes, 1975.

MATRAJT, M. Salud Mental y Trabajo. Cuernavaca: EdUAEM, 1986.

MATRAJT, M. Estudios en Salud Mental Ocupacional. México: Taller Abierto, 1994.

MATURANA, H. \& VARELA, F. O que se observa depende do observador. In: THOMPSON, W. I. (Org.) Gaia: uma teoria do conhecimento. São Paulo: Gaia, 1990.

MATURANA, H. \& VARELA, F. A Árvore do Conhecimento: as bases biológicas do conhecimento humano. São Paulo: Palas Athenas, 2001.

MENDES, R. \& DIAS, E. C. Da medicina do trabalho à saúde do trabalhador. Revista de Saúde Pública, 25: 3-11, 1991.

MINAYO-GOMEZ, C. \& LACAZ, F. A. C. Saúde do trabalhador: novas-velhas questões. Ciência E⿱ Saúde Coletiva, 10(4): 797-807, 2005.

MINAYO-GOMEZ, C. \& THEDIM-COSTA, S. M. A construção do campo da saúde do trabalhador: percurso e dilemas. Cadernos de Saúde Pública, 13(supl.2): 21-32, 1997.

NORIEGA, M. Organización laboral, exigencias y enfermedad. In: LAURELL, A. C. (Org.) Para la Investigación de la Salud de los Trabajadores. Washington, D.C.: Opas, 1993.

ODDONE, I.; MARRI, G. \& GLORIA, S. Ambiente de Trabalho: a luta dos trabalhadores pela saúde. São Paulo: Hucitec, 1986.

ODDONE, I.; RE, A. \& BRIANTI, G. Redécouvrir l'Expérience Ouvrière: vers une autre psychologie du travail? Paris: Messidor, Éditions Sociales, 1981. 
PORTO, M. F. Saúde do trabalhador e o desafio ambiental: contribuições do enfoque ecossocial, da ecologia política e do movimento pela justiça ambiental. Ciência Eु Saúde Coletiva, 10(4): 829-839, 2005.

RODRIGUES, H. B. C. No Rastro dos "Cavalos do Diabo": memória e história para uma reinvenção de percursos do paradigma do grupalismo-institucionalismo no Brasil, 2002. Tese de Doutorado, São Paulo: Instituto de Psicologia, Universidade de São Paulo.

SATO, L. As formas sutis de adoecimento no trabalho. In: DIESAT (Departamento Intersindical de Estudos e Pesquisas de Saúde e dos Ambientes de Trabalho) (Org.) Insalubridade: morte lenta no trabalho. São Paulo: Oboré, 1989.

SATO, L. Trabalho e saúde mental. In: CENTRAL ÚNICA DOS TRABALHADORES. Saúde, Meio Ambiente e Condições de Trabalho: conteúdos básicos para uma ação sindical. São Paulo: Central Única dos Trabalhadores, 1996.

SATO, L. \& BERNARDO, M. H. Saúde mental e trabalho: os problemas que persistem. Ciência Eु Saúde Coletiva, 10(4): 869-878, 2005.

SCHWARTZ, Y. Expérience et Connaissance du Travail. Paris: Messidor, Éditions Sociales, 1988.

SCHWARTZ, Y. Le Paradigme Ergologique ou un Métier de Philosophe. Toulouse: Octarès, 2000.

SCHWARTZ, Y. Ergonomia, filosofia e exterritorialidade. In: DANIELLOU, F. (Org.) A Ergonomia em Busca de seus Princípios: debates epistemológicos. São Paulo: Edgard Blücher, 2004.

SCHWARTZ, Y. Actividade. Laboreal, 1(1): 63, 2005.

SCHWARTZ, Y. \& DURRIVE, L. Trabalho Eु Ergologia. 2. ed. revista e ampliada. Niterói: EdUFF, 2010.

SELIGMANN-SILVA, E. Condições de Trabalho e de Vida em sua Repercussão sobre a Saúde Mental: estudo em operários industriais. Relatório de pesquisas apresentado ao CNPq, 1983.

SELIGMANN-SILVA, E. Crise econômica, trabalho e saúde mental. In: ANGERAMI, V. (Org.) Crise, Trabalho e Saúde Mental no Brasil. São Paulo: Traço, 1986.

SELIGMANN-SILVA, E. Desgaste Mental no Trabalho Dominado. Rio de Janeiro: Ed. UFRJ, Cortez, 1994.

SELIGMANN-SILVA, E. Saúde mental e automação: a propósito de um estudo de caso no setor ferroviário. Cadernos de Saúde Pública, 13(supl.2): 95-110, 1997.

SILVA FILHO, J. F. Saúde, trabalho e práticas sindicais. Jornal Brasileiro de Psiquiatria, 35(6): 398-399, 1986.

SILVA FILHO, J. F. Automação e doença mental. Jornal Brasileiro de Psiquiatria, 36(6): 313-315, 1987.

STENGERS, I. Quem Tem Medo da Ciência? São Paulo: Siciliano, 1990. 
VASQUES-MENEZES, I. Por onde passa a categoria trabalho na prática terapêutica? In: CODO, W. (Org.) O Trabalho Enlouquece?. Petrópolis: Vozes, 2004.

VON HIPPEL, E. Democratizing Innovation. London, Cambridge: The MIT Press, 2005.

WISNER, A. Anthropotecnologie: vers un monde industriel pluricentrique. Toulouse: Octarès, 1997.

ZARIFIAN, P. Travail, Événements et Rapports Sociaux. Paris: LATTS-ENPC, 1995.

ZARIFIAN, P. Objetivo Competência: por uma nova lógica. São Paulo: Atlas, 2001a.

ZARIFIAN, P. Mutação dos sistemas produtivos e competências profissionais: a produção industrial de serviço. In: SALERNO, M. (Org.) Relação de Serviç̧o: produção e avaliação. São Paulo, Senac, 2001b.

ZARIFIAN, P. Le Modèle de la Compétence. Paris: Liasons, 2001c. 



\title{
17. O Trabalho e a Saúde Mental no Brasil: CaMinHOS PARA NOVOS CONHECIMENTOS E NOVOS INSTRUMENTOS DE INTERVENÇÃO
}

\author{
Álvaro Roberto Crespo Merlo
}

A saúde mental dos trabalhadores pode ser afetada por numerosos fatores, tais como a exposição a agentes tóxicos, políticas de gestão de pessoas e das estruturas da empresas, até aspectos relacionados à organização do trabalho.

Os agravos à saúde psíquica muitas vezes vêm acompanhados de consequências somáticas, sendo o caso mais exuberante, atualmente, as lesões por esforços repetitivos/distúrbios osteomusculares relacionados ao trabalho (LER/Dort), embora não se possa afirmar que as condições e a organização do trabalho sejam as causas únicas para o aparecimento desse grupo de patologias.

Aspectos relacionados à (re)estruturação do mundo do trabalho e à divisão internacional da economia também têm, ainda que indiretamente, repercussões sobre a saúde psíquica (e física) dos trabalhadores, na medida em que contribuem para definir as formas diferentes de como o trabalho vai ser exercido em um determinado país, conforme seja ele de capitalismo central ou de capitalismo periférico. Como exemplo, pode-se citar a divisão internacional das formas de trabalhar, que destina aos países de capitalismo periférico atividades produtivas muito exigentes de mão de obra, tal como o que ocorre na produção do vestuário ou do calçado, que ainda funcionam em moldes tayloristas e/ou fordistas criados há pelo menos cem anos e podem produzir importantes agravos à saúde física e psíquica dos trabalhadores, não mais aceitáveis pelas legislações e fiscalizações do trabalho em seus países de origem. Não é possível esquecer, também, que as organizações e as condições de trabalho a que nos referimos ocorrem nos marcos de condições específi- 
cas de apropriação do lucro e de estruturas de poder, histórica e socialmente determinadas, definidas como modo capitalista de produção. ${ }^{1}$

Múltiplas abordagens e métodos foram criados (e serão criados no futuro) para estudar as relações entre trabalho e saúde mental, e não é intenção deste texto descrevê-los e analisá-los todos. É importante, no entanto, lembrar sempre que as realidades podem ser apreendidas de várias maneiras e que nenhum método sozinho é capaz de dar conta de todos os seus aspectos. Entendemos que as diversas abordagens utilizadas nessa área devem ser vistas, antes de mais nada, como complementares e não excludentes. Apesar dos avanços ocorridos, principalmente nos últimos vinte anos, ainda existe uma importante lacuna na compreensão das relações entre trabalho e saúde mental, que limita e cria impasses ainda não resolvidos para a atenção à saúde nos serviços que atendem os trabalhadores. Por exemplo, a questão do nexo causal entre trabalho e saúde mental ainda não é devidamente resolvida e limita a atividade dos profissionais de saúde que atuam nos Centros de Referência em Saúde do Trabalhador (Cerests), nos ambulatórios de doenças do trabalho dos hospitais universitários, nas unidades básicas de saúde etc.

Nossa proposta neste texto é oferecer subsídios para os debates da temática já citada, tendo como referência a metodologia da psicodinâmica do trabalho, com a qual trabalhamos nos últimos anos, que se oferece como um instrumento útil para conhecer as realidades de saúde mental e trabalho - mas que serve, também, para uma intervenção qualificada nos espaços de trabalho, buscando transformá-los para reduzir o sofrimento mental dos que ali atuam.

\section{A Metodologia}

Na origem da psicodinâmica do trabalho, temos as pesquisas de Le Guillant (1984), autor que, durante os anos 50, realizou as primeiras observações que permitiram estabelecer relações entre trabalho e psicopatologia. Em um estudo feito em 1956 sobre a atividade de telefonistas em Paris, ele identificou um distúrbio que nomeou de síndrome geral de fadiga nervosa, caracterizada por um quadro polimórfico que incluía alterações de humor e de caráter, modificações do sono e manifestações somáticas variáveis (angústia, palpitações, sensações de aperto torácico, de bola no estômago etc.). Falou, ainda, da invasão

1 Os regimes políticos ditos de 'socialismo real', passados ou contemporâneos, também foram (e são) geradores de muito sofrimento e agressão à saúde dos trabalhadores. As condições de trabalho nos países do antigo bloco soviético, China etc. não deixaram nada a desejar, em termos de precariedade e contaminação (dos trabalhadores e do meio ambiente), ao que ocorre nos atuais países capitalistas da periferia. 
do espaço fora do trabalho, por hábitos da atividade realizada, que chamou de síndrome subjetiva comum da fadiga nervosa. Esta síndrome caracterizavase pela manutenção do ritmo de trabalho durante as férias, manifestando-se pela sensação de irritação, por uma grande dificuldade para ler em casa e pela repetição incontrolável de expressões verbais do trabalho.

As repercussões da organização do trabalho sobre o aparelho psíquico foram muito inovadas pelo estudo de Christophe Dejours, com a publicação na França de Travail: usure mentale - essai de psychopathologie du travail, em 1980, traduzido em 1987 no Brasil com o título A Loucura do Trabalho: estudo de psicopatologia do trabalho (Dejours, 1987a). A mudança do conceito de psicopatologia do trabalho para o de psicodinâmica do trabalho deu-se a partir de um privilegiamento do estudo da normalidade sobre o da patologia. O que importava agora para a psicodinâmica do trabalho era compreender como os trabalhadores alcançavam a manutenção de um certo equilíbrio psíquico, mesmo estando submetidos a condições desestruturantes (Dejours, 1993). O autor propõe-se a estudar o espaço que separa um comportamento livre de um outro estereotipado - referindo-se a palavra livre, aqui, ao modelo comportamental que faz intervir uma tentativa visando a transformar a realidade que o circunda, conforme os desejos do sujeito, no sentido do prazer. O objetivo principal do procedimento de pesquisa seria localizar o processo de anulação desse comportamento livre (Merlo, 1999).

Dejours (1987b) define o campo da psicodinâmica do trabalho como aquele do sofrimento e do conteúdo, da significação e das formas desse sofrimento, e situa sua investigação no campo do infrapatológico ou do pré-patológico. Segundo essa concepção, o sofrimento é um espaço clínico intermediário que marca a evolução de uma luta entre funcionamento psíquico e mecanismo de defesa, por um lado, e pressões organizacionais desestabilizantes, por outro, com o objetivo de evitar a descompensação e conservar um equilíbrio possível, mesmo se ele ocorre às custas de um sofrimento, desde que preserve o conformismo aparente do comportamento e satisfaça aos critérios sociais de normalidade.

Outra característica importante da psicodinâmica do trabalho é que ela visa à coletividade de trabalho e não aos indivíduos isoladamente. Após diagnosticar o sofrimento psíquico em situações de trabalho, ela não busca atos terapêuticos individuais, mas intervenções voltadas para a organização do trabalho à qual os indivíduos estejam submetidos. Uma de suas vertentes fundamentais são as categorias da psicanálise. Assim, compreende que, ante uma situação 
de agressão ao ego, o indivíduo defende-se, primeiramente, pela produção de fantasmas, que lhe permitem construir uma ligação entre a realidade difícil de suportar, o desejo e a possibilidade de sublimação. Para Dejours (1987b), a situação de trabalho taylorizada está bloqueada entre o ego e a realidade, pois o conteúdo da tarefa, seu modo operatório e sua cadência são decididos pela direção da empresa. Nessas condições, o fantasma não serve a nada.

Para Daniellou e colaboradores (1983), existe sempre uma separação entre trabalho prescrito e real, consequente à separação entre concepção e execução. Assim, a psicodinâmica do trabalho terá, também, por referência fundamental, esse conceito ergonômico de trabalho prescrito e de trabalho real, e será no espaço entre os dois que poderão ocorrer, ou não, a sublimação e a construção da identidade.

A principal crítica que a disciplina vai dirigir ao taylorismo é a de que ele impede a conquista da identidade no trabalho, a qual ocorre, precisamente, no espaço entre trabalho prescrito e real. A organização científica do trabalho não se limitaria apenas à desapropriação do saber; ela proibiria, também, toda a liberdade de organização, de reorganização e de adaptação ao trabalho, pois tal adaptação exigiria uma atividade intelectual e cognitiva não esperada pelo taylorismo (Dejours, 1993).

A psicodinâmica do trabalho vai utilizar, também, o conceito de sublimação, que tem sua origem na teoria de Sigmund Freud sobre o desenvolvimento da sexualidade, segundo a qual, após o nascimento, os órgãos sensoriais (pele, olhos, orelhas etc.) 'solicitam satisfação por sua própria conta', dentro de um mosaico primitivo em que apenas intervém o corpo e no qual não existe aparelho psíquico para controlar essas operações (Merlo, 2002). É o momento da indiferenciação somatopsíquica. Para chegar a uma sexualidade adulta, é necessário que a criança passe por um estágio no qual ela unifique esse mosaico. Tal unificação faz-se por meio do olhar do outro e, em primeiro lugar, da mãe no momento dos cuidados com o corpo do bebê. Porém, pulsões parciais fogem a essa unificação.

A sublimação é, portanto, o processo graças ao qual essas pulsões parciais - cuja satisfação é, originalmente, de natureza sexual - encontram uma saída substitutiva em uma atividade socialmente valorizada. A ideia subjacente é a de que essas pulsões do sujeito, que deveriam desembocar em relações sexuais, são redirigidas ao trabalho, supondo-se que ocorra, preliminarmente, uma dessexualização e, também, uma atividade de substituição socialmente valorizada. No entanto, esse processo não é simples, pois implica manterem-se 
juntos os aspectos semelhantes e os aspectos diferentes e, dessa forma, fazêlos interagir. Por sua vez, o trabalho repetitivo elimina toda possibilidade de sublimação e leva, por meio da repressão, tanto a doenças somáticas como a descompensações mentais (psiconeuróticas).

Para que a sublimação possa ocorrer na atividade de trabalho, é necessário que certas condições sejam preenchidas. Desenvolveremos apenas algumas delas, devido aos limites definidos para este texto, e remetemos o leitor para Merlo (2002), onde pode ser encontrado maior detalhamento da metodologia: condições psíquicas, condições ontogenéticas e condições organizacionais.

O espaço em que pode ocorrer a epistemofilia é o mesmo em que se desenvolve o processo de sublimação, o qual não acontecerá se esse espaço for muito estreito. A organização do trabalho deverá, portanto, responder a certas características para que tal mecanismo possa funcionar. Assim, devem-se nela encontrar:

1) Um espaço entre organização do trabalho prescrita e organização do trabalho real.

2) Um espaço que permita assumirem-se responsabilidades, isto é, algum tipo de atividade de concepção.

3) Uma correspondência entre a situação de trabalho e o estado interno do sujeito. Trata-se de se estabelecer uma relação entre duas cenas, a do teatro psíquico interno - que dá forma à curiosidade - e a do teatro do trabalho, e de se passar de um teatro a outro. Essa relação - a ressonância simbólica - só poderá operar se existir uma analogia, uma semelhança, entre os dois teatros, sendo o do trabalho que irá retomar, de forma controversa, o teatro psíquico interno. As diferenças são aqui tão importantes como as coincidências, na medida em que são elas que vão permitir estimular-se novamente a curiosidade do sujeito e transformá-lo.

4) Condições éticas - a relação que existe entre a organização real e a prescrita do trabalho é sempre conflitante: o sujeito opõe-se, invariavelmente, à segunda. As atitudes inventivas e as tentativas de se realizarem experiências novas no trabalho implicam um sofrimento que se apresenta muito custoso no plano psicológico e para a saúde globalmente. Como retorno à contribuição dada pelo trabalhador à organização do trabalho, ele deve receber uma 'retribuição' que não se resume à simples atribuição de um salário ou de um prêmio por produtividade. Ela necessita ter, antes de mais nada, um caráter moral, devendo, normalmente, tomar a forma de um 'reconhecimento', o que significa que os interlocutores do trabalhador devem reconhecer que as atitudes 
deste último contribuíram para a realização do trabalho. Esse reconhecimento precisa acompanhar-se de um julgamento de utilidade, o que quer dizer que a atividade fornecida pelo empregado deve receber a gratidão dos superiores hierárquicos na empresa, como alguma coisa que tenha utilidade do ponto de vista econômico, técnico etc.

5) Condições sociais da sublimação - para que a sublimação possa produzirse, o trabalhador deverá constituir um conjunto de pares a quem dará a contribuição. A valorização da atividade do trabalhador pelos seus próprios colegas reveste-se de muita importância na medida em que não é mais a hierarquia que a faz. Dejours (1987a) chama-a de "julgamento de beleza", porque ela se baseia em critérios que são, ao mesmo tempo, estéticos e econômicos (no sentido de economia do corpo) quanto à realização do trabalho. Porém, esse julgamento, por sua vez, é baseado em critérios estritos: para ser bom juiz, é necessário pertencer ao métier e respeitar suas regras. Porém, outro critério intervém nesse julgamento: a elegância e a leveza no trabalho. Na medida em que as regras são estritamente respeitadas, elas não mais são vistas.

O julgamento de beleza é, assim, feito pelos pares, ou seja, pelo coletivo de trabalho, que é a equipe ou a comunidade à qual a pessoa pertence, e esse julgamento é necessário para que se construa a identidade no trabalho. É ele que vai abrir um espaço ao individual, ou seja, permitir a cada um fazer parte do coletivo, conservando alguma coisa a mais, uma característica particular.

Outra peculiaridade importante é que o julgamento deve referir-se ao trabalho e não à pessoa, para permitir a construção da identidade.

O julgamento de beleza refere-se às regras do métier, construídas por subversão e transgressão daquelas prescritas. Trata-se, nesse caso, de realizar a 'burla' das regras. É necessário, no entanto, em dado momento, haver um acordo mútuo quanto à maneira de transgredi-las: é preciso tornarem-se públicas as burlas do métier, para que se possa merecer o julgamento de beleza, o reconhecimento dos outros.

Assim, os trabalhadores são levados a criar espaços públicos, que são espaços comuns no trabalho, nos quais possam decidir a melhor maneira de realizar uma determinada tarefa. Essa atividade deve contar com a participação de todos, para que essas novas normas possam resultar de um consenso que as legitime. Porém, não existem apenas critérios técnicos que entram na definição desse consenso, pois a realização da burla depende da história pessoal de cada um e do seu conhecimento e experiência anteriores. 
Sem negar a importância dos cerceamentos psíquicos ligados ao trabalho na geração do sofrimento, Dejours (1993) chama a atenção para o fato de que é, principalmente, a falta de possibilidades para se mudarem, ou mesmo aliviarem esses cerceamentos, a origem dos problemas de saúde.

O sofrimento pode, assim, ter dois destinos diferentes: de um lado, a sublimação, como no exemplo dado por Dejours (1993) da atividade dos pilotos de caça, para os quais a defesa é a sublimação que permite aberturas novas; de outro, os trabalhadores submetidos à execução de tarefas repetitivas, para quem as defesas contra o sofrimento são a repressão pulsional, a autoaceleração ou a ideologia defensiva de profissão que expulsam o sujeito de seu desejo e favorecem a lógica da alienação na vontade do outro (Dejours, 1987c).

O sofrimento pode tornar-se o instrumento de uma modificação na organização do trabalho ou gerar um processo de alienação e de conservadorismo. Este segundo caminho explica-se pelo fato de que, após terem-se desenvolvido mecanismos de defesa contra a organização do trabalho, torna-se penoso tentar uma modificação nessa situação.

É com base no estudo das ideologias defensivas que se irá construir a investigação proposta pela psicodinâmica do trabalho (Dejours, 1987b).

Outra contribuição da psicodinâmica do trabalho é a sua abordagem da relação com o prazer que pode existir entre o trabalhador e seu trabalho. $\mathrm{Na}$ realidade concreta e na vivência individual do trabalho, não se encontram apenas sofrimento, mutilação e morte. A compreensão da maneira como se elaboram as duas facetas da organização do trabalho, isto é, aquelas que são, respectivamente, fonte de sofrimento e de prazer, é indispensável para se tentar uma interpretação mais global dos laços entre trabalho e saúde e, também, para se procurarem alternativas satisfatórias.

Se essa compreensão encontra sua origem na psicanálise, que é voltada para o estudo e o tratamento terapêutico dos indivíduos na sua relação com uma história singular, a psicodinâmica do trabalho termina por romper, de forma importante, com essa fonte de inspiração, ainda que sem abandonar seus conceitos essenciais. Ela constrói uma nova abordagem, na qual o trabalho não mais é percebido, unicamente, como uma terapêutica universal para remediar 'desequilíbrios mentais', vistos como o resultado exclusivo da história singular do trabalhador, que se manifestariam em um indivíduo imaginário quase insensível aos ambientes e à organização do trabalho na qual está inserido. A psicodinâmica do trabalho incorpora conceitos sociológicos para caracterizar e detalhar a organização taylorista, conceitos ergonômicos para identificar o 
espaço existente entre trabalho real e trabalho prescrito e, também, conceitos psicanalíticos, tais como os de sublimação, para apreender o indivíduo que entra no universo do trabalho como portador de uma história singular que foi construída desde sua infância.

\section{Méritos e Limitações}

O principal mérito da psicodinâmica do trabalho é, sem dúvida, ter exposto as possibilidades de agressão mental originadas na organização do trabalho e identificáveis ainda em uma etapa pré-patológica. Na medida em que não é possível falar-se, na imensa maioria das situações, de patologia que possa ser associada a uma situação específica de trabalho, o desvendamento do sofrimento psíquico desde o estado pré-patológico permite progredir-se na identificação das consequências da organização do trabalho sobre o aparelho psíquico dos indivíduos e pensar-se em uma intervenção terapêutica precoce.

Ela é uma metodologia ainda muito jovem e em construção - e isso é dito sem nenhum demérito ao enorme esforço que vem sendo feito para construí-la -, que poderá (deverá) sofrer um processo de amadurecimento, o qual the permitirá fornecer respostas mais completas sobre as relações entre saúde mental e trabalho e definir, de forma mais nítida, suas fronteiras com as outras disciplinas com as quais tem interface.

\section{A Metodologia nas Realidades de Pesquisa do Brasil}

A psicodinâmica do trabalho tem sido utilizada no Brasil de duas maneiras principais:

1) Um modo que poderia chamar-se de lato sensu. Trata-se da utilização de apenas suas categorias para tentar compreender as realidades de trabalho, buscando uma superação dos limites impostos por outros métodos existentes até aquele momento. Nessa situação, encontra-se a grande maioria de dissertações, teses e artigos que indicam a bibliografia dessa metodologia.

2) Um modo stricto sensu. Alguns pesquisadores têm buscado, nos últimos anos, reproduzir e adaptar a metodologia para as realidades de trabalho brasileiras estudadas, utilizando-a em consonância com o que é proposto originalmente (não apenas como categoria teórica) e seguindo todas as etapas da investigação. Alguns conceitos da metodologia, como sofrimento psíqui- 
co no trabalho, ${ }^{2}$ só permitem seu desvendamento mediante uma utilização estrita do método proposto, com o seguimento de suas etapas (pré-pesquisa, pesquisa, devolução e validação dos resultados etc.), aí incluídos os grupos de discussão com trabalhadores (dentro dos moldes propostos pelo método) e a identificação dos mecanismos de defesa constituídos por esses trabalhadores, individual ou coletivamente.

No grupo que faz uso stricto sensu da metodologia estão vários pesquisadores brasileiros. As temáticas estudadas foram as mais variadas e ultrapassaram as primeiras pesquisas voltadas, preferencialmente, para as atividades taylorizadas/ fordizadas tradicionais. Pensamos que todas as metodologias devem ser vistas como instrumentos de trabalho para a pesquisa em permanente construção - e por isso dinâmicas -, que precisam ser adequadas às realidades nas quais são empregadas e seus horizontes de utilização podem e devem ser muito ampliados. Com a psicodinâmica do trabalho não ocorre diferentemente. Para que haja um avanço e enriquecimento do método, no entanto, é necessário que se faça seu uso dentro do que prevê o método originalmente, buscando complementá-lo e enriquecê-lo.

\section{Algumas Pesquisas em Psicodinâmica do Trabalho no Rio Grande do Sul}

Os resultados que apresentaremos a seguir têm por objetivo exemplificar o uso desse método e são fruto de investigações nossas, feitas com alunos(as) do Programa de Pós-Graduação em Psicologia Social da Universidade Federal do Rio Grande do Sul (PPGPSI-UFRGS); outros foram produzidos com base em estudos com pacientes do Ambulatório de Doenças do Trabalho do Hospital de Clínicas de Porto Alegre (ADT-HCPA), dentro das atividades da residência em Medicina do Trabalho.

Merlo (1999), em estudo sobre a saúde dos analistas em informática de uma grande empresa estatal de processamento de dados, constatou que, embora essa atividade se beneficie de um espaço de criatividade que não poderia ser comparado com o que é oferecido em outras funções, está muito longe da imagem que é feita, habitualmente, do analista como um 'gênio criador', que desenvolve seu trabalho em completa liberdade e cuja única limitação seria aquela imposta por sua própria imaginação. Essa situação de trabalho

2 Para essa metodologia, o sofrimento psíquico no trabalho só pode apreendido a partir do uso estrito do método, na medida em que ele, na sua subjetividade, não se manifesta de forma explícita e, na maior parte das vezes, encontra-se 'escondido' atrás dos mecanismos de defesa. 
ideal, se algum dia existiu, não corresponde, em absoluto, à dos analistas de hoje. Na verdade, esses profissionais estão submetidos a importantes pressões vindas da direção da empresa para que se respeitem os prazos de produção, pela necessidade de terem de gerenciar as relações com os clientes, das exigências produzidas pelas rápidas mudanças que intervêm no conhecimento e nos produtos informáticos e que nem sempre podem ser controladas etc. Porém, se o sofrimento psíquico do qual podem ser vítimas é muito importante, ele não aparece nos dados do serviço médico da empresa na medida em que se situa, na maior parte do tempo, em um nível infrapatológico. Mesmo quando manifestações somáticas ou psíquicas são reveladas, elas são, totalmente, inespecíficas e não permitem estabelecer qualquer relação com a atividade.

Em estudo realizado com caixas-executivos de um grande banco estatal brasileiro em processo de reestruturação produtiva, Barbarini e Merlo (2002) constataram que a mobilização psíquica provocada pelas mudanças realizadas era intensa, manifestada em sentimentos de insegurança, estranhamento, desorientação e impotência diante das incertezas das propostas da empresa, sendo a perda do contato com o cliente uma das maiores fontes de sofrimento para o grupo. Havia um forte sentimento de desvalorização, presente nas queixas sobre o achatamento salarial, na perda do status que a função proporcionava e na desestruturação de um saber acumulado ao longo dos anos de exercício da função. O sofrimento psíquico desses caixas-executivos, provocado pelas reestruturações no trabalho, atingia níveis preocupantes, pois as novas formas de organização do trabalho haviam destruído a imagem do caixa como um profissional e reduzido a possibilidade de ele ser reconhecido pelo exercício de sua atividade.

Merlo e colaboradores (2003), em pesquisa realizada no ADT-HCPA, tendo como principal objetivo determinar as relações das LER/Dort com o processo produtivo e suas consequências sobre a saúde física e mental dos trabalhadores estudados, evidenciaram um sofrimento associado à dor física, mas não só a ela. Além dos aspectos fisiopatológicos da doença, percebeu-se que existe uma complexa relação que vinculava a dor às vivências subjetivas e à identidade social desses trabalhadores. Assim, se por um lado o trabalho era lembrado como fonte de prazer e produzia o lastro para o reconhecimento e para a identidade, por outro era fonte de sofrimento, pois além de lidarem com as pressões e exigências no cotidiano de trabalho, essas pessoas tiveram a doença como 'saldo' de seu engajamento no trabalho, que agora lhes trazia 
não só dor física, mas também uma série de consequências emocionais e sociais que transformaram radicalmente suas vidas.

Spode e Merlo (2006) estudaram o trabalho e a saúde mental dos capitães da Polícia Militar do Rio Grande do Sul a partir dos aspectos deste ofício que geram prazer e sofrimento. Os resultados da pesquisa revelaram que, apesar da excessiva carga de trabalho administrativo e dos perigos inerentes à profissão, havia prazer no trabalho e este estava relacionado ao exercício de atividades de gestão, as quais proporcionavam espaços de criação. Porém, as pressões impostas pelos mecanismos disciplinares de vigilância e de controle, característicos da organização desse tipo de atividade, não deixavam de se constituir como fonte de sofrimento, pois engendravam divisões entre os trabalhadores e colocavam barreiras para a criação dos vínculos de confiança e cooperação, aspectos de suma importância se considerarmos a própria natureza do trabalho, permeada por riscos.

Barfknecht e Merlo (2006) estudaram as vinculações entre prazer, sofrimento e a organização do trabalho no cotidiano dos trabalhadores de uma cooperativa inserida no movimento da economia solidária. Como proposta do estudo, articulou-se uma interpretação macrossocial do contexto socioeconômico com uma análise microssocial baseada na perspectiva da psicodinâmica do trabalho. Foram analisadas, em conjunto com os trabalhadores, as atividades de corte, costura e serigrafia desenvolvidas em um empreendimento solidário de Porto Alegre (RS). Os resultados mostraram uma identificação dos trabalhadores com o cooperativismo e com a possibilidade da criação de relações solidárias e do gerenciamento compartilhado, transformando o sofrimento em prazer, favorecendo a saúde mental por meio da rediscussão constante da organização do trabalho e da criação de novos modos de viver o trabalho.

Silva e Merlo (2007) problematizaram as vivências de psicólogos que trabalhavam em empresas privadas, discutindo suas práticas profissionais, experiências associadas ao prazer e ao sofrimento em seu cotidiano e concepções teóricas que embasam seu trabalho. Os resultados indicaram que os profissionais tinham como atividades prioritárias as ligadas à psicologia organizacional. Suas falas sugeriram que esses psicólogos tinham estilos dinâmicos de trabalho, revelaram 'apaixonamento' por ele, acreditando na sua atuação e apreciando as atividades ligadas ao desenvolvimento de pessoas na organização. Mostraram-se satisfeitos com o reconhecimento dado por outros colegas e por terem espaço para atuar conforme acreditam. As principais fontes de sofrimento foram a carga excessiva de trabalho, os 
possíveis conflitos entre os valores da empresa e os pessoais, os cerceamentos da organização, a falta de reconhecimento e a percepção de que pertencem a uma categoria profissional desprovida de força.

Traesel e Merlo (2009) apresentaram os resultados de um estudo da psicodinâmica do reconhecimento no contexto dos trabalhadores da enfermagem em um hospital de Santa Maria (RS), que teve o intuito de analisar a eficácia das formas de reconhecimento conferido a essa profissão na preservação da saúde mental desses trabalhadores. A forma de reconhecimento considerada mais importante foi a manifestada pelo paciente, que traz, subjacente, um conflito, pelo fato de esses profissionais não conseguirem prestar a atenção devida que gostariam, em razão dos múltiplos papéis e responsabilidades da profissão.

As principais estratégias defensivas identificadas na pesquisa foram: a atitude de vitimização diante dos problemas, aliada ao sentimento depreciativo em relação às suas capacidades de mudança da realidade; o individualismo, associado a uma busca de dar conta de tudo sozinho, na ilusão de que 'reconhecer-se a si mesmo' é a saída para se manter bem no trabalho; o bloqueio de seus sentimentos e emoções e a naturalização da dor e do sofrimento, alimentando uma visão falsa de si mesmo, como alguém que não fica doente, que é sempre forte e que não sofre no que diz respeito às perdas vividas pelo seu paciente, como se estivesse 'imunizado' a isso. Foi observado que algumas dessas estratégias impediam o enfrentamento de situações importantes, o que levava ao sofrimento e à morbidade, limitando, significativamente, o investimento da criatividade e da engenhosidade desses trabalhadores e, consequentemente, o reconhecimento de sua contribuição à organização de trabalho.

Baierle e Merlo (2008) buscaram compreender as implicações da reestruturação do trabalho da Guarda Municipal de Porto Alegre (RS) na produção de subjetividade de seus servidores e o impacto sobre a dinâmica saúde/sofrimento mental deles. $O$ grupo de servidores envolvidos na pesquisa foi o que se encontrava mais exposto às mudanças que estavam ocorrendo na instituição, assumindo funções de maior visibilidade, risco e exposição. Essa instituição viveu um período de transição - quando a Guarda recebeu armamento e passou a ser vista pela população da cidade como um corpo policial igual ao das polícias militares -, o que interferiu diretamente na organização do trabalho, na subjetividade e na saúde mental de seus servidores. $O$ sofrimento provocado pelo trabalho passou a ser amortecido pela cooperação mútua, pelo reconhecimento advindo de uma atuação com maior visibilidade e possibilidade do uso da inteligência astuciosa. 
Em estudo sobre o trabalho de gerentes de nível intermediário de grandes empresas, Almeida e Merlo (2008) demonstraram que essa atividade surge como um vasto campo a ser explorado, à medida que esses profissionais transitam pelo cenário contemporâneo do trabalho e vivenciam as contradições de uma posição que lhes permite mandar e lhes exige obedecer. Os resultados mostraram uma atividade em que o tema do prazer e do sofrimento psíquico estava presente no trabalho da categoria, despindo o cargo de gerente do glamour que reveste as posições de comando e dando-lhe voz para falar sobre o conteúdo do seu trabalho, sobre as relações que atravessam a rotina profissional e sobre o papel que o trabalho desempenha em suas vidas. Constataram também uma grande demanda por autonomia e reconhecimento, o ressentimento pelo tempo em demasia dedicado ao trabalho e o consequente desequilíbrio entre vida pessoal e vida profissional. $\mathrm{O}$ estudo chamou a atenção, ainda, para a importância das relações interpessoais no trabalho, como um fator capaz de fazê-lo pender para uma vivência positiva ou negativa.

\section{Comentários Finais}

Como assinalamos, algumas grandes questões estão desafiando os profissionais que atuam nessa área, e gostaríamos de citar duas delas para, no final deste capítulo, apontar para as necessárias e urgentes discussões que devemos realizar, para começarmos a buscar alguns caminhos.

A primeira (e talvez a mais importante delas) diz respeito às dificuldades atuais para que tenhamos referências e instrumentos, minimamente confiáveis e consensuais, para o estabelecimento do nexo causal entre trabalho e saúde mental e que possam ser implementados no nível dos serviços que atendem a saúde dos trabalhadores (Cerests, ambulatórios especializados de hospitais universitários, unidades básicas de saúde etc.).

A segunda refere-se ao tipo de atendimento que devemos e podemos propor para lidar com as demandas que chegam aos serviços de atenção à saúde do trabalhador - principalmente quando pensamos em situações complexas e pouco reconhecidas pelas práticas de saúde atuais em suas diversas áreas de conhecimento (médica, de enfermagem, de psicologia, de terapia ocupacional, de fisioterapia etc.), como são os casos da atual epidemia de LER/Dort, que vem, quase sempre, associada a quadros de depressão e de sofrimento psíquico importante. O que se observa, na grande maioria das situações, são queixas de trabalhadores desses serviços especializados em saúde do trabalhador, que 
se sentem impotentes e completamente despreparados para atender quadros clínicos em que há pouca ou nenhuma referência na literatura especializada, seja no nível da investigação, seja no do diagnóstico, muito menos no da intervenção terapêutica, entendida em seu aspecto mais amplo e não apenas medicamentosa.

Caso tenhamos conseguido indicar alguns caminhos para tratar das questões levantadas aqui, já teremos dado um importante passo para criarmos - e trata-se, exatamente, da necessidade de criação de novos conhecimentos e instrumentos, pois os que existem, atualmente, mostraram-se completamente insuficientes - novas formas de se lidar com os novos agravos à saúde que se apresentam em saúde do trabalhador no Brasil e construirmos formas de tratar o sofrimento dos que hoje estão expostos às duras realidades de trabalho.

\section{REFERÊNCIAS}

ALMEIDA, L. L. \& MERLO, A. R. C. Trabalho de gerência: manda quem pode, obedece quem tem juízo - prazer e sofrimento psíquico em cargos de gerência. Cadernos de Psicologia Social do Trabalho, 11(1): 139-157. 2008.

BAIERLE, T. \& MERLO, A. R. C. Saúde mental e subjetividade no trabalho de uma guarda municipal: estudo em psicodinâmica do trabalho. Cadernos de Psicologia Social do Trabalho, 11(1): 69-81, 2008.

BARBARINI, N. \& MERLO, A. R. C. Reestruturação produtiva no setor bancário brasileiro e sofrimento dos caixas executivos. Psicologia e Sociedade, 14: 103-122, 2002.

BARFKNECHT, K. S. \& MERLO, A. R. C. Saúde mental e economia solidária: análise das relações de trabalho em uma cooperativa de confecção de Porto Alegre. Psicologia e Sociedade, 18: 54-61, 2006.

DANIELLOU, F. et al. Fiction et réalité du travail ouvrier. Cahiers Français, 209: 39. 45, 1983.

DEJOURS, C. Travail: usure mentale - essai de psychopathologie du travail. Paris: Le Centurion, 1980.

DEJOURS, C. A Loucura do Trabalho: estudo de psicopatologia do trabalho. São Paulo: Oboré, 1987a.

DEJOURS, C. La méthodologie en psychopathologie du travail. In: DEJOURS, C. (Org.) Plaisir et Souffrance dans le Travail. Tome I. Paris: AOCIP, 1987 b.

DEJOURS, C. Souffrance et plaisir au travail: approche par la psychopathologie du travail. In: DEJOURS, C. (Org.) Plaisir et Souffrance dans le Travail. Tome I. Paris: AOCIP, 1987c.

DEJOURS, C. Travail: usure mentale - de la psychopatologie à la psychodynamique du travail. Paris: Bayard, 1993. 
LE GUILlANT, L. Quelle Psychiatrie pour notre Temps? Paris: Ėrés, 1984.

MERLO, A. R. C. A Informática no Brasil: prazer e sofrimento no trabalho. Porto Alegre: Ed. da UFRGS, 1999.

MERLO, A. R. C. Psicodinâmica do trabalho. In: JACQUES, M. G. \& CODO, W. (Orgs.) Saúde Mental e Trabalho: leituras. Petrópolis: Vozes, 2002.

MERLO, A. R. C. et al. O trabalho entre prazer, sofrimento e adoecimento: a realidade dos portadores de lesões por esforços repetitivos. Psicologia e Sociedade, 15: 117-136, 2003.

SILVA, P. C. da \& MERLO, A. R. C. Prazer e sofrimento de psicólogos no trabalho em empresas privadas. Psicologia: ciência e profissão, 27: 132-147, 2007.

SPODE, C. B. \& MERLO, A. R. C. Trabalho policial e saúde mental: uma pesquisa junto aos Capitães da Polícia Militar. Psicologia: reflexão e crítica, 19: 362-370, 2006.

TRAESEL, E. \& MERLO, A. R. C. A psicodinâmica do reconhecimento no trabalho de enfermagem. Psico, 40(1): 02-109, jan./mar. 2009. 



\section{A Temática do Sofrimento nos Estudos sobre Trabalho E Saúde}

Luiz Carlos Brant

Carlos Minayo Gomez

Nas últimas duas décadas, a temática do sofrimento vem ocupando boa parte da produção científica do campo da saúde do trabalhador. Indagamos as condições de possibilidade que despertam tal interesse em tantos pesquisadores e, particularmente, o que teria levado alguns estudiosos a identificar em suas investigações as manifestações do sofrimento como transtorno psíquico.

Consideramos que uma frágil delimitação conceitual entre os termos sofrimento e transtorno mental pode acarretar problemas de ordem metodológica, técnica e ética, bem como comprometer a formulação de programas de atenção à saúde dos trabalhadores. Com essa preocupação, buscamos identificar e interpretar as concepções do sofrimento e os instrumentos metodológicos empregados, no âmbito da produção científica da área da saúde do trabalhador, no período entre 1986 e 2007. Para tanto, recorremos às seguintes fontes: Banco de Dissertações e Teses da Coordenação de Aperfeiçoamento de Pessoal de Nivel Superior (Capes); Instituto Brasileiro de Informação em Ciência e Tecnologia (Ibict); Biblioteca Virtual de Saúde Pública da Biblioteca Regional de Medicina (Bireme) e o site SciELO. Foram selecionados também capítulos e/ou livros originados de teses ou dissertações que abordavam essa temática.

Totalizamos 202 trabalhos, dos quais 102 foram artigos e cem, teses e dissertações. A identificação do material se fez pelos títulos, resumos e palavras-chave. Alguns desses estudos foram analisados na íntegra. Buscamos interpretar as diversas concepções existentes acerca da temática do sofrimento e os termos empregados para a sua nomeação.

Entendemos que, para compreender as significações do sofrimento ao longo do tempo e no espaço, muito se poderia avançar com as contribuições da se- 
mântica histórica do sofrimento e sua articulação com o trabalho. Entretanto, para nos mantermos fiéis aos nossos objetivos, decidimos nos ater apenas ao conjunto selecionado. Percebemos que o termo vem sendo utilizado sem a devida precisão conceitual. Alguns autores partem do princípio da existência de uma significação única e universal para a categoria sofrimento, dispensando a sua conceituação e o delineamento das diferenças entre o sofrimento e o que seria da esfera de sua manifestação.

No conjunto das suas produções, o sofrimento caracteriza-se como um transtorno psiquiátrico menor; como uma dimensão interna do sujeito; como adoecimento; como uma instância intermediária entre a saúde e a doença.

\section{Um Transtorno Psiquiátrico Menor}

A concepção do sofrimento como transtorno psiquiátrico é encontrada essencialmente nas investigações que utilizam o Self-Report Questionnaire (SRQ-20) como um instrumento padronizado no âmbito da mensuração e prevenção da doença mental. Ainda que empregando diferentes terminologias como transtorno mental ou adoecimento mental (Borges, 1990), morbidade neurótica, pré-morbidade, distúrbios psíquicos menores (Araújo, 1999), estresse psicológico (Farina, 2004), sofrimento psíquico e estresse psíquico (Oliveira, 1998), os autores citados compartilham da premissa de que o sofrimento constitui um transtorno mental menor.

$\mathrm{Na}$ sua investigação com base em uma abordagem epidemiológica, consideram-se os resultados obtidos como reveladores da situação atual e da possibilidade de ocorrência de morbidades no futuro. Nessa perspectiva, são estudados instrumentos como o questionário World Health Organization Quality of Life (WHOQOL), utilizado por Lícia Souza (2001), ou a Escala de Prazer e Sofrimento no Trabalho, Inventário de Sintomas de Stress e Inventário de Qualidade de Vida, adotado por Lima (2004). Nesse sentido, inventários, a interpretação dos questionários, surveys e screenings têm por objetivo a coleta de dados para a reorganização de serviços de saúde.

Nesse ponto de vista, a prevenção de doenças mentais se faz tomando por base a existência e a detecção precoce de distúrbios psiquiátricos menores, o que faz com que o sofrimento acabe assumindo a conotação de uma entidade etiológica já conhecida. Repete-se assim, com essa abordagem, a mesma lógica da 'história natural das doenças' no século XIX. A triagem com fins preventivos em populações humanas aponta para uma visão do sofrimento 
como um mal a ser evitado, capaz de desencadear doenças mentais. Pesquisadores como Silva Filho e Jardim (1997) dedicaram parte de seus estudos à construção, adequação e aperfeiçoamento de instrumentos com o objetivo de localizar em categorias profissionais 'transtornos psiquiátricos menores'. Essa foi a lógica que inspirou a criação da Liga Brasileira de Higiene Mental (LBHM) na cidade do Rio de Janeiro.

As práticas preventivistas da LBHM atravessam grande parte da história da psiquiatria brasileira desde o início, chegando até as últimas décadas do século XX, tornando-se uma das metas do campo da saúde mental e trabalho. Nessa época, as intervenções psiquiátricas passaram a ocorrer, além dos hospitais e ambulatórios, em escolas, fábricas e comunidades, de modo geral. Buscava-se assim uma estratégia para antecipar a explicitação de demandas para tratamento. Portanto, em nome da 'profilaxia', o sofrimento era considerado por profissionais como transtorno mental, tornando-se motivo de intervenção médica (Carvalho, 1997; Costa, 1989).

Após a abolição da escravatura brasileira - revelam ainda esses autores -, muitos negros em busca de ocupação foram para as cidades em processo de industrialização. A maioria partia levando consigo a herança cultural do cativeiro, a busca de soluções mais dignas para a vida e um sofrimento, fruto das condições adversas. Nesse percurso, logo se depararam com a grande oferta de etílicos. O consumo diário de álcool pelos novos trabalhadores urbanos - hábito herdado da vida no engenho para apaziguar os tormentos laborais e fonte de alegria para as noites - foi diagnosticado como sinal evidente de doença mental. Por meio da "hygiene mental" - disciplina médica com foco na prevenção -, integrantes da LBHM se aproximaram desses migrantes do campo com a finalidade de adequá-los à nova vida, segundo os padrões exigidos pela sociedade da época.

Nas primeiras décadas do século XX, cabia à "hygiene mental" a missão de formar trabalhadores competentes, controlados e disciplinados. Portanto, a prevenção na área da saúde mental tinha três facetas: 1) disponibilizar sujeitos adestrados e potencialmente maximizados para a emergente indústria brasileira; 2) garantir para as empresas a reinserção de trabalhadores recuperados e livres da degeneração; e 3) retirar mendigos, malandros e alcoólatras das ruas, conduzindo-os aos sanatórios. "Em nenhuma outra corrente psiquiátrica da época, salvo a alemã, poder-se-ia encontrar a caução teórica de uma prática psiquiátrica que permitisse o uso de métodos policialescos em nome do tratamento da doença mental" (Costa, 1989: 132). 
Os hospitais e as fábricas constituíam amplos espaços para a prática de uma "hygiene mental" socializadora do discurso do aprimoramento da capacidade laborativa que, afinal, procurava adequar o homem ao trabalho. Embora todas as suas ações estivessem embasadas na prevenção, ela não passava de uma forma de controle e adestramento, notadamente, no momento em que o trabalhador manifestava sofrimento. Essa prática, embora com forte fundamentação teórico-metodológica da medicina da época, era incapaz de proporcionar uma atenção cuidadosa.

O movimento antialcoólico de 1934 não era apenas uma campanha de prevenção, mas uma forma para garantir qualidades morais nas fábricas com base nas queixas de sofrimento. Dessa forma, a República Nova e a "hygiene mental" comungavam o mesmo ideal: a formação de uma mão de obra dócil, produtiva e curvada à ditadura. A ação da polícia e as campanhas de prevenção constituíam dispositivos aceitáveis por uma ampla parcela da população que as via como proteção à saúde. Os médicos alienistas eram descritos como indivíduos dedicados ao combate da doença mental. Desenvolviam práticas voltadas para higienização do corpo e do espírito do trabalhador, considerado verdadeiro alicerce da nação em busca do tão sonhado desenvolvimento industrial. A expectativa, tanto do patronato quanto do Estado, era conseguir o máximo de produção com o menor desperdício de energia. A função do higienista não era apenas preventivista, mas disciplinar, no sentido atribuído por Foucault $(1979,1984)$.

Se, nos anos 30, numerosas práticas foram implementadas para prevenir 'doenças mentais', na década de 1970 e no início da seguinte assistimos à repetição de alguns discursos psiquiátricos preventivistas vinculados à conjuntura política do país da época. Uma longa trajetória do espectro da prevenção insistia em reafirmar-se no campo da saúde mental. Novamente, em momentos críticos da política nacional, algumas práticas médicas e o poder hegemônico se unem, apresentando-se tanto como prática educativa quanto como prevenção de doenças.

Entre as produções analisadas, o estudo de Lancman (2004) destaca-se na medida em que revela a esperança da construção de ações eficazes na área da saúde mental. A autora discute também a importância de se conhecerem os processos de adoecimento para o desenvolvimento de práticas preventivas, tratamento e reinserção laboral, garantindo assim uma participação ativa dos trabalhadores. Segundo sua concepção, o conhecimento sobre os processos de adoecimento no presente poderá evitar uma doença no futuro - o que sugere a existência de um nexo causal pensado como conexão linear, cuja correta 
dimensionalidade e a eliminação do agente 'causa-dor' evitariam sofrimentos psíquicos que poderiam ser gerados no cotidiano do trabalho.

A prevenção configura-se, portanto, como conjunto de práticas fundamentado na causalidade, dado que o critério empregado é uma relação de determinação. Nessa perspectiva, a prevenção abrigaria uma concepção linear do tempo que não leva em consideração a possibilidade da emergência de outros acontecimentos na vida do sujeito. Tal concepção não deixa espaço para a contingência e a inventividade, descartando assim a dimensão da imprevisibilidade.

\section{A Subjetividade como Dimensão Interna}

A concepção de sofrimento como decorrência de processos subjetivos no pensamento de alguns pesquisadores contempla implicitamente a ideia de indivíduo igual a si mesmo ao longo dos tempos, que se faz segundo uma natureza dada. De modo geral, essa noção comporta a acepção de permanência vinculada à dimensão identitária. Diferentemente, a ideia de sujeito associada à ação transformadora é subsumida no conjunto das investigações por nós catalogadas. Dessa forma, os termos indivíduo, sujeito e subjetividade deslizam pelo interior do campo da saúde do trabalhador de forma indiscriminada, compondo uma tessitura em que, aparentemente, não há diferença um do outro. É a noção de indivíduo e não a de sujeito que figura de modo geral tanto nos estudos de base epidemiológica como naqueles que têm nas ciências sociais e humanas o seu marco teórico. Como a noção de indivíduo prepondera nas investigações do campo da saúde do trabalhador?

Para compreender as diferenças entre esses termos, é importante assinalar alguns marcos da longa e fascinante trajetória da subjetividade na teoria do conhecimento, que vai da busca platônica da verdade à inversão cartesiana operada por Freud com a sua pergunta pela verdade do inconsciente que dificilmente poderá ser negada (Brant, 2001).

Falar em subjetividade remete necessariamente a René Descartes, o que não significa dizer que essa questão tenha surgido com a filosofia moderna. Ao investigar os domínios da subjetividade, esse pensador do século XVII transformou-a em referencial central e, às vezes, exclusivo para o conhecimento e a verdade. É na perspectiva do racionalismo que a filosofia moderna constrói uma subjetividade, no interior da qual mantém as mesmas exigências e os mesmos objetivos do discurso de Platão: a busca da objetividade pela razão. 
A subjetividade é uma das questões do platonismo, independentemente das diferentes soluções que ela tenha recebido dentro desse espaço. No entanto, ela aparece como problema para esse filosófico da modernidade. Diante da incerteza quanto à realidade do mundo objetivo, Descartes afirma a certeza do cogito. É interessante verificar que ele coloca a tônica no pensamento, enquanto o eu fica praticamente fora de sua filosofia. Quando fala do eu, não se refere a um sujeito, mas a uma substância pensante. Por mais paradoxal que possa parecer, a máxima cartesiana - cogito ergo sum - assinala a emergência da subjetividade, mas não a do sujeito. Em uma perspectiva racionalista, a concepção de homem presente em sua filosofia é de indivíduo próprio de uma espécie. Trata-se, portanto, de 'in-divíduo', o que não pode dividir, o que permanece eternamente igual a si com uma identidade fixa assegurada por um solipsismo desconhecedor da dimensão da alteridade. $\mathrm{O}$ indivíduo é um objeto no mundo entre tantos outros.

Descartes pensava o indivíduo como lugar da verdade; Freud o pensava como engendrado pela ordem da cultura, fruto de 'totem e tabu' e um eterno desamparado em seu 'mal-estar na civilização'. Ou seja, um ser de franco conflito entre os registros da pulsão e do social. Enquanto Descartes fala de um objeto da ciência, Hegel faz referência a um ser de desejo. Freud avança em relação a Hegel revelando-nos um ser de desejo inconsciente. Antes de Freud, a consciência ocupa a centralidade principalmente nas "investigações lógicas" de Husserl; a partir de Freud, torna-se necessário se perguntar pelo inconsciente e suas articulações.

No entanto, é o psicanalista francês Jacques Lacan que, ao fazer uma releitura radical da obra freudiana, introduz o termo sujeito na psicanálise, tornando possivel operar com a hipótese do inconsciente sem aniquilar sua dimensão fundamental de não sabido (insu, Unbewusste). O sujeito em Lacan não é nada de substancial, é ele momento de eclipse que se manifesta em um equívoco de linguagem (bérue, Unbewusste), o que significa dizer que esse engano será feito por um ser falante, que se interroga no campo da linguagem sobre a existência de seu 'eu'. Observa-se, assim, que a partir da teoria psicanalítica do sujeito não se pode mais identificar os termos subjetividade, sujeito e indivíduo. Desse ponto de vista, pode-se dizer que - com grande número de estudos tendo a lógica cartesiana em seu substrato - a categoria sujeito e suas relações com o sofrimento ainda não foram devidamente investigadas no campo da saúde do trabalhador (Brant, 2002).

Em alguns estudos, deparamos com pesquisadores abordando as experiências no cotidiano de trabalho utilizando a subjetividade como categoria 
de análise, oferecendo-nos assim elementos para a apreensão do sofrimento como dimensão subjetiva. Nessa perspectiva, encontram-se, entre outros, os estudos de Tittoni (1994), que investigou trabalhadores petroleiros no sul do país; Uchida (1996), que pesquisou temporalidade e subjetividade entre especialistas da informática; e Lopes (2000), que em A Voz do Dono e o Dono da Voz analisou o trabalho, a saúde e a cidadania entre operários no cotidiano de um chão de fábrica paulistano.

O sofrimento é entendido como uma instância pertencente à subjetividade, e a sua compreensão se faz por meio do deciframento das formas como o indivíduo apreende e expressa as experiências no âmbito do trabalho. Por meio da vivência e da experiência, os "trabalhadores vivenciam sua atividade, suas relações pessoais e hierárquicas, o ambiente de trabalho e, enfim, uma série de outros elementos que compõem o cotidiano de trabalho" (Tittoni, 1994: 33). A análise da subjetividade - entendida como uma dimensão intraindividual que interage com a realidade concreta, considerada externa ao sujeito - possibilitaria a apreensão dos significados que os trabalhadores atribuem às experiências laborais.

Esses estudos buscam nos domínios da subjetividade o referencial central para o conhecimento das relações entre homem e trabalho. Os pesquisadores, partindo do pressuposto cartesiano de que a verdade habita a consciência humana, faziam da experiência laboral o caminho para apreender o sentido do trabalho, ressaltando os aspectos subjetivos.

Tittoni e Bernardes (1997: 245) afirmam que "as experiências dos sujeitos e as tramas que constroem o lugar do trabalhador definem modos de subjetivação relacionados ao trabalho". Nos estudos por nós selecionados, não foi possível verificar o sentido atribuído à expressão 'modos de subjetivação'. Entretanto, constatamos que Verthein e Minayo Gomez (2000) consideram que o modo de subjetivação desenha uma armadilha para o sujeito quando se privilegia o aspecto subjetivo na análise da doença. Investigando a construção do 'sujeito-doente' em lesões por esforço repetitivo/distúrbios osteomusculares relacionados ao trabalho (LER/Dort), esses pesquisadores concluem que a categoria subjetividade pode criar a noção de um indivíduo predisposto a adoecer.

Em alguns casos, a concepção subjetiva do sofrimento evidencia a ideia de permanência que habita o interior de um indivíduo sempre idêntico a si mesmo ao longo dos tempos. Condenado pela mesmice, portanto, destituído de ações transformadoras, é representado como vítima do sofrimento no trabalho. "São elementos da organização do trabalho que levam a vivências 
de sofrimentos" (Tittoni, 1994: 176). A organização do trabalho é considerada uma prática estanque que se mantém alhures da resistência do conjunto dos trabalhadores. Como tal, ela 'naturalmente' desencadearia sofrimento, independentemente da produção e da criação dos sujeitos. Dessa forma, o trabalhador é representado como um ser que não produz a história, que não é responsável pelo seu próprio devir.

Em geral, a metodologia empregada para apreensão das relações entre sofrimento, subjetividade e trabalho privilegia técnicas como entrevista aberta, observação participante, pesquisa-ação e análise documental, compondo assim uma abordagem qualitativa. Freud (1997) salienta a importância do método etnográfico com base na proposição de que a subjetividade não se restringe apenas ao que as pessoas pensam ou conhecem, mas se expressa em outras instâncias, como costume e hábitos.

Independentemente das técnicas utilizadas, em algumas investigações constatamos uma concepção negativa e patológica do sofrimento que parece contribuir para o emprego da noção de indivíduo, em contraposição à de sujeito. Embora o sentido dos termos trabalho e castigo não seja o mesmo entre os gregos antigos e os cristãos, pesquisadores como Oliveira (1998), Tittoni (1994) e Brant (2002) recorrem à mitologia grega e à Bíblia para ilustrar as origens do sofrimento no trabalho. Para Mendes (1995), sofrimento, dano ou agravo (pathos) à saúde causado pelo trabalho constitui o objeto da patologia do trabalho. Em sua definição de sofrimento, encontram-se as palavras dor física, angústia, aflição, amargura, infortúnio, desastre e agravo. Esses autores defendem a tese da existência de uma relação histórica entre trabalho e sofrimento e que este constitui um mal a ser evitado, pois causa prejuízos à saúde. A ideia da manifestação do sofrimento como resistência e, portanto, como ação criadora de intersubjetividade capaz de engendrar novas formas de ser e estar na esfera do trabalho praticamente não é contemplada. Apenas nessa perspectiva seria possível encontrar trabalhadores que se reconhecem e se fazem sujeitos mutuamente.

\section{Adoecimento e Criatividade}

A concepção do sofrimento como uma dimensão capaz de contribuir para a compreensão das relações entre saúde e trabalho encontra-se essencialmente nas investigações em que o marco teórico é a psicodinâmica do trabalho. Nessa perspectiva, englobam-se também as categorias prazer e desejo, tendo como referencial teórico os estudos de Christopher Dejours. 
Segundo a tese de Uchida (1996), em A Loucura do Trabalho, Dejours (1992) considera a significação do trabalho e o sentido do sofrimento como elementos essenciais para a compreensão da relação saúde-trabalho. Haveria um "sofrimento singular", fruto da história psíquica própria a cada trabalhador (dimensão diacrônica), e um "sofrimento atual”, originário da situação de trabalho em que o sujeito se encontra (dimensão sincrônica). De acordo com as tentativas de enfrentamento do sujeito, o psiquiatra francês afirma a existência de um sofrimento criativo marcado pela elaboração de "soluções originais" que favoreceria a produção e a saúde. Ao contrário, ocorreria o "sofrimento patogênico" resultante de uma "retenção da energia pulsional" que impediria o fluxo adequado da carga psíquica resultando em "soluções desfavoráveis" para a produção e favoráveis ao adoecimento.

Para Brant e Minayo Gomez (2004), ao se polarizar o sofrimento dessa forma, reproduz-se uma longa tradição que, do nascimento da clínica à psicodinâmica do trabalho, transforma a manifestação do sofrimento em adoecimento. É notória a tentativa do psicopatologista de reafirmar a centralidade do sofrimento. Entretanto, ocorre repetição do modelo de explicação causal, dicotomização do sofrimento e reprodução de aspectos que visavam superar na psicopatologia do trabalho. Com uma concepção ainda negativa, Dejours $(1992,1994)$ considera o sofrimento como resultado de enfraquecimento das estratégias coletivas e não como resistência a situações experienciadas - no sentido foucaultiano do termo - na esfera do trabalho.

"Para que o trabalho seja fonte de saúde, há a necessidade do reconhecimento. Aí reside a possibilidade de dar sentido ao sofrimento. Ele é fundamental na possibilidade de transformar o sofrimento em prazer" (Merlo, Spode \& Vaz, 2003: 1). Tendo como referência a teoria dejouriana, Merlo, Spode e Vaz acreditam na possibilidade de transformação do sofrimento em prazer por meio do reconhecimento. Na tentativa de compreender as lógicas que atravessam tal convicção, buscamos localizar no material selecionado conceitos que pudessem clarear o sentido atribuído a esses termos. Nada encontramos. Partimos então da premissa de que o sufixo 're' do vernáculo 'reconhecimento' indica uma identidade em construção, o que torna o sujeito sempre dependente do outro para reconhecê-lo como tal. Como não se pode reconhecer a si mesmo, mas apenas ser reconhecido, o sujeito sofre diante da presença desse outro no campo da sua existência. Desde que estejamos na dialética do reconhecimento, o sofrimento é inexorável, pois o outro é sempre um estranho (diferente do 
eu), abrindo possibilidade para o surgimento de uma pluralidade de outros, na melhor das hipóteses.

Para o filósofo francês Jean Paul Sartre, "o inferno é o outro que me desvela". Esse outro não se refere a uma pessoa, mas às discursividades próprias da religião, da família, da política, das artes, do trabalho, entre outras, construídas pela humanidade. Dessa forma, podemos apenas afirmar que o sofrimento é contingente no que tange ao prazer. Na manifestação do sofrimento, haveria prazer, e no prazer haveria sofrimento (Freud, 1997). Visto que ambos se mesclam, a transformação do sofrimento em prazer torna-se uma impossibilidade. Uma coisa não pode se transformar em algo da qual ela é parte constituinte.

Retomando o pensamento de Dejours, é questionável fazer uma associação direta entre trabalho e sofrimento, no sentido patológico ou criativo. Seria mais apropriado dizer que o sofrimento impele o sujeito para o trabalho, para a ação. Algumas investigações embasadas na teoria dejouriana comportam uma lógica subjacente na qual encontramos a concepção do sofrimento como vivência subjetiva entre doença mental e conforto psíquico; uma luta contra as forças (ligadas à organização do trabalho) que empurrariam o indivíduo para a doença mental. Logo, sofrimento é representado essencialmente como negativo. Embora tivesse adquirido uma nova significação - sofrimento criativo -, permanecem ainda os elementos patogênicos. Nessa perspectiva, trabalho constituiria ainda fonte de 'doença mental'. Por um lado, é lembrado como prazer; por outro, é fonte de sofrimento.

Com um pensamento determinista, o trabalho é causa de prazer, sofrimento ou doença mental. As investigações que partem desse pressuposto centram-se em explicações linguísticas, deixando de lado interpretações ético-políticas. Ou seja, não há referência aos dispositivos sociofuncionais capazes de oferecer evidências materiais, além das linguísticas, nas relações entre sofrimento e adoecimento. Alguns pesquisadores, ainda que sustentando a discursividade da nova psicodinâmica, permaneciam ancorados em interpretações centradas essencialmente na linguagem, reproduzindo assim a velha psicopatologia do trabalho.

\section{Sofrimento: entre a saúde e a doençA}

O sofrimento é caracterizado também como estágio, uma dimensão entre a saúde e a doença. Isso acontece tanto nas produções que têm na área da saúde mental e trabalho (SMT) o seu referencial teórico central, bem como naquelas que empregam a psicodinâmica do trabalho. Para Seligmann-Silva 
(1997), o sofrimento situa-se na transição entre saúde e doença, podendo ser reconhecido como um estágio de mal-estar e de tensão que ainda não pode ser considerado patologia. Em Dejours (1992: 83), essa posição intermediária torna o sofrimento passível de ser transformado em doença: "Mesmo intenso o sofrimento, é razoavelmente bem controlado pelas estratégias defensivas, para impedir que se transforme em patologia”. Isso implica dizer que, em seu 'estado natural', o sofrimento comporta condições para a sua transformação em morbidade. Nessa perspectiva, o sofrimento é concebido como 'prémorbidade', como pode ser visto em Pitta (2003: 79):

Querer discutir relação entre sofrimento psíquico, este tomado como uma manifestação de mal-estar, distúrbio psíquico menor, uma etapa prévia à eclosão de uma situação patológica evidenciável pelos instrumentos habitualmente utilizados pela clínica, enquanto tecnologia fundamentada na individualidade e o trabalho hospitalar, implica necessariamente uma retomada de concepções sobre a natureza desse sofrimento.

Em grande parte dos estudos, o sofrimento é entendido como intrínseco ao trabalho, parte de sua natureza, e na maioria dos casos o trabalhador é colocado na posição de vítima. "O risco de ser invadido por ansiedade intensa e incontrolada está presente na própria natureza do trabalho" (Pitta, 2003: 65). Entretanto, Brant (2004) considera que a ansiedade manifestada na execução de atividades é contingente - no sentido rortyniano do termo - às situações de trabalho e comporta uma positividade, pois sinaliza a existência de processos que demandam criação. Corroborando essa perspectiva, Jardim (2008), partindo da concepção freudiana, afirma que o sofrimento é pertencente à condição humana. Portanto, para esses pesquisadores, não se trata de uma 'invasão natural' de ansiedade capaz de 'assaltar' o trabalhador. Pelo contrário, a ansiedade é contingencial - pode estar presente ou não - nas situações laborais.

Para Pitta (2003), haveria não apenas uma natureza do trabalho, mas também uma natureza do sofrimento. Do nosso ponto de vista, não há uma natureza do sofrimento, tampouco do trabalho, mas relações que se estabelecem entre o sujeito e situações experienciadas como adversas à vida (no caso do sofrimento), levando-o à ação. A manifestação do sofrimento opõe-se ao quietismo e só é possível na medida em que se realiza na presença do outro ('não eu'). Portanto, esse agir, visando à proteção, jamais se faz em causa própria, pois implica necessariamente o outro no campo existencial do sujeito.

Assim como Pita, Oliveira (1998: 96) realiza a sua pesquisa tendo como sujeitos trabalhadores de um hospital. O seu objetivo é "analisar de que for- 
ma o sofrimento psíquico dos trabalhadores nas enfermarias de um hospital público é influenciado pela relação destes trabalhadores com os pacientes e a organização do trabalho”. Esse autor parte da concepção da existência, a priori, de um sofrimento psíquico passível de ser influenciado. Para que algo da ordem de uma influência possa ocorrer, é condição a existência de duas situações de modo que uma tenha ascendência, predomínio ou poder sobre a outra, previamente existente. A contração da preposição 'de' e do artigo 'o', no plural, empregada pelo autor na expressão "sofrimento psíquico dos trabalhadores" introduz um sentido de portabilidade. Os sujeitos, representados como portadores de um 'sofrimento original', próprio da condição de trabalhador, sofrem influência da organização do trabalho. Entretanto, a maneira de explicitar o objetivo no texto evidencia não apenas uma dada concepção de sofrimento, mas a introdução de uma lógica para permitir o olhar investigativo de uma ciência. Pois trata-se de identificar 'de que forma' - o que pressupõe a existência de várias outras formas na natureza. Entendemos que, na tentativa de 'analisar a forma', esse pesquisador também situa o sofrimento na esfera da natureza.

\section{SOFRIMENTO: UM BEM DO SUJEITO}

No seu conjunto, as abordagens trazem em seu interior concepções negativas, patologizantes e, raramente, acepções positivas que evidenciem as transformações operadas em razão da manifestação do sofrimento. Essa psicopatologização pode ser traduzida em expressões como transtorno mental menor, distúrbio psiquiátrico menor, morbidade neurótica e pré-morbidade, entre outras. A positividade atribuída à manifestação do sofrimento está localizada, de modo geral, nos estudos cujo referencial teórico é a psicanálise e, de forma particular, naqueles que têm em Freud a sua referência central (Uchida, 1998; Brant \& Dias, 2004; Jardim, 2008). Em sua maioria, esses trabalhos ancoram-se no conceito de sofrimento do chamado 'Freud sociológico', cuja fonte comum para vários pesquisadores é O Mal-Estar na Civilização (Freud, 1997).

Diferentemente da maioria das produções analisadas, compreendemos a manifestação do sofrimento como um bem do sujeito, situando-o na dimensão da alteridade, o que implica a presença do outro no campo existencial do sujeito (Brant, 2004). Compartilhando dessa concepção freudiana, consideramos que a manifestação do sofrimento impulsiona o indivíduo para 
ações de proteção diante do perigo, trazendo uma dimensão de positividade para essa categoria.

Em Freud (1997) encontra-se uma acepção positiva do sofrimento relacionado com o perigo. Assim, a ansiedade (Angst) descreve um estado particular de espera ou preparação para o perigo, ainda que desconhecido. $O$ temor (Furcht) exige um objeto definido de que se tenha receio (Furchtet). $\mathrm{O}$ terror ocorre quando o sujeito se depara com um perigo sem estar preparado para enfrentá-lo. Portanto, o sofrimento se configura como uma reação, uma manifestação da insistência em viver sob circunstâncias que, na maioria das vezes, não são favoráveis. Embora a vida, nesse sentido, possa ser árdua, capaz de despertar decepções e remeter o homem a tarefas impossíveis, a manifestação do sofrimento leva o sujeito à ação - visto que não há esperança senão na sua ação, e que a única coisa que lhe permite a vida é o ato. Não é por obra do acaso que Goethe afirma que "no princípio era o ato".

As palavras alemãs Angst, Furcht e Lust, comuns na obra de Freud, figuram em algumas traduções para o português como medo, ansiedade e disposição, em geral de forma imprecisa e indevida. Em alemão, o termo Angst significa medo e liga-se a uma prontidão reativa ante o perigo. Em português, essa palavra foi traduzida como 'ansiedade', seguindo a vertente da tradução inglesa, ou como 'angústia', conforme a tendência francesa. Já o vocábulo Furcht (receio, temor) não abarca o pânico ou pavor imediato, estando mais associado à preocupação. A Angst é mais visceral, imediata, e indica reação intensa perante uma ameaça (real ou imaginária, específica ou genérica).

Quanto ao termo Lust, ele nos ajuda a pensar as relações entre sofrimento e prazer. Para Hanns (1996), não há nessa palavra, do ponto de vista linguístico, nada que se relacione com a sensação de alívio pela cessação do desprazer ou devido à descarga de pressão. Pelo contrário, Lust está relacionado, irredutivelmente, a sensações prazerosas e a uma animada disposição para certas ações. $\mathrm{O}$ autor conclui afirmando a existência de um hiato entre aquilo que o termo designa como prazeroso e a concepção de Lust como 'descarga' que traz alívio para um desconforto (Unlust, desprazer).

A investigação desses vernáculos diretamente no 'alemão de Freud' se faz com o objetivo de aprofundar a compreensão conceitual acerca do termo sofrimento. Estaríamos assim construindo condições mais favoráveis para identificá-lo na esfera laboral. Nesse âmbito, a expressão do sofrimento pode criar movimento pela liberdade e oferecer proteção contra as ameaças que colocam o trabalho em risco. Acreditamos que a manifestação do medo 
aparece entre trabalhadores como elemento central da resistência a situações que sinalizam perigo para a sobrevivência no emprego. $O$ temor permite a aproximação de alguns para o enfrentamento conjunto da ameaça de demissão. Mas, simultaneamente, ele dissemina a desconfiança entre esses mesmos indivíduos. Cada trabalhador vê nos colegas mais próximos um perigo, dado o desejo de permanência na empresa.

Se para Freud (1997) a ansiedade, o medo e o terror relacionam-se com o perigo, para Spinoza, no livro III da Ethica, o medo está articulado com o desejo, a dúvida e a esperança, concluindo que "não há esperança sem medo, nem medo sem esperança" (Spinoza, 1983: 214). Se o medo constitui um bem do sujeito, o perigo residiria exatamente na medicalização por meio de ansiolíticos. Ao proporcionar uma segurança (Securitas) ilusória, o anestesiamento do medo operado pela clínica contemporânea dificulta a ação, obnubilando a esperança da transformação. $O$ diagnóstico de fobia para as queixas de medo, tão comum nos serviços de atenção psicossocial, impede que o trabalhador formule a incômoda pergunta: o que está acontecendo comigo? Nesse âmbito, tem se tornado uma prática usual a explicação médica acerca da existência de transtornos neuroquímicos. Com a transformação do medo em distúrbio mental, quebra-se a organização coletiva dos trabalhadores e criam-se condições favoráveis para o aparecimento da tristeza. Quando não interpretado como depressão, esse sofrimento contribui para mudanças significativas no ambiente, criando condições mais saudáveis de trabalho, uma vez que impele o sujeito para a ação. "Quanto maior é a tristeza tanto maior é a capacidade de agir com a qual o homem se esforça para afastar a tristeza" (Spinoza, 1983: 197).

Com o intuito de defender a sua tese acerca da existência da transformação do sofrimento em adoecimento, Brant $(2002,2004)$ busca evidências tanto na sua experiência empírica como nos trabalhos de Freud, Foucault e Rorty. Para esse pesquisador, o processo de adoecimento inicia-se com o silêncio sobre o sofrimento como meio de sobrevivência. A ausência de elaboração simbólica por meio da palavra cria possibilidades para o sofrimento se manifestar no corpo. Na contemporaneidade, a ansiedade e o medo têm sido expressos na forma de dor. Trata-se de uma tentativa de manter a vida possível, ainda que essa não seja a melhor estratégia. Esses sofrimentos, tão comuns na relação entre o sujeito e a organização do trabalho, são deslocados para o interior do corpo. Entretanto, a clínica ocupacional atual tem dado pouca importância a esse processo, interpretando usualmente as queixas de dor como disfunções musculoesqueléticas ou neuroquímicas. 
No trabalho pós-industrial, os mecanismos de gestão disciplinar do corpo exigem uma acirrada vigilância de olhares sobre os trabalhadores, o que dificulta a expressão do sofrimento na esfera laboral, fazendo do sofrimento uma dimensão intolerável nas empresas. Uma vez revelado, o sofrimento é visto como sinais de adoecimento, dando início a uma longa trajetória que se inicia com uma leitura biomédica. Em tal perspectiva, uma queixa de angústia assume o significado de doença. Com um diagnóstico de depressão, o portador dessa queixa é quase sempre medicalizado. Dessa forma, nega-se a indissolúvel ligação entre um sujeito e sua manifestação de sofrimento como ato na busca de mudanças para situações vivenciadas como ameaça. No momento em que o discurso clínico fragmenta o homem em conjuntos de órgãos para ser tratado, o 'sujeito sofredor' e seu saber acerca de si mesmo desaparecem da cosmologia médica, dificultando a visibilidade da milenar articulação desse saber com o sofrimento.

Após a construção do 'sujeito nervoso' na cultura ocidental - hospedeiro de transtornos neuroquímicos -, o trabalhador aparece como usuário de instituições para tratamento de doentes mentais e/ou de psicofármacos. Dessa forma, a doença mental passa a ser identificada também pelo comportamento do indivíduo ante a organização do trabalho. A expressão de ansiedade e o medo na esfera laboral são interpretados inicialmente como desadaptação, sinais da necessidade de treinamento cuja função última é a adequação do homem ao trabalho. Uma vez persistindo a 'reclamação ou insatisfação', a hipótese médica de um 'transtorno psiquiátrico menor' é levantada, dada a desmesurada manifestação do sofrimento.

Uchida (1996) é um dos poucos que adotam a psicanálise freudiana como modelo explicativo para a abordagem do sofrimento, situando-o em seus aspectos positivos. Dessa perspectiva teórica, ele estabelece algumas articulações sobre a importância da relação entre sujeito, desejo e sofrimento, perguntando como reagem os trabalhadores diante de uma situação que os aliena como sujeitos desejantes. Portanto, o sofrimento manifestado no âmbito laboral indicaria a existência de trabalhadores construindo possibilidades para a realização do desejo vislumbrado no registro do imaginário. Ainda que impossível de ser alcançado como tal, não impediria a ação; pelo contrário, é exatamente o que sustenta o agir humano.

Diferentemente desse pesquisador, a maioria dos estudiosos aborda o sofrimento como originário de processos psíquicos ou neuroquímicos. Com frequência, nos deparamos com concepções teóricas que operam o deslo- 
camento do sofrimento das esferas relacionais para o interior do corpo do trabalhador. Em seu conjunto, essas abordagens consideram o sofrimento como 'distúrbio psiquiátrico menor', 'pré-morbidade' ou 'transtorno mental menor' - concepções que permitem o sofrimento ser quantificado, qualificado como criativo ou patogênico ou considerado como pré-morbidade.

A concepção de Joanilho (1990) acerca do sofrimento, embora apresente uma conotação fortemente negativa, assinala uma positividade quando aborda a expressão do sofrimento como resistência, ainda que de forma frágil. Para o autor, o sofrimento atinge o trabalhador por meio do corpo, sendo capaz de macerá-lo em suas vontades. O objetivo da manutenção do sofrimento no trabalho é 'impotencializar' o indivíduo para a política e potencializá-lo para as exigências de utilidade econômica. Mergulhado no sofrimento, o sujeito torna-se destituído de desejo, passando a 'funcionar' de acordo com as normas estabelecidas pela organização do trabalho. Como uma substância corrosiva, o sofrimento é interpretado como um elemento capaz tanto de deteriorar a capacidade crítica como de favorecer a construção de estratégias de resistência. Além de possuidor de elevada destrutividade, ele figura não apenas como uma dimensão desintegradora de corpo, mas também como força capaz de viabilizar a organização de instâncias defensoras de interesses dos trabalhadores.

O sofrimento para Dias (1994) é contingente ao espaço de dominação e submissão do trabalhador pelo capital, mas, igualmente, de resistência, de constituição e do fazer histórico dos trabalhadores que buscam o controle sobre as condições e os ambientes de trabalho, para torná-los mais 'saudáveis', em um processo lento, contraditório, desigual no conjunto da classe trabalhadora. Portanto, o sofrimento é resultante de um embate que se dá não entre indivíduos isolados, mas no interior de dois coletivos: os que vendem e aqueles que compram a força de trabalho; entre os que mandam e os que devem obedecer.

\section{SOFRIMENTO: UMA INSTÂNCIA PSÍQUICA}

O termo sofrimento aparece na quase totalidade das investigações associado ao psíquico. Chama a atenção a sua figuração desde o título (Farina, 2004; Souza, R. D., 2001; Santos, 1999). A expressão sofrimento psíquico sugere a existência de outro tipo de sofrimento que estaria relacionado ao físico. Estabelecido o dualismo mente/corpo, a concepção de sofrimento psíquico reforça a existência de diferentes tipos de agravos à saúde localizados no corpo e na alma, ou seja, na psique. Ao situar o sofrimento no interior do sujeito, 
estabelece-se uma segunda dicotomia - dentro e fora, interior e exterior. Criase, ainda, uma dimensão individualizante cujas origens podem ser remetidas a diferentes realidades: uma se referindo ao mundo interno cujo corpo é o seu invólucro, e outra exterior ao indivíduo. Essa abordagem entra em conflito com a tese freudiana do sofrimento relacionado à esfera da alteridade - a presença do outro no campo existencial do sujeito. O sofrimento deslocado da esfera relacional torna-se intraindividual. Dessa forma, uma acepção mais ampla do sofrimento como um bem do sujeito é relevada. Instaura-se uma verdadeira cultura do adoecimento psíquico (Brant \& Minayo-Gomez, 2004), à medida que o termo desequilíbrio psíquico é identificado como 'transtorno mental'.

Portanto, a dicotomia corpo-mente, originária no século IV a.C., cuja hegemonia é alcançada na modernidade, ainda é fortemente encontrada nos estudos do campo da saúde do trabalhador, principalmente naqueles que investigam policiais civis, metroviários, professores, enfermeiros e profissionais da saúde (Souza et al., 2007; Palácios, 1999; Oliveira, 1998; Jardim, 1994). De acordo com Pitta (2003), sinais de sofrimento psíquico como expressão verbal, comportamento neurótico e doenças psicossomáticas podem estar relacionados com aspectos específicos de certos grupos de tarefas.

\section{Instrumentos Utillzados na Investigação}

Partindo do pressuposto de que, na atualidade, a investigação da temática do sofrimento no campo da saúde do trabalhador encontra-se in statu nascendi - portanto, detentora de possibilidades e fragilidades -, perguntamos pelos instrumentos empregados, pelas consequências técnicas e éticas no que tange à vida e à carreira dos trabalhadores diante dos resultados encontrados nas pesquisas.

Constatamos que, a partir da década de 1980, muitos pesquisadores passaram a se interessar pela classificação diagnóstica e quantificação do sofrimento, empregando screenings em suas investigações. Em sua maioria, as investigações continham levantamentos de dados primários realizados com os trabalhadores, utilizando para tal algum tipo de instrumento padronizado. Em seguida, encontram-se as entrevistas semiestruturadas. Ressaltamos também algumas produções que utilizam mais de um instrumento para a 'coleta de dados' (Brant, 2002; Martinez, 2002; Oliveira, 1998). Entretanto, o que mais despertou a nossa atenção foi o elevado número de pesquisas tanto de mestrado quanto de doutorado que não explicitava o instrumento utilizado. 
De modo geral, os estudos tinham como enfoque a clássica divisão metodológica qualitativo-quantitativo. Nos trabalhos qualitativos, prevaleciam instrumentos como as entrevistas individuais e coletivas - subdivididas em semiestruturadas, estruturadas e abertas - grupo focal e pesquisa-ação. Nas abordagens quantitativas, os mais tradicionais eram os questionários socioeconômicos e screenings. Para fins de rastreamento, o instrumento mais utilizado era o Self-Report Questionnaire (SRQ-20). Com esse screening, pretendia-se diagnosticar e quantificar algumas manifestações do sofrimento, sobretudo diferenciando os distúrbios mentais menores dos maiores (Araújo, 1999; Borges, 1990). Com frequência, constatamos também o emprego da versão em português do World Health Organization Quality of Life (WHOQOL-100) utilizado para avaliação da qualidade de vida (Souza, L. B., 2001). No que diz respeito à análise da satisfação, o Occupational Stress Indicator (SF-36) era utilizado por pesquisadores como Martinez (2002).

Se a escolha do método está diretamente relacionada a uma teoria que lhe dá sustentação, nem sempre isso acontecia nas produções investigadas. A utilização de alguns instrumentos está também associada às tendências de determinada época, à hegemonia de linha de pesquisa e à presença de pesquisadores considerados como referência em instituições reconhecidas do país. Dessa forma, ocorre uma ênfase no êxito técnico das investigações centradas no método e a consequente secundarização do ato criador do pesquisador como auctor, no sentido de autoridade, conforme terminologia de Arendt (2001) - o que torna muitas investigações meras reproduções de linhas de pesquisas, já definidas a priori como sucesso técnico ou passíveis de fomento. $\mathrm{O}$ emprego do SRQ-20 constitui um bom exemplo dessa situação.

Esse screening - desenvolvido por Harding e colaboradores (1980) e validado por uma série de estudos internacionais conduzidos pela Organização Mundial da Saúde (OMS) na década de 1990 - destacou-se como um dos instrumentos de triagem de morbidade psíquica mais utilizado em países desenvolvidos e em desenvolvimento (WHO, 1994). A sua versão brasileira foi adaptada e validada no país pelo estudo de Mari e Williams (1986) em um serviço de atenção primária na cidade de São Paulo. Apesar de o SRQ-20 não ser específico para populações de trabalhadores, sua versão no Brasil já foi empregada em estudos sobre sofrimento psíquico de categorias profissionais como enfermeiros, professores de ensino fundamental, médio, superior e trabalhadores do campo da saúde, de modo geral. 
Configurado com respostas 'sim' e 'não', como responder a algumas perguntas do SRQ-20, tais como: você dorme mal? Ou: você já pensou em suicidar-se? Com uma ampla gama de interpretações em razão da elevada suscetibilidade do sono humano, o sujeito não tinha como suspender assertivamente o SRQ-20. No entanto, quem em algum momento da vida não pensou em tirar a própria vida, ainda que fosse por um lapso? A questão não é a confiabilidade, mas a forma de coação por meio de uma tipologia classificatória que esse instrumento comporta. Ele separa aqueles que estão "numa etapa prévia de eclosão de uma situação patológica”, como afirma Pitta (2003: 79), e outros que não manifestam distúrbio psíquico menor. O ponto central não é apenas o fato de o sofrimento ser definido como pré-morbidade - considerando as consequências técnicas e éticas -, mas o fato de o SRQ-20 constituir-se como instrumento típico do biopoder, segundo a clássica expressão de Foucault (1979).

Alguns pesquisadores buscam investigar a existência de sofrimento psíquico recorrendo ao SRQ-20 para rastreamento dos chamados distúrbios psíquicos menores; entretanto, não esclarecem o motivo do adjetivo 'menor' (Souza et al., 2007). Isso nos leva a pensar na existência de 'distúrbios psíquicos maiores'. $\mathrm{Na}$ literatura especializada, não encontramos nenhuma referência com essa nomenclatura. Dessa forma, o sofrimento aparece como uma dimensão que pode ser apreendida por esse screening reconhecido como 'indicador de morbidade'.

A investigação por meio da SRQ-20 e a classificação do sofrimento como 'pré-morbidade' (Pitta, 2003) ou transtorno psíquico comum (Ludemir, 1998) constituem formas de abordá-lo como uma dimensão psicopatológica, enquadrando-o no campo da psiquiatria. Dessa forma, retira a dimensão alteritária do sofrimento, destituindo-o assim da sua dimensão ético-política para situá-lo na esfera da psicopatologia. O que levaria a pensar que o sofrimento seria uma dimensão da ordem do psíquico ou da mente? Não encontramos, também, conceituações acerca do sofrimento que justificassem, teoricamente, uma qualificação para esse termo. Não temos dúvidas de que as noções de distúrbio psíquico e transtorno mental comportam dificuldades conceituais. "A palavra mente carrega algo de misterioso, incapaz de ser descrita” (Rorty, 1999: 16).

\section{Considerações Finals}

Circunscrever as diferentes concepções do sofrimento em sua especificidade conceitual implica reconhecer o inefável das palavras e a impossibilidade de apreensão do instante em que o sofrimento se manifesta em gesto, notadamente 
porque ele parece mesmo constituir um 'significante flutuante', pois comporta contradições de significados, os quais se movimentam entre os planos mais concretos e os mais abstratos.

Atravessada por um olhar patologizante da vida, a manifestação do sofrimento é entendida como malignidade capaz de tornar-se 'transtorno mental' e, portanto, justifica o exercício de uma psiquiatria preventivista e seus screenings. A operacionalização de tal prática exige a ultrapassagem das limitações da clínica individual. Fora dos consultórios, 'a psiquiatria sem quatro paredes' faz da comunidade o seu território de intervenção. Nesse caso, a perspectiva preventivista pressupõe estudos acerca da saúde mental em determinados grupos ou comunidades. Embora as produções científicas empreguem a expressão saúde mental, nenhuma menção é feita aos aspectos conceituais.

A temática do sofrimento, do ponto de vista teórico-metodológico, tem sido abordada de forma tímida nas produções da saúde do trabalhador - o que se deve, em parte, a uma considerável parcela de autores que emprega, repetidamente, técnicas e aportes teóricos 'consagrados' pelo próprio campo. $\mathrm{Na}$ medida em que muitos citam um pequeno número de pesquisadores, a repetitividade resultante dificulta o aprofundamento da temática, instaurando frágeis conceituações terminológicas. Com efeito, os termos sofrimento, sofrimento psíquico e mental são empregados indiferenciadamente, uma verdadeira sequência de vocábulos, compondo uma serialidade sinonímica. O emprego do adjetivo psíquico, além de fragmentar a categoria sofrimento, abre possibilidades para pensar outros tipos, como físico, moral e espiritual. A indiferenciação instaura a crença de uma compreensão universal dos termos, destituídos de rigor e manejados como 'coisa' - verdadeiras entidades naturais.

A utilização dessas expressões apresenta elevado grau de polissemia, dando margens a polêmicas. Elas constituem um conjunto de palavras destituídas de matrizes identitárias e mergulhadas em ambiguidades. Quando relacionadas ao trabalho, evocam sentidos que vão do medo da perda do emprego ao da designação para um novo cargo, da angústia diante de tarefas simples àquelas de alta complexidade. Em seu conjunto, quase sempre descritas pela negatividade, as produções pesquisadas pouco contribuem para o seu entendimento, mas favorecem a configuração de uma relação causal entre processo de trabalho e sofrimento.

Diante da ampla utilização do SRQ-20, questionamos a possibilidade de um único instrumento ser capaz de medir a prevalência de distúrbios mentais, avaliar a saúde mental e quantificar o sofrimento psíquico. Os termos distúr- 
bio e saúde mental figuram como opostos, ou seja, a saúde como ausência de doença - enquanto o sofrimento é visto como um distúrbio psíquico menor ou pré-morbidade. Os estudos que se dedicaram à validação e aplicação do SRQ-20 são guiados pela concepção de verdade que esse instrumento poderia 'des-velar' sobre o sofrimento, sendo justificado frequentemente o seu emprego pela inexistência de outro instrumento quantitativo, como se houvesse uma real necessidade de quantificá-lo.

O sofrimento psíquico é representado como algo que emerge do interior do sujeito por meio do contato com situações externas, situadas de modo geral no âmbito de trabalho, fazendo eclodir a angústia armazenada nas entranhas do sujeito. Nesses casos, estabelece-se uma correlação causa-efeito entre sofrimento psíquico e condições de trabalho, sendo o primeiro uma decorrência do segundo.

Ainda que no título e nas palavras-chave dos trabalhos analisados figure o termo 'saúde mental', é comum encontrar tanto no objetivo da pesquisa quanto no seu desenvolvimento descrições abordando distúrbios mentais sem a devida conceituação. Não constatamos nenhum trabalho cuja proposta de investigar a saúde mental fosse implementada conforme a proposição. Também não encontramos, com o devido rigor, uma conceituação para o termo saúde mental, embora ele fosse amplamente empregado.

A relação entre arcabouço teórico e escolha dos instrumentos de investigação deixa transparecer a existência de desenhos metodológicos repetidos por vários autores, criando muitas vezes um hiato entre a teoria e o método adotado - a preocupação excessiva com o método em detrimento da problemática pesquisada.

\section{REFERÊNCIAS}

ARENDT, H. Entre o Passado e o Futuro. São Paulo: Perspectiva; 2001.

ARAÚJO, T. Trabalho e Distúrbios Psíquicos em Mulheres Trabalhadoras de Enfermagem, 1999. Tese de Doutorado, Salvador: Universidade Federal da Bahia.

BORGES, L. Transtornos Mentais entre Trabalhadores de uma Usina Siderúrgica, 1990. Dissertação de Mestrado, São Paulo: Universidade de São Paulo.

BRANT, L. O indivíduo, o sujeito e a epidemiologia. Ciência $\mathcal{G}$ Saúde Coletiva, 6(1): 221-231, 2001.

BRANT, L. Sujeito e Sofrimento entre Trabalhadores que Ocupam Cargo Gerencial, 2002. Dissertação de Mestrado, Belo Horizonte: Faculdade de Medicina, Universidade Federal de Minas Gerais. 
BRANT, L. O Processo de Transformação do Sofrimento em Adoecimento na Gestão do Trabalho, 2004. Tese de Doutorado, Rio de Janeiro: Escola Nacional de Saúde Pública Sergio Arouca, Fundação Oswaldo Cruz.

BRANT, L. \& DIAS, E. Trabalho e sofrimento em gestores de uma empresa pública em reestruturação. Cadernos de Saúde Pública, 20(4): 942-949, 2004.

BRANT, L. \& MINAYO-GOMEZ, C. Do nascimento da clínica à psicodinâmica do trabalho: a transformação do sofrimento em adoecimento. Ciência $\mathcal{E}$ Saúde Coletiva, 9(1): 213-223, 2004.

CARVAlHO, A. O Elemento Psycho no Trabalho Humano: a Liga Brasileira de Higiene Mental e o processo de produção discursiva do campo trabalho e higiene mental no Brasil entre 1925 e 1934, 1997. Dissertação de Mestrado, Rio de Janeiro: Escola Nacional de Saúde Pública Sergio Arouca, Fundação Oswaldo Cruz.

COSTA, J. F. História da Psiquiatria no Brasil. Rio de Janeiro: Xenon, 1989.

DEJOURS, C. A Loucura do Trabalho: estudo de psicopatologia do trabalho. São Paulo: Cortez, 1992.

DEJOURS, C. et al. Psicodinâmica do Trabalho. São Paulo: Atlas, 1994.

DIAS, E. A Atenção à Saúde dos Trabalhadores no Setor Saúde (SUS), no Brasil: realidade, fantasia ou utopia?, 1994. Tese de Doutorado, Campinas: Faculdade de Ciências Médicas, Universidade Estadual de Campinas.

FARINA, H. D. Sofrimento Psíquico: um estudo entre médicos e enfermeiros em um hospital de Manaus, 2004. Dissertação de Mestrado, Rio de Janeiro: Escola Nacional de Saúde Pública Sergio Arouca, Fundação Oswaldo Cruz.

FOUCAULT M. Microfísica do Poder. Rio de Janeiro: Graal, 1979.

FOUCAULT, M. História da Sexualidade: a vontade de saber. Rio de Janeiro: Graal, 1984.

FREUD, S. O Mal-Estar na Civilização [1930]. Rio de Janeiro: Imago, 1997. (Obras completas, v. 21).

HANNS, L. Dicionário Comentado do Alemão de Freud. Rio de Janeiro: Imago, 1996.

HARDING, T. W. et al. Mental disorders in primary health care: a study of their frequency and diagnosis in four developing countries. Psychological Medicine, 10: 231241, 1980.

JARDIM, A. C. Diferentes Concepções sobre o Sofrimento Psíquico no Campo da Saúde do Trabalhador, 2008. Dissertação de Mestrado, Rio de Janeiro: Escola Nacional de Saúde Pública Sergio Arouca, Fundação Oswaldo Cruz.

JARDIM, S. Processo de Trabalho e Sofrimento Psíquico: o caso dos pilotos do metrô carioca, 1994. Tese de Doutorado, Rio de Janeiro: Instituto de Psiquiatria e Saúde Mental, Universidade Federal do Rio de Janeiro.

JOANILHO, A. O Corpo de Quem Trabalha: estratégias para a construção do trabalhador (1900-1920), 1990. Dissertação de Mestrado, Campinas: Instituto de Filosofia e Ciências Humanas, Universidade Estadual de Campinas. 
LANCMAN, S. Saúde Mental e Trabalho: repensando a ação em terapia ocupacional, 2004. Tese de Livre Docência, São Paulo: Faculdade de Medicina, Universidade de São Paulo.

LIMA, B. F. Stress, Qualidade de Vida, Prazer e Sofrimento no Trabalho de Call Center, 2004. Dissertação de Mestrado, Campinas: Pontifícia Universidade Católica de Campinas.

LOPES, J. C. A Voz do Dono e o Dono da Voz: trabalho, saúde e cidadania no cotidiano fabril. São Paulo: Hucitec, 2000.

LUDEMIR, A. B. Socioeconomic Status, Employment, Migration and Common Mental Disorders in Olinda, Northeast Brazil, 1998. Tese de Doutorado, London: London School of Hygiene and Tropical Medicine.

MARI, J. \& WILLIAMS, P. A validity study of a psychiatric screening questionnaire (SRQ-20) in primary care in the city of Sao Paulo. British Journal of Psychiatry, 148: 23-26, 1986.

MARTINEZ, M. As Relações entre a Satisfação com Aspectos Psicossociais e a Saúde do Trabalhador, 2002. Dissertação de Mestrado, São Paulo: Universidade de São Paulo.

MENDES, R. (Org.) Patologia do Trabalho. Belo Horizonte: Atheneu, 1995.

MERLO, A.; SPODE, C. \& VAZ, M. O trabalho entre prazer, sofrimento e adoecimento. Psicologia $\mathbb{E}$ Sociedade, 15(1): 117-136, 2003.

OLIVEIRA, P. O Sofrimento Psíquico e o Trabalho Hospitalar, 1998. Dissertação de Mestrado, Rio de Janeiro: Escola Nacional de Saúde Pública Sergio Arouca, Fundação Oswaldo Cruz.

PALÁCIOS, M. Sofrimento Psíquico e Trabalho, 1999. Tese de Doutorado, Rio de Janeiro: Universidade Federal do Rio de Janeiro.

PITTA, A. Hospital: dor e morte como ofício. São Paulo: Annablume, Hucitec, 2003.

RORTY, R. Ensaios sobre Heidegger e Outros. Rio de Janeiro: Relume Dumará, 1999.

SANTOS, J. A. Trabalho e Sofrimento Psíquico na Marinha Mercante, 1999. Dissertação de Mestrado, Rio de Janeiro: Escola Nacional de Saúde Pública Sergio Arouca, Fundação Oswaldo Cruz.

SATO, L. Prevenção de agravos à saúde do trabalhador: replanejando o trabalho através das negociações cotidianas. Cadernos de Saúde Pública, 18(5): 942-949, 2002.

SELIGMANN-SILVA, E. Saúde mental e automação. Cadernos de Saúde Pública, 13(supl. 2): 95-109, 1997.

SILVA-FILHO, J. \& JARDIM, S. (Orgs.) A Danação do Trabalho: relações de trabalho e sofrimento. Rio de Janeiro: Te Cora, 1997.

SOUZA, L. B. Organização do Trabalho, Qualidade de Vida e Subjetividade, 2001. Tese de Doutorado, São Paulo: Universidade de São Paulo.

SOUZA, R. D. Recortes do Cotidiano: um estudo sobre o sofrimento psíquico dos enfermeiros intensivistas, 2001. Dissertação de Mestrado, Rio de Janeiro: Escola de Enfermagem Anna Nery. 
SOUZA, E. et al. Sofrimento psíquico entre policiais civis: uma análise sob a ótica de gênero. Cadernos de Saúde Pública, 23(1): 105-114, 2007.

SPINOZA, B. Da Origem e da Natureza das Afecções [1677]. 3. ed. São Paulo: Abril Cultural, 1983. (Coleção Os pensadores).

TITTONI, J. Subjetividade e Trabalho: a experiência do trabalho e sua expressão na vida do trabalhador fora da fábrica. Porto Alegre: Ortiz, 1994.

TITTONI, J. \& BERNARDES, J. Subjetividade e trabalho. In: CATTANI, A. (Org.) Trabalho e Tecnologia: dicionário crítico. Petrópolis: Vozes, 1997.

UCHIDA, S. Temporalidade e Subjetividade no Trabalho Informatizado, 1996. Tese de Doutorado, São Paulo: Instituto de Psicologia, Universidade de São Paulo.

VERTHEIN, M. \& MINAYO GOMEZ, C. A construção do “sujeito-doente” em LER. História, Ciências, Saúde - Manguinhos, 7(2): 327-345, 2000.

WHO (World Health Organization). Expert Committe on Mental Health: user's guide reporting questionnaire (SRQ-20). Geneve: WHO, 1994. 


\section{Parte IV}

Trabalho em Serviç̧os e Questões de Gênero 



\section{Aspectos Conceituals do Setor de Serviços e a Saúde do Trabalhador}

Paulo Gilvane Lopes Pena

Atualmente, a saúde do trabalhador tem como referência o denominado "paradigma industrialista" (Orban, 2005), o qual enfatiza a própria centralidade do trabalho nas sociedades contemporâneas. Entretanto, o setor de serviços ou terciário responde atualmente por mais de dois terços do produto interno bruto (PIB) nos países desenvolvidos, empregando no Brasil cerca de três quartos da população economicamente ativa (Proni, Silva \& Oliveira, 2005). A sua importância pode ser averiguada na seguinte afirmação de Freyssinet (2005: 39): "os serviços tornaram-se o único setor criador líquido de empregos na União Europeia”. Trata-se de um setor gigante, diversificado e presente nas empresas terceiras nos demais setores econômicos. A complexidade do terciário se revela na sua função econômica, social e cultural em meio a diferentes atividades de distribuição, consumo, serviços, administração, tributação, manutenção da ordem, ritos e numerosas outras atividades similares. São serviços que se integram ao funcionamento de atividades empresariais relativas à satisfação das necessidades pessoais, além das funções de administração pública (Proni, Silva \& Oliveira, 2005).

Essa dimensão dos serviços está contida na globalização relacionada à internacionalização do capital. Segundo Ruzza (2005), esse processo se diferencia da internacionalização das firmas industriais e ainda precisa ser mais bem conhecido, principalmente nos serviços ditos tradicionais, como os do comércio e da distribuição. Nestes, em particular, o processo de internacionalização ocorre centrado no privilégio da produtividade imediata, no desenvolvimento da flexibilidade a qualquer preço e na degradação da relação salarial com o consequente aumento dos acidentes e doenças profissionais (Jean, Orban \& Mouillet, 2005). 
Esse espectro gigante, variado, difuso e internacional do setor dificulta a sua transformação em um paradigma capaz de se estabelecer como um objeto sócio-histórico e econômico, como se caracterizou o paradigma da indústria ou industriário (Orban, 2005). Nessa perspectiva, é importante construir reflexões em torno dos conceitos de setor terciário e de serviço, sua natureza e atividades que o caracterizam, como circulação, distribuição e reprodução, com o objetivo de compreender particularidades essenciais no estabelecimento de relações entre trabalho e saúde.

\section{Aspectos Conceituals e Históricos da Noção de Serviço}

O serviço está contido como componente central ou mesmo como sinônimo do setor terciário ou, mais recentemente, terciário. No que concerne à estrutura do Estado, o terciário primitivo europeu tinha como função essencial administrar o excedente produtivo na sociedade feudal. A classe dirigente recolhia o excedente produtivo, segundo modalidades de formações sociais estabelecidas, com o suporte de um forte sistema de coerção militar e religiosa (Marx \& Engels, 1982). Assegurava, dentre outras, as seguintes funções essencialmente constitutivas da configuração do Estado feudal:

- Arrecadar tributos - baseia-se na apropriação do excedente produzido e opera em nome de um direito inalienável da propriedade do senhor feudal.

- Manter a ordem social - centrada na força militar e na justiça sob controle absoluto do senhor feudal.

- Justificar e agir ideologicamente por meio da religião - a Igreja era responsável pelos serviços de saúde e educação restrita.

Tais funções eram realizadas por classes sociais diferentes, caracterizando assim as relações sociais de consumo e produção no feudalismo. A arrecadação dos tributos pelos senhores feudais estabelecia condições econômicas para o uso dos recursos, o que propiciou o nascimento de numerosas atividades em que a função original era satisfazer as necessidades de luxo da classe feudal. Com isso, os recursos dos senhores feudais mantinham a propriedade fundiária e o trabalho do servo a ela preso (Marx \& Engels, 1982). São exemplos as atividades artísticas e artesanais, o comércio interior e exterior (no sentido das relações com outros feudos). Nesse período, as possibilidades do desenvolvimento de um artesanato autônomo para responder às necessidades da agricultura eram mínimas, na medida em que a totalidade dos excedentes era apropriada pela 
classe feudal. Desse modo, as novas atividades artesanais respondiam às práticas do exercício do poder e às necessidades de consumo das classes dirigentes dos feudos. Tais modalidades de práticas artesanais eram constituídas de atividades típicas de serviços, assim como de produção na forma da indústria artesanal.

A palavra serviço surgiu no século XI e se tornou usual até o século XIII. Origina-se do latim servitium e significa estado escravo, servidão do vassalo para com o soberano, além do sentido religioso de serviço. No século XIV, adquiriu o sentido daquilo que se serve na mesa, associado à noção de servil, em que significava ser escravo, na condição de estar sujeito a, ou obedecer a, ser útil - que se desdobra em vários sentidos derivados a partir do século XVI (Gellner, Nisbet \& Touraine, 1996). Atualmente, a noção de serviço tem uma acepção ampla, que pode significar "viver ou trabalhar como servo; exercer a função de criado; pôr a mesa" (Ferreira, 1999), até serviços institucionais como o militar e outros.

Em todos esses sentidos, a noção de serviço significa as mais variadas atividades; porém, não se articula à produção de um bem, o que a diferencia das atividades inerentes à indústria, à mineração e à agricultura. Os serviços se configuram assim em atividades que o próprio indivíduo pode realizar. Explorando tal qualidade, o setor serviço no século XX criou um sistema capaz de organizar o consumidor ou usuário em sistemas complexos de autosserviço, em que este realiza tarefas serviçais antes destinadas aos trabalhadores do setor.

A noção de serviços representa o conceito histórico central para o entendimento da noção de setor terciário, sendo esta recente no debate acadêmico. Por consequência, apenas nas décadas de 1930 e 1940 se difundiu de forma mais precisa uma noção de 'setor terciário' ou 'serviços', que incluía a maioria dessas atividades reunidas como 'residuais' e sem dinamismo próprio (Proni, Silva \& Oliveira, 2005). Considerava-se que as atividades econômicas estavam essencialmente associadas ao desempenho do setor agrícola e secundário, enquanto as demais, genericamente reunidas na denominação de serviços, eram qualificadas como complementares e 'improdutivas'.

A construção da noção de serviço se constituía de qualidades essenciais, caracterizadas como a simultaneidade em que se realiza o consumo no momento em que se produz ou se executa a atividade; a não estocabilidade, que significa a incapacidade de se armazenar o produto do serviço; e a pessoalidade, caracterizada pela relação direta entre o prestador do serviço e o cliente (Proni, Silva \& Oliveira, 2005). Atualmente, com o desenvolvimento do terciário, tem sido questionada tal noção fundada nessas três características. 
Para Donnangelo e Pereira (1979), na noção de serviço médico - exemplo clássico do setor serviço - o produto se confunde com o próprio consumo na forma de cuidado com a saúde. Utilizam a noção de processo de trabalho, que consiste no conjunto de atividades desenvolvidas de forma integrada e sucessiva sobre um determinado objeto - a matéria prima - que sofre a ação do trabalho humano e o transforma, utilizando-se de meios e instrumentos para realizar um determinado produto material, imaterial ou serviço.

Segundo essa noção, o produto resultante de processo de trabalho do serviço médico seria a saúde preservada ou reconstituída. Profissionais de saúde, em modalidades organizacionais diversas, utilizando-se de variados equipamentos, medicamentos e demais técnicas, atuariam em um objeto - o corpo esquadrinhado pela divisão do trabalho - e resultaria em um produto. Neste, fruto da divisão do objeto, haveria a especificidade do processo de trabalho médico no qual, na produção do serviço, se realiza o consumo.

Essas formas de consumo de serviços médicos se diferenciariam em modalidades segundo particularidades do serviço público, privado liberal, seguro privado, conveniado e medicina de grupo e o filantrópico. Para a medicina social, por exemplo, que tem por objeto a saúde da população ou de grupos sociais, o processo de trabalho resultaria em formas de consumo ou produtos históricos de consumo, a exemplo da medicina integral, medicina preventiva, medicina da família, medicina comunitária, medicina do trabalho e outras (Donnangelo \& Pereira, 1979).

Entretanto, a complexidade da definição de serviços se expressa na reflexão de Gorz (1988), que parte do pressuposto de que Marx empregava a noção de trabalho de forma indiferenciada ao não distinguir o trabalho do operário de uma indústria com o de compositor, ou cientista, assim como das atividades do técnico, do policial, da ajudante doméstica... da prostituta. Com essa generalidade, o trabalho resultaria em bem de uma produção que gira em torno da noção do trabalho industrial. Ou seja, Marx ${ }^{1}$ considera que o trabalho se tornaria uma utilidade em razão da necessidade social e por isso mereceria ser remunerado de uma maneira ou de outra. Essa interpretação poderia levar a tipificar o trabalho em todas as atividades de serviço na esfera familiar, pois, finalmente, elas seriam úteis à sociedade. Mas onde começa e termina todo

1 Marx (1987) utilizou o conceito de processo de trabalho para enfatizar a subordinação do trabalho ao capital e construir a teoria econômica do valor e da exploração do trabalho. Nesse sentido, houve a ênfase na sua base econômica do controle do trabalho e da sua condição não apenas como valor de uso, mas, sobretudo, como valor de troca. 
esse trabalho? - pergunta Gorz (1988). Na dimensão humana, existe uma série de atividades de lazer, culinária, sexuais, reprodutivas, de educação da criança e tantas outras da esfera doméstica que poderiam ou não ser transformadas em valor econômico e grafadas pelos serviços e bens similares aos encontrados no mercado. Ou seja, nem toda atividade representa trabalho, mesmo que haja equivalente como atividade econômica, pois existem coisas e atividades realizadas na esfera privada que não são feitas para a troca com outros. Tais atividades, como o prazer de cuidar de um filho, realizar a maternidade, praticar esportes, não têm preço e são definidas no plano da satisfação, mesmo que exijam muitas vezes esforços exagerados. Transformar toda atividade humana em trabalho, inclusive serviços, implicaria aceitar um processo totalitário de monetarização da vida (Gorz, 1988). Seria necessário, portanto, entender que o sistema racional econômico e social não deveria impor a determinação do que é trabalho ou não, mas sim o sujeito, este que limitaria essa racionalidade colonizadora de todas as atividades humanas (Gorz, 1988).

O trabalho considerado serviço se caracteriza pela realização de "uma atividade do prestador em um suporte que pertence ao beneficiário" (Orban, 2005: 18). No caso da distribuição, a venda do produto não modifica a natureza dele e não incorpora a noção de trabalho produtivo em Marx. Essas atividades levam à exigência de capacidades com características próprias, envolvendo a simultaneidade da relação com clientes. Dessa condição, surgem peculiaridades nas relações de serviço, como avaliação rápida do beneficiário; compreensão e interpretação do pedido por meio da linguagem e da análise situacional do beneficiário, a qual pode ser uma relação de construção simultânea com o cliente - quando há duplo interesse na negociação em atender da melhor forma possível; conhecimento dos serviços e dos produtos oferecidos; verificação da resposta ao cliente; capacidade de avaliação imediata pelo cliente; e busca da durabilidade da relação (Orban, 2005).

Para Orban (2005), o debate sobre a ideia de que o serviço pode resultar em um produto consumido simultaneamente ocorreu nos anos 90 , quando algumas concepções afirmavam que a padronização das atividades de serviços era intensa, o que permitia a sua transformação em um "quase-produto". Nesse sentido, para Jean Gadrey (apud Orban, 2005), o serviço não é um produto, ${ }^{2}$ pois não

\footnotetext{
2 Sobre serviços domésticos, alguns autores marxistas sustentam que esse trabalho é uma forma de produção de mercadoria, na medida em que teria como resultado a mercadoria força de trabalho. Outros entendem que não há produção de mercadoria nessa forma de trabalho, pois seus produtos são valores de uso que não chegam ao mercado; fazem parte do consumo familiar e apenas de forma indireta ajudam na reprodução da força de trabalho.
} 
resulta necessariamente na produção de um bem material, o que mantém em foco diferentes concepções em torno da compreensão da noção de serviço.

Para Orban (2005), a determinação do output e do input é considerada insolúvel no setor de serviços. Este autor exemplifica a difícil caracterização do que seria um produto em algumas atividades de serviços com as seguintes indagações: o que seria uma formação? Para o doente, o que seria o resultado? O tratamento ou a cura? Na indústria estabelece que o produto é um estado - 'estável', poderíamos acrescentar - que pode ser estocado. O output da produção é determinado da seguinte forma: "produção $\rightarrow$ bem (output) $\rightarrow$ utilização; o que é diferente do serviço, que é um ato, um movimento, cujo output é indeterminado: produção $\rightarrow$ utilização (output)" (Orban, 2005: 14). No serviço, esse output indeterminado se caracteriza pela noção comumente utilizada de que produto no processo de trabalho no terciário implica o seu consumo ou utilização imediata, diferentemente dos setores primário e secundário, que resulta em um bem ou produto.

O serviço é entendido então como um suporte que não pertence ao prestador de serviço, o qual pode ser: comprador; utilizador; usuário que realiza serviço sobre um bem (conserto, manutenção, transporte etc.); gestor de capital na forma de dinheiro, títulos monetários, seguros etc.; indivíduo em suas dimensões físicas (saúde, transporte), intelectuais (formação, cultura), relacionais (comunicação, informação etc.). Esse consumo imediato do produto pode se expressar em processos saúde/doença variados e constituídos muitas vezes pela relação próxima e conflituosa entre o trabalhador e o cliente.

O estudo do setor de serviços como parcela essencial constitutiva do terciário moderno traz singularidades históricas, sociais e culturais importantes que podem compor matrizes particulares no processo de adoecimento dos trabalhadores. As modalidades de serviços historicamente constituídos são numerosas e caracterizam situações peculiares de inserção dos indivíduos que trabalham e consomem.

O aprofundamento das noções de terciário e serviço contribui para desvelar modos de compreensão da saúde do trabalhador nas especificidades desse setor gigante da economia e fortemente inserido nas transformações contemporâneas no mundo do trabalho. Trata-se de suporte no aprofundamento de problemáticas atuais para a compreensão das mutações tecnológicas mais frequentes no terciário, das modalidades de flexibilização das relações de trabalho resultantes de formas particulares de produção de mais-valia, das mudanças nas relações com os clientes na produção de serviços, do 
conhecimento da esfera subjetiva da cultura de trabalhadores servidores com seus valores e saberes, além das especificidades sociais no contexto da informalidade no mercado de trabalho.

Os estudos empíricos disponíveis e o respectivo aporte teórico centrado no materialismo dialético fazem parte desse esforço conceitual, em que a noção de processo de trabalho é central (Braverman, 1980). O aprofundamento do estudo sobre processos de trabalho e suas relações com o processo saúde-doença foi amplamente desenvolvido por diversos autores nos anos 60 a 80 (Laurell \& Noriega, 1989; Nunes, 1989; Minayo-Gomez \& Thedim-Costa, 1997), centrado na análise dos processos de produção da mais-valia nas modalidades absoluta, relativa e combinada, as quais determinam perfis epidemiológicos correspondentes.

Essa abordagem sociológica, mais precisamente da sociologia do trabalho, tem sido a principal referência no campo da investigação crítica da saúde do trabalhador. Vale dizer que o conceito de processo de trabalho, originário da escola marxiana e utilizada pelos citados autores, foi particularmente oportuno para o estudo da indústria em que os métodos tayloristas e fordistas se originaram (Gómez \& Lacaz, 2005).

O conceito de processo de trabalho é complexo, e a sua aplicação no setor serviço envolve considerações teóricas, particularidades e problemáticas diversas quando comparadas ao processo de trabalho industrial. Primeiramente, há uma grande diversidade de atividades econômicas, algumas de difícil classificação na sua diferenciação com o método industrial. Em segundo lugar, há o questionamento se na noção de serviço haveria o produto do trabalho, pois alguns autores consideram que métodos industriais foram introduzidos de forma a industrializar um serviço, transformando-o em produto (Orban, 2005). Nessa perspectiva, haveria uma perda da especificidade dos serviços.

No entanto, existem características inerentes às atividades de serviço que podem confluir para sua diferenciação quando em comparação com as atividades industriais.

\section{Considerações sobre Caracterização dos Serviços e a Saúde do TRABALHADOR}

O serviço como atividade terciária definida de forma mais ampla pode se inserir também nas funções primárias e secundárias da economia. Diferentemente da terceirização, haveria uma terciarização na indústria e na agricultura 
evidenciada empiricamente pela introdução de equipamentos de informática, comunicação e robótica, cuja utilização não revelaria diferenças ao ser comparada com atividades similares do terciário. Para Gómez e Lacaz (2005), os estudos referentes à situação dos trabalhadores terceirizados são escassos no âmbito da saúde do trabalhador, em que a saúde é também precarizada por meio do duplo padrão estabelecido pela reestruturação produtiva. Mas a escassez é ainda maior quando se trata da investigação do fenômeno da terciarização, ao menos para verificar se essa noção permitiria avanços conceituais para a análise da saúde do trabalhador.

Na compreensão da transformação do trabalho em capital na realização de atividades de serviços, apresentam-se particularidades que podem expressar condicionantes diferentes para a saúde do trabalhador. Dentre elas, estão as seguintes:

\section{Gestões sobrepostas e saúde do trabalhador}

Independentemente de a práxis do serviço ser considerada um produto ou suporte, a sujeição do servidor no desempenho das suas atividades torna-o objeto por excelência do taylorismo e do consequente 'hipertaylorismo' da atualidade.

Outro aspecto pode ser evidenciado ao se caracterizar no âmbito do serviço uma dupla dimensão da gestão (Orban, 2005). Em uma delas, o prestador do serviço - terciário - serve ao empregador industrial (primeira dimensão). Na outra, a atividade serve ao cliente da indústria (segunda dimensão), o output propriamente dito. Nesta, a atividade industrial resulta na geração de um bem a ser consumido pelo cliente, enquanto o output do serviço realizado na indústria persiste indeterminado.

Em espaços virtuais de telecomunicação, o serviço de telemarketing estabelece essa dupla relação com a demanda. Nesse sentido, há um output para o cliente-empresa que demanda serviços ao operador de telemarketing. Um segundo output resulta do atendimento do cliente-cidadão, objeto das atividades dessas centrais de serviços, não necessariamente idêntico ao primeiro (o cliente pode se satisfazer com o serviço do operador de telemarketing e permanecer insatisfeito em relação à demanda do cliente-empresa). Essa dupla dimensão gerencial (empresa-cliente e empresa telemarketing), em interação com a pressão dos clientes, torna mais complexa a análise das condições de trabalho e saúde do operador. Considerando que no setor serviço predominam formas 
de gestão centradas no controle do homem no trabalho, ${ }^{3}$ essa pressão ao cubo justifica a hipótese da organização de métodos de trabalho 'hipertaylorizados' (Lipietz, 1997), gerando perfis de morbidade extremamente elevados (ACTU, 2004; Assunção et al., 2006; Halford \& Cohen, 2003).

No plano do espaço real, o processo de trabalho e o consumo muitas vezes ocorrem no mesmo espaço e de forma sincrônica, e assim se constrói uma geografia espacial própria dessa modalidade. São exemplos funções como operadoras de chekouts em supermercados e hipermercados, onde o cliente interage e realiza tarefas sincronizadas com os operadores de caixa de saída (checkouts) (Pena, 2000). Neste serviço, o modelo checkin/chekout prioriza o controle do cliente na saída, enquanto no transporte aeroviário a organização da inspeção ocorre na entrada do espaço de serviços da empresa - checkin. Em grandes magazines, pode haver a verificação no chekout do espaço interno, mantendo-se apenas sistemas de vigilância nos acessos da loja. Em outras modalidades, como serviços bancários ou dos correios, o espaço continua dividido pelo modelo clássico do balcão de atendimento, mantendo diferenciados no plano real os espaços de trabalho e do cliente. Finalmente, existem atividades de serviços diversos em que a divisão espacial não se estabelece pela modalidade do cuidado praticado.

As novas tecnologias nos anos 80, a exemplo da robótica, da automação, do desenvolvimento da informática na produtividade, reorganizaram a dimensão do trabalho. Segundo Schwartz e Durrive (2003), elas têm uma natureza que modifica a dimensão do problema, não apenas as atividades do trabalho, mas também a maneira como as relações sociais vão se agenciar, as relações de poder, as relações entre a atividade de trabalho e o local de trabalho, as categorias socioprofissionais. Essas tecnologias se associam à nova economia e a muitas mudanças sociais. A esfera virtual das empresas, do trabalho e do consumo resultou da informática associada à revolução comunicacional da Internet. No espaço virtual sociocibernético e sociocultural, todas as citadas modalidades organizacionais da prestação de serviços se reproduzem não necessariamente de forma idêntica ao verificado no espaço real.

Tais características organizacionais estabeleceram modos de conflitos particulares e outros condicionantes para os processos de adoecimento nas relações

\footnotetext{
Na dimensão microindustrial, o fordismo (microfordismo) representa predominantemente a aplicação da racionalidade cibernética da organização da técnica do trabalho, enquanto o taylorismo responde pela intervenção na organização do homem no trabalho, subordinando-o ao complexo técnico (Lipietz, 1997). O fordismo redesenhou o método de produção da primeira revolução industrial ao transformar o espaço da fábrica em uma grande máquina, na qual inclui o ser humano como mero suplemento na engrenagem cibernética.
} 
de serviços entre os trabalhadores e os clientes, assim como nas formas de supervisões e controle de ambos, tanto nas empresas reais quanto na esfera do trabalho no ciberespaço.

\section{Marketing e a saúde do trabalhador e do consumidor}

O marketing dos produtos age diretamente sobre o cliente e resulta em forte interação com o trabalhador. A indução ao consumo é onipresente em certos espaços do terciário, em particular nos supermercados e hipermercados.

O marketing atual procura mudar hábitos para construir mercados de consumo estimulando a compra compulsiva e construindo ou reconstruindo hábitos. Tais mudanças são determinadas socialmente e podem resultar de construções mercadológicas. Na atualidade, a engenharia sensorial, componente das técnicas de marketing, cria estímulos sensoriais no ambiente, como odores, ruídos, estímulos visuais e táteis, que levam a lembrar o produto com suas sensações e imagens para cativar o consumo (Mazoyer, 2000). Tais técnicas são utilizadas em hipermercados e fast-foods para estimular o apetite e a formação de novos hábitos alimentares (Freitas \& Pena, 2007). Como exemplo, nas salas de cinema observam-se novos estímulos olfativos, visuais, sonoros e táteis, que geram a compulsão alimentar, com baldes de pipocas, litros de refrigerantes e outros conteúdos em excesso, que se constituem em novos símbolos de consumo construídos pelo mercado. Antes, assistia-se ao filme; hoje, as salas se transformaram em comedouros construídos pelo marketing sensorial.

Os trabalhadores de serviços inseridos nesses mesmos espaços não podem ser abstraídos da influência das ações cognitivas e sensoriais do marketing para a promoção do consumo muitas vezes compulsivo dos clientes. Nos hipermercados, por exemplo, a engenharia sensorial atua em todos os domínios (Pena \& Thébaud-Mony, 2005), e os estímulos olfativos, visuais, auditivos e táteis podem significar um novo mapa de riscos com possíveis consequências para a saúde dos trabalhadores expostos.

\section{A Relação Complexa do Setor Serviço com 0 Cliente e a Saúde do TRABALHADOR}

Diversos estudos têm acentuado o conflito existente entre o trabalhador e o cliente nas atividades de serviços em vários setores (Jean, Orban, \& Mouillet, 2005; Cunha \& Orban, 2005; Assunção et al., 2006; Santos, 2004). 
O conflito pode gerar diversas formas de agravos à saúde, formas de violências morais, sexuais, físicas, com repercussões físicas e psíquicas as mais diversas. Geralmente, o cliente, ao estabelecer a relação de proximidade real ou virtual com o trabalhador, expressa nele sentimentos de revolta para com a empresa e suas mazelas na atividade mercadológica.

Em outras modalidades, como os serviços de saúde, adiciona-se outro conflito quando o paciente ou usuário apresenta risco potencial de contaminação por doenças transmissíveis para o trabalhador. Entretanto, outras características emergem dessa relação:

1) Interação com o trabalho e execução de tarefas nas atividades de autosserviço: a emergência do cliente 'estressor' do trabalhador

O cliente vivencia temporariamente o exercício de atividades taylorizadas organizadas de acordo com o modelo microfordista de execução de tarefas em espaços de vendas pela modalidade de autosserviço. São tarefas em forma de cadeia da produção de serviços em que, a exemplo da linha de circulação da mercadoria na esteira rolante do checkout, se conduz o cliente a realizar diversas tarefas em articulação com a operadora de caixa. Inicialmente, após o cumprimento das tarefas da fila, ele retira os artigos do carrinho de compras e os organiza na esteira rolante, em um ritmo determinado pela trabalhadora, até o ensacamento deles na saída da mesa do caixa (Pena, 2000). O cliente adquire momentaneamente a condição do exercício de tarefas concebidas na mesma ótica taylorista, fordista e, recentemente, hipertaylorista na organização desses serviços. Essa condição de divisão de tarefas entre o cliente e o trabalhador não ocorre na indústria e se constitui em particularidade do setor de serviços.

Dentre essas características, algumas tarefas de gerenciamento foram destinadas aos clientes com os objetivos de acelerar, avaliar, vigiar o trabalho dos prestadores de serviços. São exemplos os operadores de caixas bancários, de supermercados, de telemarketing e tantas outras operações em que o cliente assume a tarefa inconsciente de supervisão e imposição de ritmo de trabalho. Nesse posto de trabalho, a modalidade de organização da fila de clientes na aceleração do trabalho tem se tornado evidente nos últimos anos (Jean, Orban \& Mouillet, 2005; Pena \& Thébaud-Mony, 2005). As formas de organização da fila não estão apenas relacionadas a interesses de marketing, mas podem se constituir em modalidades de transferência para o cliente de algumas tarefas gerenciais. São funções de vigilância do trabalho do operador 
de caixa em que o cliente substitui o olhar do supervisor administrativo, avalia imediatamente a qualidade do trabalho e o resultado dele e, sobretudo, vigia o ritmo do trabalho, mantendo-o acelerado.

Nos postos de trabalho dos operadores de telemarketing, emerge a dimensão do espaço virtual e do teletrabalho, em processos interativos virtuais (no sentido digital) em uma relação sincrônica com o cliente. No teletrabalho, a fila é consequentemente virtual. No aspecto relacionado à avaliação do trabalho, Zarifian (apud Orban, 2005: 15) considera que o serviço prestado define "o resultado e a maneira pela qual foi atingido e são submetidos a um julgamento, em função de valores (uma avaliação) pelos protagonistas e pela coletividade". Dessa forma, uma avaliação do operador representa uma atividade administrativa transferida ao cliente e pode causar impacto no ritmo de trabalho e, consequentemente, na saúde do trabalhador. Por isso, são comuns a gravação da comunicação entre o cliente e o operador para avaliações futuras e, sobretudo, a solicitação da nota sobre o resultado do trabalho após a consulta do cliente. Essa avaliação ocasiona condições de estresse na relação entre o operador de teleatendimento e o cliente, sendo aquele subordinado a este em uma relação temporal exígua no plano de cada atendimento, porém duradoura no âmbito do conjunto dos atendimentos de clientes.

Ao executar tarefas gerenciais, o cliente assume uma condição hierárquica na interação com a organização do trabalho em profunda imersão na dinâmica quantitativa e qualitativa das tarefas de trabalhadores na modalidade de autosserviço. No posto de serviço de chekout em hipermercados, a operadora de caixa em muitas tarefas está subordinada momentaneamente ao cliente, que assume funções intermediárias junto ao supervisor de caixa no momento em que frequenta a atividade de estar na fila (Pena, 2000). A queixa de um cliente sobre o ritmo de trabalho de uma operadora pode trazer sérias consequências, inclusive ameaça de desemprego, e resultar em verificação imediata do atendimento. Uma rede de hipermercados na França chegou a delegar ao cliente na fila a tarefa de liberar ou não a operadora de caixa para realizar intervalos de ida ao toalete ou simplesmente parar o atendimento e estabelecer uma minipausa para beber água. Obviamente, o gerente da loja sabia que o cliente sob a pressão do tempo da fila não autorizaria esse intervalo, assegurando, assim, o ritmo acelerado de trabalho sem pausas (Pena, 2000). O cliente é conduzido, desse modo, a se tornar um agente 'estressor' do trabalhador, como um cliente-risco para sua saúde. 
Com a introdução de novas racionalidades inerentes ao modelo oriundo do ohnismo ${ }^{4}$ ou toyotismo, o conflito existente na relação com os clientes faz emergir novas características mercadológicas, antes não existentes em serviços tradicionais, como saúde e educação. Dentre elas, a mudança pelas empresas das noções de usuário, paciente e aluno, em setores tradicionais de serviços, para a noção mercadológica de cliente.

No Sistema Único de Saúde (SUS), o usuário estabelece uma condição de consumo de serviços de saúde para além da noção de paciente (em que considera apenas o doente) em relações de ofertas de serviços necessários à saúde do cidadão. A transformação dessa relação em outra, substituindo as noções de paciente ou de usuário por cliente, cria a oferta de serviços e marketing em relações absolutamente mercantis. Nesse sentido, podem ser oferecidos serviços comerciais diversos na sala de espera, associando-se a atenção à saúde com a disponibilidade de outros similares de lazer, bem-estar, transformando hospitais em centrais de compras ampliadas em razão do poder aquisitivo da clientela.

Tal situação se repete no ensino particular, ao se substituir a noção de aluno pela de cliente. Assim, muitas faculdades particulares no Brasil têm se transformado em verdadeiros minicentros comerciais, em que o aluno passa a ser considerado cliente, mudando a relação com o professor, que deve oferecer apenas o conhecimento como mais uma mercadoria que apresenta interesse comercial. Tal relação inverte a subordinação clássica entre professor e aluno, agravando o conflito existente, transformando o ex-aluno em um avaliador algoz do trabalho do professor. Essas novas condições necessitam de estudos para se verificarem mudanças em processos de adoecimento no trabalho no setor de serviços, em especial nos ramos citados.

2) A noção de autosserviço e a necessidade de se construir uma disciplina para o comportamento do cliente nos espaços de venda: a saúde do trabalhador e do cliente sob racionalidades similares

O manejo dos clientes nos espaços de venda como objetos da organização de serviços no setor terciário estabelece novas características na organização do processo de trabalho. Com as técnicas de marketing, as massas de clientes tornam-se objetos de gestão para a sua circulação nos espaços de venda, em particular nos supermercados e hipermercados, grandes centros comerciais, terminais rodoviários e aeroportos. A presença do consumidor/cliente no

4 O termo ohnismo faz referência ao engenheiro Ohno, da empresa Toyota, que concebeu e colocou em prática o processo de reengenharia na fábrica de automóveis no Japão nos anos 70 (Coriat, 1991). 
espaço de trabalho ou a sua proximidade no desenvolvimento das atividades gera situações de grande circulação de pessoas que demandam racionalidades não muito evidentes na indústria.

Como visto, numerosas atividades humanas sem objetivos mercadológicos e não caracterizadas como produção de bens foram transformadas em trabalho quando ganharam significado econômico (Gorz, 1988). Na prática de autosserviço, esse movimento se inverte quando muitas tarefas inscritas nos serviços de venda e já tipificadas nas relações de trabalho como valores de troca são deslocadas para o cliente, que as realiza na forma apenas de valores de uso não remunerados.

O modelo de organização do terciário fundado no autosserviço se difundiu em quase todos os domínios do comércio. Essa nova fórmula arrasou as feiras populares e os pequenos comerciantes em vários países, nos quais medidas restritivas tiveram que ser tomadas para impedir a redução drástica ou mesmo o desaparecimento dos pequenos comerciantes com o avanço dos hipermercados, em razão das graves consequências sociais (Mottez, 1961). Os serviços de vendas praticados de forma artesanal, característicos do pequeno comércio e de mercadores antes da emergência do fordismo nas práticas do terciário, se caracterizavam pela venda e/ou troca de seus produtos em um lugar público: mercado popular e feiras.

A escassa divisão do trabalho era e é uma característica do pequeno comércio na sua forma clássica, a exemplo de açougue, mercearia, padaria, lojas etc., e a organização desses serviços se baseava na existência de um balcão que dividia as atividades do comerciante e seus ajudantes e as dos clientes. Nesse modelo, o balcão representava uma lógica de divisão espacial nas relações entre clientes e prestadores de serviços de venda. O cliente não estabelecia nenhum contato prévio com mercadorias, exceto aquelas expostas no balcão, e não circulava no interior da loja em meio às prateleiras de produtos colocados à venda. Ele fazia o pedido de compras e recebia os produtos adquiridos 'montados', ou seja, o conjunto de artigos ordenados e embalados em pacotes ou arranjos que representavam o produto do processo de trabalho na modalidade de serviços. A tarefa de coletar os artigos das prateleiras ou estoques era do próprio funcionário e não do cliente, como passou a ser no autosserviço.

Segundo Mottez (1961), os grandes magazines surgiram na Europa durante o Segundo Império na França e se espalharam rapidamente para os países ocidentais. Trata-se de uma longa história de transformações para se chegar 
às formas de comércio informacional e virtual (telecompras por telefone e Internet). Nessa mesma dinâmica, grandes transformações urbanas deslocaram cada vez mais equipamentos e estruturas dos centros congestionados para as periferias pavimentadas das cidades, notadamente essas novas e gigantescas modalidades de comércio que representam os hipermercados e centros comerciais (Dayan, 1992).

No desenvolvimento do comércio, as lojas populares tomaram um sentido diferente dos mercados populares e das grandes lojas de departamentos. Os supermercados e, mais tarde, os hipermercados resultaram de outra vertente de transformações na organização das vendas no varejo, fundados na racionalidade de organização do trabalho, que teve como fundamento a adoção de princípios cibernéticos conhecidos na indústria (Pena \& Thébaud-Mony, 2005). ${ }^{5}$

Em relação ao marketing, Mazoyer (2000) afirma que a pesquisa foi um elemento essencial para a origem do conceito comercial de supermercado. No início da década de 1950, grandes grupos da distribuição nos Estados Unidos e na Europa investiram na pesquisa de 'motivações', com o objetivo de estudar o "comportamento do homem na rua para incitá-lo a comprar este ou aquele produto sem ele se dar conta; procuram 'esvaziar' o subconsciente das pessoas; caracterizar as diferentes personalidades (ansiosos, passivos, hostis) e encontrar suas fraquezas profundas" (Mazoyer, 2000: 23).

Para comprarem produtos sem resistências, tais pesquisas resultaram na configuração de um elenco de características psíquicas e sociais dos consumidores, demandando, de uma parte, a disponibilidade do artigo para o cliente ver, tocar, sentir odores. Nota-se a ruptura com a lógica do armazém ou mercearia com balcões entre clientes e prateleiras, impedindo que tais condições ocorram e propiciando o 'livre' acesso dos clientes aos espaços de venda. ${ }^{6}$ O supermercado tornou-se central na aplicação de novas estratégias de marketing, passando a representar mais que a feira popular ou a simples soma de mercearias sob um mesmo espaço de vendas, pois significaria uma nova ordem técnica e organizacional do modo de consumo dos clientes e do trabalho.

5 Para Mottez (1961), a modalidade de autosserviço em supermercado se tornou viável graças ao progresso técnico de embalagens, relacionado ao armazenamento, exposição de vendas de artigos, criado nos Estados Unidos e introduzido na Europa nos anos 50. Essa inovação se generalizou rapidamente na Europa, onde se chegou a 15.066 lojas de autosserviços em 1957.

6 Também houve a introdução de características nos produtos para estimular o narcisismo do consumidor, oferecendo-lhe segurança emotiva, além de assegurar que o produto seja merecido pelo cliente, que o artigo esteja inscrito nos valores da época do cliente, que lhe dê sentimento de potência, de imortalidade, de autenticidade e, finalmente, de criatividade. O produto perde a sua natureza de valor de uso, quase única antes, para se tornar algo que 'falta' ao consumidor (Mazoyer, 2000). 
A indução ao consumo por meio da ação direta do marketing se associa a uma leve imposição de tarefas aos clientes, com o cuidado necessário para não os sobrecarregar até o limite de se afastarem das lojas. As interações com os clientes se ampliaram não apenas nos espaços de vendas, mas em todos os domínios da empresa, desde a chegada ao estacionamento, no caso de hipermercados, até o retorno ao estabelecimento. Paradoxalmente, e sem que os clientes percebam, o autosserviço está associado à redução da autonomia ou da liberdade de escolha no consumo e se organiza em interação com a redução da necessidade de contratação de trabalhadores. ${ }^{?}$

Os clientes fazem um percurso por setores e prateleiras e circulam como em linhas de produção, onde montam carrinhos dos artigos a serem comprados - o que simboliza a metamorfose organizacional de difusão do fordismo industrial para o setor de serviços em empresas do tipo supermercado/hipermercado. O consumo de massa pode, nesse espaço, ser organizado, dispor do tempo de consumo rigorosamente medido e dinamizado por técnicas cibernéticas em comunhão com recursos de marketing. Como todo fluido em fluxo, existe um sentido, e dessa forma há uma montante (entrada do hipermercado), um meio de circulação dos setores em vias divididas pelas prateleiras de artigos, e uma jusante, a linha de caixas de saída. ${ }^{8}$

No imaginário do cliente, o hipermercado representa a 'liberdade' para escolha dos artigos de consumo. Entretanto, o cliente aceita a submissão ao exercício de tarefas, torna-se objeto da ação do marketing, negociando a sua condição de liberdade muitas vezes sem perceber. As tarefas começam para os clientes no estacionamento, no momento em que pegam o carrinho de compras até quando voltam com suas compras ao mesmo local e recebem em troca o preço do autosserviço - moeda caucionada. ${ }^{9}$ As tarefas a serem

7 No modelo fordista de organização de hipermercado, a transferência de atividades para os clientes se associava à redução de trabalhadores a serem contratados pela empresa, enquanto no modelo que incorpora elementos do ohnismo essa relação se estabelece como estratégia de redução da terceirização, na medida em que as tarefas transferidas ao cliente geralmente estão fora daquelas consideradas centrais e integradas ao 'núcleo duro' de trabalhadores da empresa (Pena, 2000).

8 Sobre a circulação de clientes na loja, Fady e Seret (2000: 99) expressam a concepção hidrodinâmica da organização do fluxo de clientes ao afirmar: "antes de proceder à instalação da loja é preciso criar eixos de circulação que devem permitir a atração da clientela ao fundo da loja; quanto mais larga for a via de circulação, mais ela permite a multidão circular e 'drenar' toda a superfície de vendas e, dessa forma, evita a existência de uma parte do magazine sem 'irrigação' do fluxo de clientes” (tradução livre do autor; destaques nossos).

9 No Brasil, o método para o cliente recolocar o carrinho de compras no mesmo local onde o apanhou ainda não foi introduzido, como na Europa. Tal serviço é feito por trabalhadores contratados para tal finalidade. Na França, o uso do carrinho de compras está condicionado à introdução de uma moeda em compartimento próprio e automático, que só pode ser retirada com a colocação do carrinho de compras no mesmo local. Caso o cliente não faça essa tarefa, ele perde o valor depositado como caução. 
cumpridas pelos clientes são várias, e a sua negação em fazê-las rompe o pacto do autosserviço, impedindo a realização do processo de compras.

A noção de autosserviço é típica do terciário, embora esteja associada também a algumas atividades na indústria que podem ser deslocadas para a residência do consumidor. $\mathrm{O}$ autosserviço se difundiu e se tornou uma atividade da sociedade moderna, mesmo que o lugar esteja na dimensão virtual e distante (autosserviços virtuais ou telesserviço ou teletrabalho). A noção de autosserviço possibilita o deslocamento de atividades do mundo do trabalho para as práticas de consumo e vice-versa, e é essencial para análise do modo de introdução da racionalidade fordista/taylorista em setores do comércio como restaurantes, supermercados, postos de combustíveis, caixas de bancos, telemanutenção de softwares por meio de teleatendimento e tantos outros serviços típicos do setor terciário.

$\mathrm{Na}$ organização do trabalho do modelo toyotista, houve a introdução do fluxo inverso da informação, que partia da venda do produto e se dirigia para todos os setores da fábrica. Esse método, segundo Coriat (1991), originou-se no supermercado típico, na medida em que as vendas de artigos registradas no caixa de saída geravam informações imediatas sobre a demanda; em consequência, se dispunha de informações sobre a reposição de produtos nas prateleiras e nos depósitos, evitando-se assim grandes estoques. Os fluxos de informações no sentido jusante/montante já era uma característica da organização do hipermercado fordista, que foi adaptada à indústria, e retorna redimensionada quando o modelo ohnista passa a ser aplicado aos supermercados e hipermercados.

A compreensão da noção de serviço, vista aqui, permite entender como esse setor se tornou o lugar privilegiado da estratégia de autosserviço capaz de induzir o sujeito consumidor a realizar atividades que eram antes de responsabilidade da empresa. As tarefas semelhantes às existentes na organização do trabalho passaram a ser transferidas para o consumidor, inclusive tarefas complexas de gestão e controle do trabalho que o próprio cliente não tem consciência da sua realização.

Nos serviços de saúde, o cliente tinha a qualidade de ser um veículo de doenças transmissíveis ou era condicionado a oferecer riscos de agravos à saúde do trabalhador, em razão do seu comportamento nos conflitos relacionais nos mais diversos ramos do setor serviço. Agora, ao realizar práticas de autosserviço, o cliente pode executar tarefas gerenciais e assim compor modelos nocivos de organização do trabalho com possíveis impactos na saúde (Pena \& Thébaud- 
Mony, 2005). É importante enfatizar que as consequências podem recair sobre o cliente obrigado a frequentar filas estressantes, expondo-se a outros riscos, e essa perspectiva do campo da saúde do trabalhador pode ser objeto de reflexão para melhor entendimento da saúde do consumidor.

\section{Sucessões Históricas de Modelos de Organização do Trabalho nos SERVIÇOS}

A análise dos processos de trabalho na indústria mostra que esta determinou modelos de organização de serviços no setor terciário. Difundiu-se então o próprio método industrial geral para o terciário, tal como caracterizou Engels (1985) na revolução industrial, que se seguiu do fordismo e taylorismo e, finalmente, do ohnismo/toyotismo na terceira revolução industrial.

No ohnismo/toyotismo, a concentração da ação da empresa na fabricação do seu produto final passa a ser no cliente, que se transforma no eixo central do novo método de produção e organização de serviços em geral. Trata-se da inversão da racionalidade fordista, segundo Coriat (1991), em que se centraliza o cliente no processo de reestruturação produtiva ${ }^{10}$ e, assim, os modos de consumo geram demandas que passam a interferir imediatamente, em tempo real (just in time), na dinâmica das linhas de produção. Isso faz com que o empresariado busque a flexibilização da técnica e das relações de trabalho para permitir a introdução, na racionalidade de produção e de execução dos serviços, do princípio do consumo como organizador do sistema (Coriat, 1991). Essa reengenharia significou profundas intervenções na indústria fordista, pois as informações sobre os desejos dos clientes passaram a interferir diretamente no processo de fabricação, com o fluxo invertido de informações contrário ao fluxo da linha de produção, porém modificando-o sempre que necessário.

No setor de serviços, no supermercado e, em seguida, no hipermercado, desde a sua origem, a introdução do autosserviço proporcionou a construção de um novo modelo de vendas baseado na presença do consumidor como organizador direto do processo de trabalho. Os impactos dessas transformações na saúde do trabalhador e do consumidor ainda necessitam de mais estudos.

Os processos saúde e doença têm condicionantes similares na indústria e no serviço para as atividades dos trabalhadores, os quais têm fundamentos na

${ }^{10}$ A centralidade do cliente se refere à sua condição de consumidor e não ao debate acadêmico sobre a centralidade no trabalho. 
mesma racionalidade socioeconômica citada. A hipótese de nocividade para a saúde do trabalhador fundada na racionalidade industrial tem, portanto, bases similares para os trabalhadores do setor de serviços, além de distinções que demandam mais pesquisas.

Não se trata, portanto, de transposição de modelos de processos industriais para o setor terciário, e sim do aprofundamento para precisar melhor a abordagem da saúde do trabalhador. Nesse sentido, necessita-se de análises construídas pela distinção entre os processos de trabalho nos setores terciário e industrial, embora contenham fundamentos comuns que caracterizam a base social e cultural do processo de trabalho capitalista.

\section{CONCLUSÃO}

No contexto da crise do mundo do trabalho, questiona-se a hegemonia do paradigma industriário, ainda central nas referências analíticas da saúde do trabalhador. Concomitantemente, são consistentes as evidências sobre a emergência de um novo paradigma caracterizado pelo grande crescimento do setor de serviços em um processo de terciarismo da sociedade, que a construção histórica e social da saúde do trabalhador não poderá desconsiderar.

A saúde do consumidor tem sido abordada no âmbito da vigilância sanitária por meio da existência ou não de riscos químicos, físicos e biológicos em produtos variados, como brinquedos e alimentos contaminados, a exemplo dos agrotóxicos. Entretanto, ao tomar a noção de autosserviço (self-service) como uma especificidade em ramos do setor terciário, ele se caracteriza pela realização de tarefas pelos clientes, muitas vezes oriundas das atividades dos trabalhadores, os quais se submetiam aos clássicos processos de gestão e organização do trabalho. As problemáticas da organização do trabalho e da ergonomia se apresentam também, nesses casos, na execução das tarefas de autosserviços. Essa constatação, para a área da saúde do trabalhador, requer uma abordagem que estude a interface entre processo de trabalho, saúde e consumo.

Neste capítulo, buscou-se relacionar aspectos capazes de colaborar para a reflexão teórico-conceitual da noção de serviços. Pretende-se assim contribuir para o debate no campo da saúde do trabalhador, em especial na hipótese da emergência de um século centrado no setor terciário em substituição ao paradigma industriário dos séculos XIX e XX. 


\section{ReFERÊNCIAS}

ASSUNÇÃO, A. A. et al. Abordar o trabalho para compreender e transformar as condições de adoecimento na categoria dos teleatendentes no Brasil. Revista Brasileira de Saúde Ocupacional, 31(114): 47-62, 2006.

AUSTRALIAN COUNCIL OF TRADE UNIONS (ACTU). Call Centre Minimum Standards Code. Disponível em: <www.actu.asn.au/public/campaigns/callcentral. html>. Acesso em: 10 abr. 2004.

BRAVERMAN, H. O Trabalho e o Capital Monopolista: a degradação do trabalho no século XX. São Paulo: Zahar, 1980.

CORIAT, B. Penser à l'Envers: travail e organisation dans l'entreprise japonaise. Paris: Christian Bourgois Éditeur, 1991.

CUNHA, D. C. \& ORBAN, E. Uma abordagem ergológica da carga e da intensidade de trabalho: notas conceituais a partir do estudo de caso da empresa La Poste. In: DIEESE; CESIT \& UNIVERSIDADE ESTADUAL DE CAMPINAS (Orgs.) Trabalho e Abordagem Pluridisciplinar: estudos Brasil, França e Argentina. São Paulo, Campinas: Dieese, Cesit, Unicamp, 2005.

DAYAN, A. Manuel de la Distribution: fonctions - structures - évolution. Paris: PUF, 1992. DONNANGELO, M. C. F. \& PEREIRA, L. Saúde e Sociedade. São Paulo: Duas Cidades, 1979.

ENGELS, F. A Situação da Classe Trabalhadora na Inglaterra. São Paulo: Global, 1985.

FADY, A. \& SERET, M. Le Merchandising: techniques modernes du commerce en détail. Paris: Librairie Vuibert, 2000.

FERREIRA, A. B. H. Novo Aurélio Século XXI: dicionário da língua portuguesa. Rio de Janeiro: Nova Fronteira, 1999.

FREITAS, M. C. S. \& PENA, P. G. L. Segurança alimentar e nutricional: a produção do conhecimento com ênfase na cultura. Revista de Nutrição, 20(1): 69-81, 2007.

FREYSSINET, J. As transformações das estruturas do emprego na União Europeia. In: DIEESE \& CESIT (Orgs.) O Trabalho no Setor Terciário: emprego e desenvolvimento tecnológico. São Paulo: Dieese, Cesit, 2005.

GELlNER, E.; NISBET, R. \& TOURAINE, A. Dicionário do Pensamento Social do Século XX. Rio de Janeiro: Jorge Zahar, 1996.

GÓMEZ, C. M. \& LACAZ, F. A. C. Saúde do trabalhador: novas e velhas questões. Ciência Ë Saúde Coletiva, 10(4): 797-815, 2005.

GORZ, A. Métamorphoses du Travail: quête du sens - critique de la raison économique. Paris: Galilée, 1988.

HALFORD, V. \& COHEN, H. H. Technology use and psychosocial factors in the self reporting of musculoskeletal disorder symptoms in call center workers. Journal Safety Research, 34(2): 167-173, 2003. 
JEAN, R.; ORBAN, E. \& MOUILLET, F. Organização produtiva e relação salarial no ramo "hipermercados" França do grupo Carrefour: constatação de fatores em jogo. In: DIEESE; CESIT \& UNIVERSIDADE ESTADUAL DE CAMPINAS (Orgs.) Trabalho e Abordagem Pluridisciplinar: estudos Brasil, França e Argentina. São Paulo, Campinas: Dieese, Cesit, Unicamp, 2005.

LAURELL, A. C. \& NORIEGA, M. Processo de Produção de Saúde: trabalho e desgaste operário. São Paulo: Hucitec, 1989.

LIPIETZ, A. Le monde de l'après fordisme. In: APPAY, B. \& THÉBAUD-MONY, A. (Orgs.) Précarisation Sociale, Travail et Santé. Paris: Inserm/Iresco, 1997.

MARX, K. O Capital: crítica da economia política. Livro 1: O processo de produção do capital. São Paulo: Bertrand Brasil, Difel, 1987.

MARX, K. \& ENGELS, F. Marx e Engels: Obras escolhidas. v. 1. Lisboa: Avante, Progresso, 1982.

MAZOYER, F. L'irrésistible perversion du besoin: consomateur sous influence. Le Monde Diplomatique. Paris, déc. 2000. Disponível em: <www.monde-diplomatique. $\mathrm{fr} / 2000 / 12 / \mathrm{MAZOYER} / 14548>$.

MINAYO-GOMEZ, C. \& THEDIM-COSTA, S. M. F. A construção do campo da Saúde do Trabalhador: percurso e dilemas. Cadernos de Saúde Pública, 13(supl. 2): 21-32, 1997.

MOTTEZ, B. Les professions non industrielles. In: PARIAS, L.-H. Histoire Générale du Travail: la civilisation industrielle. Paris: Nouvelle Librairie de France, 1961.

NUNES, E. D. A categoria trabalho na medicina. In: NUNES, E. D. (Org.) Pensamento Social em Saúde na América Latina. Rio de Janeiro: Cortez, Abrasco, 1989.

ORBAN, E. O serviço é um produto? In: DIEESE \& CESIT (Orgs.) O Trabalho no Setor Terciário: emprego e desenvolvimento tecnológico. São Paulo: Dieese, Cesit, 2005.

PENA, P. G. L. LER: la premiére épidemie d'origine robotique? Une étude sur la robotique gestionnaire, l'organization du travail dans les hipermarchés et la santé, 2000. Tese de Doutorado, Paris: École des Hautes Études en Sciences Sociales.

PENA, P. G. L. \& THÉBAUD-MONY, A. Transformações organizacionais e inovações técnicas em hipermercados na França e no Brasil. In: DIEESE; CESIT \& UNIVERSIDADE ESTADUAL DE CAMPINAS (Orgs.) Trabalho e Abordagem Pluridisciplinar: estudos Brasil, França e Argentina. São Paulo, Campinas: Dieese, Cesit, Unicamp, 2005.

PRONI, M. W.; SILVA, R. A. \& OLIVEIRA, H. S. A modernização econômica no setor terciário no Brasil. In: DIEESE e CESIT (Orgs.) O Trabalho no Setor Terciário: emprego e desenvolvimento tecnológico. São Paulo: Dieese, Cesit, 2005.

RUZZA, R. O trabalho nos processos de internacionalização dos serviços: o caso Carrefour (elementos de uma síntese). In: DIEESE; CESIT \& UNIVERSIDADE ESTADUAL DE CAMPINAS (Orgs.) Trabalho e Abordagem Pluridisciplinar: estudos Brasil, França e Argentina. São Paulo, Campinas: Dieese, Cesit, Unicamp, 2005. 
SANTOS, V. C. As múltiplas tarefas e atividades interferentes em centrais telefônicas e atendimento telefônico. Revista Brasileira de Saúde Ocupacional, 29(109): 21-29, 2004.

SCHWARTZ, Y. \& DURRIVE, L. Le Travail Change. Toulouse: Octarès, 2003. 


\section{Entre o Criativo e o Prećário: reflexões SOBRE CONSTRANGIMENTOS E POSSIBILIDADES DO TRABALHADOR DA SAÚDE EM TEMPOS LÍQUIDOS}

Élida Azevedo Hennington

Em suma: a vida líquida é uma vida precária, vivida em condições de incerteza constante. As preocupações mais intensas e obstinadas que assombram esse tipo de vida são os temores de ser pego tirando uma soneca, não conseguir acompanhar a rapidez dos eventos, ficar para trás, deixar passar as datas de vencimento, ficar sobrecarregado de bens agora indesejáveis, perder o momento que pede mudança e mudar de ramo antes de tomar um caminho sem volta.

Bauman (2007a: 8)

Este capítulo pretende discutir o trabalho em saúde no Sistema Único de Saúde (SUS) na perspectiva de sua configuração na contemporaneidade e diante dos desafios impostos pelas significativas mudanças na vida e saúde dos trabalhadores "no líquido cenário da vida moderna", como definido pelo sociólogo polonês Zygmunt Bauman (2004: 8). Reflete sobre possibilidades e constrangimentos impostos aos trabalhadores da saúde diretamente envolvidos com o cuidado e a assistência, em tempos de ampliação do mercado de trabalho, aumento e complexificação de demandas e necessidades em saúde pública, e também de desregulamentação e flexibilização de direitos em um ambiente precarizado, com reflexos evidentes na forma de realizar o trabalho, bem como no ideário e na subjetividade dos trabalhadores com diferenciadas repercussões na saúde.

\section{Tempos Líquidos: 0 processo de globalização e um nOVO MOdO DE SER}

\section{E DE ESTAR NO MUNDO}

Bauman (2007b) refere-se a uma passagem da fase 'sólida' da modernidade para a fase 'líquida', caracterizada pela volatilidade das organizações sociais, a 
separação entre o poder e a política, a redução da segurança, o esgarçamento da rede de solidariedade social, o limite do planejamento e das ações a longo prazo e, finalmente, o afloramento da figura do free-chooser, ou seja, da responsabilização individual no equacionamento de dilemas voláteis e instáveis da atualidade e dos riscos inerentes às escolhas impostas às pessoas.

Em um mundo inseguro e de futuro incerto, constituímos uma massa "heterônoma, infeliz e vulnerável" (Bauman, 2007b: 13), esmagada por forças que não controlamos e tampouco entendemos totalmente, atropelada por transformações rápidas e imprevisíveis, buscando defender-se dos riscos e perigos da modernidade em uma sociedade globalizada em que muitas vezes o outro parece constituir o maior e principal perigo.

Incapazes de reduzir o ritmo estonteante da mudança, muito menos prever ou controlar sua direção, nos concentramos nas coisas que podemos, acreditamos poder ou somos assegurados de que podemos influenciar: tentamos calcular e reduzir o risco de que nós, pessoalmente, ou aqueles que nos são mais próximos e queridos no momento, possamos nos tornar vítimas dos incontáveis perigos que o mundo opaco e seu futuro incerto supostamente têm guardado para nós. Nossa atenção é chamada para observar "os sete sinais do câncer”, ou "os cinco sintomas da depressão”, ou para exorcizar o espectro da pressão alta, do nível alto de colesterol, do estresse ou da obesidade. Em outras palavras, buscamos alvos substitutos sobre os quais possamos descarregar o medo existencial excedente que foi barrado de seus escoadouros naturais, e encontramos esses alvos paliativos ao tomarmos cuidadosas precauções contra a inalação da fumaça do cigarro de outra pessoa, a ingestão de comida gordurosa ou de "más" bactérias (ao mesmo tempo em que sorvemos os líquidos que prometem conter as "boas"), a exposição ao sol ou o sexo desprotegido. Aqueles que podem dar-se ao luxo de se fortalecerem contra todos os perigos, visíveis ou invisíveis, atuais ou previstos, familiares ou ainda desconhecidos, difusos, porém ubíquos, protegendo-se por trás de muros, equipando os acessos a moradias com câmeras de TV, contratando seguranças armados, dirigindo carros blindados (...), usando trajes à prova de balas ou aprendendo artes marciais. (Bauman, 2007b: 17; grifo do autor)

Com o desmantelamento do Estado e o enfraquecimento de movimentos e instituições representativas de grupos sociais, cada vez mais destituídos de poder em uma sociedade de mercado que de forma contínua abala os mecanismos de coesão e de solidariedade, aparentemente só resta às pessoas buscar soluções individuais para problemas socialmente produzidos, embora sem dispor de instrumentos adequados ou recursos suficientes para essa tarefa. As cidades 
tornaram-se depositórios sanitários de problemas globalmente forjados, e daí decorre o paradoxo do fortalecimento de políticas locais em um mundo a todo e a cada momento redefinido por processos globais. A noção de progresso é associada atualmente à ênfase ao descarte e à sobrevivência individual em uma economia baseada no consumo. Conforme afirma Bauman (2007b: 97), "os medos contemporâneos mais assustadores são os que nascem da incerteza existencial".

As mensagens dirigidas dos centros do poder político tanto para os ricos como para as classes populares apresentam "mais flexibilidade" como a única cura para uma insegurança já insustentável - e assim retratam a perspectiva de mais incerteza, mais privatização dos problemas, mais solidão e impotência e, na verdade, mais incerteza ainda. Elas excluem a possibilidade de uma segurança existencial que se baseie em alicerces coletivos, assim não oferecem incentivo a ações solidárias; em lugar disso, encorajam seus ouvintes a se concentrarem na sua sobrevivência individual ao estilo "cada um por si e Deus por todos" em um mundo incuravelmente fragmentado e atomizado, portanto cada vez mais incerto e imprevisível (Bauman, 2007b: 20).

A cidade caótica que atrai e repele propicia, na imposição e no confronto com o diferente, o impulso segregacionista, mas ao mesmo tempo a possibilidade do espaço aberto, público e convidativo que também pode resultar na “compreensão mútua” e na "experiência compartilhada” (Bauman (2007b: 97).

Esse mundo em aguda e constante transformação e sua dinâmica individualista e fragmentadora repercutiram de maneira contundente no ethos do trabalho, na forma de ser e de fazer o trabalho. Claro está que houve uma mudança essencial na sua natureza e qualidade. No Brasil, mesclam-se processos produtivos atrelados ao antigo modelo taylorista-fordista, caracterizado pela produção em série, verticalizado, monótono e repetitivo com novos formatos e concepções 'flexibilizados' e organizados conforme a demanda do mercado. Em um contexto de intensa competitividade, os nichos de produção esmeramse pela incorporação de avançadas tecnologias e inovadoras formas e modelos de gestão organizacional na busca por alta produtividade e qualidade na oferta de bens e serviços (Antunes, 1999).

O trabalho tornou-se variado e complexo, com maior exigência de ordem subjetiva e de mobilização da inteligência em um ambiente de estímulo a uma pretensa autonomia na condução das atividades cotidianas. Hoje, elementos como informação e comunicação tornaram-se fundamentais à produção. Ocorreu também uma espécie de apropriação e exploração de capacidades 
humanas no mundo do trabalho até então não consideradas: a criatividade, a capacidade organizativa e de cooperação, a comunicação e a habilidade dos trabalhadores na resolução de problemas passam a ser valorizadas e reconhecidas como imperativos no novo ideário produtivo (Antunes, 1999; Rosenfield, 2004; Hardt \& Negri, 2005). As posturas ativas no trabalho, a troca de informações, o trabalho em equipe, a supremacia das atividades simbólicas e a valorização do trabalhador flexível e polivalente tornaram-se fundamentais nesse novo cenário, fenômeno fortemente observado inclusive na área da saúde.

Com a ampliação do quadro de competências necessárias para ingressar no mercado de trabalho com chances de aproveitamento, apresenta-se a figura do trabalhador multifuncional, polivalente. A necessidade de formação ou de qualificação/requalificação constante tem sido estimulada, e o desemprego e demais formas de precarização influenciam de maneira perversa o posicionamento dos indivíduos no mundo do trabalho. Ele se vê obrigado a assumir novas funções e a arcar com a sua própria qualificação, imergindo em um ambiente cuja ideologia meritocrática conclama sistematicamente sua dedicação, iniciativa e comprometimento. Difunde-se a ideia de 'parceria' e de 'colaboração' com uma suposta comunhão de objetivos e interesses entre capital e trabalho, o que na prática tem gerado a intensificação do trabalho e a subordinação do trabalhador coletivo ao capital, à produção e seu processo de valorização. A redução da força de trabalho industrial e o significativo aumento do setor de serviços observados nos dias atuais não levaram a uma ruptura com os mecanismos de exploração e produção de mais-valia, lucro e de expansão do capital (Antunes, 1999; Amorim, 2006).

Nesse quadro de expressivas mudanças, tudo parece se apresentar de maneira efêmera e volátil, e certamente o trabalho também mudou, acompanhando essa tendência. A carreira, antes estável, no presente é pautada por reorientações, e o emprego de hoje poderá não mais existir amanhã. Postos de trabalho são extintos a todo momento, e formas precarizadas de inserção no mercado de trabalho tornam-se usuais. A reestruturação produtiva impôs o surgimento de processos em que, além da capacidade física, a cognição, a comunicação e a subjetividade do trabalhador tornaram-se elementos-chave. Direitos trabalhistas têm sido rotineiramente solapados nesse imbricado e ainda obscuro contexto brasileiro, em que coabitam formatos tayloristas-fordistas com modos de gestão e de organização do trabalho orientados por uma nova lógica produtiva e a sucessiva incorporação de máquinas, equipamentos e processos complexificados e de tecnologia de ponta. 
O advento do neoliberalismo, o desmonte do Welfare State e o fim de direitos sociais nos países do Norte e a preconização do Estado mínimo tiveram graves consequências no mundo do trabalho. No entanto, contrariando as teses que apregoam o deslocamento da categoria 'trabalho' e a perda de sua relevância como elemento central e estruturante da sociedade, advoga-se que esse cenário hoje é marcado pela heterogeneidade, fragmentação e complexificação. Com a retração do taylorismo-fordismo e a emergência do processo de reestruturação produtiva do capital, predominam certas características tais como a transnacionalização do capital e do sistema produtivo, o aumento da população feminina no mercado de trabalho e da participação de assalariados médios no setor de serviços, a expansão do desemprego e a redução do contingente de trabalhadores estáveis e com vínculo formal de trabalho e uma difusão de modalidades como terceirização, subcontratação, part-time job e outras formas de precarização (Antunes, 1995, 1999; Antunes \& Alves, 2004). Ao lado disso, a subsunção do trabalho configura-se pela tentativa de captura da subjetividade dos trabalhadores pelo capital induzindo ao estranhamento e alienação em relação ao que se produz e para quem se produz. Entretanto, como elemento vivo, o trabalho persiste medindo forças e gerando conflitos e oposições em uma constante disputa entre alienação e desalienação na vida cotidiana (Antunes \& Alves, 2004).

Múltiplas formas de fetichizações e reificações poluem e permeiam o mundo do trabalho, com repercussões enormes na vida fora do trabalho, na esfera da reprodução societal, na qual o consumo de mercadorias, materiais ou imateriais, também está em enorme medida estruturado pelo capital. Dos serviços públicos cada vez mais privatizados, até o turismo, no qual o "tempo livre" é instigado a ser gasto no consumo dos shoppings, são enormes as evidências do dominio do capital na vida fora do trabalho, que colocam obstáculos ao desenvolvimento de uma subjetividade autêntica, ou seja, uma subjetividade capaz de aspirar a uma personalidade não mais particular nem meramente reduzida a sua "particularidade". A alienação/estranhamento e os novos fetichismos que permeiam o mundo do trabalho tendem a impedir a autodeterminação da personalidade e a multiplicidade de suas qualidades e atividades (Antunes \& Alves, 2004: 349; grifos dos autores)

Segundo Bauman (1998), esse mundo contemporâneo incerto, incontrolável e indeterminável prejudica nossa capacidade de aferir efeitos pela inconstância de ação. Ele assusta pela falta de direção e incoerência, e pela amplidão de possibilidades que vaticina. A nova desordem do mundo privado de uma estruturação visível e lógica faz aflorar presságios de guerra civil disse- 
minada, pragas, conflagrações, miséria. Os dois blocos de poder sucumbiram, e atualmente cerca de vinte países ricos enfrentam o resto do mundo que já não segue seus princípios de progresso e felicidade, mas que persiste de algum modo na dependência econômica e/ou política. A desregulamentação universal provocada pela competição de mercado, a total liberdade outorgada ao capital e às finanças em detrimento de todas as outras liberdades, a pulverização das redes societais de segurança e a rejeição de todas as razões que não as econômicas impulsionam aquilo que outrora era aplacado pelas estruturas legais do Estado de bem-estar, pelos sindicatos, pela legislação de trabalho, por alguns órgãos internacionais. Mesmo a rica Europa conta atualmente com cerca de três milhões de desabrigados, mais de 21 milhões de expulsos do mercado de trabalho, cerca de 39 milhões de trabalhadores que vivem abaixo da linha de pobreza. Nesse novo mundo em que nenhum emprego é garantido e não há posições seguras, houve o desvio do projeto comunitário de defesa do direito universal a uma vida decente e digna para a promoção do mercado como garantia de oportunidades universais, o que só faz aumentar o sofrimento dos pobres, insultados, humilhados e marcados "com a negação da liberdade do consumidor, agora identificada com a humanidade” (Bauman, 1998: 34).

\section{Aspectos sobre 0 Trabalho em Saúde em Tempos de Insegurança e de InCERTEZA}

Caracterizado economicamente como prestação de serviço, o trabalho em saúde relacionado à assistência está situado entre o material e o imaterial, entre o cognitivo-afetivo e o instrumental, entre a atividade dotada de maior dimensão intelectual e a atividade física com dispêndio de energia. Sua principal característica é o caráter relacional e a peculiaridade de lidar com o sofrimento humano; é sua dimensão subjetiva envolvendo cuidado, interação humana e manipulação de afetos.

Segundo Nogueira (2007: 59), o trabalho em saúde é processo, é serviço e é fundado em uma inter-relação pessoal muito intensa, em um laço "particularmente forte e decisivo para a própria eficácia do ato". Situa-se como serviço que se realiza não sobre coisas ou objetos, mas sobre pessoas (e com pessoas) em que o usuário é copartícipe no processo de trabalho e, desse modo, corresponsável pela ação terapêutica; é processo de trabalho abstrato pois se realiza de numerosas formas e com numerosas características e apresenta dimensão teleológica como qualquer outro processo de trabalho, traduzindo- 
se na necessidade de adequação constante ao particular porque relacional e circunstancial. É trabalho intelectual, porém permanece igualmente manual, sendo na atualidade resultado de ação coletiva e da fragmentação de atos a partir de uma direcionalidade oriunda da autoridade técnica e social ainda hoje imposta pela racionalidade médica.

De acordo com Hardt e Negri (2005), trabalho imaterial seria aquele que cria produtos imateriais, tais como serviço, produto cultural, conhecimento, informação, comunicação, relações interpessoais. Eles reforçam a ideia de que a imaterialidade do trabalho está relacionada não à atividade em si, pois em qualquer trabalho é preciso engajamento de corpo e cérebro, mas sim ao seu 'produto'. Para os autores, mesmo quando físico e afetivo, o trabalho em saúde é imaterial porque seus produtos são inatingíveis - conforto, bem-estar, satisfação. Segundo Hardt (1993: 148), "informação, comunicação, conhecimento e afeto passam a desempenhar um papel estrutural nos processos produtivos".

Em resumo, para Hardt e Negri existiriam três tipos de trabalho imaterial: o primeiro seria o relacionado à produção industrial que incorporou a informática e tecnologias de informação; o segundo seria aquele com ênfase no desenvolvimento de tarefas analíticas e simbólicas; e, finalmente, o trabalho que envolve a produção e manipulação de afetos, requerendo tanto esforço físico como contato humano, virtual ou real. Reconhecendo o caráter ambíguo do conceito, os autores afirmam que, em vez de trabalho imaterial, melhor seria tratá-lo como "trabalho biopolítico", ou seja, que não cria apenas bens materiais, mas também relações e, em última instância, a própria vida social.

O trabalho de cuidar de alguém está, certamente, imerso no corpóreo, no somático, mas os afetos que produz são, apesar disso, imateriais. O que o trabalho afetivo produz são redes, formas comunitárias, biopoder. Aqui pode-se reconhecer mais uma vez que a ação instrumental da produção econômica foi unida à ação comunicativa das relações humanas; neste caso, entretanto, a comunicação não ficou empobrecida, mas a produção foi enriquecida até o nível de complexidade da interação humana. (Hardt \& Negri, 2005: 314)

O trabalho imaterial produz subjetividade e valor econômico, articulando economia, poder e saber (Lazzarato \& Negri, 2001). Interação e cooperação sociais são inerentes ao trabalho imaterial e conformam a produtividade, a riqueza e a criação de superávits sociais por meio de redes linguísticas, de comunicação e afetivas. Ainda segundo Hardt e Negri (2005: 315), uma das 
principais características do trabalho imaterial é a cooperação, apontando de forma otimista para a potencialidade "de um tipo de comunismo espontâneo e elementar”. Esses autores defendem a ideia de que a cooperação e a autonomia presentes na conformação dos processos produtivos pós-fordistas no capitalismo levariam à construção do trabalhador social, emancipado.

Contrariamente, o que se nota no cotidiano produtivo é o aparente controle do capital das formas de trabalho cognitivo e da capacidade dos indivíduos de agir e tomar decisões, o que tem ocorrido segundo necessidades construídas e impostas pelo próprio capital. Este utiliza a seu favor as capacidades intelectuais do trabalhador que se prestam então à sua valorização. $O$ conhecimento passa a ser retido como valor de troca, e o 'tempo livre' resultante da substituição do homem pela máquina e a execução de atividades propiciada pelo desenvolvimento tecnológico têm-se dado não de forma positiva, mas pelo desemprego, subemprego, banco de horas e outras modalidades de precarização do mercado, e sem a possibilidade efetiva de seu usufruto (Amorim, 2006).

A reestruturação produtiva atinge a sociabilidade do trabalho pela constante tentativa de captura da subjetividade do trabalhador submetido a uma série de dispositivos organizacionais e também pelo desemprego e precarização do emprego e do salário, com reflexos não só na quantidade de empregos mas também na sua qualidade, com fragmentação e pulverização do coletivo de trabalhadores, mediante mecanismos que apresentam dimensão política e estratégica como a terceirização, que enfraquece a organização e o seu poder de barganha e resistência (Alves, 2000).

\section{Trabalhador da Saúde na Corda Bamba: entre 0 material e 0 IMATERIAL, ENTRE 0 ESTRANHAMENTO E A CRIATIVIDADE, ENTRE 0 CONTROLE E \\ A AUTONOMIA}

Coadunado à política de abertura comercial, privatizações e à busca de estabilidade econômica que caracterizou os anos 90 no Brasil, houve o avanço de medidas de desregulamentação e flexibilização do mercado de trabalho. Ocorreu uma redução de mais de um milhão de empregos na indústria de transformação no período e aumento expressivo do desemprego. Grande parte desses trabalhadores migrou para o mercado informal ou para o setor de serviços, que apresenta, usualmente, maior heterogeneidade das condições de emprego, com contratos de baixa qualificação e baixos salários, além de desorganizada representação sindical. No campo do direito trabalhista, houve 
alteração de regras de vínculo contratual, jornada de trabalho e salário: contrato de trabalho por tempo determinado, trabalho em tempo parcial, suspensão temporária do contrato de trabalho por motivos econômicos, banco de horas, redução salarial com redução de jornada foram alguns dos ajustes feitos nas regras e leis trabalhistas, caracterizando um verdadeiro desmonte dos direitos duramente conquistados ao longo de décadas de luta dos trabalhadores. Ainda hoje, rondam no Congresso Nacional propostas de alteração do artigo 618 da Consolidação das Leis do Trabalho (CLT) que fazem sobrepor os acordos coletivos privados ao que determina a lei trabalhista, ao lado daquelas que defendem mudanças democráticas e necessárias na estrutura corporativa e na CLT (Costa, 2005).

Em tempos de reestruturação produtiva, o setor de serviços ampliou significativamente a participação na economia, e a área de saúde consolidou a participação na oferta de empregos. Desse modo, o mercado de trabalho em saúde no Brasil tem-se caracterizado nos tempos atuais pelo seu dinamismo, complexidade e competitividade.

As reformas neoliberais no campo da saúde na América Latina propugnaram a flexibilização da força de trabalho com o objetivo de reduzir custos e aumentar a eficiência, restringindo benefícios e impondo condições de trabalho, carga, horário, local de trabalho, com a possibilidade de demitir o funcionário livremente (Ugalde \& Homedes, 2005). Pesquisas evidenciaram que o enfoque na produtividade gerou impacto negativo na atenção ao usuário, especialmente no cuidado direto (ILO, 1998; Egger, Lipson \& Adams, 2000; Rigoli \& Dussault, 2003). Estudo realizado com trabalhadores de enfermagem de países da América Latina, inclusive o Brasil, demonstrou que a flexibilibização levou a um aumento do estresse e da insatisfação no trabalho, com repercussões na dedicação ao paciente e a redução de algumas atividades em saúde que requerem tempo adicional, como as educativas (Guevara \& Mendías, 2002). No entanto, sistemas de gratificação por produtividade acabam não perdurando e/ou originam descompromisso e maléfica competição entre trabalhadores (Cherchiglia et al., 1998).

Kabene e colaboradores (2006), ao discutirem a força de trabalho em saúde, destacam questões comuns no mundo inteiro que precisam ser abordadas, tais como tamanho, composição, distribuição, mobilidade, necessidades de treinamento e de capacitação, dentre outras. Franco, Bennett e Kanfer (2002) destacam que suficiência e competência na força de trabalho são essenciais, mas não bastam para para garantir o sucesso das reformas com melhoria da 
qualidade de serviços, eficiência e equidade dos sistemas públicos de saúde. Eles reforçam a ideia de que incentivos financeiros são importantes para motivar os trabalhadores, porém somente a compensação financeira não consegue resolver problemas referentes à gestão e ao cumprimento de metas, apontando para a relevância de determinantes individuais, cultura organizacional e contexto de trabalho, além de fatores socioculturais. Fritzen (2007), por sua vez, chama a atenção para as capacidades, a performance e os fatores motivacionais envolvidos no trabalho em saúde e na dissociação, muitas vezes existente, entre a atividade para a qual o trabalhador tem habilidades e é capacitado para desempenhar e aquilo para o qual se sente motivado e 'empoderado' para fazer. O estudo da força de trabalho em saúde tem ganhado destaque na medida em que a relação direta entre gestão da força de trabalho e efetividade dos sistemas de saúde tornou-se cada vez mais evidente. Apesar do papel fundamental nos sistemas de saúde, ainda muito pouco é conhecido sobre composição, treinamento e performance desse grupo de trabalhadores (Beaglehole \& Dal Poz, 2003).

Em 2002, o Brasil apresentava cerca de 2.200.000 empregos em saúde, o que significava 12,5 empregos/1.000 habitantes, com 466.110 empregos médicos, 88.952 de enfermeiros, 56.995 de odontólogos, 28.670 empregos de farmacêuticos e 471.904 de técnicos e auxiliares de enfermagem. Não há escassez de força de trabalho no país, mas problemas na sua distribuição, com falta de profissionais nas zonas rurais e periferias das grandes cidades (Machado, Moysés \& Oliveira, 2006). De acordo com o Departamento Intersindical de Estatística e Estudos Socioeconômicos (Dieese, 2004), o perfil do trabalhador da saúde nos mercados metropolitanos (Belo Horizonte, Porto Alegre, Recife, Salvador, São Paulo) e Distrito Federal configura-se atualmente pela expressiva presença feminina, faixa etária acima de 25 anos de idade e melhoria da escolaridade. Grande parte dos trabalhadores da saúde tem vínculo adicional e significativa extensão da jornada de trabalho, com média entre as regiões de 57 horas de trabalho semanais.

A municipalização dos serviços foi uma marca no Brasil a partir da década de 1990 com o crescimento da oferta de postos de trabalho no setor público, cuja participação em 1992 representava 21\% do total de empregos públicos do SUS, aumentando em 65\% em 2002. Em oposição a um cenário de crescimento do desemprego no país, o setor saúde demonstrou vigor e aumentou exponencialmente sua força de trabalho com a absorção em 2003 de 4,3\% do total da população ocupada. O município passou a gestor da maioria dos 
serviços públicos (94,1\% do total) e é hoje o grande empregador do segmento público $(66,3 \%$ do total) por meio da expansão, principalmente, do segmento ambulatorial. O setor público passou a ser o maior empregador do sistema de saúde; o setor privado domina o segmento hospitalar e de apoio à diagnose e terapia. Do ponto de vista da análise macroeconômica, com sua capacidade de gerar emprego e renda, o setor saúde tem sido capaz de amortecer o impacto social do desemprego nos grandes centros urbanos com a incorporação de força de trabalho excedente. Entretanto, a desregulação, a desregulamentação e a flexibilização do trabalho atingiram também o setor que hoje tem cerca de 30\% dos empregos regidos por contratos irregulares, ou seja, precários (Girardi \& Carvalho, 2002; Machado, Moysés \& Oliveira, 2006; Machado \& Oliveira, 2006).

A despeito da incorporação de novas tecnologias, esse mercado necessita de força de trabalho intensiva, por isso permanece absorvendo grande contingente de trabalhadores, ao mesmo tempo que exige novas qualificações. A tendência à cooperativização e à terceirização no sistema público de saúde parece irreversível para manter o funcionamento de determinados programas após o advento da Lei de Responsabilidade Fiscal, a persistência de crises administrativas e orçamentárias e a disseminação de cooperativas de profissionais no SUS. Além do grande número de contratos precários, a municipalização foi acompanhada pelo rebaixamento salarial em todas as categorias profissionais (Machado, Moysés \& Oliveira, 2006; Machado \& Oliveira, 2006).

Para Dejours (2004b: 28), o trabalho é "aquilo que implica, do ponto de vista humano, o fato de trabalhar: gestos, 'saber-fazer', um engajamento do corpo, a mobilização da inteligência, a capacidade de refletir, de interpretar e de reagir às situações; é o poder de sentir, de pensar e de inventar, etc.". O trabalho ultrapassa o limite da temporalidade e, como caminho que não pode ser antecipado, deve ser descoberto ou inventado a cada momento pelo sujeito que trabalha. "Trabalhar é preencher a lacuna entre o prescrito e o real". É a realidade em oposição às prescrições, previsões, procedimentos. E seria de modo afetivo que o real se manifesta para o sujeito trabalhador, resultando em sentimentos de irritação, fracasso, impotência, decepção ou esmorecimento. "Assim, é numa relação primordial de sofrimento que o corpo faz simultaneamente a experiência do mundo e de si mesmo".

O trabalhador tem a necessidade de se reconhecer no próprio trabalho e também do reconhecimento do outro; precisa da valorização de seu trabalho e da coletivização, da presença de espaços públicos para troca de 
experiências. $\mathrm{O}$ adoecimento surge com o embrutecimento, a mecanização e o gesto automático e repetitivo, com a ausência de sentido e finalidade ou quando o trabalho é considerado aquém de suas capacidades. $\mathrm{O}$ isolamento e o sentimento de indignidade são engendrados quando o trabalhador perde a noção de seu caráter teleológico e de seu devir como movimento de criação (Dejours, 1987, 2004a).

Nesse contexto de precarização em tempos líquidos, a intensificação do trabalho também é uma realidade, e o trabalhador tem sido cada vez mais cobrado por resultados e por maior envolvimento em todos os espaços produtivos que se estendem para além da carga horária e dos locais de trabalho. Mais do que esforço físico, a intensidade relaciona-se a todas as capacidades do trabalhador: corpo, mente, afetividade, saberes adquiridos e transmitidos; portanto, está presente também no chamado trabalho imaterial, com efeitos fisiológicos, mentais, emocionais e relacionais na busca de aumento ou melhoria de resultados.

Além do envolvimento pessoal, o trabalhador faz uso de relações estabelecidas com outros sujeitos trabalhadores sem as quais o trabalho se tornaria inviável. As relações de cooperação com o coletivo dos trabalhadores, a transmissão de conhecimento entre si, que permite um aprendizado mútuo, as relações familiares, grupais e societais, que acompanham o trabalhador em seu dia a dia e que se refletem nos locais de trabalho, quer como problemas, quer como potencialidades construtivas, são levadas em conta na análise da intensificação do trabalho. (Dal Rosso, 2006: 68)

A esse respeito, Dal Rosso (2006: 73) afirma que, com a expansão do setor de serviços e do chamado "trabalho imaterial", surge a necessidade de se "desenvolver a noção de mais-valia relativa para responder às questões do trabalho intelectual e do envolvimento afetivo na geração do valor”, na medida em que se rompe com a rigidez do padrão de tempo de trabalho e de não trabalho, tornando-se cada vez mais difusa a fronteira entre eles e evidente a invasão do tempo de trabalho no de não trabalho. De acordo com pesquisa realizada pelo autor, o padrão da relação trabalho imaterial e saúde do trabalhador, representado em seu estudo pelos trabalhadores de telefonia, incluiu problemas de saúde, especialmente relacionados à esfera da saúde mental e outros problemas decorrentes de atividade predominantemente intelectual e relacional. Essa mesma pesquisa demonstrou que trabalhadores do ramo médico-hospitalar apresentaram altos índices de atestados médicos em decorrência de sobrecarga de trabalho $(33,3 \%$ do total). 
De alguma maneira, esse conjunto de condições negativas da saúde do trabalhador decorre de qualidades próprias do trabalho imaterial denso: tarefas que se repetem ininterruptamente por períodos prolongados, pressão sobre os trabalhadores sob a forma de cobranças de resultados por chefes e administradores, pressão, através das formas de controle sobre a quantidade e a qualidade do trabalho realizado, pressão por parte das exigências da clientela, que impõem um esforço mental e um controle emocional sobre-humanos, efeitos sobre o lado psíquico e relacional do trabalhador que deixam marcas sobre o corpo nas formas de tendinites, gastrites, hipertensões e que extrapolam o ambiente de trabalho, com reflexo sobre a vida familiar e social dos indivíduos. (Dal Rosso, 2006: 85)

No caso do setor saúde, poderíamos somar como fatores relacionados ao desgaste do trabalhador os baixos salários e as precárias condições de trabalho a que usualmente estão submetidos nos serviços, além de outras questões sociais como as decorrentes do crescimento da violência urbana nas grandes cidades esse trabalhador vive a violência e presta atendimento a pessoas vitimadas pela violência -, o que tem exposto esses trabalhadores a um perfil diferenciado de acidentes e doenças que necessitariam ser mais bem investigados (Chiodi \& Marziale, 2006; Assunção et al., 2007).

Além disso, muitas vezes, sob a "aparência de um despotismo mais brando", como diria Antunes (1999: 131), como tantos outros, o trabalhador da saúde se vê imerso em estranhamento, cooptado pelas formas e pelos mecanismos de estímulo ao engajamento e à participação e submetidos às necessidades do capital. Sob um discurso fetichizado, recorre-se, por exemplo, a termos como 'empregabilidade' para transferir aos trabalhadores a responsabilidade de sua qualificação, colocando-a como pré-requisito para uma possível entrada e permanência em um mercado altamente inseguro e cada vez mais excludente.

\section{Autonomia do Trabalho em Saúde: uma questão em debate}

Uma questão que não será aqui aprofundada, mas que se reveste de grande importância e controvérsia quando se discute gestão dos processos de trabalho e a saúde do trabalhador da saúde, é o tema 'autonomia', que remete à liberdade e criação no âmbito do trabalho. Para Rosenfield (2004), no novo padrão produtivo em que o trabalho tornou-se mais complexo, de natureza e conteúdo mais ricos e com maior demanda de investimento subjetivo e de mobilização das capacidades intelectuais e cognitivas, ensejou-se a criação de dispositivos que procuram garantir maior autonomia ao trabalhador, de modo 
a controlar imprevistos e impedir o comprometimento da qualidade e rapidez nos processos produtivos. Haveria o incitamento à criação para, em seguida, integrá-la à norma, pois se trata de autonomia submetida à ordem econômica e concebida 'pelos' agentes da concepção 'para' o trabalhador.

A empresa busca, portanto, aumentar sua capacidade de reação aos problemas mais diversos, melhorar a qualidade dos produtos, dispor de meios mais confiáveis, favorecer a flexibilidade da produção e controlar rigidamente os custos de produção. Para alcançar tais objetivos, revela-se necessário um dispositivo organizacional e de gestão de pessoas que permita aos trabalhadores maior autonomia e responsabilidade, melhoria nas condições de trabalho e de segurança, um trabalho interessante e, ainda, a evolução das competências. (Rosenfield, 2004: 204)

Rosenfield (2004) define autonomia como a preservação da capacidade de decidir, escolher, intervir nos rumos da produção ou influenciá-los, como margem de independência em relação ao prescrito. Aproxima-se da definição de "brecha das normas" proposta pela ergologia de Schwartz (2002) como forma e possibilidade de resistência dos trabalhadores em um universo, de modo geral, regido por protocolos preestabelecidos. No entanto, em vez de uma autonomia real, o que se percebe é uma autonomia outorgada, uma regra, uma fórmula prescritiva dos tempos modernos de maneira a incluir o inesperado à regra. Em oposição à autonomia no seu sentido positivo, ou seja, aquela que remete ao 'fazer bem' e que preserva o grupo como base identitária conferindo sentido ao trabalho, a autonomia outorgada seria instrumental - funcionaria como instrumento de coordenação das relações de trabalho visando a atingir um objetivo econômico de gestão, fato observado tanto no ambiente privado como no público.

A respeito do tema, Cecílio (1999) afirma que a questão do poder é central nas organizações de saúde pública e que controle e autonomia se encontram em constante tensionamento nos processos gestionários, mesmo naqueles pretensamente democráticos e participativos. Desprezando-se a concepção funcionalista de recursos humanos como um dos recursos necessários para o funcionamento do sistema, o autor defende a ideia de que não se deve reconhecer o trabalhador como tipo ideal ou mesmo por suas funções, atribuições, definições rígidas ou papéis na organização. Afirma que os conceitos de 'equipe' e de 'trabalhador de saúde' também devem ser problematizados na medida em que eles obscurecem distintos estamentos profissionais, assimetrias entre portadores de poderes/saberes, "constituindo arranjos institucionais muito 
complexos, instituídos nos seus interesses, arranjos, ocultamentos e esquemas de todos os tipos" (Cecílio, 1999: 324). Daí a necessidade de criação de dispositivos ou contextos de negociação - em um processo complexo, permanente e dialógico - para encontro e confrontação de todos os seus sujeitos e das numerosas racionalidades organizacionais.

O mesmo autor, ao discutir a micropolítica do trabalho em saúde e a gestão do cuidado, traz à baila o conceito de 'trabalhador moral' na saúde, apresentando instigante reflexão acerca dos riscos de uma "visão objetivante e instrumentalizadora dos trabalhadores de saúde, substimando seu protagonismo e sua força instituinte" (Cecílio, 2007: 351). O trabalhador moral seria aquele que faria adesão automática a determinados conceitos, modos de se organizar o cuidado e modos de se fazer a gestão, formulados por militantes/ intelectuais/gestores engajados na reforma sanitária, por serem eles, em princípio, justos e necessários. Cecílio (2007) destaca ainda a necessidade de se fugir da tentação de capturar, mesmo que de forma sutil, aquilo que há de liberdade e autonomia no fazer dos trabalhadores por meio de dispositivos de controle "democráticos e participativos" quando os movimentos instituintes desses atores não se dão nos sentidos desejados.

Por essa razão penso que o ponto de partida de toda a pretensão de se conduzirem mudanças verdadeiras na forma de se fazer a gestão e de se organizar o cuidado em saúde deva ser a capacidade de aprender a interrogar o mundo do trabalho, antes de propor aprioristicamente conceitos e/ou modos muito prescritivos de se fazer a gestão. Os dispositivos de gestão, se é que podemos chamá-los assim, são o próprio ato de interrogar. Talvez o mais difícil seja não pretender penetrar nesse mundo já armado com fórmulas, definições prévias de modelos, métodos ou arranjos de intenções "democratizantes" e conseguir construir uma postura de interrogação do mundo do trabalho no seu dia a dia concreto. (Cecílio, 2007: 348)

Talvez a melhor forma de se enfrentar a exploração do trabalhador nesses tempos líquidos seja o resgate de poder dos próprios trabalhadores sobre o seu processo de trabalho, de modo a atenuar os seus efeitos deletérios. É tornar possível a participação na tomada de decisões no âmbito dos ambientes produtivos; é conhecer o trabalho, as atividades, discuti-las, refletindo e agindo para mudanças. É enfrentar conflitos e buscar consensos no cotidiano, integrando redes e assumindo responsabilidades e compromissos com o coletivo. É preciso resgatar fundamentalmente espaços de negociação que propiciem a construção de laços de solidariedade. 
Trabalhador de saúde que vê sua autonomia ameaçada por mecanismos sutis (ou nem tão sutis) de captura, uniformização e padronização, não poderá de forma verdadeira contribuir para o fortalecimento da autonomia daquele de quem cuida. O trabalhador só poderá entender e, o que é mais importante, praticar o conceito de que estar sadio é manter, recuperar ou ampliar a autonomia no modo de administrar a vida, na medida em que vivenciar sua própria autonomia, cultivada e amadurecida a cada dia nas relações concretas que estabelece com os demais atores que constroem a sempre precária realidade organizacional. Sua autonomia referenciada, da forma plena possível, à autonomia do outro - um encontro de autonomias. (Cecílio, 2007: 350)

De acordo com Rollo (2007), existem ainda outros significativos obstáculos para viabilizar a valorização do trabalho e dos trabalhadores da saúde, como a baixa legitimidade social do SUS e o subfinanciamento do sistema, não chegando os gastos em saúde a $\mathrm{R}$ \$1,00/dia/habitante no Brasil. A saída passa pela formação de alianças e construção de movimentos político-sociais que forcem a destinação de mais recursos para o sistema e a melhoria da gestão 'no' e 'do' SUS, além do fomento de processos moleculares dos atores - trabalhadores, gestores, usuários - para produzir mudanças nos espaços cotidianos das práticas de atenção e gestão na saúde (Rollo, 2007). O impacto da desregulamentação e da liberalização no âmbito dos serviços de saúde com o processo de precarização observado no contexto público incluiu mudanças nas condições de emprego e renda, o enfraquecimento da coesão e de movimento dos trabalhadores e a piora das condições de trabalho, indicando a premência de desprecarização de vínculos de trabalho nas três esferas de governo.

\section{Considerações Finals}

Parte da vida, o mundo do trabalho, antes aparentemente tão organizado e estável, é caracterizado por agudas transformações no contemporâneo. Para além do debate em torno de sua centralidade, o trabalho permanece marco de sociabilidade, constituindo-se como possibilidade identitária e de construção de laços sociais. Além de garantir a sobrevivência, não há como negar que, ainda hoje, as pessoas se reconhecem e se situam na sociedade a partir do trabalho, e ele toma grande parte do tempo e do espaço da vida de cada um. No entanto, há algo de inusitado na relação com o trabalho, mudanças e processos que estamos vivenciando nesse momento e que ainda não foram por nós totalmente compreendidos ou assimilados. Nesse cenário, há algo 
de novo e surpreendente no ar, alguma coisa ainda indeterminada e que nos tem feito transitar de uma postura ingênua ou demasiadamente otimista ao pessimismo e total incredulidade, deixando a todos perplexos com a fluidez e imprecisão desses novos processos.

Nesse cenário 'líquido', deve-se reconhecer que o trabalhador da saúde pública não é um só nem está inserido em um só contexto - ele se diferencia por meio dos seus vários atores, das várias corporações, estratos e classes, de relações de gênero, raça e etnia, de vínculo e inserção nas instituições e serviços, do encerramento de saberes/poderes. Porém, creio ser possível falar de uma certa unidade do trabalho em saúde ou de algo em comum a todo o grupo de trabalhadores que se dedicam ao cuidado de outras pessoas. É um trabalho relacional e de caráter coletivo; mistura trabalho intensivo e tecnológico com troca de saberes e de afetos; coloca em xeque diariamente subjetividades na interação e no lidar com o sofrimento humano. Seu aspecto relacional impõe que as questões referentes ao mundo do trabalho e, especificamente, à saúde do trabalhador sejam definitivamente incorporadas nas reflexões e discussões cotidianas no âmbito da sociedade, no intuito de informar e sensibilizar o conjunto de atores envolvidos na atenção à saúde e estimular processos solidários e de (re)conhecimento do outro. Para além das discussões puramente teórico-conceituais, é trabalho de gente com gente, o que irremediavelmente nos remete a um plano pluridimensional, de indefinições e de renormalizações que se constituem no âmago das relações e da solidariedade, de defesa da vida, este o ponto comum.

A tentativa de romper com o elo dor-desprazer-trabalho ${ }^{1}$ no campo da saúde implica pensar em novas situações, refletir sobre possibilidades humanas. É pensar o individual e o coletivo, pois o trabalho em saúde requer necessariamente a socialização, a cooperação, a emergência de ações grupais, a coparticipação, a conformação de redes. É levar em consideração as exigências contemporâneas de uma incessante e rápida incorporação de novos conhecimentos e tecnologias por parte dos trabalhadores e do desenvolvimento de habilidades comunicacionais e de manejo de informações de forma contínua. É entender esse labor no seu profundo e irremediável envolvimento com o universo da saúde e da doença, da dor, da vida e da morte e suas inevitáveis repercussões físicas, mentais e sociais (Hennington, 2008).

Bauman (2001), referindo-se aos sociólogos, afirma que, como os poetas, sua vocação é buscar arruinar muros que nos separam do desconhecido; é demolir

1 Tema abordado por Barros e Barros (2007) no capítulo "Da dor ao prazer no trabalho", ao discutir a valorização dos trabalhadores da saúde pela Política Nacional de Humanização. 
muralhas das evidências e do óbvio para uma aproximação das possibilidades humanas ainda ocultas. A realidade não se encontra encoberta, esperando por nós e pronta a ser desvelada. Em uma sociedade flutuante e porosa de indivíduos frágeis, em que a velocidade tornou-se valor máximo de sobrevivência, resta-nos a reflexão. No entanto, o pensamento a longo prazo demanda pausa e descanso, tempo, recapitulação, exame e sabedoria a respeito do ponto que alcançamos. O autor salienta que não é possível deixar de reconhecer a natureza contingente e mutante do homem e da não inevitabilidade da ordem social que nos leva à infelicidade. Nem é possível recusar nosso destino de viver em conjunto e de cultivar a liberdade das escolhas. Ele nos diz ainda que "uma sociologia descomprometida é uma impossibilidade” (Bauman, 2001: 246). Pesquisar e refletir, investigar, pensar alternativas, buscar a compreensão e possíveis caminhos de enfrentamento das inquietações presentes no mundo do trabalho hoje é uma tarefa árdua e necessária. Parafraseando Bauman (2001: 232), uma pesquisa descomprometida é uma impossibilidade. Criar/descobrir é quebrar regras, e "talvez o verso que o poeta procura tenha estado 'sempre lá".

\section{REFERÊNCIAS}

ALVES, G. O Novo (e Precário) Mundo do Trabalho: reestruturação produtiva e crise do sindicalismo. São Paulo: Boitempo Editorial, 2000.

AMORIM, H. J. D. A Valorização do Capital e o Desenvolvimento das Forças Produtivas: uma discussão crítica sobre o trabalho imaterial, 2006. Tese de Doutorado, Campinas: Universidade Estadual de Campinas.

ANTUNES, R. L. C. Adeus ao Trabalho? São Paulo: Cortez, 1995.

ANTUNES, R. L. C. Os Sentidos do Trabalho: ensaio sobre a afirmação e a negação do trabalho. São Paulo: Boitempo Editorial, 1999.

ANTUNES, R. L. C. \& ALVES, G. As mutações no mundo do trabalho na era da mundialização do capital. Educação $\mathcal{E}$ Sociedade, 25(87): 335-351, 2004.

ASSUNÇÃO, A. A. et al. Recursos humanos e trabalho em saúde: os desafios de uma agenda de pesquisa. Cadernos de Saúde Pública, 23(supl.2): S193-S201, 2007.

BARROS, R. B. \& BARROS, M. E. B. Da dor ao prazer no trabalho. In: SANTOSFILHO, S. B. \& BARROS, M. E. B. (Orgs.) Trabalhador da Saúde: muito prazer! Protagonismo dos trabalhadores na gestão do trabalho em saúde. Ijuí: Ed. Unijuí, 2007.

BAUMAN, Z. O Mal-Estar da Pós-Modernidade. Rio de Janeiro: Jorge Zahar, 1998.

BAUMAN, Z. Modernidade Liquida. Rio de Janeiro: Jorge Zahar, 2001.

BAUMAN, Z. Amor Liquido: sobre a fragilidade dos laços humanos. Rio de Janeiro: Jorge Zahar, 2004. 
BAUMAN, Z. Vida Liquida. Rio de Janeiro: Jorge Zahar, 2007a.

BAUMAN, Z. Tempos Líquidos. Rio de Janeiro: Jorge Zahar, 2007b.

BEAGLEHOLE, R. \& DAL POZ, M. R. Public health workforce: challenges and policy issues. Human Resources for Health, 1: 4, 2003. Disponível em: <www.humanresources-health.com/content/1/1/4>. Acesso em: 10 maio 2007.

CECÍLIO, L. C. O. Autonomia versus controle dos trabalhadores: a gestão do poder no hospital. Ciência E⿱ Saúde Coletiva, 4(2): 315-329, 1999.

CECÍLIO, L. C. O. O "trabalhador moral” na saúde: reflexões sobre um conceito. Interface: comunicação, saúde, educação, 11(22): 345-363, 2007.

CHERCHIGLIA, M. L. et al. Remuneración y productividade: el caso de la Fundación Hospitalaria del Estado de Minas Gerais, Brasil, 1992-1995. Revista Panamericana de Salud Pública, 4(2): 112-120, 1998.

CHIODI, M. B. \& MARZIALE, M. H. P. Riscos ocupacionais para trabalhadores de unidades básicas de saúde: revisão bibliográfica. Acta Paulista de Enfermagem, 19(2): 212-217, 2006.

COSTA, M. S. O sistema de relações de trabalho no Brasil: alguns traços históricos e sua precarização atual. Revista Brasileira de Ciências Sociais, 20(59): 111-131, 2005.

DAL ROSSO, S. Intensidade e imaterialidade do trabalho e saúde. Trabalho, Educação e Saúde, 4(1): 65-91, 2006.

DEJOURS, C. A Loucura do Trabalho: estudo de psicopatologia do trabalho. 2. ed. São Paulo: Cortez, Oboré, 1987.

DEJOURS, C. Da Psicopatologia à Psicodinâmica do Trabalho. Rio de Janeiro, Brasília: Editora Fiocruz, Paralelo 50, 2004a.

DEJOURS, C. Subjetividade, trabalho e ação. Revista Produção, 14(3): 27-34, 2004b.

DIEESE (Departamento Intersindical de Estatística e Estudos Socioeconômicos). O Trabalhador da Saúde em Seis Regiões Metropolitanas Brasileiras. Nota Técnica n. 33, set. 2006. Disponível em: <www.dieese.org.br/notatecnica/notatec33saude.pdf>. Acesso em: 9 out. 2007.

EGGER, D.; LIPSON, D. \& ADAMS, O. Issues in Health Services Delivery: human resources for health. Geneva: World Health Organization, 2000.

FRANCO, L. M.; BENNETT, S. \& KANFER, R. Health sector reform and public sector health worker motivation: a conceptual framework. Social Science $\mathcal{E}$ Medicine, 54: 1.255-1.266, 2002.

FRITZEN, A. S. Strategic management of the health workforce in developing countries: what have we learned? Human Resources for Health, 5: 4, 2006. Disponível em: <www. human-resources-health.com/content/5/1/4>. Acesso em: 14 maio 2007.

GIRARDI, S. N. \& CARVALHO, C. L. Configurações do mercado de trabalho dos assalariados em saúde no Brasil. Formação, 2(6): 15-36, 2002. 
GUEVARA, E. B. \& MENDÍAS, E. L. A comparative analysis of the changes in nursing practices related to health sector reform in five countries of the Americas. Revista Panamericana de Salud Pública, 12: 347-353, 2002.

HARDT, M. O trabalho afetivo. In: PELBART, P. P. \& COSTA, R. (Orgs.) Cadernos de Subjetividade: o reencantamento do concreto. São Paulo: Hucitec, 2003. (Núcleo de Estudos e Pesquisas da Subjetividade do Programa de Estudos Pós-Graduados em Psicologia Clínica da PUC/SP.)

HARDT, M. \& NEGRI, A. Império. 7. ed. Rio de Janeiro: Record, 2005.

HENNINGTON, E. A. Gestão dos processos de trabalho e humanização em saúde: reflexões a partir da ergologia. Revista de Saúde Pública, 42(3): 555-561, 2008.

ILO (International Labor Organization). Terms of Employment and Working Conditions in Health Sector Reforms. Report for discussion at the Joint Meeting on Terms of Employment and Working Conditions on Health Sector Reforms. Geneva: ILO, 1998.

KABENE, S. M. et al. The importance of human resources management in health care: a global context. Human Resources for Health, 4: 20, 2006. Disponível em: <www. human-resources-health.com/content/4/1/20>. Acesso em: 10 maio 2007.

LAZZARATO, M. \& NEGRI, A. Trabalho Imaterial e Subjetividade. Rio de Janeiro: DP\&A, 2001.

MACHADO, M. H. \& OLIVEIRA, E. S. Mercado de trabalho em saúde: em que trabalham e quem emprega estes trabalhadores? In: MACHADO, M. H.; MOYSÉS, N. M. N. \& OLIVEIRA, E. S. Trabalhadores de Saúde em Números. v. 2. Rio de Janeiro: Escola Nacional de Saúde Pública Sergio Arouca, 2006.

MACHADO, M. H.; MOYSÉS, N. M. N. \& OLIVEIRA, E. S. Trabalhadores de Saúde em Números. v. 2. Rio de Janeiro: Escola Nacional de Saúde Pública Sergio Arouca, 2006.

NOGUEIRA, R. P. O Trabalho em Serviços de Saúde. Disponível em: <www.opas.org. br/rh/publicacoes/textos_apoio/Textos_3.pdf>. Acesso em: 8 out. 2007.

RIGOLI, F. \& DUSSAULT, G. The interface between health sector reform and human resources in health. Human Resources for Health, 1: 9, 2003. Disponivel em: <www. human-resources-health.com/content/>. Acesso em: 14 maio 2007.

ROLLO, A. A. É possível valorizar o trabalho na saúde num mundo "globalizado"? In: SANTOS-FILHO, S. B. \& BARROS, M. E. B. (Orgs.) Trabalhador da Saúde: muito prazer! Protagonismo dos trabalhadores na gestão do trabalho em saúde. Ijuí: Ed. Unijuí, 2007.

ROSENFIELD, C. L. Autonomia outorgada e apropriação do trabalho. Sociologias, 12(6): 202-227, 2004.

SCHWARTZ, Y. A abordagem do trabalho reconfigura nossa relação com os saberes acadêmicos: as antecipações do trabalho. In: SOUZA-E-SILVA, M. C. P. \& FAÏTA, D. (Orgs.) Linguagem e Trabalho: construção de objetos de análise no Brasil e na França. São Paulo: Cortez, 2002.

UGALDE, A. \& HOMEDES, N. Las reformas neoliberales del sector de la salud: déficit gerencial y alienación del recurso humano en América Latina. Revista Panamericana de Salud Pública, 17(3): 202-209, 2005. 


\section{Condições de Trabalho e Saúde dos \\ Trabalhadores da Saúde}

Ada Ávila Assunção

\section{Antecedentes}

Os trabalhadores da saúde ocupam posição-chave na sociedade, pois assistem os indivíduos e suas comunidades. No entanto, eles mesmos constituem um grupo vulnerável, pois as manifestações de insatisfação e de adoecimento convivem com as carências de medidas de proteção à saúde. Embora esparsos, incompletos e fragmentados, os dados sobre as condições de saúde e trabalho desse grupo indicam o aumento da frequência das doenças e dos acidentes ocupacionais, ambos evitáveis com a adoção de medidas preventivas (Smith, Leggat \& Araki, 2007; WHO, 2006).

Existem evidências de que as diferenças em saúde estão relacionadas aos fatores sociais que configuram as condições de vida das populações (ONU, 2005; Marmot, 2005). Entre as condições gerais de vida, as de trabalho constituem-se em indicadores das desigualdades sociais geradas em contextos específicos.

As condições de trabalho incluem dois polos: 1) as condições de emprego que dizem respeito à natureza da relação entre o empregador (ou a empresa) e o empregado; 2) as condições de trabalho propriamente ditas - que designam as pressões e os constrangimentos presentes no ambiente físico e organizacional em que as tarefas são desenvolvidas.

No mundo contemporâneo, a força de trabalho encontra-se distribuída desigualmente quanto às características contratuais do emprego. Os trabalhadores sem contrato de trabalho padrão estão sujeitos a longas jornadas, a menos acesso à informação sobre a exposição aos riscos ambientais e ao desamparo diante dos afastamentos por adoecimento, entre outras situações (Papadopoulos et al., 2010). 
As circunstâncias em que os processos de trabalho são desenvolvidos não se constituem, na maioria das vezes, objeto de debate e permanecem invisíveis para a gestão dos sistemas. O reconhecimento de determinadas circunstâncias como sendo condições de trabalho tem relação direta com o enfrentamento das forças sociais contraditórias que norteiam os processos produtivos, incluída a produção de serviços de saúde.

Por esse prisma, as circunstâncias de realização de determinada atividade são definidas e 'reconhecidas' (ou negadas) como condições de trabalho em um determinado contexto histórico-social. Por isso, as condições de trabalho não são dadas a priori, estão abertas a novos critérios e não são inerentes aos processos de trabalho, por serem marcadas pela sua historicidade.

Do ponto de vista dos trabalhadores em saúde, os relatórios do I Fórum Mundial sobre Recursos Humanos para a Saúde em Kampala (2008); ${ }^{1}$ Alliance Mondiale pour les Personnels de Santé (OMS, 2008); 3a Conferência Nacional de Saúde do Trabalhador (Brasil, 2005); 3a Conferência Nacional de Gestão do Trabalho e Educação em Saúde (2005)² sinalizam enfrentamentos cotidianos diante das condições inadequadas de trabalho. Várias queixas são relatadas: por um lado, eles nem sempre contam com os recursos e meios necessários para desenvolver as suas tarefas (faltam medicamentos, a equipe está incompleta, a referência não funciona, o laboratório está subdimensionado etc.); por outro, estão cansados, os salários são baixos, falta reconhecimento pelos investimentos pessoais no desenvolvimento das tarefas e as avaliações de desempenho levam em conta os números e não os resultados.

As inquietações expostas e as iniciativas dos governos e das agências provocaram, nos últimos anos, o debate sobre o trabalho no setor saúde, visando construir uma infraestrutura humana para os sistemas. Propõem-se ações para melhorar a saúde e a satisfação dos trabalhadores da saúde (OMS, 2008; UFMG, 2007).

Desde a Cúpula das Américas realizada no Quebec, em 2001, os representantes dos países têm reconhecido que o trabalho é a melhor via para vincular crescimento econômico e qualidade de vida dos cidadãos. Nessa perspectiva, impulsionada pelo apoio dos ministros do trabalho de 34 países membros da Organização dos Estados Americanos (OEA), a Organização Pan-Americana da Saúde (Opas) incorporou o tema da saúde dos trabalhadores no marco do Trabalho Decente da Organização Internacional do Trabalho e da Iniciativa

1 Disponível em: <www.who.int/mediacentre/news/releases/2008/pr06/es/print.html>.

2 Disponível em: $\langle$ http://portal.saude.gov.br/portal/arquivos/pdf/cadernos_rh.pdf〉. 
de Ambientes de Trabalho Saudáveis da Organização Mundial da Saúde (UFMG, 2007).

A Organização Mundial da Saúde (OMS) e a Opas dedicaram o ano de 2006 aos recursos humanos em saúde. Ações concretas marcaram o Dia Mundial da Saúde e a Semana Pan-Americana da Saúde, quando foi realizado um conjunto de eventos que divulgaram e promoveram a valorização dos recursos humanos que atuam em saúde (OMS, 2006).

Na mesma direção, o Ministério da Saúde do Brasil consagrou 2006 como o Ano dos Trabalhadores em Saúde. Juntamente com a Opas/OMS, elaborouse uma proposta, cujo tema "Gente que faz saúde" sinaliza a necessidade de ampliação das ações em prol dos trabalhadores em saúde no país (OPS, 2006).

Iniciativas governamentais e de gestão buscam a proteção contra as situações de violência presentes nos estabelecimentos de saúde ou contra acidentes que provocam contato com fluidos corpóreos contaminados por vírus das hepatites ou síndrome da imunodeficiência humana. Ações diversas visam à elaboração de medidas que abarcam desde a fabricação de seringas até o seu descarte, com ênfase nas precauções universais (National Institute Occupational of Safety and Health, 2007).

Condições outrora desconhecidas ou consideradas inerentes aos processos são encaradas, na atualidade, como inadmissíveis pela gestão, pelos estados, pelos organismos internacionais e pela organização dos trabalhadores (PrüssÜstün, Rapiti \& Hutin, 2003). No entanto, os resultados obtidos até agora são insuficientes, a julgar pelo exposto nas pesquisas que serão apresentadas neste texto.

Vale ressaltar as transformações recentes nas práticas de saúde, entre elas a mudança de paradigma sobre o cuidado que introduz novos conceitos e técnicas com reflexos sobre os processos de trabalho. Paralelamente, a rápida expansão da tecnologia inova os procedimentos no cotidiano dos estabelecimentos de saúde, acentuando a complexidade das tarefas. Os custos para o funcionamento dos sistemas aumentaram e provocam desafios para a gestão orçamentária, implicando restrições quando o assunto se refere às condições de trabalho.

A dinâmica do perfil epidemiológico das populações atendidas nos estabelecimentos da saúde origina a justaposição dos riscos profissionais clássicos (químicos e físicos) aos riscos biológicos emergentes e aos relacionados ao excesso de demanda e à polivalência (riscos psicossociais), como se verá adiante. Exemplificando, na atualidade, mais de cem diferentes tipos de quimioterápicos 
antineoplásicos (QA) estão em uso, e outros tipos estão sendo desenvolvidos a fim de melhorar a qualidade de vida dos pacientes com câncer até a cura total. A maior carga do câncer e o tipo de terapia (altas doses de QA, combinações de vários medicamentos, uso de QA para outros tipos de doenças) aumentarão o potencial de exposição ocupacional nos ambientes sanitários (Connor $\&$ McDiarmid, 2006). Chegam para o atendimento pacientes desconhecidos quanto à possibilidade de transmissão de doenças infecciosas; e mudanças demográficas explicam o aumento do número de pacientes com idade avançada e dependentes, demandando cuidados que exigem esforço (físico e emocional) dos profissionais para agirem diante das doenças crônicas, entre elas as neurológicas. Os sintomas psíquicos e a prevalência aumentada de doenças mentais em nível global acentuam o cenário de múltiplas demandas para os trabalhadores e para o trabalho em saúde (Mawn et al., 2010).

Tudo isso significa que os objetivos das reformas sanitárias implicam satisfazer as demandas dos usuários. No entanto, os recursos materiais, técnicos e organizacionais disponíveis são, na maioria dos casos, insuficientes para responder de modo adequado e eficiente às diversas solicitações.

Apresenta-se aqui panorama multifacetado e, ainda, pouco conhecido das condições de trabalho no setor saúde.

\section{As Condições de Emprego dos Trabalhadores da Saúde no Brasil}

Múltiplas instituições, de caráter público ou privado, formadoras ou empregadoras, compõem o setor saúde. Escolas ou faculdades conferem diplomas, os quais são certificados pelas diferentes corporações específicas a cada profissão. São diferentes tipos de organizações, como hospitais, laboratórios, unidades de saúde, rede pública de serviços etc., as quais operam com diferentes lógicas e visões, baseadas em distintas regulamentações e vocações.

No Brasil, em 2007, foram registrados 2.566.694 empregos no setor saúde. Entre eles, 56,4\% estão no setor público e 43,6\%, no setor privado. Quanto à esfera administrativa, a distribuição dos empregos é a seguinte: 4,1\% federais; 13,5\% estaduais; $38,8 \%$ municipais; $24,9 \%$ privados, com fins lucrativos; e 18,6\% privados, sem fins lucrativos. Cada esfera emprega com regime próprio Consolidação das Leis Trabalhistas ou Regime Jurídico Único. As mulheres representam quase $80 \%$ da força de trabalho em saúde (Brasil, 2007).

A gama de profissionais contempla aqueles responsáveis pela atividade-fim e os inseridos no âmbito da gestão, do desenvolvimento e da manutenção dos 
estabelecimentos de saúde. Essa diversidade impõe análises complexas, as quais são intensificadas pela constatação dos diferentes vínculos e contratos possíveis, como se verá adiante.

Estudando a geração dos novos postos de trabalho em consequência da ampliação da cobertura dos serviços de atendimento à saúde, fica nítido o potencial elevado de formalização do emprego no setor se comparado com a média do mercado de trabalho brasileiro. Analisando os dados obtidos, Dedecca e colaboradores (2005) concluem que: o impacto do gasto do setor saúde para a geração de ocupações extrapola a dimensão da sua atividade-fim; é ponderável o efeito da geração de ocupações do setor (4,2\% da população economicamente ativa); há elevado potencial de formalização dessas ocupações.

Apesar das tendências de expansão e de formalização do emprego, a análise do banco de dados da pesquisa de Dedecca e colaboradores (2005) evidenciou que 23.862 do universo de 198.153 médicos estavam, em 2000, trabalhando sem carteira assinada, e que os demais estavam distribuídos nas categorias dos empregadores ou dos trabalhadores por conta própria e estagiários.

No universo dos atendentes de enfermagem (não diplomados), a distribuição encontrada dos profissionais foi a seguinte: 132.080 empregados com carteira assinada; 41.740 empregados pelo Estado; 32.305 empregados sem carteira de trabalho assinada; 7.230 estagiários; 766 não remunerados.

As condições básicas de trabalho são bastante diferenciadas entre as ocupações nucleares; a recorrência de mais de um emprego é específica para os médicos; o maior número de trabalhos tende a ser associado a uma remuneração/hora mais baixa.

Com base nos dados apresentados, pode-se dizer que a expansão do emprego em saúde se dá na ausência de um contrato de trabalho padrão, à semelhança do que já vem ocorrendo no Brasil, onde essa situação abrange em torno de $42 \%$ da força de trabalho metropolitana (Ramos \& Ferreira, 2006).

Globalmente, proliferam o contrato não regulamentado, o contrato de trabalho por tempo parcial, o emprego por tempo determinado, a terceirização, a subcontratação e até contratos verbais estabelecidos entre prefeituras e médicos ou entre prefeituras e agentes comunitários de saúde. No setor público, há cargos comissionados, contratos temporários, terceirizados ou triangulados com as universidades (Brasil, 2007; Coelho, Assunção \& Belisário, 2009). O cenário exposto explica a vigência de mais de uma conduta normativa para orientar os contratos nos estabelecimentos de saúde, dificultando a negociação de reivindicações entre as diferentes entidades de trabalhadores e gestores. 
No Brasil, está constituída a Mesa Nacional de Negociação Permanente do Sistema Único de Saúde (SUS), organizada em duas bancadas, designadas bancada governamental e sindical, cujo objetivo é estabelecer um fórum permanente de negociação entre empregadores e trabalhadores do SUS. Entre os protocolos assinados, estão as diretrizes nacionais para a instituição de Planos de Carreira, Cargos e Salários no âmbito do SUS (Brasil, 2006, Flegele et al., 2010).

O panorama do emprego em saúde reflete os caminhos da reforma do setor no Brasil, o qual aumentou as responsabilidades sanitárias dos municípios, levando à necessidade de incremento da força de trabalho para a execução das novas políticas de saúde. Preocupados em atender às novas demandas dos modelos assistenciais (Programa de Saúde da Família, por exemplo) e diante dos limites legais para os gastos financeiros, os municípios optaram por contratar trabalhadores, utilizando alternativas ao contrato padrão (Machado, 2005; Cordeiro, 2001).

Em suma, identifica-se uma discrepância entre a expansão das contratações de recursos humanos e a criação de novos postos no mercado de trabalho e a insuficiência do volume orçamentário a elas destinado.

Vale lembrar que a proposta de reforma defendeu a substituição do modelo administrativo do Estado sem, contudo, atingir propriamente os problemas de fundo que geram a desigualdade no país, permanecendo, entre eles, o padrão de financiamento do Estado (Soares, 2000). Nesse quadro, a saída encontrada pelo sistema foi restringir o acesso aos direitos trabalhistas e sociais.

A iniciativa dos empregadores da saúde está em consonância com as tendências de desregulamentação do trabalho vigentes no mundo. $O$ processo de precarização do emprego em saúde se dá à semelhança do ocorrido em outros setores da produção. A precarização é processo social constituído pela amplificação e pela institucionalização da instabilidade e da insegurança, expressas nas novas formas de organização do trabalho - em que a terceirização/ subcontratação ocupa um lugar central - e no recuo do papel do Estado como regulador do mercado de trabalho e de proteção social por meio das inovações da legislação do trabalho e previdenciária (Thébaud-Mony \& Druck, 2007).

Em Belo Horizonte, o emprego sem contrato de trabalho padrão predominou ao longo do período de 2002 a 2006, coincidindo com a implantação do Programa de Saúde da Família (PSF). Coelho, Assunção e Belisário (2009) evidenciaram a redução do poder de compra dos médicos, dentistas, técnicos de nível superior e agentes de saúde. Para as autoras, o quadro justificaria as políticas governamentais, visando à reversão da tendência assinalada. 
No plano do trabalho, há efeitos agudos gerados na dinâmica das novas formas de empregos e de contratos. Entre tais efeitos, destaca-se a tendência de os trabalhadores sob regime precário estarem expostos a piores condições de trabalho. As opções de organização da produção interferem nas estratégias de gestão adotadas pelas empresas. Essas opções afetam as políticas de emprego, mas também influenciam e marcam a divisão de tarefas, a organização temporal do trabalho, os prazos e adoção das normas técnicas (Daubas-Letourneux \& Thébaud-Mony, 2003).

Os resultados apresentados neste texto confirmam a tendência contemporânea assinalada por Antunes (2007). Para este autor, de forma geral, os trabalhadores sem contrato padrão vivem com menos segurança em seus ambientes ocupacionais, como será evidenciado nos estudos sobre prevalências de acidentes e de taxa de vacinação. Com este quadro de precarização estrutural, a flexibilização da legislação social trabalhista aumenta ainda mais os mecanismos de intensificação do trabalho e de seus efeitos sobre a saúde.

Quanto à formação e ao desenvolvimento de competências, problemas adicionais são impostos. Os profissionais sem contrato de trabalho padrão desempenham funções menos exigentes do que poderiam executar (Galeazzi, 2007) e teriam menos chance de aprendizagem ao longo da vida, o que é fundamental para atribuir sentido ao trabalho e para enfrentar os efeitos das transformações registradas no ambiente. No conjunto, essa realidade pode explicar as iniquidades em saúde do trabalhador evidenciadas nos estudos contemporâneos citados a seguir.

\section{A Saúde dos Trabalhadores da Saúde}

Trabalhar em saúde pode ser uma via para a autorrealização e para a construção de identidades, haja vista o objetivo central em assistir o outro que demanda cuidado. Na maioria dos casos, é um trabalho portador de sentido para os seus protagonistas. Porém, há sinais de insatisfação associados aos indicadores de adoecimento nas diversas categoriais profissionais que representam o setor.

Os efeitos psicológicos negativos gerados pelos contatos diretos com a dor e o sofrimento dos doentes e pelos níveis excessivos de responsabilidade exigidos são agravados nas situações em que o tempo para planejar e preparar o trabalho é insuficiente, as interrupções são constantes e o poder de decisão é mínimo (Demerouti et al., 2000). Para Demerouti e colaboradores, tais efeitos são preditores do burnout. 
A exaustão emocional, a despersonalização e a diminuição da realização pessoal no trabalho são as três dimensões relacionadas ao burnout. A síndrome de burnout é uma reação emocional crônica do profissional por lidar constantemente com as demandas dos usuários (Maslach \& Jackson, 1981).

Os trabalhadores da enfermagem relatam que, às vezes, são atacados fisicamente, outras vezes enfrentam os discursos hipersexualizados dos seus pacientes internados em enfermarias psiquiátricas. Escabiose e pediculose foram citadas pelos sujeitos entrevistados como resultantes da aproximação física durante os procedimentos clínicos ou de higiene. Hematomas, contusões, fraturas e edemas são destacados como consequências das agressões vivenciadas, mas, também, como marcas visíveis dessas agressões. Adicionalmente, são identificadas experiências psicológicas negativas expressas pelo sentimento de culpa dos profissionais diante dos episódios de agressividade dos pacientes (Carvalho \& Felli, 2006).

Nos Estados Unidos, 34\% dos auxiliares de enfermagem estudados por Tak e colaboradores (2010) sofreram lesões físicas (incluindo mordeduras) resultantes dos ataques de residentes em casas de repouso, no período de um ano que antecedeu ao inquérito. A chance de apresentar lesões relacionadas aos ataques dos residentes foi maior no grupo que realizava horas extras e também no grupo que informou não ter tempo para assistir aos residentes durante o desenvolvimento de atividades cotidianas. Os autores sugerem o treinamento dos trabalhadores da saúde para lidar com as situações nas quais os pacientes seriam propensos a atos violentos. $O$ treinamento permitiria estancar os episódios, principalmente aqueles que são mais prováveis em certas condições clínicas (demência, por exemplo) e também beneficiaria o 'empoderamento' necessário para a satisfação no trabalho.

Vale, no entanto, lembrar as ponderações de Ramminger e Brito (2008) sobre os princípios da ergologia e da clínica da atividade. As pesquisadoras sinalizam as possibilidades de criação e de autoria, de uma sobrecarga, mesmo em casos de excessiva responsabilização do trabalhador por suas decisões e escolhas. O cuidado em saúde mental exigiria, na atualidade, um trabalhador implicado política e afetivamente com a transformação dos modos de cuidar e de se relacionar com a loucura. Vistos por esse ângulo, os âmbitos do trabalho em saúde mental guardariam oportunidades de construção de saberes, de experiências e de identidades.

Mas nem sempre as condições de trabalho críticas são conhecidas da gestão hospitalar, como sublinhado nos estudos apresentados neste texto. O desconhecimento pode ser entendido como um indicador de baixo suporte social 
e ter implicações negativas no que diz respeito às oportunidades mencionadas por Ramminger e Brito (2008). O apoio da gestão é um fator importante nas situações em que as tarefas são ambíguas e definidas em uma zona de incerteza, como é o caso do setor saúde, porque não há precisão na definição das tarefas; elas 'fluem' de acordo com as necessidades particulares dos pacientes.

A satisfação e a segurança para a realização das tarefas assim caracterizadas dependem do apoio e do suporte social dos gestores e das possibilidades efetivas para se construir o trabalho coletivo e para se estabelecerem as relações sociais, as quais se revelam fundamentais em situações de trabalho cuja natureza implica satisfazer a necessidade de um usuário (Falzon \& Lapeyriére, 1998).

Envolvidos em sua missão, às vezes sem as condições materiais para desenvolver as tarefas, os trabalhadores podem se sentir fracassados e impotentes para ajudar o usuário. Nessas situações, o suporte social (da gestão e dos colegas) pode conferir equilíbrios indispensáveis. No entanto, as pesquisas evidenciam fraco retorno dos gestores com relação aos resultados obtidos pelos trabalhadores, limitada participação dos sujeitos nas tomadas de decisão e enfraquecimento dos laços de cooperação horizontal e vertical (Falzon \& Lapeyrière, 1998).

Os médicos de Salvador (BA) indicaram ausência de oportunidade para desenvolver habilidades especiais, falta de liberdade para tomar decisões e de poder para influenciar as decisões e ausência de decisões democráticas no trabalho (Sobrinho et al., 2006). Em Salvador, houve crescimento do trabalho informal, subcontratação, terceirização e precarização do trabalho médico no setor público, mas principalmente no setor privado, com redução do trabalho assalariado. Quanto aos distúrbios psíquicos menores, a prevalência de $26 \%$ encontrada no grupo foi maior que a encontrada em outras categorias profissionais no Brasil.

O editorial da revista Lancet debateu, em 1996, o aumento do estresse e a diminuição da satisfação dos médicos nas reformas dos serviços de saúde na Inglaterra (Ramirez et al., 1996). Por sua vez, Jonge, Mulder e Nijhuis (1999) focalizam a mudança da natureza do trabalho em saúde implicando aumento da carga emocional e mental. Para os autores, o ritmo de trabalho é cada vez mais ditado pelos usuários, tendo como consequência a sobrecarga de trabalho, que pode se expressar como efeito adverso à saúde, insatisfação e burnout.

Outro estudo realizado em um serviço de urgências em Belo Horizonte, Minas Gerais, objetivou, diante das queixas de esgotamento dos médicos, descrever fatores intervenientes no atendimento pediátrico, principalmente 
aqueles ligados ao processo de trabalho (Melo, Assunção \& Ferreira, 2007). Foram realizadas observações diretas do trabalho, entrevistas individuais e coletivas em uma amostra de 44 pediatras do serviço citado. Para os autores, os serviços de urgência do SUS destinados às crianças gravemente enfermas são também frequentados por crianças com doenças mais simples; e as famílias, por motivos ligados às deficiências na atenção básica, os utilizam como porta de entrada no sistema. As razões aventadas explicam a elevada procura pelos serviços de urgências, interferindo no atendimento aos pacientes agudos, que são obrigados a enfrentar as filas, embora cada serviço apresente um sistema de priorização mais ou menos eficiente.

Dilemas éticos foram manifestados pelos pediatras durante as entrevistas coletivas e parecem estar ligados à insatisfação com o trabalho, pois eles relataram perceber prejuízo na qualidade do atendimento quando a fila de espera aumenta. Viu-se que os casos especiais solicitam capacidade de escutar, decidir e agir. Muitas vezes, o acompanhante não entende as perguntas feitas, e os pediatras têm que explicar novamente. Esse ato torna-se complexo, uma vez que a mãe precisa de tempo para expressar as suas angústias, justificar o seu comportamento e assimilar uma orientação.

As crianças em observação são avaliadas periodicamente, demandando tempo do pediatra, enquanto a fila aumenta na recepção, principalmente nos meses de maior incidência de problemas respiratórios nas comunidades. $\mathrm{O}$ tempo de espera pelo atendimento pode variar muito, relacionando-se estreitamente com a demanda quantitativa e qualitativa das consultas efetivadas. Nos períodos de alta demanda, registrou-se tempo de espera de até sete horas, gerando quadro de angústia, desconforto e irritabilidade nos usuários, cuja face mais visível é a frequência de agressões físicas e verbais e a abertura de processos contra erros médicos.

No Reino Unido, a prevalência de morbidade psiquiátrica variou de $22 \%$ a 46\% nas populações de médicos estudados (Coomber et al., 2002). Estes autores lembram que a natureza dos fatores mencionados não diz respeito aos recursos materiais em si, mas à percepção sobre o reconhecimento social conferido à especialidade e às responsabilidades requeridas no trabalho das unidades de terapia intensiva (UTI).

Coomber e colaboradores (2002) evidenciaram associações entre insatisfação com a escolha da carreira de intensivista e os escores obtidos no inquérito sobre morbidade psiquiátrica. Os fatores estressores mais frequentes nas respostas foram: ocupação de leitos, sobrecarga de trabalho, alteração da vida 
pessoal e familiar provocada pelos estressores ocupacionais e rotinas padronizadas quando os recursos são escassos.

As urgências não são o único foco dos estudos sobre as condições de trabalho no setor saúde. Um estudo de revisão encontrou, no período de 1990 a 2005, 279 publicações enfocando riscos ocupacionais no setor saúde. Os seguintes descritores foram utilizados: saúde pública, riscos ocupacionais, acidentes de trabalho, doenças ocupacionais e enfermagem (Chiodi \& Marziale, 2006). No conjunto das publicações encontradas, apenas 12 diziam respeito às unidades básicas de saúde (UBS), foco do interesse das autoras.

Temperatura ambiente desconfortável e ruído incômodo e irritante foram abordados em sete estudos da amostra selecionada pelas autoras. Dermatites em razão do uso frequente de sabão, álcool e luvas foram mencionadas em duas pesquisas. Posturas inadequadas para administração de vacinas e medicamentos e transporte manual de carga foram associadas ao elevado índice de absenteísmo, identificado em três investigações. Os acidentes perfurocortantes foram destacados em oito trabalhos, com ênfase na exposição dos trabalhadores aos líquidos corpóreos dos seus pacientes.

Em todos os estudos do subconjunto de artigos selecionados (12) foi identificada a exposição a riscos psicossociais nas UBS, com destaque para os seguintes: estresse, sobrecarga mental, violência sofrida pelos profissionais e agressividade dos usuários. Viu-se que os trabalhadores consideram o ambiente estressante, e eles destacaram a rapidez que é exigida no atendimento à semelhança do estudo realizado nas urgências pediátricas. Os sujeitos enfrentam situações perigosas (agressões e visitas a locais distantes) consideradas parte do seu cotidiano. Ademais, relataram que as tarefas são repetitivas e, constantemente, interrompidas.

O estudo ergonômico de Machado e colaboradores (2008) também identificou interrupções no trabalho desenvolvido pelas auxiliares de enfermagem em uma UBS de Belo Horizonte, Minas Gerais. As interrupções se explicaram pela necessidade de deslocamentos constantes na busca de alternativas para suprir a ausência de médicos, os quais não se fixam devido às características da área de risco. Diante da dificuldade de os usuários menos escolarizados entenderem as prescrições das receitas, viu-se a trabalhadora personalizar as caixas dos medicamentos: colar a foto do respectivo membro da família, quando vários deles usam medicamentos controlados; desenhar símbolos para identificar o horário e marcar (com letras garrafais) o número de comprimidos a ingerir em cada momento específico (D’Ávila, Assunção \& Belisário, 2007). 
Os recursos educativos adotados demandam tempo para a sua realização. Não sendo 'reconhecidos' pela gestão, não são considerados no planejamento do efetivo. Essas autoras sinalizam a importância das estratégias operatórias identificadas para os objetivos do sistema, mas alertam para a falta de tempo específico para a sua realização e para as consequências negativas no que se refere ao bem-estar no trabalho, em razão das interrupções, da sobreposição de tarefas, da pressão temporal etc. Todas as condições mencionadas são consideradas estressantes e estão associadas a eventos mórbidos.

A precariedade ou a ausência de espaços apropriados são referidas pelos profissionais de uma UTI como um dos fatores perturbadores da comunicação do estado do paciente internado aos seus familiares (Santos \& Silva, 2006). Para os entrevistados, as constantes interferências auditivas e visuais, pessoas transitando com ou sem objetos e falando no momento em que o profissional está conversando com os familiares acentuam o desafio dos profissionais ao abordarem a família quando as condições clínicas do familiar internado são graves. Tensão e ansiedade são comuns diante desses impedimentos.

A mobilização dos doentes, os deslocamentos constantes, a permanência por longos períodos em pé, os movimentos finos e sustentados para realização dos pequenos cuidados prestados aos pacientes são constrangimentos físicos associados aos problemas musculoesqueléticos (Buckle \& Devereux, 2002). O grupo dos fisioterapeutas é particularmente exposto aos riscos citados. Verificou-se relato de dor nas costas em $78 \%$ dos fisioterapeutas $(n=41)$ na cidade de Málaga, Espanha (Morales et al., 2003).

É possível que as dores estejam relacionadas ao tipo de exigência física das tarefas dos fisioterapeutas, como cargas e aplicação de forças. Ademais, o grupo estudado trabalha, em média, sete horas por dia para tratar 21 pacientes. Estudando os períodos de descanso durante a jornada, constatou-se que apenas $54 \%$ das mulheres usufruem esses momentos contra $82 \%$ dos homens que o fazem rotineiramente. Em torno de $46 \%$ das mulheres realizam todas as atividades domésticas, ao passo que apenas 5,8\% dos homens se ocupam desse tipo de afazeres.

Esses achados são consistentes com os estudos (Strazdins \& Bammer, 2004) sobre a segregação da força de trabalho segundo o sexo e o persistente desequilíbrio das relações de gênero no trabalho doméstico, o qual leva as assalariadas à dupla exposição: fatores de risco ocupacionais e os da vida doméstica. Desfavorecidas pelas relações de gênero, as mulheres estão sobre- 
carregadas pelas tarefas domésticas e têm menos tempo para as atividades de lazer. Sem repouso, a recuperação do organismo que responde às exigências do trabalho ficaria prejudicada, com mais chance de manifestação dos sintomas musculoesqueléticos, desencadeados nas atividades laborais.

No estado de São Paulo, 651 trabalhadores participaram do inquérito de Monteiro, Alexandre e Rodrigues (2006). A ocorrência de doença musculoesquelética com diagnóstico médico foi registrada 244 vezes no período de abril a junho de 2002. A prevalência foi maior entre indivíduos que desenvolvem trabalhos com demandas predominantemente físicas, como os auxiliares de serviço e oficiais da manutenção. Houve maior concentração de casos entre as mulheres, nos grupos com menos escolaridade, entre os que realizam atividade doméstica e entre os que executam as tarefas pesadas há mais tempo. Evidenciase a pertinência de se abordar o trabalho em saúde na ótica das relações de gênero, entre outras razões porque nesse âmbito são geradas, pelo menos em parte, as iniquidades em saúde (Strazdins \& Bammer, 2004).

Curiosamente, registrou-se menor prevalência de doenças musculoesqueléticas entre aqueles que trabalhavam mais de quarenta horas por semana. Não houve diferenças entre aqueles que trabalhavam em mais de um emprego quando comparados aos com emprego único. Strazdins e Bammer (2004) evocam o efeito trabalhador sadio para explicar os resultados, ou seja: os sujeitos possivelmente atingidos não conseguiram manter os seus postos, o duplo emprego ou o prolongamento da jornada de trabalho.

Sobre as condições relacionadas aos acidentes durante deslocamento, a pesquisa em um hospital de Campinas, São Paulo, evidenciou a ocorrência de 531 casos, sendo 37 (7\%) acidentes típicos que acometeram a coluna vertebral. Houve diferença estatisticamente significativa na distribuição dos acidentes segundo a categoria profissional. Os atendentes de enfermagem foram os mais atingidos; o piso escorregadio foi referido como o principal responsável pelos acidentes (32,1\%). O estado do piso e a utilização de protetores de tecidos nos pés explicaram as quedas importantes e consequente lesão dorsal (Parada, Alexandre \& Benatti, 2002).

A esse respeito, há convergência no tocante aos principais riscos de acidentes mencionados pelos sujeitos da amostra em um hospital de Campinas, São Paulo: material perfurocortante, principal risco $(76,8 \%)$, seguido por chão molhado e escorregadio $(51,8 \%)$ e esforço físico ou postura não ergonômica $(35,7 \%)$ (Benatti \& Nishide, 2000). Todos os fatores mencionados são passíveis de controle por meio de programas de vigilância. 
Outras profissões em saúde também são atingidas pelas doenças do aparelho musculoesquelético. As lombalgias são mais frequentes no grupo dos trabalhadores da enfermagem em comparação a outros grupos profissionais. Quanto aos médicos, os obstetras/ginecologistas durante a prática clínica e cirúrgica estão expostos a posturas estereotipadas e à manutenção de esforço muscular estático prolongado, ambas consideradas condições de risco de lombalgias ocupacionais (Dolan \& Martin, 2001).

O inquérito realizado na Irlanda obteve o retorno de 93,9\% (107/114) questionários enviados aos obstetras/ginecologistas. A maioria dos respondentes (72\%) relatou episódios de lombalgia. Encontrou-se diferença estatisticamente significativa da prevalência dos sintomas de acordo com o tipo de posição que o paciente assume para permitir ao obstetra/ginecologista realizar o procedimento cirúrgico indicado. $\mathrm{O}$ agravamento das lombalgias foi associado à realização dos seguintes procedimentos: cirurgia abdominal, cirurgia ginecológica e exame pélvico. Dolan e Martin (2001) sugerem medidas ergonômicas visando melhorar os constrangimentos posturais a que os sujeitos dessas especialidades estão expostos.

Foi descrita a prevalência de sintomas musculoesqueléticos entre ultrassonografistas na Colúmbia Britânica, Canadá (Russo et al., 2002). Dos 211 respondentes ao questionário, 192 (91\%) relataram dor ou desconforto, principalmente nos membros superiores, pescoço e dorso. Mais da metade referiu sintomas graves e frequentes relacionados ao número de horas trabalhadas por dia e ao número de jornadas dedicadas ao trabalho com o equipamento. A maioria (65\%) procurou consulta médica em razão do problema; entre eles, $62 \%$ receberam tratamento e a doença foi declarada, indicando a gravidade do quadro.

Russo e colaboradores lembram o caráter estressante da atividade, dada a importância do resultado do exame ultrassonográfico para o diagnóstico e a conduta do médico que o solicitou. A técnica ultrassonográfica solicita desempenho sensório-motor dos especialistas, pois para manipular o equipamento são adotadas posturas estereotipadas na aplicação de pressão contra os tecidos examinados, no posicionamento do paciente e na manutenção de postura sentada ou de pé durante períodos prolongados. Tais atividades podem provocar carga muscular estática e dinâmica da musculatura dos membros superiores, ombros, pescoço e dorso.

Desajustes ergonômicos são notados, uma vez que nem sempre há coerência entre as dimensões do leito do paciente, plano de trabalho do especialista que manipula o equipamento e outros dispositivos associados ao posto de trabalho. 
Outros tipos de procedimentos de diagnóstico também trazem efeitos ocupacionais. Os equipamentos radiológicos portáteis são frequentemente utilizados nas unidades de terapias intensivas, unidades de internações, centros cirúrgicos e unidades coronarianas, entre outras. Do ponto de vista ocupacional, alerta-se para a exposição dos trabalhadores não diretamente envolvidos nos exames radiológicos dos recém-nascidos em uma unidade de terapia neonatal de Florianópolis, Santa Catarina (Flor \& Kirchhof, 2006). Os resultados das observações diretas do trabalho evidenciaram a exposição sem proteção à radiação durante a atividade de apoio ao procedimento radiológico realizado no leito do recém-nascido.

Contrariamente aos trabalhadores da unidade de terapia neonatal, os técnicos em radiologia do mesmo hospital demonstraram conhecer os princípios básicos de proteção radiológica e relataram existir atitude descuidada dos profissionais da enfermagem, mesmo quando estes são avisados para se afastar do ambiente.

Vários aspectos foram problematizados pelos autores, merecendo destaque os seguintes: permanência no local sem usar os equipamentos de proteção individual quando o exame radiológico está sendo realizado no leito do recémnascido; demonstração de pouco conhecimento sobre os mecanismos deletérios associados à exposição à radiação ionizante; escassez de equipamentos de proteção individual plumbíferos; volume expressivo de procedimentos realizados na unidade neonatal analisada. Finalmente, menciona-se a ausência de formação no âmbito da segurança em ambientes com forte carga de radiação ionizante.

Essa pesquisa deixa margens para questionarem-se os limites do que eles nomeiam de "descaso quanto à exposição à radiação ionizante por parte de alguns profissionais" (Flor \& Kirchhof, 2006: 277). Os extratos das entrevistas reproduzidas no artigo mencionam razões como envolvimento com os recém-nascidos no momento do procedimento e necessidade de conter o recém-nascido para garantir a qualidade do exame, ambas indicadoras do lócus ético da atividade, ou seja: é plausível supor a existência de contradições entre o objetivo da atividade de cuidar do outro e o cuidar de si.

Diversas substâncias químicas são utilizadas no setor saúde com finalidades distintas, como esterilização, medicação, desinfecção, manutenção dos equipamentos. Quatro categorias abarcam o conjunto das principais substâncias empregadas (Costa \& Felli, 2005): 1) substâncias químicas de modo geral: óxido de etileno, glutaraldeído, formaldeído, hipoclorito de sódio, sabões, éter, benzina; 2) substâncias de uso medicamentoso: gases anestésicos, qui- 
mioterápicos, antibióticos, antissépticos; 3) poeiras e fumaças; 4) substâncias protetoras fabricadas com borracha: luvas, por exemplo.

A falta de rotulagem adequada de tais substâncias dificulta a informação dos trabalhadores expostos (Flor \& Kirchhof, 2006). As autoras alertam para o escasso conhecimento no país acerca da exposição e dos efeitos, os quais dizem respeito a uma gama de doenças, como processos alérgicos, infertilidade, câncer. A frequência de abortos espontâneos é mais elevada em enfermeiras que trabalham em salas de cirurgia durante a gravidez. Aventa-se a hipótese sobre a exposição aos gases anestésicos estar influenciando a ocorrência de malformações congênitas, abortos espontâneos e diminuição da capacidade para o trabalho. Cita-se a possibilidade de transferência de produtos químicos para o leite materno das enfermeiras expostas.

A variedade de riscos químicos presente nos hospitais pode provocar intoxicações agudas ou estados crônicos pré-patogênicos de várias doenças ocupacionais, segundo afirmam Flor e Kirchhof (2006). Há menção aos problemas de anencefalia, espinha bífida, defeitos no sistema urinário e genital em descendentes de trabalhadores expostos ocupacionalmente a gases anestésicos, gases esterilizantes, mercúrio e radiações X.

Entre 1979 e 2000, foram publicados 37 artigos sobre os riscos ocupacionais químicos a que se submetem os profissionais da enfermagem (Xelegati $\&$ Robazzi, 2003). Viu-se que a ocorrência de troca de cromátides irmãs é mais elevada em enfermeiras expostas ao manuseio de drogas antineoplásicas do que naquelas não expostas.

O inquérito realizado no Hospital da Universidade de São Paulo contou com a participação de 430 trabalhadores da enfermagem (64,66\% - 665). Encontrou-se média de seis substâncias químicas utilizadas por trabalhador. Os trabalhadores de enfermagem que relataram contato com os produtos químicos mencionaram problemas de pele e sintomas respiratórios.

Sobre as medidas de proteção passíveis de aprimoramento e implantação, a porcentagem das respostas obedeceu à seguinte ordem: uso de equipamento de proteção individual, desenvolvimento ou implantação de novos produtos, cuidados na manipulação, medidas de proteção coletiva, medidas administrativas e de recursos humanos, manipulação na farmácia ou local adequado (Costa \& Felli, 2005).

As doenças transmissíveis e incuráveis, cuja prevalência tem aumentado em todos os estabelecimentos de saúde, alertam para a necessidade de habilitar os trabalhadores da saúde para atuarem preventivamente em seu cuidado. No 
entanto, os escassos estudos disponíveis na literatura atual não são animadores, pois predominam, ao menos nos casos estudados, baixa taxa de vacinação contra hepatite $\mathrm{B}$ e baixa adesão às práticas padrão.

As hepatites virais, por exemplo, são importante problema de saúde pública no mundo e no Brasil. Para a OMS, cerca de dois bilhões de pessoas já tiveram contato com o vírus da hepatite B. No mundo, são aproximadamente 325 milhões de portadores crônicos da hepatite B e 170 milhões da hepatite $C$ (Brasil, 2002).

Os casos crônicos de hepatite $\mathrm{B}$ e $\mathrm{C}$ devem corresponder a cerca de 1,0\% e 1,5\% da população brasileira, respectivamente. $\mathrm{O}$ vírus da hepatite $\mathrm{C}$ predomina em adultos jovens, mas não se conhece a distribuição da prevalênciaincidência no Brasil (Ciorlia \& Zanetta, 2007), reforçando a importância da adesão às práticas padrão.

Estudo realizado em São José do Rio Preto, São Paulo, evidenciou maior prevalência de anti-HCV entre os trabalhadores da saúde quando comparados aos seus colegas do setor administrativo do hospital universitário e ao grupo dos doadores de sangue que fizeram parte da amostra. Observou-se que os trabalhadores da saúde com sorologia positiva tinham mais tempo de serviço no hospital e 50\% mais de chance de ser anti-HCV positivo a cada cinco anos de atividade. Segundo os autores, os resultados obtidos sugerem que os cuidados diários com os pacientes podem contribuir para o aumento de infecção pelo HCV (Ciorlia \& Zanetta, 2007).

A prevalência de vacinação completa contra a hepatite B foi de $64,61 \%$ no estudo em uma população de 1.249 trabalhadores de unidades da saúde na cidade de Florianópolis, Santa Catarina (Garcia \& Facchini, 2008). Contudo, as taxas não são as mesmas se comparadas por categoria profissional ou por tipo de contrato de trabalho.

A maior prevalência de vacinação foi encontrada entre enfermeiros (85,19\%), seguidos pelos dentistas (84,48\%). Quanto aos vínculos, observou-se prevalência de vacinação significativamente menor entre os trabalhadores com formas de contratação mais precárias (terceirizados ou estagiários). Ao lado do número expressivo de trabalhadores não protegidos, Garcia e Facchini (2008) relataram que $20,9 \%$ da amostra não receberam treinamento sobre saúde e segurança no trabalho.

Verificou-se cobertura vacinal completa contra hepatite B em 72,8\% dos acidentados (379) com exposição a líquidos corpóreos na rede estadual de saúde de São Paulo (Almeida \& Benatti, 2007). Alerta-se para a gravidade do quadro, uma vez que para $43,5 \%$ dos acidentados foi indicada a quimioprofilaxia com 
antirretroviral; para 32,1\% foram indicadas quimioprofilaxia e vacina contra hepatite B; e 1,2\% recebeu imunoglobulina humana contra hepatite B.

O paradoxo exposição versus proteção também está presente no estudo em uma população de dentistas de Montes Claros, Minas Gerais. No conjunto de 296 dentistas entrevistados, 28 (9\%) não tinham recebido nenhuma dose da vacina contra hepatite $B$, seis (2\%) apenas uma dose, quarenta (14\%) relataram duas doses e 221 (75\%) profissionais apresentaram esquema completo da vacina. A necessidade de mais informações foi alegada por 37\% dos dentistas que responderam sobre a não vacinação ou vacinação incompleta (Martins \& Barreto, 2003).

O quadro não é animador, pois uma porcentagem expressiva não foi vacinada de maneira adequada e está reconhecidamente exposta, a julgar pelas respostas de $13 \%$ dos sujeitos, indicando já terem atendido pacientes com sorologia positiva para o HIV; 15\% afirmaram assistência a pacientes sabidamente portadores do HBV. A prevalência de acidentes com instrumento perfurocortante foi de $26 \%$ nos seis meses anteriores à pesquisa e $75 \%$ durante a vida profissional.

A OMS estima em torno de $2,5 \%$ os casos de HIV e $40 \%$ os casos de HBV ou HCV entre os trabalhadores da saúde resultantes de acidentes perfurocortantes em situações de trabalho. A transmissão do HCV após acidente com agulha pode ocorrer com risco aproximadamente dez vezes mais alto do que a transmissão pelo HIV, sem a possibilidade de prevenção após a exposição. A ocorrência de HCV entre os trabalhadores da saúde varia de 2\% a 10\%, associando-se o risco de contágio com o tempo de serviço, realização de procedimentos invasivos e ocorrência de acidentes percutâneos.

Não reencapar agulhas é uma prática padrão, pois protege contra os acidentes perfurocortantes relacionados à exposição aos vírus citados. Em Abeokuta (Nigéria), 31,9\% dos respondentes a um questionário admitiram reencapar agulhas rotineiramente. A adoção da prática aconselhada de não reencapar agulhas foi maior entre os trabalhadores da enfermagem formados $(58,2 \%)$ do que na categoria médica (28,3\%) (Sadoh et al., 2006).

A maioria dos 515 profissionais de enfermagem de um hospital universitário no Brasil relatou reencapar agulhas pelo menos alguma vez $(74,4 \%-312)$. Aqueles trabalhadores com menos de dois anos de experiência estiveram mais aderentes à adoção da prática de não reencapar agulhas (Brevidelli \& Cianciarullo, 2001). Uma parcela da amostra não recebeu treinamento sobre as práticas padrão $(38,4 \%$ - 300). 
No estudo realizado em seis hospitais de Brasília, Distrito Federal, foram descritos acidentes com material biológico em 39,1\% (223/570) dos sujeitos que participaram do inquérito (Caixeta \& Barbosa-Branco, 2005). As categorias relacionadas à maior prevalência foram: cirurgiões-dentistas, médicos e técnicos de laboratório. A categoria dos farmacêuticos-bioquímicos apresentou o mais baixo coeficiente de acidentabilidade, mas, para esses autores, o risco de exposição é mais baixo entre esses profissionais quando comparados às outras categorias estudadas.

O grupo de respondentes que afirmou conhecer todas as normas de biossegurança foi o que mais se acidentou. De acordo com os autores, provavelmente eles devem estar mais expostos do que os seus colegas, por isso são mais informados. Aludiu-se também à hipótese de possível desvalorização da exposição relacionada aos anos vivenciados no hospital.

Entre os profissionais do estudo de Caixeta e Barbosa-Branco (2005), houve predominância dos acidentes entre os trabalhadores do sexo masculino. A prática de reencapar agulhas é mais frequente entre os homens, podendo explicar, segundo os autores, a diferença encontrada.

Ao contrário do que foi evidenciado no estudo de Caixeta e BarbosaBranco (2005), os homens estiveram 28\% mais protegidos contra os acidentes de trabalho perfurocortantes quando comparados às mulheres no estudo de Ciorlia e Zanetta (2007). Segundo esses autores, a diferença seria explicada pela divisão do trabalho entre os sexos, uma vez que os homens teriam menos contato com os objetos perfurocortantes, por estarem mais envolvidos com as tarefas que exigem força física.

Entre 412 funcionários de um hospital em Cuba, 28,2\% relataram ter sofrido lesão por objetos perfurocortantes. Do total de acidentados, 95,7\% não foram avaliados periodicamente após a lesão, e a maioria (95,7\%) não informou o acidente aos seus superiores (Díaz et al., 2003). Evidenciam-se nos dois últimos casos a ausência de formação e o sub-registro de informações, os quais podem ser encarados como indícios de um ambiente desprotegido e frágil quanto aos mecanismos de vigilância da saúde dos seus trabalhadores.

Avaliando-se 35 casos de acidentes com material potencialmente contaminado pelo HIV em funcionários do Hospital Universitário da cidade de Ribeirão Preto, São Paulo, encontraram-se, entre os profissionais de saúde, os auxiliares de enfermagem como a categoria mais atingida, provavelmente porque eles estão em contato direto com os pacientes (Machado et al., 1992). Em coerência com outros estudos, os mais experientes foram mais atingidos do 
que os novatos na profissão. As partes do corpo mais lesionadas foram mãos e dedos, evidenciando a necessidade de formação e de proteção, tendo em vista o conhecimento prévio sobre a vulnerabilidade dos membros superiores em situações de preparo e administração de medicação, curativos, tratamento de feridas, punção venosa para exames etc.

Os trabalhadores da limpeza também são vítimas de acidentes perfurocortantes, apesar de não realizarem os procedimentos citados anteriormente. No estudo empreendido na rede estadual de saúde de São Paulo, 13,2\% dos acidentes ocorreram entre os agentes da limpeza, antecedidos, em termos de prevalência, pelos trabalhadores da equipe de enfermagem (71,5\% dos acidentes) (Almeida \& Benatti, 2007).

Na amostra do estudo, a agulha foi o principal agente causador dos acidentes $(74,7 \%)$. No entanto, há diferenças quanto ao tipo de objeto que provoca a lesão de acordo com a categoria profissional. Entre os profissionais da limpeza, os principais objetos foram agulhas e lâminas abandonadas no ambiente, evidenciando mais uma vez a precariedade da vigilância e de seus mecanismos de prevenção e de promoção da saúde dos trabalhadores.

No estudo referido, não foi possível identificar o paciente-fonte, limitando as abordagens previstas nos protocolos de controle pós-exposição (OPS, 2005). É plausível supor que os acidentes ocorreram fora do momento da realização do procedimento, indicando carência de medidas educativas sobre o armazenamento de objetos cortantes após a sua utilização nos procedimentos de rotina.

A diferença na distribuição dos acidentes diz respeito não somente ao tipo, à ocupação ou ao objeto envolvido na lesão. Há subsetores mais vulneráveis. Em Passo Fundo, Rio Grande do Sul, uma pesquisa (Jorge et al., 2000) revelou a seguinte distribuição espacial da ocorrência de 226 acidentes com material biológico: centro cirúrgico $(17,3 \%$ - 39), seguido pela enfermaria pediátrica $(9,3 \%-21)$ e pela emergência geral $(6,2 \%-14)$.

\section{Considerações Finais}

Há convergências quanto aos resultados encontrados no tocante aos distúrbios psicológicos, queixas musculoesqueléticas, dermatites, acidentes, taxas de vacinação, ignorância sobre os efeitos das substâncias químicas e radiações, medo de agressões físicas e psicológicas, baixos salários. A distribuição das frequências não é homogênea; ela depende da ocupação, do conteúdo da tarefa, do setor, refletindo a riqueza e complexidade do trabalho em saúde. 
Os resultados dos estudos indicam iniquidades relacionadas ao gênero e ao contrato de trabalho. Diferenças de exposição aos riscos conhecidos foram largamente mencionadas pelos autores.

Apesar do reconhecimento do papel fundamental dos recursos humanos para os objetivos dos sistemas de saúde produzidos no seio das reformas sanitárias no mundo todo (Fritzen, 2007), permanecem desafios para as políticas de saúde, pois, independentemente da heterogeneidade quanto aos arcabouços conceituais e metodológicos e dos efeitos estudados por diferentes autores, está claro existir uma situação insegura aliada a frágeis mecanismos de vigilância à saúde dos trabalhadores da saúde nos estabelecimentos do setor.

As condições de trabalho citadas são indicadoras do fraco reconhecimento social quanto aos investimentos pessoais dos trabalhadores da saúde para dar conta de suas tarefas (Reinhardt \& Fischer, 2009). Pouca ou nenhuma informação sobre os riscos a que estão expostos, fragilidade dos mecanismos de assistência para os acidentados e doentes, ausência de comunicações diretas com a gestão, avaliação de desempenho exclusivamente quantitativa, sem levar em conta as estratégias inéditas para resolver os problemas e aliviar o paciente, entre outros fatores, confirmam as tendências mundiais e podem atingir o sentido do trabalho.

Contudo, não há trabalho sem trabalhadores, e eles buscam sentido naquilo que fazem. O sentido diz respeito ao modo de um indivíduo relacionar seus atos profissionais à construção de seu próprio futuro (Zarifian, 2001). A utilidade social daquilo que estão fazendo e as ocasiões de aprendizagem e de se desenvolver no trabalho são fatores preponderantes para o sentido do trabalho (Morin, 2008).

Por esse prisma, o trabalho em saúde pode ser visto, desde uma primeira aproximação, como sendo repleto de sentido porque seu objeto é a saúde das pessoas; portanto, configura-se um ato essencialmente humano. É lúcido esperar que seja fonte de satisfação. Mas os trabalhadores em sua maioria se encontram insatisfeitos e esgotados.

A qualidade do cuidado à saúde depende também da maneira pela qual o sistema encara as necessidades e a subjetividade dos trabalhadores no exercício de suas tarefas. Seria saudável buscar políticas para resgatar o valor do trabalho e proteger a saúde dos protagonistas dos sistemas de saúde. 


\section{REFERÊNCIAS}

ALMEIDA, C. A. F. \& BENATTI, M. C. C. Exposições ocupacionais por fluidos corpóreos entre trabalhadores da saúde e sua adesão à quimioprofilaxia. Revista da Escola de Enfermagem da USP, 41(1): 120-126, 2007.

ANTUNES, R. Dimensões da precarização estrutural do trabalho. In: FRANCO, T. \& DRUCK, G. (Orgs.) A Perda da Razão Social do Trabalho: terceirização e precarização. São Paulo: Boitempo Editorial, 2007.

BENATTI, M. C. C. \& NISHIDE, V. M. Elaboração e implantação do mapa de riscos ambientais para a prevenção de acidentes do trabalho em uma unidade de terapia intensiva de um hospital universitário. Revista Latino-Americana de Enfermagem, 8(5): 13-20, 2000.

BRASIL. Ministério da Saúde. Programa Nacional de Hepatites Virais: avaliação da assistência às hepatites virais no Brasil. Brasília: Ministério da Saúde, 2002.

BRASIL. Ministério da Saúde. $3^{a}$ Conferência Nacional de Saúde do Trabalhador. Relatório final. Brasília, 2005. Disponível em: <http://bvsms.saude.gov.br/bvs/trabalhador/ pdf/coletanea_textos_econf.pdf>. Acesso em: 21 nov. 2010.

BRASIL. Ministério da Saúde. Conselho Nacional de Saúde. Mesa Nacional de Negociação Permanente do SUS/Ministério da Saúde, Conselho Nacional de Saúde. 2. ed. Brasília: Ministério da Saúde, 2006. (Série D. Reuniões e Conferências). Disponível em: 〈http://portal.saude.gov.br/portal/arquivos/pdf/cartmesa06.pdf>. Acesso em: 21 nov. 2010.

BRASIL. Ministério da Saúde. Secretaria de Gestão do Trabalho e da Educação na Saúde. Indicadores de Gestão em Trabalho em Saúde. Brasília: Ministério da Saúde, 2007. (Manual de apoio para Programa de Qualificação e Estruturação da Gestão do Trabalho e da Educação no SUS - ProgeSUS).

BREVIDELli, M. M. \& CIANCIARUllO, T. I. Aplicação do modelo de crenças em saúde na prevenção dos acidentes com agulha. Revista de Saúde Pública, 35(2): 193-201, 2001.

BUCKLE, P. \& DEVEREUX, J. The nature of work-related neck and upper limp musculoskeletal disorders. Applied Ergonomics, 33: 207-217, 2002.

CAIXETA, R. B. \& BARBOSA-BRANCO, A. M. Acidente de trabalho, com material biológico, em profissionais de saúde de hospitais públicos do Distrito Federal, Brasil, 2002/2003. Cadernos de Saúde Pública, 21(3): 737-746, 2005.

CARVALHO, M. B. \& FELLI, V. E. A. O trabalho de enfermagem psiquiátrica e os problemas de saúde dos trabalhadores. Revista Latino-Americana de Enfermagem, 14(1): 61-69, 2006.

CHIODI, M. B. \& MARZIALE, M. H. P. Riscos ocupacionais para trabalhadores de Unidades Básicas de Saúde: revisão bibliográfica. Acta Paulista de Enfermagem, 19(2): 212-217, 2006. 
CIORLIA, L. A. S. \& ZANETTA, D. M. T. Hepatite C em profissionais da saúde: prevalência e associação com fatores de risco. Revista de Saúde Pública, 41(2): 229-235, 2007.

COELHO, M. C. R. V.; ASSUNÇÃO, A. A. \& BELISÁRIO, S. A. Employment and sociodemographic characteristics: a study of increasing precarity in the health districts of Belo Horizonte, Brazil. Human Resources for Health; 1(1), 2009.

CONNOR, T. H. \& MCDIARMID, M. A. Preventing occupational exposures to antineoplastic drugs in health care settings. CA: A Cancer Journal for Clinicians, 56: 354-365, 2006.

COOMBER, S. et al. Stress in UK intensive care unit doctors. British Journal of Anaesthesia, 89(6): 873-881, 2002.

CORDEIRO, H. Descentralização, universalidade e equidade nas reformas da saúde. Ciência Ë Saúde Coletiva, 6(2): 319-328, 2001.

COSTA, T. F. \& FELLI, V. E. A. Exposição dos trabalhadores de enfermagem às cargas químicas em um hospital público universitário da cidade de São Paulo. Revista Latino-Americana de Enfermagem, 13(4): 501-508, 2005.

DAUBAS-LETOURNEUX, V. \& THÉBAUD-MONY, A. Work Organization and Health at Work in the European Union: European Foundation for the Improvement of Living and Working Conditions. Luxembourg: Office for Official Publications of the European Communities, 2003.

D’ÁVILA, L. S.; ASSUNÇÃO, A. A. \& BELISÁRIO, S. A. Fatores relacionados à atividade de dispensação de medicamentos em uma UBS de Belo Horizonte. In: SIMPÓSIO CONDIÇÕES DE SAÚDE E TRABALHO NO SETOR SAÚDE, 1. Belo Horizonte: Nescon, 2007. CD-ROM.

DEDECCA, C. S. et al. A dimensão ocupacional do setor de atendimento à saúde no Brasil. Trabalho, Educação e Saúde, 3(1): 123-142, mar. 2005.

DEMEROUTI, E. et al. A model of burnout and life satisfaction amongst nurses. Journal of Advanced Nursing, 32(2): 454-464, 2000.

DÍAZ, R. L. A. J. et al. Riesgo ocupacional por exposición a objetos cortopunzantes en trabajadores de la salud. Revista Cubana de Higiene y Epidemiología, 41(1), 2003.

DOLAN, L. M. \& MARTIN, D. H. Backache in gynaecologists. Occupational Medicine, 51(7): 433-438, 2001.

FALZON, P. \& LAPEYRIÈRE, S. L'usager et l'opérateur: ergonomie et relations de services. Le Travail Humain, 6(1): 69-88, 1998.

FLEGELE, D. S. et al. Trabalhadores de saúde e os dilemas das relações de trabalho na Estratégia Saúde da Família. Revista Brasileira de Pesquisa em Saúde, 12(2): 5-11, 2010. FLOR, R. C. \& KIRCHHOF, A. L. C. Uma prática educativa de sensibilização quanto à exposição à radiação ionizante com profissionais de saúde. Revista Brasileira de Enfermagem, 59(3): 274-278, 2006. 
FRITZEN, A. S. Strategic management of the health workforce in developing countries: what have we learned? Human Resources for Health, 5(4), 2007. Disponível em: <www. human-resources-health.com/content/5/1/4>. Acesso em: 22 nov. 2010.

GALEAZZI, I. M. S. O trabalho por conta própria num contexto de precarização laboral. In: BASTOS, R. L. A. (Org.) Dimensões da Precarização do Mercado de Trabalho na Região Metropolitana de Porto Alegre. Porto Alegre: Fundação de Economia e Estatística (FEE), 2007.

GARCIA, L. P. \& FACCHINI, L. A. Vacinação contra a hepatite B entre trabalhadores da atenção básica à saúde. Cadernos de Saúde Pública, 24(5): 1.130-1.140, 2008.

JONGE, J.; MULDER, M. J. G. P. \& NIJHUIS, F. J. N. The incorporation of different demand concepts in the job demand-control model: effects on health care professionals. Social Science Ë Medicine, 8: 1.149-1.160, 1999.

JORGE, R. et al. Acidentes biológicos em hospital universitário. Revista Médica do Hospital São Vicente de Paulo, 11(26): 19-22, 2000.

MACHADO, A. A. et al. Risco de infecção pelo vírus da imunodeficiência humana (HIV) em profissionais da saúde. Revista de Saúde Pública, 26(1): 54-56, 1992.

MACHADO, A. P. et al. O trabalho em uma Unidade Básica de Saúde: uma abordagem da ergonomia. In: CONGRESSO BRASILEIRO DE ERGONOMIA, 15, Porto Seguro, Bahia, 2 a 6 de novembro de 2008. CD-ROM.

MACHADO, M. H. Trabalhadores de saúde e sua trajetória na Reforma Sanitária. In: LIMA, N. T. (Org.) Saúde e Democracia: história e perspectivas do SUS. Rio de Janeiro: Editora Fiocruz, 2005.

MARMOT, M. Social determinants of health inequalities. Lancet, 365: 1.099-1.104, 2005.

MARTINS, A. M. E. B. L. \& BARRETO, S. M. Vacinação contra hepatite B entre cirurgiões dentistas. Revista de Saúde Pública, 37(3): 333-338, 2003.

MASLACH, C. \& JACKSON, S. E. The measurement of experienced burnout. Journal of Occupational Behaviour, 2: 99-113, 1981.

MAWN, B. et al. Health disparities among health care workers. Qualitative Health Research, 20(1): 68-80, 2010.

MELO, E. M. C.; ASSUNÇÃO, A. A. \& FERREIRA, R. A. O trabalho dos pediatras em um serviço público de urgências: fatores intervenientes no atendimento. Cadernos de Saúde Pública, 23(12): 3.000-3.010, 2007.

MONTEIRO, M. S.; AlEXANDRE, N. M. C. \& RODRIGUES, C. M. Doenças musculoesqueléticas, trabalho e estilo de vida entre trabalhadores de uma instituição pública de saúde. Revista da Escola de Enfermagem da USP, 40(1): 20-25, 2006.

MORALES, N. M. et al. Estudio transversal de las algias vertebrales en los fisioterapeutas. Fisioterapia, 25(1): 23-28, 2003.

MORIN, E. Sens du Travail, Santé Mentale et Engagement Organisationnel. Québec: Institut de Recherche Robert-Sauvé en Santé et en Sécurité du Travail, 2008. (Rapport R-543) 
NATIONAL INSTITUTE OCCUPATIONAL OF SAFETY AND HEALTH. Health Care Workers, 2007. Disponível em: <www.cdc.gov/niosh/topics/healthcare/>. Acesso em: 18 dez. 2007.

OMS (Organización Mundial de la Salud). Colaboremos por la Salud, 2006. Disponível em: <www.who.int/world-health-day/previous/2006/es/index.html>. Acesso em: 22 nov. 2010.

OMS (Organisation Mondiale de la Santé). Directives: mesures incitatives pour les professionnels de la santé. Genéve: Organisation Mondiale de la Santé, 2008.

ONU (Organización de las Naciones Unidas). Objetivos de Desarrollo del Milenio: una mirada desde América Latina y el Caribe. Santiago del Chile: Naciones Unidas, 2005.

OPS (Organización Panamericana de la Salud). Salud y Seguridad de los Trabajadores del Sector Salud: manual para gerentes y administradores. Washington, D.C: OPS, 2005.

PAPADOPOULOS, G. et al. Occupational and public health and safety in a changing work environment: an integrated approach for risk assessment and prevention. Safety Science, 48(8): 943-949, 2010.

PARADA, E. O.; ALEXANDRE, N. M. C. \& BENATTI, M. C. C. Lesões ocupacionais afetando a coluna vertebral em trabalhadores de enfermagem. Revista Latino-Americana de Enfermagem, 10(1): 64-69, 2002.

PRÜSS-ÜSTÜN, A.; RAPITI, E. \& HUTIN, Y. Sharps Injuries: global burden of disease from sharps injuries to health-care workers. Geneva: World Health Organization, 2003. (Environmental Burden of Disease Series, 3)

RAMIREZ, A. J. et al. Mental health of hospital consultants: the effects of stress and satisfaction at work. The Lancet, 347: 724-728, 1996.

RAMMINGER, T. \& BRITO, J. C. O trabalho em saúde mental: uma análise preliminar relativa à saúde dos trabalhadores dos serviços públicos. Revista Brasileira de Saúde Ocupacional, 33(117): 36-49, 2008.

RAMOS, L. \& FERREIRA, V. Padrões espacial e setorial da evolução da informalidade no período 1991-2005. Pesquisa e Planejamento Econômico, 36(3): 471-488, 2006.

REINHARDT, E. L. \& FISCHER, F. M. Barreiras às intervenções relacionadas à saúde do trabalhador do setor saúde no Brasil. Revista Panamericana de Salud Pública, 25(5): 411-417, 2009.

RUSSO, A. et al. The prevalence of musculoskeletal symptoms among British Columbia sonographers. Applied Ergonomics, 33(5): 385-393, 2002.

$\mathrm{SADOH}$, W. E. et al. Practice of universal precautions among healthcare workers. Journal of the National Medical Association, 98(5): 722-726, 2006.

SANTOS, K. M. A. B. \& SILVA, M. J. P. Percepção dos profissionais de saúde sobre a comunicação com os familiares de pacientes em UTIs. Revista Brasileira de Enfermagem, 59(1): 61-66, 2006.

SMITH, D. R.; LEGGAT, P. A. \& ARAKI, S. Emerging occupational hazards among health care workers in the new millennium. Industrial Health, 45(5): 595-597, 2007. 
SOARES, L. T. As atuais políticas de saúde: o risco do desmonte neoliberal. Revista Brasileira de Enfermagem, 53: 17-24, 2000.

SOBRINHO, C. L. N. et al. Condições de trabalho e saúde mental dos médicos de Salvador, Bahia, Brasil. Cadernos de Saúde Pública, 22(1): 31-140, 2006.

STRAZDINS, L. \& BAMMER, G. Women, work and musculoskeletal health. Social Science Eु Medicine, 58(6): 997-1.005, 2004.

TAK, S. et al. Workplace assaults on nursing assistants in US nursing homes: a multilevel analysis. American Journal of Public Health; 100(10): 1.938-1.945, 2010.

THÉBAUD-MONY, A. \& DRUCK, G. Terceirização: a erosão dos direitos dos trabalhadores na França e no Brasil. In: FRANCO, T. \& DRUCK, G. (Orgs.) A Perda da Razão Social do Trabalho: terceirização e precarização. São Paulo: Boitempo Editorial, 2007.

UFMG (Universidade Federal de Minas Gerais). Núcleo de Estudos em Saúde Coletiva. Condições de Trabalho e Saúde dos Trabalhadores da Saúde. Belo Horizonte: UFMG, 2007. (Cadernos Série Técnica 1). Disponível em: <www.nescon.medicina.ufmg.br/pdf/ [2008]nescon_informes_tecnicos_1.pdf>. Acesso em: 22 nov. 2010.

WHO (World Health Organization). The Global Shortage of Health Workers and its Impact. Fact sheet, n. 302. Geneva: World Health Organization, 2006.

XELEGATI, R. \& ROBAZZI, M. L. C. C. Riscos químicos a que estão submetidos os trabalhadores de enfermagem: uma revisão de literatura. Revista Latino-Americana de Enfermagem, 11(3): 350-356, 2003.

ZARIFIAN, P. Objetivo Competência: por uma nova lógica. São Paulo: Atlas, 2001. 


\section{A Ergologia como Perspectiva de Análise: A SAÚdE DO TRABaLHADOR E 0 TRABALHO EM SAÚdE}

Jussara Brito

A ergologia não se caracteriza como uma nova disciplina ou um novo campo de saber, mas sim como uma perspectiva de análise e de intervenção sobre o trabalho gestada entre o final dos anos 60 e o início dos anos 80 . Portanto, não corresponde a um campo a mais que se somaria à sociologia, à psicologia, à medicina, nem mesmo a uma disciplina de síntese, como a ergonomia, ou uma abordagem da saúde mental, como a psicodinâmica do trabalho (entre outras). Como perspectiva de análise e intervenção sobre os problemas que emergem do trabalho, a ergologia explora o ponto de vista da atividade humana em suas circulações, entendendo que a atividade de trabalho opera como uma matriz. Indica a exigência de uma dupla confrontação: dos diferentes saberes 'constituídos' (acadêmicos/científicos/técnicos) e destes com os saberes 'investidos' (produzidos/investidos na atividade de trabalho).

Ao contrário de buscar respostas gerais sobre o que ocorre com o trabalho, por meio de fórmulas exaustivamente utilizadas, a ergologia propõe uma análise 'situada', apostando na potência humana de compreendertransformar o que está em jogo, (re)inventando, criando novas condições e um novo meio pertinente. Constitui-se, assim, em uma maneira de pensar que desestabiliza positivamente modos consagrados (conservadores ou críticos) de ver o trabalho na sociedade contemporânea, colaborando para o seu desenvolvimento.

Neste capítulo, apresentamos, inicialmente, de forma sintética as bases da ergologia. Veremos que ela provém de uma linhagem materialista (passando por Marx) e emerge no cruzamento de três importantes acontecimentos: as repercussões da reflexão de Georges Canguilhem a respeito do que é a vida 
e a saúde; a descoberta (no plano acadêmico, a nosso ver, revolucionária) da defasagem entre trabalho prescrito e realizado; os encaminhamentos do modelo operário italiano (MOI) de luta pela saúde.

Após a apresentação das partes que constituem a base da ergologia, examinaremos, muito sucintamente, seus princípios e o dispositivo de três polos (um modelo de produção de conhecimento que propõe a articulação entre saberes e diferentes disciplinas), para ao final fazer considerações sobre algumas contribuições da perspectiva ergológica para as pesquisas de pós-graduação relacionadas à saúde.

\section{Canguilhem, Oddone e Wisner: três Pensadores fundamentais para a ERGOLOGIA}

O que há em comum entre esses três pensadores? Em que o MOI se aproxima da ergonomia da atividade? Por que o conceito vitalista de saúde presente na obra de Canguilhem é fertilmente agregado pela ergologia?

Para responder a essas perguntas, vamos destacar as ideias-chave de Canguilhem, do MOI (e de Ivar Oddone) e da ergonomia da atividade (e de Alain Wisner). Cabe mencionar que Ivar Oddone, Alessandra Re e seus companheiros (alguns também ligados à ergonomia), mesmo que por caminhos diferentes, chegaram a uma conclusão semelhante à que foi enunciada pelos ergonomistas belgas e franceses (como Alain Wisner, Pierre Cazamian, Catherine Teiger, Jacques Durrafourg, Antoine Laville, François Daniellou), de que as transgressões e as microcriações fazem parte do cotidiano de trabalho até mesmo daqueles que realizam atividades consideradas simples, manuais. Portanto, os trabalhadores detêm conhecimentos importantes sobre o processo de trabalho que operam - ao contrário da ideia tão difundida pelo taylorismo (e que muitos de seus críticos absorveram). Na Itália, esta descoberta foi sinalizada, por exemplo, pela criação da expressão 'experiência operária'; na França, pelos conceitos de 'trabalho real' e 'prescrito' (assim como 'variabilidade' e 'regulação').

Em ambos os casos, é indicada a existência de dois tipos de conhecimento, duas culturas e duas linguagens sobre o trabalho: de um lado, o que é veiculado pela organização formal; de outro, o que é compartilhado pelos trabalhadores. Além disso, veremos que ao refletir sobre o conceito de saúde (como 'capacidade normativa'), Canguilhem (1990) contribui de forma significativa para compreendermos por que, apesar de toda a rigidez organizacional, 
os trabalhadores desenvolvem experiência e produzem saberes ao buscarem dar conta do trabalho que lhes foi prescrito, ante as 'infidelidades do meio', incidindo com novas infidelidades, gerando mais complexidade (recentrando o meio como 'seu' meio).

\section{A Relação Homem-Meio no Centro do Conceito de Saúde de CANGUILHEM}

Filósofo-médico, militante da resistência francesa ao nazismo (período em que, ainda assim, defendeu sua tese de doutorado sobre o normal e o patológico), Canguilhem contribuiu de forma decisiva para uma concepção de saúde associada ao "meio" (termo que ele prefere a ambiente). Em suas palavras, o meio é sempre infiel (instável, adverso), sendo a saúde uma margem de tolerância a essas infidelidades e a capacidade dos indivíduos (individual e coletivamente) de criarem novas normas (Canguilhem, 1990), ou seja, de agirem sobre o meio. É nesse sentido que Canguilhem fala em saúde como uma polaridade dinâmica entre o indivíduo (ou indivíduos) e o 'seu' meio. Em outras palavras, para analisar a saúde, é preciso considerar esses dois polos - de um lado, os indivíduos; de outro, o meio em que vivem - e como cada um desses polos afeta o outro. Portanto, Canguilhem indica que uma das características do ser humano é sua vitalidade, que se manifesta na tentativa permanente de adequar o meio (inclusive de trabalho) às suas necessidades e anseios (como seu meio), ou simplesmente, conforme o autor prefere, às suas "normas". Assim, Canguilhem chama a atenção para o fato de que a vida está sempre presente, mesmo nas situações em que parece inexistir, como no caso da organização taylorista do trabalho:

As reações operárias à extensão progressiva da racionalização taylorista, revelando a resistência do trabalhador às medidas que lhe são impostas do exterior, devem, portanto, ser compreendidas tanto como reações de defesa biológica quanto como reações de defesa social e, nos dois casos, como reações de saúde. (Canguilhem, 2001: 116; grifo nosso)

Ora, se para Canguilhem todo ser humano quer ser sujeito de suas próprias normas, no ambiente de trabalho isto não é diferente, pois os trabalhadores buscam se manter vivos, e a vida se faz presente ali por meio de suas microcriações (as chamadas transgressões, os 'jeitinhos', as soluções engendradas no cotidiano), que tornam viável - quiçá prazeroso - trabalhar. Vamos ao encontro aqui, então, das descobertas da ergonomia da atividade e do MOI, 
que sustentam a perspectiva ergológica - especialmente a compreensão de que o ser humano é normativo, capaz de criar novas normas de vida.

No que tange às interfaces com a ergonomia da atividade, é interessante chamar a atenção para dois pontos. Em primeiro lugar, segundo Canguilhem, a vida é compreendida como uma atividade que se opõe à inércia, ou seja, viver é agir sobre o mundo, o que pressupõe um ser ativo (por exemplo: o cérebro é antes de mais nada um órgão de antecipação, colocação de problemas). O outro ponto de interface se refere à ideia de adaptação do trabalho aos homens e às mulheres que trabalham. Ao dizer que os indivíduos buscam modificar seu meio, de acordo com suas próprias normas, Canguilhem aponta um caminho proposto pela ergonomia da atividade desde o pós-guerra, invertendo a lógica taylorista predominante de adequar as pessoas ao trabalho (Guérin et al., 2001; Daniellou, 2004): 'adaptar o trabalho ao homem'. Esse também foi o caminho escolhido pelo MOI, que visou a compreender-transformar as situações de trabalho, de modo que estas não gerassem danos à saúde e que permitissem aos trabalhadores expressarem "ao máximo sua capacidade produtiva como seres pensantes" (Oddone, 2007: 5).

\section{Adaptar 0 Trabalho aos Homens e às Mulheres que Trabalham:}

\section{A PROPOSTA DA ERGONOMIA DA ATIVIDADE}

Para a ergonomia da atividade, a adaptação do trabalho às pessoas exige reconhecer a forma que elas encontram para viver determinada situação, como agem, que estratégias utilizam. Esse é o sentido maior destes dois importantes conceitos: 'trabalho real' e 'trabalho prescrito'. Um dos méritos de tais conceitos é o fato de terem sido baseados em estudos desenvolvidos em situações reais de trabalho, tipicamente tayloristas, isto é, nas quais se supunha que aos trabalhadores cabia apenas executar fielmente o prescrito. No entanto, a análise dessas situações permitiu evidenciar que o trabalho é muito mais do que o previsto e percebido do exterior; possibilitou mostrar que o trabalho tem duas faces.

O conceito de trabalho prescrito refere-se a uma dessas faces: o que é esperado no âmbito de um processo de trabalho específico, com suas características particulares. É vinculado tanto a regras e objetivos fixados pela organização do trabalho quanto às condições dadas. Observa-se, assim, que trabalhar implica lidar com uma diversidade de fontes de prescrição, estabelecer prioridades entre elas e provavelmente não conseguir respeitá-las simultaneamente (Leplat 
\& Hoc, 1998). Entretanto, a prescrição é fundamental, porque sua ausência pode gerar consequências negativas tanto para o desenvolvimento do trabalho quanto para a saúde do trabalhador.

O esforço conceitual sinalizado na expressão 'trabalho real' está vinculado ao pressuposto de que as prescrições são sempre recursos incompletos, isto é, que desde a sua concepção não são capazes de contemplar todas as situações encontradas no exercício cotidiano de trabalhar. Nesse sentido, é dada ênfase ao papel das pessoas como protagonistas ativos do processo produtivo (e não como 'fator' ou 'recurso' humano). Até no caso de tarefas muito repetitivas, cabe ao trabalhador fazer regulações/ajustes/desvios - mesmo que infinitesimais.

Fundamentalmente, a defasagem sempre existente entre o trabalho prescrito e o trabalho real se deve ao fato de as situações reais de trabalho serem dinâmicas, instáveis e submetidas a imprevistos - ou “infiéis", como diz Canguilhem. Portanto, a atividade de trabalho envolve estratégias de adaptação do prescrito às situações reais de trabalho, atravessadas pelas variabilidades e pelo acaso. A atividade de trabalho é sempre singular, dado que caracteriza o trabalho de indivíduos singulares e instáveis/variáveis, efetuado em contextos singulares e variáveis (em suas dimensões materiais, organizacionais ou sociais).

A perspectiva ergológica reteve (desenvolvendo) os conceitos de trabalho prescrito e trabalho real (e sua defasagem), mas a influência de Canguilhem colaborou para que esses fossem tratados como normas que antecedem ou que são criadas no curso da atividade, conforme veremos adiante. Da mesma forma, a lição apreendida de que o trabalho nunca é pura execução contribuiu para desenvolver o conceito de atividade, com a colaboração da ergologia.

No que tange aos cruzamentos da ergonomia da atividade com o MOI, é interessante registrar que Theureau (2002), ergonomista francês, afirmou em entrevista que as "pesquisas fantásticas" realizadas nas empresas pelo movimento sindical italiano marcaram também o desenvolvimento de seus estudos, de sua formação. Além disso, Alessandra Re - psicóloga de destaque no MOI - é hoje responsável pelo Laboratório Interdepartamental de Ergonomia da Universidade de Turim. Há, de fato, pontos em comum entre a ergonomia da atividade e o MOI. Por exemplo: a desconstrução da visão de trabalho como mera execução está presente também no MOI - movimento que mudou a perspectiva de análise, seja em relação à concepção marxista de alienação, seja em relação à prática de uma certa psicologia do trabalho 'escrita' que era impregnada pelo taylorismo (Vicenti, 1999). 
De fato, o movimento italiano trouxe à tona a questão de que o processo de contínua aprendizagem, que se desenvolve por via da experiência, por sua transmissão e pela reflexão coletiva nela originada, é encontrado mesmo nos trabalhos mais simples. Nos seminários realizados com delegados sindicais ou membros de conselhos de fábrica, os trabalhadores se referiam a seus trabalhos como algo estimulante e dinamizador de sua inteligência, habilidade psicomotriz e capacidade de criação (Oddone et al., 1981).

\section{Modelo Operário Italiano de Luta pela Saúde}

Em meados dos anos 60, em Turim, um grupo composto de médicos, sociólogos, psicólogos, estudantes, trabalhadores e sindicalistas deu início ao que se denominou de "comunidades científicas ampliadas", as quais se desenvolveram em todo o território nacional. Pela confrontação entre os saberes formais dos pesquisadores e os saberes informais dos trabalhadores, essas comunidades elaboraram um novo modelo de conhecimento e de estratégia sindical a respeito das condições de vida e de trabalho. Essa nova abordagem afirmava o valor científico da subjetividade dos trabalhadores, validada pelo 'grupo homogêneo' de produção, desenvolvendo uma forma original de pesquisa-ação, na qual todos os atores se tornariam coautores da pesquisa, como portadores de seus saberes específicos (Vicenti, 1999).

Milhares de mapas 'brutos' de riscos foram feitos à mão, entre os anos 60 e 70, pelos operários, estudantes, médicos e psicólogos engajados nas lutas pela saúde nos locais de trabalho. De acordo com o conceito de "não delegação", construíram-se as bases de uma cooperação entre esses atores, calcada em um processo de validação dos conhecimentos científicos por parte do grupo homogêneo. O objetivo do modelo era usar o conhecimento científico em benefício dos interesses do trabalhador: "o importante é aprender a lidar com o conhecimento, mesmo o mais acadêmico, e não fugir dele e chamar o técnico para tomar o seu lugar, mas chamá-lo para 'traduzir' a linguagem, esmiuçar um detalhe” (Gawryszewski, 1989: 40).

Discutindo a influência do MOI na construção da saúde do trabalhador, Ferreira da Silva (2003) ressalta que o princípio de 'conhecer para transformar', assim como os conceitos 'não delegar', 'grupo homogêneo' e 'validação consensual', marcaram profundamente o campo, enquanto o conceito de 'comunidade científica ampliada' não frutificou. Da mesma forma, outro 
importante instrumento do MOI, a técnica da 'instrução ao sósia', ${ }^{1}$ ainda está por ser mais bem difundido e explorado entre nós.

Na França, Clot (2006) procura avançar no caminho iniciado pelo MOI na construção de uma clínica da atividade, também proposta por Schwartz (2000b), em que a técnica da 'instrução ao sósia' tem sido aprimorada. Também na França, o 'mapa de riscos' é um dos elementos centrais do Sistema Interativo de Saúde no Trabalho (Sist), que reúne dados sobre os ambientes de trabalho, as atividades de trabalho e o território, viabilizando a identificação do número de pessoas expostas a riscos e o diálogo entre profissionais de saúde, trabalhadores e governo local (Re et al., 2006). Como diz Keller (2003), o Sist nasceu do encontro predestinado entre os herdeiros da tradição autogestionária de uma sociedade de ajuda mútua, baseada em uma concepção militante da saúde, propagando 'pequenas comunidades científicas' na região, reunindo médicos, pesquisadores e trabalhadores na pesquisa e eliminação das nocividades industriais.

A obra de Oddone foi determinante para Schwartz, para quem o conceito de comunidade científica ampliada permitia ter uma visão menos redutora do trabalho. Porém, mesmo reconhecendo a importância científica, cultural, social e política do conceito, Schwartz (2000a) mostra alguns de seus limites, que de forma geral estão ligados às mudanças do contexto histórico em que a experiência italiana se desenvolveu.

Um de seus problemas seria o de transmitir a ideia de que o conhecimento sobre a atividade de trabalho pertence ao domínio científico no sentido clássico, levando à ocultação das diferentes competências e saberes do conjunto de atores envolvidos. Para ele, o conceito de comunidade científica ampliada oculta um pouco tanto as competências próprias de cada um dos parceiros quanto a dificuldade do projeto, absolutamente necessário, de fazer com que os protagonistas trabalhem conjuntamente (Schwartz, 2000a). Nas comunidades científicas ampliadas, havia algo que contribuía para esse trabalho conjunto: a consciência de classe e os valores emancipatórios da classe operária, via militância sindical. Hoje, os parceiros não são mais somente militantes operários;

\footnotetext{
A técnica de instrução ao sósia foi desenvolvida durante os seminários de formação operária com os trabalhadores da Fiat, consistindo de um diálogo orientado pela seguinte proposição: "Supondo que eu seja idêntico a você do ponto de vista físico e amanhã eu vá te substituir, diga-me como eu deveria me comportar em relação à sua tarefa, a seus colegas de trabalho, à hierarquia e à organização sindical de modo que não percebam que se trata de outra pessoa" (Oddone, Re \& Briante, 1981: 67). Trata-se de uma técnica que propicia a coanálise das atividades, dando maior ênfase ao 'como' do que ao 'porquê' delas. Esta técnica vem sendo aperfeiçoada por Clot (2006) e os pesquisadores da Clínica da Atividade.
} 
são também desempregados, trabalhadores do setor de serviços e profissionais de diversos ramos, inclusive gerentes, microempresários, cooperativados etc. Portanto, Schwartz acredita que a cooperação não pode ser fundada de maneira exclusiva nas relações com os sindicatos. Foi assim que ele deu visibilidade ao fato de que o MOI operava com um terceiro polo - ético-epistêmico -, em seu caso dinamizado pelo sindicato.

$\mathrm{O}$ que nos parece particularmente interessante nessa proposta é que ela problematiza e desconstrói (revelando ainda mais sua riqueza, ao lado de seus limites) um instrumento experimentado no $\mathrm{MOI}$, em razão de um novo cenário social e político, marcado pelas 'reestruturações' produtivas e por uma mudança nas relações de força em favor do capital, com efeitos na ação sindical voltada para a transformação das condições de trabalho. Afinal, como salienta Kuchenbecker (1992), o entendimento de que os idealizadores do modelo operário tenham tido uma preocupação em construir um instrumento acabado parece pouco plausível, pois o modelo tem suas características e especificidades baseadas em sua inerente historicidade.

\section{Conceitos e Princíplos da Ergologia}

Após termos esboçado as bases da ergologia, procuraremos apresentar alguns dos seus conceitos de referência e os princípios que orientam essa perspectiva de análise e intervenção. Sabemos, contudo, que tal apresentação será certamente redutora, pois, considerando a complexidade do tema, não nos propomos aqui discuti-lo em profundidade.

Primeiramente, vamos destacar a contribuição da ergologia na ampliação dos significados das noções de trabalho prescrito e trabalho real (Alvarez \& Telles, 2004). Schwartz (2000b) identifica que, além das formas de prescrição relativas à organização do trabalho e às condições dadas ao trabalhador, há normas mais gerais (no sentido dado por Canguilhem) que também têm o papel de antecipar/predefinir as atividades. São chamadas de 'normas antecedentes', pois estão disponíveis antes mesmo de a atividade se iniciar. Elas apresentam dois aspectos: 1) são vinculadas a aquisições da experiência coletiva (e, por isso, são bens comuns, de todos), materializadas nos saberes técnicos, científicos e culturais, imprescindíveis para o desenvolvimento do trabalho; 2) dizem respeito à divisão social do trabalho e às relações de poder.

Para Schwartz, entre essas normas de caráter geral e a estrita imposição de modo de execução, há uma série de normas antecedentes, mais ou menos rele- 
vantes. Ademais, tais normas antecedentes sinalizam valores (saúde, educação, direito ao trabalho, ao lazer, segurança, preservação ambiental, igualdade etc.) sobre os quais há sempre um campo de lutas e em nome dos quais se busca instituir dispositivos legais, em uma conjuntura social específica. Portanto, elas têm uma dimensão sociopolítico-jurídica e não apenas monetária. Enfim, as normas antecedentes estão vinculadas aos regulamentos, procedimentos e tecnologias encontradas em determinada situação de trabalho, no nível de conhecimento técnico-científico e cultural de uma certa sociedade e aos valores nela presentes.

Em uma situação concreta de trabalho, há concorrência entre as várias normas (muitas vezes contraditórias) - princípios, regras, modelos, formação técnico-científica, recursos disponíveis etc. -, sendo os trabalhadores obrigados a fazer escolhas, permanentemente. Dito de outra forma, os trabalhadores se encontram sempre imersos em uma pluralidade de normas e vivenciam constantemente a tensão de se confrontar com elas. Ao fazer opções, buscam soluções e desenvolvem novas técnicas, que mais tarde poderão ser incorporadas às normas antecedentes.

Mas não é só isso: sendo o trabalho um lugar de debates de normas e valores, é também um espaço em que novas normas se instauram, pois, como já assinalamos, em relação aos desafios do cotidiano, há a tendência dos seres humanos de produzir novas normas. Esse movimento é denominado pela ergologia (Canguilhem) “renormatização". Em síntese, há normas que são propostas ou impostas (normas antecedentes), assim como há normas instauradas na própria atividade, ligadas ao próprio indivíduo. Pensar o trabalho como reprodução idêntica das normas econômicas e técnicas subentendidas na atividade de trabalho seria pensá-lo em uma perspectiva apenas adaptativa, o que na verdade não dá conta da complexidade da vida e do trabalho.

O conceito de 'atividade' é central para a ergologia e remete simultaneamente às normas antecedentes (instituídas e presentes no processo de trabalho) e às renormatizações. Assim, para a ergologia, a atividade é entendida como um debate de normas e valores. Diante das normas antecedentes, na situação real de trabalho, os trabalhadores (re)criam estratégias, em um movimento contínuo de (re)normatização. É nesse sentido que Schwartz, na linhagem de Canguilhem, afirma que em toda atividade de trabalho há sempre 'uso de si'. De um lado, 'uso de si pelos outros', como nos é mais visível; de outro, algo que é mais difícil de considerar: 'uso de si por si'. Nas situações reais de trabalho, é necessário que os trabalhadores façam também 'uso de si por si': que se mobilizem (corporal, cognitiva, afetiva e socialmente), que façam uso de suas próprias capacidades, de 
seus próprios recursos e de suas próprias escolhas; que mobilizem o patrimônio coletivo, criem novos coletivos, para equacionar os problemas emergentes, gerir as diferentes normas e, acima de tudo, viver, 'levar a vida'.

Para Schwartz (2005), a atividade humana atravessa o biológico, o psicológico e o cultural, o individual e o coletivo, o fazer e os valores, o privado e o profissional, o imposto e o desejado - porque o fazer é impregnado de valores, o privado se articula com o profissional etc. Logo, a atividade de trabalho não pode ser vista apenas de um ângulo; compreendê-la exige o diálogo entre diferentes disciplinas, abordagens e campos de saberes, envolvendo necessária e sistematicamente os protagonistas do trabalho em análise.

Nessa perspectiva, o foco sobre a atividade de trabalho está ligado tanto aos condicionantes econômicos e sociais dos processos produtivos quanto à história singular que se produz no cotidiano. A atividade de trabalho faz a mediação entre o local e o global (seu contexto social, econômico e político). É nesse sentido que, na perspectiva ergológica, propõe-se um vaivém entre micro e macro: um dado olhar sobre as dificuldades e as possibilidades encontradas nas situações concretas de trabalho, buscando identificar as marcas da história de uma sociedade (seu desenvolvimento científico e cultural, as relações de poder instituídas) e seus valores.

\section{A Confrontação de Saberes: uma exigência para compreender e TRANSFORMAR AS SITUAÇÕES DE TRABALHO}

Para Schwartz (2000b), a ciência tradicionalmente busca a generalização, e assim acaba neutralizando as singularidades ligadas à atividade. Entretanto, os saberes gerados na atividade (na linguagem de Oddone, a 'experiência') são potencialmente uma fonte para compreensão das situações de trabalho. Ao considerá-los, os conceitos científicos são postos à prova. Encontramos no "dispositivo dinâmico de três polos" (Schwartz, 2000b) um modelo de produção de conhecimento que propõe a articulação entre as diferentes disciplinas científicas ("polo dos conceitos"), os saberes e valores gerados pelas experiências dos trabalhadores nas atividades ("polo das forças de convocação e de validação") e, por fim, o "polo das exigências éticas e epistemológicas", que propicia o encontro fecundo dos dois primeiros. Esse terceiro polo é a 'liga' do dispositivo, pois diz respeito à ética necessária à construção de parcerias. É também um polo epistemológico porque trata das condições necessárias para que o intercâmbio entre os dois primeiros polos seja frutífero no que tange ao conhecimento. 
Esse polo se constitui, portanto, em um 'espaço' que viabiliza os acordos e as negociações necessários à produção de conhecimento e às transformações esperadas. Se no MOI, como foi explicitado por Schwartz, esse terceiro polo era dinamizado pelo sindicato, devemos estar atentos à possibilidade de que outros atores operem como agenciadores do intercâmbio desejado.

Ao propor um dispositivo de três polos, a ergologia procura dinamizar a interação entre os saberes que se afirmam no conhecimento científico e na experiência do trabalho, algo já vislumbrado pelo MOI, mas considerando que isso não é nada simples. $\mathrm{O}$ intercâmbio entre experiência e conceito deve permitir o debate sobre as grades conceituais utilizadas na análise dos casos, que apresentam uma visão genérica, avançando na compreensão dos processos, nas suas singularidades. Nesse sentido, o polo da experiência contribui com essa dinâmica, para o desenvolvimento das várias disciplinas e para seu próprio desenvolvimento. Por sua vez, esse intercâmbio deve permitir também uma transformação das condições em que os trabalhadores realizam o trabalho e da forma como eles buscam intervir sobre elas. Deve haver, simultaneamente, o enriquecimento dos dois polos: do conhecimento científico e das forças de convocação e validação.

O dispositivo de três polos pressupõe uma relação dialética entre os diferentes saberes de tipo científico e entre estes e os saberes da experiência. Não se trata de um modelo fechado, mas sim de um referencial transformativo que se agrega ao epistemológico, com efeitos teóricos e metodológicos. Logo, é um dispositivo que pode adquirir formatos diversos e ser adotado em ações diversas, não apenas para fins de pesquisa científica.

Como chama a atenção Schwartz (2002), as intervenções representam sempre o risco de se subestimarem as dinâmicas da atividade estudada. Para esse autor, toda a panóplia de diagnósticos, interpretações e preconizações acaba se constituindo em uma intervenção na vida dos outros - os trabalhadores com seus valores e saberes advindos de um cotidiano de confrontação com as situações de trabalho.

\section{Considerações Finals: a propósito da CONtribuição da ergologia para AS PESQUISAS dE PÓS-GRADUAÇÃO NA Área dA SAÚdE}

Para concluir, é interessante assinalar de que forma a ergologia tem se mostrado uma ferramenta importante para o desenvolvimento, no Brasil, de dissertações e teses relativas à saúde coletiva, tanto do ponto de vista metodológico quanto do teórico-conceitual. 
Do ponto de vista metodológico, vemos que o dispositivo dinâmico de três polos inspirou fortemente os estudos de Ferreira da Silva (2003), Masson (2007) e Zambroni de Souza (2006). Na tese de Ferreira da Silva (2003), esse dispositivo é pensado como uma possibilidade de desenvolvimento de ações de promoção da saúde a partir dos locais de trabalho. No caso da dissertação de Masson (2007), buscou-se estabelecer uma comunidade ampliada (e dialógica) de pesquisa (Brito et al., 2003; Botecchia, 2006) com auxiliares de enfermagem da unidade neonatal, objetivando dar visibilidade aos aspectos de mais difícil percepção da atividade dessas trabalhadoras, mediante sua 'colocação em palavras' e a sinergia/debate entre os polos dos conceitos e o da experiência da prática, tendo como foco articulador a atividade de trabalho.

$\mathrm{Na}$ investigação de Zambroni de Souza (2006), com pessoas com transtornos mentais graves, a perspectiva ergológica guiou a concepção do estudo também pelo fato de ter suscitado questões sobre transformações desejáveis no trabalho, apontando assim para as 'reservas de alternativas' existentes. Nessa mesma linha, Telles (2002) identificou que as ideias da reforma psiquiátrica e do cooperativismo popular integram a constituição das normas antecedentes da organização do trabalho de uma cooperativa de usuários de serviços de saúde mental.

Mas é como ferramenta de compreensão do trabalho, com base no seu arcabouço teórico-conceitual, que a ergologia tem sido especialmente útil. Há, por exemplo, um conjunto de estudos acadêmicos que se utilizou da perspectiva ergológica para tratar do trabalho em saúde. Santorum (2003), em sua análise sobre a atividade de vigilância em saúde do trabalhador (VST), mostrou o hiato entre suas normas antecedentes e o que se faz na ação. Esse hiato está associado a um grande desconhecimento sobre o que os trabalhadores que protagonizam a vigilância enfrentam no cotidiano: as decisões que tomam, as soluções que encontram, as dificuldades com que se deparam etc. Nesse sentido, afirma que o debate relativo às diretrizes da VST precisaria incorporar a experiência desses trabalhadores.

Do mesmo modo, Barbosa da Silva (2006), ao se aproximar do que realmente os profissionais do Programa Saúde da Família (PSF) operam no confronto com as situações reais de trabalho, deparou-se com modos de agir e saber-fazer diversos dos encontrados nos manuais do PSF. Para a autora, a defasagem entre o prescrito e o real é agravada no caso do PSF pelo fato de ser este um modelo ainda não suficientemente experimentado. A prescrição do trabalho no PSF também foi tratada na tese de Scherer (2006), cuja conclusão 
é de que a interdisciplinaridade como atividade real se produz na gestão do trabalho no cotidiano com os profissionais e os usuários.

No campo da educação, podemos citar as pesquisas de Silva (2006) e de Souza (2005). A primeira mostrou que o cotidiano dos professores é marcado pela tensão de valores existentes entre os valores mercantis impostos ao meio acadêmico na forma de indicadores de performance e os valores inerentes à historicidade dos professores - valores dimensionados e sem dimensão, conforme Schwartz (2000b). Por sua vez, Souza (2005) indicou que os professores procuram reverter as situações adversas que podem prejudicar a saúde, a motivação para o trabalho e a interação com os alunos, por meio das renormatizações.

A 'dimensão gestionária do trabalho' foi explorada também em várias pesquisas. No caso de Barker (2005), essa questão foi associada ao conceito de "agir em competência" (Schwartz, 2000b) em sua pesquisa com jovens mães trabalhadoras, moradoras de espaços populares, contribuindo para o reconhecimento não apenas dos sofrimentos relacionados ao trabalho, mas da complexidade de suas atividades e da capacidade delas de gerir as situações.

Em pesquisa com trabalhadores de telemarketing, Oliveira (2007) indicou a necessidade de que a dimensão gestionária do trabalho fosse reconhecida pelos próprios trabalhadores, profissionais de saúde e pesquisadores, para a prevenção de adoecimentos e para a promoção da saúde.

Ruiz (2003) sinalizou para a possibilidade de cada pessoa envolvida nos serviços de saúde mental assumir a coautoria de sua produção e gestão, refutando, assim, a ideia de que a contribuição principal da Reforma Psiquiátrica seria ter fornecido um novo modelo, pensado por especialistas gestores, a ser adotado por especialistas clínicos.

França $(2002,2007)$ mostrou que a tarefa na recepção de um hospital universitário não se constitui apenas da marcação e do registro de exames, pois envolve uma complexa gestão de fluxo dos pacientes, que se processa segundo valores ligados à história do coletivo de trabalho. $\mathrm{O}$ trabalho hospitalar foi também tratado por Muniz (2000), que teve o objetivo de compreender como os profissionais regulavam os problemas organizacionais, visando a garantir a assistência ao paciente de neurocirurgia e a evitar o prolongamento do seu tempo de permanência, constatando seu papel fundamental na gestão desses problemas, seja procurando evitá-los (antecipação), seja buscando minimizar suas consequências (recuperação).

Percebemos que esse conjunto de pesquisas está vinculado especialmente a duas áreas/temas da saúde coletiva; o objeto de uma parte desse conjunto 
é fundamentalmente o 'trabalho em saúde', ao passo que as problemáticas tratadas em um segundo grupo de pesquisas se inserem no campo de estudos da 'saúde do trabalhador'. São pesquisas que remetem ao modo como os trabalhadores (da saúde e outros) vivem no cotidiano de trabalho, envolvendo descobertas que podem ser úteis à atualização de políticas públicas. De fato, pensamos que os desafios apresentados pela complexidade dos problemas encontrados nas situações de trabalho de nosso país poderão ser mais bem enfrentados com a contribuição desse referencial. Assim, esperamos que este capítulo tenha contribuído para um melhor entendimento das ferramentas e da proposição da ergologia, no que tange ao modo de produção de conhecimento sobre o trabalho, em suas relações com a saúde.

\section{REFERÊNCIAS}

ALVAREZ, D. \& TELLES, A. L. Interfaces ergonomia-ergologia: uma discussão sobre trabalho prescrito e normas antecedentes. In: FIGUEIREDO, M. et al. (Orgs.) Labirintos do Trabalho: interrogações e olhares sobre o trabalho vivo. Rio de Janeiro: DP\&A, 2004.

BARBOSA DA SILVA, A. C. A Gestão de Unidades Básicas de Saúde Frente ao Desafio da Estratégia Saúde da Família: exercício de análise do "ponto de vista da atividade", 2006. Dissertação de Mestrado, Rio de Janeiro: Instituto de Psicologia, Universidade do Estado do Rio de Janeiro.

BARKER, S. As Dramáticas do Uso de Si de Jovens Mães Trabalhadoras: cartografias do trabalho em insuspeitáveis territórios, 2005. Tese de Doutorado, Rio de Janeiro: Escola Nacional de Saúde Pública Sergio Arouca, Fundação Oswaldo Cruz.

BOTECCHIA, F. O Desafio de Compreender-Desenvolver um Regime de Produção de Saberes sobre o Trabalho e suas Relações: a comunidade ampliada de pesquisa, 2006. Dissertação de Mestrado, Rio de Janeiro: Instituto de Psicologia, Universidade do Estado do Rio de Janeiro.

BRITO, J. et al. (Orgs.) Programa de Formação em Saúde, Gênero e Trabalho nas Escolas: caderno de textos. João Pessoa: Editora da UFPb, 2003.

CANGUILHEM, G. O Normal e o Patológico. 3. ed. revisada e aumentada. Rio de Janeiro: Forense Universitária, 1990.

CANGuilhem, G. Meio e normas do homem no trabalho [1947]. Pro-posições, 12(2-3): 35-36, 2001.

CLOT, Y. A Função Psicológica do Trabalho. Petrópolis: Vozes, 2006.

DANiElloU, F. (Org.) A Ergonomia em Busca de seus Princípios: debates epistemológicos. São Paulo: Edgard Blücher, 2004. 
FERREIRA DA SILVA, E. Trabalhadores de Escolas e Construção de uma "Comunidade Ampliada de Pesquisa": a busca da Promoção da Saúde a partir do local de trabalho, 2003. Tese de Doutorado, Rio de Janeiro: Escola Nacional de Saúde Pública Sergio Arouca, Fundação Oswaldo Cruz.

FRANÇA, M. Uma Comunidade Dialógica de Pesquisa: atividade e movimentação discursiva nas situações de trabalho de recepcionistas de guichê hospitalar, 2002. Tese de Doutorado, São Paulo: Pontifícia Universidade Católica de São Paulo.

FRANÇA, M. Uma Comunidade Dialógica de Pesquisa: atividade e discurso em guichê hospitalar, 2007. São Paulo: Fapesp, Educ, 2007.

GAWRYSZEWSKI, M. Uma proposta de ação sindical na luta pela saúde. Saúde em Debate, 24: 37-41, 1989.

GUÉRIN, F. et al. Compreender o Trabalho para Transformá-lo: a prática da ergonomia. São Paulo: Edgard Blücher, 2001.

KELLER, D. Système d'Information Concrete: une promenade de santé pour l'ergologie?, 2003. Monografia, Aix-Marseille: Département d'Ergologie, Université de Provence.

KUCHENBECKER, R. O modelo operário italiano 30 anos depois. Saúde em Debate, 36: 48-50, 1992.

LEPLAT, J. \& HOC, J.-M. Tarea y actividad en el análisis psicológico de situaciones. In: CASTILlO, J. \& VILLENA, J. (Orgs.) Ergonomía: conceptos y métodos. Madrid: Editorial Complutense, 1998.

MASSON, L. A Dimensão Relacional do Trabalho de Auxiliares de Enfermagem de Unidade Neonatal: uma análise do ponto de vista da atividade, 2007. Dissertação de Mestrado, Rio de Janeiro: Escola Nacional de Saúde Pública Sergio Arouca, Fundação Oswaldo Cruz.

MUNIZ, H. A Gestão do Tempo de Permanência do Paciente de Neurocirurgia no Hospital Universitário Clementino Fraga Filho, 2000. Tese de Doutorado, Rio de Janeiro: Universidade Federal do Rio de Janeiro.

ODDONE, I. et al. Rédecouvrir l'Éxpérience Ouvrière. Paris: Éditions Sociales, 1981.

ODDONE, I. Psychologie de l'Organisation de la Santé, 1999. (Mimeo.) (Disponível na Biblioteca do Départment d'Ergologie, Université de Provence, França).

ODDONE, I. Entrevista: reflexiones sobre el modelo obrero italiano. Salud, Trabajo y Medio Ambiente, 5: 4-8, 2007.

OLIVEIRA, S. Um Olhar sobre a Saúde a Partir da Dimensão Gestionária do Trabalho: contradições e ambiguidades no telemarketing, 2007. Tese de Doutorado, Rio de Janeiro: Escola Nacional de Saúde Pública Sergio Arouca, Fundação Oswaldo Cruz.

RE, A. et al. A general physician-centred system for preventing environmental diseases. In: WORLD CONGRESS ON ERGONOMICS, 16, 2006. (CD-ROM).

RUIZ, V. A Dimensão Gestionária da Clínica: a experiência em serviço de saúde mental, 2003. Dissertação de Mestrado, Rio de Janeiro: Instituto de Psicologia, Universidade do Estado do Rio de Janeiro. 
SANTORUM, K. Pelas Fendas do Trabalho Vivo: textos, contextos e atos na atividade de vigilância em saúde do trabalho, 2003. Tese de Doutorado, Rio de Janeiro: Escola Nacional de Saúde Pública Sergio Arouca, Fundação Oswaldo Cruz.

SCHERER, M. O Trabalho da Equipe no Programa Saúde da Família: possibilidades de construção da interdisciplinaridade, 2006. Tese de Doutorado, Florianópolis: Universidade Federal de Santa Catarina.

SCHWARTZ, Y. A comunidade científica ampliada e o regime de produção de saberes. Trabalho e Educação, Revista do Nete, 7: 38-46, 2000a.

SCHWARTZ, Y. Le Paradigme Ergologique ou un Métier de Philosophe. Toulouse: Octarès, 2000b.

SCHWARTZ, Y. Intervenir dans la vie des autres. In: COLLOQUE EDF: LE NUCLÉAIRE ET L'HOMME, Paris, 2002. Disponível em: <www.comprendre-agir. org/images/fichier-dyn/doc/2006>.

SCHWARTZ, Y. Actividade. Laboreal, 1(1): 63-64, 2005. Disponível em: <http:// laboreal.up.pt/revista/artigo.php?id=48u56oTV658223469:53635622>. Acesso em: 7 nov. 2010.

SILVA, M. Artífices de um Ofício ou Operários da Fábrica do Conhecimento? A tensão de valores no quotidiano de trabalho dos professores de uma universidade pública, 2006. Dissertação de Mestrado, Belo Horizonte: Universidade Federal de Minas Gerais.

SOUZA, D. L. Interação Professor/Aluno: que relações com a saúde?, 2005. Dissertação de Mestrado, Rio de Janeiro: Escola Nacional de Saúde Pública Sergio Arouca, Fundação Oswaldo Cruz.

TELLES, A. L. Trabalhando como Loucos: em busca de novas formas de organização do trabalho a partir de um estudo da Cooperativa da Praia Vermelha, 2002. Tese de Doutorado, Rio de Janeiro: Coordenação dos Programas de Pós-Graduação em Engenharia, Universidade Federal do Rio de Janeiro.

THEUREAU, J. Contributions à l'histoire de l'ergonomie, 2002. Entretien filmé avec Jacques Theureau, réalisé par Antoine Laville \& Christian Lascaux. Disponível em: <http://www.coursdaction.net/>. Acesso em: 4 ago. 2008.

VICENTI, A. Ivar Oddone, intellectuel organique et chercheur hétérodoxe. Les Territoires du Travail, 3: 33-42, 1999.

ZAMBRONI DE SOUZA, P. C. O Trabalho como Possível: o caso das pessoas com "transtornos mentais graves", 2006. Tese de Doutorado, Rio de Janeiro: Instituto de Psicologia, Universidade do Estado do Rio de Janeiro. 


\title{
23. Relações Socials de Gênero e Divisão Sexual do Trabalho: uma convocaç̃̃o teórico-analitica PARA ESTUDOS SOBRE A SAÚdE DAS TRABALHADORAS DA EDUCAÇÃO
}

\author{
Mary Yale Neves | Jussara Brito \\ Anísio José da Silva Araújo | Edil Ferreira da Silva
}

A existência de uma heterogeneidade de práticas sociais nos mundos do trabalho levou um grupo de pesquisadoras a desenvolver uma avaliação crítica das categorias de análise dominantes no âmbito da sociologia do trabalho, da qual resultou a proposta de uma nova conceituação de trabalho como prática sexuada.

Nessa direção, nos estudos realizados por Kergoat (1986), destaca-se a necessidade de se considerar simultaneamente as esferas da produção e da reprodução, no que se refere tanto aos homens quanto às mulheres. A partir da década de 1970, explicitam-se questionamentos acerca da 'dinâmica' da articulação entre essas esferas, bem como da concepção tradicional de trabalho (ampliando-o ao trabalho doméstico, trabalho não remunerado, trabalho informal). Concretiza-se, assim, a recusa em compreender o trabalho como prática assexuada, apontando-se para a divisão sexual do trabalho (Hirata, 1993, 2002).

Se, por um lado, reconhecemos um avanço na produção de conhecimento e na visibilidade desse debate; por outro, constatamos que ele ainda não se encontra suficientemente presente, como questão transversal, nos estudos dos mundos do trabalho. Nesse sentido, este capítulo se propõe a situar o debate atual em torno da ótica das relações sociais de gênero e da divisão sexual do trabalho, focalizando, sobretudo, como a incorporação dessa perspectiva de investigação pode contribuir para procedermos de forma mais apropriada na análise das especificidades da saúde e do trabalho docente, realizado majoritariamente por mulheres (Brito, 1999; Neves, 1999; Araújo et al., 2006). Mas não só: os benefícios desse enriquecimento no quadro de análise se estendem 
para todo o setor de serviços, ampliado em razão das recentes mudanças nos mundos do trabalho, no qual a participação feminina é, sem dúvida, uma de suas marcas.

\section{A Indissociabilidade das Relações Sociais de Gênero e da Divisão Sexual do Trabalho'}

No debate acerca da utilização do conceito de relações sociais de sexo versus gênero, Kergoat (1996) credita sua opção conceitual pelo primeiro à teoria marxista que sustenta o movimento feminista francês (fazendo analogia com relações sociais de classe). A autora invoca ainda as seguintes justificativas para esta escolha conceitual: em primeiro lugar, a expressão relações sociais de sexo indica de forma mais clara aquilo de que se pretende tratar e, em segundo lugar, alude ao caráter de reciprocidade dessas relações, o que não acontece, de acordo com seu ponto de vista, com o termo gênero, mais comumente associado a estudos sobre mulheres. Em suas palavras:

a aproximação relação social (forçosamente fato da cultura) com a palavra sexo (sempre percebido como fato da natureza) tem um efeito detonador, interrogativo, subversivo, efeito que, para nós, é positivo, já que pensamos que essa abordagem conduz a repensar a epistemologia das ciências sociais. (Kergoat, 1996: 25)

Kergoat defende a ideia de que a divisão sexual do trabalho permite demonstrar a existência de uma relação social específica entre os grupos de sexo. Partindo da premissa de que as relações sociais de sexo e a divisão sexual do trabalho são duas proposições inseparáveis de um mesmo sistema, conclui que a indissociabilidade desses conceitos, em todo o seu dinamismo, conduz a uma visão sexuada dos fundamentos e da organização da sociedade (Kergoat, 1996, 2002).

Essa problemática é ilustrada com o tipo de qualificação exigido às mulheres, em que se incluem destreza, minúcia, paciência, cuidados com o outro etc. Entretanto, por serem consideradas qualidades inatas (próprias da 'natureza feminina') e, desse modo, não adquiridas em canais institucionais

1 Mesmo cientes do debate em torno da abordagem anglo-saxônica (categoria de gênero) e da corrente francesa (relações sociais de sexo), e concordando com várias das considerações feitas por Kergoat (1996), conforme veremos a seguir, optamos em nosso texto pela utilização da terminologia do referencial de relações sociais de gênero. Acrescente-se que tem sido mais usual, na literatura latino-americana pertinente, o uso do conceito 'relações sociais de gênero' do que seu similar 'relações sociais de sexo'. 
de formação, não são reconhecidas e valorizadas socialmente, o que deixa de explicitar que decorrem de uma aquisição coletiva, possibilitada desde a infância pelos trabalhos realizados no âmbito do espaço doméstico (Kergoat, 1986; Hirata, 1986a).

Para Kergoat (1986), as relações sociais de sexo, em face da divisão sexual do trabalho (como materialidade daquelas), ao mesmo tempo que preexistem como noção, são posteriores na condição de problemática. Assim, a autora indica que a incorporação da dimensão sexual nos anos 70, até então escamoteada na elaboração teórica da categoria trabalho, deve-se ao ressurgimento, nos anos 60, do movimento feminista, ou seja: foi esse movimento que possibilitou a emergência da categoria sexo em sua acepção social. Nessa perspectiva, o conceito de relações sociais de sexo rompe com a perspectiva biologizante das práticas sociais masculinas e femininas, como modelos universais, e afirma a construção social e histórica das diferenças, ancorando-se em uma base não apenas ideológica, mas fundamentalmente material. São relações que repousam, por sua vez, em relações de 'poder' entre os sexos e que assinalam a divisão desigual e hierárquica existente entre eles. Mediante a compreensão da divisão sexual do trabalho e a sua incorporação à categoria trabalho, foi possível conhecer mais profundamente a natureza do trabalho feminino (Kergoat, 1986, 1996; Hirata, 1986b, 1993, 2002).

No tocante à questão da hegemonia da categoria de classe ou sexo, Kergoat acredita na necessidade do aprofundamento teórico em termos da rede de relações sociais. Para esta autora, "as relações sociais de sexo dinamizam todos os campos do social. Toda relação social é sexuada, enquanto que as relações sociais de sexo são perpassadas por outras relações sociais" (Kergoat, 1996: 23), o que a leva a defender, juntamente com Hirata (1993) e outras pesquisadoras francesas, tais como Daune-Richard (2003), a necessidade de uma sociologia das relações sociais em que os conceitos classe e sexo sejam transversalmente percebidos.

Em função disso, Kergoat $(1986,1996)$ propõe pensar as relações entre os sexos (opressão) e as relações de classes (exploração) como coextensivas, uma vez que elas se atravessam, acarretando desdobramentos teóricos para o campo do trabalho. Em outras palavras, como forma de enfrentar a divisão entre a produção e a reprodução, essa autora reivindica uma revisão do conceito homogeneizador de trabalho, cujo parâmetro é o trabalho masculino, pretendendo, dessa forma, invocar as assimetrias de sexo presentes nas práticas de opressão/dominação ocultadas pela exploração econômica (Neves, 1988). 
Nessa direção, Hirata (1986a) e Lobo (1991) apresentam uma crítica ao capitalismo, problematizando-o como relação social de classe atravessada por relações sociais de sexo, mostrando a necessidade de uma análise das formas de desmascaramento da mercadoria força de trabalho (irrupção das relações de opressão homens/mulheres na esfera dos processos de trabalho). Como sublinha Hirata (1986b: 12), a

força de trabalho não é uma categoria universal, quantificável e homogênea, mas concretamente, para os capitalistas dentro do processo de produção: masculina ou feminina, jovem ou velha, casada ou solteira, e que o capital se apresenta por vezes mais como relação de exploração do trabalho (pessoa) do que da força de trabalho.

Cabe acrescentar que, ao longo do processo de inserção no mercado formal de trabalho, as mulheres foram ocupando alguns dos espaços anteriormente exclusivos dos homens, como é o caso do magistério. É sobre esta atividade que nos deteremos a seguir para analisarmos o modo como se configura o trabalho feminino nas escolas do ensino fundamental.

\section{Trabalho Docente: precarização e feminização de uma prática profissional}

Há muito se reconhece a presença maciça de mulheres no âmbito da escola, principalmente na primeira fase do ensino fundamental. ${ }^{2}$ Uma das possibilidades de análise desse processo é conceber o magistério como uma atividade profissional feminina, construída historicamente, com base em elementos das esferas sociais, culturais, políticas e econômicas (Pessanha, 1994). No entanto, no Brasil - como, aliás, em considerável parcela das sociedades ocidentais, obviamente considerando as diferenças históricas, socioeconômicas e culturais entre os países - a instituição escolar é, originalmente, masculina e religiosa (Enguita, 1991; Nóvoa, 1995a, 1995b; Apple, 1995; Carpentier-Roy, 1992; Neves \& Seligmann-Silva, 2001). ${ }^{3}$

Arroyo (1985) assinala que, no século XIX, se o professor poderia ser visto como o mestre do ofício de ensinar, sendo ao mesmo tempo proprietário, diretor

2 No campo específico da educação, principalmente a partir da segunda metade da década de 1980 - por meio de artigos pioneiros (nacionais e estrangeiros), como os de Bruschini e Rosemberg (1982), Rosemberg (1996), Louro (1997), Apple (1995) e Carvalho (1998), que chamavam a atenção para o processo pelo qual as mulheres se tornaram professoras e para a identificação das repercussões que essa inserção trouxe para o exercício do magistério -, é que o referencial das 'relações sociais de gênero', desenvolvidas em outros campos de conhecimento, conforme expusemos, passou a ser incorporado nos estudos sobre o trabalho docente.

3 No caso brasileiro, os primeiros professores leigos só surgem a partir de meados do século XVIII, quando os religiosos deixam de monopolizar as práticas de ensino (Saffioti, 1976; Costa, 1995; Louro, 1997). 
e professor da escola, cuja integração com a comunidade era muito próxima, gradativamente ele se transforma em profissional assalariado do ensino. É sobre esse ofício já existente, caracterizado na época como trabalho docente, que o Estado vai delinear e estruturar a organização escolar brasileira e o tipo de profissional que deve atender à necessidade progressiva de expansão da rede de ensino (crescimento da educação elementar de massa), decorrente do processo de urbanização e industrialização em curso (Saffioti, 1976; Costa, 1995).

Vamos, entretanto, encontrar no debate acerca da condição do professorado, seja em outros países, seja no Brasil, a presença de continuidades ou rupturas, em que magistério e escola, como atividades ou instituições sociais, transformam-se historicamente. Os sujeitos que circulam nesse espaço se diversificam, e a instituição, em razão dos vários aspectos aí presentes, ganha novos contornos. Entre as mudanças que marcam, de forma mais evidente, esse processo está a "feminização do magistério" (Louro, 1997: 94).

Os homens, que até o final do século XIX ocupavam os postos de ensino, retiram-se gradualmente dessa atividade no início do século XX em razão de profundas alterações no processo de trabalho docente, decorrentes da combinação de relações de gênero (aumento do nível de escolaridade feminina, possibilitando a entrada das mulheres) e de pressões econômicas sobre o magistério. Tal alteração se verificou porque, com a expansão e as exigências introduzidas de formalização do ensino - o fim do trabalho em tempo parcial, o aumento do número de dias letivos, a perda relativa da autonomia -, além do surgimento de novas oportunidades de emprego masculino, o magistério tornou-se cada vez menos atraente para os homens, cujo trabalho foi sendo, em contrapartida, assumido pelas mulheres. É essa reviravolta que permite uma melhor compreensão das nuances em jogo no exercício da docência no ensino fundamental como trabalho de mulher.

Acreditamos, no entanto, que as relações de gênero assumem formas diferentes em cada momento histórico e em cada classe ou fração de classe. Mais claramente, em cada classe, a decisão sobre o 'destino da mulher', revelada pelo encaminhamento profissional, vai estar submetida aos interesses que a classe, ou fração de classe, tem naquele momento histórico.

No Brasil, percebe-se como consenso a visão de que, do início do século XX até a década de 1960, a origem socioeconômica do professorado do ensino fundamental era principalmente de mulheres das classes médias e que, a partir dos anos 70, parecia ocorrer uma mudança desse perfil, com suas integrantes, em grande parte, oriundas dos estratos médios baixos e das classes trabalhadoras. 
Aqui cabe frisar-se a indiscutível deterioração dos salários no magistério em todo o país nos últimos anos, provocando a gradativa precarização das condições de vida das professoras. ${ }^{4} \mathrm{O}$ dimensionamento do processo de precarização das relações de trabalho da categoria docente na sociedade brasileira torna-se explícito com a visualização da sua remuneração como um trabalho não qualificado.

Sem dúvida, o caráter de classe é fundamental para entendermos o processo de trabalho docente; porém, essa categoria não nos parece suficiente como referencial para explicar as mudanças (de classe) e as tendências de continuidade (reprodução das relações de gênero) no professorado, principalmente da primeira fase do ensino fundamental. Como frisa Hypólito (1997), ocorreu um processo de 'feminização' do magistério brasileiro, que é definidor de muitas das características, inclusive de classe, desse professorado. Este passou por profundas transformações em termos de origem de classe, a partir do momento em que as mulheres nele se inseriram. Apple (1995) já afirmava, em relação ao Reino Unido e aos Estados Unidos, que essa ocupação (de ensinar) não é mais a mesma de antigamente. $\mathrm{O}$ mesmo pode ser dito em relação ao Brasil (Louro, 1997; Hypólito, 1997).

Convém observar que, entre as alternativas possíveis no século XIX para o confinamento doméstico de determinados segmentos de classe do sexo feminino, encontram-se comumente as profissões de magistério, de enfermagem e outros empregos ligados ao domicílio. A inserção dessas mulheres no mercado de trabalho se dá em profissões que têm (ou que passam a ter), como vimos anteriormente, características similares às da esfera doméstica; no caso, atividades de 'cuidados' e responsabilidade relativas à casa, aos filhos e ao esposo. De fato, as profissões que reconhecidamente envolvem 'cuidados' estarão marcadas pela relação entre as atividades dentro e fora de casa, o que favorecerá a concentração de mulheres nesses tipos específicos de trabalho, reforçando a segregação sexual (Novaes, 1992; Hirata, 1993; Mello, 1993; Louro, 1996; Meyer, 1996; Bruschini, 2007; Sorj, Fontes \& Machado, 2007).

A incorporação das relações sociais de gênero e da divisão sexual do trabalho, como categorias sociais de análise, mostra, portanto, como ideias específicas sobre homens e mulheres são produzidas socialmente, qualificando

4 Independentemente da regra gramatical (que se constitui ela mesma em uma produção social), estaremos nos referindo às professoras que compõem principalmente a primeira fase do ensino fundamental de escolas públicas no feminino, devido ao fato de sua configuração ser majoritariamente de mulheres. Mas, ao longo da seção "A saúde (mental) das professoras", manteremos a forma adotada pelos autores em suas respectivas publicações. 
as mulheres como mais relacionais, pacientes e afetuosas, atributos que não corresponderiam à imagem dos homens (Hirata \& Kergoat, 1988). Nessa direção, apresentam-se como referências fundamentais para a compreensão do trabalho no magistério, uma vez que a representação sobre o que é ser professor(a) realça características femininas presentes no processo de socialização. É mediante essa visão universal e a-histórica de homens e mulheres que estas passam a ser consideradas mais adequadas para o magistério da primeira fase do ensino fundamental, uma vez que detêm as características por ele requeridas e, por sua vez, as reproduzem nas relações diferenciadas que estabelecem com alunos e alunas.

Tornar-se professora, na linha de argumentação de Kergoat (1996) e Hirata (1986a), mais do que uma opção profissional, significa então uma oportunidade que a mulher em geral encontra para pôr em prática habilidades e atitudes aprendidas em seu processo de socialização. Nesse sentido, podemos afirmar que o magistério constitui uma prática social sexuada, na medida em que, sobretudo, a primeira fase do ensino fundamental demanda determinadas atribuições que não se enquadram apenas no âmbito dos conhecimentos técnicos e científicos, mas também em qualidades tidas como 'intrínsecas' às mulheres, tais como atenção, paciência, abnegação, dedicação e carinho.

Entretanto, como essas características são consideradas próprias da natureza feminina, são desqualificadas tanto no nível simbólico quanto no econômico (Hirata, 1986b). Lopes (1996: 57), ao analisar o trabalho das enfermeiras, assinala os valores simbólicos e vocacionais da profissão de enfermagem como exemplo da concepção de trabalho feminino baseado em um 'sistema de qualidades (e não qualificações) ditas naturais'.

Vianna (1998) e Lelis (1996) sinalizam, contudo, que é possível que o envolvimento afetivo com os alunos seja necessidade de homens e mulheres que exercem o magistério. ${ }^{5}$ Apenas com a desnaturalização e a historicização das concepções de homem e mulher, masculinidade e feminilidade, é que estaremos atentos para as possibilidades de variações históricas e culturais no ser e estar professor(a). ${ }^{6}$

Além disso, segundo indica Carpentier-Roy (1992) acerca da diferenciação dos investimentos afetivos no exercício plural de homens e mulheres no

\footnotetext{
5 Para maior aprofundamento acerca da dimensão afetiva e do 'cuidado' como atributos da docência, principalmente da primeira fase do ensino fundamental, ver Neves e Seligmann-Silva (2001).

6 Se observarmos outras culturas, com suas especificidades, veremos a inserção não só de mulheres, mas também de homens nesse tipo de atividade.
} 
magistério, é importante acrescentar que essa distinção também se reproduz em outras esferas da vida, como bem atesta o trabalho doméstico. Essa diferenciação constitui-se em elemento fundamental para a compreensão efetiva das implicações diversas que o trabalho pode ter para o processo (sempre inacabado) de construção identitária e para a sua saúde.

\section{A Saúde (Mental) das Professoras}

Em se tratando de trabalho docente do ensino fundamental, o atual cenário de diversas sociedades apresenta um quadro de precarização e excludência, no qual se visualiza a deterioração progressiva das condições de trabalho e saúde dos professores e professoras - de acordo com pesquisas realizadas na Espanha (Esteve, 1999), no Canadá (Carpentier-Roy, 1992; Messing, Seifert \& Escalona, 1995), no México (Márquez, Talamante \& Garduño, 1995), na Argentina (Martínez, 1993; Fernández, 1994), na França (Cordié, 1998) e no Brasil (dentre eles, Diniz, 1998; Codo et al., 1999; Neves, 1999; Brito \& Athayde, 2003; Araújo et al., 2006; Neves \& Seligmann-Silva, 2006; Gomes \& Brito, 2006; Carlotto e Palazzo (2006); Neves et al., 2007; Noronha, Assunção \& Oliveira, 2008). Nos últimos anos, os estudos que analisam o processo de trabalho docente destacam principalmente a presença significativa, no meio educacional, de um 'mal-estar' entre os professores e professoras, em razão de sinais generalizados de sofrimento, sufocamento, estresse, esgotamento, ansiedade, depressão e fadiga no trabalho. A expressão desses sintomas, que se manifestam em pessoas sem patologias anteriores, está relacionada com as situações de trabalho - no sentido de que esses(as) trabalhadores(as) desenvolvem seus medos, manifestando sentimentos de incapacidade.

Entretanto, a compreensão da saúde em geral e, especificamente, da saúde mental dos(as) que exercem a docência se dá por enfoques teórico-metodológicos muito diferenciados. Vamos encontrar desde abordagens de cunho mais reducionista e impactológico até aquelas que tentam apreender a dinâmica complexa da saúde no trabalho. Além disso, nos estudos que se propõem a compreender a relação saúde e trabalho docente, nem todos incorporam a dimensão de gênero - e entre aqueles que assim procedem existem também, a nosso ver, os que o fazem de forma equivocada, ou não exploram as devidas consequências da materialização das relações sociais de gênero nos mundos do trabalho e na configuração de padrões diferenciados de sofrimento e desgaste entre homens e mulheres submetidos(as) a determinadas condições laborais. 
Para efeito deste texto, apresentamos a seguir alguns estudos que versam sobre a saúde dos(as) docentes, agrupando-os pela proximidade do tipo de abordagem, resguardadas suas diferenças (uns de cunho epidemiológico que adotam ou não o referencial do burnout; e outros que adotam distintas abordagens calcadas na psicanálise, na teoria do desgaste, na ergonomia, na psicodinâmica do trabalho, assim como aqueles que se fundamentam em uma perspectiva teórico-metodológica pluridisciplinar). Nosso objetivo principal é identificar aqueles que incorporam ou não a ótica das relações de gênero nas suas análises e, em caso afirmativo, apontar, ainda que de forma breve, alguns dos seus limites e possibilidades.

Desde os anos 70, pesquisas realizadas nos Estados Unidos assinalam a presença de um burnout (esgotamento profissional) no professorado, cujo quadro clínico é caracterizado por fadiga, esgotamento, ansiedade e depressão, e estudos realizados em outros países desenvolvidos sobre a saúde (em geral) dos professores mostram o risco de esgotamento físico ou mental a que estão expostos, assim como seu desdobramento em um acentuado absenteísmo. Entretanto, essas diferentes pesquisas que tratam do burnout (como do estresse), os quais constituem a maioria, abordam-no de formas diferenciadas, assim como obtêm resultados distintos, apesar de as condições e a organização do trabalho se apresentarem bastante semelhantes.

Assim, é a partir principalmente da década de 1990, embora em número reduzido, como é o caso do Brasil, que aparece um conjunto de trabalhos que amplia o quadro de análise da saúde (mental) dos professores e das professoras, ao incorporarem em suas análises a perspectiva de gênero. Cabe destacar que muitos desses estudos se limitam simplesmente a indicar a presença majoritariamente feminina em detrimento do sexo masculino.

Esteve (1999), na Espanha, indica a presença de um 'mal-estar' difuso entre os professores, que pode desembocar ou não no aparecimento do burnout e no aumento da ansiedade, com consequências para a autoimagem e a identidade. Essa situação aflitiva (incômodo indefinível) por que passam os docentes seria decorrente não apenas da crise que assola o sistema educacional de vários países diante das mudanças aceleradas e das novas exigências do contexto social (não sendo, portanto, peculiaridade exclusiva do sistema educacional espanhol), mas sobretudo daqueles fatores que dizem respeito diretamente à atuação do professor em sala de aula: recursos materiais e condições de trabalho, e violência nas instituições escolares. Assim, segundo esse autor, não obstante as consequências desses fatores, os professores não são afetados igualmente, 
sendo possível localizar muitos que souberam dar respostas efetivas e criativas ao novo contexto, outros que reduziram sua eficácia e renunciaram ao ensino de qualidade (recorrendo, defensivamente, a um mecanismo de inibição) e, por fim, um último grupo, o daqueles que acabam sendo pessoalmente atingidos por estresse, neurose ou depressão, que, embora representem um contingente relevante, não constituem fenômeno alarmante. $\mathrm{O}$ número mais significativo corresponderia aos que recorrem ao mecanismo de inibição e rotinizam seu trabalho ou abandonam a profissão.

Codo e Vasquez-Menezes (1999), em pesquisa realizada em âmbito nacional, afirmam que 48\% dos trabalhadores brasileiros em educação da rede pública apresentam nível preocupante de sofrimento em pelo menos uma das três subescalas que compõem o burnout, concebida como uma síndrome da desistência, que acomete aqueles que ainda se encontram no trabalho. Para tanto, recorrem a instrumentos quantitativos que aferem a presença de exaustão emocional, baixo envolvimento no trabalho e despersonalização, desenvolvidos com relação à existência de tensão emocional crônica que, por sua vez, seria provocada pelo excessivo contato afetivo com outros seres humanos. Com base em resultados empíricos encontrados, os autores entendem que as origens do burnout nesses educadores são decorrentes do conflito existente entre o afeto e a razão, das relações sociais de trabalho e da exigência de controle sobre o meio ambiente. Paradoxalmente, como os próprios autores enfatizam, apesar da grande evasão docente, os achados da pesquisa indicam o percentual de 90\% de satisfação entre os educadores. ${ }^{7}$

No caso específico deste estudo, é importante ressaltar que, apesar de Batista e Codo (1999) sinalizarem para a dimensão de gênero, o fazem, a nosso ver, de maneira equivocada e, por vezes, ambígua, pois na contramão dos estudos realizados no Brasil e no exterior, que apontam para uma feminização da profissão, principalmente no ensino fundamental, em razão da presença majoritária de mulheres, tais autores sustentam que estaria em curso uma 'desfeminização' dessa profissão - com base, sobretudo, na elevação do ingresso de homens. Em verdade, generalizam algo que se apresenta em maior nível no ensino médio (e, em proporção menor, na segunda fase do ensino fundamental), o que, por vezes, não fica suficientemente claro em sua análise. Vale lembrar

7 Apesar de não se constituir em objetivo deste texto, já que seu foco remete fundamentalmente para a importância do referencial de gênero nos estudos sobre o trabalho, e se estes incorporam ou não tal perspectiva, ressaltamos que uma devida problematização e uma apreensão crítica (da obtenção) desses resultados (e daqueles dos estudos subsequentes, como também das suas diferenças) acerca da saúde dos docentes se fazem necessárias. 
aqui o que já foi assinalado por Neves e Seligmann-Silva (2001), quando estas autoras sublinham o processo sócio-histórico de feminização como não circunscrito apenas à presença progressivamente maciça das mulheres, mas que esse fenômeno estaria vinculado também por certa maneira - considerada feminina - de perceber e exercer o magistério, tal como visto na seção anterior (Carpentier-Roy, 1992; Costa, 1995; Apple, 1995; Lopes, 1996; Louro, 1997; Araújo et al., 2006). ${ }^{8}$

Carlotto e Palazzo (2006) realizaram um estudo epidemiológico em escolas particulares de uma cidade da região metropolitana de Porto Alegre, Rio Grande do Sul, que envolveu 190 professores (87,5\%) de uma população de 217 docentes do ensino fundamental e médio, sendo que destes 78,9\% eram do sexo feminino. Tiveram como objetivo identificar o nível da síndrome de burnout, buscando possíveis associações com variáveis demográficas, laborais e fatores de estresse percebidos no trabalho. Os resultados mostraram que os docentes apresentam níveis baixos nas três dimensões que compõem o burnout: exaustão emocional, despersonalização e diminuição da realização pessoal no trabalho. Uma tendência de exaustão emocional (que atingiu índice mais elevado que as outras dimensões) está relacionada a fatores de risco como o excesso de alunos e a carga horária de trabalho. Os fatores de estresse no trabalho foram associados às expectativas que os familiares dos alunos têm sobre o trabalho docente, ao mau comportamento de parte desse alunado e à pouca participação nas decisões da gestão da escola. Quanto às variáveis demográficas, dentre elas o sexo, as autoras apontam, respaldadas em alguns estudos que adotam o referencial do burnout, para a ausência de diferenças estatisticamente significativas associadas a esta síndrome, diferentemente do que atesta o estudo de Araújo e colaboradores (2006), também de cunho epidemiológico. Nessa direção, indagamo-nos, como frisado anteriormente, na linha de estudos como o de Araújo e colaboradores (2006), que têm como dimensão norteadora as implicações das relações sociais de gênero no trabalho docente na saúde, se a não incorporação desse olhar (de gênero) é o que produz essa diferença analítica.

Em 2006, Araújo e colaboradores realizaram estudo epidemiológico censitário com 794 professores (47 homens e 747 mulheres) do ensino público fundamental de Vitória da Conquista, Bahia, cujos objetivos eram descrever

8 Vale lembrar que pesquisa realizada pela Unesco (2004), com professores dos ensinos fundamental e médio, confirma que o magistério continua sendo predominantemente exercido por mulheres, que somam $81,5 \%$, contra $18,5 \%$ de homens. 
aspectos da relação entre trabalho docente e saúde, na perspectiva de gênero; avaliar possíveis diferenças entre as características do trabalho dos homens e das mulheres na escola; e descrever condições de saúde referidas por docentes, segundo gênero. Esse estudo indica alguns pressupostos equivocados que norteiam as pesquisas acerca da saúde no trabalho, tais como: 1) as mulheres engajadas em trabalho não pago não estão sujeitas à produção de estresse; 2) as mulheres inseridas em atividades pagas estão sujeitas aos mesmos estressores que os homens; e 3) experiências ocupacionais similares às dos homens produziriam novo padrão de doenças entre as mulheres, o qual é comparável àquele observado em homens. Entre as conclusões, os autores sinalizam que a escola tem demarcações, atravessadas pelo gênero, reproduzindo relações que tornam as mulheres mais vulneráveis aos postos de trabalho considerados como menos qualificados, com menores salários e baixo status social. Afirmam ainda que o setor educacional tem ampla participação feminina, o que significa, segundo os autores, que as investigações deveriam dialogar com a condição do feminino, demarcando-se a importância de se avaliar a carga total de trabalho (dupla jornada), ou seja, incluir o trabalho doméstico nas discussões acerca das possíveis repercussões do trabalho sobre a saúde. Por fim, sustentam a existência de diferenças relevantes entre o perfil dos professores segundo o sexo, já que as mulheres adoecem mais, apesar de fazerem a ressalva que os resultados obtidos devem ser avaliados com cautela, devido ao fato de que as mulheres professoras têm idade em média superior à dos homens.

Encontramos também estudos que partem do referencial psicanalítico, como o de Cordié (1998), na França, e de Diniz (1998), no Brasil (em Belo Horizonte, MG). As duas autoras mencionam a existência de profundo malestar nas professoras e nos professores, bem como identificam um sentimento de impotência resultante das dificuldades enfrentadas no trabalho. Para tanto, Cordié examina as implicações pessoais dos educadores no exercício da função, invocando o lugar do inconsciente, e Diniz chama a atenção para as constantes ausências dos professores da sala de aula, muitas vezes justificadas por licenças médicas. Esta última autora se interroga ainda em que medida tais ausências possibilitam que as professoras suportem o mal-estar do trabalho pedagógico ou, melhor, a grande insatisfação manifestada com o trabalho.

Fernández (1994), que adota também o enfoque psicanalítico, ao estudar as origens da construção do corpo e algumas relações entre corporeidade, gênero sexual e pensamento de um discurso cultural no contexto argentino, constata a exigência de que se esconda a sexualidade da professora primária 
e de que ela anule sua corporeidade (situando-a em paradoxal categoria: 'senhorita virgem e mãe'). A queixa, que é muito comum entre as professoras, pode expressar, segundo essa autora, um lamento impotente em relação a sua realidade, reproduzindo, dessa forma, uma situação de resignação, de imobilização e de dependência (o que é, aliás, muito estimulado pela instituição escolar), ou apresentar-se como queixa-reclamação, aproximando-se, às vezes, de uma reflexão crítica sobre essa realidade.

Messing, Seifert e Escalona (1995), por sua vez, ao realizarem uma análise ergonômica da atividade docente no Canadá, chamam a atenção para uma gama de habilidades técnicas e posturais que têm de ser dominadas pelos professores e professoras, focalizando, em especial, as consequências dessas habilidades na saúde em geral. Esse estudo procurou identificar particularmente a carga de trabalho global expressa em dificuldades enfrentadas em razão de turmas numerosas, crianças com problemas de aprendizagem, desconforto térmico nas salas de aula, carga horária extensiva, grande investimento emocional, necessidade de concentração intensa, situações que provocam a exaustão física e mental desses(as) trabalhadores(as).

Na perspectiva de identificação de cargas de trabalho, encontramos também a pesquisa de Márquez, Talamante e Garduno (1995) desenvolvida no México. Este estudo privilegia o enfoque de gênero por sua capacidade de apreender o contexto geral de incorporação das mulheres nos mundos do trabalho e as especificidades de seu processo saúde-doença, enfatizando a expressão da identidade materna no magistério. Os fatores de desgaste das mestras dizem respeito às cargas físicas (ruído, temperatura, iluminação), químicas (pó de giz, contaminação), biológicas (infecção por micro-organismos), fisiológicas (esforço físico, posição incômoda, esforço visual) e psíquicas (atenção e interação com os alunos, relações conflitantes com as autoridades e com os colegas, desqualificação do trabalho docente, falta de estímulo, envolvimento afetivo com os alunos e seus problemas, reduzido tempo de descanso, ansiedade e culpa por não cumprir as tarefas domésticas). Tais fatores se expressam em patologias relativas: 1) à saúde mental (que incluem os transtornos psíquicos não graves - insônia, irritabilidade, dores de cabeça, fadiga, angústia, temores, depressão, com implicações em seu cotidiano de trabalho -, as enfermidades psicossomáticas - colite, gastrite, hipertensão -, além de patologias mais graves - esquizofrenia, depressão); 2) ao sistema respiratório (problemas de garganta, olhos e pulmões, como faringite, laringite, disfonia, bronquite); 3) ao esforço e posição (lombalgias, transtornos de coluna, miopia, vista can- 
sada); 4) ao aparelho digestivo (infecções gastrointestinais, anemia crônica); 5) a enfermidades infecciosas (sarampo, rubéola, varíola).

Martínez (1993) e Carpentier-Roy (1992), por sua vez, chamam a atenção para as implicações que a perspectiva de burocratização e de racionalização econômica do sistema escolar acarreta para as relações de trabalho e a saúde mental. Segundo Martínez, pesquisadora argentina, um dos eixos fundamentais da problemática do processo de trabalho docente reside no fato de a pedagogia - como prática e saber que confere identidade ao professor e conteúdo a seu ofício - ter sido substituída por uma pseudotecnologia educativa. Isso provoca a desvalorização da docência, a burocratização do sistema, a rotinização e a perda de autonomia no fazer cotidiano do professor e a deterioração da produção intelectual como trabalhador da cultura (Martínez, 1993).

Essa perda de autonomia no trabalho, de acordo com Carpentier-Roy (1992), tem implicações não só ao nível do conteúdo da tarefa, mas também nas relações afetivas que, no caso específico, o(a) professor(a) estabelece com os alunos e com os outros colegas e que, inclusive, extrapolam as esferas curriculares. Nesse sentido, a liberdade no trabalho do(a) professor(a) é fundamental para lhe assegurar a realização não apenas do conteúdo, mas também de um projeto pessoal como educador(a).

O estudo de Carpentier-Roy (1992) sobre a saúde mental dos professores e das professoras de Québec, no Canadá, com base na então chamada psicopatologia do trabalho, ${ }^{9}$ situa-se, na classificação da própria autora, na esfera pré-patológica, área em que coabitam prazer e sofrimento e na qual os efeitos sobre a saúde mental podem ser ocultados por uma normalidade de comportamentos. Carpentier-Roy interroga-se sobre o que estará sob essa normalidade, cujo objetivo é prevenir e evitar a evolução em direção à patologia, como o burnout.

A autora aponta para a falta de reconhecimento, por parte da direção, dos colegas de trabalho e da comunidade em geral, como fator de risco da síndrome de esgotamento profissional. Outro elemento constatado diz respeito à insatisfação do professorado em relação às pressões sofridas sobre a atividade realizada, tais como: vigilância, duplicidade de função (professor/policial), controle rígido do tempo, mudanças de conteúdo dentro de uma mesma disciplina impostas subitamente, carga pesada de algumas disciplinas, insuficiência de recursos instrumentais adequados, falta de tempo livre para trocas

9 Expressão que, posteriormente, passará a ser substituída por psicodinâmica do trabalho. 
entre elas e classes numerosas. Além desses aspectos, Carpentier-Roy sublinha a existência de medo e ansiedade, o que aumenta a 'penosidade' psíquica da docência. Os fatores ansiógenos identificados nessa investigação são: vivência de isolamento, que gera a ideia de falta e culpabilidade individuais; ansiedade provocada por taxas de reprovação e abandono dos alunos; avaliação direta ou indireta da competência da professora; relações hierárquicas (burocráticas e autoritárias); cumplicidade com um sistema escolar desumano; desilusão de ver o conhecimento transformado em bem de consumo; e o medo do esgotamento profissional. Para Carpentier-Roy, a presença ou a falta de suporte, de ordens cognitivas e afetivas, age como moduladores em relação ao prazer e ao sofrimento no trabalho, sendo a maior fonte de satisfação a relação prazerosa que as professoras e os professores mantêm com seus alunos.

Em pesquisa realizada no município de João Pessoa, Paraíba, Neves (1999) trata principalmente das vivências de prazer e sofrimento psíquico das professoras do ensino fundamental, a forma pela qual estas constroem/ reconstroem o sentido do trabalho em condições tão adversas. Os materiais de campo evidenciam uma série de tendências de desqualificação e desvalorização do trabalho docente marcadas pelas relações sociais de gênero e classe, com sérias implicações na saúde dessas professoras. A vivência das professoras em relação à saúde, mais precisamente em relação à doença, contempla, com ênfase, problemas relacionados à voz, à alergia, à visão, à coluna vertebral, a músculos e a varizes. Completam esse quadro as enfermidades psicossomáticas, expressas por cansaço, alterações digestivas e de sono (insônia) e dores de cabeça, determinando que a economia psicossomática se apresente como elemento estratégico da investigação em saúde mental no trabalho docente. Diante das diversas situações de constrangimento no trabalho, as professoras manifestam um rol de sinais e sintomas de sofrimento psíquico, expresso em desânimo, fadiga, frustração, depressão, impotência, insegurança ao realizar as atividades cotidianas, manifestações de irritação, angústia e, até mesmo, 'sensação de enlouquecimento'. A investigação realizada levantou determinados fatores que, na maioria dos casos, incidem sobre o sofrimento das professoras: as relações hierárquicas, a longa e exaustiva jornada de trabalho (somada ao trabalho doméstico), a dificuldade de operar o 'controle de turma', o crescente rebaixamento salarial, a contaminação das relações familiares e, principalmente, a progressiva desqualificação e o não reconhecimento social de seu trabalho. A maior fonte de prazer diz respeito à relação que essas professoras mantêm com seus alunos. Identificaram-se, também, algumas formas pelas quais elas 
conseguem enfrentar as dificuldades presentes em seu cotidiano de trabalho, tornando-o, em muitos casos, psiquicamente estruturante.

Os estudos desenvolvidos inicialmente por Brito e colaboradores (2001), no estado do Rio de Janeiro, incidem sua análise nos fatores que contribuem para a "sobrecarga de trabalho" - expressão usada pelos(as) trabalhadores(as) -, buscando revelar também que tipos de movimentos são feitos pelos professores e professoras para instaurar novas normas de saúde diante de condições tão adversas. Nas análises, os autores ressaltam que o trabalho real do(a) professor(a) extrapola os limites da jornada e do espaço no interior da escola.

De acordo com a prescrição da tarefa, esse(a) profissional deveria cumprir por semana um determinado número de horas em sala de aula, e outro tempo seria reservado para elaboração de aulas e demais atividades. Entretanto, devido às variabilidades - como número elevado de alunos por turma, espaço inadequado para desenvolver as atividades fora da sala de aula (sala dos professores), más condições de trabalho (ruído, falta de recursos materiais, como computador, livros, folhas e revistas), tempo insuficiente, constantes interrupções por parte dos alunos etc. -, uma regulação feita pelas professoras e professores é ocupar o que seria o seu tempo livre com essas atividades, invadindo as suas vidas domésticas, com maiores implicações para as mulheres professoras, já que são estas que tradicionalmente assumem o trabalho realizado no espaço privado (doméstico) (Gomes \& Brito, 2006). Adotando uma perspectiva de cruzamento de métodos de investigação, foram analisados também os dados oficiais sobre 'readaptação profissional' referentes a um período de cinco anos (1993-1997), considerando a readaptação como um indicador do quadro saúdedoença no trabalho. Merece atenção o fato de que, para os(as) professores(as), ampliaram-se as readaptações por problemas vocais, evidenciando modificações nas condições e na organização do trabalho, que tornaram a atividade docente potencialmente mais nociva ao longo dos cinco anos pesquisados.

Esses últimos estudos sobre a saúde dos professores e professoras encontramse no âmbito de uma intervenção mais global voltada para a análise da saúde dos(as) trabalhadores(as) da educação, realizada por pesquisadores, a partir de 1998, no Rio de Janeiro (Fundação Oswaldo Cruz e Universidade do Estado do Rio de Janeiro) e, posteriormente, na Paraíba (Universidade Federal da Paraíba). Eles referem-se a uma experimentação que envolve programas integrados de pesquisas articulados a programas de formação-intervenção, respeitando as singularidades de cada contexto. Essa experimentação é uma maquinação coletiva engendrada segundo o dispositivo Comunidade Ampliada de Pesquisa 
(CAP) proposto por Brito e colaboradores (2001), ${ }^{10}$ inspirado no dispositivo Comunidades Científicas Alargadas (Oddone, Re \& Briante, 1981), que envolve um regime de troca de saberes entre trabalhadores e pesquisadores de instituições envolvidas. As diversas experiências daí decorrentes tiveram também como suportes teórico-metodológicos a ergonomia da atividade e a psicodinâmica do trabalho, na perspectiva ergológica (Schwartz \& Durrive, 2007). Esses estudos e intervenções vêm propiciando a compreensão das situações de trabalho dos(as) docentes das escolas públicas nesses estados, construindo mudanças das condições de trabalho e potencializando o poder de luta desses trabalhadores e trabalhadoras nas questões referentes à saúde, na perspectiva das relações sociais de gênero (Brito, Athayde \& Neves, 2003b; Brito \& Athayde, 2003; Neves et al., 2007; Neves, Brito \& Athayde, 2010).

\section{Para Finalizar...}

Vimos que o processo de ocupação do magistério, principalmente do ensino público fundamental, pelas mulheres não só favoreceu o rebaixamento salarial e a desvalorização dessa profissão como sedimentou um determinado tipo de fazer. De fato, encontramos certa tradição, com todo o seu arsenal simbólico, na construção das representações sobre o trabalho docente - tradição que parece estar atravessada por uma perspectiva essencialista do gênero feminino e do magistério, cuja associação é percebida como intrínseca. A representação do magistério como uma profissão feminina, tal como verificada em diversos estudos realizados nos mais diferentes países e regiões do Brasil, influi e determina não apenas a 'opção' pelo magistério como também o funcionamento das salas de aula e os modos de realizar esse ofício. É nesse sentido que se pode evidenciar a 'feminização' do magistério não só pela presença maciça das mulheres nessa atividade de trabalho, mas também por certa maneira considerada feminina - de percebê-lo e exercê-lo.

Julgamos que a análise sobre a relação trabalho docente e saúde não encontra sentido se não se ancora também na ótica das relações de gênero, a nosso ver não apenas uma categoria de análise que se compõe com outras para desvendar uma realidade. Tal posicionamento é um pressuposto básico,

10 Ver, a esse respeito, Cadernos de Método e Procedimentos (Brito, Athayde \& Neves, 2003a) e Cadernos de Textos (Brito, Athayde \& Neves, 2003b), concebidos pelo Programa de Formação em Saúde, Gênero e Trabalho nas Escolas, como instrumentos de orientação para a constituição das CAPs que venham a se desenvolver com o objetivo de dar início a ciclos de formação e pesquisa-intervenção dirigidos aos trabalhadores e trabalhadoras de escola. 
uma condição capital, sem o que qualquer compreensão se torna impossível. A relação com o trabalho - e as evidências mencionadas anteriormente são abundantes nessa direção - é toda perpassada por construções históricas que destinam aos homens e às mulheres determinados lugares sociais.

O reconhecimento da dupla jornada de trabalho e das 'competências' requeridas às mulheres para atuar, principalmente, na primeira fase do ensino fundamental é indispensável para apreender o quadro de sofrimento e adoecimento docente, o que nem sempre está presente nos estudos realizados, ou não é devidamente considerado.

O caso exemplar mencionado demonstra a necessidade de se incorporar, na análise da saúde dos trabalhadores e trabalhadoras em geral, esse vasto patrimônio de reflexões em torno da ótica das relações sociais de gênero, sob pena de nos defrontarmos com análises enviesadas, desprovidas da sustentação que poderiam ter caso incluíssem em seus estudos a perspectiva de gênero. A abundância de argumentos aqui enunciada em favor da incorporação da ótica das relações sociais de gênero nas análises sobre os mundos dos trabalhos revela-se ainda mais pertinente quando nos defrontamos com o alargamento do setor terciário. Um olhar com a lupa evidencia que a mesma lógica que preside a feminização do magistério se estende para outras tantas atividades, como os call centers, nos quais as 'competências' femininas são demandadas, reproduzindo uma discriminação histórica. Não se trata, portanto, de adicionar mais uma categoria de análise, mas de embeber o nosso olhar com essa perspectiva, sem o que prosseguiremos na tradição de ocultamento que marcou (e ainda marca) os estudos sobre o trabalho e a saúde das trabalhadoras.

\section{REFERÊNCIAS}

APPAY, B. Précarisation sociale et restructurations productives. In: APPAY, B. \& THÉBAUD-MONY, A. (Dir.) Travail et Santé. Paris: Centre National de la Recherche Scientifiques (CNRS)/Inserm, 1997.

APPLE, M. W. Trabalho Docente e Textos: economia politica das relações de classe e de gênero em educação. Porto Alegre: Artes Médicas, 1995.

ARAÚJO, T. M. et al. Diferenciais de gênero no trabalho docente e repercussões sobre a saúde. Ciência Eु Saúde Coletiva, 11(4): 1.117-1.129, 2006.

ARROYO, M. G. Mestre, Educador, Trabalhador: organização do trabalho e profissionalização, 1985. Tese de concurso para titular, Belo Horizonte: Faculdade de Educação, Universidade Federal de Minas Gerais. 
BATISTA, A. S. \& CODO, W. Crise de identidade e sofrimento. In: CODO, W. (Org.) Educação: carinho e trabalho. Petrópolis, Brasília: Vozes, CNTE-UnB, 1999.

BRITO, J. Saúde, Trabalho e Modos Sexuados de Viver. Rio de Janeiro: Editora Fiocruz, 1999.

BRITO, J. \& ATHAYDE, M. Trabalho, educação e saúde: o ponto de vista enigmático da atividade. Trabalho, Educação e Saúde, 1(2): 239-265, 2003.

BRITO, J.; ATHAYDE, M. \& NEVES, M. Y. (Orgs.) Cadernos de Método e Procedimentos. João Pessoa: Editora UFPB, 2003a.

BRITO, J.; ATHAYDE, M. \& NEVES, M. Y. (Orgs.) Cadernos de Textos. João Pessoa: Editora UFPB, 2003b.

BRITO, J. et al. Relatório de Atividades do Programa de Formação em Saúde, Gênero e Trabalho nas Escolas. Rio de Janeiro, João Pessoa: Associação Brasileira de Saúde Coletiva (Abrasco), Fundo de Igualdade de Gênero (FIG), Agência Canadense para o Desenvolvimento Internacional (CIDA), 2001.

BRUSCHINI, C. \& ROSEMBERG, F. (Orgs.) Trabalhadoras do Brasil. São Paulo: Brasiliense, Fundação Carlos Chagas, 1982.

BRUSCHINI, M. C. A. Trabalho e gênero no Brasil nos últimos dez anos. Cadernos de Pesquisa, 37: 537-572, 2007.

CARLOTTO, M. S. \& PALAZZO, L. S. Síndrome de burnout e fatores associados: um estudo epidemiológico com professores. Cadernos de Saúde Pública, 22(5): 1.0171.026, maio 2006

CARPENTIER-ROY, M. C. Organisation du Travail e Santé Mentale chez les Enseignantes e les Enseignants du Primaire et du Secondaire. Relatório de Pesquisa. Québec, Canadá, 1992.

CARVALHO, M. P. Gênero e trabalho docente: em busca de um referencial teórico. In: BRUSCHINI, C. \& HOLANDA, H. B. (Orgs.) Horizontes Plurais: novos estudos de gênero no Brasil. São Paulo: FCC, Ed. 34, 1998.

CODO, W. et al. Educação: carinho e trabalho. Petrópolis, Brasília: Vozes, Confederação Nacional dos Trabalhadores em Educação (CNTE)-UnB, 1999.

CODO, W. \& VASQUEZ-MENEZES, I. O que é burnout? In: CODO, W. (Org.) Educação: carinho e trabalho. Petrópolis, Brasília: Vozes, Confederação Nacional dos Trabalhadores em Educação (CNTE)-UnB, 1999.

CORDIÉ. A. Malaise chez l'Enseignant: l'éducation confrontée à la psychanalyse. Paris: Éditions du Seuil, 1998.

COSTA, M. W. Trabalho Docente e Profissionalismo. Porto Alegre: Sulina, 1995.

DAUNE-RICHARD, A-M. Qualificações e representações sociais. In: HIRATA, H. \& MARUANI, M. (Orgs.) As Novas Fronteiras da Desigualdade: homens e mulheres no mercado de trabalho. São Paulo: Editora Senac, 2003.

DINIZ, M. De que sofrem as mulheres-professoras? In: LOPES, E. M. T. L. (Org.) A Psicanálise Escuta a Educação. Belo Horizonte: Autêntica, 1998. 
ENGUITA, M. F. Tecnologia e sociedade: a ideologia da racionalidade técnica, a organização do trabalho e a educação. In: SILVA, T. T. (Org.) Trabalho, Educação e Prática Social: por uma teoria da formação humana. Porto Alegre: Artes Médicas, 1991.

ESTEVE, J. M. O Mal-Estar Docente: a sala de aula e a saúde dos professores. Bauru: Edusc, 1999.

FERNÁNDEZ, A. A Mulher Escondida na Professora: uma leitura psicopedagógica do ser mulher, da corporalidade e da aprendizagem. Porto Alegre: Artes Médicas, 1994.

GOMES, L. \& BRITO, J. Desafios e possibilidades ao trabalho docente e à sua relação com a saúde. Estudos e Pesquisas em Psicologia, 1: 1-14, 2006.

HIRATA, H. Vida reprodutiva e produção: família e empresa no Japão. In: KONTCHEVSKY, A. et al. (Orgs.) O Sexo do Trabalho. Rio de Janeiro: Paz e Terra, 1986a.

HIRATA, H. Trabalho, família e relações homem/mulher: reflexões a partir do caso japonês. Revista Brasileira de Ciências Sociais, 1(2): 8-21, out. 1986 b.

HIRATA, H. Paradigmes du travail, un "point de vue transversal”. Futur Antérieur, 16: 5-10, 1993.

HIRATA, H. Nova Divisão Sexual do Trabalho? Um olhar voltado para a empresa e a sociedade. São Paulo: Boitempo Editorial, 2002.

HIRATA, H. \& KERGOAT, D. Rapports sociaux de sexe et psychopathologie du travail. In: DEJOURS, C. (Dir.) Plaisir et Souffrance dans le Travail. Paris: Éditions de l'Association pour l'Ouverture du Champ d'Investigation Psychopathologique (AOCIP), 1988.

HYPÓLITO, A. M. Processo de trabalho na escola: algumas categorias para análise. Teoria e Educação, 4: 3-21, 1997.

KERGOAT, D. Em defesa de uma sociologia das relações sociais: da análise crítica das categorias dominantes à elaboração de uma nova conceituação. In: KONTCHEVSKY, A. et al. (Orgs.) O Sexo do Trabalho. Rio de Janeiro: Paz e Terra, 1986.

KERGOAT, D. Relações sociais de sexo e divisão sexual do trabalho. In: LOPES, M.; MEYER, D. \& WALDOW, V. (Orgs.) Gênero e Saúde. Porto Alegre: Artes Médicas, 1996.

KERGOAT, D. A relação social de sexo: a reprodução das relações sociais à sua subversão. Pro-posições, 13(1): 47-59, 2002.

LELIS, I. A. A Polissemia do Magistério: entre mitos e histórias, 1996. Tese de Doutorado, Rio de Janeiro: Pontifícia Universidade Católica.

LOBO, E. S. A Classe Operária tem Dois Sexos. São Paulo: Brasiliense, 1991.

LOPES, M. J. M. Divisão do trabalho e relações sociais de sexo: pensando a realidade das trabalhadoras do cuidado de saúde. In: LOPES, M.; MEYER, D. \& WALDOW, V. (Orgs.) Gênero e Saúde. Porto Alegre: Artes Médicas, 1996.

LOURO, G. L. Nas redes do conceito de gênero. In: LOPES, M. J. M.; MEYER, D. E. \& WALDOW, V. R. Gênero e Saúde. Porto Alegre: Artes Médicas, 1996. 
LOURO, G. L. Gênero, Sexualidade e Educação: uma perspectiva pós-estruturalista. Petrópolis: Vozes, 1997.

MÁRQUEZ, M.; TALAMANTE, C. \& GARDUÑO, M. La salud-enfermedad de las maestras: una experiencia participativa. In: BLANCAS, P. R.; RAMÍREZ, J. C. R. \& PÉREZ-GIL ROMO, S. E. (Coords.) Género y Salud Femenina: experiencias de investigación en México. Guadalajara: Instituto Nacional de la Nutrición, 1995.

MARTÍNEZ, D. El Riesgo de Enseñar. Buenos Aires: Secretaria de Cultura y Educación Suteba, 1993.

MELLO, G. N. de. Magistério de $1^{\circ}$ Grau: da competência técnica ao compromisso político. 10. ed. São Paulo: Cortez, 1993.

MESSING, K.; SEIFERT, A. M. \& ESCALONA, E. El minuto de 120 secundos: analizar la actividad de trabajo para prevenir problemas de salud mental en educadoras de escuelas primarias. Revista Salud de los Trabajadores, 7(2): 69-88, 1995.

MEYER, D. E. Do poder ao gênero: uma articulação teórico-analítica. In: LOPES, M. J. M.; MEYER, D. E. \& WALDOW, V. R. (Orgs.) Gênero e Saúde. Porto Alegre: Artes Médicas, 1996.

NEVES, M. Y. Divisão Sexual do Trabalho e Relações de Gênero: anotações sobre o tema. In: ENCONTRO ANUAL DA ANPOCS, XII, Águas de São Pedro, 1988. (Mimeo.)

NEVES, M. Y. Trabalho Docente e Saúde Mental: a dor e a delicia de ser (tornar-se) professora, 1999. Tese de Doutorado, Rio de Janeiro: Instituto de Psiquiatria, Universidade Federal do Rio de Janeiro.

NEVES, M. Y.; BRITO, J. \& ATHAYDE, M. Mobilização das professoras por saúde. In: RAAB GLINA, D. M. \& ROCHA, L. E. (Orgs.) Saúde Mental no Trabalho: da teoria à prática. São Paulo: Roca, 2010.

NEVES, M. Y. \& SELIGMANN-SILVA, E. Trabalho docente: precarização e feminização de uma prática profissional. In: ATHAYDE, M. et al. (Orgs.) Trabalhar na Escola? Só inventando o prazer. Rio de Janeiro: Ed. Cuca-Ipub/UFRJ, 2001.

NEVES, M. Y. \& SELIGMANN-SILVA, E. A dor e a delícia de ser (estar) professora: trabalho docente e saúde mental. Estudos e Pesquisas em Psicologia, 6(1), 2006.

NEVES, M. Y. et al. Comunidade ampliada de pesquisa: pesquisadores e trabalhadores/as de escolas públicas colocam seus saberes em sinergia na busca da promoção da saúde a partir dos locais de trabalho. In: KRUTZEN, E. C. \& VIEIRA, S. B. (Orgs.) Psicologia Social, Clínica e Saúde Mental. João Pessoa: Editora UFPB, 2007.

NORONHA, M. M. B.; ASSUNÇÃO, A. A. \& OLIVEIRA, D. A. O sofrimento no trabalho docente: o caso das professoras da rede pública de Montes Claros, Minas Gerais. Trabalho, Educação e Saúde, 6(1): 65-85, 2008.

NOVAES, M. E. Professora Primária: mestra ou tia. São Paulo: Cortez, Autores Associados, 1992.

NÓVOA, A. (Org.) Vida de Professores. Porto: Porto Editora, 1995a. (Coleção Ciências da Educação) 
NÓVOA, A. Diz-me como ensinas, dir-te-ei quem és: e vice-versa. In: FAZENDA, I. (Org.) A Pesquisa em Educação e as Transformações do Conhecimento. Campinas: Papirus, $1995 b$.

ODDONE, I.; RE, A. \& BRIANTE, G. Redécouvrir l'Expérience Ouvrière: vers une autre psychologie du travail? Paris: Messidor, Éditions Sociales, 1981.

PESSANHA, E. C. Ascensão e Queda do Professor. São Paulo: Cortez, 1994.

ROSEMBERG, F. Educação infantil, classe, raça e gênero. Cadernos de Pesquisa, 96: 58-65, fev./abr. 1996.

SAFFIOTI, H. I. B. A Mulher na Sociedade de Classes: mito e realidade. Petrópolis: Vozes, 1976.

SCHWARTZ, Y. \& DURRIVE, L. (Orgs.) Trabalho e Ergologia: conversas sobre a atividade humana. Niterói: EdUFF, 2007.

SORJ, B.; FONTES, A. F. \& MACHADO, D. C. Políticas e práticas de conciliação entre família e trabalho no Brasil. Cadernos de Pesquisa Fundação Carlos Chagas, 37(132): 573-594, set./dez. 2007.

UNESCO (Organização das Nações Unidas para a Educação, a Ciência e a Cultura). O Perfil dos Professores: o que fazem, o que pensam, o que almejam. São Paulo: Moderna, 2004.

VIANNA, C. Entre o desencanto e a paixão: desafio para o magistério. In: BRUSCHINI, C. \& HOLANDA, H. H O. B. (Orgs.) Horizontes Plurais: novos estudos de gênero no Brasil. São Paulo: Fundação Carlos Chagas, Editora 34, 1998. 


\section{Relação de Servilço, Telemarketing e Saúde: ALGUMAS APROXIMAÇ̃̃ES}

Simone Santos Oliveira

\section{A Telecomunicaşão e 0 Telemarketing}

Para o atual desenvolvimento econômico e social do capitalismo mundial, o setor de telecomunicações é considerado vital. Segundo alguns analistas, estaríamos na transição de uma sociedade industrial, cujo símbolo foi a indústria automobilística, para uma sociedade informacional, cujo símbolo seriam as telecomunicações (Laranjeira, 2003). Em tal conjuntura, a atividade de telemarketing tem um importante papel na economia globalizada ao transferir diversas atividades, na maioria serviços prestados em interação direta, para serviços por telefone. Essa transformação geral da divisão do trabalho, somada à figura do consumidor e favorecida pelas novas capacidades de transmissão de dados, leva, por sua vez, a uma multiplicação de empregos nos diversos tipos de centrais de atendimento (serviços financeiros, vendas por telefone, serviços ao consumidor, serviços públicos, tecnologias e telecomunicações etc.).

Tal panorama se constata pelo índice de geração de novos empregos. Nele, os setores de serviços vêm se destacando cada vez mais. Esse crescimento pode ser visto também na Pesquisa Anual de Serviços (PAS) do Instituto Brasileiro de Geografia e Estatística (IBGE, 2006). ${ }^{1}$ Os serviços de telecomunicações representaram $67,1 \%$ da receita dos serviços de informação em 2005, contra $67,9 \%$ em 2004. Dentre os vinte produtos dos serviços de informação com maiores participações na receita, 11 pertencem ao segmento de telecomunicações, destacando-se os serviços complementares de telecomunicação por fio

1 Disponível em: <www.ibge.com.br/home/presidencia/noticias/noticia_visualiza.php?id_ noticia=933\&id_pagina=1>. Acesso em: mar. 2006. 
(assinaturas, mudanças de titularidade etc.) e os serviços de interconexão de telefonia móvel celular, que ocuparam as duas primeiras posições no ranking das atividades de informação, com 8,6\% e 7,2\%, respectivamente.

Os serviços de interconexão de telefonia móvel celular estavam na sexta posição no ranking dos serviços de informação em 2004, e subiram para a segunda em 2005, com receita de $\mathrm{R}$ 9,3 bilhões, contra R \$ 6,1 bilhões em 2004. Esses produtos, somados aos serviços complementares de telecomunicações por fio, aos serviços de telefonia celular pós-pagos e aos serviços fixo-móvel de telecomunicações por fio, ocuparam as quatro primeiras posições no ranking dos serviços de informação, correspondendo a mais de 40,0\% do segmento de telecomunicações (IBGE, 2006).

São mais de 800 mil pessoas atuando nesse setor, segundo a Associação Brasileira de Telesserviços (ABT, 2006). Cerca de 80\% das centrais de atendimento estão no eixo São Paulo-Rio de Janeiro. Em tamanho, 20\% dos call centers têm mais de setecentas posições de atendimento (PAs); 29\% têm mais de cem PAs; e 51\% têm mais de dez PAs. Do total de profissionais, 76\% são mulheres, e $80 \%$ estão na faixa etária entre 20 e 30 anos. Mas, considerando-se que $53 \%$ dos call centers são terceirizados, temos duas realidades diferentes a considerar. Nos call centers próprios, 33,3\% dos atendentes possuem diploma universitário; 59,3\% têm ensino médio completo e 7,4\%, até o ensino fundamental completo. Nos call centers terceirizados, $11,7 \%$ são atendentes com diploma universitário; $86,7 \%$ têm até o ensino médio concluído e $1,7 \%$, até o ensino fundamental concluído. Sem dúvida, nos serviços, é o setor que mais gera empregos (ABT, 2006).

A necessidade das empresas de se posicionarem no segmento da proximidade com o cliente (identificado como um fator essencial da concorrência) faz da telemática lugar-chave na melhoria da relação cliente-empresa, com seu caráter estratégico na capacidade de captar informações que emanam do mundo da demanda (Ruzza, 2002). Mas, com uma denominação comum, as centrais de atendimento agrupam uma grande variedade de atividades. Partindo do princípio de conhecer as necessidades e atender ao cliente, essas atividades vão da assistência (apoio jurídico ou suporte técnico) à enquete por telefone, ao telemarketing, passando por atividades de gestão comercial.

No Brasil, a primeira atividade envolvendo o telemarketing ocorreu com o catálogo de telefones Páginas Amarelas do jornal O Estado de S. Paulo. Donas de casa, em sua maioria, eram contratadas para atuarem em casa com planilhas e telefones fornecidos pelo jornal, o que caracteriza o telemarketing 
ativo, que se desenvolveu a partir dos anos 80 , com a chegada de corporações norte-americanas.

No final da década de 1990, aconteceram grandes mudanças no setor de telefonia, decorrentes da privatização. As empresas de telefonia fixa e móvel, que possuíam um grande número de postos de trabalho, terceirizaram o serviço de telemarketing. No início, o termo telemarketing era conhecido apenas como vendas por telefone; mais tarde, passou a identificar outras ações, principalmente o serviço de atendimento ao cliente (SAC).

Para a Associação Brasileira de Telesserviços (ABT, 2006), a definição de telemarketing seria: toda e qualquer atividade desenvolvida através de sistemas de telemática e multimídia, objetivando ações padronizadas e contínuas de marketing. Segundo Monteiro (1999), trata-se de um diálogo em tempo real a distância, de forma padronizada e sistemática, com o intuito de estreitar relacionamentos e realizar negócios. De maneira geral, as centrais de atendimento operacionalmente se caracterizam pela conectividade entre telefonia e informática; pela organização de trabalho com parcelamento das tarefas, rígido controle hierárquico, seguida de avaliação da atividade como medida de produtividade para definição dos salários. Deve-se ressaltar que esse setor é impactado por uma evolução constante, justamente por causa do componente tecnológico de acoplamento entre telefonia e informática. As tendências atuais se orientam por uma melhoria da qualidade de serviços e uma diversificação da atividade pela integração de serviços via Internet e de mensagens eletrônicas.

A problematização do tema se torna estratégica em razão da generalização das relações de serviço por toda a sociedade, indicando que novos parâmetros devem ser considerados na formulação das políticas públicas. O telemarketing assim é limítrofe na consideração desses novos parâmetros oriundos das relações de serviço para além da referência de produção industrial. É possível vislumbrar tendências mais gerais em que a organização do trabalho, a questão do gênero e a própria questão de saúde ganham conformação mais complexa, exigindo maiores esforços na direção da prevenção e da promoção da saúde.

É necessário considerar, assim, como o trabalho no setor de serviços atravessou um desenvolvimento acelerado, acompanhando essas tendências mais gerais, impulsionado pela interação com as tecnologias informacionais. $\mathrm{O}$ setor de serviço como um todo, segundo Braga (2006), pode ser classificado em três áreas distintas: serviços domésticos baseados na produção de valores 
de uso fora da família e na mercantilização das atividades domésticas; serviços informacionais, com o uso da Internet e das telecomunicações; e serviços às empresas, baseados nas terceirizações de atividades das indústrias.

Os serviços criados para auxiliar a produção e a distribuição dos bens passam a ser mais importantes do que a produção de bens. São transformados de bens em serviços, ou seja, os produtos passam a ser coadjuvantes, já que o serviço que vem incluso na compra do bem predomina na hora da compra (Braga \& Antunes, 2009). Nesse novo sistema, são os serviços e as melhorias que contam. $\mathrm{O}$ cliente não compra somente o produto em si, mas também o serviço que é oferecido.

No contexto dessa nova relação entre produção e consumo, os consumidores passam a ter necessidade de suporte ao longo da vida útil do produto adquirido (Bagnara, 2000). Esse processo de 'desmaterialização' do processo de trabalho também possibilitou a transformação da informação em mercadoria. O setor de serviço estabelece uma comunicação produtiva mais intensa, em que grande parte está baseada no intercâmbio contínuo de informações e conhecimentos. Como a produção de serviço não resulta em um bem material ou durável, alguns autores o denominam de trabalho imaterial (Hardt, 2003).

Lazzarato e Negri (2001) propõem o conceito de trabalho imaterial para dar conta das dimensões pós-industriais, por meio do setor de serviços, em que a comunicação entre produção e consumo se verifica de forma mais intensa. $\mathrm{O}$ trabalho imaterial é o que se encontra no cruzamento; seria a interface da nova relação produção/consumo, cabendo ao trabalho imaterial ativar e organizar essa relação. Portanto, para os autores,

Um produto antes de ser fabricado, deve ser vendido (...). Esta estratégia se baseia sobre a produção e o consumo de informação. Ela mobiliza importantes estratégias de comunicação e de marketing para reapreender a informação (conhecer a tendência do mercado) e fazê-la (construir o mercado). (Lazzarato \& Negri, 2001: 44)

Trata-se de uma mudança da lógica taylorista/fordista, que se baseava no ciclo produção/mercado/cliente e que, a partir da atual flexibilização, passa a se dar no sentido inverso cliente/mercado/produção (Hardt \& Negri, 2001). Daí o trabalho imaterial ser ponto de fundamental importância nessa nova relação, que, além de produzir objetos, produz informação, conhecimento, serviços, valores. E ele é definido como imaterial também porque incide sobre algo imaterial, que é a subjetividade humana. 
Outros autores preferem utilizar o conceito de 'relação de serviço' para tratar das relações e interações entre os atores da oferta e da demanda, da dinâmica do trabalho e da produção nas empresas contemporâneas - uma vez que é pouco explicativo classificar a atividade econômica em setores industrial e de serviço, pois a indústria incorpora cada vez mais, nos seus negócios e nas suas estratégias competitivas, serviços associados aos seus produtos, como garantia, assistência técnica e serviço de atendimento ao consumidor, entre outros (Zarifian, 2001a).

Esta situação pressupõe uma relação com o destinatário, usuário ou cliente, como observa Zarifian, exigindo dos trabalhadores competências relacionais, discursivas e comerciais - transformações da relação entre produtor e consumidor que, na década de 1980, fez surgir o trabalho de telemarketing, buscando o contato e a comunicação de forma mais constante e eficaz, possibilitando acessar o consumidor e diversos públicos ao mesmo tempo, prescindindo da localização geográfica.

No entanto, essa relação se dá sob grande tensão, que aparece fortemente na atividade de telemarketing e identificada nas atividades de serviços de maneira geral, como define Offe (1999). Por um lado, temos a busca da particularidade e, por outro, as regras, regulamentações e valores gerais. Para ser bem-sucedido, o trabalho em serviço deve produzir um equilíbrio entre esses dois aspectos, a especificidade do caso e a generalidade da norma.

O conceito serviço é capaz de exprimir uma nova maneira de ver e avaliar a produção em qualquer setor. A 'produção de serviço' é um modo de elaborar conceitos sobre as tensões que persistem acerca do modelo industrialista taylorista e sua superação. Produzir serviço será obter uma mudança na situação de uma pessoa ou de um bem de uma instituição, envolvendo trabalho real e qualificação profissional para se atingir essa transformação. Esse serviço, que produz a mudança, produz também valor. Esse valor pode ser considerado de várias perspectivas, inclusive pela validade social do serviço (Zarifian, 2001b).

Dessa forma, o valor do serviço se baseia principalmente na avaliação da transformação das condições de atividade, onde o serviço deve ser considerado o efeito - o resultado - nas condições de exercício da atividade (Zarifian, 2001b). O investimento do trabalhador condiciona quase sempre o uso dos produtos, sendo decisivos a pessoa ou o grupo, pois o investimento de si mesmo é o elemento-chave para o sucesso do serviço, para a produção de resultados. O valor do serviço pelos recursos se baseia na competência profissional, em que a busca da eficiência é a origem da pertinência do serviço, que é uma 
organização e uma mobilização, o mais eficiente possível, de recursos para interpretar, compreender e gerar a modificação perseguida, nas condições de atividade do destinatário. Esse novo mundo do trabalho exige não apenas maior qualificação dos trabalhadores, mas também uma nova dimensão do conteúdo de suas capacidades profissionais, com maior entendimento do processo da produção e do desenvolvimento de competências (Market, 2002a).

A noção de competência, segundo Hirata (1994), é bastante imprecisa e decorreu da necessidade de se avaliarem e classificarem essas novas habilidades e conhecimentos criados a partir das novas exigências de situações concretas de trabalho - associada aos novos modelos de produção e gerenciamento, substitutiva da noção de qualificação, ancorada nos postos de trabalho, e das classificações profissionais que lhes eram correspondentes. $\mathrm{O}$ debate em torno do conceito de competência gira em torno da seguinte questão: essas mudanças determinam apenas uma instrumentalização das novas qualificações adquiridas no capitalismo tecnologicamente avançado, dessa forma moldando a subjetividade dos trabalhadores ao novo nível da acumulação, ou se trata de uma mudança que pode indicar a superação das limitações do homem na produção capitalista (Market, 2002b). Não pretendemos aqui fazer uma discussão sobre tema tão complexo, mas buscamos nos apropriar dessa noção compreendendo que ela amplia a capacidade de conhecer o trabalho, uma vez que combina conhecimentos, destrezas, experiências e qualidades pessoais usadas efetivamente e apropriadamente como resposta às várias circunstâncias relativas à prática profissional (Zarifian, 2003).

Portanto, nas relações de serviço, competência profissional consiste em construir uma interpretação das consequências a serem produzidas para o cliente segundo o que ele mesmo propõe, mas também com base em informações que espelham outras perspectivas. É necessário compreender, identificar o sentido que o cliente dá à transformação que ele deseja de sua atividade, estabelecer uma comunicação autêntica, isto é, ser capaz de se perguntar: o que esse destinatário está procurando resolver? A compreensão do evento não se dá apenas no relacionamento momentâneo entre as pessoas; ela mobiliza também toda a experiência dos empregados de uma empresa, todo o conhecimento da organização, toda a competência da retaguarda (back office). A contraefetuação precisa gerar soluções para um problema compreendido, produzidas de maneira eficiente: rotineiras (automáticas) quando recorrentes, pré-padronizadas com necessidade de ajustes quando aparecem com menor frequência, ou serem criadas quando forem exceções. Elaboradas, as soluções 
devem efetuar a transformação efetiva das condições de atividade do destinatário, como explica Zarifian (2001b).

Esse novo perfil de ocupação nos serviços tem apresentado para a gerência das empresas o problema de como regular a relação empregado/consumidor em um contexto de interação. Mas se a supervisão pessoal, direta e constante pode prejudicar a eficácia do serviço, retirando dele sua qualidade espontânea e interpessoal, como tornar previsíveis as reações dos empregados a situações de trabalho tão diversificadas? A partir desse questionamento, Sorj (2000) afirma que o que caracteriza essas ocupações é a qualidade da interação estabelecida que produz significados que operam como importantes sinalizadores para os consumidores do valor do produto. Ou seja, o próprio trabalhador é parte do produto que está sendo oferecido ao cliente. Estabelece-se uma estreita relação entre características pessoais dos empregados, e sua adequação ao trabalho transforma traços como aparência, idade, educação, gênero e raça em potencial produtivo, de tal forma que características e competências individuais são a condição mesma da empregabilidade. Daí resulta, de acordo com a autora, uma forte estratificação do mercado de trabalho, em que níveis inferiores de emprego, em tempo parcial ou temporário, são preenchidos predominantemente por mulheres e jovens com poucas oportunidades de carreira e mobilidade (Sorj, 2000).

Esse conjunto de mudanças traz consequências para os trabalhadores segundo o sexo, pois elas "requerem novas competências, especificamente, e inclusive competências femininas" (Hirata, 2000: 23). A adoção de políticas neoliberais, de acordo com Hirata, aumenta a concorrência e aumenta, portanto, a necessidade de diminuição de custos, e as mulheres são as mais solicitadas quando se trata de diminuí-los, para o aumento da competitividade e da rentabilidade da produção.

\section{A Relação de Serviço e a Perspectiva das Relações de Gênero}

Na diversidade dos mundos do trabalho, precisamos introduzir a dimensão sexuada que contribui para expandir os limites da definição de trabalho e a sua compreensão. Os estudos que enfocam as relações de gênero propiciam o entendimento de que essas relações atravessam o mundo do trabalho, constituindo-se em mais um componente de sua complexidade (Brito, 2005).

É no setor de serviços que vamos encontrar maior concentração das mulheres nas atividades, seja porque a ausência de vínculo empregatício facilita a 
compatibilização da vida doméstica com a necessidade de gerar rendimentos, seja porque as atividades de serviço são excluídas de uma representação em termos de tecnicidade e consideradas pertencentes a um universo de trabalho em que se requerem qualidades inerentes à 'natureza feminina', mascarando as competências mobilizadas no trabalho assalariado (Brito, 2005).

Segnini (2001) nos mostra que, em 1999, entre as mulheres empregadas (41,9\%), com base em vários indicadores (rendimento, jornada de trabalho, registro em carteira e direitos no trabalho), existe uma desigual condição da maioria dessas mulheres, que ocupam, sobretudo, postos de trabalho que demandam menor qualificação reconhecida efetivamente pela remuneração.

Com relação ao trabalho de telemarketing bancário, Segnini (2001) revela que, nesse mesmo período, $88,8 \%$ do trabalho é realizado por mulheres, sendo que, em $40 \%$ das centrais de atendimento nos bancos brasileiros, só existem operadoras e, em 60\% das centrais restantes, consideradas mistas, 70\% (em média) são mulheres. O objetivo do trabalho em telemarketing é, ao atender aos clientes, concretizar a dimensão singular que cada um deles significa para a prestação do serviço. E as mulheres são consideradas mais 'apropriadas' - e não mais qualificadas - para esse tipo de tarefa, em decorrência de atributos pessoais, construídos mediante estereótipos sexistas - como 'voz mais suave', 'convincente'; 'são mais disponíveis para ouvir', 'mais pacientes', 'têm mais jeitinho para lidar com clientes irritados', acrescendo-se o fato de a voz feminina ser considerada 'mais confiável' para realizar operações bancárias a distância (Segnini, 2001).

Em investigação com o objetivo de avaliar a relação da interação dos fatores na gênese das lesões por esforço repetitivo (LER) em telefonistas, Goulart (2002) observa que o gênero interfere no processo e na organização do trabalho. As mulheres sofrem a intensificação da repetitividade das tarefas, pois atendem mais clientes e entram com mais dados em uma mesma jornada de trabalho, aumentando o uso das estruturas osteomusculares, elevando os riscos de LER para esse grupo. Goulart conclui que as exigências das tarefas variam conforme a tecnologia empregada, o sexo do atendente, o período de exercício da função e o tipo de vínculo empregatício. E que o processo de seleção é sexista e provoca a feminização da ocupação em horários de maior produtividade e intenso esforço repetitivo. A divisão sexual do trabalho naturaliza os riscos e inibe a tomada de medidas efetivas para reduzir a repetição das tarefas.

Portanto, a feminização do trabalho em telemarketing, com procedimentos altamente padronizados e controlados, no intuito de aumentar sua eficiência 
e diminuir custos, é uma das expressões de sua racionalização (Segnini, 2001). Persiste uma segmentação do mercado de trabalho pela divisão sexual do trabalho com a permanência de guetos ocupacionais. Isto também está evidenciado no trabalho de Nogueira (2006), em que são reafirmadas as posições hierárquicas diferenciadas, sendo reservados às mulheres salários inferiores em relação aos homens, assim como as responsabilidades domésticas.

Dedecca (2009) faz uma reflexão sobre a relação entre trabalho, gênero e uso do tempo no capitalismo e observa que a política de flexibilização desconsidera suas implicações sobre a organização socioeconômica. Nesse debate, discutem-se apenas os efeitos da flexibilização sobre o uso do tempo de trabalho de caráter econômico (jornada de trabalho), ignorando-se alterações em outras dimensões da ordem econômico-social, como é o caso do aumento da demanda por energia elétrica. A padronização da jornada de trabalho diurna nos dias úteis foi fundamental para a compatibilidade entre trabalho e vida familiar, coincidindo os horários de trabalho, de escola e de creche. A ampliação da jornada em regime excepcional rompe essa compatibilidade, principalmente no caso das mulheres.

Apesar da tendência de uma jornada de trabalho de caráter econômico exercida pelas mulheres, elas têm uma jornada total superior à dos homens. Estar desempregado não significa maior jornada em afazeres domésticos. No entanto, para as mulheres, o ingresso no mercado de trabalho não representa menor jornada em afazeres domésticos. A flexibilização da jornada de trabalho encontra-se estreitamente associada à consolidação da cultura do consumo individual difundida no capitalismo nos últimos vinte anos. A difusão dessa cultura tem associado cidadania e consumo e transformado os termos em quase sinônimos (Dedecca, 2009).

Essa necessidade de compatibilização fica expressa em pesquisa realizada em central de atendimento por Rocha e colaboradores (2005), quando verificam que a satisfação das mulheres no trabalho estava relacionada à jornada de seis horas diárias, possibilitando a conciliação do trabalho com tarefas domésticas e de cuidado com filhos. Ao mesmo tempo, pela mesma razão, observa-se também que a necessidade de elas trabalharem nos fins de semana era considerada um aspecto negativo, e que muitas vezes são necessários arranjos familiares, com envolvimento de outras mulheres (Nogueira, 2006).

As pesquisas de gênero contribuíram para dar visibilidade às relações sociais entre homens e mulheres, ampliando a compreensão da complexidade do trabalho. 


\section{Processo e a Organização de Trabalho no Telemarketing}

As atividades realizadas no telemarketing podem assumir duas formas: ativa e receptiva. $\mathrm{Na}$ forma ativa, o operador toma a iniciativa do contato telefônico com o cliente, e as atividades estão relacionadas a vendas de produtos e serviços; na forma receptiva, a iniciativa do contato telefônico parte do cliente, que comanda a ligação.

O atendimento receptivo é uma operação direcionada ao relacionamento da empresa com os clientes. A empresa disponibiliza meios de contato para serem utilizados pelo público. Conforme Mancini (2001), o objetivo do atendimento receptivo é atender bem a qualquer solicitação dos clientes, pois essa pode ser a diferença que manterá um cliente satisfeito e fiel a uma marca ou a um serviço, com a fidelização dos clientes. Em termos operacionais, temos então o seguinte processo: o cliente liga para a empresa; a empresa gera cadastro nos contatos; o operador segue um roteiro (script) para a abordagem; o público comanda a demanda de ligações, formando-se picos de demandas sazonais. $\mathrm{O}$ telemarketing receptivo inclui os serviços de atendimento ao cliente (SAC), serviços de reclamações e sugestões, prestação de informações, suporte técnico e vendas.

Sempre que a empresa toma a iniciativa de contatar seus clientes, parceiros, fornecedores ou consumidores, de maneira sistemática, programada e direcionada, temos o atendimento ativo, que é uma ferramenta muito utilizada na comercialização, para ações de vendas e campanhas promocionais. Para Mancini (2001), o atendimento ativo tornou-se mais importante com as mudanças que vem sofrendo o mercado. A rotina operacional apresenta as seguintes características: a empresa liga para o cliente que, para isso, deve ter um cadastro para a emissão das ligações; um script deve ser seguido pelo operador, que comanda a ação; os picos são previsíveis em razão da colocação de novos produtos no mercado. Nesse tipo ativo, há maior resistência por parte dos clientes.

Apesar do uso indiscriminado dos variados termos para a função e o segmento, verifica-se uma tentativa dos profissionais da área de qualificar a atividade como telemarketing ou teleatendimento e as instalações, de central de atendimento ou call center (Marquez, 2002). Ruy Braga propõe a utilização do termo 'teleatividade', por parecer mais afinado com o tipo de trabalho em questão (Braga \& Antunes, 2009), pois se trata de uma forma de atividade de produção e não simplesmente de chamada ou contato telefônico; também 
utiliza o termo 'centrais de teleatividade' (CTA). Optamos por utilizar a denominação telemarketing por ser a de mais ampla utilização.

A organização do trabalho em uma central de atendimento é particularmente regida por um parcelamento das tarefas, seguido de um rígido controle e avaliação das atividades dos operadores. A função de operador de telemarketing, segundo a Classificação Brasileira das Ocupações - n. da CBO: 3-80.25 (Brasil, 2010)-, no que se refere às suas atribuições, é definida como a exercida por aqueles que: atendem ligações telefônicas, fornecendo informações, prestando serviços e efetuando transações de operações bancárias adaptadas para atender à solicitação de clientes. $\mathrm{O}$ trabalho dos operadores é realizado na posição de atendimento (PA), composta por um terminal de computador integrado ao sistema de telefonia.

A profissão de operador de telemarketing só passou a ter regulamentação específica no início de 2007. Ela engloba as funções de atendente, digitador e telefonista. Entre outras prescrições, a lei estabelece jornada com duração máxima de seis horas contínuas de trabalho por dia ou 36 horas semanais, mas admite a extensão dessa jornada em regime de hora extra, e a base salarial é de $\mathrm{R} \$ 480,00$ mensais.

No perfil do operador, devem figurar minimamente, de acordo com as empresas: ensino médio completo; experiência em uso de terminais de informática; agilidade no uso do teclado; conhecimento sobre os produtos oferecidos pela empresa e sobre os sistemas utilizados. As habilidades do operador ideal para uma empresa seriam: boa compreensão verbal; corretas expressão verbal, dicção e vocalização; boa argumentação; conhecimento de ortografia; voz agradável; escuta ativa; capacidade de análise de problemas; capacidade de comunicação; trabalho em equipe; capacidade de aprendizado; tolerância ao estresse; disciplina; sensibilidade interpessoal; empatia (Sakamoto, 2001).

A diferença entre operadores e supervisores é muito pequena, inclusive salarialmente, mas do ponto de vista da organização do trabalho é uma distinção importante, que Zarifian (2001a) classifica de front office (operadores) e de back office (supervisores, chefes e gerentes). Os supervisores reportam-se hierarquicamente ao gerente de área de atendimento e são os responsáveis diretos pela supervisão, orientação e qualidade das atividades dos operadores. O supervisor tem o seguinte perfil sugerido: universitário ou formação superior completa; experiência no uso de terminais informáticos e na área de atendimento; ótimos conhecimentos dos produtos oferecidos pela empresa e sobre os os sistemas utilizados (Sakamoto, 2001). 
As equipes de trabalho são divididas e agrupadas nas denominadas ilhas, contendo em média de quinze a vinte operadores com um supervisor por equipe. A principal prescrição dos operadores e operadoras é fornecer as informações solicitadas pelos clientes no menor tempo possível por atendimento. Cada empresa utiliza um padrão para esse tempo, definido como tempo médio de atendimento (TMA), que também pode variar internamente dependendo do tipo de serviço. Em média, esse tempo varia de um minuto e quarenta segundos a três minutos. As pausas são de aproximadamente quinze minutos para lanche e cerca de cinco a sete minutos para ida ao banheiro.

Os procedimentos de trabalho, como os scripts, frases padronizadas e tempos para o atendimento, são definidos pela empresa em razão de determinado serviço planejado por setores hierarquicamente superiores. O controle do trabalho é realizado pessoalmente pelo supervisor e, indiretamente, pelo setor de monitoria por meio de escutas telefônicas, em tempo real ou posteriormente, pela gravação da chamada. O setor denominado monitoria se ocupa de fazer escutas aleatórias das ligações e, semanal ou mensalmente, emite avaliações individuais que indicam a qualidade do atendimento de acordo com os parâmetros definidos por empresa. Esses parâmetros, segundo Ferreira (2004), são: TMA; rapidez na identificação da demanda do cliente; qualidade no atendimento; adequação ao script; erros fatais (informações incorretas repassadas aos clientes); solução da chamada no primeiro contato; gestão de satisfação dos clientes (GSC); número de reclamações registradas pelos clientes do serviço junto à Agência Nacional de Telecomunicações (Anatel); número de informações repassadas via unidade de resposta audível (URA - vocalização); índice de rechamadas por cliente (IRC); número de planos vendidos por número de chamadas atendidas (taxa de conversão de vendas); absenteísmo.

Os operadores estão, assim, submetidos a uma série de mecanismos de controle no trabalho: controle de tempo, do conteúdo da informação prestada e dos resultados obtidos. Dessa forma, a atividade de telemarketing se encontra diante de um paradoxo: de um lado, há uma finalidade de ação comunicacional; de outro, existe a interdição que é feita aos operadores em relação ao interlocutor, via restrições organizacionais (Ruzza, 2002).

A seguir apresentamos alguns estudos em que as análises sobre organização do trabalho em telemarketing expressam essa contradição fundamental entre duas lógicas. Por um lado, teríamos estudos que destacam as centrais de teleatendimento com padrões de organização segundo uma perspectiva taylorista, representada pelas tarefas repetitivas e rotineiras e pelo trabalho desprovido de 
sentido, provocando a desqualificação do trabalhador. E por outro lado, teríamos os estudos que valorizam a diversidade de situações concretas de trabalho que podem ser observadas nas centrais de teleatendimento, mostrando a sua complexidade. Temos assim diversas nuances para expressar essa contradição.

No Brasil, os estudos de Venco (1999, 2006), em central ligada a uma instituição financeira, apontam para uma organização do trabalho pautada por princípios tayloristas, caracterizada por fatores como a divisão entre execução e concepção, controle dos tempos e movimentos e a administração científica dos trabalhadores. Da mesma forma, Mascia e colaboradores (2000), ao analisarem a organização e as características do trabalho em telemarketing bancário e de cartões de crédito, afirmam que a estrutura organizacional, o processo de trabalho e a concepção das tarefas estão baseados nos paradigmas tayloristas. Segundo eles, algumas empresas misturam iniciativas modernas com outras extremamente convencionais originadas na escola taylorista-fordista. Afirmam, ainda, que nas centrais de atendimento há um forte componente de imprevisibilidade no relacionamento com o usuário, que demanda autonomia por parte do operador para lidar com situações diversas, inclusive o tipo de linguagem utilizada pelo cliente. Antagonicamente a essa necessidade, o script se transforma em uma camisa de força. No entanto, o uso estrito e controlado de scripts é uma tentativa de padronização e aceleração dos atendimentos que, segundo pesquisa de Assunção e colaboradores (2006), não se mostra suficiente para a resolução dos problemas reais do atendimento.

Sznelwar, Zidan e Martins (1999) e Sznelwar, Abrahão e Mascia (2006) realizaram estudos sobre operadores de telemarketing no setor financeiro e verificaram que a atividade concebida parece ser simples, rápida e facilmente controlável, mas é, na realidade, complexa e variável, exigindo dos operadores um esforço continuado para dar conta das demandas. Quanto à complexidade da tarefa a ser executada pelo operador de telemarketing, ela também fica evidenciada no artigo de Castro e colaboradores (2006), em que a atividade de teleatendimento, para os autores, exige tomadas de decisões, criatividade, paciência, gentileza, além de experiência e competência dos operadores para conduzirem a conversa e solucionarem os problemas. No estudo de Santos (2002), é destacado que os operadores estão expostos a um grande volume de trabalho, realizando múltiplas tarefas, sob controle rígido dos tempos de execução. A imposição da redução do tempo médio do atendimento ocasiona a execução simultânea de atividades, havendo interferência entre elas. De acordo com o tipo de serviços e produtos ofertados e o universo de usuários, 
os operadores ficam sujeitos a uma variabilidade importante de problemas a resolver e a uma imprevisibilidade da ordem de entrada de chamadas, seja pelo conteúdo, seja pelo tipo de comportamento do cliente. Dessa forma, as más condições de trabalho nas centrais de atendimento, segundo Santos (2002), não têm sua gênese situada só nesse setor, mas também emergem do funcionamento global e organizacional da empresa. Situação semelhante é observada por Castro e colaboradores (2006).

Da mesma forma, Silva (2004) demonstra, em estudo realizado em central de teleatendimento que presta serviços a diversas empresas, que se verificam padrões heterogêneos de organização do trabalho, conjugando tarefas com conteúdo complexo e simplificado, muitas vezes em uma mesma atividade. Um exemplo nesse sentido relaciona-se à atividade de fidelização e retenção de usuários, considerada de complexidade média. $\mathrm{O}$ atendimento de reclamações e o recebimento de sugestões apresentam baixa complexidade e um elevado grau de aderência ao script, bem como menor tempo de atendimento, enquanto a atividade de retenção de usuário mostra-se mais complexa, requerendo capacidade de argumentação e negociação do teleoperador, pouca aderência ao script e flexibilidade no tempo do atendimento. A atividade de vendas, por sua vez, é aquela que apresenta menores níveis de complexidade, pois dispõe de uma base de dados simplificada. Para a atividade de fidelização e retenção de usuários, a autonomia de decisão é parcial, visto que as rotinas de retenção permitem ao teleoperador maiores margens de negociação com os usuários, enquanto nas rotinas de fidelização o teleoperador se limita a registrar a sugestão ou reclamação do usuário. Os maiores níveis de autonomia de decisão foram encontrados na atividade de suporte técnico.

A pesquisa de Algodoal (2002) também deixa evidente a complexidade desse trabalho e a importância das práticas de linguagem do operador de telemarketing, pois o tipo de discurso associado à qualidade vocal pode fazer com que o operador seja mais eficiente no processo de persuasão do cliente.

Em estudo realizado na Espanha, Bono (2000) aborda os processos de reestruturação e descentralização das atividades em uma empresa do ramo das telecomunicações e diz que as margens de ação individual dos teleoperadores encontravam-se limitadas pela execução de tarefas repetitivas e pelo ritmo intenso de trabalho, resultando na inexistência de autonomia de decisão. Outro aspecto destacado pela autora refere-se aos níveis hierárquicos e às formas rígidas de controle. Ele constata ainda o enrijecimento das formas clássicas de organização, bem como a perda do controle sobre o processo de trabalho 
por parte dos trabalhadores e a imposição de um ritmo de trabalho ditado pelo sistema informatizado.

$\mathrm{Na}$ França, os estudos de Cousin em centrais de atendimento confirmam o que ele chama de hiper-racionalização de trabalho, expresso na onipresença do controle - fenômeno possível graças à avaliação permanente dos operadores, possibilitada principalmente pelos sistemas informatizados, que são capazes de "decupar o ato do trabalho ponto a ponto, em tempo real" (Cousin, 2002: 509; tradução livre).

No entanto, ainda assim, há espaço para a regulação, destacado também por Buscatto, em seus estudos sobre centrais de teleatendimento especializadas em vendas de seguros, exclusivamente por telefone e mídias eletrônicas. Mesmo nesse ambiente altamente controlado, os operadores são capazes de desenvolver práticas autônomas, descartando parte das prescrições gerenciais. Segundo Buscatto (2002: 192, tradução livre), "não somente os operadores interpretam a atividade à sua maneira, mas escolhem os termos dessa interpretação que melhor se ajustam à sua personalidade”. Para eles, a tarefa assim reinvestida seria individualizada, resultado de cada personalidade. Serge Leroux (2000) também destaca a propensão dos trabalhadores de acompanhar o processo de individualização que integra as estratégias capitalistas de introdução de inovações tecnológicas. E Johann Petit (2002) salienta a tendência da confrontação mediante a diversidade de prescrições por meio da formação de grupos de trabalho. A própria informática facilita essa troca de informações, permitindo a criação de uma dinâmica coletiva de produção de serviço.

É nesse sentido que Ruzza (2002) alerta para a necessidade de uma visão mais complexa dessa atividade, justamente com relação às possíveis características do taylorismo. Se este modelo pode ser o ponto de chegada de alguns estudos, torná-lo o ponto de partida seria um erro metodológico. No modelo produtivo tayloriano clássico, o departamento de métodos define o produto a ser realizado. Dentre um conjunto de possibilidades, o processo deve resultar na melhor realização (one best way). Os operadores devem se conformar a esse modo operatório sob pena de sanções eventuais. No entanto, os clientes não se questionam sobre esse modo operatório e, por diferentes modos, podem interferir na qualidade do produto. Nas centrais de teleatendimento, a gerência não pode definir o produto sem ao mesmo tempo prescrever o modo operatório; existe uma coconstrução entre os operadores e seus interlocutores para redefinir o produto e o modo operatório. Mesmo se a gerência tenta negá-la ou eliminá-la, essa interação tem efeitos de retorno sobre a própria prescrição. 
Portanto, deve-se reafirmar a importância do reconhecimento da complexidade do trabalho, especialmente no telemarketing. Como observa Boutet (2006: 81), os teleoperadores mobilizam recursos da língua e aplicam competências ou saberes pessoais adquiridos no decorrer de sua socialização inicial, mas esses conhecimentos não são suficientes, essas "competências linguísticas exercem-se nas práticas de linguagem, nas ações que eles coconstroem discursivamente com os usuários: traduzir, explicar, provar, etc.". Esse reconhecimento é fundamental, e pensamos que dar visibilidade à criação cotidiana dos operadores pode fornecer pistas e indicar caminhos mais efetivos para maior compreensão, apontando mudanças possíveis no processo de trabalho do telemarketing, como indicado em Oliveira, Santos e Brito (2006).

\section{Aspectos da Relação Saúde e Trabalho no Telemarketing e Regulamentações}

Alguns estudos sobre a relação saúde e trabalho no telemarketing apontam para os riscos físicos do ambiente de trabalho, como ruído elevado, provocando perda da capacidade auditiva, principalmente nos momentos de pico do atendimento. A falta de tratamento acústico interfere na compreensão da solicitação do cliente, trazendo consequências também para a qualidade do atendimento (Santos, 2002). Outros estudos vão procurar identificar a presença da carga física como possível fator desencadeante de lesões por esforços repetitivos/distúrbios osteomusculares relacionados ao trabalho (LER/Dort), apresentando resultados que estabelecem relação entre a presença de dor e a percepção de desconforto em relação ao mobiliário (Frigeri \& Vidal, 1999). A existência de elevada incidência de disfunções osteomusculares também é atribuída a momentos de intensificação do trabalho ou a mudanças organizacionais e estruturais (Sznelwar \& Massetti, 2000; Oliveira, 2002).

Os estudos que buscam fazer uma análise psicossocial da atividade de telemarketing identificam como fatores de estresse: a rapidez no atendimento em conflito com a qualidade do atendimento; a constante mudança entre as informações referentes aos produtos e serviços e a necessidade de conhecimentos; a repetitividade da tarefa em contraste com a complexidade. Esses trabalhos mostram a importância das trocas intersubjetivas como um suporte social gerado pelas relações sociais estabelecidas no trabalho, a fim de se diminuír o impacto dos fatores de risco e possibilitar a convivência com 
tarefas monótonas e pouco criativas (Marquez, 2002; Glina \& Rocha, 2003; Fernandes, Tejo di Pace \& Passos, 2002).

A combinação de altas demandas e baixo controle sobre o trabalho também se relaciona aos altos níveis de estresse (Rocha et al., 2005). Como aponta Galasso (2005), os operadores não alteram a voz, mas ficam doentes, e um número expressivo se queixa de dores musculares, ansiedade e irritabilidade, indicando estresse e sofrimento psíquico. A contradição gerada na atividade, em que os empregados são pressionados pelo ritmo imposto pelo cliente que solicita maior tempo do que o previsto para responder às suas demandas específicas, vai de encontro ao da empresa, que exige deles um tempo padrão; já que 'a boa' produtividade situase em torno do número de ligações/atendentes, isso se transverte em queixas, dores, fadigas, tanto na esfera física quanto na mental (Leal \& Soares, 2002). Para Santos (2002), a organização do trabalho do telemarketing se baseia em controles de tempo e impõe ritmos incompatíveis com as capacidades humanas, além de as características do público e dos aspectos culturais de cada região interferirem no trabalho das atendentes e no tempo médio de atendimento. Esse nível de exigência (rapidez, precisão na informação, assim como a pressão que o cliente impõe no atendimento) é maior nos grandes centros.

Queixas relativas a sensações de cansaço, esgotamento mental e impotência diante de uma rígida organização de trabalho também são apontadas por Vilela e Assunção (2004), que evidenciaram os diversos mecanismos de controle do trabalho a que estão submetidos os operadores: controle do tempo, do conteúdo, do comportamento, do volume de serviços realizados e dos resultados. A empresa, para conseguir uma interação com o cliente e a satisfação deste, depende do esforço mental e afetivo dos operadores, que não podem ultrapassar os tempos previstos de acordo com as metas comerciais ou romper o controle imposto. Essas contradições entre métodos de gestão e metas comerciais levam ao adoecimento dos trabalhadores. A sensação de estarem constantemente vigiados também acaba trazendo grande ansiedade e extremo mal-estar (Assunção et al., 2006).

A carga cognitiva também é apontada como predominante no estudo de Torres e Abrahão (2002), em razão da complexidade das tarefas e das diferentes solicitações de processos cognitivos. E a carga psíquica foi associada ao componente cognitivo, em razão das exigências do atendimento ao público e das pressões da organização do trabalho, determinando a sua natureza desgastante. As vivências de sofrimento estão associadas tanto às condições nas quais as atividades são realizadas quanto às relações socioprofissionais (Ferreira, 2004). 
Temos assim um preocupante quadro de adoecimento, em que pode ser longo e penoso o processo de reconhecimento do acidente e da doença do trabalho, pois, em geral, as empresas se recusam a emitir Comunicações de Acidentes de Trabalho (CAT), e a Previdência tem dificultado o reconhecimento para pagamento do benefício específico dos que se acidentam ou adoecem em razão do trabalho. A principal fonte de dados estatísticos sobre acidentes no Brasil é o Instituto Nacional do Seguro Social (INSS), que se baseia nas CATs, cujos dados oficiais se referem apenas aos acidentes registrados e ocorridos com trabalhadores segurados, sendo a maioria deles concentrados nos acidentes causadores de traumas. O problema dos acidentes de trabalho assume maiores proporções do que as estatísticas existentes permitem estimar, e o seu dimensionamento real, inclusive quanto ao custo social, tem sido dificultado por diversos fatores.

As entidades dos trabalhadores vêm contribuindo nesse processo, e pensamos ser importante que se estruturem cada vez mais, em busca de atender às demandas que são cada vez maiores. As LER/Dort se alastram como uma epidemia no mercado de trabalho, em que cerca de $70 \%$ dos 62 mil casos de doenças ocupacionais registrados entre 2001 e 2003 pela Previdência Social são desse tipo e deixam inválidos, em média, cinco mil trabalhadores por ano. O número de benefícios, a título de auxílio-doença comum e auxílio-doença por acidente de trabalho, concedidos pela Previdência Social em 2003, evidencia o problema da subnotificação. Foram concedidos 1.371 .221 benefícios a título de auxílio-doença comum, contra 145.769 por acidente de trabalho. Não se pode afirmar que $100 \%$ dos auxílios-doença comuns sejam gerados pelo trabalho, mas grande parte deles encobre doenças reconhecidas e não reconhecidas oficialmente como do trabalho, como é o caso, por exemplo, das LER/Dort e das doenças mentais. A subnotificação envolve aspectos econômicos, políticos e éticos, na medida em que implica perdas para os trabalhadores, que não são só econômicas; também encobre a existência de riscos e agravos à saúde, dificultando a intervenção sindical e das políticas públicas (INST/CUT, 2006). ${ }^{2}$

Mesmo com uma Constituição Federal que assegura a saúde como direito de todos e dever do Estado, garantindo como direito social aos trabalhadores a redução dos riscos inerentes ao trabalho, poucas são as ações voltadas para assegurar a saúde e a segurança no trabalho. Em 1977, a lei n. 6.514 tornou

2 INST/CUT (Instituto Nacional de Saúde no Trabalho/Central Única dos Trabalhadores). Disponível em: 〈www.cut.org.br/estudos〉. Acesso em: ago. 2006. 
obrigatória no Brasil a observância de normas de segurança e medicina do trabalho, introduzindo dois artigos. $\mathrm{O}$ art. 198 restringiu a $60 \mathrm{~kg}$ o peso máximo que um trabalhador pode remover individualmente, e o art. 199 tornou obrigatória a colocação de assentos que assegurem a postura correta ao trabalhador. Em 1978, a portaria n. 3.214 aprovou as normas regulamentadoras (NRs) relativas à segurança e medicina do trabalho. A NR-17, na sua primeira versão, tratou do levantamento e transporte de cargas, bancadas, mesas e assentos nos locais de trabalho. Em 1990, foi apresentada nova redação, que estabelecia parâmetros e introduzia a obrigatoriedade do estudo da organização do trabalho (Tessler, 2002). A NR-17 se reporta à ergonomia e às condições de trabalho e estabelece parâmetros que permitem a adaptação das condições de trabalho às características do trabalhador. Ela é aplicável a todas as categorias.

Em 30 de março de 2007, a portaria n. 9 aprovou o anexo II da NR-17 Trabalho em Teleatendimento/Telemarketing - regulamentando o trabalho do teleoperador. O anexo II da NR-17 versa sobre mobiliário e equipamentos dos postos de trabalho; condições ambientais de trabalho; organização do trabalho; capacitação dos trabalhadores; condições sanitárias de conforto; programas de saúde ocupacional e de prevenção de riscos ambientais. Esse anexo fixa prazos que vão de 90 a 180 dias para as empresas se adequarem às mudanças e cumprirem as novas determinações. Para as mudanças estruturais, como mobiliário, os prazos serão mais longos, mas as empresas terão de garantir melhores condições de trabalho e prevenir as LER/Dort. A elaboração da norma se apoiou nos resultados de pesquisas, nos relatórios técnicos das inspeções do Ministério do Trabalho e Emprego (MTE) e nas numerosas queixas de adoecimento físico e mental dos trabalhadores. $O$ processo de elaboração do anexo está descrito detalhadamente no artigo de Peres e colaboradores (2006). Apesar do avanço que ela representa e de sua negociação ter sido longa e difícil entre governo, patronato e organização dos trabalhadores, algumas das demandas que beneficiariam os operadores não foram contempladas, como no caso do tempo estipulado para pausas, o que ainda exigirá um esforço atento e continuado na sua aplicação.

Outra instância reguladora do setor foi criada no contexto de privatização, em 1997. O órgão regulador das telecomunicações, a Agência Nacional de Telecomunicações (Anatel), visa a regular a exploração dos serviços de telefonia. A agência não faz qualquer referência à saúde dos trabalhadores e apenas tece observações sobre aspectos econômicos e o conceito de qualidade de atendimento, que está baseado nos tempos de espera do consumidor, 
implicando aumento da pressão sobre o tempo médio de atendimento do operador (Assunção et al., 2006; Marinho-Silva, 2007).

Historicamente, é por meio da aliança dos órgãos de saúde pública e dos sindicatos que as doenças têm tido seu reconhecimento concretizado. Com o anexo II da NR-17, aumentam-se as possibilidades de ações e intervenções na perspectiva da prevenção. Pensamos ser esse um momento importante para trazermos reflexões sobre a compreensão dos riscos e a perspectiva da prevenção prescritiva adotada usualmente pelas práticas das instâncias institucionais.

\section{REFERÊNCIAS}

AlgODOAL, M. J. As Práticas de Linguagem em Situação de Trabalho de Operadores de Telemarketing Ativo de uma Editora, 2002. Tese de Doutorado, São Paulo: Pontifícia Universidade Católica de São Paulo.

ABT (Associação Brasileira de Telesserviços). 6a Pesquisa Anual de Telemarketing. Disponível em: <www.abt.org.br>. Acesso em: 7 fev. 2006.

ASSUNÇÃO, A. A. et al. Abordar o trabalho para compreender e transformar as condições de adoecimento na categoria dos teleatendentes no Brasil. Revista Brasileira de Saúde Ocupacional, 31(114): 47-62, 2006.

BAGNARA, S. Towards Telework in Call Centres. Euro-Telework, Call Center Report, 2000. Disponível em: 〈www.telework-mirti.org/bagnara.htm>. Acesso em: abr. 2004.

BONO, A. del. Call centers, el trabajo del futuro? El caso de estrategias telefónicas S. A. (Estratel). Sociologia del Trabajo, 39: 3-31, 2000.

BOUTET, J. A atividade do trabalho nas centrais de atendimento: um trabalho de linguagem. Revista Brasileira de Saúde Ocupacional, 31(114): 73-82, 2006.

BRAGA, R. \& ANTUNES, R. (Orgs.) Infoproletários: degradação real do trabalho virtual. São Paulo: Boitempo, 2009.

BRASIL. Ministério do Trabalho e Emprego. Classificação Brasileira das Ocupações, 2010. Disponível em: < www.mte.gov.br/empregador/cbo/procuracbo/conteudo/ tabela3.asp? gg=3\&sg=8\&gb=0>.

BRITO, J. Trabalho e Saúde Coletiva: o ponto de vista da atividade e das relações de gênero. Ciência E⿱ Saúde Coletiva, 10(4): 879-890, 2005.

BUSCATTO, M. Les centres d'appels, usines modernes? Les rationalisations paradoxales de la relation téléphonique. Sociologie du Travail, 44(1): 99-117, 2002.

CASTRO, I. A. et al. Diferenças interindividuais em teleatendimento de emergências: explicitação por meio da entrevista de autoconfrontação. Revista Brasileira de Saúde Ocupacional, 31(114): 83-96, 2006.

COUSIN, O. Les ambivalences du travail, les salariés peu qualifiés dans les centres d'appels. Sociologie du Travail, 44(4): 499-520, 2002. 
DEDECCA, C. S. et al. Gênero e jornada de trabalho: análise das relações entre mercado de trabalho e família. Trabalho, Educação e Saúde, 7(1): 65-90, mar./jun. 2009.

FERNANDES, S. R. P.; TEJO DI PACE, D. M. \& PASSOS, M. F. D. Organização e condições de trabalho em telemarketing: repercussões na saúde psíquica dos trabalhadores. In: JACQUES, M. G. \& CODO, W. (Orgs.) Saúde Mental Eु Trabalho: leituras. Petrópolis: Vozes, 2002.

FERREIRA, M. C. Interação teleatendente-teleusuário e custo humano do trabalho em central de teleatendimento. Revista Brasileira de Saúde Ocupacional, 29(110): 7-15, 2004.

FRIGERI, F. \& VIDAL, M. C. Lesões por esforços repetitivos ou distúrbios musculoesqueléticos relacionados ao trabalho no setor de teleatendimento. In: CONGRESSO BRASILEIRO DE ERGONOMIA, 9, 1999, Salvador. Anais... Salvador: Abergo, 1999.

GALASSO, L. M. R. Humor e Estresse no Trabalho: fatores psicossociais e benéficos no trabalho dos operadores de telemarketing, 2005. Tese de Doutorado, São Paulo: Faculdade de Saúde Pública, Universidade de São Paulo.

GLINA, D. M. R. \& ROCHA, L. E. Fatores de estresse no trabalho de operadores de centrais de atendimento telefônico de um banco de São Paulo. Revista Brasileira de Medicina do Trabalho, 1(1): 31-39, 2003.

GOULART, V. Gênero, Saúde e Trabalho: fatores que interagem no desenvolvimento de LER em trabalhadores telefônicos, 2002. Dissertação de Mestrado, Belo Horizonte: Universidade Federal de Minas Gerais.

HARDT, M. O trabalho afetivo. In: PÁl PELBART, P. \& COSTA, R. (Orgs.) O Reencantamento do Concreto. São Paulo: Hucitec, 2003.

HARDT, M. \& NEGRI, A. Império. Rio de Janeiro: Record, 2001.

HIRATA, H. Da polarização das qualificações ao modelo de competência. In: FERRETTI, C. J. (Org.) Novas Tecnologias, Trabalho e Educação: um debate multidisciplinar. Petrópolis: Vozes, 1994.

HIRATA, H. Globalização, trabalho e gênero. In: JERUSALINSKY, A. et al. (Orgs.) O Valor Simbólico do Trabalho e o Sujeito Contemporâneo. Porto Alegre: Artes e Ofícios, 2000.

LARANJEIRA, S. G. A reestruturação das telecomunicações e os sindicatos. Revista Brasileira de Ciências Sociais, 18(52): 81-215, jun. 2003.

LAZZARATO, M. \& NEGRI, A. Trabalho Imaterial: formas de vida e produção de subjetividade. Rio de Janeiro: DP\&A, 2001.

LEAL, L. \& SOARES, R. G. Análise ergonômica em uma central de teleatendimento. In: CONGRESSO LATINO-AMERICANO DE ERGONOMIA, 7, 2002, Recife. Anais... Recife: Abergo, 2002.

LEROUX, S. Telétravail: une nouvelle dimension du travail à propôs de quelques travaux de recherche. Syndicalisme et Societé, 2(2): 343-357, 2000.

MANCINI, L. Call Center: estratégia para vencer. São Paulo: Summus, 2001. 
MARINHO-SILVA, A. Condições de trabalho e adoecimento dos trabalhadores em teleatendimento: uma breve revisão. Revista de Gestão Integrada em Saúde do Trabalho e Meio Ambiente, 1(3), 2007. Disponível em: <www.interfacehs.sp.senac.br/artigos. asp?ed=3\&cod_artigo $=45>$.

MARKET, W. L. Trabalho, universalidade, comunicação e sensibilidade: aspectos teórico-metodológicos para um conceito dialético de competência, 2002a. Disponível em: 〈www.anped.org.br/reunioes/24/T0942718982086.doc〉. Acesso em: ago. 2006.

MARKET, W. L. Trabalho e comunicação: reflexões sobre um conceito dialético de competência. Educação Eु Sociedade, 23(79): 189-211, 2002 b.

MARQUEZ, M. B. Carrapateando: uma análise psicossocial da atividade de telemarketing, 2002. Dissertação de Mestrado, São Paulo: Faculdade de Psicologia, Universidade Católica de São Paulo.

MASCIA, F. L.; MARX, R. \& ARBIX, G. Old Paradigms for New Jobs in Call Centers. Universidade de São Paulo. Proceedings of the IEA 2000/HFES 2000.

MONTEIRO, N. A. Aspectos Ergonômicos do Trabalho em Atividade de Teleatendimento Bancário, 1999. Dissertação de Mestrado, São Paulo: Universidade de São Paulo.

NOGUEIRA, C. M. O Trabalho Duplicado: a divisão sexual no trabalho e na reprodução - um estudo das trabalhadoras do telemarketing. São Paulo: Expressão Popular, 2006.

OFFE, C. Capitalismo Desorganizado: transformações contemporâneas do trabalho e da política. São Paulo: Brasiliense, 1999.

OLIVEIRA, S. \& ANJOS, L. H. Análise Ergonômica do Trabalho em uma Empresa de Teleatentimento, 2002. Monografia, Rio de Janeiro: Coppe/UFRJ, 2002.

OLIVEIRA, S.; SANTOS, M. \& BRITO, J. Saberes e estratégias dos operadores de telemarketing frente às adversidades do trabalho. Revista Brasileira de Saúde Ocupacional, 31(14): 125-134, 2006.

PERES, C. et al. Uma construção social: o anexo da norma brasileira de ergonomia para o trabalho dos operadores de telemarketing. Revista Brasileira de Saúde Ocupacional, 31(14): 35-46, 2006.

PETIT, J. L. Parcellisation du Travail selon la Diversité de Prescriptions: conséquences de la mise en place d'un call center. Paris: Société d'Ergonomie de Langue Française (Self), 2002.

ROCHA, L. E. et al. Contra o relógio: trabalhos em centrais de atendimento telefônico devem ser revistos do ponto de vista ergonômico e de tempo estipulado para atendimento. Revista Proteção, 165: 57-64, 2005.

RUZZA, R. La prescription du travail dans le centres d'appels telephoniques. La Revue de l'IRES, 43: 3-24, 2002.

SAKAMOTO, K. Como Implementar um Call Center. São Paulo: Happy Few, 2001.

SANTOS, V. A Ergonomia e a Intensificação do Trabalho nas Centrais de Atendimento: a gestão temporal de múltiplas tarefas e de tarefas intermitentes, 2002. Tese de Doutorado, Rio de Janerio: Coppe, Universidade Federal do Rio de Janeiro. 
SEGNINI, L. R. P. Relações de gênero e racionalidade do trabalho em serviços de atendimento a distância. In: SALERNO, M. S. (Org.) Relação de Serviço: produção e avaliação. São Paulo: Editora Senac, 2001.

SILVA, L. F. C. Novos Cenários de Emprego nas Telecomunicações: trabalho e qualificação em um call center de Porto Alegre, 2004. Dissertação de Mestrado, Porto Alegre: Instituto de Filosofia e Ciências Humanas, Universidade Federal do Rio Grande do Sul.

SORJ, B. Sociologia e trabalho: mutações, encontros e desencontros. Revista Brasileira de Ciências Sociais, 15(43): 25-34, 2000.

SZNELWAR, L. I.; ABRAHÃO, J. \& MASCIA, L. Trabalhar em centrais de atendimento: a busca de sentido em tarefas esvaziadas. Revista Brasileira de Saúde Ocupacional, 31(14): 97-112, 2006.

SZNELWAR, L. I. \& MASSETTI, M. Sofrimento no trabalho: uma leitura a partir de grupos de expressão. In: SZNELWAR, L. \& ZIDAN, L. (Orgs.) O Trabalho Humano com Sistemas Informatizados no Setor de Serviços. São Paulo: Plêiade, 2000.

SZNELWAR, L. I.; ZIDAN, L. N. \& MARTINS, M. C. Contribuição ao estudo da atividade de operadores de teleatendimento, a nova velha forma de organização. In: SEMINÁRIO DE ERGONOMIA DA BAHIA, 3, 1999, Recife. Anais... Salvador: Abergo, 1999.

TESSLER, J. S. Macroergonomia em Call Center de Ambiente Universitário, 2002. Dissertação de Mestrado, Porto Alegre: Escola de Engenharia, Universidade Federal do Rio Grande do Sul.

TORRES, C. \& ABRAHÃO, J. As atividades nas centrais de atendimento: outra realidade, as mesmas queixas. In: CONGRESSO BRASILEIRO DE ERGONOMIA, 7, 2002, Recife. Anais... Recife: Abergo, 2002.

VENCO, S. Telemarketing nos Bancos: o emprego que desemprega, 1999. Dissertação de Mestrado, Campinas: Departamento de Ciências Sociais Aplicadas à Educação, Universidade Estadual de Campinas.

VENCO, S. Centrais de atendimento: a fábrica do século XIX nos serviços do século XXI. Revista Brasileira de Saúde Ocupacional, 31(114): 7-18, 2006.

VILELA, L. V. O. \& ASSUNÇÃO, A. A. Os mecanismos de controle da atividade no setor de teleatendimento e as queixas de cansaço e esgotamento dos trabalhadores. Cadernos de Saúde Pública, 20(4): 1.069-1.078, 2004.

ZARIFIAN, P. Mutação dos sistemas produtivos e competências profissionais: a produção industrial de serviço. In: SALERNO, M. (Org.) Relação de Serviço: produção e avaliação. São Paulo: Editora Senac, 2001a.

ZARIFIAN, P. Valor, organização e competência na produção de serviço: esboço de um modelo de produção. In: SALERNO, M. (Org.) Relação de Serviço: produção e avaliação. São Paulo: Editora Senac, 2001b.

ZARIFIAN, P. O Modelo da Competência: trajetória histórica, desafios atuais e propostas. São Paulo: Editora Senac, 2003. 


\section{Formato: 16 × $23 \mathrm{~cm}$}

Tipologia: Gill Sans e Goudy Old Style

Papel: Pólen Bold 70g/m2(miolo)

Cartão supremo $250 \mathrm{~g} / \mathrm{m} 2$ (capa)

CTP, impressão e acabamento: Imprinta Express Gráfica e Editora Ltda.

Rio de Janeiro, março de 2011.

Não encontrando nossos títulos em livrarias, contactar:

\section{Editora Fiocruz}

Av. Brasil, 4036 - térreo - sala 112 - Manguinhos

CEP 21040-361 - Rio de Janeiro - RJ.

Tel.: (21) 3882-9039 e 3882-9041 - Telefax: (21) 3882-9006

editora@fiocruz.br | www.fiocruz.br/editora 